\title{
Wur.or
}



BINDING LIET SEF 151927 

Digitized by the Internet Archive in 2007 with funding from Microsoft Corporation 
J 
DEPARTMENT OF THE INTERIOR, CANADA

Hon. Sir James Lougheed, Minister; W. W. CORY, Deputy Minister FORESTRY BRANCH-BULLETIN No. 61

R. H. CAMPBELL, Director of Forestry

\section{NATIVE TREES \\ of \\ CANADA}

BY

B. R. MORTON, B.Sc.F.

With notes on nomenclature and utilization by

R. G. LEWIS, B.Sc.F.

Th

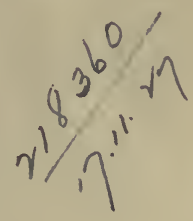

ISSUED BY DIRECTION OF

THE HON. SIR JAMES LOUGHEED, MINISTER OF THE INTERIOR

OTTAWA, 1921

PRICE 50 OENTS 

Introduction

The Pines.

The Larches.

The Spruces.

The Hemlocks

The Douglas Fir Group.

The Firs.

The Cedars

The Western Cypresses.

The Junipers

The Yews.

The Walnuts.

The Hickories

The Willows.

The Poplars

The Birches

The Alders.

The Ironwoods.

The Blue Beeches.

The Beeches.

The Chestnuts

The Oaks

The Elms.

The Hackberries.

The Mulberries.

The Magnolias

The Tulip Trees

The Papaws.

The Sassafras.

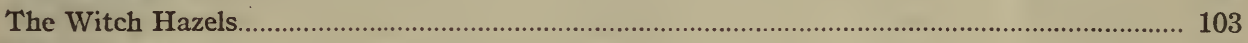

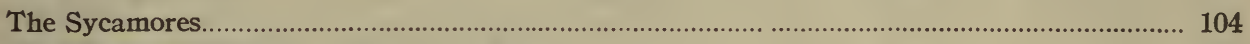

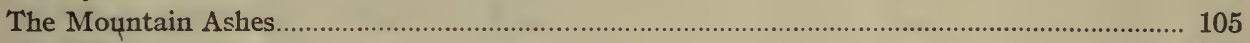

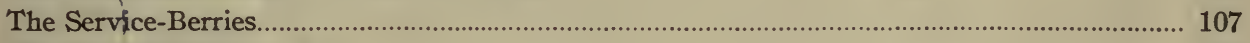

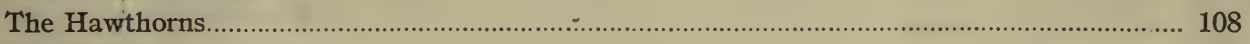

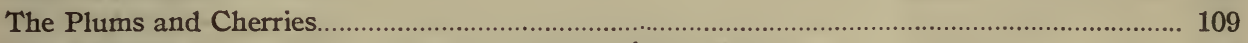

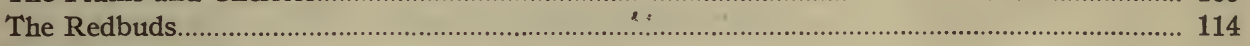

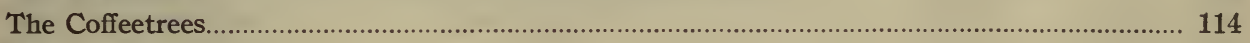

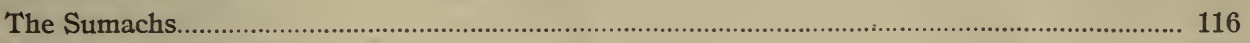

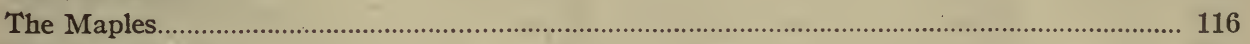

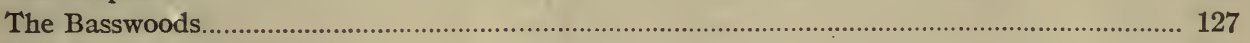

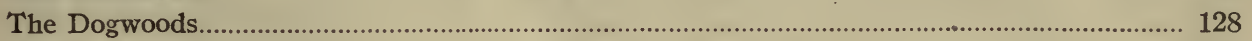

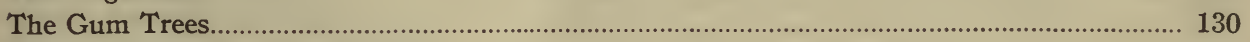

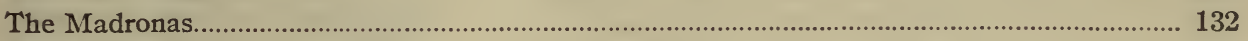

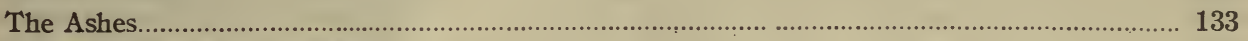

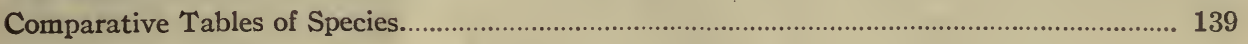





\section{ILLUSTRATIONS-LEAVES, TWIGS, AND FRUIT}

Pine cones and leaves

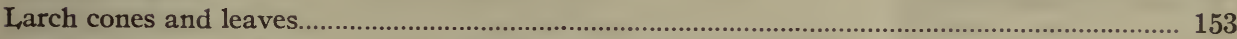

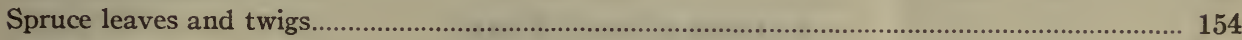

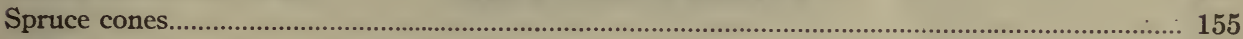

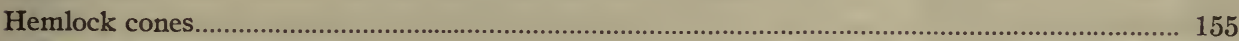

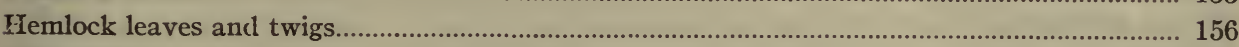

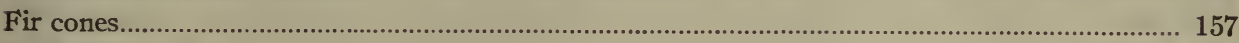

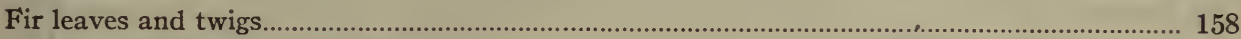

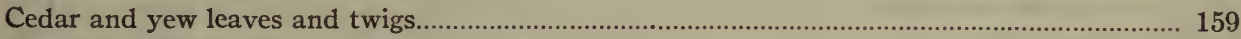

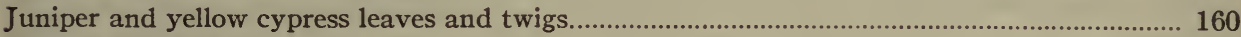

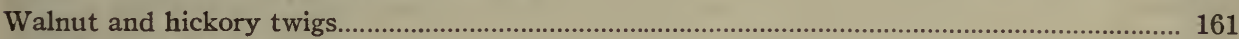

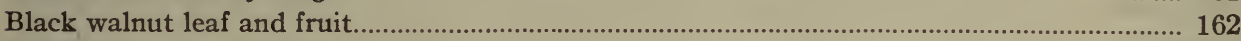

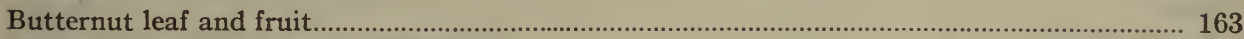

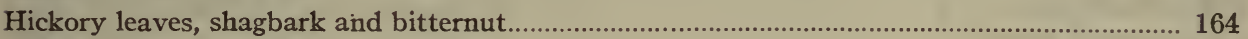

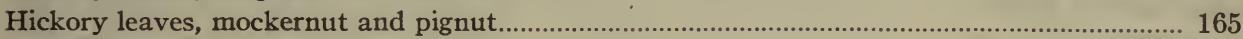

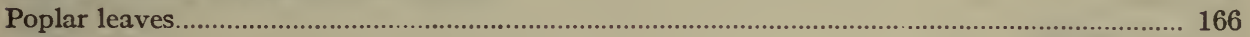

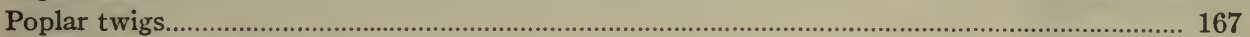

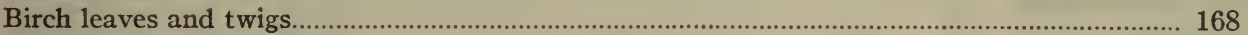

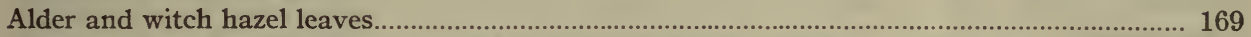

Chestnut, beech, service-berry, ironwood, and blue beech leaves............................................ 170

Chestnut, beech, service-berry, ironwood, blue beech, and ash twigs..................................... 171

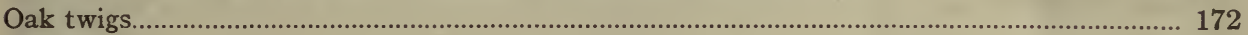

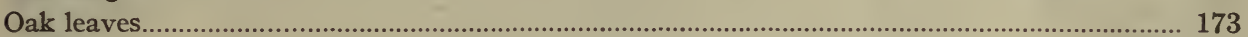

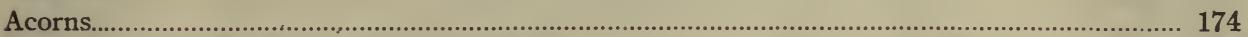

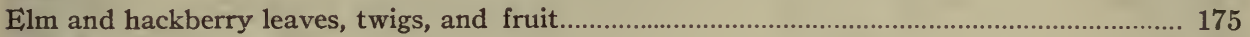

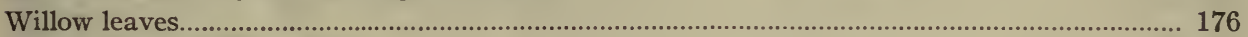

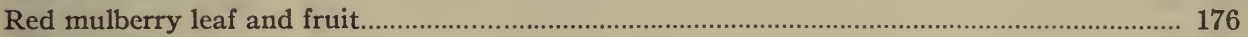

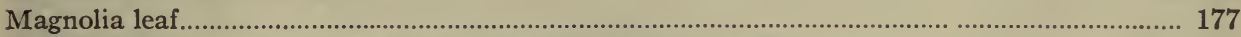

Tulip tree leaf and fruit cone with carpels partly fallen away................................................ 177

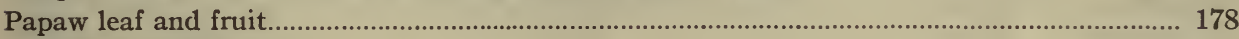

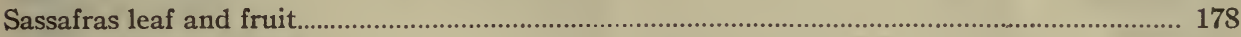

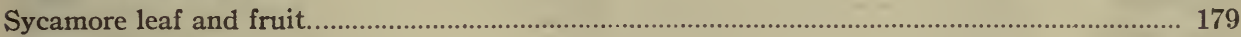

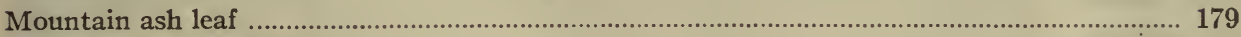

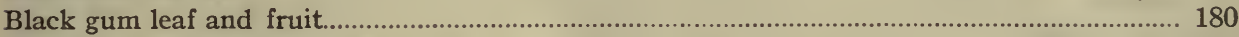

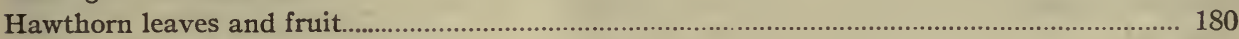

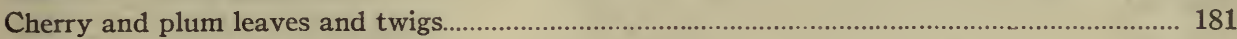

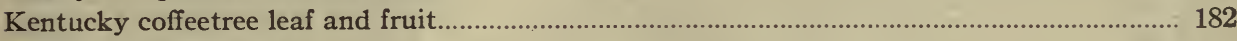

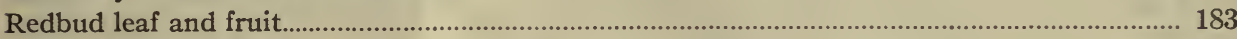

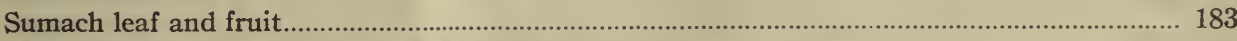

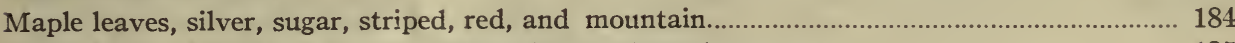

Maple leaves, Manitoba, dwarf, vine, and broad-leaved........................................................ 185

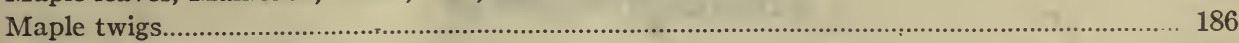

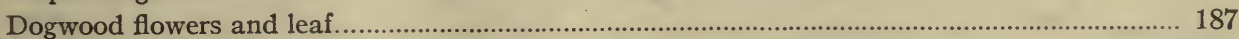

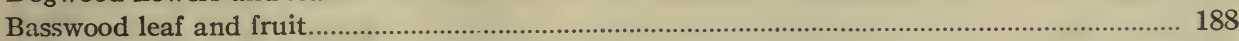

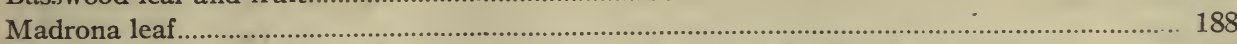

Miscellaneous twigs: Willow, sassafras, sycamore, basswood, mulberry, and redbud............... 189 
Miscellaneous twigs: Witch hazel, sumach, alder, coffeetree, magnolia, tulip tree, black gum, and mountain ash.

Ash, white, leaf and fruit

Ash, black, leaf and fruit

Ash, red, leaf and fruit.

Ash, green, leaf and fruit

Ash, blue, leaf and fruit

\section{ILLUSTRATIONS-BARK}

White pine.

Western white pine.

Pitch pine.

Sitka spruce.

Douglas fir and western cedar.

Western yellow pine.

Cedar.

Paper birch.

Hemlock

Western hemlock

Large-toothed aspen.

Cottonwood.

Shagbark hickory...

Bitternut hickory.

Butternut.

Yellow birch.

Ironwood

Kentucky coffeetree

Dogwood...

Black gum

White oak

Red oak

Bur oak.

Beech.

White elm.

Sycamore

Black cherry

Hackberry

Sugar maple

Silver maple

Manitoba maple

Basswood.

White ash.

\section{ILLUSTRATIONS-TREES}


Pitch pine.

Page

Limber pine

Douglas fir

Western yellow pine

White spruce.

Black spruce

Western hemlock

Eastern hemlock

Balsam fir.

Alpine fir.

White cedar

Red cedar.

Black walnut

Black gum

Bitternut

hickory

213

Shagbark hickory

213

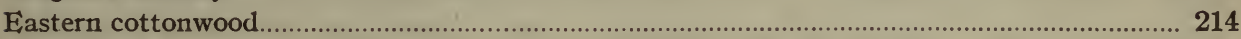

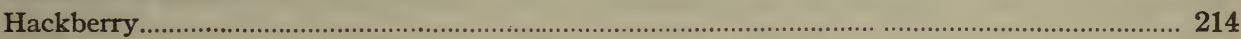

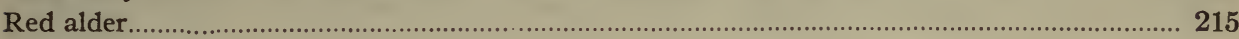

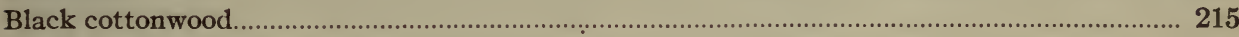

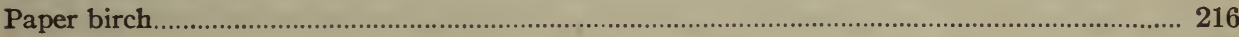

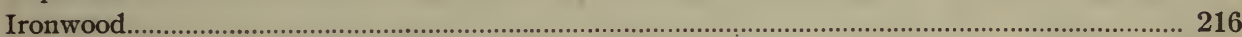

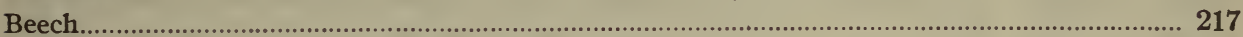

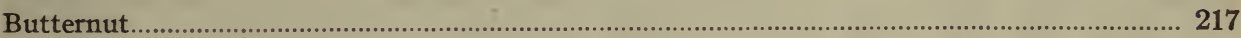

White oak

Red oak

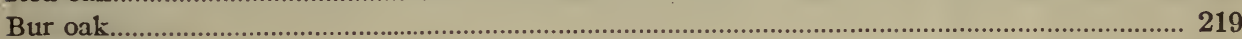

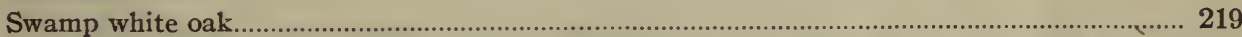

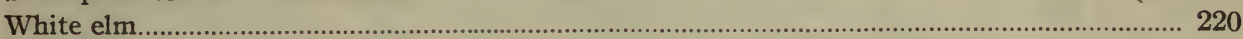

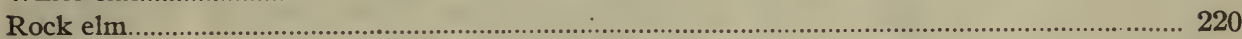

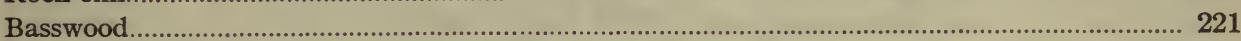

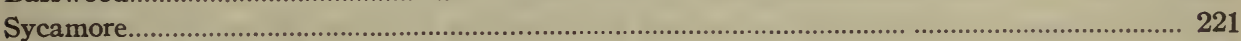

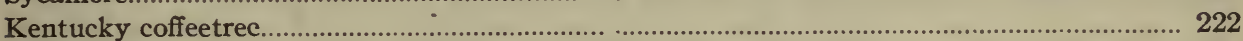

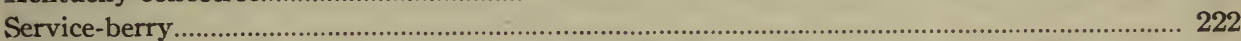

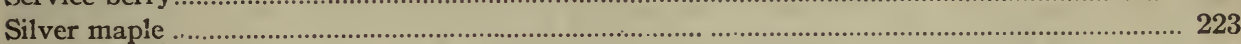

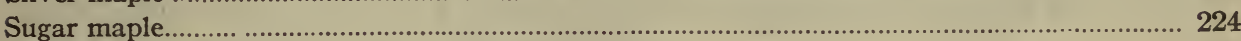

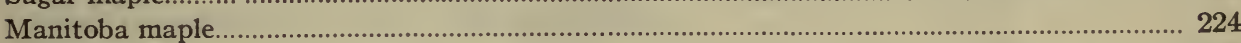

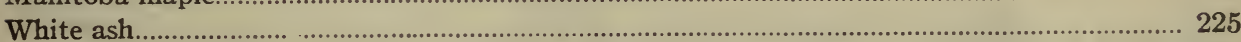

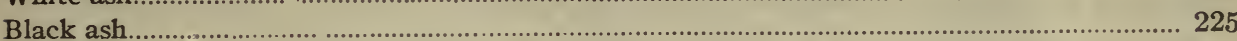

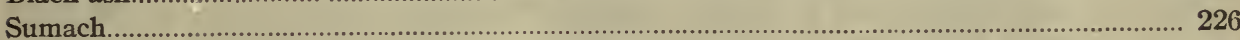

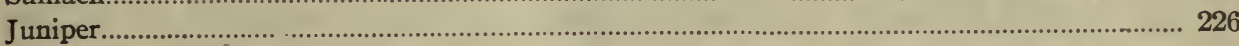





\section{INTRODUCTION}

This book has been prepared to meet a growing demand on the Forestry Branch for publications of this kind. In it are described over one hundred tree species native to Canada, including all the commercial species and many of minor or no economic importance. Several of the species described are ordinarily little better than shrubs but are found in arborescent form somewhere in their natural range of occurrence. No distinct line can be drawn between trees and shrubs. They grade one into the other. Many trees are reduced to mere bushes when growing under unfavourable circumstances.

The descriptions have for the most part been confined to those features of the tree by which it may be readily recognised in the field and, in order that the book may best serve its purpose, terms which are unfamiliar to one who has not made a study of botany have been avoided as far as possible. [Those desiring a more complete and scientific description are recommended to consult such well known books as Sargent's "Manual of the Trees of North America" or Gray's "New Manual of Botany."]

The description includes in the case of the more important commercial species a brief paragraph on the physical properties and uses of the wood. Where a genus is represented by many species, especially when they occur in the same range or where there is likely to be confusion between trees of different genera, their distinguishing features have been arranged in tabular form for the sake of ease in comparison.

The region over which each species occurs naturally in Canada is briefly described in the text and in some cases is shown by the hatched areas on accompanying maps. It is not claimed that these descriptions and maps are absolutely correct, as the exact range of many of the species has not yet been clearly defined, especially of those trees extending into the unsettled north. However, from the reports of surveyors and explorers, as well as from a knowledge of the requirements of each species in regard to soil, climate, etc., the approximate range of the more important ones has been fairly well determined.

The province of Ontario, and especially that portion of it forming the peninsula between the Great Lakes, possesses a greater variety of tree species than any other part of the Dominion. Here are found growing trees occurring nowhere else in Canada. Trees such as the tulip, chestnut, black gum, papaw, flowering dogwood, and others characteristic of the forests of Ohio and other states to the south, reach their northern limits here. Similarly in the province of British Columbia, the mild and humid climate of the southern coast, Vancouver island, and portions of the Columbia and Kootenay valleys permits the occurrence of many species which are typical of more southern forests and which are not found elsewhere in Canada. 
The drawings herein were made by the author, for the most part from specimens in the collection of the Faculty of Forestry of the University of Toronto. To this Faculty thanks are due for the kind permission to use their collection. Thanks are also due to the British Columbia Forest Branch for the information regarding the range of trees native to that province.

So far as space on a page of this size would permit the engravings illustrating the different species of the same genera have been arranged so that they may be conveniently compared.

\section{Nomenclature}

In selecting the common or vernacular names for the trees described in this book the chief consideration has been to avoid confusion. Existing names that have enjoyed accepted common use for many years have been retained wherever possible, if their use is consistent. Where two or more names are equally common one has been selected that best describes the characteristics of the tree and has, therefore, the highest name value.

In this connection the name "red pine" has been chosen in place of "Norway pine" for Pinus resinosa, because of the darker colour of the wood as compared to white pine and the distinct reddish colour of the bark; whereas the name "Norway pine" has little or no real significance.

When one name is used to describe two or more different trees confusion is sure to arise. In all such cases the aim has been to avoid this confusion, even at the expense of the name value of the name adopted.

Two different trees, Ostrya virginiana and Carpinus caroliniana are called "ironwood," "hornbeam," and "hop hornbeam" indiscriminately. The name "blue beech" is also applied to Carpinus as the tree has smooth bark and is not unlike a young beech tree in general appearance. The name has never been applied to Ostrya, and it has therefore been used in this book, as it is at least distinctive. The names "hornbeam" and "hop hornbeam" have been discarded.

In deciding among several possibilities common names were favoured when these were translations of the botanical names, as in the case of limber pine (Pinus flexilis). There are certain species native to British Columbia and the Pacific coast that are not found east of that province, although other species of the same genera are found in Eastern Canada. Among such cases are western hemlock (Tsuga heterophylla) and western white pine (Pinus monticola). In British Columbia these trees would be known as "hemlock" and "white pine" but the prefix "western" has been added in each case to distinguish these trees from their eastern relatives, hemlock (Tsuga canadensis) and white pine (Pinus Strobus).

The first name given in the description of any species is the accepted botanical name following the Vienna Rules of Nomenclature (so called because they were adopted at an international convention of botanists held in Vienna in 1905). After the name of the tree is given the abbreviation of the name of the botanist who is credited with having first properly described the species. At the right hand side 
of the page is given the accepted common name adopted by the Forestry Branch in all its publications. Following this is a list of the common or vernacular names used in Canada and the northern United States. Where the name has only local use confined to a certain region, this region is indicated in brackets after the name. Where a common name is marked by an asterisk the fact is indicated that the name is also used to describe one or more entirely different trees, or that its use is to be avoided because of some other inconsistency.

The importance of having a standardized list of common names of trees, if only for purposes of reference, is evident from the difficulties that frequently arise out of this confusion of common names.

A purchaser of lumber, structural timber, pulpwood, ties, cooperage stock, or other forest products should be able to specify the wood of a certain species without the possibility of misunderstanding. He can only do this by resorting to the botanical name or to a standardized common name. The average layman has neither the time nor the inclination to memorize botanical names, although he is able to recognize the different species and to give them the common name used in his neighbourhood. If, however, this common name does not correspond to the name used elsewhere he is sure to be misunderstood.

While the universal adoption of a standard list of common names is only an ideal it is hoped that the list given in this book will at least be a step in the direction of uniformity of nomenclature. 



\section{THE PINES}

The pines (Pinus) are widely distributed throughout the northern hemisphere. Eighty species are known and thirty-five or so are found on this continent. Nine occur in Canada.

Three of our pines are found only in Eastern Canada, four in the West, and one species extends right across from the Atlantic to British Columbia.

All pines are evergreens and have needle-like leaves which are clustered in bundles of from two to five. One species, not native, has solitary leaves. The leaves vary in length from one to fifteen inches.

The cone takes from two to three years to ripen. No cones ripen in less than two years.

The native pines are sometimes divided into two groups, the soft and the hard pines. The soft pines have their leaves in bundles of five and their cones are pendulous and have thin scales. The hard pines have their leaves in bundles of two or three and have cone scales which are quite thick and woody.

The soft pine group includes

$\begin{array}{ll}\text { White pine, } & \text { Pinus Strobus } \\ \text { Western white pine, } & \text { Pinus monticola } \\ \text { Limber pine, } & \text { Pinus flexilis } \\ \text { White-barked pine, } & \text { Pinus albicaulis }\end{array}$

The hard pines are

$\begin{array}{ll}\text { Red pine, } & \text { Pinus resinosa } \\ \text { Jack pine, } & \text { Pinus Banksiana } \\ \text { Pitch pine, } & \text { Pinus rigida } \\ \text { Western yellow pine, } & \text { Pinus ponderosa } \\ \text { Lodgepole pine, } & \text { Pinus Murrayana }\end{array}$

PINUS STROBUS, Linn.

WHITE PINE

Common names: White pine, cork pine, Weymouth pine, pattern pine, sapling pine, pumpkin pine, eastern white pine, yellow pine*, Quebec pine (England).

French names: Pin blanc, pin jaune*, pin potiron, pin Weymouth, pin baliveau, pin du lord.

This tree under favourable conditions sometimes reaches the height of $175 \mathrm{it}$. and the diameter of $5 \mathrm{ft}$; ; but in the average stand it is rarely found cver $100 \mathrm{ft}$. high or more than 2 to $3 \mathrm{ft}$. in diameter. It is the tallest and most stately of all conifers in Eastern Canada. 
It has the smoothest bark of any eastern pine. On limbs and young trunks under 6 in. in diameter it is, as a rule, greenish-brown in colour and quite smooth. Later it becomes roughened by shallow, flat-topped, broad, longitudinal ridges, greyish-brown in colour. On account of its thin, resinous bark it is greatly subject to damage by fire.

The branches usually grow out at right angles to the trunk in more or less regular whorls of five. On old trees, or those growing in crowded stands, this is not so apparent. The crown is more or less cone-shaped in young trees, becoming flat-topped when old.

Its wide-spreading roots and deep tap-root make it very wind-firm and, as a rule, it is only the much-exposed mature trees that are overthrown.

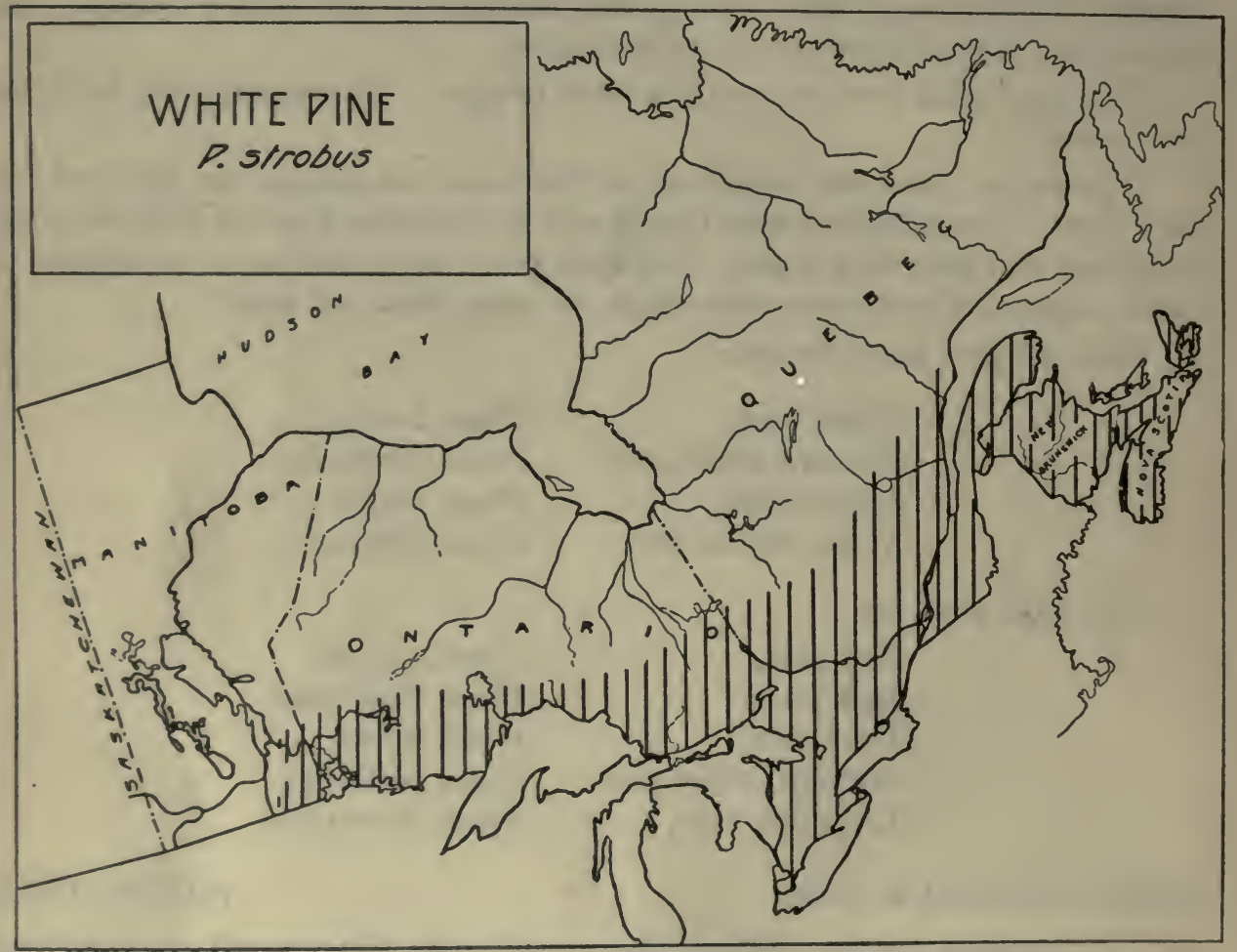

The needle-like leaves grow in bundles of five and are from 3 to 5 in. long, soft, delicate, and of a clear light green colour. In cross-section the leaves are triangular. It is the only native pine east of British Columbia with five leaves in a bundle, and is, therefore, not likely to be confused with any other.

The cones are from 5 to $10 \mathrm{in}$. long, slender, curved, and stalked. The scales are thin and have no prickles at their tips.

The white pine ranges from Newfoundland to Manitoba. It does not extend north of the height of land dividing the waters of the St. Lawrence and the Great 
Lakes from those of Hudson bay. Its best development as a timber tree is reached in the Great Lakes region, where it is frequently found in pure stands on sandy lands. It will grow well on either sand or clay, but does best on well-drained sandy lands.

For many years white pine was the most important lumber tree in Canada, but of late years it has given way to spruce. The wood is soft, easy to work, easy to season, and, once properly conditioned, holds its shape as well as any other coniferous wood known to commerce. It is used in every part of the construction of buildings from shingles to sills, and a list of its other uses would include practically every wood-using industry in Canada.

PINUS MONTICOLA, Dougl.

WESTERN WHITE PINE

Common names: Western white pine, silver pine, mountain Weymouth pine, white pine (British Columbia).

French name: Pin argenté.

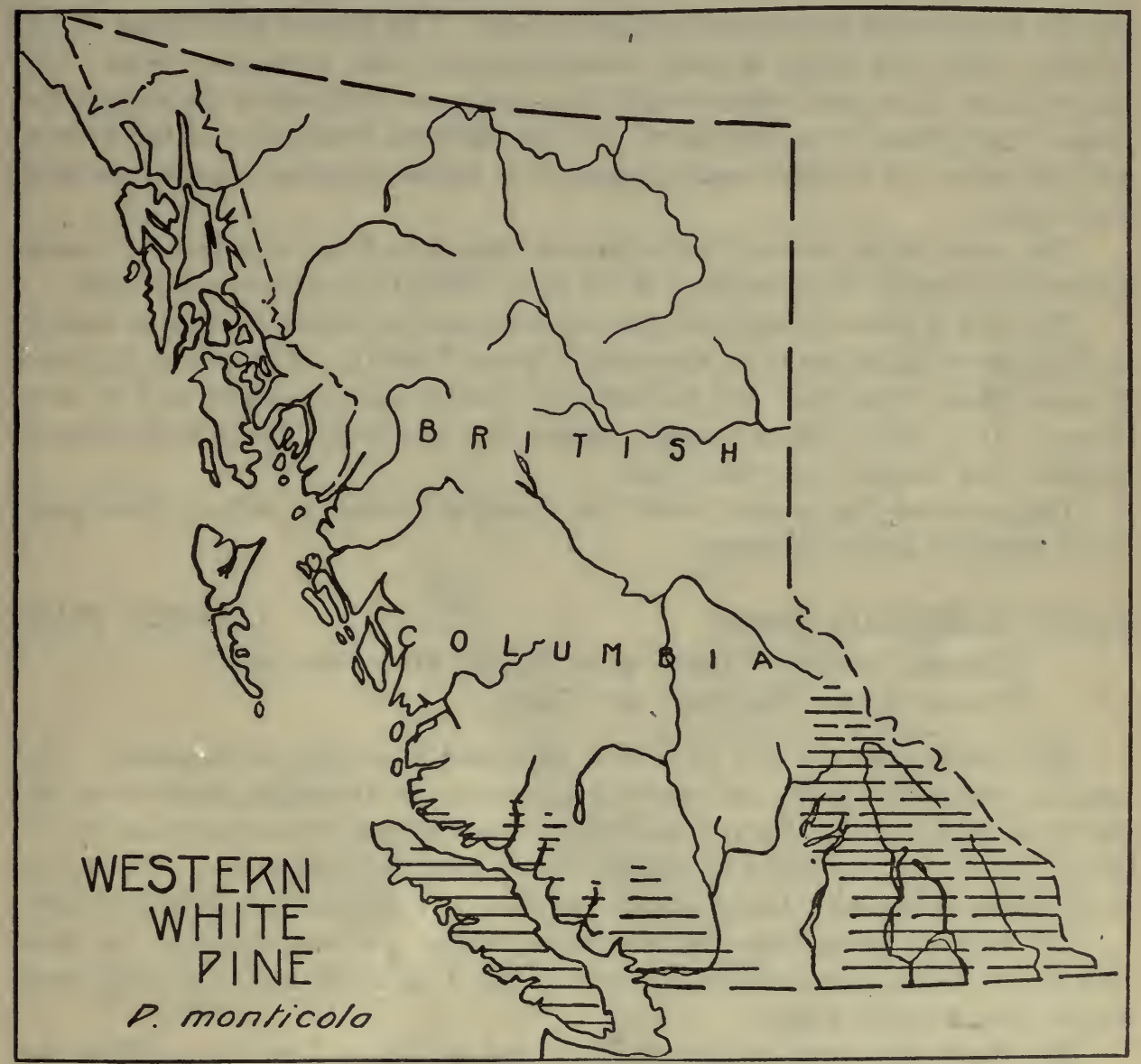

The height of the average western white pine tree is about $90 \mathrm{ft}$. and its diameter about $2 \mathrm{ft}$. It occasionally reaches a diameter of $6 \mathrm{ft}$. and a height of $250 \mathrm{ft}$. 
In dense stands it produces a tall, slender trunk and a narrow, conical crown of short, wide-spaced branches. The branches are usually slender and drooping, but when growing in the open it frequently extends one or more stout, horizontal branches 10 or $15 \mathrm{ft}$. beyond the others. This peculiar habit enables a person to distinguish the tree from a considerable distance.

The bark on young trees and branches is silvery-grey, thin, and smooth. On older trees it is purplish to brown and broken into square blocks about 1 in. thick. The inner bark has a cinnamon-red colour. Owing to the thinness of the bark the tree is easily damaged by fire. Its fairly deep root-system protects it from serious injury by strong winds.

The leaves are bluish-green in colour and are borne in clusters of five. They are from 2 to 4 in. long and, as a rule, shorter, coarser, and stiffer than those of the white pine of the East. These two trees, having widely-separated ranges, are not liable to be confused. The only five-needled trees within the range of this tree are the limber pine and the white-barked pine. The general appearance of the western white pine makes it easily distinguishable from these two trees. The leaves of the limber and white-barked pines are more clustered at the ends of the twigs. The cones of the two latter trees are different from those of the former, and the trees are usually found growing at a higher elevation than the western white pine.

The cones of the western white pine are from 6 to $18 \mathrm{in.}$ long and very much larger than those of the white pine of the East, which they otherwise resemble.

The tree is found throughout the southern part of British Columbia, including Vancouver island, up to an elevation of about $6,000 \mathrm{ft}$. It is commonly found on poor, sandy situations, but prefers deep, porous soils on slopes and in river valleys. It is rarely found in pure stands, but is usually mixed with western hemlock and Douglas and white firs.

Lumber sawn from western white pine is similar to that of eastern white pine, and is used for similar purposes.

\section{PINUS FLEXILIS, James}

LIMBER PINE

Common names: Limber pine, Rocky Mountain pine.

French name: Pin blanc de l'Ouest.

The limber pine is a tree 25 to $40 \mathrm{ft}$. high and 12 to $24 \mathrm{in}$. in diameter. The trunk is short, thick, limby, and crooked and the crown is irregular, due to irregular whorls of thick limbs. Much of the limber pine growth is little better than shrubbery. In old trees the lower branches are very long and hang down. The young branches are exceedingly limber, hence the name. The wood is used locally only.

The bark on young trees and branches is whitish-grey and smooth. On trees over $12 \mathrm{in}$. in diameter it is dark brown, nearly 2 in. thick, and broken by deep fissures into irregular plates.

The leaves are borne in clusters of five and are $11 / 2$ to $3 \mathrm{in.}$ long. They are dark green in colour, stout and rigid, and densely clustered at the ends of the branches. 
The cones are 4 to $10 \mathrm{in.} \mathrm{long}$ and of yellowish-brown colour. The scales are very much thickened at the tips. This characteristic helps one to distinguish the tree from the western white pine. At maturity the cones split open and the seed escapes. The colour of the cone also fades after a time.

This tree is found in Canada only in the Rocky mountains in southern British Columbia and Alberta, at an altitude of 5,000 to $6,000 \mathrm{ft}$. It usually occurs singly or in small stands. It is adapted to a great variety of soils, but is most often found on dry, rocky, and exposed slopes. In southern Alberta it is found on the tops of the foot-hills.

PINUS ALBICAULIS, Engelm.

WHITE-BARKED PINE

Common names: White-barked pine, white-stemmed pine, scrub pine.

French name: Pin à blanche écorce.

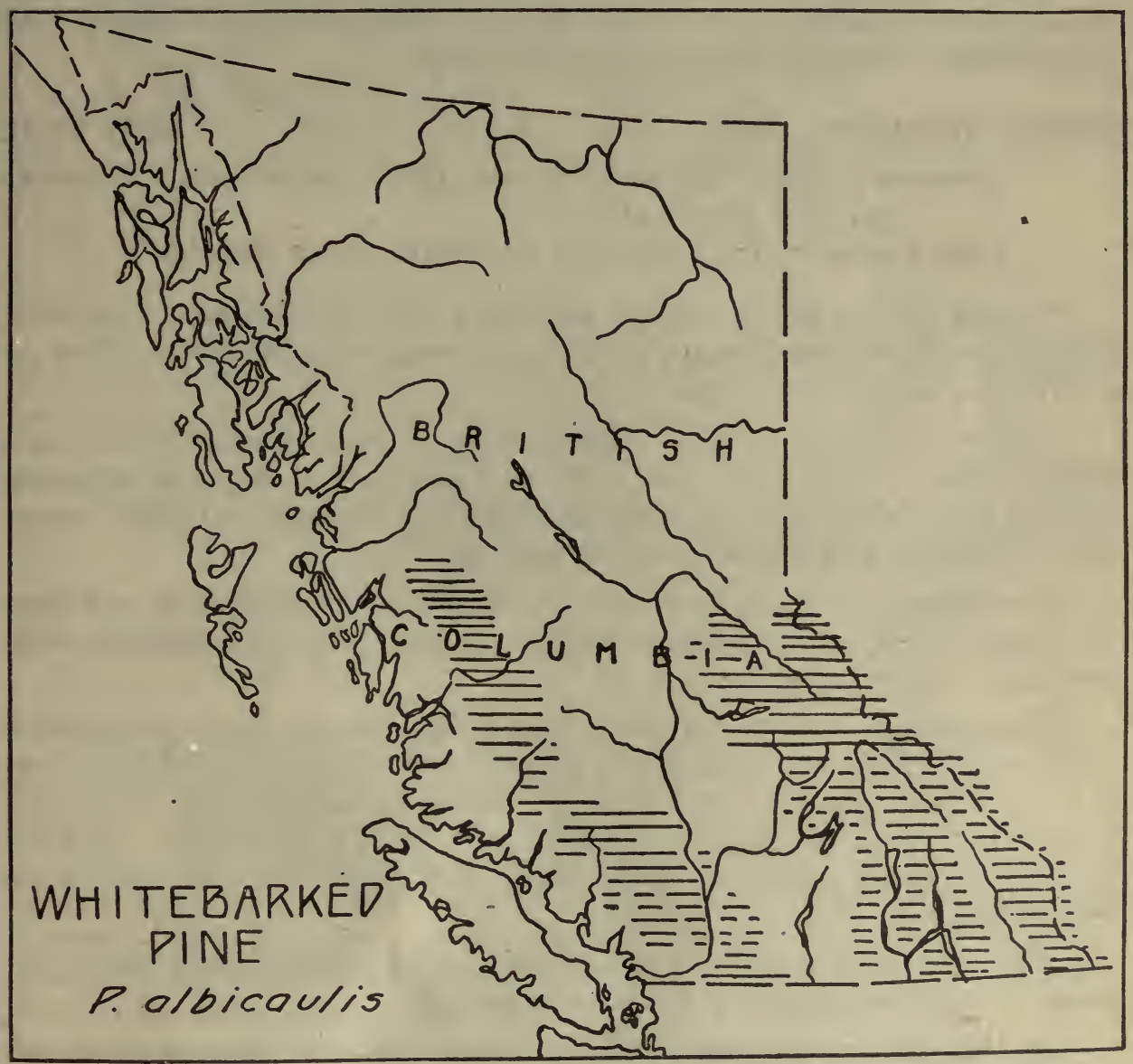

The white-barked pine is a small, scrubby tree, very much stunted, and in exposed sites is reduced almost to a creeping shrub. It sometimes reaches a height 
of $30 \mathrm{ft}$. and a diameter of 10 to $18 \mathrm{in.}$ The crown is matted and the root-system spreading and strong. The wood is used only for firewood.

The bark is whitish and little broken except at the base of the trunk, where narrow cracks break it into whitish scales. It is rarely over $1 / 4$ in. thick.

The leaves are stout, rigid, and curved, of a dark yellowish-green colour, and $13 / 4$ to $21 / 2 \mathrm{in}$. long. They are borne in bundles of five and are usually much clustered at the ends of the branches.

The cones are $1 \frac{1}{2}$ to $31 / 2$ in. long, much shorter than those of the limber pine.

The scales are very thick and of a purplish colour. The colour does not fade as readily as in the case of limber pine. The cone does not split and allow the seed to drop out, as with the limber pine, but remains closed and retains the seed for some years.

This tree forms the timberline on the mountains in British Columbia and Alberta, and is generally found in inaccessible places at an altitude of 6,000 to 7,000 ft., on shallow, rocky soils in open, park-like stands.

\section{PINUS RESINOSA, Aiton}

RED PINE

Common names: Red pine, Norway pine*, yellow pine*, Canadian red pine (England).

French names: Pin rouge, pin resineaux, pin de Norvège*.

The red pine is a tree 75 to $125 \mathrm{ft}$. high and 2 to $3 \mathrm{ft}$. in diameter. The trunk is erect and has very little taper, and, when growing in dense stands, is clear for over three-quarters of its length.

The bark, which is intensely reddish-brown in colour, separates into broad, irregular, flaky scales. In contrast with the darker bark of the white pine, with which it is frequently found growing, the trunk has a scraped or rubbed appearance. The bark is thick and resists fire fairly well.

The branches come out in distinct whorls and the crown is round and open. The twigs are red, and stouter than those of the white pine. The roots are widespreading, deep and wind-firm.

The leaves are needle-like, 3 to $6 \mathrm{in}$. long, flexible, flat on one side, and rounded on the other. They are borne two in a bundle and are distinguished from those of the jack pine, the only other pine in Eastern Canada with two leaves in a bundle, by their greater length and the fact that they are not twisted. Seen at a distance the foliage appears to be growing in dark green tufts at the ends of the heavy branches.

The cones are 2 to $2 \frac{1}{2}$ in. long and more or less spherical when open. The scales are thickened at the top and have no prickle.

The red pine is found from Nova Scotia to lake Winnipeg but reaches its best development in Ontario. It grows best on deep, loamy sand or gravel, and on such soil is often found in pure stands. 


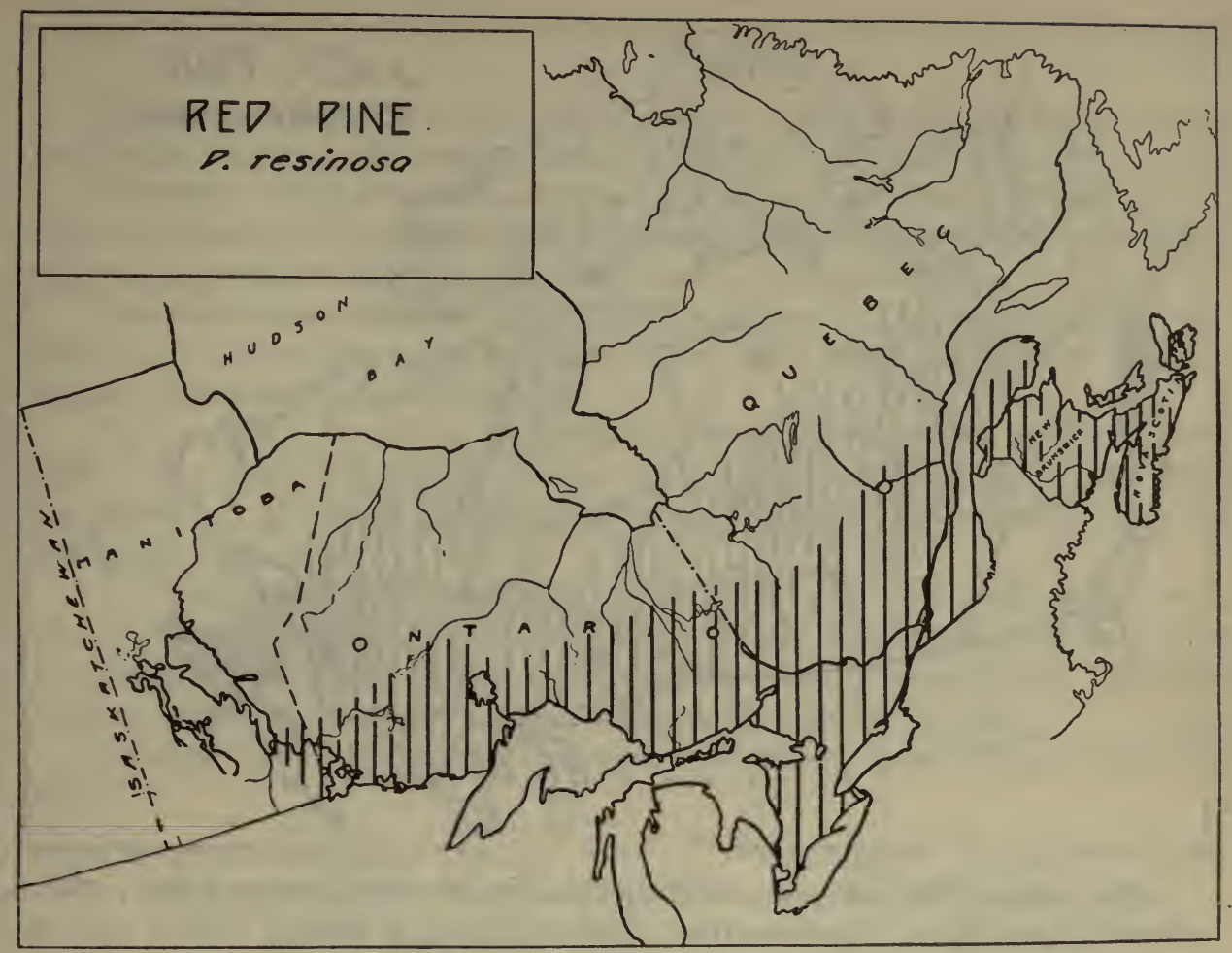

Red pine lumber is not always separated from white pine on the market. The wood is more resinous and darker in colour than white pine, and, being harder and stronger, is more valuable for structural timber.

PINUS BANKSIANA, Lam.

JACK PINE

Common names: Jack pine, Banksian pine, princess pine, grey pine, scrub pine*, cypress* (Quebec and Maritime Provinces), juniper* (Quebec).

French names: Pin gris, pin de Banks, pin chétif, cyprès*, pin des rochers.

The jack pine is found right across Canada from Nova Scotia to the Rocky mountains and the valley of the Mackenzie. It reaches its best development as a timber tree in northern Manitoba, Saskatchewan, and Alberta.

In the open or on unfavourable sites the jack pine is small and scrubby, but when growing in pure dense stands it develops a straight, clear trunk and reaches a height of $60 \mathrm{ft}$. and a diameter of $24 \mathrm{in}$. It grows on very poor soils and is found growing in pure stands on dry, deep, coarse, sandy lands. It is also found growing on bare, rocky situations in scrubby, open stands. In northwestern Alberta the jack pine meets the lodgepole pine (Pinus Murrayana), a tree whicin it closely resembles and which is sometimes difficult to distinguish from it. For a comparison of these two species see Lodgepole Pine. 


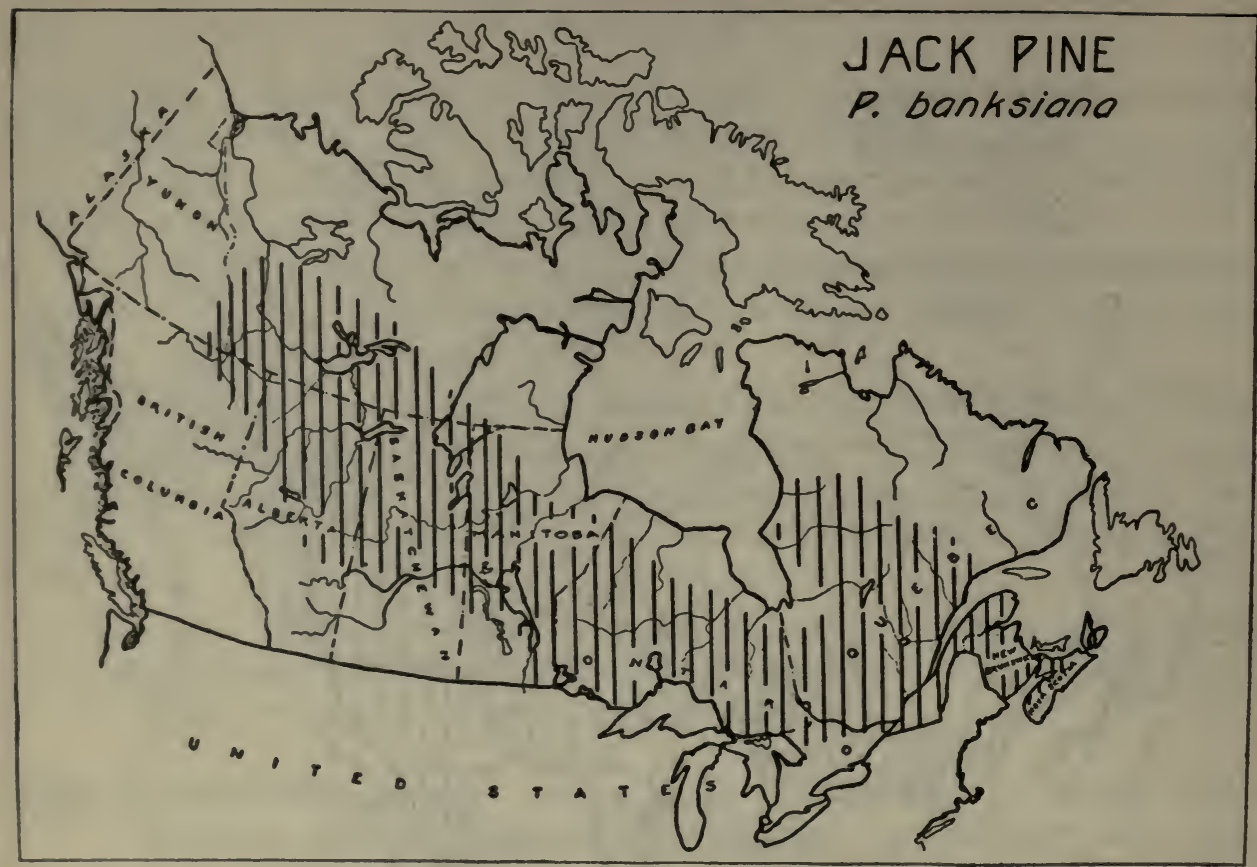

The bark of the jack pine, which is thin, has a reddish-brown colour, with a yellowish tinge in the top of the tree. The inner bark is slightly reddish near the base. It is roughened by narrow, rounded ridges which separate into small, thick plates. The leaves are very short, $1 / 2$ in. to $1 \frac{1}{2}$ in. long, twisted, and in bundles of two. In cross-section they are very flat and in colour are bright yellowish-green.

The cones are from 1 to 2 in. long and are usually found in pairs, one on each side of the twig, curved and pointed towards the tip of the branch. The scales are thickened at the tip but are without a prickle, except on young cones. The cones are persistent and remain on the branches many years.

Jack pine is often considered a tree weed, but its wide distribution and common occurrence in Canada make it a tree of considerable commercial importance. It is used to a large extent for railway ties and fuel and in the manufacture of kraft pulp. The wood is weak, brittle, and perishable, and is usually of small dimensions and knotty, but it is sawn into lumber and used for rough construction work. It is often sold mixed with red pine.

PINUS RIGIDA, Mill.

PITCH PINE

Common names: Pitch pine, scrub pine*, jack pine*, rigid pine.

French name: Pin à feuilles rigides.

Under the most favourable conditions the pitch pine will reach a height of $60 \mathrm{ft}$. and a diameter of $2 \mathrm{ft}$., but usually it is a low tree about $30 \mathrm{ft}$. high and 6 to 8 in. in diameter. The broad, open crown and the many crooked and persistent dead branches give the whole tree a very scraggy appearance. This is our only conifer that possesses the power of sprouting from the stump. 
The bark is reddish-brown in colour and coarse-scaled. On old trees it is thick and deeply furrowed with broad ridges which separate into loose scales.

The twigs, which are stout, remain rough for some time after the leaves drop. They are frequently found sprouting in clusters directly from the bark of the trunk. The roots penetrate deeply into the soil where it is not too heavy.

The leaves are needle-like and in clusters of three. They are 2 to $5 \mathrm{in}$. long, stiff, and somewhat triangular in cross-section. This is the only pine in Eastern Canada with three leaves in a bundle.

The cones are $1 / 2$ to 3 in. long, spherical in shape when open, and without a stalk. The scales are thickened at the tip and have a stiff, curved prickle. The cones are very persistent and dead ones often remain sticking to the branch for five or six years.

The pitch pine has a very limited range in Canada. It barely extends from the Northeastern States across the Canada-United States boundary into New Brunswick, Quebec, and Ontario. It enters the latter province at the Thousand Islands, where it is found growing with the red pine among the rocks.

The only use of this pine in Canada is for firewood, and it has no commercial value.

PINUS PONDEROSA, Dougl.

WESTERN YELLOW PINE

Common names: Western yellow pine, bull pine (British Columbia) yellow pine, British Columbia soft pine, jack pine*.

French name: Pin à bois lourd.

Under particularly favourable conditions the western yellow pine reaches the majestic height of 160 to $170 \mathrm{ft}$., or more, and a diameter of 5 to $6 \mathrm{ft}$. Ordinarily it attains a height of 75 to $80 \mathrm{ft}$. and a diameter of 2 to $2 \frac{1}{2} \mathrm{ft}$. Grown in a dense stand the trunk is straight, clear of branches, and has very little taper.

The bark on old trees is very thick, 3 to $4 \mathrm{in}$., and is broken into plates $3 \mathrm{ft}$. long. The surface of each plate is flat and scaly and of a reddish tinge, while the furrows are deep and dark grey in colour. The bark of young trees is dark and fissured into firm, scaly ridges. On account of its thick bark this tree, except when very young, is rarely damaged by ground fires.

The branches are short, stiff, much branched, and turned up towards the end, giving the tree a very characteristic appearance. Young twigs when broken have a smell similar to that of orange peel.

This pine is peculiar in having leaves in clusters of both three and two leaves. Three is the more common number to find. The leaves are very stout and stiff, and vary in length from 5 to 11 in. They are dark green in colour and grow in heavy, brush-like clusters at the ends of the branches. This is the only pine native to western Canada with three leaves in a bundle.

The cones are $2 \frac{1}{2}$ to $5 \frac{1}{2}$ in. long, and $1 \frac{1}{2}$ to 2 in. in diameter. Their colour, when ripe, is extremely variable and runs from grass-green to dark purple. The scales are tipped with a prickle. When the cone drops a few of the scales at its base are often left sticking to the branch. 
In Canada this tree is found only in the interior of southern British Columbia. It will grow on almost any kind of soil and, owing to its deep tap-root, will thrive in very dry, sandy, and gravelly situations.

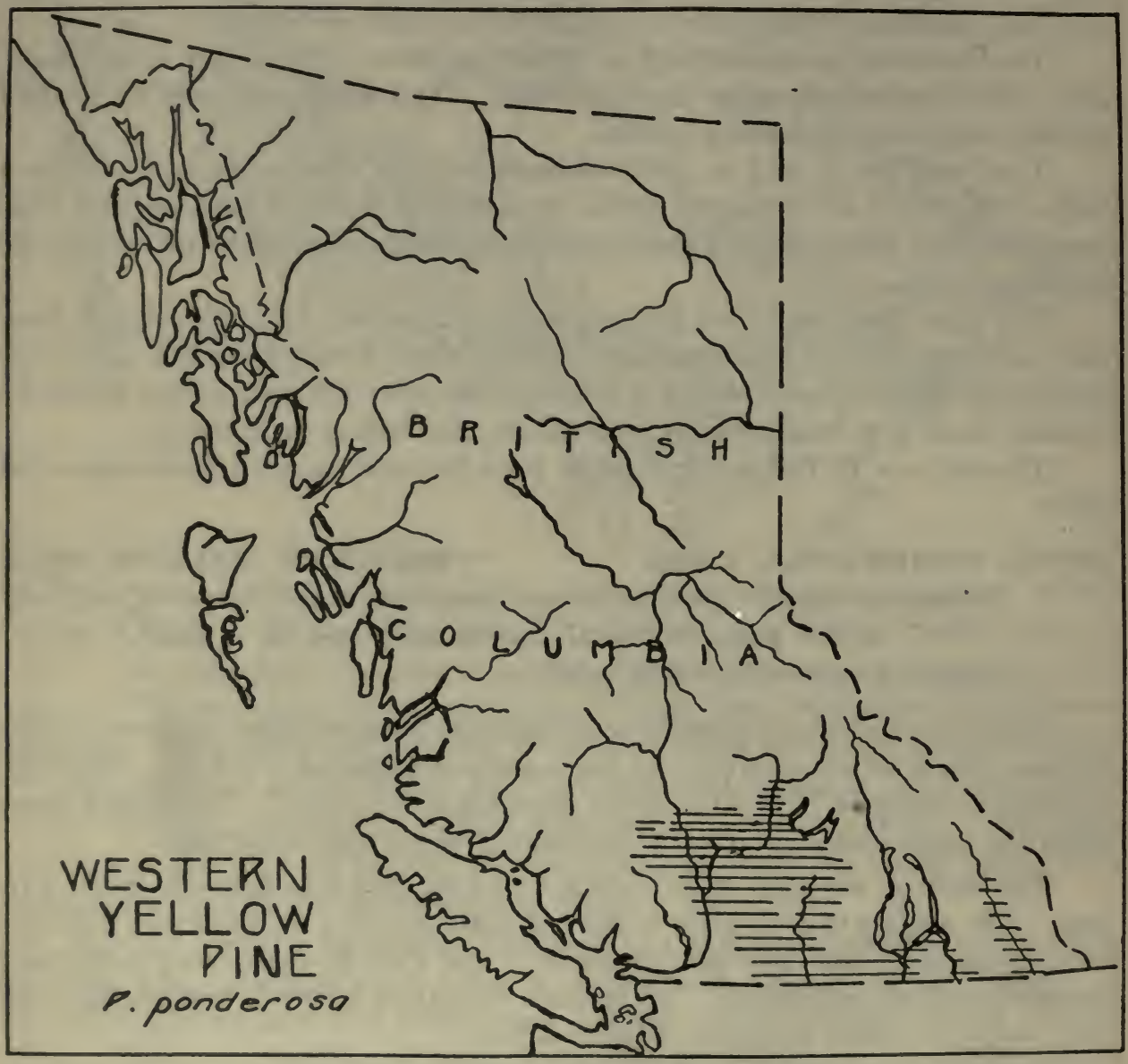

The wood of the western yellow pine is fairly soft and the better grades resemble the wood of white pine (Pinus Strobus).

PINUS MURRAYANA, Balf.

LODGEPOLE PINE

Common names: Lodgepole pine, black pine, scrub pine*, shore pine

(Coast of British Columbia), western jack pine, white pine* (Alberta), cypress* (Southern Alberta and Saskatchewan.)

French name: Pin de Murray.

The lodgepole pine has a very large range, extending over the whole of British Columbia and into the Yukon territory on the north and the western part of Alberta on the east; and is extremely variable in its characteristics. In the western part 
of its range, near the Pacific coast, the tree is ordinarily 20 to $40 \mathrm{ft}$. high and 6 to $20 \mathrm{in}$. in diameter, while farther east it is 50 to $100 \mathrm{ft}$. high and has a diameter of 12 to 24 in: The eastern variety, usually growing in dense stands, develops a tall, clean, slender trunk. The coast trees are shorter and have branches extending all the way down the stem. The thickness of the bark is another variable feature. Throughout its western range it is 1 in. thick, reddish-brown, and deeply furrowed. In Alberta and throughout the eastern part of its range the bark is thinner, greyishbrown in colour, and comparatively smooth.

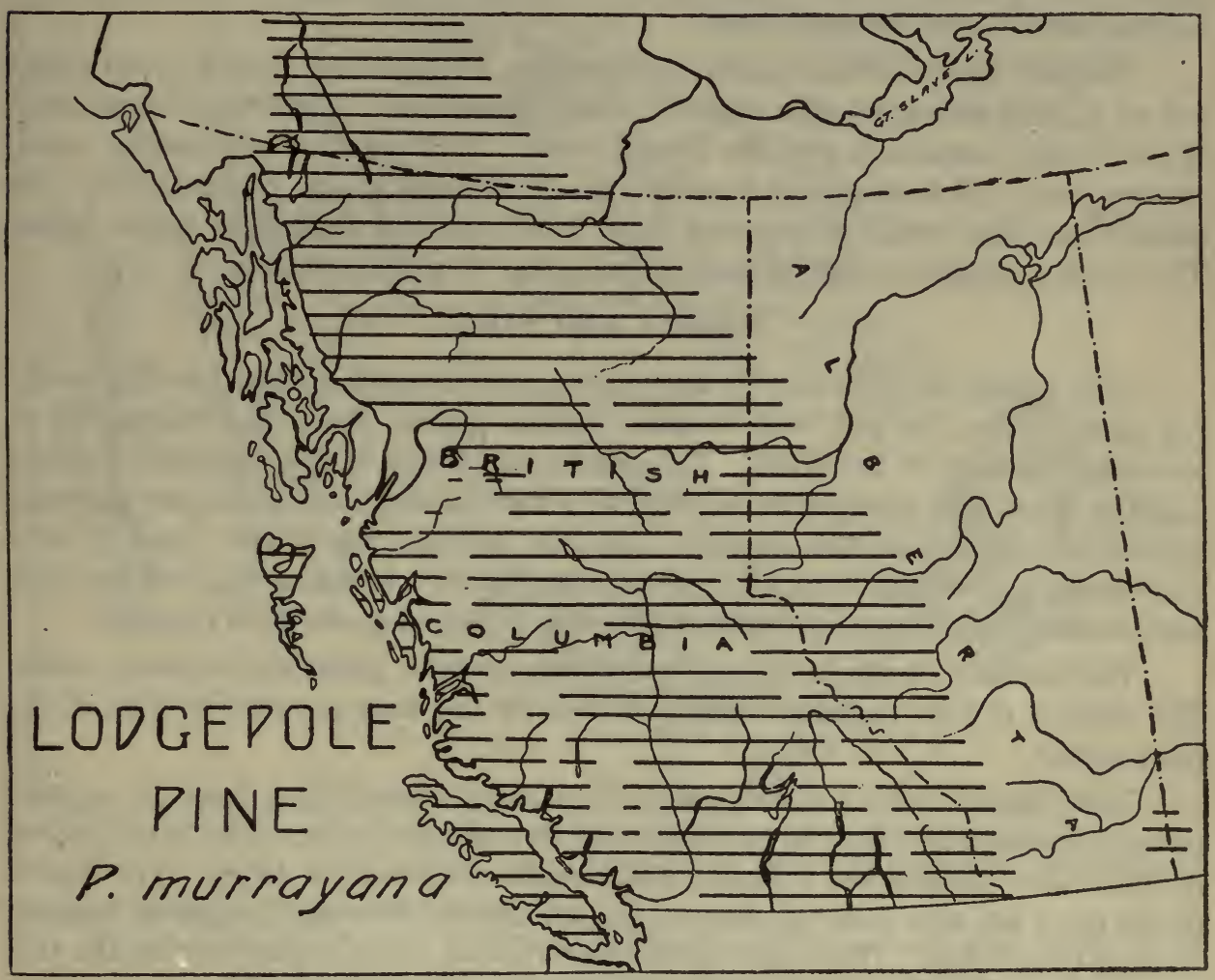

Its leaves, which are borne two in a bundle, are $1 / 2$ to 1 in. long on the coast, and 2 to $3 \mathrm{in}$. long in its eastern range. The leaves on the eastern trees are thicker than those of the coast.

The cones are of a shiny-brown colour and the scales are tipped with a prickle. On the coast they are $3 / 4$ to $1 \frac{1}{4} \mathrm{in}$. long and farther east 1 to $2 \mathrm{in.} \mathrm{long.} \mathrm{Like} \mathrm{those}$ of the jack pine (Pinus Banksiana), open or closed, they adhere to the branches for a great many years after maturing. Like the jack pine, the lodgepole pine produces cones at the early age of 7 to 10 years.

In northwestern Alberta, in the region about Lesser Slave lake, this species meets the jack pine (Pinus Banksiana), which it closely resembles, and these two 
trees are sometimes difficult to distinguish. The bark of the lodgepole pine, however, is as a rule thinner, darker, and broken into finer scales than that of the jack pine. The foliage, too, is darker than that of the jack pine, and the leaves have the appearance of being more bunched towards the ends of the twigs in plumelike clusters. The leaves of the jack pine are more scattered along the twigs and slightly more twisted. The cones of the lodgepole pine are, as a rule, a little more slender than those of the jack pine. They are also more roughened by knobs and have a prickle at the tip of the scale, which is ordinarily absent in the mature jack pine cone. The cones on both trees are curved; those of the jack pine slightly more so than those of the lodgepole pine.

This tree grows best on sandy, moist slopes, and plateaus, but is found growing on a great variety of soils from dry gravel to swamps. This is the "jack pine" of the Rocky mountains and the Pacific coast. It is used for mine props, poles, railway ties, and fencing, and is sawn into lumber for rough construction. Its earliest use, from which its common name is derived, was for Indian teepee poles. The wood is similar to that of eastern jack pine (Pinus Banksiana).

\section{THE LARCHES}

Nine species of larch (Larix) are known, most of them confined to the northern parts of the Old and New Worlds. Three species occur in Canada two of which are confined to the West. The only species found in the East also extends into the West, and, along with the black and the white spruces, forms the northern limit of tree growth in this country. A new species, the Alaska larch (Larix alaskensis), has recently been discovered in the North. It has as yet been but very little studied but it is possible that it may also be found in northern Canada.

The larches as a whole are tall trees, with straight, gradually tapering stems. The wood is of high technical value and used for the same purposes as that of the hard pines.

They can be readily distinguished from other cone-bearing trees on account of their leaves being borne in brush-like clusters of from twelve to forty at the end of short spur-like growths or knobs which stand out from the twigs. The leaves of the pines are also borne in clusters, but are always done up in separate bundles of from two to five. The leaves of the larches drop off each year leaving the tree bare during the winter. No other native cone-bearing trees do this.

LARIX LARICINA (Du Roi) Koch

TAMARACK

Common names: Tamarack, larch, hackmatack (Maritime Provinces), American larch, juniper* (Maritime Provinces), black larch.

French names: Tamarac, mélèze d'Amérique, épinette rouge*.

The tamarack is a tree 60 to $70 \mathrm{ft}$. high and 1 to $2 \mathrm{ft}$. in diameter. The trunk is straight and cylindrical. On young trees or those growing in dense stands the crown is narrow, but as the tree becomes older the crown opens up and becomes irregular. With slight crowding the trunk clears itself quickly of branches. 
The bark is roughened by small, roundish, flat scales of reddish colour which flake off abundantly.

The twigs are slender and pliable and in winter covered with knobby buds. They are from yellowish- to reddish-brown in colour.

The leaves, needle-like and $3 / 4$ to $1 \frac{1}{4}$ in. long, are somewhat triangular in cross-section and grow in clusters of from twelve to twenty on short, spur-like growths or knobs on the twig. They drop off every fall and leave the tree bare in winter, as is the case with all the larches.

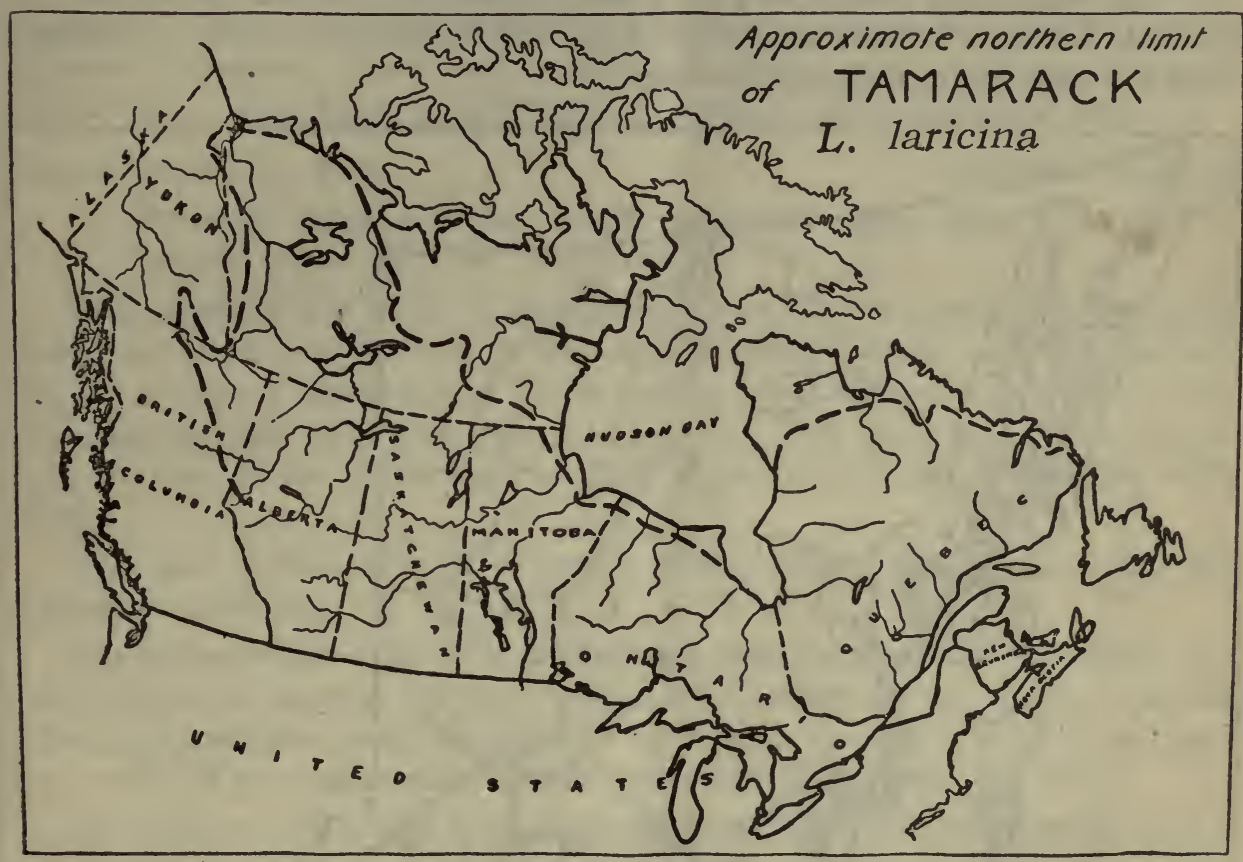

The cones are small, rarely more than $1 / 2 \mathrm{in}$. long, stalked, and composed of about twenty chestnut-brown scales.

This tree is found from Labrador to the Rocky mountains and north to the mouth of the Mackenzie river, where, along with the black spruce, it is found at the northern limit of tree growth. In the southern part of its range it is confined chiefly to bogs and swamps and there associates with black ash and balsam fir. In the north it is found in better-drained situations, such as slopes of rivers and streams.

For strength and durability the wood of the tamarack is surpassed in Canada only by that of Douglas fir, which it closely resembles. Its use for shipbuilding was extensive in past years but the supply of suitable material for this purpose is now very limited. The wood is valued for pumps, tanks, and cisterns, for building construction, and vehicle supplies. It is highly valued for ties on account of its strength and hardness, and for poles on account of its tapering form. 
LARIX OCCIDENTALIS, Nutt.

WESTERN LARCH

Common names: Western larch, larch, western tamarack, tamarack.

French name: Mélèze occidental.

The western larch is a large and symmetrical tree 100 to $180 \mathrm{ft}$. high and 3 to $4 \mathrm{ft}$. in diameter. The trunk is very long and clear, and the crown is very small and narrow when growing in crowded stands.

The bark on old trees is very thick and a splendid protection against fire. It is deeply furrowed to form large ridges and is reddish-brown in colour. On young trees it is thin, scaly, and greyish-brown.

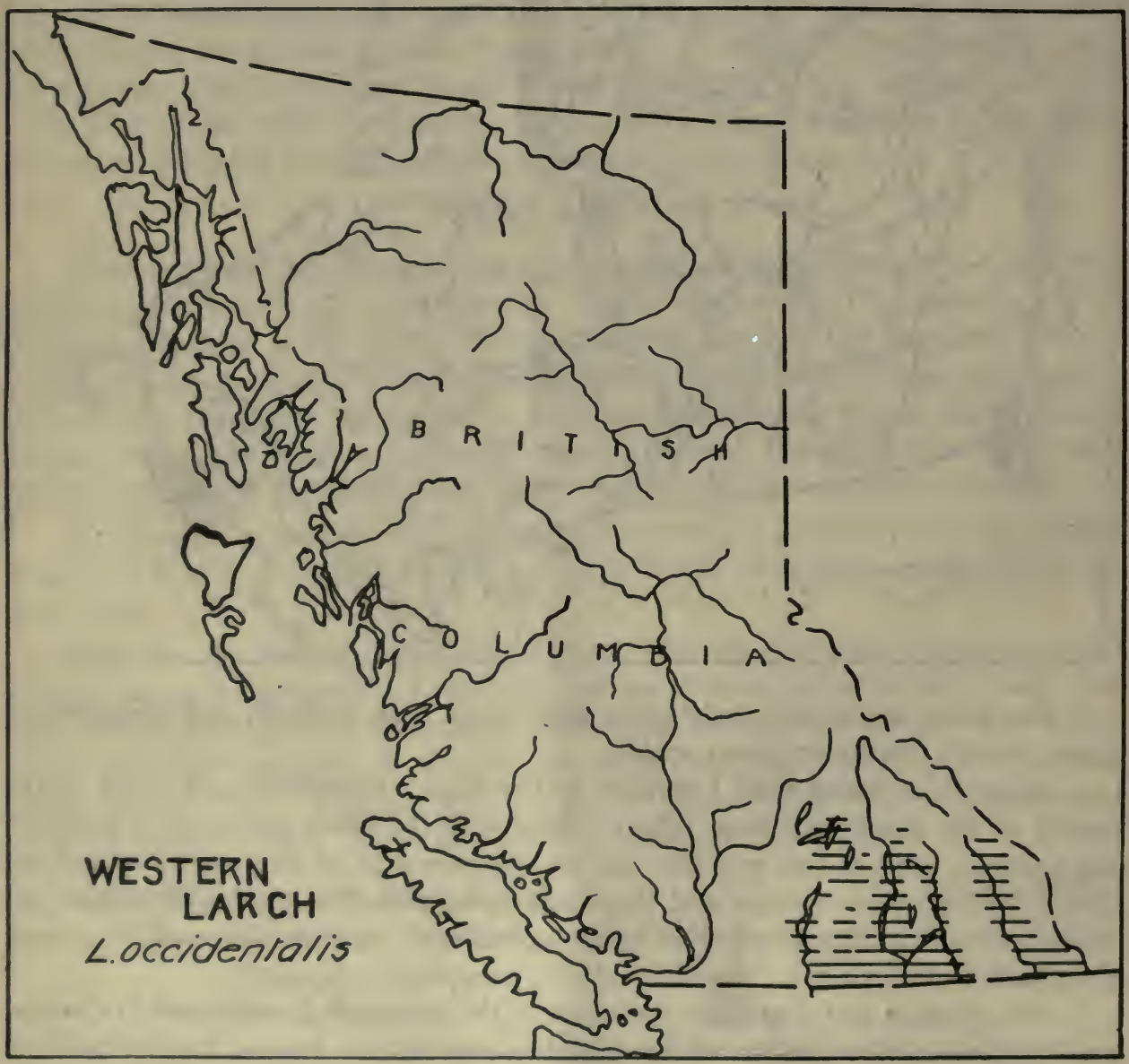

The leaves are 1 to $2 \mathrm{in}$. long, triangular in cross-section and a pale yellowishgreen colour. They grow in clusters of fourteen to thirty at the ends of little spurs along the twigs. They all drop off in the fall as do those of the other larches.

The twigs are brittle and somewhat downy. 
The cones are 1 to $1 \frac{1}{2}$ in. long, stalked, and the scales densely coated with down. The pointed bracts, which are attached to the underside of the scale, project beyond the margin and are bent backwards.

This tree in Canada is found only in southeastern British Columbia. It makes its best growth on heavy, deep soils where there is an abundance of moisture. Sometimes it is found in pure stands but often mixed with lodgepole pine and Douglas fir.

The wood of the western larch is similar to that of the eastern species. As it is possible to obtain material in large dimensions the wood is used extensively for structural purposes. Sawn into lumber it is used for shipbuilding and house construction. 'Ties, poles, and piles are also among its more important uses.

\section{LARIX LYALLII, Parl.}

ALPINE LARCH

\section{Common names: Alpine larch, mountain larch, Lyall's larch.} French name: Mélèze de Lyall.

The alpine larch is 30 to $40 \mathrm{ft}$. high and 1 to $2 \mathrm{ft}$. in diameter. : The trunk tapers very much from the base to the top and is very branchy, and in general the tree has a stunted appearance. The branches, which extend widely and usually turn up at the end, form a very irregular crown. They are tough and not brittle as in the case of the western larch. New shoots are covered with a fine white down.

The bark is thin, even in old trees, reddish-brown, and furrowed into flat ridges of loose scales.

The leaves, which drop off in the fall and leave the tree bare, are needle-like, 1 to $1 \frac{1}{2}$ in. long, more or less four-sided in cross-section and are borne in clusters of thirty or more on a spur-like growth. A cross-section of a leaf shows one resin duct in each of two angles while that of the western larch shows only one.

The cones are $1 \frac{1}{2}$ to $2 \mathrm{in}$. long, somewhat larger than those of the western larch, and are reddish-purple in colour. The scales have a fringe of white hair on their margin. The pointed bract attached to the underside of the scales projects out much beyond them and is then bent back. These bracts are not seen in the tamarack, and in the western larch they are as a rule only slightly bent.

The alpine larch is strictly a tree of the mountains and forms the upper timberline in British Columbia and Alberta. Usually it is found at an elevation of 6,500 to $7,000 \mathrm{ft}$. on open, grassy slopes associated with the limber and white-barked pines.

The wood is used locally only.

\section{THE SPRUCES}

The spruces (Picea) are widely spread throughout the northern hemisphere. Eighteen species are recognized of which seven occur in North America and five in Canada. Two of the native spruces are confined to the West and one to the East. The other two species are to be found from the Atlantic westward and northward to the mouth of the Mackenzie river on the Arctic ocean. 
The spruces can be readily distinguished from all other evergreens by their leaves which are sharp-pointed and, with two exceptions, four-sided in cross-section. They are single and stemless, and each is borne on a tiny projection on the bark of the twig. In arrangement they are not distinctly two-ranked, as is the rule with the hemlocks and firs, but either bristle out from all sides or, on horizontal branches, are twisted and crowded densely towards the upper side of the twig.

The Norway spruce (Picea excelsa), a native of Europe, is extensively planted on this continent for ornamental purposes. It can be readily distinguished from our native spruces by its twigs and small branches, which have a decided tendency to droop, and by its cones, which are considerably longer -4 to 5 in.

The wood of the different species is very similar. It resembles that of the soft pines, but is lighter in colour, less durable, has a finer grain and is tasteless and non-resinous. Generally speaking the main uses of the spruces are for lumber, dimension timber, and pulp.

PICEA MARIANA (Mill.) B. S. P. BLACK SPRUCE

Common names: Black spruce, red spruce*, double spruce, water spruce, swamp spruce.

French names: Epinette noire, épinette jaune, épinette bâtarde, épinette rouge*, sapinette noire (France), sapin noir.

The height of the black spruce is about 35 to $40 \mathrm{ft}$. and the diameter from 6 to 9 in. At the extreme north of its range it is dwarfed to a mere shrub.

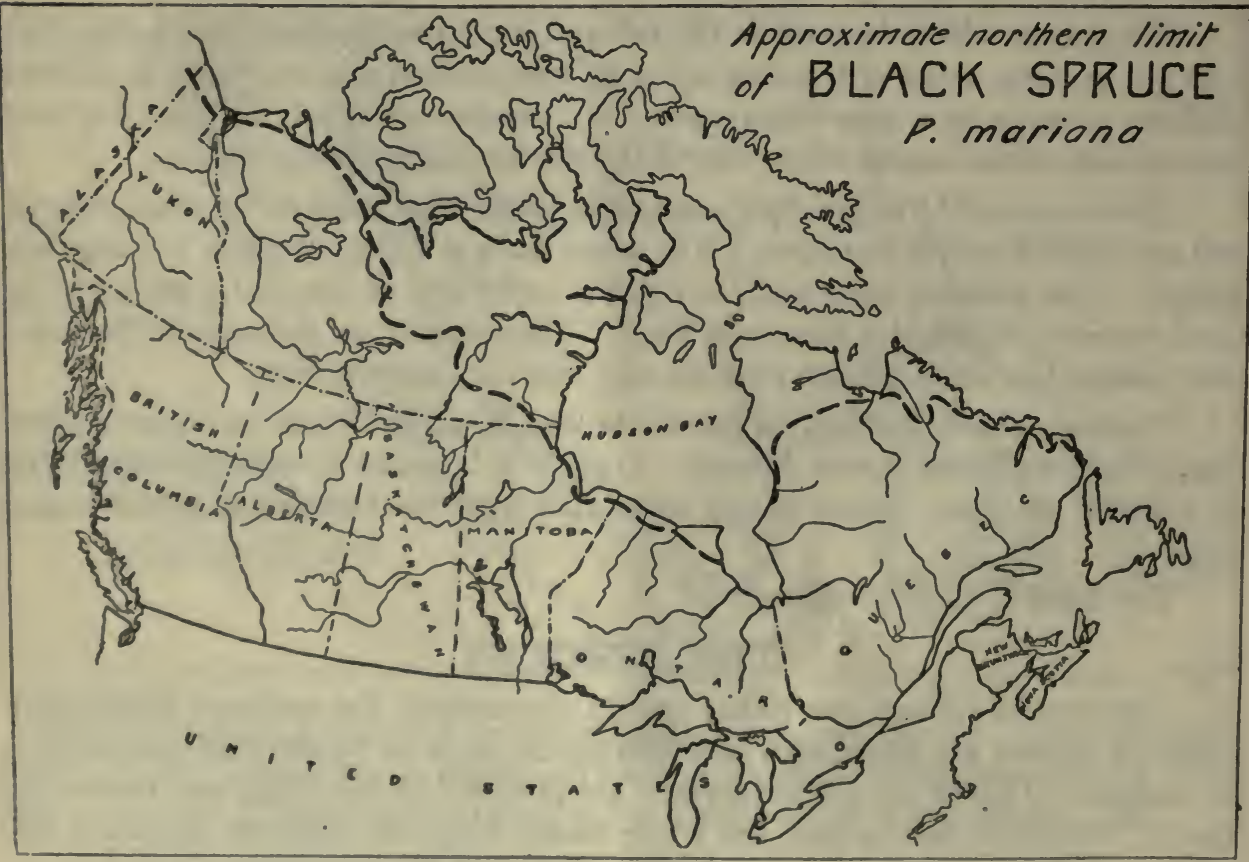


Young trees have a beautiful, regular, and symmetrical outline but on old trees the slender, drooping branches, with upturned ends, form a narrow, open, irregular, and unsightly crown.

The bark is thin, greyish-brown, and scaly. The inner bark has a reddish tinge. The end twigs are slightly coated with rusty-coloured hair.

The leaves are $1 / 4$ to $3 / 4$ in. long and without stalks. They are blunt-pointed and four-angled in cross-section. Their colour is bluish-green.

The cones are $1 / 2$ to $1 \frac{1}{2}$ in. long, and spherical in shape when open. The scales are stiff and will break if crushed. The scales are toothed on the margin, while those of the white spruce and red spruce are not. The stem of the cones is slightly curved and the cones are bent forward. Cones are not confined to the upper portion of the tree as with the red and white spruces. They remain on the trees several years after the seed has been shed.

This tree ranges right across the continent from Labrador and the Maritime Provinces to Alaska and the mouth of the Mackenzie river. It is one of the most northerly-growing trees. In the East it is confined for the most part to swamps and undrained places. In the North it is found in well-drained valleys and on stony slopes. It reaches its best development in Saskatchewan and Manitoba. It is associated chiefly with tamarack and aspen.

Owing to the comparatively small size attained by this tree, its wood is of less value, commercially, than that of either the white spruce or red spruce. As a rule its slower growth produces stronger and more durable wood of finer grain, and on this account it is preferred to the other species for mining timbers, ties, and cooperage. It is usually mixed with the other two eastern species when sawn into lumber or sold as pulpwood.

\section{PICEA RUBRA (Du Roi) Dietr.}

RED SPRUCE

\section{Common names: Red spruce, yellow spruce.} French name: Epinette rouge.

The red spruce is a tree 50 to $75 \mathrm{ft}$. high and 1 to $2 \mathrm{ft}$. in diameter. The trunk is very straight but, unless grown in a dense stand, very branchy. The crown is conical and narrow. The branches extend out at right angles to the trunk, the lower ones drooping slightly. The new twigs are reddish-brown and slightly hairy. The root-system is shallow and spreading, and the tree is, therefore, frequently overthrown by winds.

The bark is extremely thin and easily damaged by fire. It is reddish-brown in colour, covered with tight scales of irregular shape.

The leaves are $1 / 2 \mathrm{in}$. long, four-sided and pointed. They are straight or curved and, like all spruces, are without stalks. Their colour is yellowish-green.

The cones are $1 \frac{1}{4}$ to $2 \mathrm{in}$. long, oval, and oblong. They are stiff and very harsh to the touch when dry. They do not remain hanging on the tree as with the black spruce, but drop off during the first winter.

The range of this tree in Canada is not wide. It is confined to Nova Scotia, New Brunswick, and the eastern part of Quebec. It grows on a variety of soils 
but develops best in well-drained, moist valleys. It forms pure stands but is often found mixed with balsam fir, hemlock, white birch, yellow birch, and sugar maple.

On account of its fine grain and texture, and its distinct reddish tinge, the wood of this species is often preferred to that of the other spruces, especially for interior

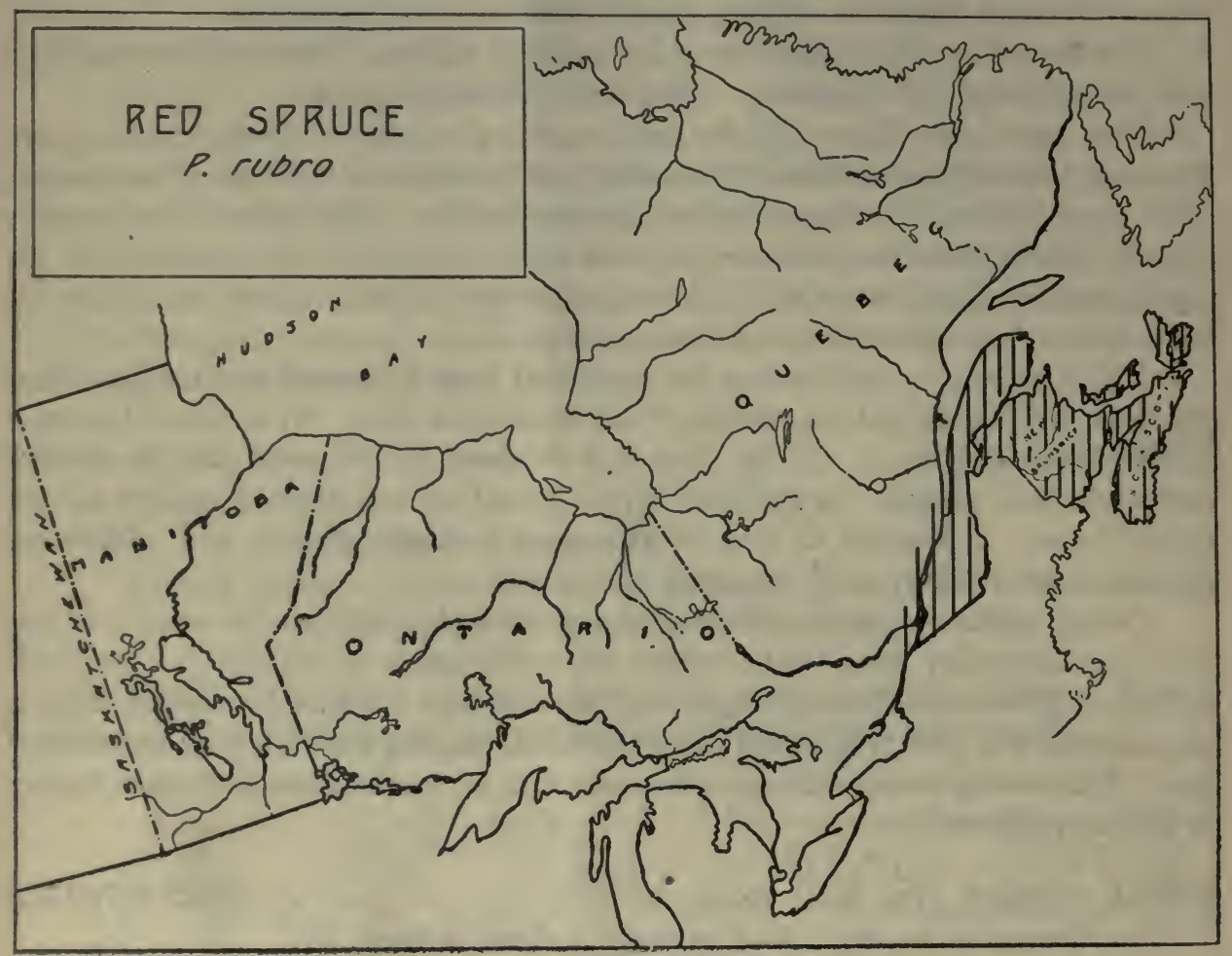

finish. The wood is stronger and more durable than white spruce, but is not always separated from the other species when sawn into lumber. It is a valuable pulp species and is used as lumber much in the same way as white and black spruce.

PICEA CANADENSIS (Mill.) B. S. P. WHITE SPRUCE

Common names: White spruce, single spruce, skunk spruce, northern spruce (Labrador), pine* (Hudson Bay), cat spruce (Nova Scotia).

French names: Epinette blanche, épinette grise, épinette à bière, sapinette blanche (France), sapin blanc.

In favourable situations the white spruce reaches a height of $100 \mathrm{ft}$. and a diameter of $4 \mathrm{ft}$. The average height is much less, however, being about $50 \mathrm{ft}$. with a diameter of $11 / 2$ to $2 \mathrm{ft}$.

The trunk is often branchy, and the crown is deep except in very dense stands. The crown is also very symmetrical and narrow and at a distance has a very spirelike appearance. It is very shallow-rooted. 
The bark is thin and smooth, becoming flaky, with small ashy-brown scales. On account of its thin bark it is very susceptible to fire damage.

The leaves are $1 / 3$ to $3 / 4$ in. long and four-sided in cross-section. They are sharp-pointed, pale blue-green in colour, and give out a very characteristic skunklike, pungent odour when crushed. They come out from all sides of the twig, but are twisted and crowded to the upper side. As with all spruces, the leaves are without stalks, but are borne on little spur-like projections of the twig.

The cones are $11 / 2$ to $2 \mathrm{in.} \mathrm{long.} \mathrm{The} \mathrm{scales} \mathrm{are} \mathrm{narrow} \mathrm{in} \mathrm{proportion} \mathrm{to} \mathrm{their}$ length and very flexible and elastic. If a cone is crushed in the hand it will regain

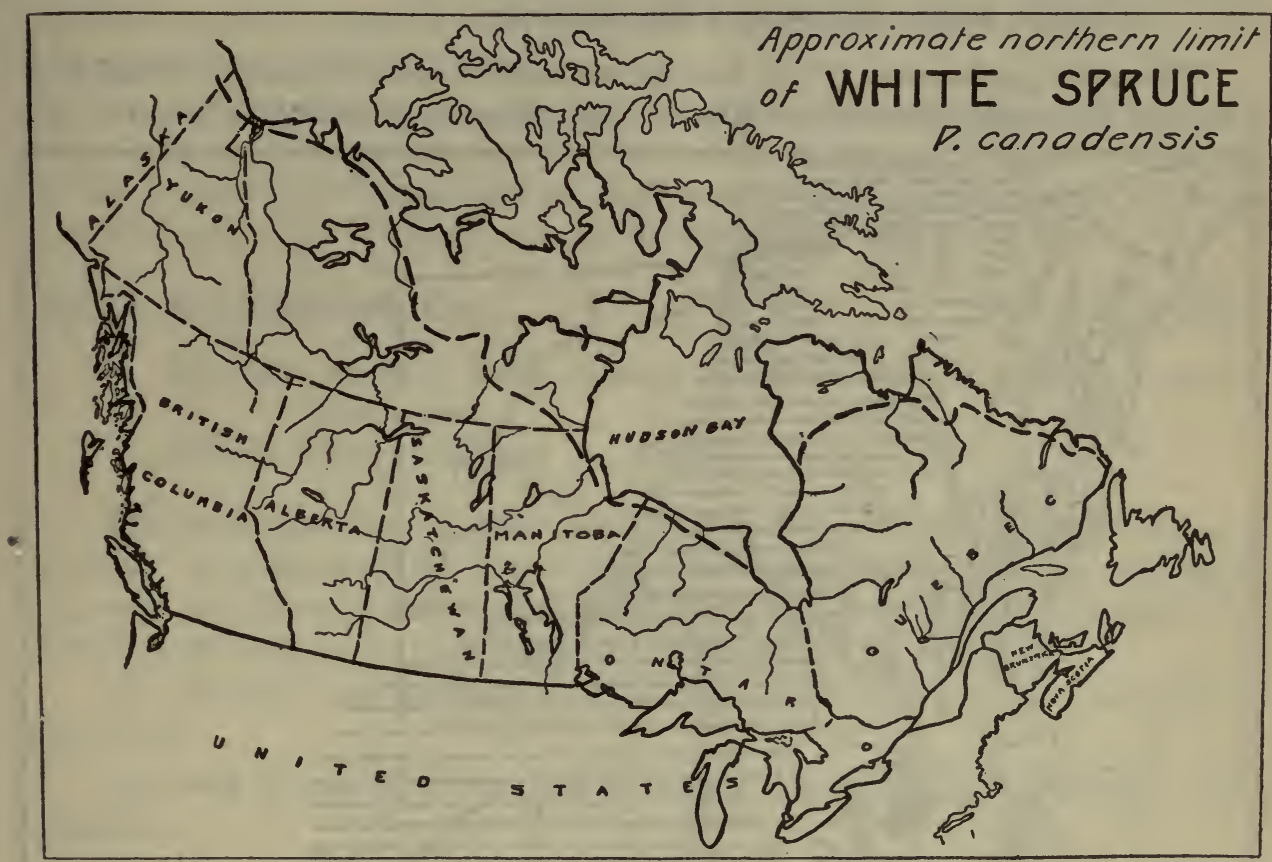

its shape when released and not break as with the black spruce. The cone scales are smooth on the margin and not ragged as those of the black spruce. The cones do not remain long on the tree after the seed has fallen out of them but drop off before the new crop of cones is produced.

The white spruce extends across Canada from Labrador to Alaska. It occurs west of the Rocky mountains in British Columbia and the Yukon but does not reach the Pacific coast.

It grows best on well-drained, moist, gravelly soil, but is not very exacting for it is found on rocky slopes and borders of lakes and streams. It frequently occurs in pure stands, but is often mixed with red and black spruce, tamarack, birch, and aspen, and, in the foot-hills of Alberta, with Engelmann spruce.

White spruce is the most important commercial tree in Canada, heading the list in the production of both lumber and pulpwood. Owing to the wide distribution and abundance of the tree its lumber is gradually taking the place of pine, for 
which it is a good substitute. White spruce has been claimed as the best pulpwood obtainable in North America, on account of its long, tough, colourless fibre, and its comparative freedom from resin. The wood is also used extensively for cooperage, mine-props, ties, poles, posts, and rails and has always been a favourite material for masts and spars of all kinds of vessels.

PICEA ENGELMANNI, Engelm. ENGELMANN SPRUCE

Common names: Engelmann spruce, mountain spruce, Rocky Mountain spruce, western white spruce.

French name: Epinette d'Engelmann.

The average diameter of the Engelmann spruce, when mature, is about 2 or $3 \mathrm{ft}$. and the height about 80 or $100 \mathrm{ft}$. The crown is symmetrical, narrow, and

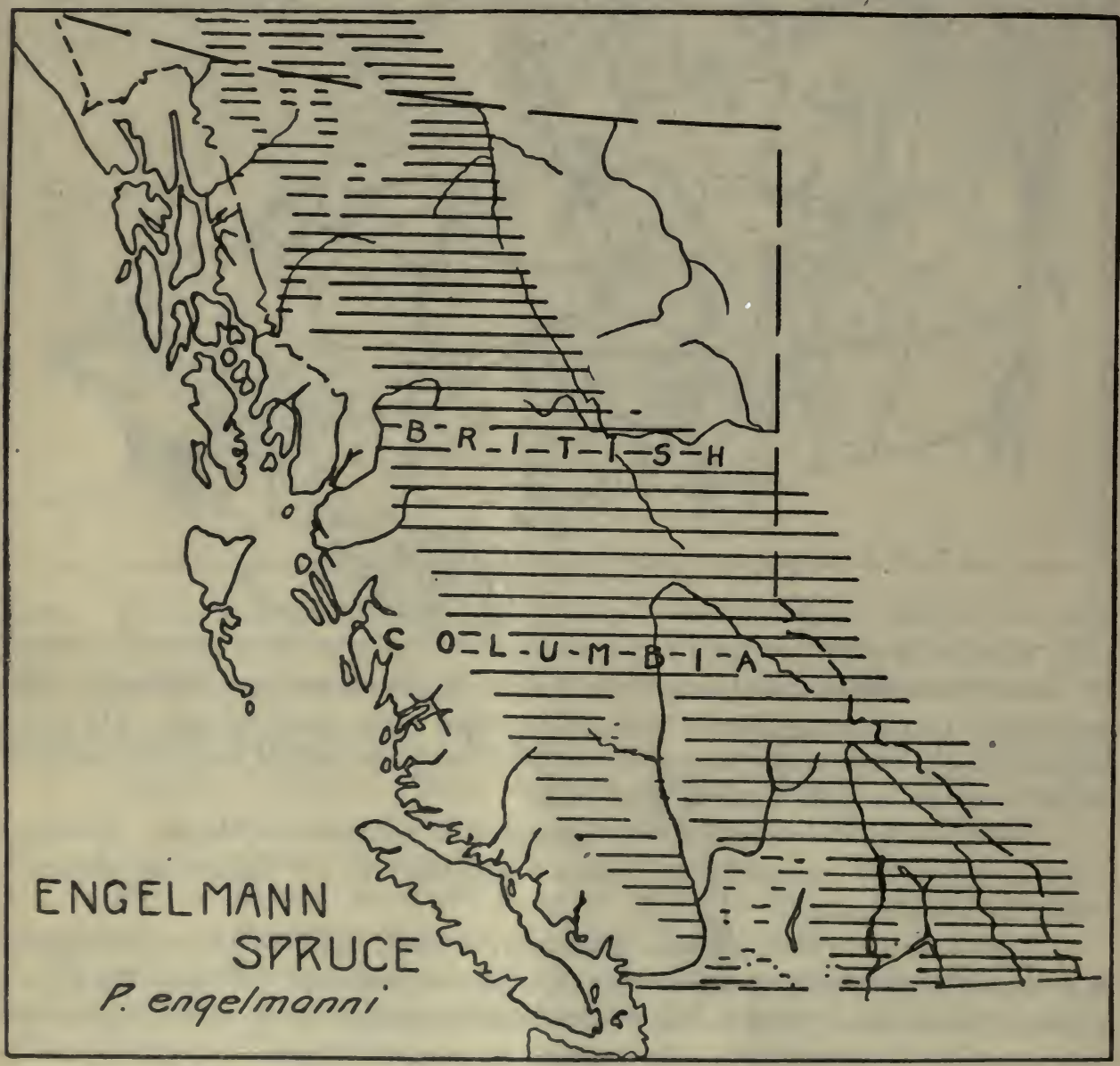

spire-like and, except in very dense stands, extends nearly to the ground. The lower branches are often drooping. The roots are shallow and wide-spreading and, therefore, the tree is very subject to windfall. The bark is thin, brown, and scaly. 
The leaves are about $1 \mathrm{in.} \mathrm{long} \mathrm{and} \mathrm{have} \mathrm{short,} \mathrm{flat} \mathrm{points.} \mathrm{They} \mathrm{are} \mathrm{crowded}$ and curved to the upper side of the twig but are flexible and soft to the touch. When crushed they have a disagreeable odour. The colour is more or less blue. Branchlets are minutely hairy.

The cones are 1 to 3 in. long, green at maturity but later turning brown. The ends of the scales are squarish but sometimes pointed and notched.

This tree is found in Yukon territory, British Columbia, and the foot-hills of Alberta. It will grow on almost any kind of soil, providing there is sufficient moisture. It rarely forms pure stands, and its great shade-enduring qualities enable it to thrive amongst other trees. In Alberta it is largely found mixed with white spruce and lodgepole pine.

The wood of this tree, usually sold as mountain spruce, competes with that of white spruce (Picea canadensis) in the Prairie Provinces. The two woods are similar in quality but Engelmann spruce is usually obtainable in greater dimensions free from defect. It is a common mine timber in the Rocky mountains.

PICEA SITCHENSIS, Carr.

SITKA SPRUCE

Common names: Sitka spruce, Menzies spruce, tideland spruce, coast spruce.

French name: Epinette de Sitka.

The Sitka spruce is 80 to $125 \mathrm{ft}$. high and 3 to $5 \mathrm{ft}$. in diameter. It is the largest and most imposing of all the spruces, and the only one found in the region in which it grows. In dense stands it produces a long, clear trunk with a rather swollen base, but growing in the open it retains its limbs right to the ground.

The branches are horizontal, frequently with many slender, hanging side branchlets.

The bark is reddish-brown and extremely thin. It peels off in large, thin, flat scales.

- The leaves are stiff, thick, sharp-pointed, and four-angled in cross-section. They bristle out all around the twig. New twigs are smooth and yellowish-browri.

The cones are $2 \frac{1}{2}$ to 4 in. long, oval and short-stalked, and hang downwards. Their colour varies from green to dark red when mature. The scales are thin and papery.

This tree grows along the full length of the British Columbia coast southward from Alaska. It is confined chiefly to the country between the coast and the western slope of the Coast range. It occurs mostly along the courses of streams and on alluvial and sandy flat lands along the coast. Most of it is found below the elevation of 400 feet and it rarely goes higher than 3,000 feet, except (contrary to the general rule) in the northern part of its range, where it follows up the stream beds. In the north it is found in pure stands, but it associates a great deal with the western hemlock.

Sitka spruce lumber can be obtained in greater dimensions, clear of defect, $22510-3$ 
than that of any other native spruce. It is valued on this account for structural purposes and for masts and spars of large vessels. Generally speaking, its uses are similar to those of the other spruces. It is an important pulpwood and is used

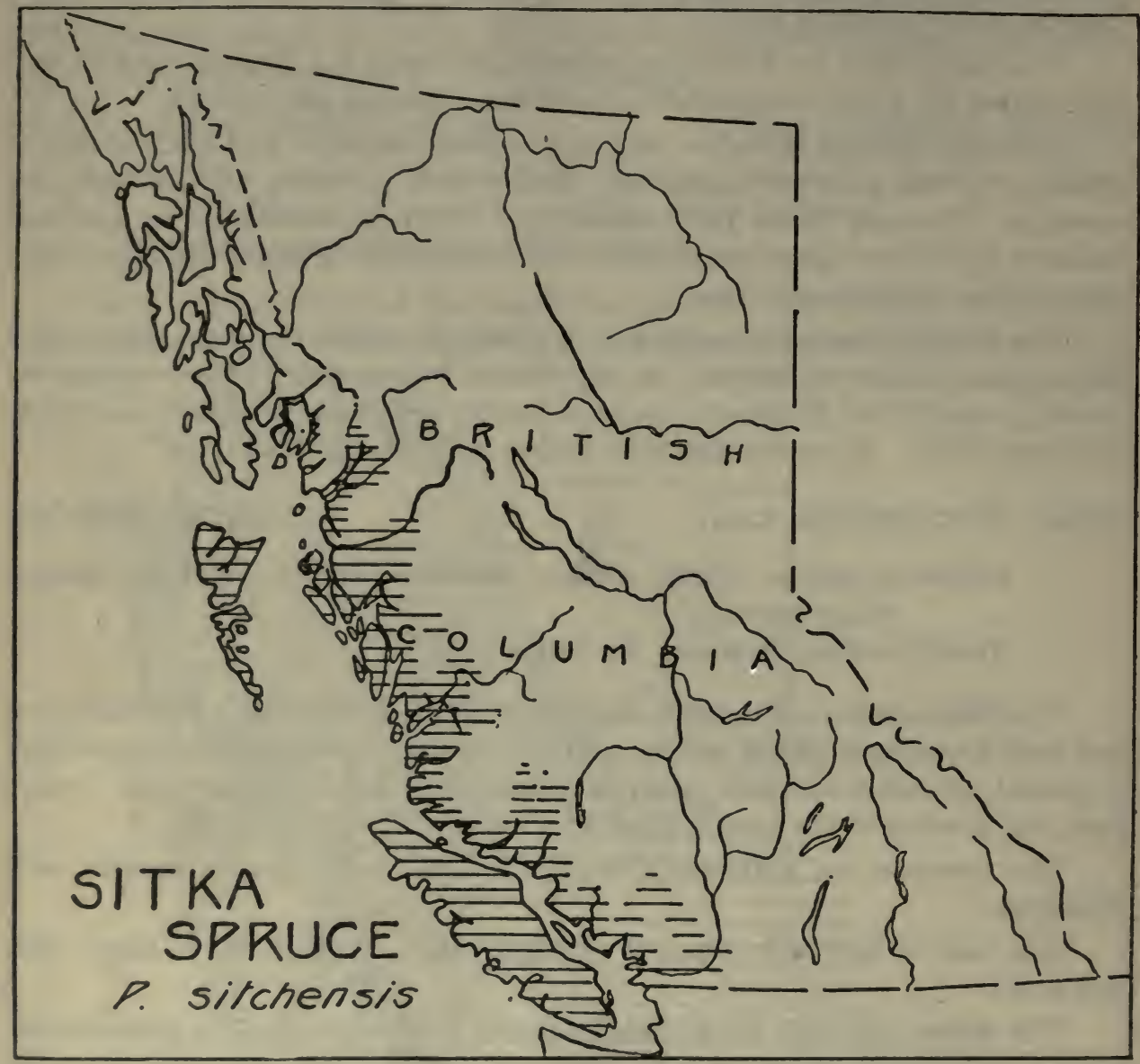

for organ pipes and sounding-boards. Its use for aeroplane frames is a recent development.

\section{THE HEMLOCKS}

Seven species of hemlock (Tsuga) are known. Four are found in North America of which three occur in Canada. Two of the native species are found in British Columbia and one in the eastern provinces. The other species are found in eastern Asia and Japan, where they are used considerably for decorative planting.

The hemlocks can be readily recognized from our other evergreens by their leaves. These leaves resemble those of the firs (Abies) in their two-ranked, or feather-like arrangement on the twig, but differ from them in that each leaf has a distinct, tiny, thread-like stem which is attached to a small projection on the bark of the twig. The species can be distinguished from each other by their leaves and cones. 
TSUGA CANADENSIS (L.) Carr.

HEMLOCK

Common names: Hemlock, eastern hemlock, Canadian hemlock, hemlock spruce* (England), white hemlock.

French names: Pruche, pérusse (France), tsuga du Canada, sapin du Canada*.

The hemlock averages $11 / 2$ to $2 \mathrm{ft}$. in diameter and 50 to $70 \mathrm{ft}$. in height. The trunk is usually straight but tapered much from the base upwards. In the open the tree is very branchy but in dense stands it has a small, short crown. Its. branchlets are very slender and flexible, and are roughened by the raised projections left by the dropped leaves. The roots are very shallow and spreading.

The bark is reddish-brown in colour and roughened with shallow furrows and narrow, scaly ridges.

The leaves are flat, blunt, $1 / 2$ in. long, dark green on the upper side with pale lines beneath. They are distinctly stalked and each is attached to a small pro-

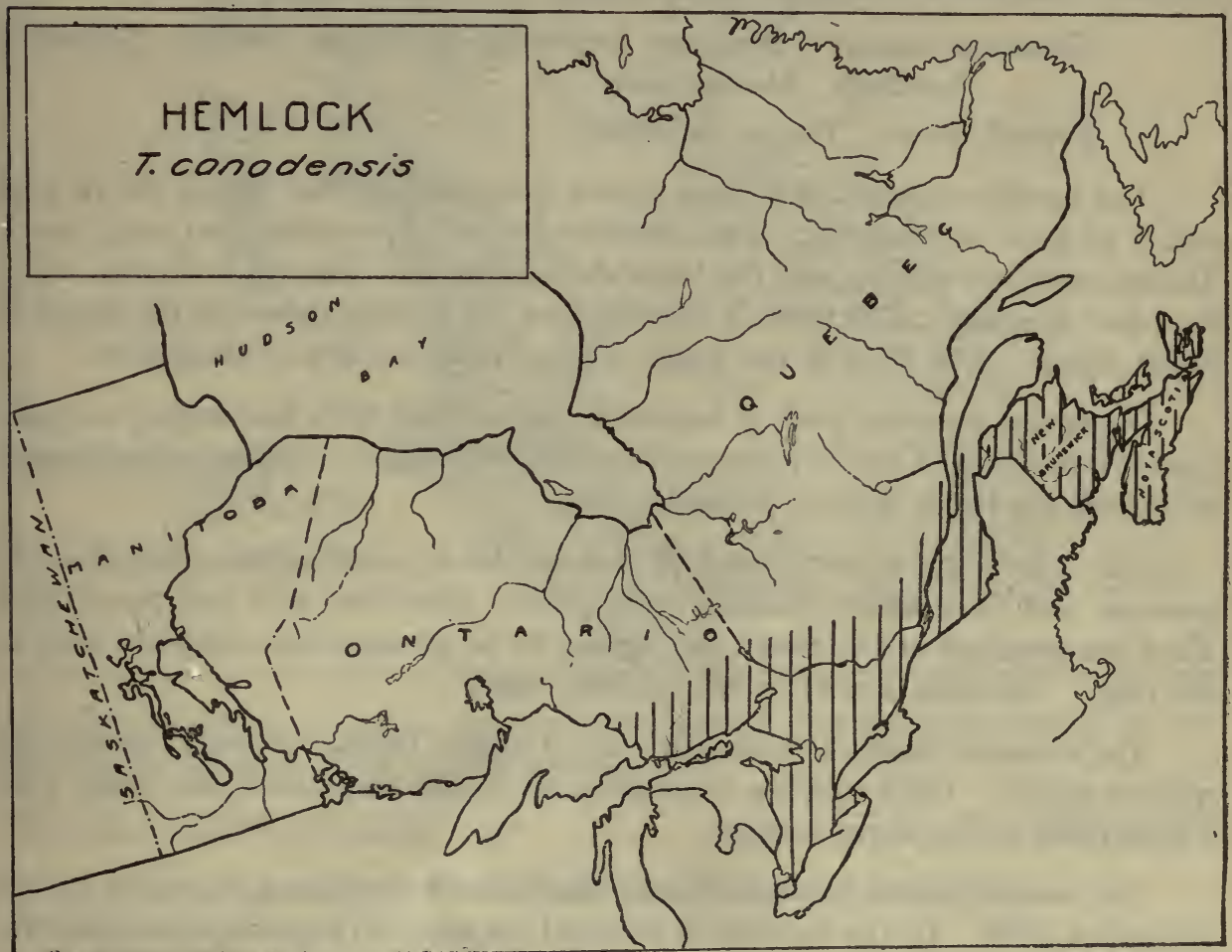

jection on the bark of the twig. They are twisted, and arranged in two distinct ranks. The fact that the leaves are distinctly stalked makes the tree readily distinguishable from any of the firs. 
The cones are very small, $3 / 4$ in. long. They are stalked and hang downwards from the twigs. The scales are thin, oval, and tan in colour.

The hemlock is found from Nova Scotia, throughout the St. Lawrence river valley and Ontario to the western end of the Great Lakes. It is sometimes found in pure stands, but is more often mixed with pines or hardwoods. It occurs on a wide variety of soils, but demands a fair amount of moisture. It makes best growth on rich bottom lands.

Cheapness, abundance, and strength are the chief qualities that make hemlock lumber important commercially. The wood is coarse in texture, splintery, brittle, cross-grained, and not so durable as pine. Upland trees produce superior lumber often distinguished as "white hemlock." The wood is used for frames of buildings, rough construction, boxes, ties, and poles. It is occasionally used for pulp manufacture. Tannin is extracted from the bark for use in the tanning industry.

\section{TSUGA HETEROPHYLLA (Raf.) Sarg.}

WESTERN HEMLOCK

Common names: Western hemlock, hemlock, British Columbia hemlock, Alaska pine*.

French name: Tsuga de 1'Ouest.

The western hemlock is a large, rather slow-growing tree 125 to $150 \mathrm{ft}$. high and 3 to $4 \mathrm{ft}$. in diameter. The crown is narrow, pyramidal, and very dense. The branches are slender and the branchlets drooping. The tip is slender, whiplike, and drooping. The trunk is usually clear for three-quarters of its length in dense stands. The base of the trunk is often much swollen or thickened.

On young trees the bark is brownish and covered with fine scales; on older trees it is darker and deeply furrowed into wide, flat ridges. Owing to the thinness of its bark the tree is severely injured by fires.

The leaves which vary much in size are flat in cross-section, conspicuously grooved, and have blunt, rounded ends. Their stalks are thin and thread-like. They are arranged in two ranks and appear to be growing from opposite sides of the twig. The twig is more or less minutely hairy.

The cones are small, seldom over 1 in. in length, reddish-brown in colour, and without stalks. The scales, few in number, are longer than broad and coated with a faint down on the upper surface.

The western hemlock is found from Alaska southward along the whole British Columbia coast. In the interior it is found up to 5,000 feet elevation wherever there is abundant rainfall. It thrives best on deep, porous soils, but will grow in thin, poor ones where there is sufficient moisture. It seldom occurs in pure stands but is usually mixed with Douglas fir, Sitka spruce, and western red cedar in the lower elevations, and mountain hemlock and the various firs in the higher ones. 
The wood of western hemlock is much superior to that of the eastern species, being easier to work and less liable to warp, check, and splinter, but is usually utilized for the same purposes. It is an important box material and is used extensively for pulp manufacture in British Columbia. The name "Alaska pine" is

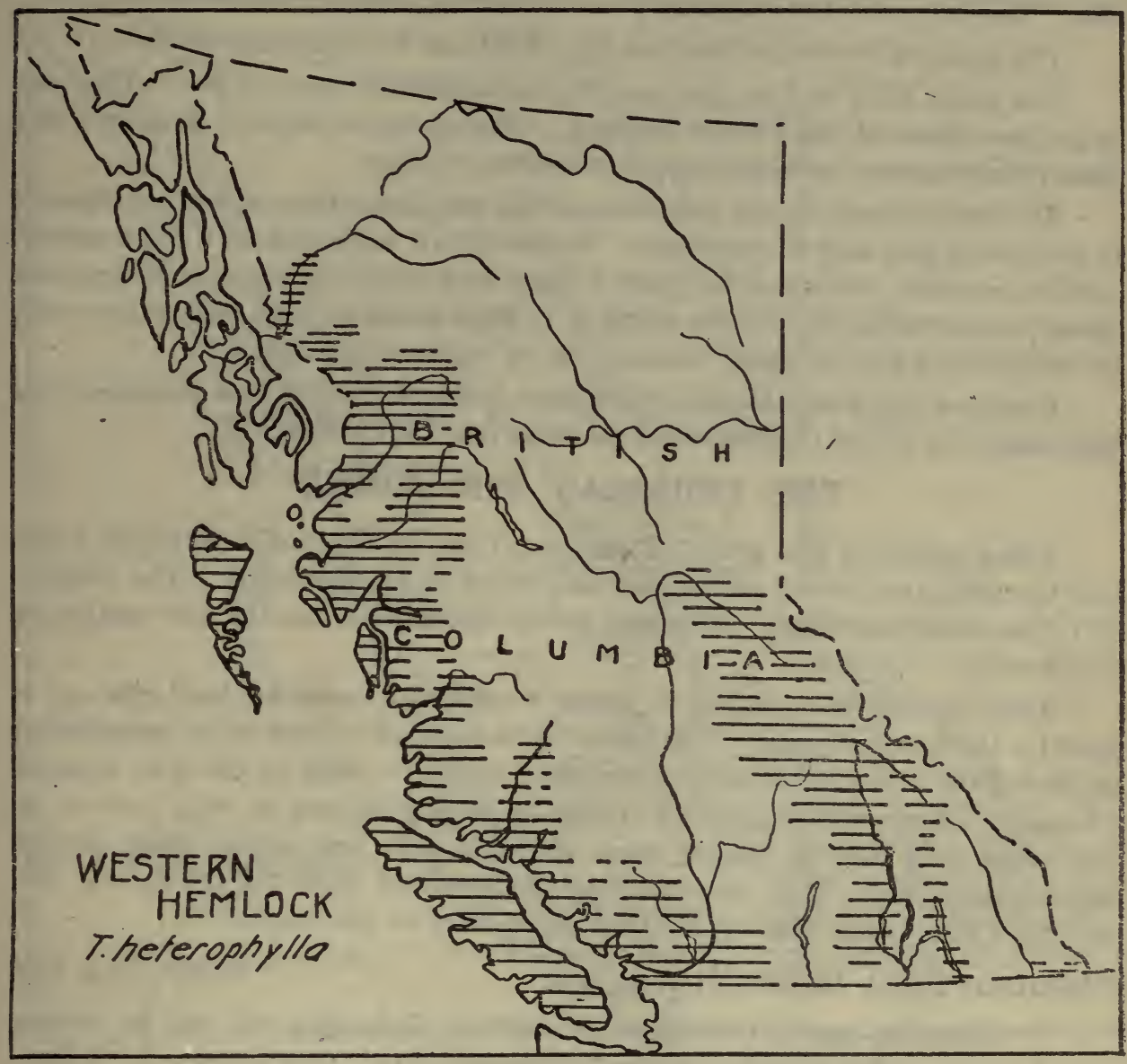

sometimes used to overcome the prejudice against the wood caused by the objectionable qualities of the eastern species.

TSUGA MERTENSIANA, Carr.

BLACK HEMLOCK

Common names: Black hemlock, mountain hemlock. French name: Tsuga de Patton.

The black hemlock is a small tree 25 to $50 \mathrm{ft}$. high and 10 to 20 in. in diameter. The trunk, except when much crowded, is not clear for any length but usually has branches down to the ground. It has many, slender, lash-like, drooping branchlets.

The branchlets often have erect side branches. 
The bark is a dark reddish-brown and is roughened by hard, narrow, rounded ridges.

The leaves are blunt-pointed, plump, or round in cross-section and stalked. They stand out all around the branch but seem somewhat thicker on the upper side. They resemble the leaves of spruce rather than those of hemlock.

The scales of the winter buds are tipped with an awl-shaped projection.

The cones are 1 to $3 \mathrm{in.}$ long and $3 / 4$ in. in diameter when closed. They are larger than those of the western hemlock. The scales are broader than long and from yellowish-green to bluish-purple or brown in colour.

This tree is found on the timberline of the mountains from Alaska southward. It is found in pure and mixed stands. In the north it associates with Sitka spruce, western hemlock, and alpine fir; farther south with white-barked pine, Engelmann spruce, and amabilis fir. In the north it is often found in bogs, but farther south on well-drained soils, in shady ravines, and on northern exposures.

Wherever this tree is found with western hemlock it is cut and marketed with that wood, but it is of slight commercial importance in Canada.

\section{THE DOUGLAS FIR GROUP}

Three species of this group (Psendotsuga) are known, one a native of Japan and the other two natives of the western portion of this continent. The Douglas fir (Psendotsuga mucronata) is the only one of importance, also the only one native to Canada.

They all produce hard, heavy, strong wood which resembles hard pine and is used for the same purposes. The name "false hemlock" is due to the resemblance of their flat, somewhat stalked, two-ranked leaves to those of the true hemlock (Tsuga). They resemble the firs (Abies) in having blisters or resin pockets on the young bark, also in having cones provided with long bracts which project beyond the scales. They can easily be distinguished from the firs by the fact that their cones hang down and do not stand erect on the branch.

PSEUDOTSUGA MUCRONATA, Sud.

DOUGLAS FIR

Common names: Douglas fir, British Columbia fir, red fir, yellow fir, Douglas spruce*, Douglas pine*, Oregon pine*, Oregon spruce*.

French names: Sapin de Douglas, pin de Douglas*.

Under favourable conditions the Douglas fir averages $180 \mathrm{ft}$. in height and 3 to $4 \mathrm{ft}$. in diameter, but it sometimes reaches a height of $350 \mathrm{ft}$. and a diameter of $10 \mathrm{ft}$. The trunk is straight and free of limbs for 70 feet and more. The crown is sharply pyramidal at first, becoming more or less flat in old trees. The branches have many long, hanging side branchlets.

The bark is thin and smooth at first but later becomes very thick and deeply furrowed. It has the heaviest bark of any tree in Canada, sometimes 10 to $12 \mathrm{in}$. thick. 
The leaves are flattened and sharp-pointed, dark green above, and pale beneath. They are slightly narrowed at the base but not distinctly stalked and, upon dropping off, leave the twig marked with round, raised scars. They are arranged in two ranks but not as distinctly so as those of the balsam fir. The buds

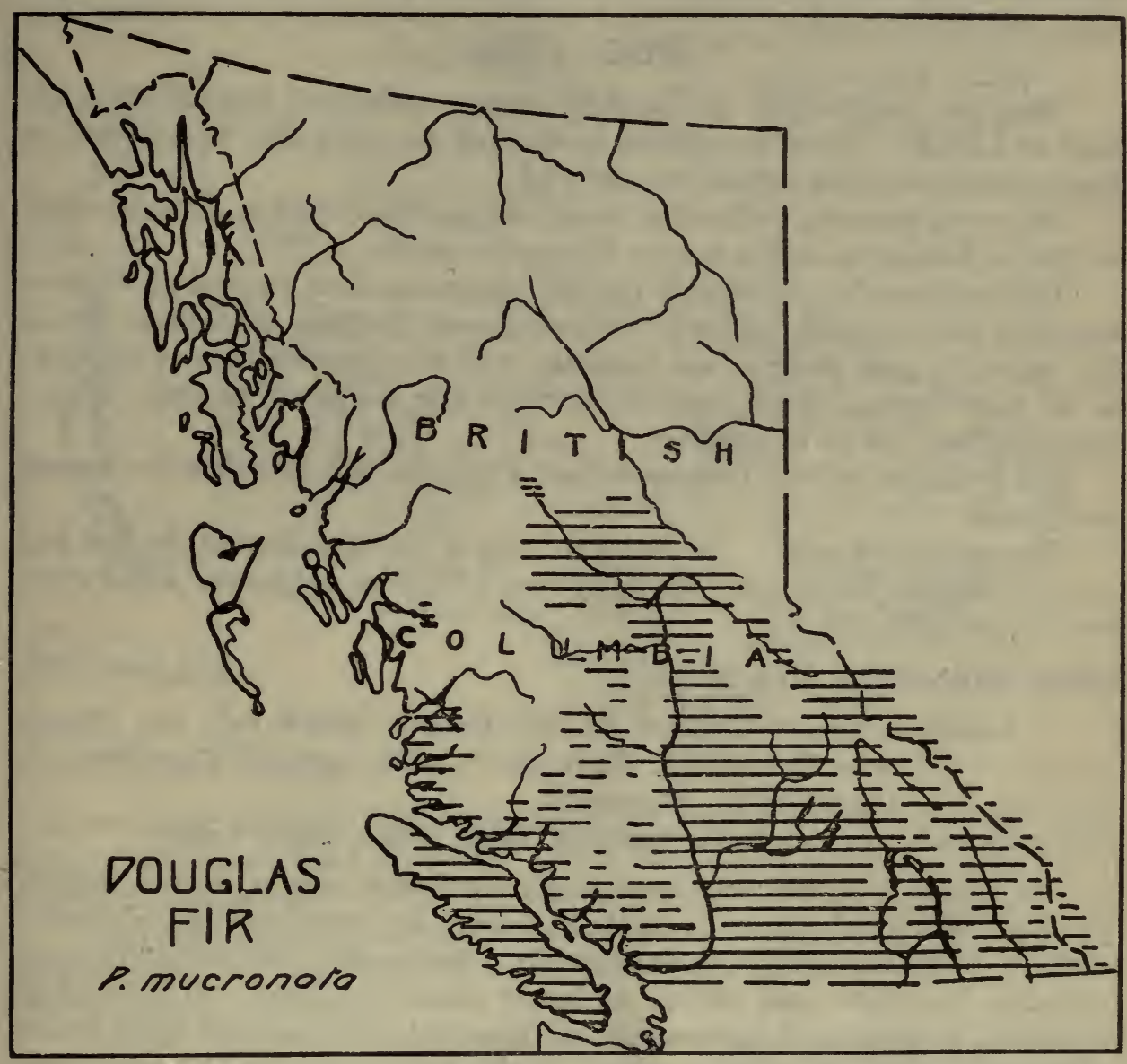

are sharp-pointed and not covered with resin in the winter. The cones are 2 to $41 / 2$ in. long and hang down instead of standing erect as in the firs (Abies). The three-pointed bracts which are attached to the back of the scales are long and conspicuous.

In Canada this tree ranges from the east slope of the Rocky mountains in Alberta through to the coast in British Columbia. In Alberta it is found as far north as the headwaters of the Athabaska river, but in the interior of British Columbia its range extends to lakes Babine and Stuart.

Larger structural timbers can be obtained of Douglas fir than of any other American tree. Its use for structural purposes is most imporant on account of its strength, stiffness, and durability, but of late years the wood has gained popularity 
for interior decorative work, on account of its pleasing grain and figure. Douglas fir is a valuable material for ties and paving blocks. In the West its uses are almost universal, limited only by the fact that the wood is difficult to work when seasoned. In the East it is used for bridges, docks, framework in buildings and cars, paving blocks, and wooden pipes.

\section{THE FIRS}

There are twenty-three species of fir (Abies) recognized, four of which are found in Canada. Three are western species and the other may be described as an eastern species which extends into the West.

The crown is usually pyramidal, dense, and narrow at the top. The branches are slender, horizontal, and in more or less regular whorls.

The leaves are flat and blunt at the tip. Sometimes near the end of vigorous branchlets they are sharp-pointed. In arrangement they are two-ranked; that is they appear to grow more or less distinctly from two opposite sides of the twig. On the more vigorous twigs, especially on those near the top of the tree, this arrangement may not be so apparent.

The hemlocks and the Douglas fir (not a true fir) also have this two-ranked arrangement.

. The cones stand erect The scales are shed at the same time as the seed and leave the central spike-like axis erect and bare. The cone of no other native evergreen breaks up in this way.

ABIES BALSAMEA (L.) Miller

BALSAM FIR

Common names: Balsam fir, fir, balsam, white fir*, var (Maritime Provinces), silver pine*, white spruce* (Cape Breton), Canadian fir (England).

French names: Sapin baumier, sapin blanc, sapin rouge.

The balsam fir is one of the most widely distributed trees in Canada, ranging from Nova Scotia to Labrador along the east coast, then westward and northward through New Brunswick, Quebec, and Ontario to Hudson bay, the Prairie'Provinces and Great Slave lake; and thence northward almost to Alaska. It is found in pure stands or mixed with red spruce in the East and with black and white spruce and tamarack throughout all its range. In the East it grows in the more moist situations but in the North it is found on bare, rocky hillsides.

It is a tree 50 to $60 \mathrm{ft}$. in height and 1 to $2 \mathrm{ft}$. in diameter. The regular whorls of horizontal branches produce a broad, symmetrical, pyramidal crown of considerable depth in proportion to the length of the clear trunk. Where crowded the crown is short, and narrow, and sharp. The root-system is shallow and the tree is easily overthrown by winds.

The bark is very smooth, and thin, and conspicuously marked with raised blisters, or pockets, containing oily resin or balsam. The colour is greyish-brown.

The leaves are $1 / 2$ in. long, dark green and shiny, pale below, flat, grooved, and very blunt or sometimes slightly notched at the tip. They are without stalks and are not curved. Usually the leaves are divided into two ranks along the twig 
as in hemlock, but on leading shoots and fruit-bearing twigs they have generally a more upright, bristling arrangement.

The twigs frequently come out from the branch in pairs and almost opposite each other. They are smooth and, after the leaves have dropped off, are marked

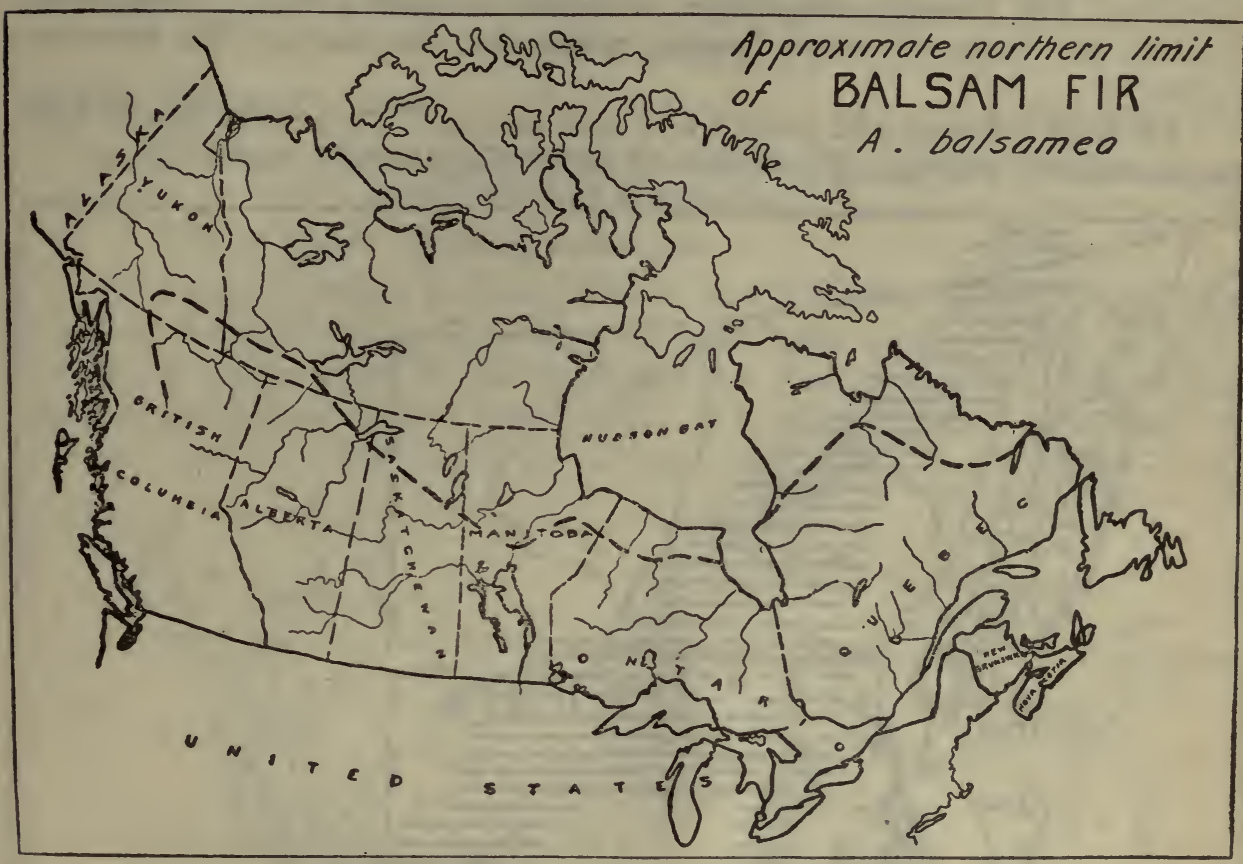

with small, circular scars left by the base of the leaf. The winter buds are small, covered with resin, and not pointed. These features aid in distinguishing it from the Douglas fir, which has pointed buds that are free from resin.

The cones are 2 to $4 \mathrm{in}$. long and $1 \mathrm{in}$. broad. As with all firs they stand erect on the branch, and, when ripe, the scales drop off leaving the core, or axis, standing. They are purplish in colour.

This is a tree which has only in late years been properly appreciated. Its wood forms at least one-quarter of the pulpwood produced annually, and the pulp manufactured is equal in many respects to that made of white spruce. The tree is sawn into lumber in the Maritime Provinces and used for rough constructon. It is not used extensively elsewhere except for pulp and poles.

ABIES LASIOCARPA (Hook.) Nutt.

ALPINE FIR

Common names: Alpine fir, mountain fir, white balsam, white fir*, western balsam fir, caribou fir (Northern British Columbia).

French name: Sapin concolore.

The alpine fir, as the name designates, is a tree of the mountains. It is found in British Columbia, Alberta, and Yukon territory at elevations of 2,000 to 7,000 
feet. It occurs in patches at or near the timberline and in inaccessible places. It associates with Douglas fir, lodgepole, limber, and white-barked pine.

The alpine fir, when well developed, averages 1 to $2 \mathrm{ft}$. in diameter and 60 to $70 \mathrm{ft}$. in height. It is a slow-growing tree. The crown is extremely narrow and spire-like. The branches are stubby and form a dense growth. Dead lower branches are frequently found hanging down along the trunk. The roots are shallow.

The bark is smooth and marked with resin blisters. The smooth part is light grey in colour. The base of the tree is frequently roughened by narrow cracks.

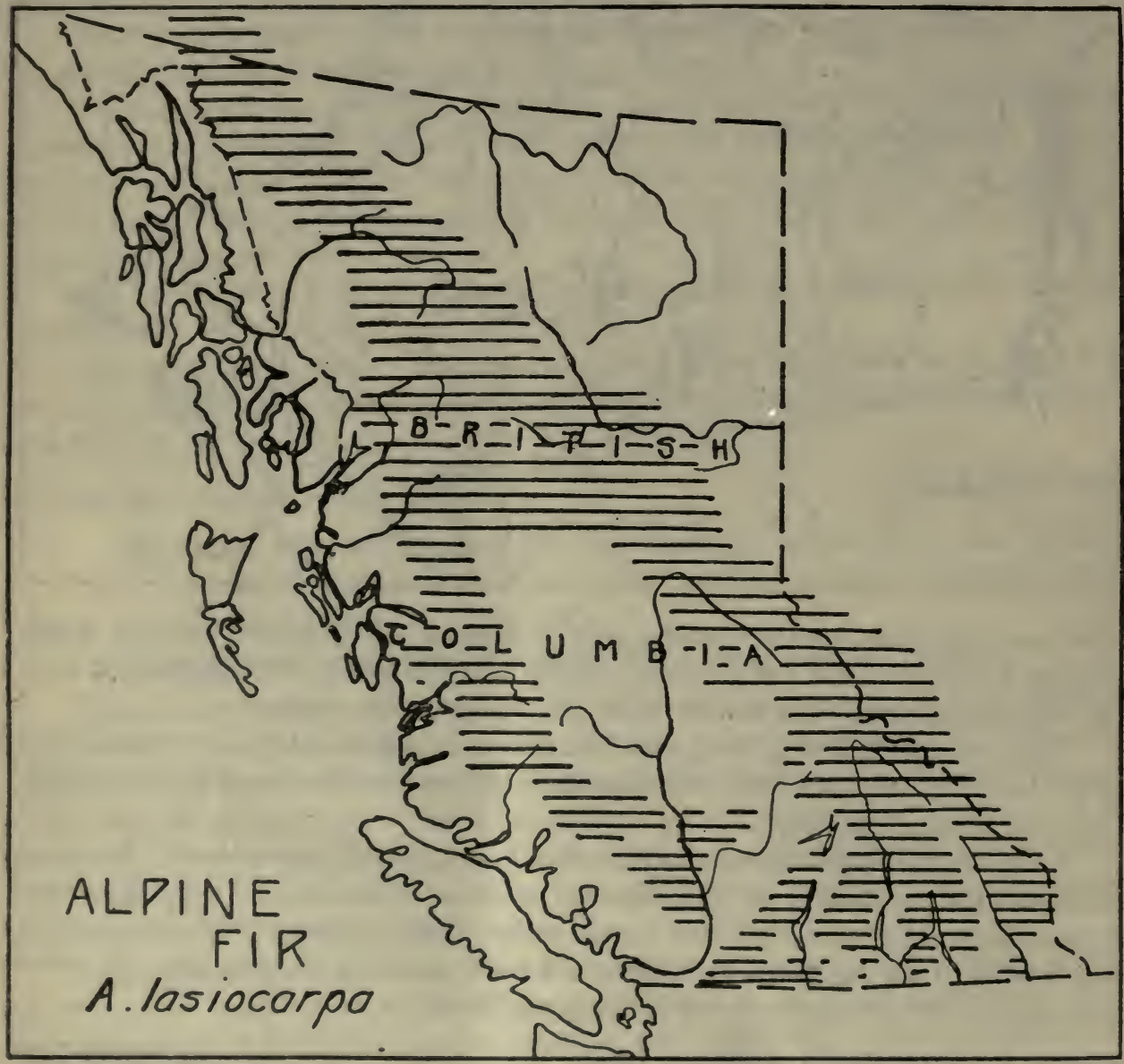

The twigs are downy, and, when the leaves have dropped, marked with small circular scars. The buds are blunt and covered with resin.

The leaves are $1 \frac{1}{4}$ to $21 / 4$ in. long, stalkless, and flat. They are whitish when young and deep blue when older. The tips of the leaves are notched except on some of the top branches. They are characteristically curved and twisted toward the upper side of the branch. 
The cones are $21 / 2$ to 4 in. long, $1 \frac{1}{2}$ in. in diameter, and intensely purple in colour. They stand erect on the branch and shed their scales when ripe as do all firs.

This is the most important lumber-producing species of its genus in the Rocky mountains, where it is often sold mixed with Engelmann spruce. It is used chiefly for rough building purposes and mine timbers.

ABIES GRANDIS, Lind.

LOWLAND FIR

Common names: Lowland fir, white fir*, western balsam, silver fir*, larch* (British Columbia).

French name: Sapin grandissime.

The range of lowland fir is very limited, and in Canada it is found only along the coast of British Columbia, about as far north as the northern end of Vancouver islanc. It prefers moist, well-drained situations and is, therefore, chiefly found along stream bottoms and on lower slopes. It is seldom found in pure stands but

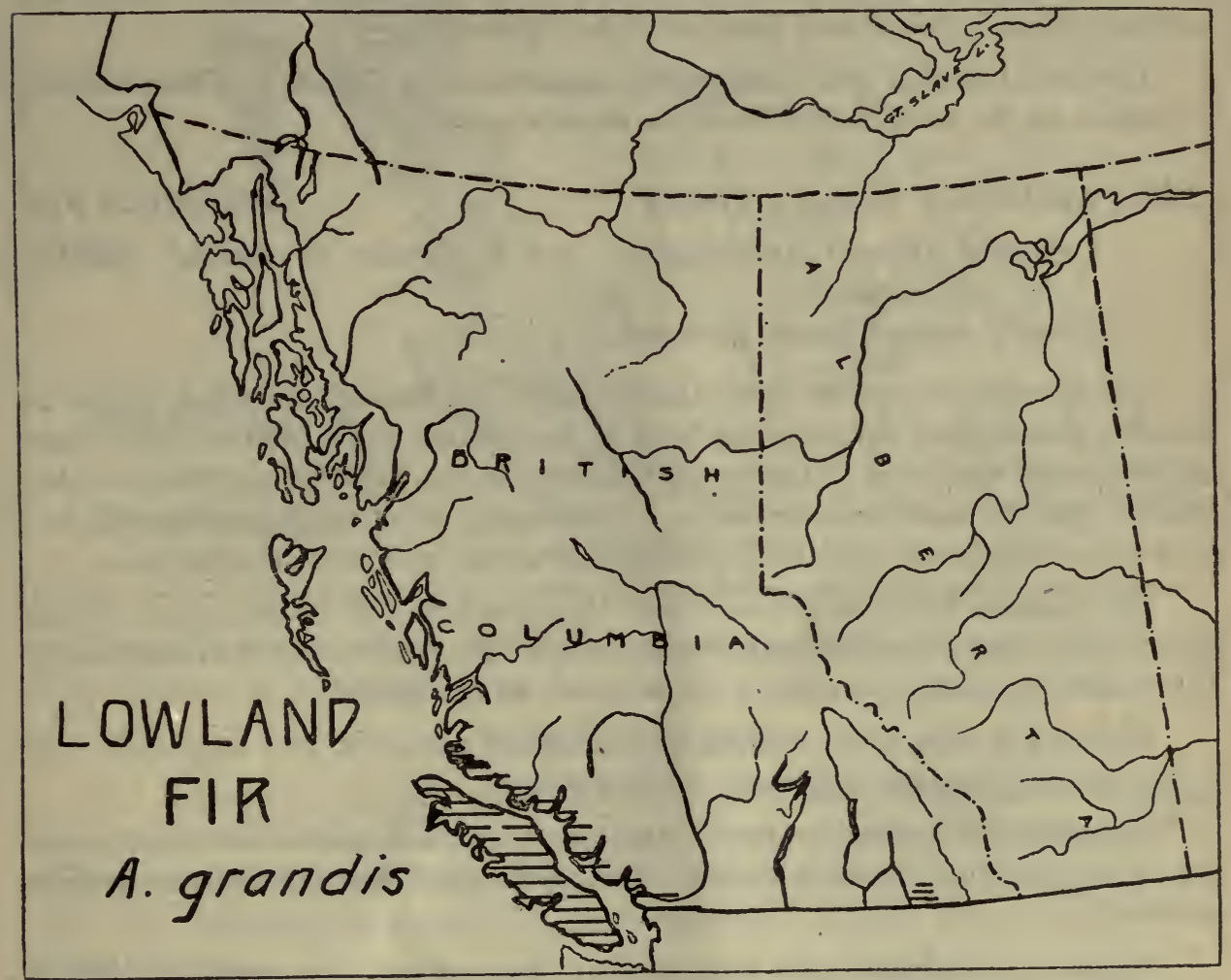

usually mixed with Douglas fir, western red cedar, western hemlock, and black cottonwood.

The lowland fir averages 2 to $3 \mathrm{ft}$. in diameter and 100 to $125 \mathrm{ft}$. in height. The trunk is tall, straight, and clear, except when growing in the open. The 
branches have a tendency to droop slightly and then turn up at the ends. The lower branches on old trees of ten hang down, causing the crown to appear wider near the middle than at the base.

The bark is rather thick for a fir and often cut by narrow furrows into hard, sharp, horny ridges. On young trees it is smooth and brown with whitish patches. It is marked with resin blisters.

The leaves, like those of the hemlock, appear to grow from opposite sides of the branch and are $11 / 4$ to $21 / 4$ in. long. In the upper part of the tree they are not quite so long and are usually more crowded and bristling in their arrangement. Like the leaves of other firs these are stalkless, flat, usually notched at the tip, and conspicuously white on the underside. On vigorous shoots they are sometimes four-sided.

The buds are blunt and covered with resin.

The cones are $2 \frac{1}{2}$ to 4 in. long and 1 to $1 \frac{1}{3}$ in. in diameter. They are yellowish-green in colour and stand erect on the branch.

This tree is not of great commercial importance in Canada. Where utilized it is mixed on the market with the other western species.

\section{ABIES AMABILIS (Doug1.) Forbes}

AMABILIS FIR

Common names: Amabilis fir, red fir, alpine fir, larch* (British Columbia).

French name: Sapin gracieux.

The amabilis fir extends from Alaska southward through the whole length of British Columbia but is mostly confined to the western slope of the Coast range and to Vancouver island. It grows on the lower slopes, benches, and flats on welldrained, gravelly sand or sandy loams. Occasionally it is found in pure stands but more often mixed with Douglas fir, western hemlock, and western white pine.

The amabilis fir grows 150 to $170 \mathrm{ft}$. high and 3 to $4 \mathrm{ft}$. in diameter. In the forest it has a short, conical crown, but in the open the crown extends to the ground. The branches towards the bottom of the crown droop markedly.

The bark is thin, grey, smooth, and unbroken except in very large trees. It is conspicuously marked with large, white patches.

The twigs are yellowish-brown, minutely hairy, and scarred with the marks left by the bases of the fallen leaves. The winter buds are rounded and covered with resin.

The leaves are about $11 / 4 \mathrm{in}$. long, stalkless, flat, notched at the ends, and whitish beneath. They have the appearance of being pulled around toward the upper side and are closely pressed together to form a stiff, fuzzy branch.

The cones are 4 to $5 \mathrm{in}$. long and 2 to $2 \frac{1}{2} \mathrm{in}$. thick, and dark purple in colour. They stand upright on the branch. 
The quality of the wood of both this tree and the lowland fir is usually considered to be superior to that of the common eastern species. In Canada the wood

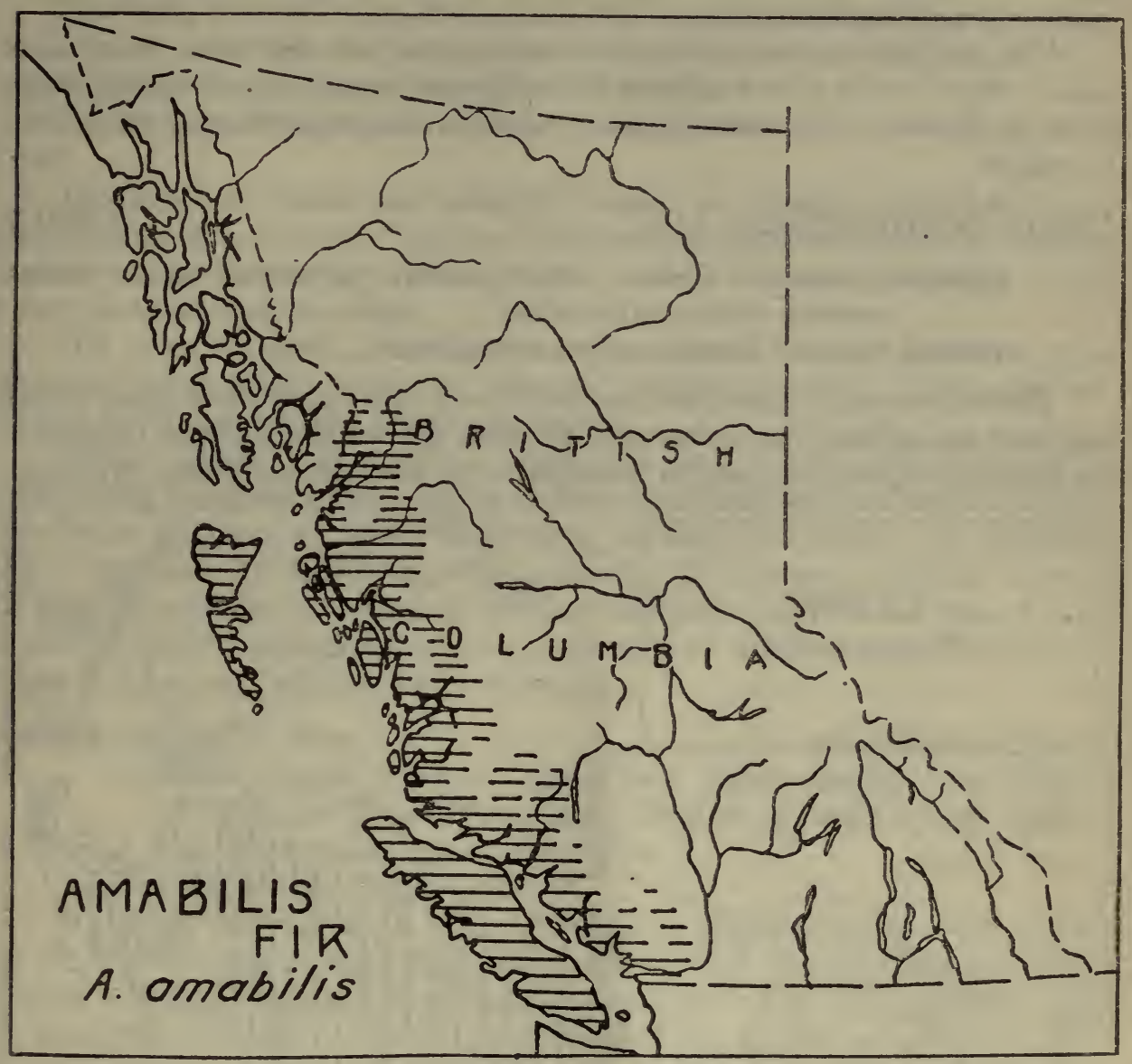

is sold on the market mixed with that of the other western species, and is not of great commercial importance.

\section{THE CEDARS}

The cedars (Thuja) vary from medium-sized to large-sized trees. There are four species known of which two are native to Canada and the United States. The other two are native to China and Japan, but are sometimes planted on this continent for decorative purposes. Many ornamental varieties have been produced by nurserymen.

The two native species differ widely in range; one is confined to British Columbia, and the other does not extend west of Manitoba.

The bark of all species is thin and shreddy. The wood is highly aromatic and is much used on account of its lightness and durability. 
The foliage consists of tiny, overlapping, scale-like, evergreen leaves, which occur in pairs pressed to opposite sides of the twig. The brancllets are characteristically arranged in flat sprays.

The fruit is a tiny cone which matures in one year and sheds many small seeds. Each seed is almost surrounded by its two narrow, membraneous wings, except in the case of the Asiatic species which have larger and heavier secds without wings.

THUJA OCCIDENTALIS, Linn.

CEDAR

Common names: Cedar, white cedar, northern white cedar, eastern cedar, arbor-vitæ.

French names: Thuja, cèdre, cèdre blanc.

The white cedar is found from eastern Nova Scotia and Prince Edward Island westward throughout New Brunswick, southern Quebec and southern Ontario to the south end of James bay, and in Manitoba to the southern end of lake Winnipeg.

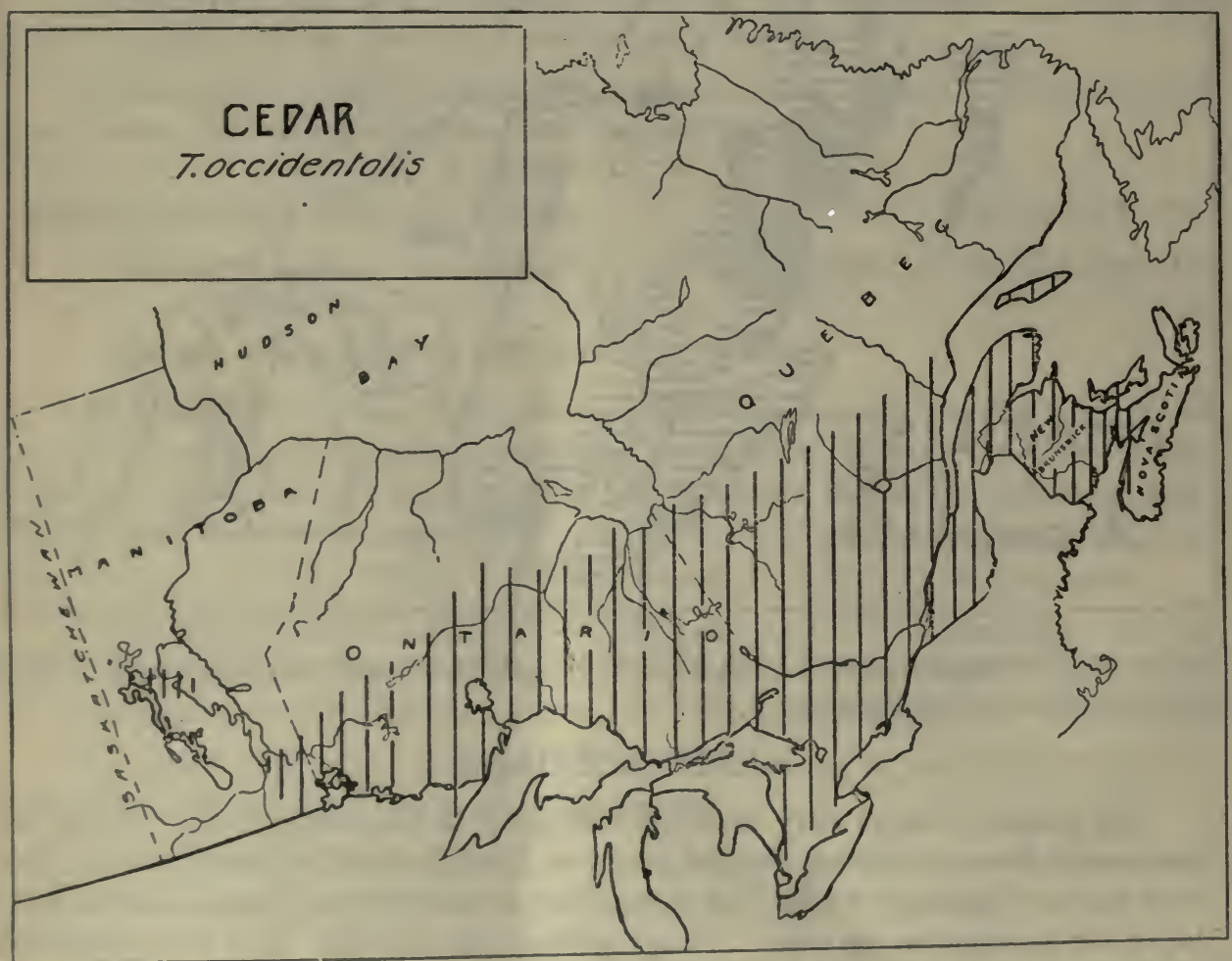

It also occurs in an isolated patch near the north end of lakes Winnipeg and Winnipegosis.

It is usually found in swamps or moist situations, but will also grow readily on the thin soil of limestone ridges. It occurs in pure stands of considerable size, but also grows mixed with spruce, tamarack, black ash, and alder. 
It is a small tree, averaging about $45 \mathrm{ft}$. in height and $1 \mathrm{ft}$. in trunk diameter but sometimes reaching a height of $80 \mathrm{ft}$. and a diameter of $3 \mathrm{ft}$.

The trunk is short and much tapered, while the crown is conical, dense, long, and narrow. When grown in the open it has a very trim, artificial appearance, and is, therefore, much used for ornamental planting.

The bark is reddish-brown in colour, thin, and shreddy, often with a spiral twist.

The leaves are minute and scale-like, in pairs on opposite sides of the twig, and arranged in four rows. They are evergreen and completely cover the fan-like branchlets, overlapping like the shingles on a roof. When crushed they give out a very pleasant aromatic odour.

The cones are small, $1 / 3$ to $3 / 4$ in. long, composed of eight to twelve pale cinnamon-brown scales, which are arranged opposite in pairs. The seeds are winged and two in number under each scale.

Cedar is Canada's most durable coniferous wood, and has long been held in high esteem for shingles and building construction where exposed to the weather. The tree is the most important material in Canada for telegraph and telephone poles, especially in the shorter length classes. It is also a valuable railway tie material, and is used extensively for fence-posts and rails. In the form of sawn lumber the wood is used in greatest quantities in house construction, boat-building, tanks, cisterns, and straight stave cooperage.

THUJA PLICATA, Don.

WESTERN CEDAR

Common names: Western cedar, red cedar, western red cedar, British Columbia cedar, British Columbia red cedar, giant cedar, giant arbor-vitæ.

French name: Thuja géant.

In Canada the western red cedar is confined to British Columbia, being found on the Pacific coast northward as far as Alaska, and throughout the southern portion of the province and the Columbia-Kootenay valley. It is usually found on moist sites in deep, porous soil on cool slopes and in gulches, and occasionally on comparatively dry sites, but here, however, it is stunted. It occurs singly or in scattered patches. No pure stand of any size is found. In the north it usually associates with the Sitka spruce and yellow cypress and further south with the western hemlock and Douglas fir.

It is a very large tree. Its height is 150 to $175 \mathrm{ft}$. or even more, and the diameter of the trunk 4 to $8 \mathrm{ft}$. or more. The trunk is very much tapered, and the butt is usually very much swollen. Except where the tree is very much crowded, the branches remain on the lower part of the trunk until it reaches the diameter of $11 / 2 \mathrm{ft}$. or more, and thus produce a long, conical crown.

The bark is thin, and, like that of the eastern white cedar, is divided by shallow grooves into broad ridges which break into long, loose shreds.

The leaves are similar to those of the eastern white cedar and cover the flat sprays in the same manner. They may be mistaken for those of the yellow cypress at first sight, but a comparison will show them to have the points of the leaves less 
sharp and more closely pressed against the twig. Those of the yellow cypress have sharp, spreading points which make the sprays harsh and prickly to the touch.

The cones are about $1 / 2$ in. long with six fruiting scales.

Western cedar is one of the most important lumber trees in British Columbia. More shingles are made from its wood than from that of any other tree in Canada.

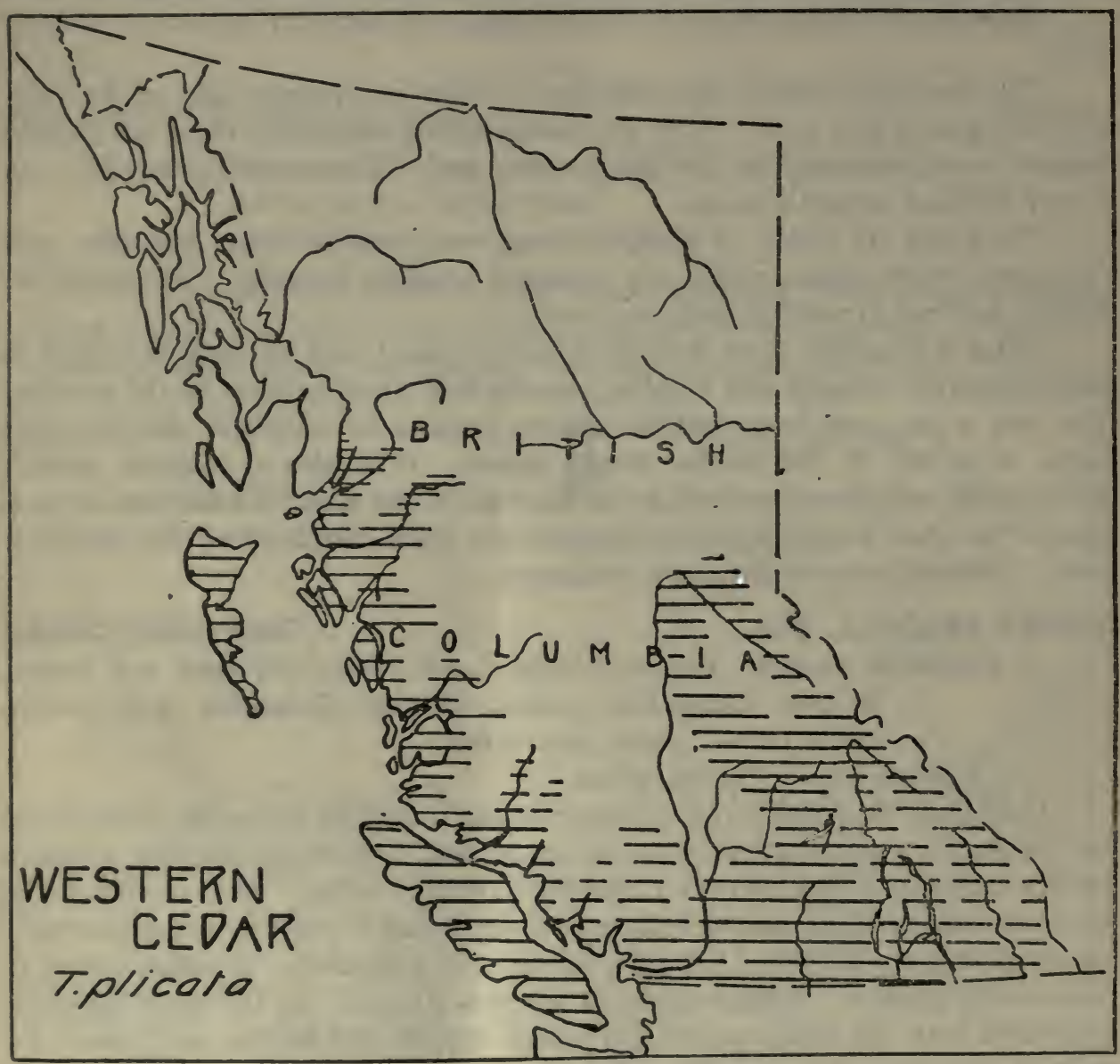

Western cedar poles predominate in the greater length classes. The wood probably equals that of eastern cedar for durability, but it is much softer and weaker and is not used to such an extent as the eastern species for railway ties. Lumber can be obtained in large dimensions free from knots and defects and is used for sash, doors, building material, boxes, and boat-building.

\section{CHAMAECYPARIS (THE WESTERN CYPRESSES)}

Six species of Chamaecyparis are known, three in eastern Asia and three on this continent. Only one species, Chamaecyparis nootkatensis, occurs in Canada.

This small group of trees somewhat resembles in appearance the Thujae, to which belong our eastern cedar or Arbor vitae and our western red cedar. They 
differ, however, in having more nearly spherical cones instead of the narrow, elongated ones of the Thujae. The wood, too, is much heavier and harder, and lacks that characteristic cedar odour of the Arbor vitae.

The Asiatic species are of great importance in China and Japan. They can be distinguished from those of this continent by the lighter colour on the under side of the leaves and by their longer cones.

CHAMAECYPARIS NOOTKATENSIS, Spach. YELLOW CYPRESS

Common names: Yellow cypress, yellow cedar*, Alaska cypress, Alaska cedar*, Nootka cypress.

French names: Cyprès jaune, faux cyprès de Nootka.

The yellow cypress is confined to the Pacific coast, and in Canada is found from Alaska to the Canada-United States boundary, along the west slope of the Coast

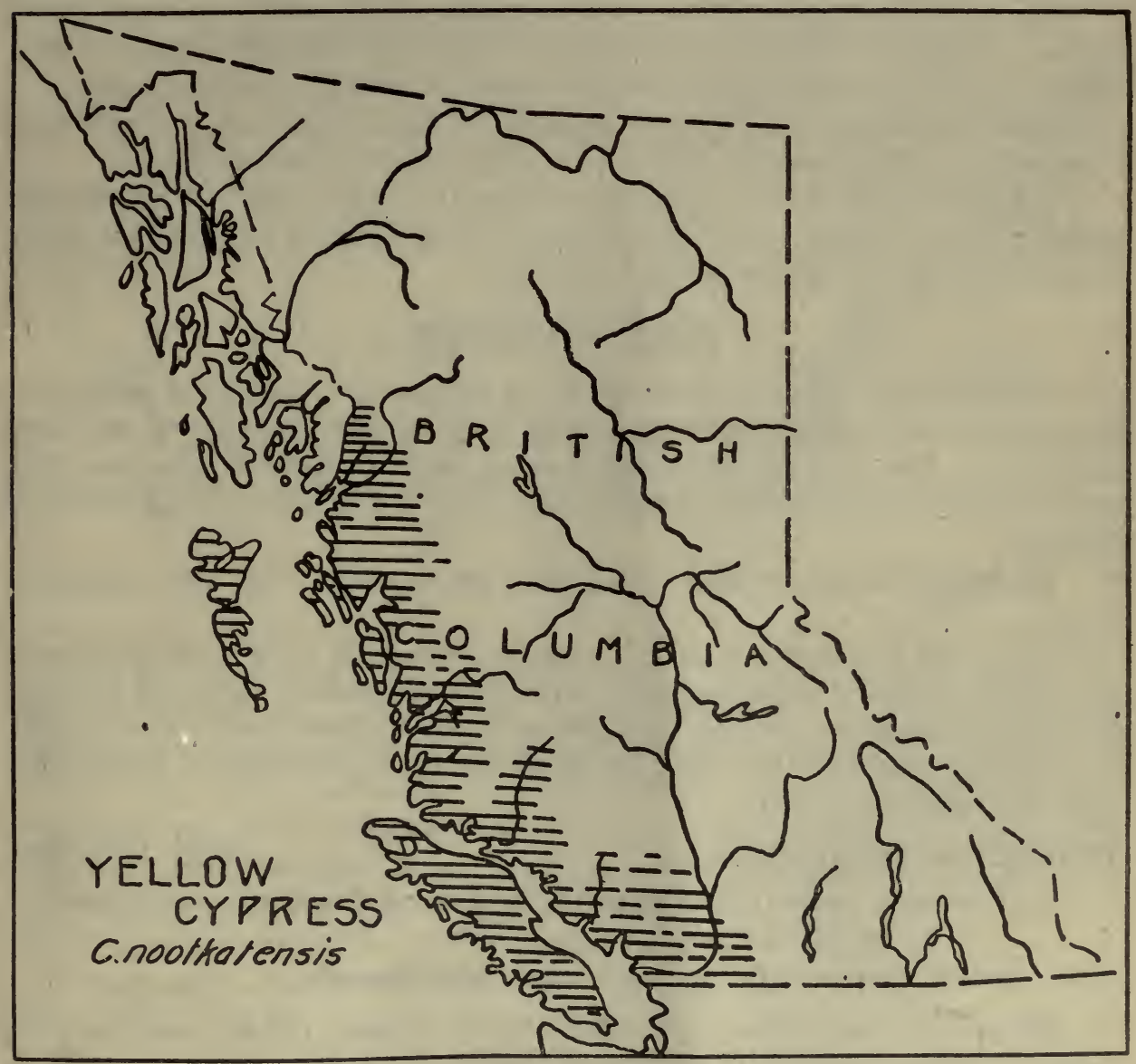

range and on the islands. It grows for the most part in the bottom lands and along streams, associated with the Sitka spruce and western red cedar; occasionally on $22510-4$ 
higher elevations with the alpine fir and Engelmann spruce. Sometimes it occurs in pure stands but usually scattered or in patches.

It is a very large tree, 75 to $80 \mathrm{ft}$. high, and with a trunk diameter of 3 to $4 \mathrm{ft}$. On the whole it is a smaller tree than the western red cedar for which it is very often mistaken. One of the best means of distinguishing it from that tree is by the yellowish colour of the wood.

The trunk is very much tapered. The crown is conical and narrow and has slightly drooping or horizontal branches. The small twigs or sprays are very flexible, and droop. The tip of the tree is very slender and often bent like the end of a whip.

The bark is very thin, ashy-brown outside and cinnamon-red within. The surface is broken by irregular, shallow fissures into flat ridges which flake off into narrow strips.

The leaves are scale-like, blue-green in colour, and resemble very much those of the western red cedar. They are best distinguished from the latter by their distinctive, sharp, spreading points which make the spray harsh to the touch.

The cones are spherical in shape and about $1 / 2 \mathrm{in}$. in diameter, a deep russetbrown with a whitish bloom. Two to four seeds are borne under each scale.

The wood of the yellow cypress is used on the Pacific coast for fine cabinet work and finish in houses and boats. It has been considered as a possible source of material for pencil slats in British Columbia.

\section{THE JUNIPERS}

The thirty-five or more known species of juniper (Juniperus) are widely distributed over the northern hemisphere and range from low shrubs to mediumsized trees. The majority of species are of small importance, commercially, because of their small size and irregular bole. The wood itself is of high technical quality.

The bark of all the species is usually thin and shreddy. The fruit is always a berry.

The dwarf, or common juniper (Juniperus communis), is the most widespread one in Canada, being found across the Dominion from east to west. It is of importance only from a decorative standpoint, since it is a mere bush which is ordinarily distinguished from the other native species by its low habit of growth and radiating, upturned branches.

JUNIPERUS VIRGINIANA, L.

RED JUNIPER

Common names: Red Juniper, juniper, red cedar*, pencil cedar*, pencil juniper.

French names: Génévrier rouge, cèdre rouge*.

The red juniper is found in Nova Scotia, in southern Quebec, and along the valley of the St. Lawrence to lake Huron and Georgian bay.

It is not a large tree in Canada, commonly 25 to $35 \mathrm{ft}$. in height and 7 or $8 \mathrm{in}$. in trunk diameter. When young it has a narrow, compact, and pyramidal head 
which becomes open and irregular as the tree becomes older. The trunk is very irregular in cross-section and tapers rapidly in young trees.

The bark is reddish-brown, stringy, and separates into shreddy strips.

The twigs are somewhat four-sided and are covered with minute leaves. They are not arranged in a flat, spreading spray like those of the white cedar (Thuja occidentalis) but have an irregular habit of growth.

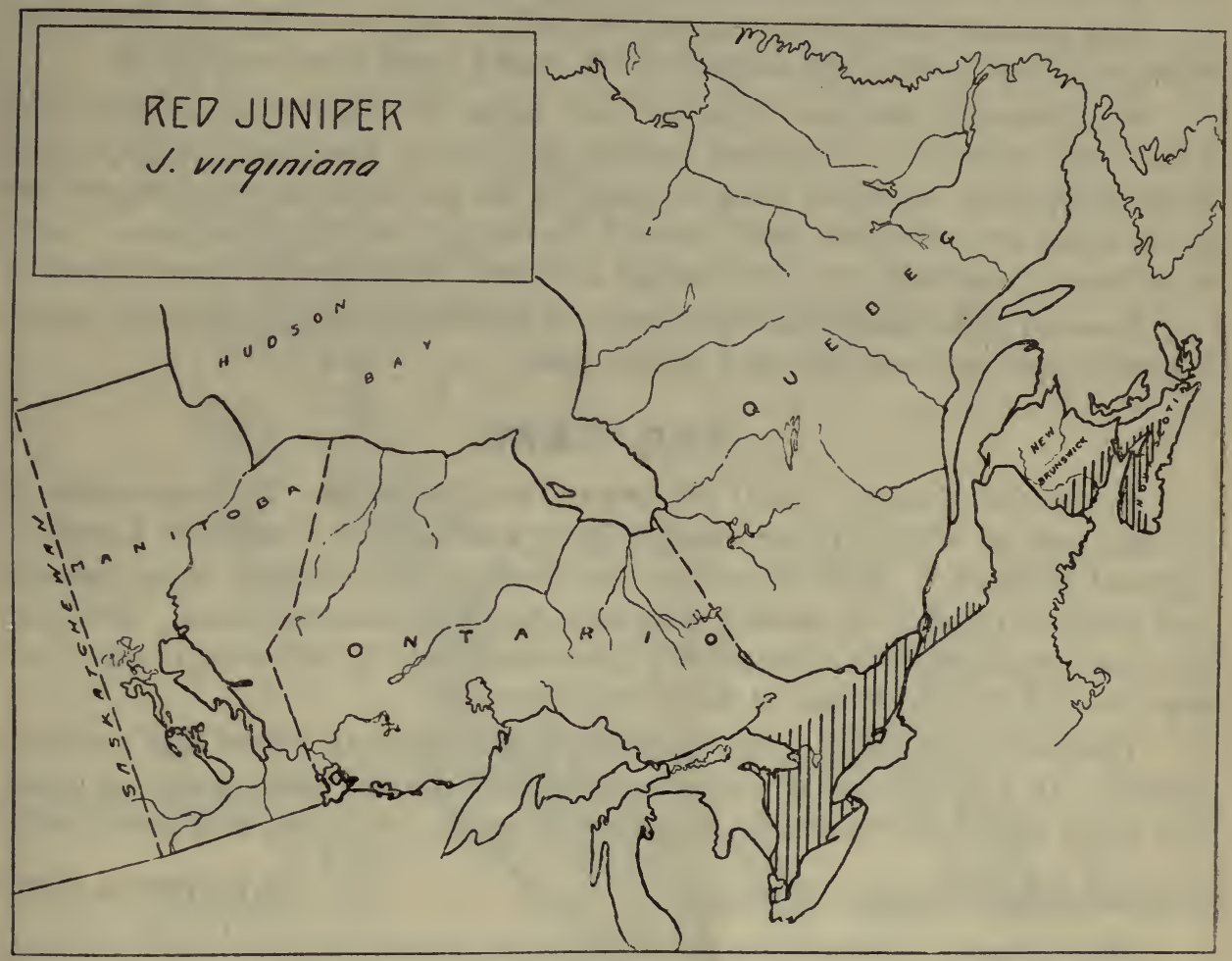

The leaves are dark green, somewhat rusty-brown in winter, and have a characteristic odour when crushed. They are of two kinds. On young shoots, especially on young trees, they are as a rule awl-shaped, narrow, and sharp-pointed, $1 / 2$ to $3 / 4$ in. long, in pairs and opposite or in threes and standing well out from the twig. The other form, which is more typical for the species and found on the older trees, is a minute scale-like leaf. These leaves are closely pressed to the twig, opposite, and in pairs, and lie overlapping They are sharp-or blunt-pointed and often have a glandular dot on the back which is missing in the other form.

The fruit is a fleshy, dark blue, bloom-covered berry the size of a pea, which has a peculiar, sweet, resinous taste. These berries are borne in large numbers on vigorous shoots of the female tree and remain on the tree all winter.

The red juniper, or red cedar as it is commonly called, is used locally in Canada for fence-posts. It seldom reaches sawlog sizes and is used mostly "in the round." 
In the United States the tree grows to a larger size and is extremely valuable, as its wood is used exclusively for the better class of lead pencils. The lumber is also valuable for moth-proof chests and wardrobes.

\section{JUNIPERUS SCOPULORUM, Sarg.}

ROCKY MOUNTAIN JUNIPER

The Rocky Mountain juniper is found in the foot-hills of southern Alberta, and westward through southern British Columbia to the Pacific coast.

It is a small, bushy tree, ordinarily 10 to $20 \mathrm{ft}$. high, sometimes in favourable, sheltered sites, reaching the height of $30 \mathrm{ft}$., and a trunk diameter of $12 \mathrm{in}$.

In appearance this tree resembles very much the red juniper, or red cedar (Juniperus virginiana), of eastern Canada, and was at one time thought to be a form of that tree It differs from it chiefly in the fact that its berries require two years to mature and ripen, while those of the eastern tree require but one. However, the tree has been very little studied and much remains to be learned about it.

Its wood is like that of the other species of juniper and could be used for similar purposes, such as pencil slats and cabinet work.

\section{THE YEWS}

Six species of yew (Taxus) are known, mostly shrubs. Two are native to Canada, one of which (Taxus canarlensis) is a shrub and commonly known as "ground hemlock." Their leaves are flat, narrow, lance-shaped, sharp-pointed, and resemble those of the hemlocks in their two-ranked arrangement. The yews can, however, be readily distinguished from these trees by difference of habit and fruit, which latter in the case of the yews is berry-like

The wood of the yews is fine-grained, of great strength and of high technical quality. In former times it was extensively used for the manufacture of bows, but today is of little importance because of its rarity, small size, and slow growth.

TAXUS BREVIFOLIA, Nutt.

WESTERN YEW

The western yew west of the Coast range has its habitat limited to the islands and mainland of the Pacific coast, and farther east to both sides of the Selkirk range from the Canadian Pacific railway to the Canada-United States boundary. It is nowhere found in large stands, but usually in small groups or singly; comparatively rarely as a tree, more commonly as a shrub.

It is a small tree, ordinarily 18 to $25 \mathrm{ft}$. in height and 4 to 6 in. in diameter. The larger trees are found in the canyons near the streams or on moist flats. On the higher, dry, gravelly soils they are small. The wood is of little commercial importance in Canada.

The trunk is much tapered and usually fluted. The crown is conical and when growing in full light, extends right to the ground. It is composed of many horizontal branches which bear many slender, drooping branchlets.

The trunk is covered with thin, purple scales which are easily removed, leaving a reddish-purple under-bark. 
The leaves are flat, sharp-pointed, lance-shaped, yellowish-green, and soft to the touch. They are so twisted on the twig as to have a two-ranked, or featherlike arrangement. They remain on the tree for several years.

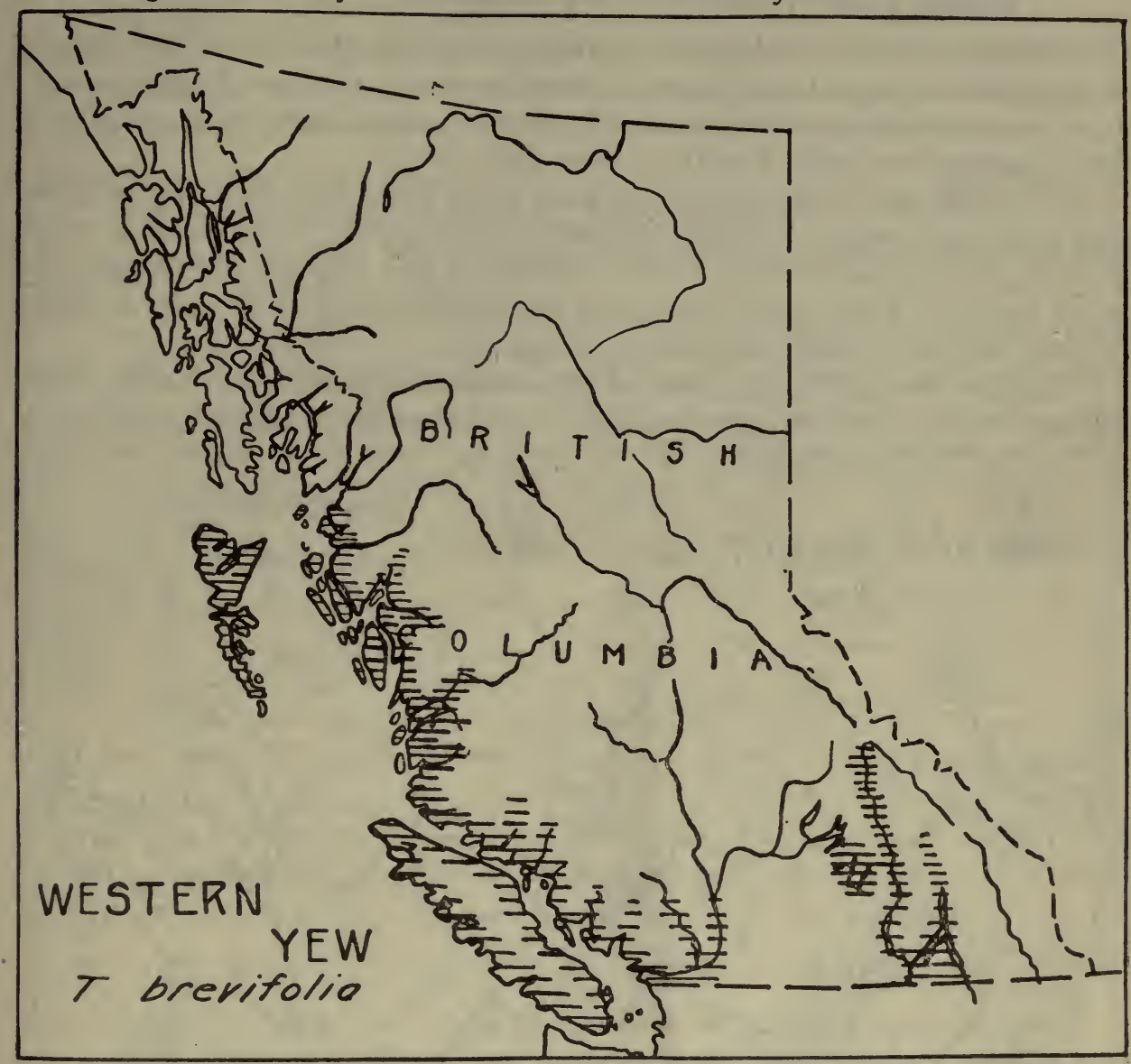

The fruit when ripe is bright red, fleshy, and berry-like and contains a single' seed which often protrudes beyond the outer covering.

\section{THE WALNUTS}

The ten or more known species of walnut (Juglans) are widely distributed throughout North and South America, southern Europe, northern Africa, and Asia. Four species are native to North America and two species are found in Eastern Canada. No walnuts occur west of Ontario in Canada.

The wood of the walnuts is very valuable, but of small commercial importance in Canada because of the limited supply. The Circassian walnut wood is yielded by the English or Persian walnut (Juglans regia) which also produces the common walnut of commerce.

The walnuts are related to the hickories and resemble them in many points. However, there are many features by which they can be readily separated. 
JUGLANS NIGRA, Linn.

\section{BLACK WALNUT}

Common names: Black walnut, walnut, American walnut.

French name: Noyer noir (d'Amérique).

The black walnut is a large tree 50 to $90 \mathrm{ft}$. in height and 2 to $5 \mathrm{ft}$. in diameter. Growing in the open it has an immense, rounded crown; the lower branches sometimes drooping almost to the ground. In the dense forest, however, it produces a tall, columnar trunk with a small, narrow, rigid head.

It requires deep, rich, well-drained loam and is found growing singly or mixed with other hardwoods. It occurs naturally in Canada only in southern Ontario, bordering lakes Ontario, Erie, and St. Clair and is now very scarce. Where protected from cold winds it has been grown considerably north of its natural limits. It is very tolerant of shade and a fairly fast grower.

The bark is roughened by rounded ridges which intersect each other like those of the white ash. The bark is much darker in colour than that of the butternut, a tree

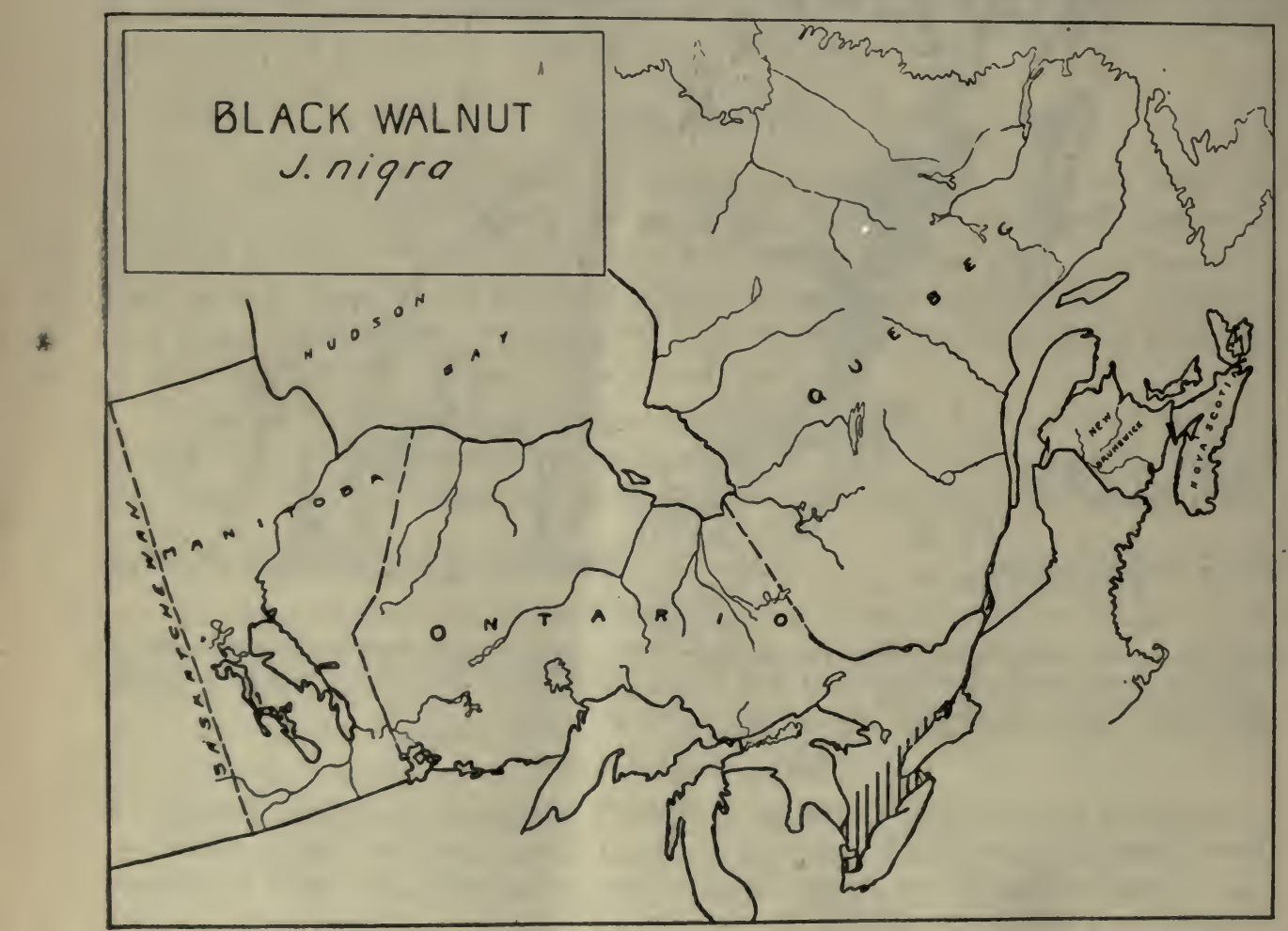

which might be mistaken for it. Young trees of the walnut and butternut are readily distinguished by their twigs and winter buds.

The leaves are compound, fifteen to twenty-three leaflets on a stem 1 to $2 \mathrm{ft}$. in length, thin, and bright yellowish-green in colour. The black walnut and the butternut are about the last trees of the Canadian woods to open their leaves in the spring. 
The nut is almost round, $1 \frac{1}{4}$ to $1 \frac{1}{2}$ in. in diameter, and has a hard, black shell which is cut into sharp ridges. The husk is blackish with an aromatic odour. The kernel is oily, sweet and edible: The nut has a good market value.

The popularity of black walnut for fine cabinet-work has resulted in the almost commercial extinction of the tree in America. Owing to the rich brown colour and the grain of the wood, it is still used for piano and organ case work and for high class furniture, in spite of its scarcity and almost prohibitive price.

JUGLANS CINEREA, Linn.

BUTTERNUT

Common names: Butternut, white walnut.

French names: Noyer tendre, noyer gris, arbre à noix longues; noyer cendré.

In Canada the butternut is found from New Brunswick up the valley of the St. Lawrence and throughout the hardwood region in Ontario, east and south of

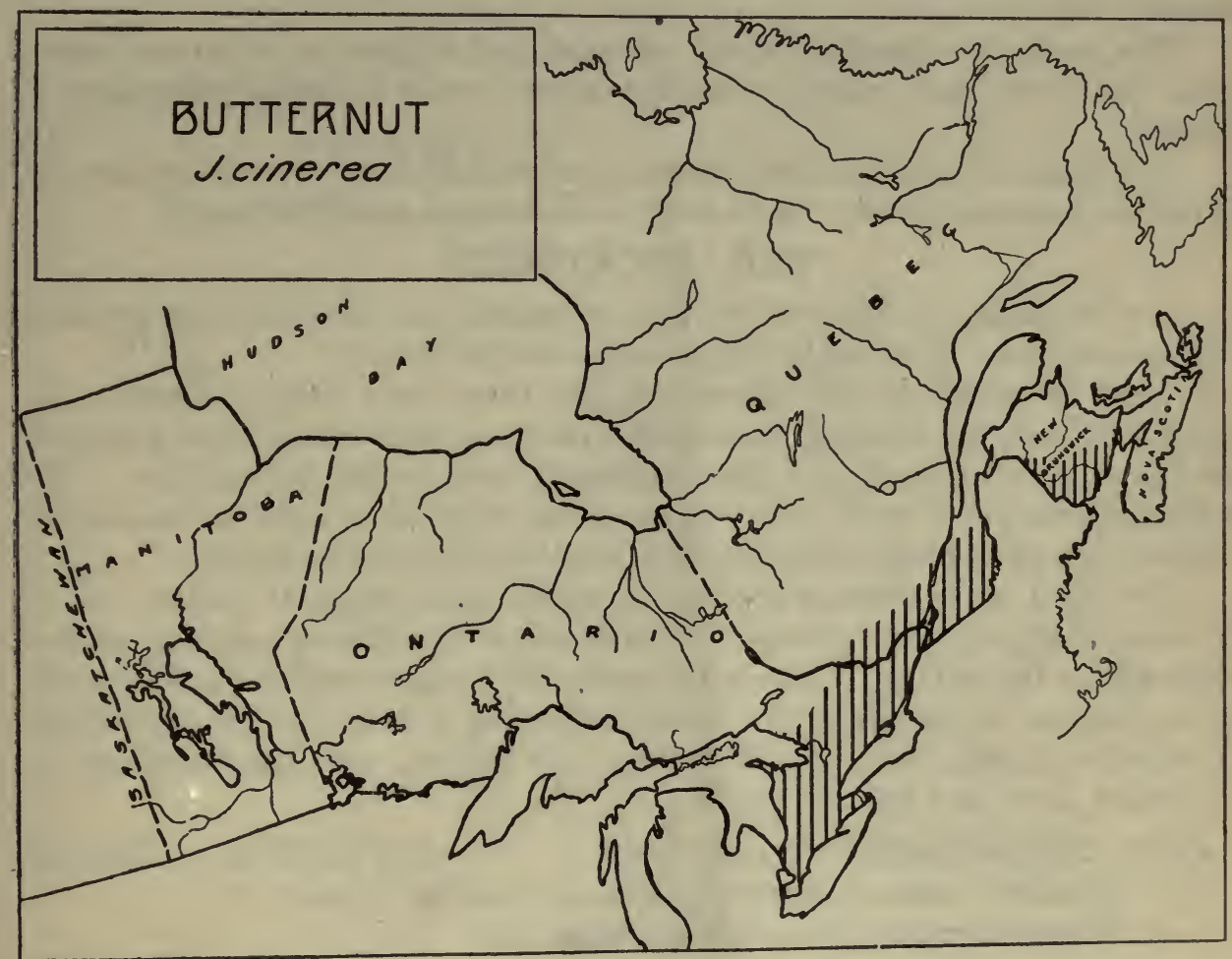

Georgian bay. It prefers rich, well-drained loam and is found solitary or in small groups associated with other hardwood species.

It is a medium-sized tree 40 to $50 \mathrm{ft}$. in height and $1 \mathrm{fo} 3 \mathrm{ft}$. in diameter. The trunk divides into several large branches which spread, forming a triangular-shaped crown in outline. The smaller branches dip down and turn up again in a manner characteristic of many of our nut trees. 
When young the butternut much resembles the black walnut, but they can readily be separated upon comparing their twigs and winter buds. In older trees the bark and fruit are sufficient to distinguish them.

The bark of the butternut is light grey with broad, smooth-topped ridges, which at a distance appear like whitish, interlacing, vertical stripes. The bark of the black walnut is much rougher and darker.

The leaves are compound, i.e. composed of many leaflets attached to a common stalk. This stalk is 10 to $25 \mathrm{in}$. long. The leaflets number from nine to seventeen and are an oblong oval in shape, saw-toothed, and pointed.

The twigs are downy and clammy and the pith, like that of the black walnut, is chambered. The winter buds are light brown, longer than broad, and downy.

The nut is oblong, pointed at one end, and 2 to $3 \mathrm{in.} \mathrm{long.} \mathrm{The} \mathrm{shell} \mathrm{is} \mathrm{deeply}$ furrowed, leaving many fine, hard, sharp, irregular ridges. The husk, or outer covering, is brown, very sticky, and will stain the hands if much handled. The kernel is edible.

The wood of the butternut is soft and weak, and is lighter in weight and colour than that of the black walnut, otherwise the two woods are similar in grain and texture.

In Canada it is used for boat-building and interior finish. As the occurrence of the tree is comparatively rare its wood is not common on the market.

\section{THE HICKORIES .}

Twelve species of hickory (Carya) are recognized and all of them are confined to this continent. Six occur in Canada, none west of Ontario.

They are related to the walnuts and, like them, have compound leaves and produce hard-shelled nuts which are surrounded by an outer shell or husk, but there are many points in which they differ sufficiently to be readily distinguished. The different species of hickory, however, are rather difficult to separate because of intermediate forms being sometimes developed by natural hybridization.

The wood of the different species is so similar in its technical qualities that it is usually sold simply as "hickory." The lumber of the different species is seldom separated on the market. The wood is among the hardest, toughest, and strongest of the timbers of commerce, few woods surpassing it in any of these qualities. It is used in Canada chiefly for vehicle stock, tool-handles, agricultural implements, machinery parts, and sporting goods.

CARYA CORDIFORMIS (Wang.) Koch

BITTERNUT HICKORY

Common names: Bitternut hickory, swamp hickory.

French names: Carya amer, noyer dur.

The bitternut hickory is a tree 50 to $60 \mathrm{ft}$. high and 1 to $11 / 2 \mathrm{ft}$. in diameter. The crown in the open is large and spreading.

The bark is a light granite grey, close-fitting, and roughened by shallow fissures and narrow ridges.

The twigs are slender as compared with the shagbark or mockernut hickories but not quite as delicate as those of the pignut. Recent shoots are an orangegreen colour and dotted. 
The winter buds are chief points of distinction. While the buds of all other hickories are brown the bitternut hickory has sulphur-yellow buds. They are long, curved, flattened, and pointed. Buds on the side of a twig are shorter and rounder than those at the end. Usually one or two buds on a stem still remain closed after the others have opened in the spring.

The leaves have from seven to eleven leaflets on one stem. The leaflets are narrower than those of any other hickory. Both upper and lower surfaces are smooth.

The nut is often broader than long and is covered with a thin husk. It has four ridges reaching almost half way from the point to the base. The shell is very thin; it is the thinnest-shelled hickory. The kernel is very bitter.

The bitternut hickory is found in southern Ontario from Georgian bay eastward and throughout the southwestern part of Quebec. It prefers low, wet

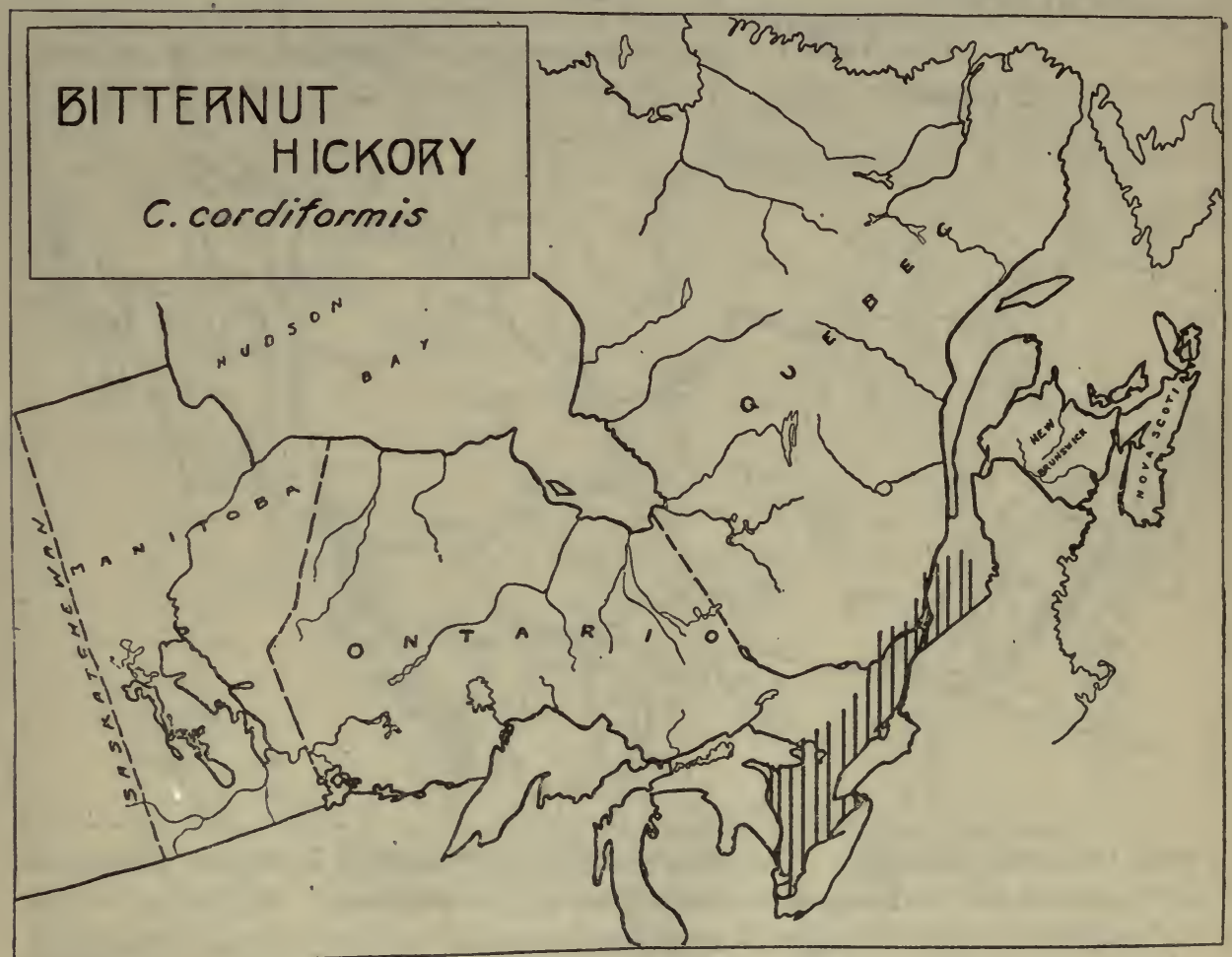

situations near streams, but is also found on higher ground in good soil. It is fairly tolerant of shade and grows scattered through other hardwoods. The rate of growth is rapid for a hickory, but, at best, is only medium when compared with other trees.

This is an important Canadian hickory on account of its wide distribution and common occurrence, but its wood is not usually so strong as that of the other species. 
CARYA OVATA (Mill.) Koch SHAGBARK HICKORY Common names: Shagbark hickory, shellbark hickory.

French names: Carya blanc, noyer écailleux, noyer blanc d' Amérique.

The shagbark hickory reaches a height of 50 to $80 \mathrm{ft}$. and a diameter of 1 to $2 \mathrm{ft}$., and is one of the largest hickories. The trunk is straight and columnar, topped with a small, flat crown when grown in a dense stand. In the open the trunk is shorter and is divided into a few short, heavy, spreading limbs forming a crown which in outline resembles an inverted cone.

The bark is light grey in colour, and flaky. It shags off in large plates which are free at both ends. This peculiarity gives it its common name and distinguishes

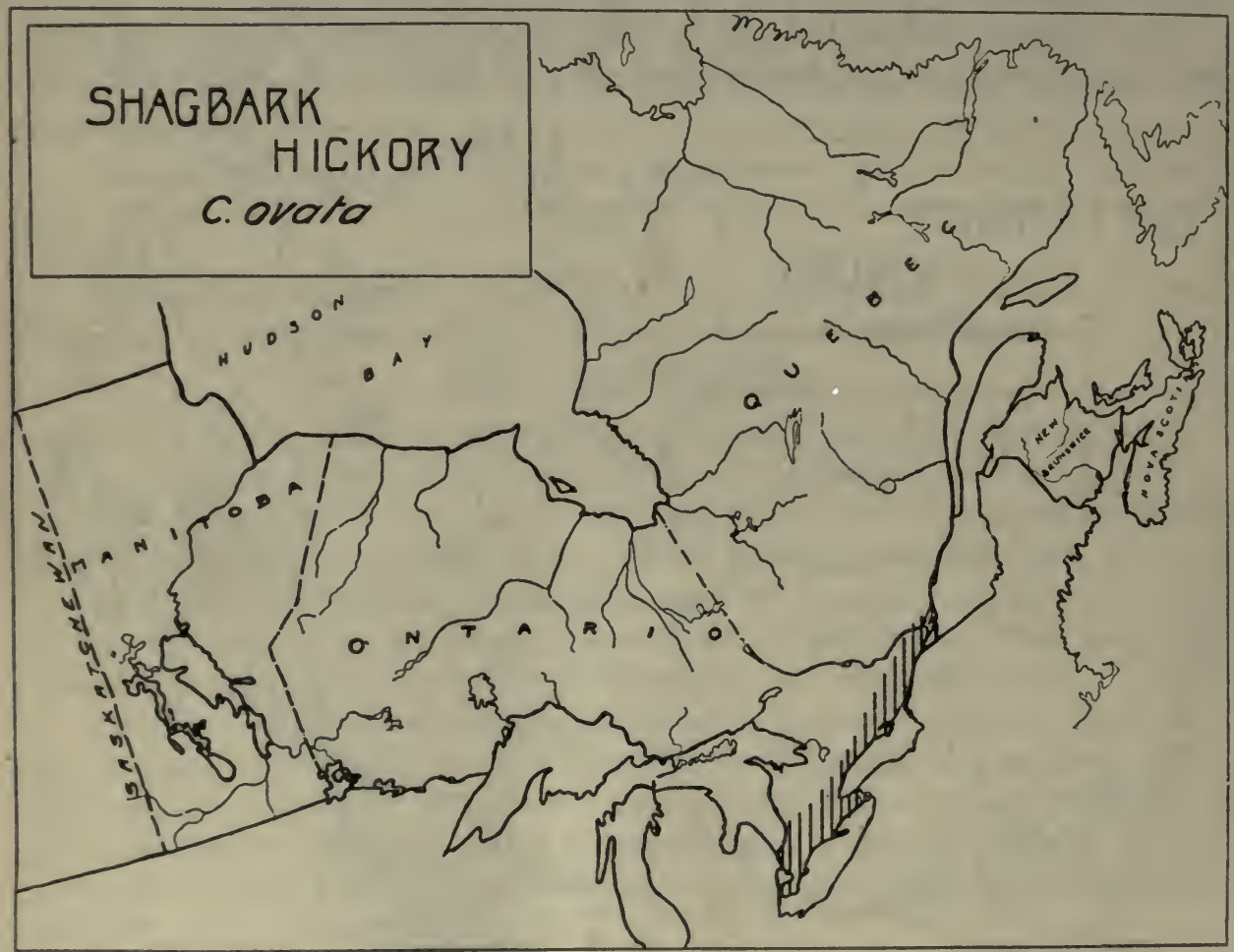

it from the other hickories. The bark of the pignut hickory is slightly shaggy on some trees but not to the same extent as that of the shagbark. The twigs, winter buds, and fruit of these two species are points by which they can be readilyseparated.

The twigs of the shagbark are coarse, reddish-brown, and shiny, sometimes slightly downy, and greyish.

The buds are yellowish-brown and large, and have two dark, projecting outer scales which are not found on the other hickories.

The leaves have five to seven leaflets on a stem, usually five. The leaflets are 4 to $8 \mathrm{in.}$ long, thin, yellowish-green, and usually have hair on their margins. The leaf-stem is rough. 
The shape of the fruit varies but is usually compressed laterally and is four-ridged. The husk splits and breaks into four sections. The kernel is sweet and edible, and the nut is of greater commercial value than that of any other native hickory.

The shagbark hickory has a long tap root and requires a deep, fresh, fertile, well-drained soil. It sprouts readily from the stump, endures considerable shade, and is usually found mixed with other hardwoods.

In Canada it is confined to southern Ontario and southwestern Quebec.

CARYA ALBA (L.) Koch

MOCKERNUT HICKORY

Common names: Mockernut hickory, whiteheart hickory, bigbud hickory.

French names: Carya tomenteux, noyer dur, noyer à noix douces, noyer blanc.

The mockernut hickory is a tall tree 75 to $90 \mathrm{ft}$. high when growing in the forest. Isolated it is shorter with a broad, round-topped crown. The lower branches have a tendency to droop more or less.

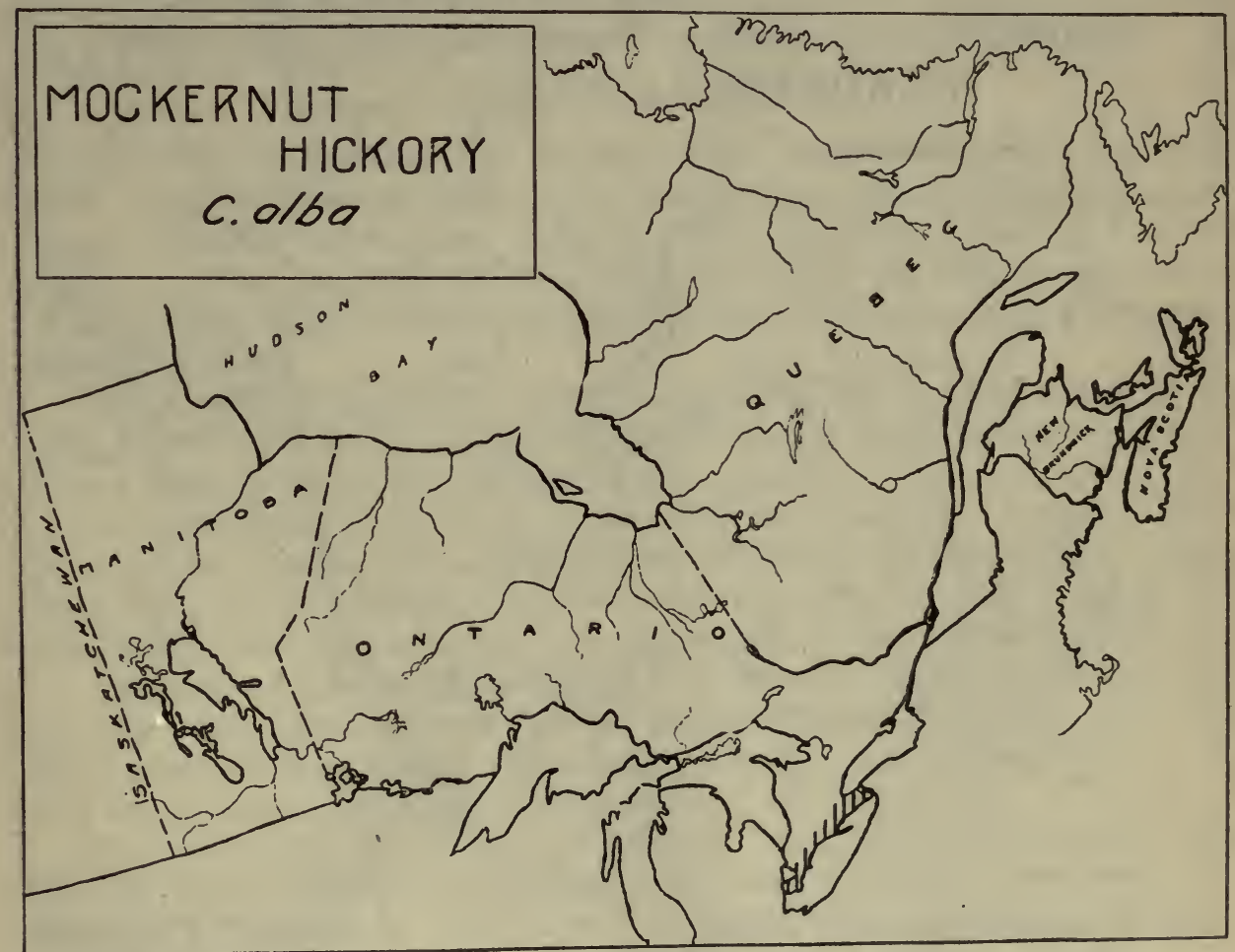

The bark is grey, smooth, not shaggy, and broken by close, wavy furrows. The tops of the ridges being a lighter shade of grey than the rest of the bark give to the trunk a somewhat rubbed or sand-papered appearance.

The twigs are very coarse and the winter buds large. The buds are slightly larger than those of the shagbark hickory and can be distinguished from them by 
their lack of persistent, projecting outer scales. They are hard, round, yellowishbrown, and downy.

The leaves are composed of seven to nine leaflets which are a deep yellowishgreen and rough-downy beneath. When crushed they are fragrant.

The nut is large but the shell is so thick that, when opened, the kernel is disappointing. The name "mockernut" is probably due to this peculiarity. It has the thickest shell of all hickories. The husk is hard and thick, and when the nut is ripe it splits in four directions from the tip half-way to the base. The kernel is sweet but difficult to extract.

The mockernut is found growing on a wide variety of soils but prefers welldrained, rich slopes. In Canada this tree is found in the counties bordering lakes St. Clair, Erie, and Ontario.

The wood of this species is sometimes considered to be superior to that of the other hickories.

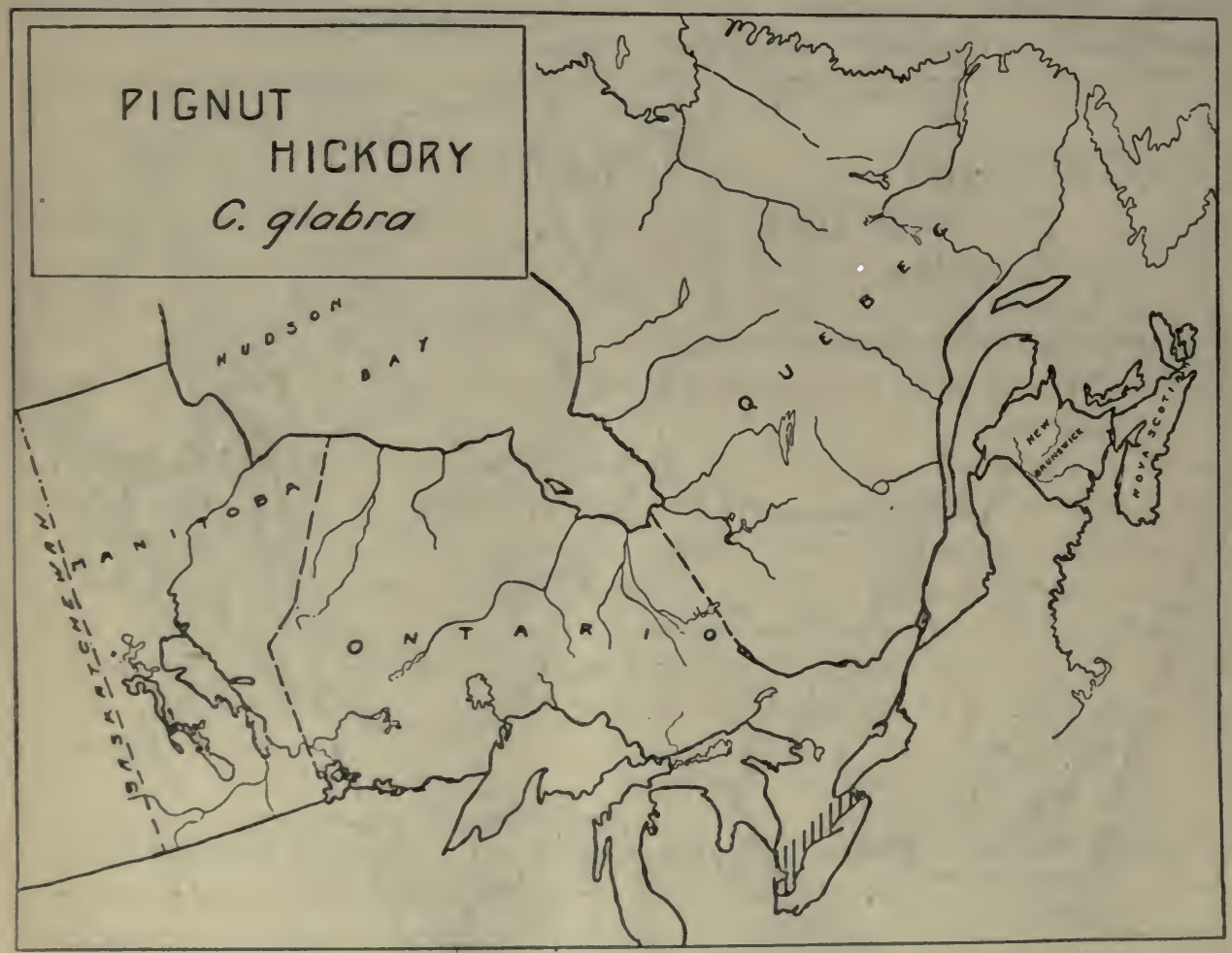

CARYA GLABRA (Mill.) Spach.

PIGNUT HICKORY

Common names: Pignut hickory, brown hickory, black hickory.

French names: Carya glabre, noyer à noix de cochon, carya des pourceaux. .

The pignut hickory is a tree 40 to $60 \mathrm{ft}$. in height and 2 to $3 \mathrm{ft}$. in diameter. When growing in the open the crown is very narrow and long, extending well down 
the trunk. The branches are frequently much twisted and contorted, the lower ones hanging towards the ground.

The bark is grey, tight-fitting in apearance, at times not unlike that of the white ash. Frequently it is slightly shaggy.

The twigs are delicate, being finer than those of the other hickories. They are inclined to droop or hang down.

The winter bud is yellowish-brown, round or egg-shaped, and smaller than that of any other hickory.

The leaves are composed of from five to nine leaflets (usually seven and rarely nine). They are a rich yellowish-green in colour and smooth on both sides.

The nuts vary in size. They are usually pear-shaped but some are oval. Others, again, are perfectly round or broader than long. The kernel is bitter or sweet. The husk splits only half-way to the base and, as a rule, falls off the tree with the nut.

It prefers rich, well-drained soils but grows under a variety of conditions. In Canada it is found in the Niagara peninsula and the counties bordering lake Erie.

The little pignut (Carya microcarpa) is considered a variety of this tree.

\section{THE WILLOWS}

The willow (Salix) is one of the most widely distributed trees in the whole world. Over one hundred and seventy species have been described, of which seventy-five are found in North America and of these fifty or more in Canada. Owing to the fact that they hybridize among themselves the varieties and crosses produced are seemingly without number and this makes the separation of the species extremely difficult.

The separation is mainly by floral characteristics which can be examined for only a short time in the spring, but even then their determination is often a matter of great difficulty and requires considerable experience.

The species differ very widely in size and habit of growth. The majority of the indigenous species never reach tree size but grow as shrubs in thickets, sometimes only a few inches high. They occur, for the most part, along the borders of rivers and streams but frequently occupy large areas of comparatively dry land.

The willows can be readily recognized from the other trees by their bitter bark and their winter buds, which are covered by single scales. In most species these winter buds are long, narrow, and pointed, and sometimes slightly curved, and have the appearance of being pressed against the side of the twig.

The wood of the different species is similar. It is light, soft, and tough, and does not swell or shrink after seasoning. It is very perishable when exposed to moisture. In Canada the wood is used for artificial limbs, cricket bats and slack cooperage.

\section{THE POPLARS}

The poplars (Populus), various species of which genus are called also aspens and cottonwoods, are widely distributed throughout the northern portion of both the eastern and western hemispheres. There are some twenty-five or twenty-six species known, of which eight are native to Canada. Many exotic species, such 
as the familiar silver poplar (Populus alba), distinguished by a dense, white, persistent down on the under surface of the leaf, and the tall, erect Lombardy poplar (Populus nigra var. Italica), have been introduced and are growing all through the older settled portion of Eastern Canada.

The poplars are related to the willows and resemble them in their habit and in their method of reproduction. Even the leaves of some species resemble those of the willow. They are readily distinguished from these trees, however, by their winter buds. The buds of the poplars have many scales and those of the willows have but one.

The seed is very minute, light, and tufted and is easily carried long distances by the winds. This, together with its abundance, probably accounts for the widespread distribution of the poplars.

Many of the species propagate by means of suckers that spring from the roots, and most of them sprout readily from the stump when cut. The artificial reproduction of these trees is done chiefly by planting cuttings.

POPULUS TREMULOIDES, Michx.

ASPEN

Common names: Aspen, asp, trembling aspen, quaking asp, aspen poplar, white poplar, popple, smooth-barked poplar, poplar.

Frencl names: Tremble, peuplier faux-tremble, peuplier tremble, peuplier d'Athènes, bois blanc*, peuplier.

The aspen is a tree of very wide distribution, extending completely across Canada from Labrador and Hudson bay to the mouth of the Mackenzie river and Alaska.

It is not a very large tree, averaging about $40 \mathrm{ft}$. in height and 8 to $10 \mathrm{in}$. in diameter, but sometimes reaching a height of $90 \mathrm{ft}$. and a diameter of $24 \mathrm{in}$. The trunk is slender and the crown round-topped and open.

The bark is rough with flat ridges and deep furrows, becoming paler on limbs.

The twigs are slender, reddish, and smooth and the winter buds small, shiny, and slightly sticky.

The leaves are $11 / 2$ to $21 / 2 \mathrm{in}$. long and in outline are almost circular. The apex is pointed and the base often slightly heart-shaped. The margin is finely toothed. The upper surface is dark green and the lower surface slightly paler. The leafstem is much flattened sideways making the leaves very unstable and causing them to tremble in the smallest breeze.

It is a very prolific seeder, shedding seed early in the summer. The seed is very minute and light, and attached to a downy tuft which causes it to be carried long distances by the wind. For this reason it is often the first tree to come in on a burned area.

It grows best on well-drained loam, but is found on a large variety of soils. It occurs most frequently in pure stands or mixed with other light-seeded species, such as the balsam poplar, large-toothed aspen, or the birches. The growth is rapid but not persistent. It is much subject to certain forms of fungus disease and is not a long-lived tree. 
The aspen much resembles the large-toothed aspen in general habit, but these two trees can be readily distinguished by their buds in winter and their leaves in summer.

$\Lambda$ s this tree is found in Canada over large areas where other timber is scarce it is often cut into lumber and used in other forms, merely because it can be easily

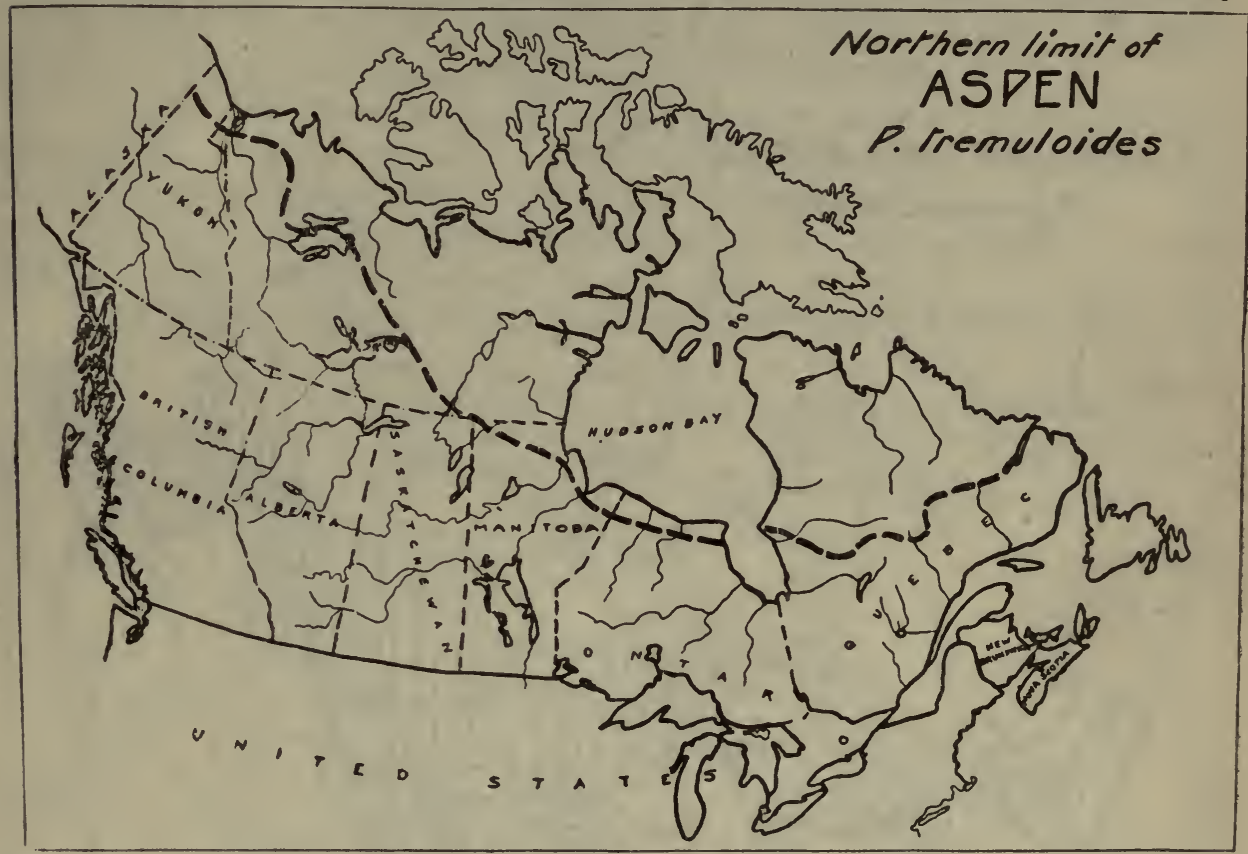

obtained. It is a very valuable firewood in the Prairie Provinces. As lumber it is difficult to season and very perishable. It is often preferred to other woods for excelsior, boxes and barrels for foodstuffs, and in the manufacture of certain kinds of wood-pulp. The wood is light, soft, and very tough, and in Europe is used almost exclusively for match sticks.

\section{POPULUS GRANDIDENTATA, Michx. LARGE-TOOTHED ASPEN}

Common names: Large-toothed aspen, big-toothed poplar, poplar.

French names: Grand tremble, peuplier à grandes dents.

In Canada the large-toothed aspen is found from Nova Scotia and New Brunswick westward, throughout Quebec and Ontario, south of the height of land dividing the watersheds of the Great Lakes and Hudson bay.

The large-toothed aspen is a medium-sized tree 40 to $50 \mathrm{ft}$. in height and 1 to $2 \mathrm{ft}$. in diameter. The top is narrow, round-topped, and very open.

The bark on young trees is smooth and greenish-grey, on older trees it becomes cracked. It resembles that of the aspen, except that on old trees it is not so deeply furrowed.

The twigs are stout, reddish-brown, and, at first, more or less downy. The winter buds are shorter than those of the aspen and, on the whole, stand out more 
from the twig. They are dull, and not sticky, and the margin of the scale is grey and downy.

The leaves are coarse, thick, and with margins coarsely notched with rounded teeth. They are 3 to 4 in. long-larger than those of the aspen.

The tree grows on the same soils as the aspen, but seems to prefer moist, sandy slopes or borders of streams. It is found in pure stands or mixed with aspen,

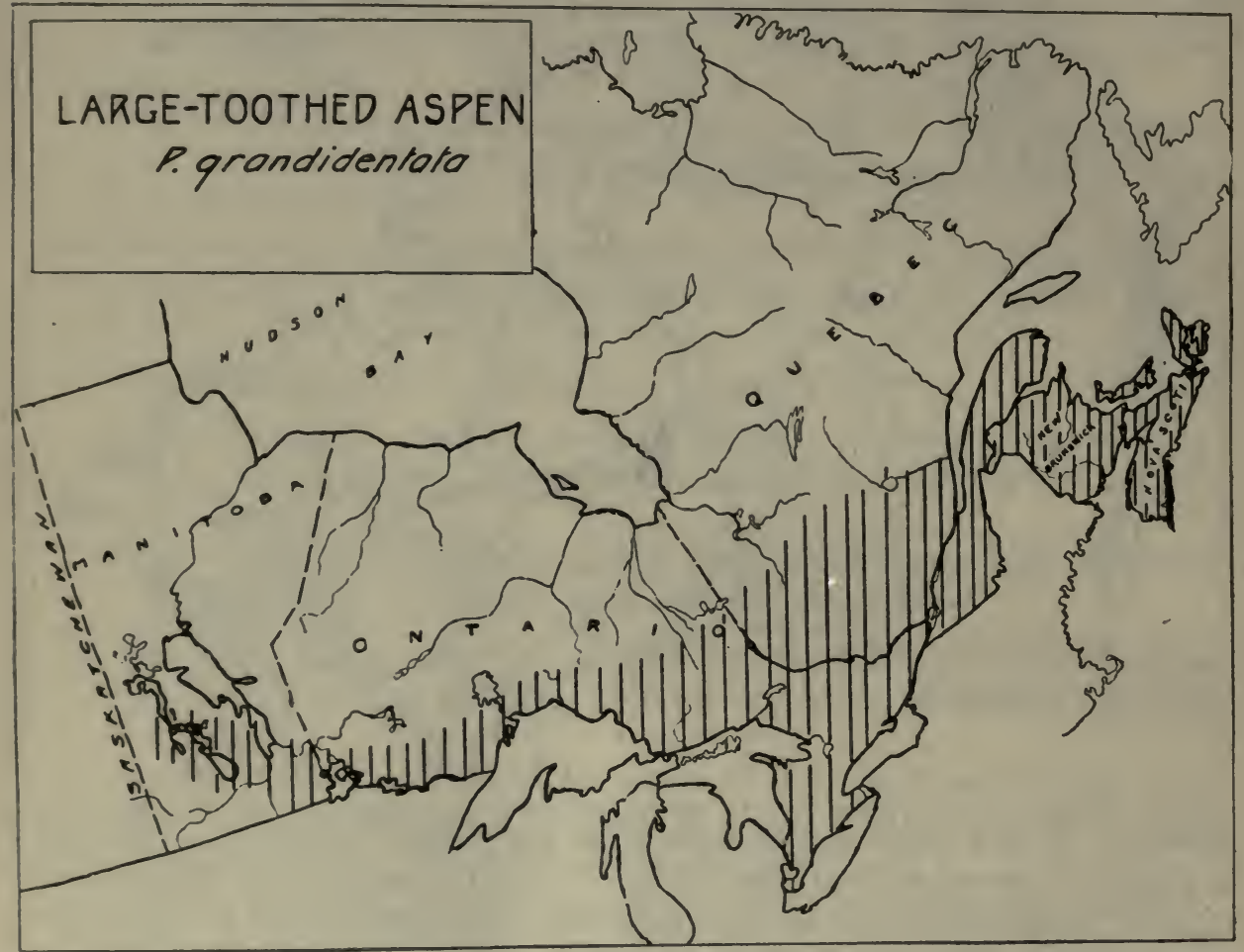

balsam poplar, and birch. Iike the aspen it is a good seeder and comes in quickly on burned areas where a few mature trees have escaped the flames.

This tree is cut and used locally for firewood, but is seldom sawn into lumber in Canada.

POPULUS BALSAMIFERA, L.

BALSAM POPLAR

Common names: Balsam poplar, balm, balm poplar, black poplar, balm of Gilead*, rough-barked poplar, poplar, tacamahac (Quebec and Maritime Provinces).

French names: Peuplier baumier, baumier.

The balsam poplar is distributed across Canada from Labrador to the mouth of the Mackenzie river, and to the Pacific ocean in northern British Columbia.

It is a medium-sized tree 50 to $60 \mathrm{ft}$. in height and 1 to $2 \mathrm{ft}$. in diameter. In the Peace River country of Alberta it sometimes reaches the height of $100 \mathrm{ft}$. The top is narrow and open. 
The bark is brown or grey, and roughened by dark excrescences. It is rougher than that of the aspen.

The twigs are warty and much coarser than those of the aspen. The buds are large and sealed with a fragrant, sticky gum.

The leaves are 3 to 5 in. long and more oval or egg-shaped than those of either of the aspens. The margin is finely toothed and the base rounded. The leafstem is round in cross-section, or only the lower half is flattened.

In summer it is easily distinguished from the other poplars of Eastern Canada by its leaves. No other poplar has leaves of such an oval outline. The teeth on the margin are also much finer than those of either of the aspens.

It grows on rich, moist sites such as banks of rivers, bottom lands, etc., and is found in small groups or mixed with willows, alders, and spruce.

When sawn into lumber balsam poplar is usually classed as cottonwood. Its

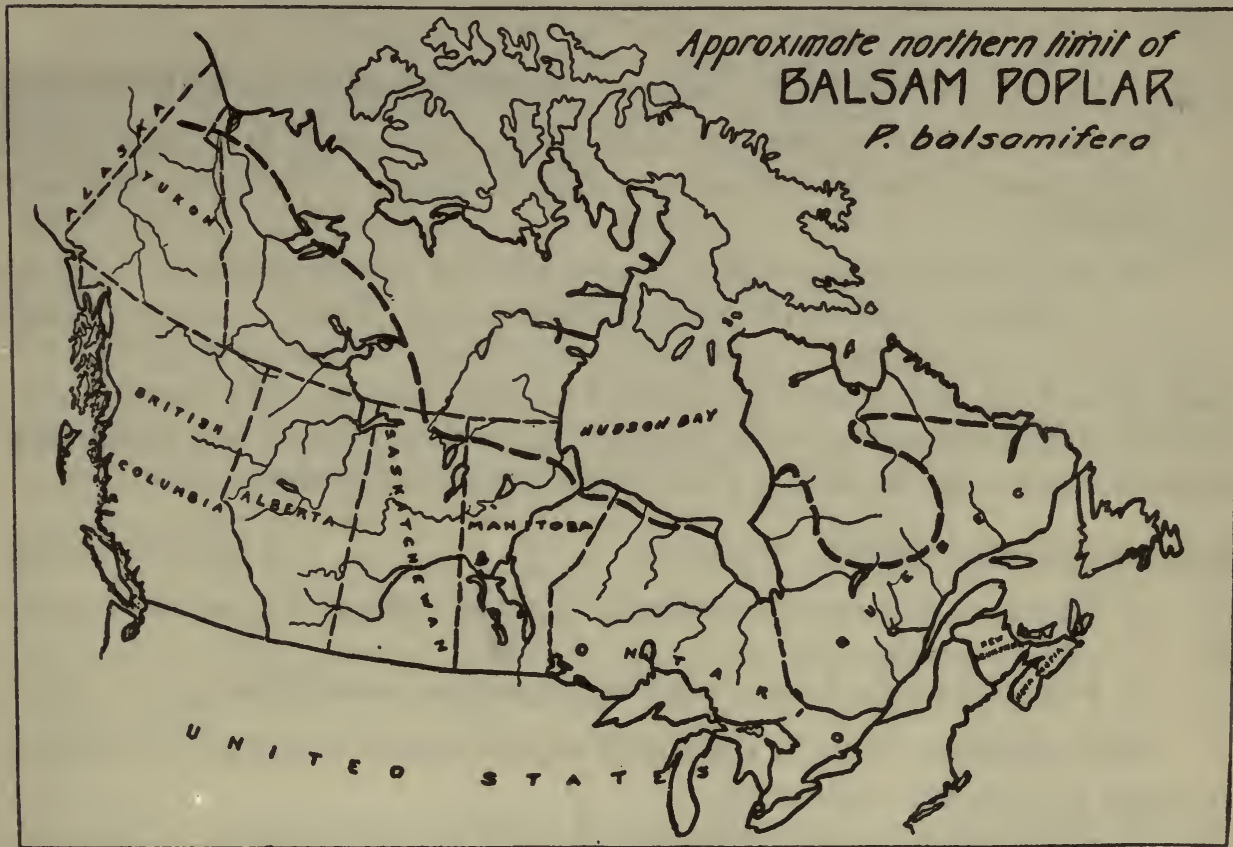

wood is tougher than that of aspen, but is useless as firewood. Otherwise its uses are similar to those of aspen.

The balm of Gilead (Populus candicans) is considered by many a variety of the balsam poplar. It can be distinguished from the latter tree by the more heart-shaped base of its leaves.

POPULUS ACUMINATA, Ryd.

LANCELEAF COTTONWOOD

The lanceleaf cottonwood is a medium-sized tree 35 to $40 \mathrm{ft}$. high and 1 to $11 / 2$ $\mathrm{ft}$. in diameter, with a rounded or pyramidal crown formed by stout, spreading branches.

22510-5 
It is not abundant in Canada, being confined in its distribution to the banks of streams in southern Alberta, and is of no commercial value. In habit and distribution it is like the narrowleaf cottonwood and is often mistaken for that tree.

The bark on young trees is smooth and nearly white, on old trunks it is greyish-brown and deeply cut into broad, flat ridges.

The twigs are slightly four-angled in cross-section and roughened by projecting leaf-scars. Their greenish-brown colour distinguishes them from the orangebrown twigs of the narrowleaf cottonwood.

The winter buds are longer, more curved, more resinous, and the points are more drawn out than those of the narrowleaf cottonwood.

The leaves are 2 to 4 in. long and $3 / 4$ to 2 in. wide, and more coarsely notched than those of the narrowleaf cottonwood. The base is tapered and the tip long drawn out. They are dark green and shiny above and have a slender, yellow midrib.

\section{POPULUS ANGUSTIFOLIA, James NARROWLEAF COTTONWOOD}

The narrowleaf cottonwood is a medium-sized tree, 35 to $40 \mathrm{ft}$. high and 12 to $18 \mathrm{in}$. in diameter, and with a narrow, pyramidal crown. Its wood is seldom used commercially.

Like the lanceleaf cottonwood it is confined to the banks of streams in southern Alberta and Saskatchewan, and is often mistaken for it. These trees can be readily distinguished by their leaves, those of the narrowleaf cottonwood being 2 to 3 in. long, $1 / 2$ to $1 \mathrm{in}$. wide, narrow, tapering, and sharp-pointed. The leaf resembles more the leaf of a broadleaf willow than that of a poplar. The base is rounder, the notching is finer, and the stem is shorter than that of the lanceleaf cottonwood.

POPULUS DELTOIDES, Marsh.

COTTONWOOD

Common names: Cottonwood, common cottonwood, eastern cottonwood.

French names: Liard, cotonnier, peuplier monalifère.

The cottonwood is one of the largest of the poplars, averaging 75 to $100 \mathrm{ft}$. in height and 2 to $4 \mathrm{ft}$. in diameter.

The crown is conical and fairly dense on young trees, but spreads out and opens up as they become older.

On old trees the bark is dark grey and more broken than on most poplars.

The tree can be distinguished from the other poplars in winter by the yellowishness of the twigs and by the divergent buds. Ridges run down both sides of the twig from the bases of the leaf-scars. Young sprouts are, also, often angled.

The winter buds are glossy and resinous, but have less resin than most of the poplars. They are $1 / 2 \mathrm{in}$. long, somewhat flattened, and chestnut-brown in colour.

The leaves are a good distinguishing feature in summer. They are triangular in outline and coarsely toothed. The base is square and the apex long and pointed. The length and width are about the same. The stems are compressed sideways. 
The cottonwood is a very rapid grower and fairly hardy, and for that reason is used considerably by the farmers in western Canada for planting in shelter-belts and for fuel.

At the Dominion Forest Nursery Station at Indian Head, Saskatchewan, these trees have reached the height of $20 \mathrm{ft}$. six years after planting them as seedlings.

The tree produces seed abundantly but unless conditions are very favourable the seed does not germinate. It is most conveniently reproduced by cuttings or sprouts.

In Eastern Canada this tree is found scattered from Quebec westward throughout southern Ontario, but is nowhere abundant. In Western Canada it is found in the southern part of the three Prairie Provinces. It is a tree that requires considerable moisture and is, therefore, mostly confined to the banks of streams and bottoms of river valleys.

Cottonwood lumber is usually considered to be more valuable than that of the other poplars on account of its toughness. Cottonwood is imported for the manufacture of vehicle body work, but in Canada the tree is not common and is only valuable commercially in a purely local way.

\section{POPULUS TRICHOCARPA, Torr. \& Gray BLACK COTTONWOOD}

Common names: Black cottonwood, balsam cottonwood, balm cottonwood, western balm, cottonwood.

French name: Peuplier de l'Ouest.

The black cottonwood is found from southern Alaska sonthward along the coast of British Columbia, where it grows mixed with various conifers such as Sitka spruce and Douglas fir, and occasionally occurs in small, pure groves. It demands a moist soil and is therefore confined mostly to river bottoms.

It is a tree 80 to $125 \mathrm{ft}$. in height and 3 to $4 \mathrm{ft}$. in diameter, and is one of our largest and most rapid-growing native broad-leaved trees. It is very intolerant of shade and when growing with other trees it survives only by virtue of its rapid growth which enables it to keep ahead of the other species with which it occurs. Grown in a dense stand it produces a long, clear bole with a small, round open crown.

The bark is grey and thick and, on large trees, well marked with deep, regular furrows. The twigs are shiny and yellowish in colour. When young they are slightly angled but later become rounded in cross-section.

The winter buds are $3 / 8$ to $3 / 4$ in . long, reddish-yellow, and slightly resinous and fragrant. They are frequently curved or bent near the middl.

The leaves are very much like those of the balsam poplar in outline, but are paler beneath and more leathery in texture. The stem is round in cross-section.

Black cottonwood lumber is the only wood of its kind in Britisin Columbia, and is, therefore, used for purposes for which the eastern species are seldom 11sed. It is the largest soft, non-resinous wood in the province, and is used chiefly for boxes and cooperage. 


\section{THE BIRCHES}

The thirty species of birch (Betula) recognized are confined chiefly to the north temperate zone and range in size from very large trees to very small shrubs. Nine species occur in Canada of which four inhabit the Pacific coast region. Certain species are found at the very limit of tree growth in the north.

The bark of all birches is characteristically marked with long horizontal slits or lenticels, and on young trees of most species it can be separated into papery layers.

The leaves are alternate in their arrangement on the twig, that is they do not come out in pairs from the opposite sides of the twig, although on twigs one year old they are of ten produced in pairs on each side of a bud.

The birches are related to the alders, and, like them, produce their seed in small, scaly cones. These cones in the case of the birches fall to pieces when ripe, while those of the alders remain intact.

BETULA POPULIFOLIA, Marsh.

WHITE BIRCH

Common names: White birch, grey birch, wire birch, poplar. leaved birch.

French names: Bouleau gris, bouleau à feuilles de peuplier, bouleau rouge*.

The white birch ranges from the Maritime Provinces westward through the St. Lawrence river valley to eastern Ontario. It is found growing on dry, gravelly

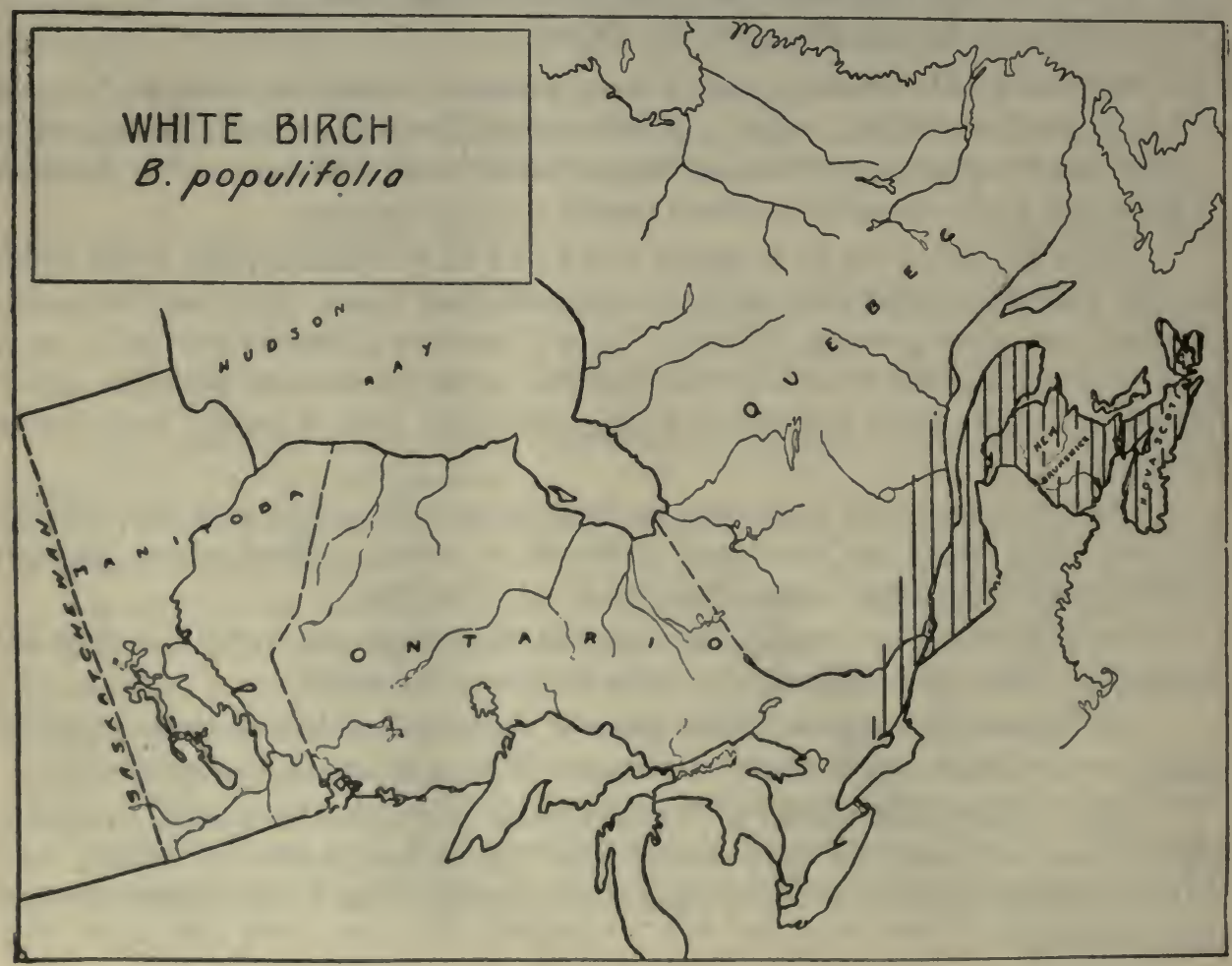


soils and is often one of the first trees to spring up after a forest fire. Occasionally it is found in wet ground along the margin of streams and swamps.

It is a small tree, rarely over 30 or $35 \mathrm{ft}$. in height. The trunk usually extends undivided to the top of the tree. The branches are slender and divide into many long, fine, flexible branchlets that have a tendency to droop. The ends of the twigs are rough to the touch.

The bark on the trunk and larger branches is thin and white, but it does not split readily into papery layers as does that of the canoe birch. On the trunk beneath each limb is a triangular black spot that is characteristic of this tree. The bark at the base of the trunk on the larger trees is frequently broken by irregular fissures.

The winter buds are slender, brown, about $1 / 4$ in. long, pointed, and waxy. Those of the canoe birch, for which this tree might be mistaken, are larger and somewhat sticky.

The leaves are $2 \frac{1}{2}$ to 3 in. long, triangular in outline, with a long, tapering point. The margin is double-toothed and the upper surface is bright green and shiny. The stems are smooth and long, longer than those of the paper or canoe birch, and the leaves are therefore agitated by the slightest breeze and flutter as freely as those of the aspen.

As this tree rarely reaches commercial size in Canada its wood is seldom used. It is the toughest of all the birches and the most perishable. It is used occasionally for barrel hoops and hockey sticks.

BETULA ALBA, L., var. PAPYRIFERA (Marsh.) Spach. PAPER BIRCH Common names: Paper birch, canoe birch, silver birch, white birch*.

French names: Bouleau blanc*, bouleau à papier, bouleau à canot.

The paper, or canoe, birch has an extremely wide range in Canada, being found from Labrador and the Maritime Provinces westward to Yukon territory and to the north Pacific coast. Along with tamarack, white spruce and black spruce, balsam poplar and aspen, it reaches its northern limit near the mouth of the Mackenzie river.

It is a tree rarely over $70 \mathrm{ft}$. in height or with a diameter over $18 \mathrm{in.}$ Ordinarily it is about $50 \mathrm{ft}$. high and 8 to $10 \mathrm{in}$. in diameter. In the forest the trunk is long and clear but in the open it is short, and the crown is large, irregular, and composed of many upright branches.

The white, tough, easily split, thin, papery bark of the trunk and larger limbs is too well known to need further description. The white birch is the only other tree the bark of which is likely to be mistaken for that of this tree; and the white birch can be distinguished from it by the fact that the bark of the latter is usually of a dirty white colour, with a chalky surface, and will not separate into thin sheets as readily as that of the paper birch.

The branches are stouter than those of other birches, and they do not tend to droop as do those of the white birch. The twigs are also smoother and coarser 


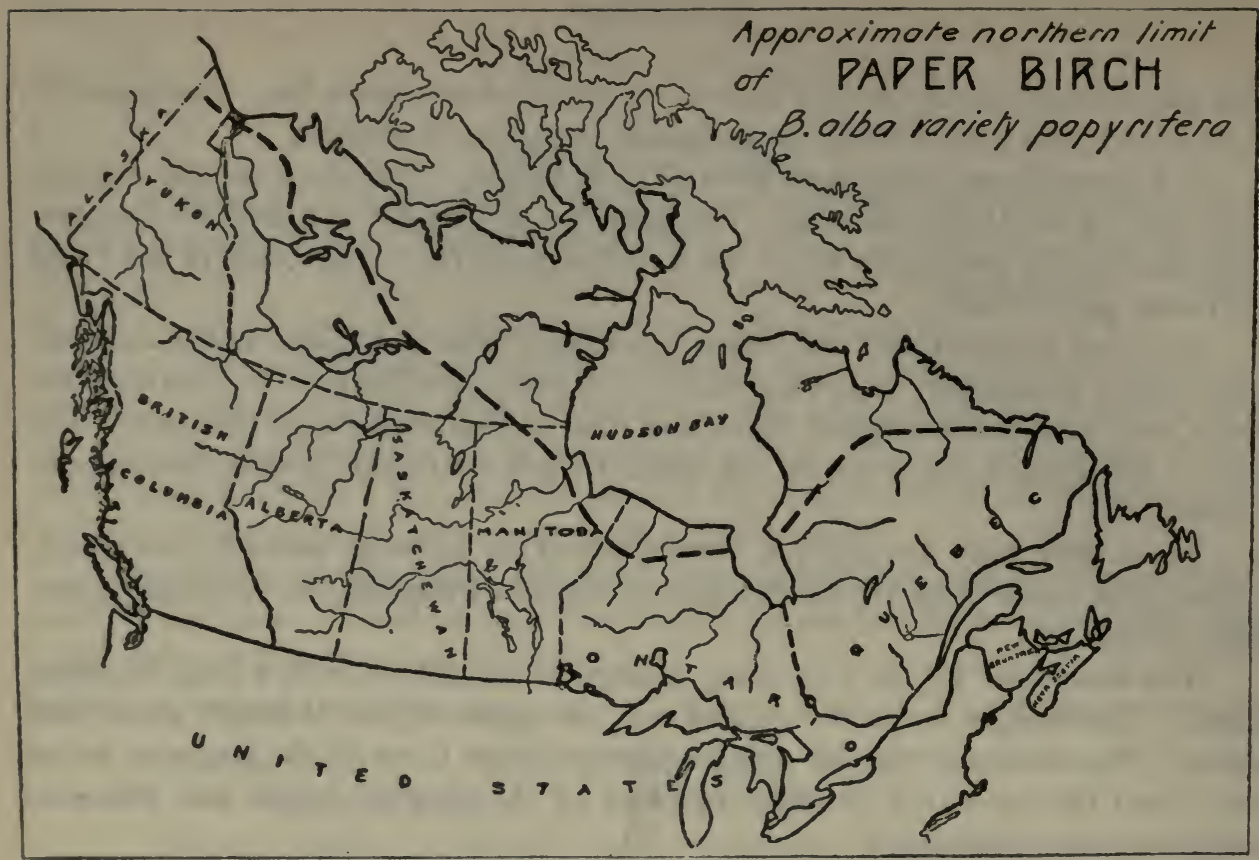

than those of the white birch, and they are somewhat sticky near the point of attachment of the winter bud. The winter buds, themselves, are sticky and larger than those of the other birches.

The leaves are good features by which to distinguish most birches, since they differ considerably in many points. Those of the paper birch are 2 to $3 \mathrm{in}$. long, and oval in general outline. The teeth are coarse and irregular. The upper surface is dull green and smooth, and the stems are short and downy.

This tree is often considered as a "tree weed" but of late years the use of its wood has been increasing rapidly. While the wood is soft and perishable it is tough, compact, and easily worked, and valuable for the manufacture of spools, bobbins, dowels, clothes-pins, shoe-pegs, and shanks, and all small woodenware generally.

It is from the bark of this tree that the Indians have for generations made their famous birch-bark canoes; hence one of its common names.

BETULA OCCIDENTALIS, Hooker

WESTERN BIRCH

Common names: Western birch, British Columbia birch, black birch.

French name: Bouleau occidental.

The range of the western birch in Canada is imperfectly defined, but it is probably confined to southwestern British Columbia, mainly to the Fraser river valley. It is one of the largest birches on this continent and the only one of commercial importance on the Pacific coast. It is sawn into lumber and used for interior finish in British Columbia. 
It is frequently found with a height of 70 to $80 \mathrm{ft}$. and a trunk diameter of 3 to $31 / 2 \mathrm{ft}$. The trunk of the forest tree is clear of branches for 50 or $60 \mathrm{ft}$. The crown is cone-shaped and open.

The bark of the trunk is brown, smooth, and shiny, and can be separated into thin layers.

The leaves are $2 \frac{1}{2}$ to $3 \mathrm{in}$. long, dull, deep green, and broadly oval in outline. The base at times is almost a straight line which gives the leaf a triangular outline. Those of the Alaska and mountain birches, the two other Pacific coast birches, are smaller.

BETULA LUTEA, Michx.

YELLOW BIRCH

Common names: Yellow birch, tall birch, curly birch, gold birch (Nova Scotia), red birch*, hard birch, black birch*.

French names: Merisier, bouleau jaune, merisier jaune, merisier ondé, merisier rouge*.

The yellow birch is found from Newfoundland and the Maritime Provinces westward to the east side of lake Superior, also west of this lake from Fort William along the Canada-United States boundary to the lake of the Woods.

It is the largest of our native birches and is sometimes found $100 \mathrm{ft}$. high and with a trunk diameter of 3 to $4 \mathrm{ft}$. In the forest the trunk is long and clear and has a moderate amount of taper. In the open the crown is widespread, but the central axis is fairly well defined.

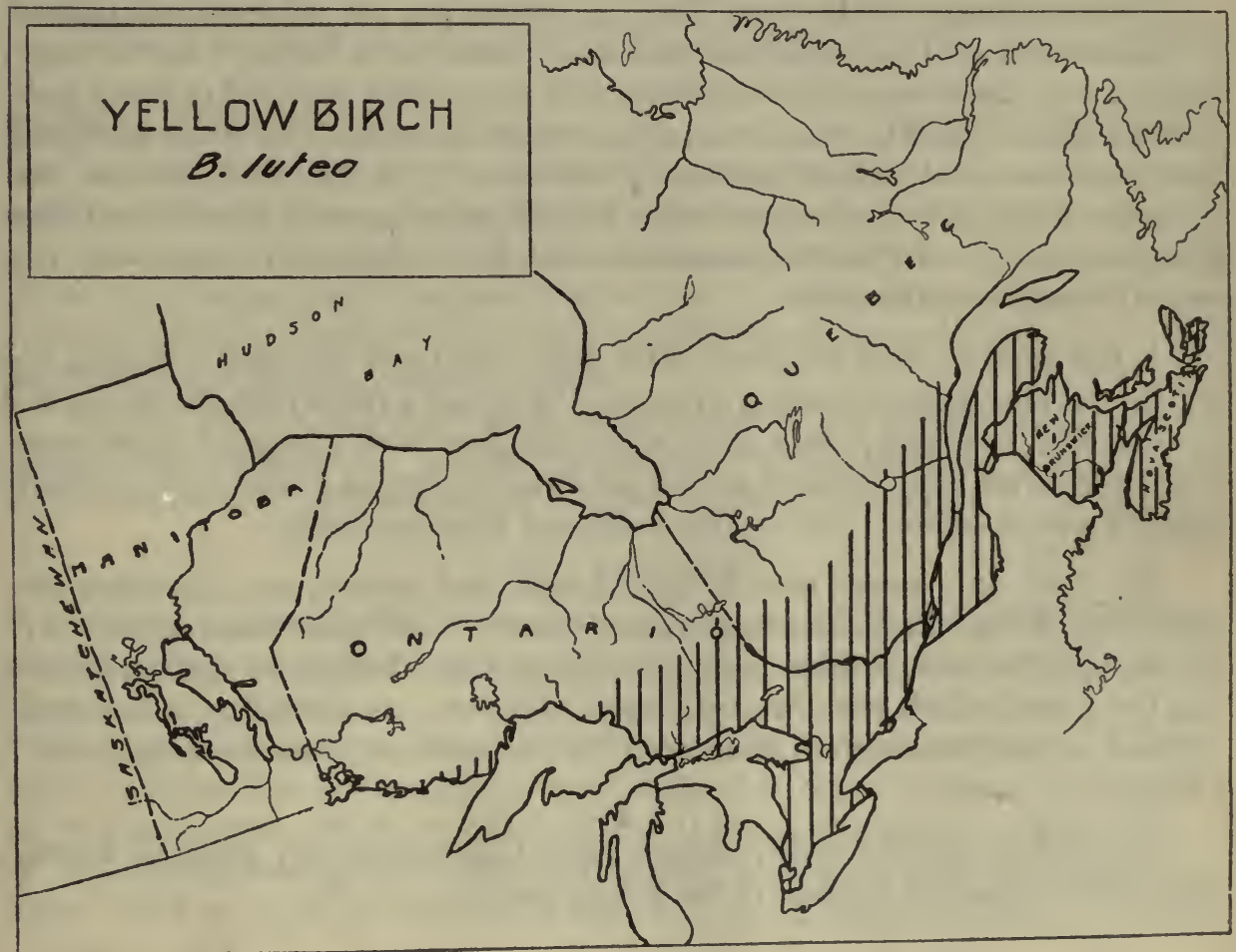


This birch gets its name from its yellowish, straw-coloured bark. On young trees it is smooth but as the tree gets older it peels into papery bands with curled ends, which form a fringe along the length of the trunk.

The twigs are light brown, shiny, and smooth, and the winter buds are pointed, light chestnut-brown, and about $1 / 4$ in. long.

The leaves are 3 to 4 in. long, and coarsely toothed as compared with those of the other birches. They are dull green above and downy beneath, especially along the veins. The stems are short, slender, grooved, and downy.

Birch is the most important hardwood sawn into lumber in Canada, and yellow birch forms the greater part of the birch lumber produced. The use of the wood is steadily increasing for such purposes as flooring, furniture, interior finish, vehicle stock, agricultural implements, and handles. Small trees and mill waste are used in wood distillation.

BETULA LENTA, Linn.

SWEET BIRCH

Common names: Sweet birch, cherry birch, red birch, black birch.

French names: Bouleau merisier, merisier rouge, merisier odorant, bouleau acajou, bouleau à sucre.

The distribution of the sweet birch in Canada has not yet been well defined. It has been reported by lumbermen and others from Nova Scotia to northwestern Ontario, but there are reasons to believe that it has been confused in many cases with the yellow birch (Betula lutea), a tree which occasionally develops specimens with bark somewhat resembling that of this tree. It is, therefore, possible that the sweet birch does not extend much beyond those parts of Quebec and New Brunswick that border on the Canada-United States boundary, where the tree enters Canada from the south.

It is a medium-sized tree about $50 \mathrm{ft}$. high with trunk diameter averaging $11 / 2$ to $2 \mathrm{ft}$., but occasionally reaching a height of $75 \mathrm{ft}$. and a trunk diameter of $31 / 2$ or 4 ft. On very poor soil it is a mere shrub-like tree with a stunted appearance. The branches are numerous and spread out from the stem at a wide angle, but form rather a narrow crown. The smaller twigs and branches droop.

The bark on younger trees is dark brown and smooth, and resembles very much that of the cherry, whence the name "cherry birch" sometimes applied to it. On old trees the bark is thick and almost black, and is broken by shallow grooves into flat plates, which turn up at the edge. It is very aromatic and is frequently distilled for the winter-green flavouring that is produced from an ethereal oil it contains.

The shiny, brown, slender, smooth twigs have also a very aromatic flavour; more distinct than in the case of the yellow birch. 
The winter buds are slender, pointed, reddish-brown, and, like those of most birches, set upon small, spur-like shoots. They stand off more from the twig than do those of the yellow birch.

The leaves are $21 / 2$ to $5 \mathrm{in}$. long, and dark waxy-green in colour. In outline they are oval-pointed and have many fine teeth, finer than those of the yellow birch. The base is more deeply scalloped or heart-shaped than that of the leaf of any other birch. The under side is hairy. The stems are stout, hairy, and deeply grooved.

The wood is more highly prized for furniture and cabinet work than that of yellow birch, because of its deeper colour and its satiny lustre. As a general rule the two species are not separated as lumber and are sold together as "hard birch."

\section{BETULA ALASKANA, Sarg.}

ALASKA BIRCH

Very little is known of the Alaska birch or its range. It has been found from central Saskatchewan to the mouth of the Mackenzie river and westward in northern British Columbia, Yukon district, and Alaska.

It is a small tree commonly 20 to $30 \mathrm{ft}$. in height but occasionally higher, and at the present time it is of no commercial importance.

The bark is white to reddish-brown, thin, and firm, but can be separated into thin scales. The bark of the mountain birch cannot be separated in this way.

The leaves are very much like those of the western birch, except that they are usually smaller and their tips are longer or more drawn out. They are thin, smooth, and dark green. The stems are slender and reddish.

The cones, which are 1 to $1 \frac{1}{4} \mathrm{in}$. long, are larger than those of the mountain birch.

\section{BETULA FONTINALIS, Sarg.}

MOUNTAIN BIRCH

The mountain birch is a small, shrub-like tree 15 to $20 \mathrm{ft}$. high, of little or no commercial importance. Its range is not perfectly known but it has been reported in various places throughout British Columbia, south of the Peace river, and east of the Coast range, also in western Alberta in the foot-hills of the Rocky mountains. It is distinguished from,the other western birches by its dark red, shiny bark that does not peel or separate into thin layers.

The leaves, too, are much smaller than those of the western birch and more nearly circular in outline. The margins are very coarsely toothed. The cones are, on the whole, shorter than those of the other western species.

\section{THE ALDERS}

Twenty species of alder (Alnus) are recognized. They are widely distributed throughout the temperate and cooler regions of this continent, also in South America, Europe, and southern Asia. A few of them attain tree size, but for the most part they are shrubs growing in dense thickets along the banks of streams and on wet slopes Of the five or six native species the red, Sitka, and mountain alders of the Pacific coast and the speckled alder of the East sometimes reach tree size.

All the alders resemble each other in their astringent bark and their winter buds, which are stalked or raised on more or less well-defined stems. The witch 
hazel has also this stalked bud, but can be distinguished by the fact that it is more densely downy than those of the alders.

\section{ALNUS INCANA (L.) Muench.}

SPECKLED ALDER

Common names: Speckled alder, hoary alder, alder.

French name: Aune commun.

The speckled alder is common in the swamps and along the borders of streams from the Atlantic to the prairies. It is a small, shrubby tree 6 to $15 \mathrm{ft}$. in height, and usually composed of several stems which spring off close to the ground.

The bark is smooth, greyish-brown, and blotched with white spots. The twigs are slender and somewhat zigzag in growth. They are greyish-brown, usually dorrny towards the tip, and conspicuously marked by white lenticels.

The winter buds are distinctly stalked and resemble somewhat those of the witch hazel but are not so densely downy.

The leaves are a broad oval in outline, usually with rounded base, dark green, and conspicuoulsy veined with straight ribs. The underside is usually covered with a hoary bloom.

The flowers are in catkins clustered at the ends of the drooping tips of the twigs, while the fruit is an oval, woody cone, $1 / 2$ in. long, which remains on the tree all winter. The seed is winged, small, and flattened.

ALNUS OREGONA, Nutt.

RED ALDER

Common names: Red alder, Oregon alder, western alder.

French name: Aune de 1'Oregon.

The red alder is confined to the Pacific coast, and in Canada is found only on the Coast range and the islands of British Columbia.

It is the largest alder in Canada, frequently $40 \mathrm{ft}$. high by $1 \mathrm{ft}$. in diameter, but sometimes much larger.

The trunk is usually straight, and the branches are slim. The bark is light grey, smooth except on large trees, when it is roughened by thin, narrow, flat ridges. The twigs are shiny, dark red, and covered with numerous light-coloured spots. The winter buds are dark red and downy. The leaves are 3 to $5 \mathrm{in}$. long, deep yellowish-green, underside slightly hairy, and margins somewhat turned up.

The fruit is cone-like, $1 / 2$ to $1 \mathrm{in}$. long, and the tiny seeds have a very thin, wing-like margin.

The wood of this tree is sometimes used commercially for interior finish, furniture frames, turnery, and handles. It has a fine, even grain and is fairly hard and strong. It is also said to be teredo proof.

ALNUS SITCHENSIS (Regel) Sargent

SITKA ALDER

The Sitka alder occurs from the Arctic circle southward through Alaska and the valley of the Yukon river, along the coast of British Columbia and the Rocky mountains to the Canada-United States boundary. In the United States it grows as far south as Colorado. It is fairly common in the northern part of its range 
where it grows in moist bottoms and marshy flats along with the willow, but is not ordinarily distinguished from other alders.

It is usually a shrub, but sometimes becomes a tree $30 \mathrm{ft}$. in height and $8 \mathrm{in}$. in trunk diameter. Its wood is used with that of red alder (Alnus oregona).

The bark is smooth and grey with a bluish tinge. The twigs are yellowishbrown, shiny, and minutely hairy.

The leaves are thin, papery, yellowish-green, shiny beneath, and, when young, sticky. In shape they are much like those of the red alder, except that they are often a little more drawn out and pointed. The margin, too, is more sharply toothed.

The cone is $5 / 8$ to $3 / 4$ in. long. The tiny seed has a wing that is much more conspicuous than that of either the red or the mountain alder.

MOUNTAIN ALDER

The mountain alder ranges from Yukon territory southward throughout British Columbia. It received its common name because of its high mountain habitat by which it is ordinarily distinguished.

Commonly it is only a shrub growing in dense thickets, but sometimes becomes a crooked tree 20 to $25 \mathrm{ft}$. in height.

The bark is smooth, thin, and greyish-brown on the trunk. On new twigs it is pale brown, shading from purple-red to grey. The twigs of the Sitka alder on the other hand are a shiny yellowish-brown, marked with light-coloured specks.

The leaves of the mountain alder closely resemble those of the Sitka alder but on the whole are a little more coarsely toothed.

\section{THE IRONWOODS}

Three of the five known species of ironwood (Ostrya) are found in North America, of which only one occurs in Canada. The others are found in southern Europe, southwestern Asia and in Japan. They are small trees of minor importance but are sometimes planted for decorative purposes.

OSTRYA VIRGINIANA (Mill.) Koch

IRONWOOD

Common names: Ironwood, rough-barked ironwood, hornbeam*, hop hornbeam*.

French names: Ostryer de virginie, bois dur*, bois de fer.

The ironwood is a small tree found from Nova Scotia to Ontario, and is associated with such hardwoods as beech, sugar maple, white ash, and white elm.

It reaches the height of 25 to $35 \mathrm{ft}$. and a diameter of $12 \mathrm{in}$.

Its bark is light grey and roughened by thin, flat flakes or scales, which loosen at the ends. This characteristic distinguishes it readily from the beech. The twigs of these two species are somewhat alike in winter but can be distinguished by the shorter buds on the ironwond.

'The leaves of the ironwood are somewhat like those of the birch in general appearance. 'They are finely-toothed, light green, rough to the touch, and have stems about $1 / 2$ in. long. 
The fruit is hop-like in appearance and each contains a small, seed-like nut. The fruit remains on the tree during the winter.

Its wood is one of the hardest and toughest of native woods and is used locally for vehicle stock, handles, and spring-poles. Owing to the small size usually

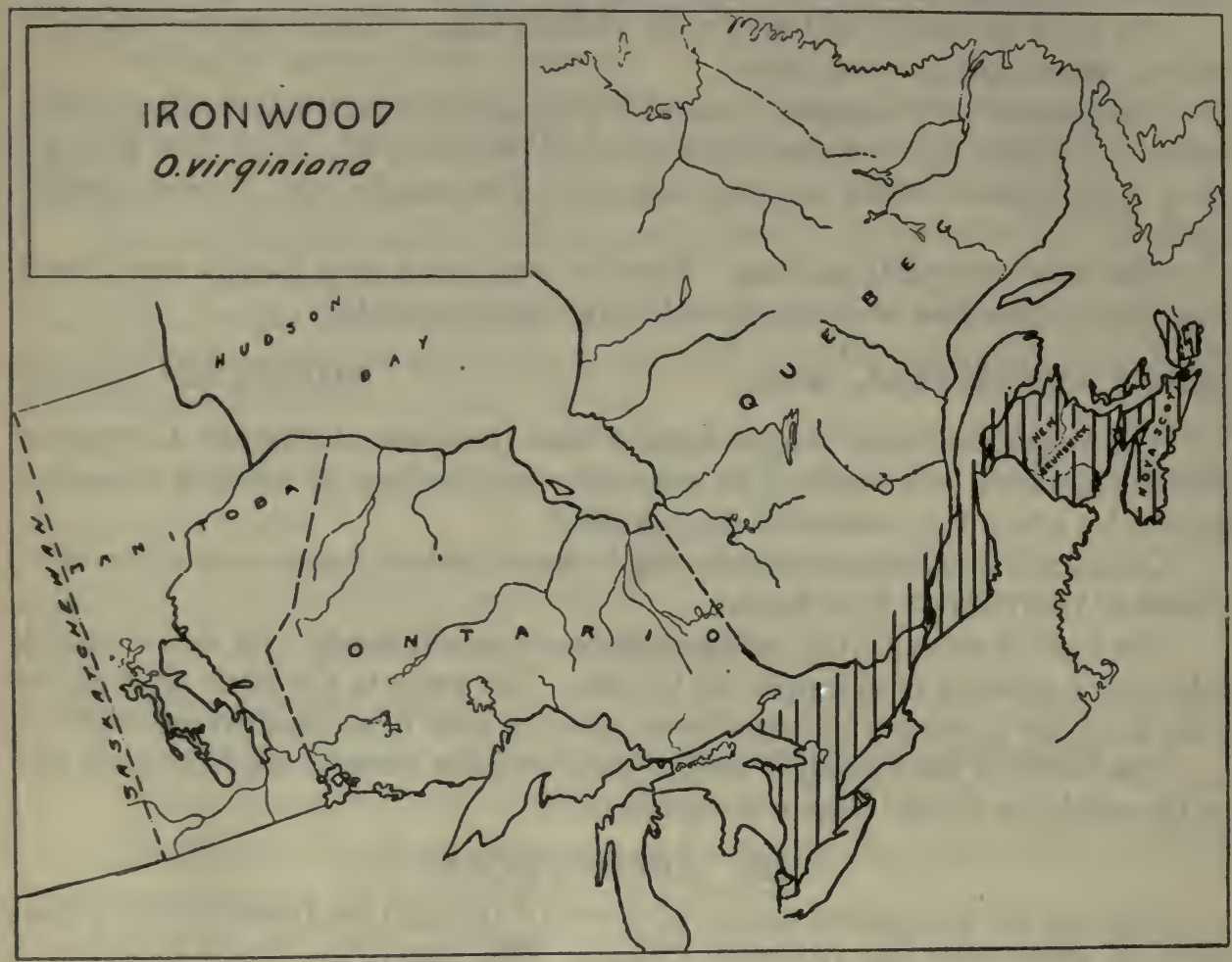

attained the tree is not important as a lumber producer, but is used to a great extent for wood distillation.

\section{THE BLUE BEECHES}

About a dozen species of Carpinus are known, but only one is native to this continent, and it is small in size and in economic importance. One of the largest species, Carpinus Betulus, is found in Siberia where it is of considerable importance.

These trees belong to the same family as our ironwoods, birches, alders, and hazelnuts, which resemble one another in many respects, but can all readily be distinguished one from another by their fruits.

CARPINUS CAROLINIANA, Walt.

BLUE BEECH

Common names: Blue beech, water beech*, ironwood*, smoothbarked ironwood, hornbeam*, hop hornbeam*.

French name: Charme d'Amérique.

The blue beech is common throughout the hardwood region of Quebec and Ontario, where it is found in nearly every farmer's woodlot. It is not a true becch, 
but derives its name from the fact that its bark resembles that of a beech.

It is a small tree, ordinarily 15 to $20 \mathrm{ft}$. in height and 4 to $8 \mathrm{in}$. in diameter. It is frequently an unshapely, bushy tree with a leaning trunk. The crown is flattened and composed of long branches of irregular growth and many fine, supple, drooping twigs which are arranged in a flat, spreading spray. The bark of the trunk is smooth and close-fitting, and resembles that of the beech, except that it is a darker or bluish grey. The trunk is often swollen in ridges or fluted.

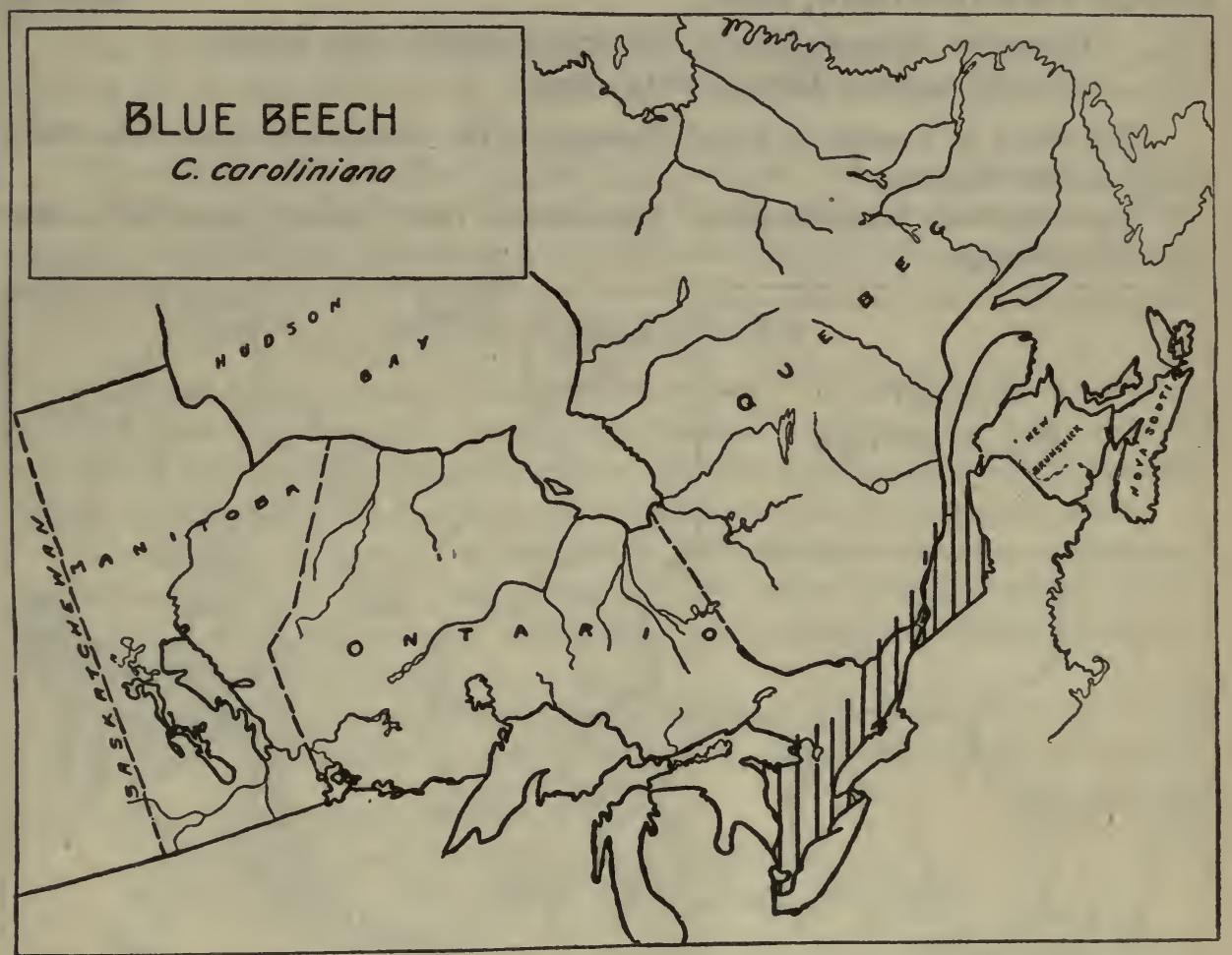

The leaves are 2 to 4 in. long, ovate-oblong in shape, margins unevenly toothed and coarse in texture. The stems are about $1 / 2 \mathrm{in}$. long.

The fruit is in the form of a tiny nutlet. These occur in pairs and are attached to three-lobed, leaf-like wings.

The character of its bark and the fact that it is found growing in the shade of other hardwoods are the only points in which it resembles the true beech. The winter buds, leaves, and fruit are quite different and any of these would enable these two trees to be distinguished.

The wood is used locally on account of its hardness and toughness, but it does not reach a size to make it commercially important. It is used with other hardwoods in wood distillation. 


\section{THE BEECHES}

Five species of beech (Fagus) are known and all are found in the northern hemisphere. One species is native to this continent, the so-called "blue beech" (Carpinus caroliniana), being entirely distinct from the true beech. Several ornamental varieties of European origin are grown by nurserymen.

The beeches are readily recognized by their three-angled nuts, smooth grey bark, and long, sharp-pointed, lance-shaped buds.

FAGUS GRANDIFOLIA, Ehrh.

BEECH

Common names: Beech, American beech, red beech.

French names: Hêtre, hêtre rouge.

The beech in Canada is found throughout the hardwood region from Nova Scotia to lake Superior.

It is sometimes found in almost pure stands, but is usually mixed with other native hardwoods.

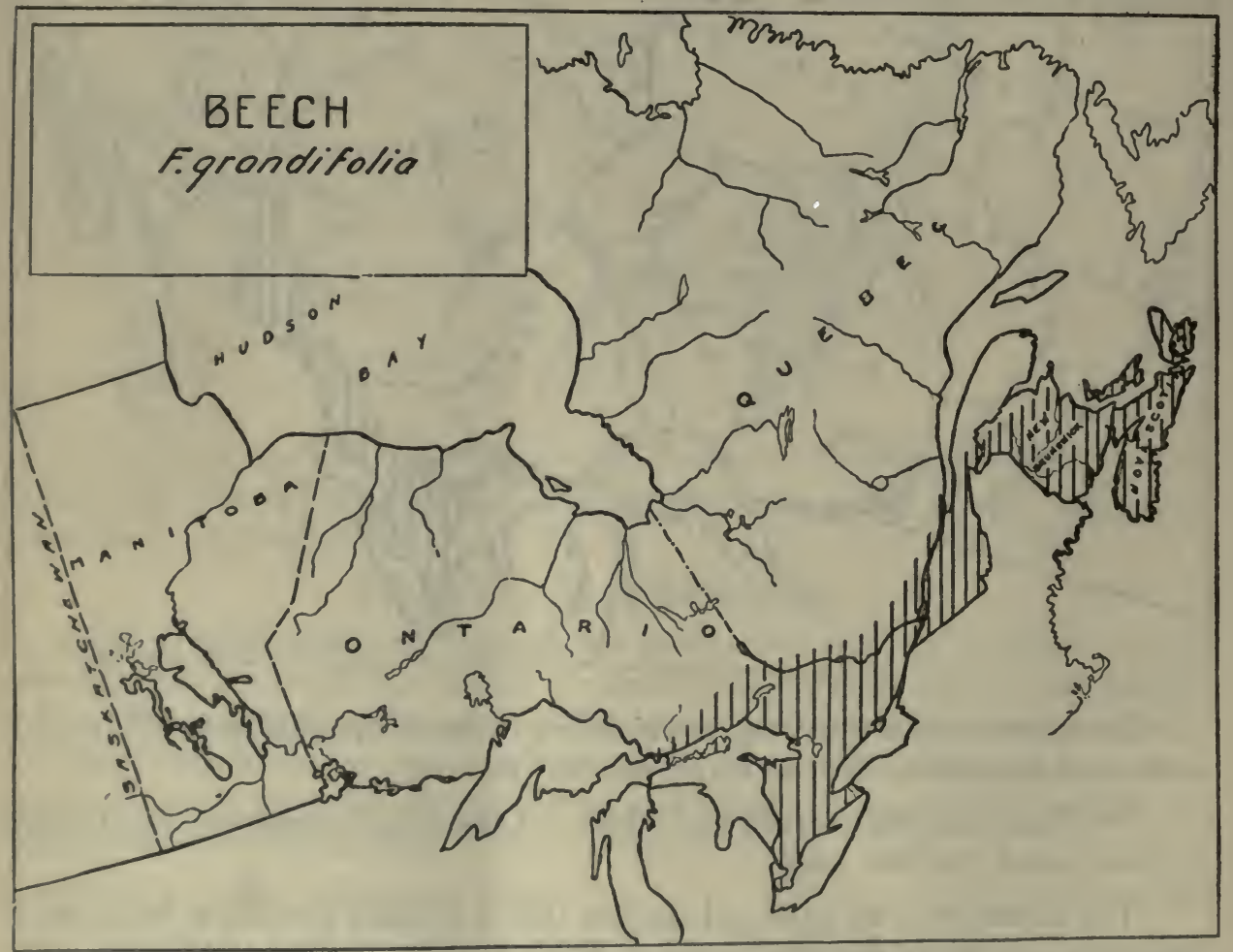

When growing in a dense stand it reaches a height of 70 to $80 \mathrm{ft}$. and a diameter of 2 to $4 \mathrm{ft}$. In the open the clear trunk is much shorter and the crown is large and rounded.

The clean, smooth, close-fitting, light grey bark of the trunk has made this tree one of the best known wherever it occurs. Except when young it is rarely mistaken for any other tree, even in winter. 
The blue beech (Carpinus carcliniana) has a bark somewhat similar to that of the true beech and for that reason is sometimes mistaken for this tree. They are, however, readily distinguished by their winter buds, leaves, and fruit.

The twigs of the beech are brown, smooth, lustrous, and set with shining, brown, pointed buds about 1 in. long.

The leaves in outline are oblong and pointed, with the margin sharply sawtoothed. The veining is conspicuous, the fine veins running straight from the centre rib to the edge. The texture is exceedingly fine and the leaf is soft to the touch.

The fruit is a tiny, three-cornered, sharp-pointed nut, occuring in pairs enclosed in a prickly bur or husk. When ripe this bur splits into four sections and allows the nuts to drop out.

The wood is used for flooring, furniture, vehicle stock, cooperage, handles, wood distillation, and firewood, and is one of the cheapest hardwoods on the market. It is difficult to season, perishable, and often cross-grained, but is hard, strong, and tough.

\section{THE CHESTNUTS}

Four species of chestnut (Castanea) are known. Three of them are native to North America of which only one is found in Canada. The common horse chestnut (Aesculus hippocastanum) is not a true chestnut, neither is it a native of this country although largely planted as an ornamental tree in our eastern towns and cities.

The chestnut (Castanea) is frequently cultivated for its nuts, and several horticultural varieties have been produced. The wood is highly prized for the manufacture of tanning extracts, and also for posts and poles, because of its durability in contact with the soil.

The chestnut can be easily distinguished from any other native tree by its very spiny bur which contains one or more shiny, brown, thin-shelled, sweet, edible nuts.

CASTANEA DENTATA (Marsh.), Borkh.

CHESTNUT

Common names: Chestnut, sweet chestnut.

French names: Châtaignier d'Amérique, châtaignier.

The chestnut is found growing naturally in Canada only in a small part of southern Ontario, viz., that part from the Niagara river and lake Ontario westward to the Detroit river and lake St. Clair. Here it is fairly common throughout the farmers' woods, associated with the various other hardwoods of that region. 'This is the tree that produces the sweet or edible chestnut and, as stated above, should not be mistaken for the horse chestnut.

It is a large tree 75 to $80 \mathrm{ft}$. in height, and 2 to $3 \mathrm{ft}$. in diameter, sometimes reaching a height of $100 \mathrm{ft}$. The trunk is usually long and straight, and has little taper except when grown in the open, where it divides into a few, heavy branches not far from the ground and forms a very broad, rounded crown.

The bark is roughened by deep longitudinal furrows into coarse ridges on the larger trunks, but on young trees up to about $8 \mathrm{in}$. in diameter it is comparatively smooth and resembles that of the red oak. 
The twigs have a yellowish tinge and are stout and smooth. In cross-section they are somewhat irregular, due to slight ridges that run from each side of the leafscars.

The winter buds are $1 / 4 \mathrm{in}$. long, rounded, and chestnut-brown in colour. They are not clustered at the end of the twig as are those of the oaks, trees with which the chestnut might be confused.

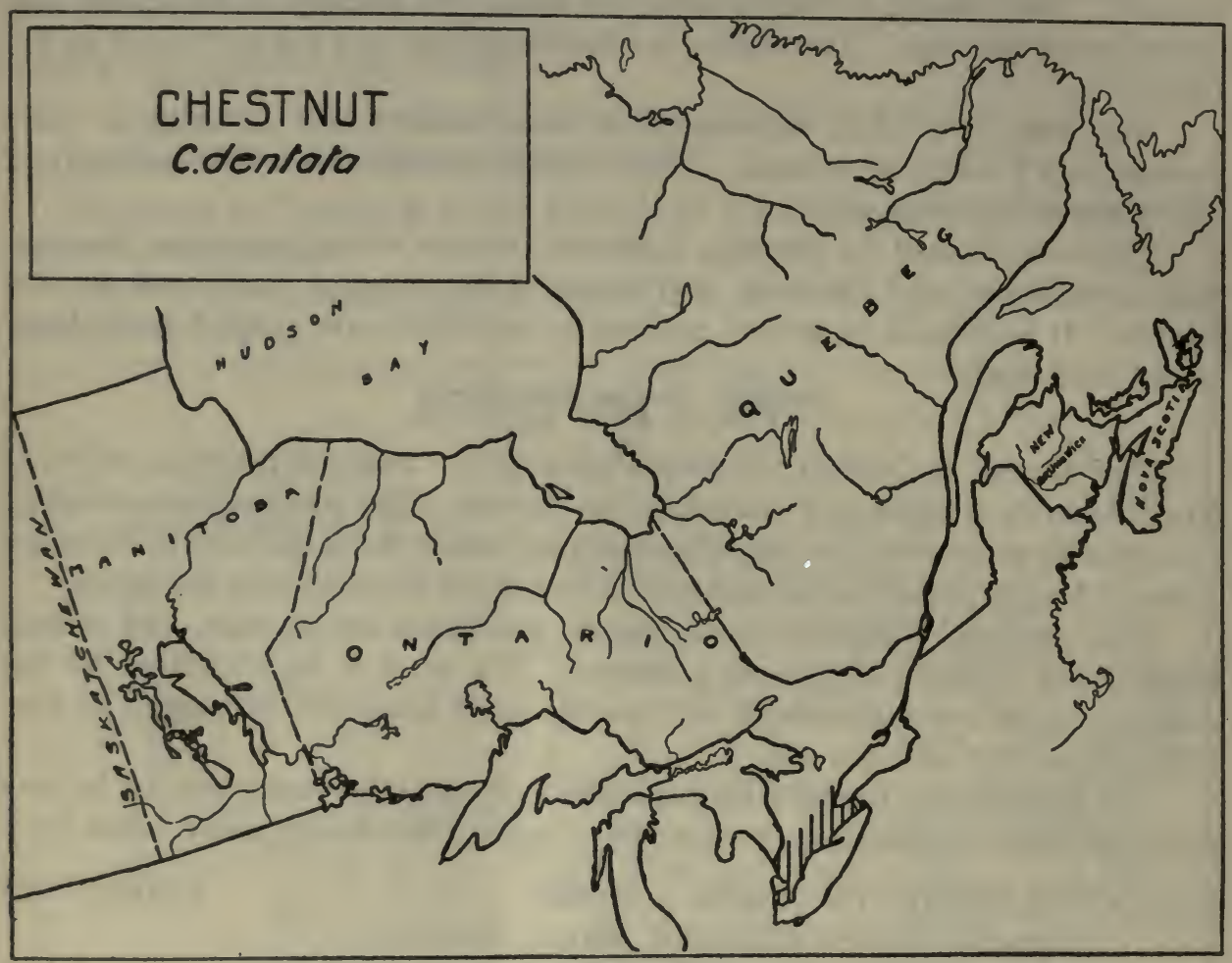

The leaves are 6 to 8 in. long, narrow, and taper-pointed. The margin is coarsely toothed with curved teeth that resemble those of a circular saw. The veining is prominent and feather-like, and the dark, shiny, green surface has a corrugated appearance.

The somewhat wedge-shaped nuts are protected by an extremely spiny bur. They are thin-shelled and edible, and too well known to need further description.

The wood of this tree is used extensively in Canada for veneer cores. It has a coarse grain and texture and takes glue well, and in addition is very durable. The wood is also used in cabinet-work generally, for slack cooperage, railway ties, and poles. It is a valuable source of tanning extracts.

\section{THE OAKS}

The oaks (Quercus) are widely distributed throughout the north temperate zone of both hemispheres. Only a few species are found south of the equator. Approximately three hundred species have been described. Fifty-two species are 
found in North America of which forty-seven reach tree size. Twelve species have been found in Canada, most of them confined to the southwestern peninsula of Ontario. One species is found in British Columbia. All the native species reach tree size except the dwarf chinquapin oak (Quercus prinoides).

The oaks are of very great importance commercially because of the high technical qualities of their wood. The better grades bring a higher price than any other hardwood in Canada, with the exception of walnut and cherry. In Canada the supply is nearly exhausted.

The native species are divided into two groups:

1. White oaks

Fruit matures in one year

Inner surface of the acorn shell usually smooth

Leaves with lobes rounded.

2. Black oaks

Fruit matures in two years

Inner surface of the acorn shell covered with silky down

Leaves with lobes pointed and bristle-tipped.

The white oak group includes the following:

White oak

Quercus alba

Garry oak

Quercus Garryana

Post oak

Quercus stellata

-Swamp white oak

Quercus bicolor

Bur oak

Quercus macrocarpa

Chinquapin oak

Chestnut oak

Quercus Muehlenbergii

Dwarf chinquapin oak

Quercus prinus

Quercus prinoides

The black oak group includes the following:

Black oak

Red oak

Quercus velutina

Pin oak

Scarlet oak

Quercus rubra

Quercus palustris

Ouercus coccinea

There is a great difference in the quality of the wood of the different species. As a whole the wood of the white oaks is superior to that of the black oaks.

In both the white and black groups there are species which retain their green leaves throughout the winter and are known as evergreen oaks. None of these is native to Canada. They are chiefly confined to the southern Pacific coast.

QUERCUS ALBA, Linn.

WHITE OAK

Common names: White oak, stave oak.

French name: Chêne blanc.

The white oak is found on well-drained soils in southern Quebec and southern Ontario. It has a trunk diameter of 2 to $4 \mathrm{ft}$. and a height of 50 to $100 \mathrm{ft}$. It is 
a stately tree and in the open develops a very massive, broad crown, composed of far-reaching, stout, twisted limbs.

The bark is light grey, shallow-fissured, and scaly. This scaliness extends to branches $1 \mathrm{in}$. in diameter. The twigs, which are smooth, are sometimes covered with a bloom which can be rubbed off.

The winter buds are reddish-brown, $1 / 8 \mathrm{in}$. long. They are larger and more pointed than those of the swamp white oak, but less pointed than those of the yellow oak.

The leaves are 5 to $9 \mathrm{in}$. long and 3 to $4 \mathrm{in.} \mathrm{broad.} \mathrm{The} \mathrm{lobes} \mathrm{are} \mathrm{rounded,} \mathrm{or}$ blunt, and the notches or indentations are fairly deep, most of them $1 / 2 \mathrm{in}$. or over. The leaves of the swamp white oak are not so deeply notched.

The acorns are $3 / 4$ to $1 \mathrm{in}$. in length and are sometimes borne on slender stalks. The cup is shallow and covered with warty scales, which do not form a fringe at the

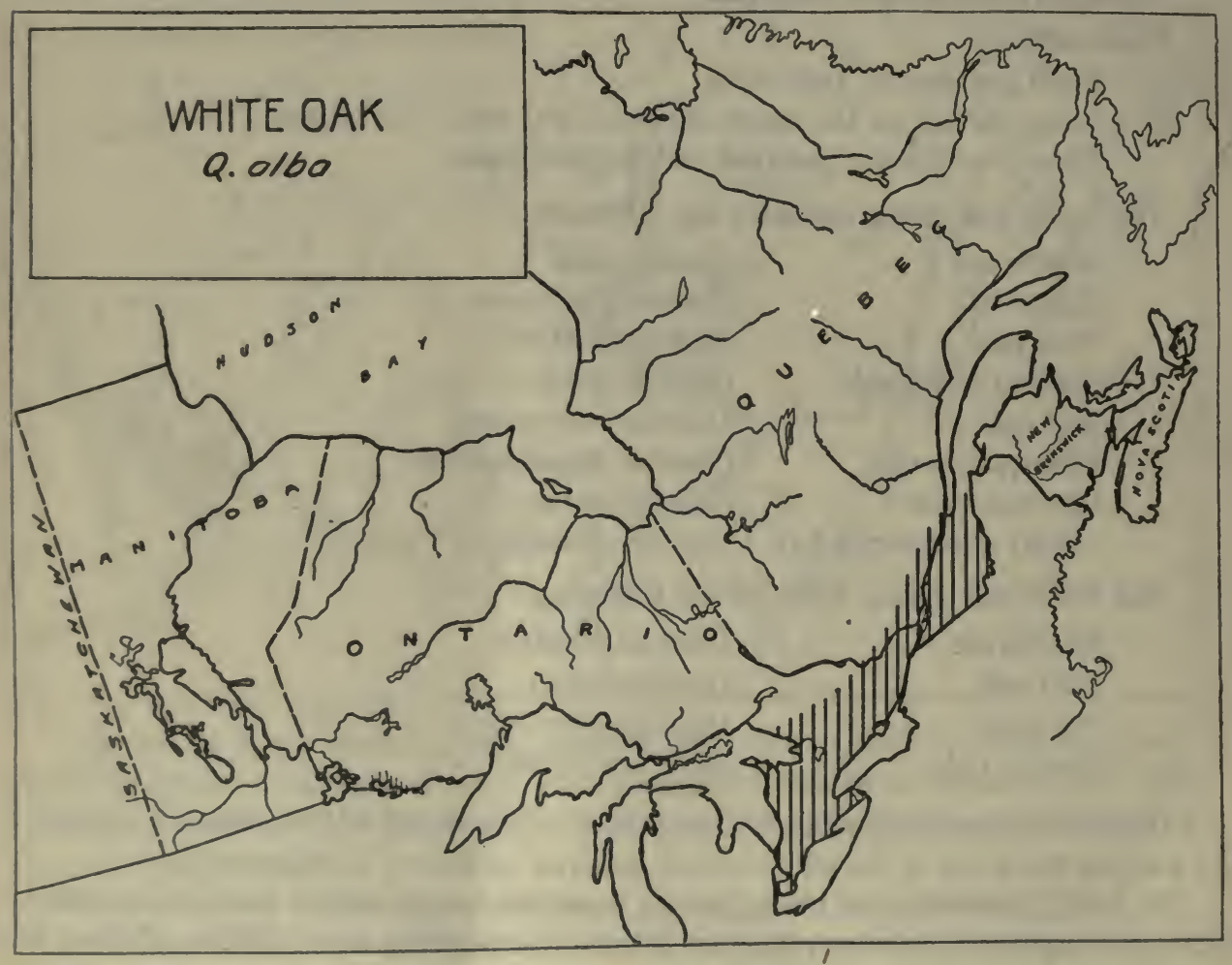

margin. The inside of the shell is smooth and the kernel is sweet. The acorns take but one year to mature.

The technical qualities of this wood have long been understood and appreciated. It is generally conceded to be the most valuable of the oak species. Its more important uses depend on its two main characteristics; its strength and its appearance. The wood is used in greatest quantity at present for interior finish, cabinetwork, and furniture, but in addition to these uses it is purchased by manufacturers 
of boats, vehicles, cars, caskets, handles, pianos, organs, pumps, refrigerators, and machinery frames. White oak, exclusively, is used for tight cooperage for alcoholic liquids.

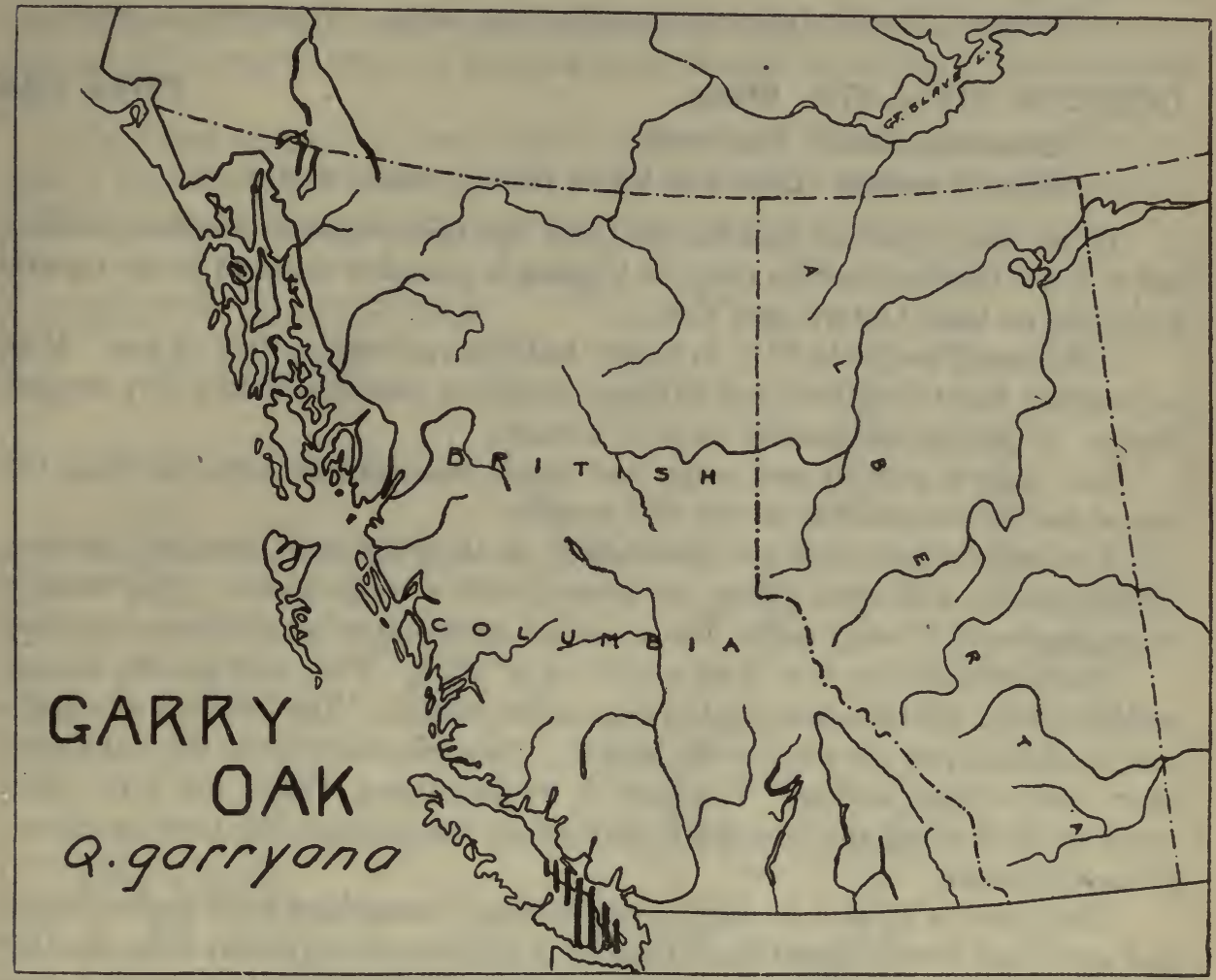

QUERCUS GARRYANA, Douglas

GARRY OAK

Common names: Garry oak, Pacific post oak, Oregon oak, Pacific white oak, British Columbia oak.

French name: Chêne de Garry.

The Garry oak in Canada is found only in British Columbia, along the east coast of Vancouver island, on the islands of the strait of Georgia, and on the mainland in the lower valley of the Fraser river. It is not a common tree and has no value commercially. shrub.

On good sites it is a tree 50 to $60 \mathrm{ft}$. high, and in poor locations is merely a

It is the only oak native to the Pacific coast in Canada, and therefore not difficult to distinguish from other trees with which it associates.

The young twigs and winter buds are conspicuously hairy. The puds are large for an oak, $1 / 4$ to $1 / 2$ in. long. 
The leaves in outline resemble those of the white oak of the East. They are deep green in colour, and shiny and smooth on the upper surface. In texture they are leathery and thick.

The acorn is large and the cup is shallow and hairy. The kernel is sweet.

\section{QUERCUS STELLATA, Wang.}

POST OAK

\section{Common name: Post oak.}

French names: Chêne à lobes obtus, chêne étoile.

It has been reported that the post oak has been found in southern Ontario, but it is not common and its range in Canada is probably confined to the counties bordering on lakes Ontario and Erie.

It is a small tree 25 to $30 \mathrm{ft}$. in height, but often a shrub of $10 \mathrm{ft}$. or less. It has a straggling habit of growth and its stout, spreading branches form a very irregular crown. It has no commercial value in Canada.

The bark is greyish and scaly, and much resembles that of the white oak, except that it is somewhat darker and rougher.

The twigs, which come out abundantly all along the stout branches, are stout, reddish-brown, and when young are covered with a rough down. They soon become roughened by scaly bark. The leaf-scars are raised on conspicuous projections.

The leaves are 5 to $8 \mathrm{in}$. long and 3 to $6 \mathrm{in}$. wide. They vary greatly in shape and have what has been described as a sprawling outline. The lobes are all rounded and the middle pair are usually the largest. This frequently gives the leaf a somewhat cross-shaped outline. The base is wedge-shaped. They are very coarse, rough on both sides, and of a shiny, dark green, which makes the tree conspicuous at some distance.

The acorn is $1 / 2$ to $1 \mathrm{in}$. long, reddish-brown, sometimes with darker stripes, and somewhat downy at the tip. The cup is top-shaped and covers from one-third to one-half the nut. The scales are thin and flat. The kernel is sweet and ripens in one year.

QUERCUS BICOLOR, Willd.

SWAMP WHITE OAK

Common names: Swamp white oak, blue oak*.

French names: Chêne bicolore, chêne bleu*.

The swamp white oak, as its name implies, is found in low, damp woods, bordering on swamps and streams. In Canada its range extends from eastern Ontario westward throughout southwestern Ontario.

It is a medium-sized tree commonly 50 to $60 \mathrm{ft}$. in height, and 2 to $3 \mathrm{ft}$. in diameter. Its wood is similar to that of white oak (Quercus alba) and is sold mixed with the other white oaks.

The bark on the trunk is greyish-brown and flaky. It resembles that of the white oak except that it is more deeply fissured and looser. On the small branches it peels off in layers.

The small, crooked branchlets which hang from the larger limbs are very characteristic of the tree. The twigs are smooth and seldom downy. They are 
coarser, shorter, and rounder in cross-section than those of the white oak.

The winter buds are a pale chestnut-brown, $1 / 4$ in. long, smaller and less pointed than those of the white oak. They are sometimes hairy above the middle, as in the case of the scarlet oak, but they are more rounded, or blunter, than the buds of that tree.

The leaves are 5 to 6 in. long and 3 to 4 in. broad. The shape is something like that of the white oak leaf, except that as the notches are not as deep the margin is

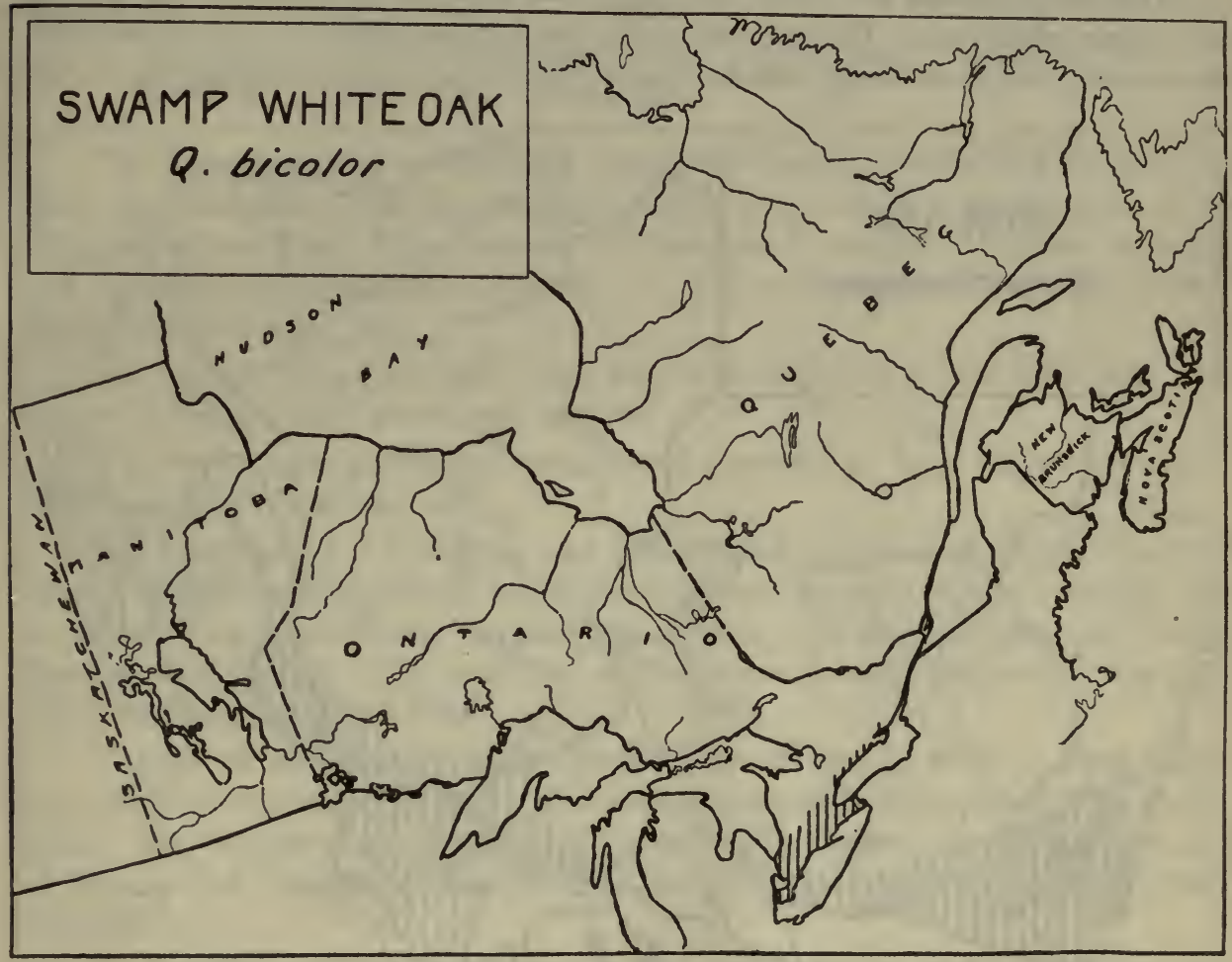

more wavy. They are thick, shiny, pale green above, and sometimes whitish below.

The acorn is from 1 to $11 / 2$ in. long. The cup is thick and encloses about onethird of the nut. The scales sometimes form a slight fringe on the margin of the cup. The inside of the shell is smooth and the kernel is sweet. The acorns are borne singly or in pairs on stalks longer than the leaf-stems, a characteristic feature. They take only one year to mature.

QUERCUS MACROCARPA, Michx.

BUR OAK

Common names: Bur oak, scrub oak, blue oak*, mossy oak, mossycup oak, overcup oak.

French names: Chêne à gros glands, chêne blanc frisé.

The bur oak does not reach the large size in Canada that it does farther south, rarely being found more than 40 to $50 \mathrm{ft}$. in height and 1 to $2 \mathrm{ft}$. in diameter. It 
has a range in this country from Nova Scotia to Manitoba, and is found farther north and west than any other of our eastern oaks.

The crown is broad and round, and the branches are wide-spreading, except in the northwestern part of its range, where it is often little better than a shrub and is known by the name of "scrub oak."

The tree is confined mostly to the rich bottom lands and sides of valleys.

The bark is brown and flaky, but somewhat firmer in appearance than that of the eastern white oak. The bark on twigs that are from three to four seasons old, forms corky ridges or wings which remain for several years, disappearing as the

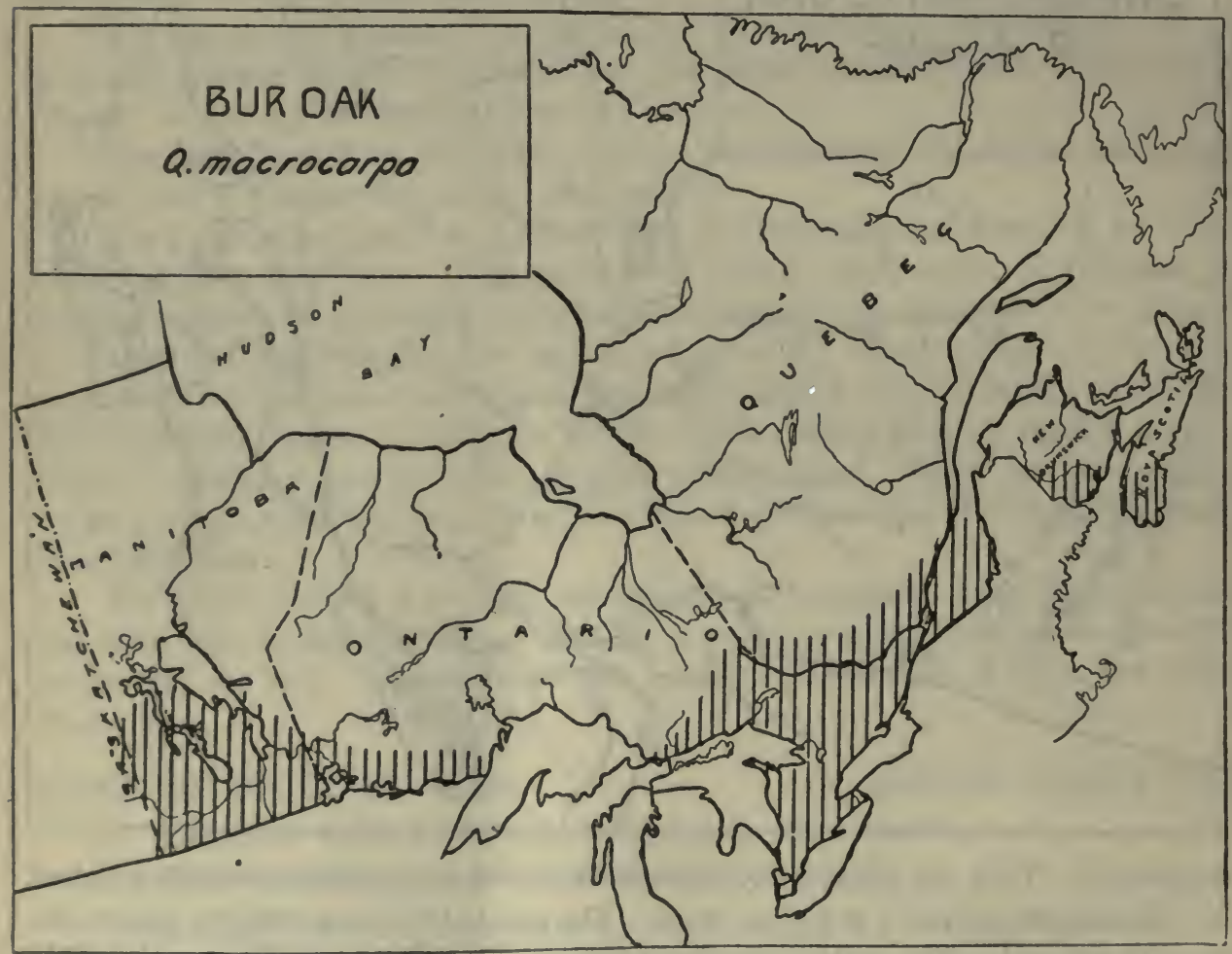

branch becomes older. This peculiarity forms one of the best features for distinguishing this tree from the other oaks.

The winter buds are $1 / 8$ to $1 / 4 \mathrm{in}$. long, a light reddish-brown in colour, and frequently have a somewhat flattened appearance as though pressed against the twig.

The leaves vary greatly in size and outline, but nevertheless bear a marked resemblance. The long, deep notches on either side of the main rib, which almost meet and cut the leaf in two, are very characteristic and a good distinguishing feature. They are thick, leathery leaves, bright green and shiny above, and somewhat hairy on the underside. 
The acorns are very large as a rule, often larger than those of the red oak. The kernel is sweet. The cup is peculiar in that the scales on the margin are elongated and form a distinct fringe.

Bur oak wood is often used locally in Canada in making axe and pick handles, and vehicle stock. It is the hardest and toughest wood of the commercially important native oaks.

QUERCUS MUEHLENBERGII, Engelm.

CHINQUAPIN OAK

Common names: Chinquapin oak, yellow oak*, chestnut oak.

French name: Chêne chinquapin.

The chinquapin oak in the forest sometimes reaches a height of 80 to $90 \mathrm{ft}$., or more, but ordinarily, when growing in the open, it is a medium-sized tree 35 to 40 $\mathrm{ft}$. in height and 1 to $2 \mathrm{ft}$. in diameter. The crown is composed of many branches, and in shape is narrow with a rounded top. The wood when utilized in Canada is sold with white oak.

The bark is thin, grey, and flaky, and resembles that of the white oak. On the twigs it is reddish-brown and smooth.

The winter buds are chestnut-brown and about $1 / 4$ in. long. They are smaller than those of the chestnut oak.

The leaves are 4 to 7 in. long, and somewhat like the leaf of the chestnut oak, except that the lobes are more pointed and curved like the teeth of a circular saw. In outline they are half-way between the leaves of the chestnut oak and those of the chestnut proper. The crowding of the leaves towards the ends of the twigs gives the foliage a tufted look.

The nut of the acorn is a light chestnut-brown, oval, $1 / 2$ to $3 / 4$ in. long; smaller than those of the chestnut oak. The kernel is sweet. The cup is thin, downy inside, and encloses one-half or less of the nut. The scales are knobby at the base of the cup but towards the margin they become thinner and form a slight fringe along the rim.

In Canada this tree is confined to the southwestern part of Ontario, from Niagara westward along the north shore of lake Erie, where it is found on hillsides and bottom lands.

QUERCUS PRINUS, Linn.

CHESTNUT OAK

Common names: Chestnut oak, rock oak.

French name: Chêne prin.

The chestnut oak is a small tree 35 to $40 \mathrm{ft}$. high and 1 to $2 \mathrm{ft}$. in diameter, but when growing in a crowded forest condition will often reach a greater height. The crown is broad and open.

The bark, which is a very dark brown, does not flake but is roughened by deep furrows forming firm, flat-topped ridges on medium-sized trees; on young trees and branches it is smooth. 
The twigs are reddish-brown in colour, stout, smooth, and somewhat bitter to the taste when chewed. As compared with those of the white oak they are more ridged.

The winter buds are a light chestnut-brown shade, pointed, and $1 / 4$ to $1 / 2$ in. long. They are long in proportion to their width. The margin of the scale is pale, a feature which assists in distinguishing the buds from those of the red oak.

The leaves are 5 to $9 \mathrm{in.} \mathrm{long}$ and 3 to 4 in. wide. In appearance the leaf resembles somewhat that of the chestnut tree. The points on the margin are, however, more rounded, and, the notches being of uniform depth, the outline has more of a wavy than a toothed appearance.

The nut is a bright chestnut-brown, oval, two to three times as long as broad. The kernel is sweet. The cup is thin, top-shaped and rarely covers more than onethird of the nut. The outside of the cup is knobby.

In Canada the chestnut oak has a very limited range, being found only in Ontario; and only in that part of the province that borders lakes Erie and St. Clair. It grows on well-drained slopes and ridges along with shagbark hickory, red oak, and various other hardwoods.

The wood of the chestnut oak is usually considered to be inferior to that of the other white oaks. The same opinion is held of the wood of the chinquapin oak but neither the chestnut oak nor the chinquapin oak is commercially important in Canada.

QUERCUS VELUTINA, Lam.

BLACK OAK

Common names: Black oak, yellow oak*, yellow-barked oak, red oak*.

French names: Chêne des teinturiers, chêne noir.

The black oak is confined to southwestern Ontario, where it is found growing on the poorer gravelly and sandy soils.

It is a large tree 60 to $70 \mathrm{ft}$. high and 2 to $3 \mathrm{ft}$. in thickness through the trunk. Growing in the open it develops a crown sometimes tall and narrow, and at other times wide and spreading. When sawn into lumber it is sold as red oak.

The bark is a very dark brown or almost black on old trees. It is very deeply furruwed and considerably rougher than that of either the red or scarlet oaks. The yellow, bitter, inner hark, which will colour the saliva if chewed, is a good distinguishing feature of this tree. The reddish-brown twigs will also colour the saliva.

The winter buds are brown and $1 / 8$ to $1 / 4$ in. long. They are larger and more angled in cross-section than those of the scarlet or red oaks, and are completely covered with pale red down.

The leaves are 4 to $6 \mathrm{in.} \mathrm{long}$ and 3 to $5 \mathrm{in}$. wide. The lobes are bristlypointed and the notches are deep. The notches are deeper and the lobes narrower 
than those of the red oak. The indentations might be described as more circular and the lobes less wedge-shaped than those of the red oak. The mature leaf is dark green and the upper surface glossy.

The acorn is smaller and the cup is deeper than in the case of the red oak. The cup embraces one-third to one-half the nut and the scales form a distinct fringe on

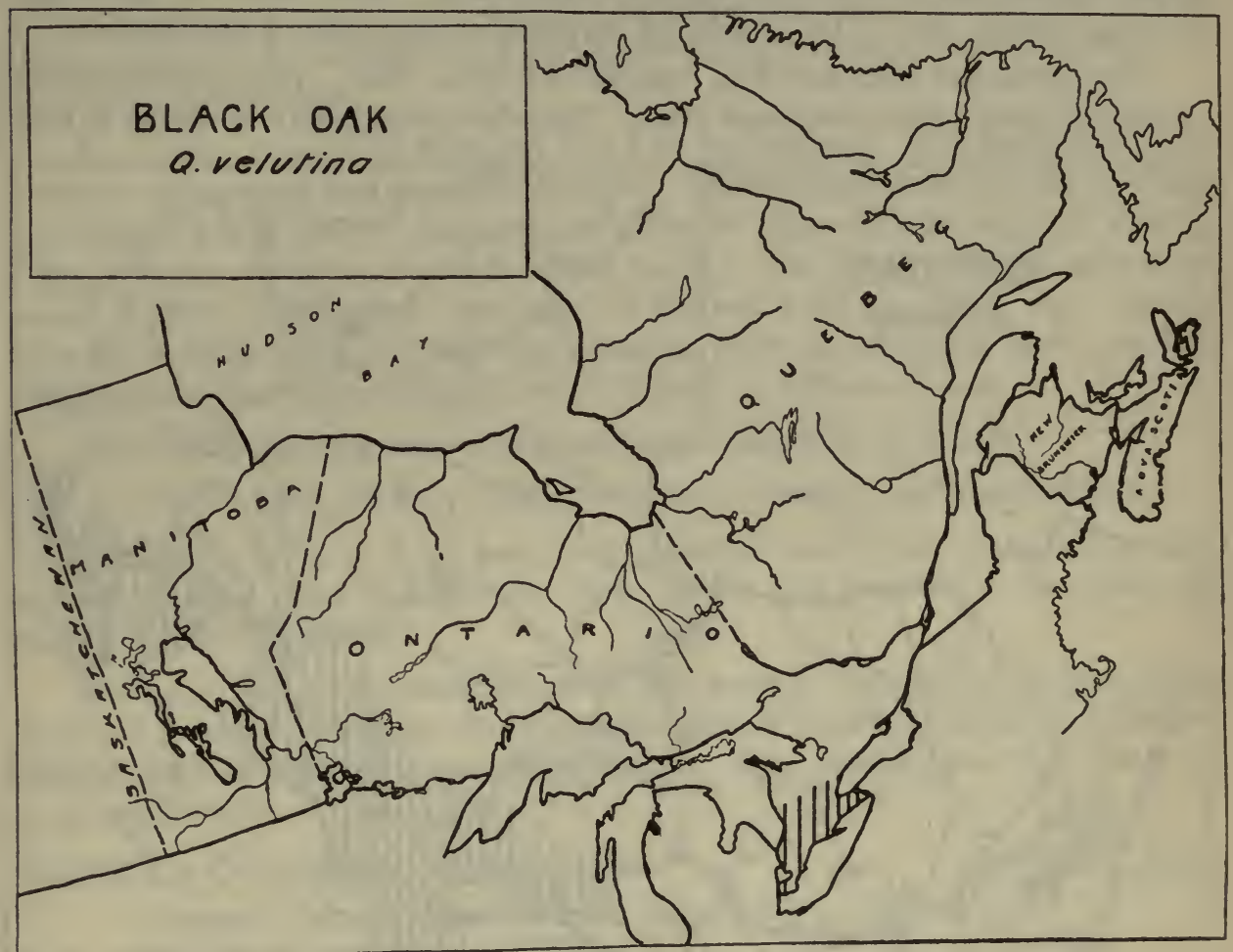

the margin. The inside of the shell of the nut is downy, and the kernel is yellow and bitter. The acorn takes two years to mature.

QUERCUS RUBRA, Linn.

RED OAK

Common names: Red oak, black oak*.

French name: Chêne rouge.

The red oak is found more or less abundantly from Cape Breton in Nova Scotia to Georgian bay in Ontario, and, occasionally, west of this along the north shore of lake Huron and the east shore of lake Superior to the height of land dividing the watershed of the Great Lakes from that of James bay.

It is our most rapid-growing native oak and does well on a wide variety of soils, but prefers those which are well drained.

It is a large tree 60 to $70 \mathrm{ft}$. or more high and 2 to $3 \mathrm{ft}$. in diameter, and when grown in the open develops a large, round-topped head composed of stout, farspreading branches. 
The bark on young trees, and even on those of considerable size, is smooth. The limbs and upper part of the trunk are smooth and clean cut.

The winter buds are pointed, $1 / 4$ in. long, chestnut-brown, and usually smooth, except for a few red hairs at the tip. They resemble the buds of the chestnut oak, but are flatter and have no pale margin to the scales. They have the appearance of being stalked, due to the bud being narrower at the point of attachment.

The leaves are from 5 to $9 \mathrm{in}$. long and 4 to $6 \mathrm{in}$. wide. They have from nine to thirteen lobes - more than most oaks. The lobes are pointed and appear to taper

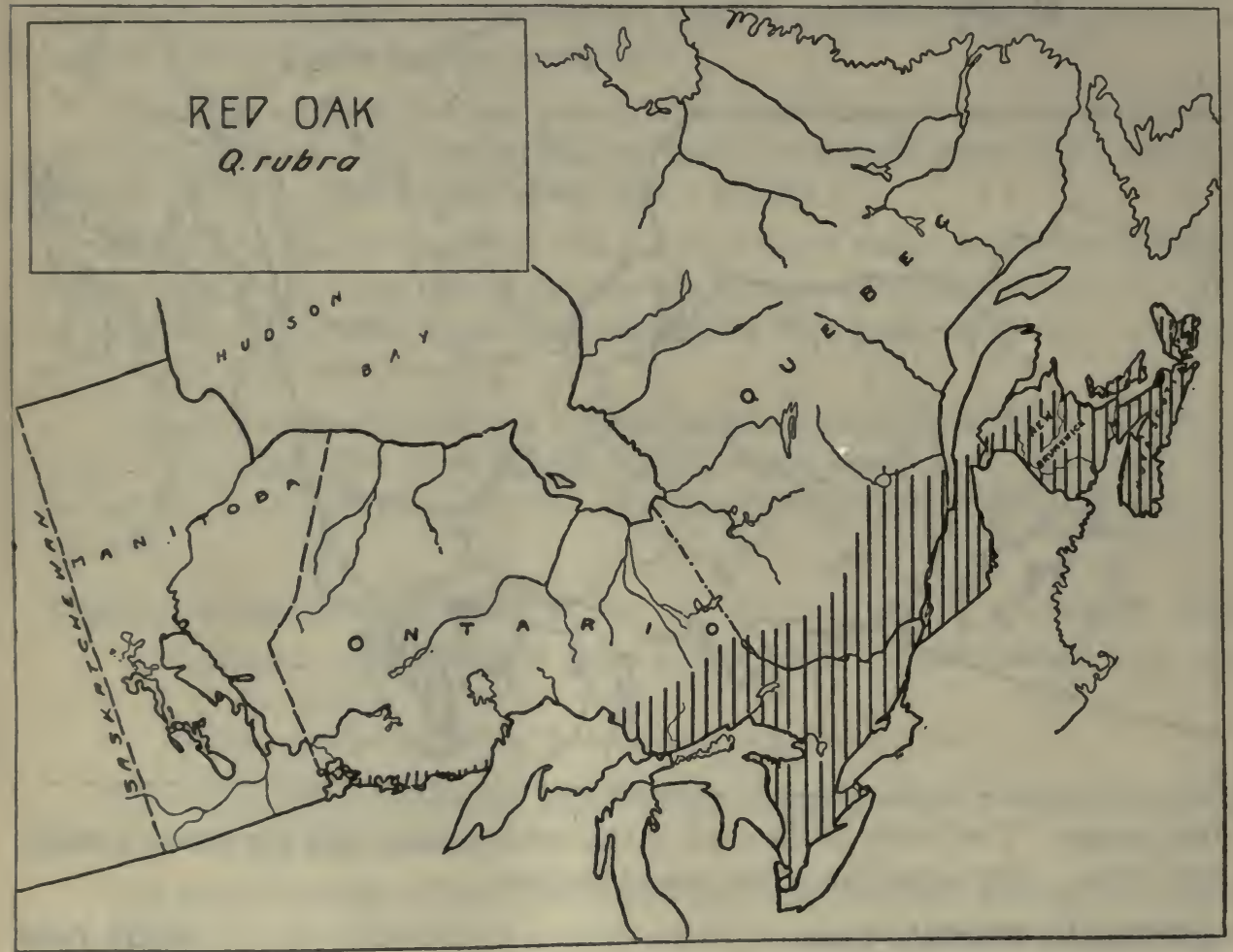

more from the base to the tip than those of the black oak. The notches as a rule extend half way to the midrib. They are dark green and smooth, and in autumn turn a rich red.

The acorns are characteristic and one of the best means of identifying the tree. They are very large, $3 / 4$ to $1 \frac{1}{4}$ in. long. The cup is very shallow and thick. The scales are close and form no fringe at the margin. The kernel is white and bitter. The inside of the shell is somewhat downy. The acorn takes two years to develop.

The wood of the black oak group, of which this is the most important commercial species, is not so strong as that of the white oaks, and, having narrower medullary rays, does not possess the same attractive figure when quarter-sawn. In many cases, however, the oaks are used for similar purposes without distinction. 
QUERCUS PALUSTRIS, Muench.

PIN OAK

Common names: Pin oak, water oak, swamp oak.

French name: Chêne de marais.

The pin oak, in Canada, is confined to the southwestern part of Ontario, from Niagara westward in the counties bordering on lake Erie and the Detroit river, where it is frequently found growing in damp positions, such as the borders of swamps and streams.

It is a tree 50 to $60 \mathrm{ft}$. high and 1 to $2 \mathrm{ft}$. in diameter. The trunk is tall and straight, and extends well up into the crown. Young trees growing in the open are very graceful and readily distinguished by their characteristic habit of sending their branches out horizontally from the trunk. The lower branches sometimes droop slightly. The name "pin oak" is derived from the many tiny, slender branchlets which stand out from the branches, which at a distance have a pin-like appearance. The wood when utilized in Canada is sold as red oak.

The bark is smooth, somewhat shiny, and steel-brown in colour.

The winter buds are very small, $1 / 8$ in. long, pointed, and chestnut-brown.

The leaves are 4 to $6 \mathrm{in}$. long, and resemble much those of the scarlet oak, but are smaller. The incisions are deep, broad, and rounded. The lobes are pointed and bristle-tipped.

The acorn has a very small cup with thin scales. The nut is less than $1 / 2$ in. long, and is wider than long. It is light brown and striped. The kernel is bitter and the inside of the shell is somewhat downy. The acorn takes two years to develop and ripen.

QUERCUS COCCINEA, Muench.

SCARLET OAK

Common names: Scarlet oak, black oak*, red oak*. French name: Chêne écarlate.

The scarlet oak in Canada is confined to the southwestern part of Ontario, from Toronto westward, where it is found growing on sandy and gravelly lands along with other oaks. It is a tree 40 to $50 \mathrm{ft}$. in height and 1 to $3 \mathrm{ft}$. in diameter. Growing in the open it forms a narrow, rounded, more or less open crown. Its lumber is sold with that of the other black oaks.

The bark of the trunk is dark brown and shallow-fissured; in roughness it has been described as intermediate between that of the red and black oaks. The inner bark is yellowish but not bitter, as in the case of the black oak.

The winter buds are $1 / 8$ to $1 / 4$ in. long and dark reddish-brown. The upper half of the bud is covered with hair, the lower half is smooth. In this latter respect the buds somewhat resemble those of the swamp white oak, but can be distingtiished by the more pointed tip of the scarlet oak buds.

The leaves are 3 to $6 \mathrm{in}$. long and 2 to $5 \mathrm{in}$. broad. The lobes are pointed and bristle-tipped. The notches or indentations are very wide and deep, deeper than 
those of any other native oak, and give the foliage a very ragged appearance. The lower pair of lobes are usually at right angles to the midrib.

The acorns are $1 / 2$ to $1 \mathrm{in}$. long, smaller than those of the red oak. The cup, too, is deeper than that of the red oak. The scales do not form a fringe at the mar-

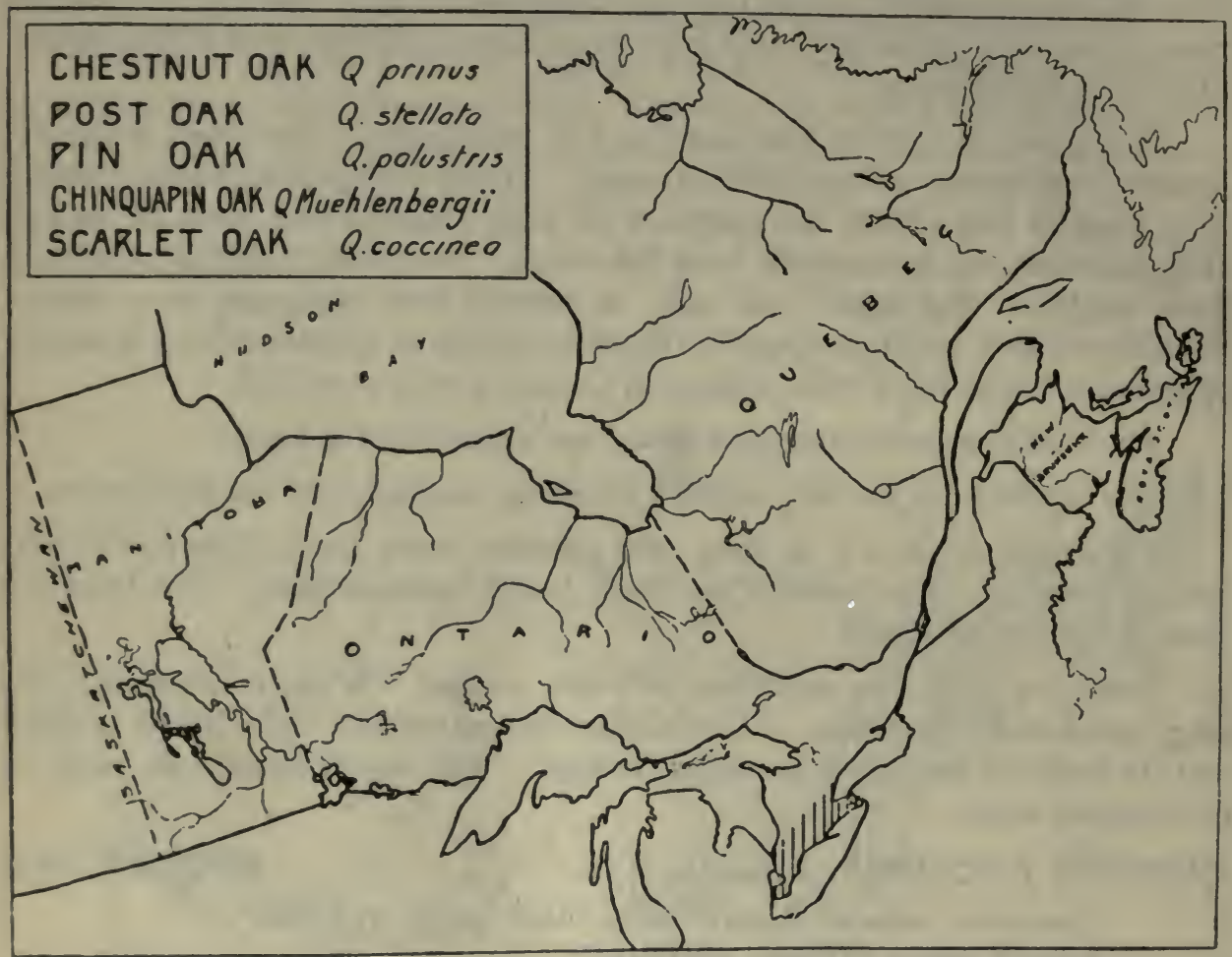

gin. This aids in distinguishing it from the black oak. The inside of the shell is somewhat downy and the kernel is white and bitter. It takes two years for the acorn to mature.

\section{THE ELMS}

Sixteen species of elm (Ulmus) are recognized throughout the world. Six are known to occur in North America and three of these are native to Canada. Several exotic species have been brought to this country for ornamental planting, of which the two most common are the English elm (Ulmus campestris) and the Scotch elm (Ulmus montana). They have larger fruit than the native species.

The wood of the elms as a whole is tough and hard to split, but warps badly in seasoning. It is of great commercial importance and considerable quantities are cut every year.

The elms belong to the same group as the hackberry (Celtis occidentalis), a comparatively rare tree, but which might be mistaken for an elm. They can be 
readily separated by their fruit which in the case of the hackberry is berry-like, and in the case of the elm consists of small flat seeds surrounded by a thin, papery wing.

ULMUS FULVA, Michx.

RED ELM

Common names: Red elm, slippery elm, slippery-barked elm, soft elm, budded elm.

French names: Orme rouge, orme gras, orme fauve.

The red elm averages 50 to $60 \mathrm{ft}$. in height and 1 to $2 \mathrm{ft}$. in diameter.

It develops a crown similar to that of the white elm, and, except when it has grown in the forest, the trunk is comparatively short.

It prefers rich, well-drained soil and is found along the banks of streams.

Its range in Canada is confined to the St. Lawrence valley, not extending north or west of lake Superior.

The bark is greyish-brown and rough. The white layer which is characteristic of the white elm is not present. The fragrant, mucilaginous inner bark, from

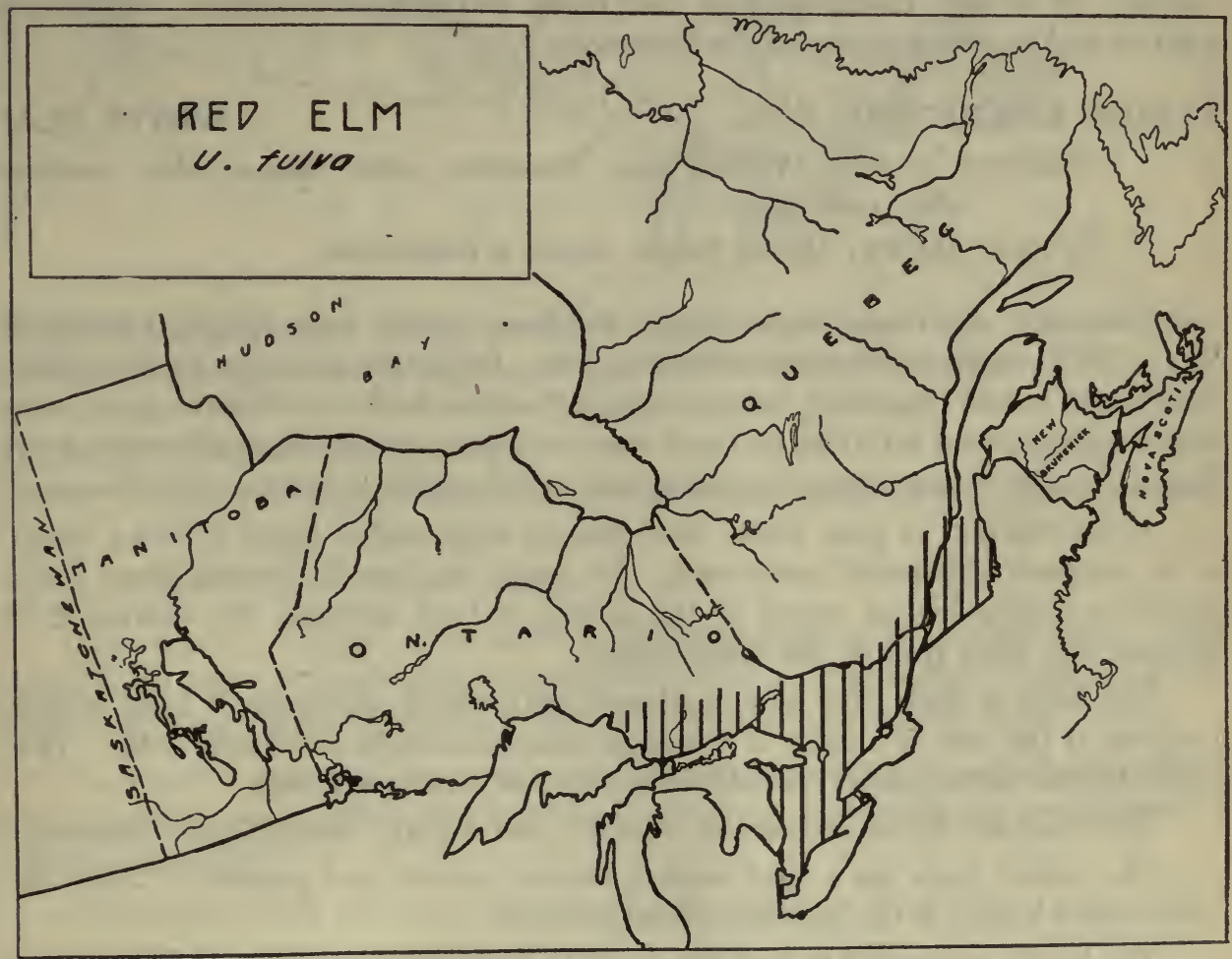

which it derives one of its common names, "slippery," is a peculiarity by which it is distinguished from the white or rock elms.

The twigs at first are green but later become ashy-grey. They are stouter 
than those of the white elm and very much more mucilaginous. The scars left by the leaves are more conspicuous.

The winter buds differ considerably from those of the other elms, and are one of the easiest means of distinguishing it. They have a heavy covering of reddish-brown hair, while those of the rock elm are as a rule only fringed with hair along the margin of the scales, and those of the white elm are smooth. They are larger, rounder, and softer looking than those of the latter species.

The roughness of the leaves is another feature by which this tree is readily distinguished from the other elms; they are not only rougher to the touch but rough whichever way they are rubbed. Those of the white elm are rough only one way. The leaves of the red elm are, on the whole, larger than those of the other elms.

The wing surrounding the seed is larger and somewhat more nearly circular in outline than that of the white elm. The margin is hairless while that of the white has a hairy fringe.

The wood of the red, or slippery, elm is the poorest in quality of the three native species. It is soft, coarse-grained, and liable to mechanical defects, and is not used in any quantity in any of the industries.

ULMUS AMERICANA, Linn.

WHITE ELM

Common names: White elm, American elm, water elm, swamp elm, rock elm*.

French names: Orme blanc, orme d'Amérique.

The white elm is one of our largest and most stately trees, having a height of 50 to $125 \mathrm{ft}$., and a trunk diameter of 2 to $7 \mathrm{ft}$. In the forest it rises to a considerable height before branching, but growing in the open field it divides comparatively close to the ground into two or three main branches, which gradually spread out forming a high triangular or fan-like crown with branchlets more or less drooping.

It thrives best in rich, moist, well-drained soils, and is found growing singly or in mixture with other hardwoods. Its range in Canada extends from Nova Scotia to Saskatchewan, south of the height of land dividing the watershed of Hudson bay from that of the Great Lakes.

The bark is dark grey and roughened with broad, flat-topped, flaky ridges. Looking at the side of a ridge it shows an occasional layer of whitish bark. This characteristic distinguishes it readily from the red, or slippery, elm.

The twigs are brownish, slender, smooth, and slightly mucilaginous if chewed.

The winter buds are a light reddish-brown, conical, and pointed. They are smooth and have not the hairiness of the red elm.

The leaves are from 4 to $6 \mathrm{in}$. long, and uneven-based, giving them a lop-sided appearance. The underside is soft and hairy. The red elm on the contrary is rough to the touch. The veining is coarse.

It flowers in April and seeds abundantly in May and June. 
White elm is one of the most generally, useful hardwoods in America, and is valued chiefly on account of its strength and toughness. It is mostly used in manufacturing slack staves, hoops, and heading; furniture, boxes, veneer baskets,

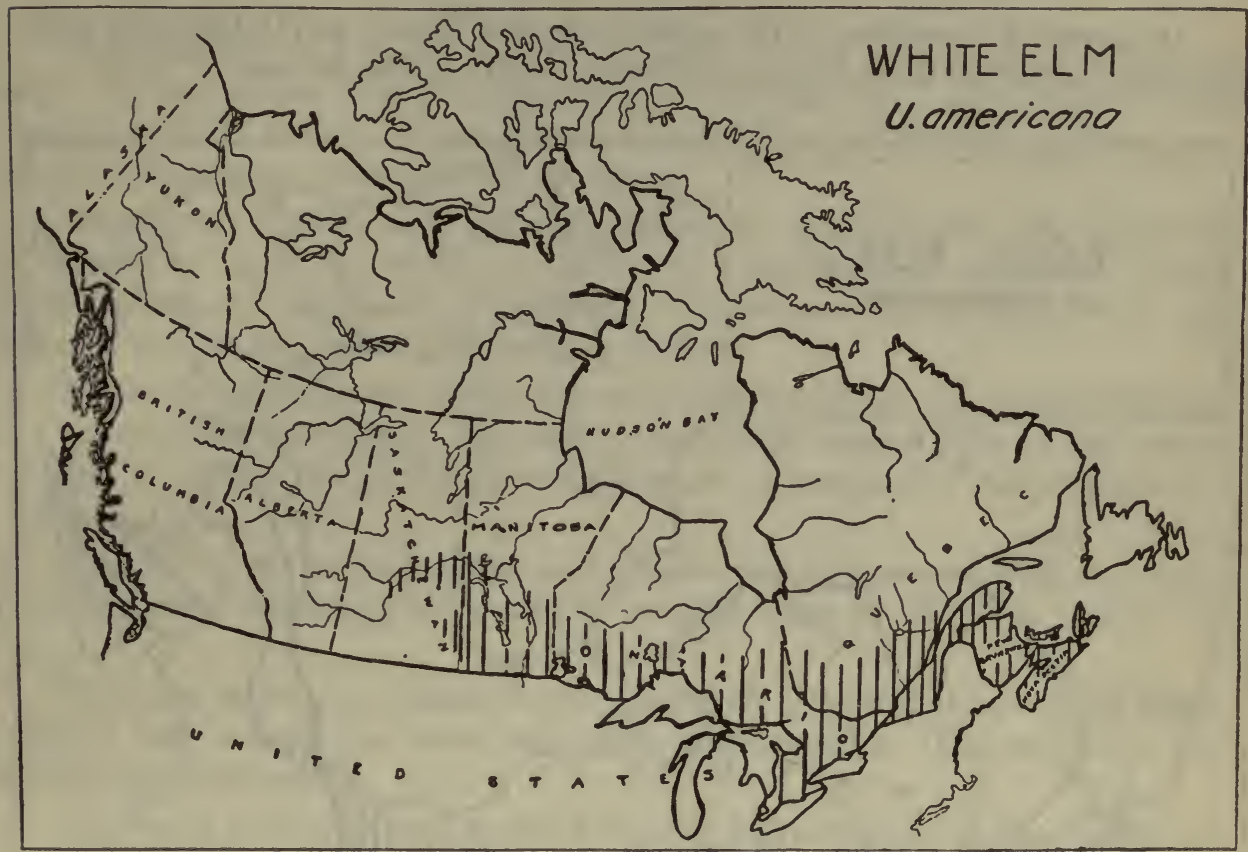

cheese-boxes, and other veneer products; vehicle stock (especially wagon hubs); framework for agricultural implements and machinery; and hockey sticks.

ULMUS RACEMOSA, Thomas

ROCK ELM

. Common names: Rock elm, cork elm, hickory elm, cork-barked elm, white elm*.

French name: Orme liège.

The rock elm averages 50 to $60 \mathrm{ft}$. in height and about $2 \mathrm{ft}$. in diameter. The trunk is slender and erect, and the branches, coming off at a wider angle from all sides than those of the white or red elms, form a somewhat round-topped crown.

Its general shaggy appearance, and the fact that even the small branchlets and twigs have corky ridges growing from thcir sides, render this tree unmistakable for the other elms.

The winter buds are somewhat larger and narrower than those of the white elm and the leaves are on the whole smaller. Like the leaves of all elms they are unequal at the base.

The wing of the fruit is hairy. The seeds are greater in proportion to the size of the wing than those of other elms. 
The rock elm grows on a wide range of soils, from dry and gravelly or heavy clay soils to the rich, moist banks of streams. It is found solitary or mixed with other hardwoods.

In Canada it is confined to the southern parts of Quebec and Ontario and probably does not extend north beyond the Ottawa river or Georgian bay.

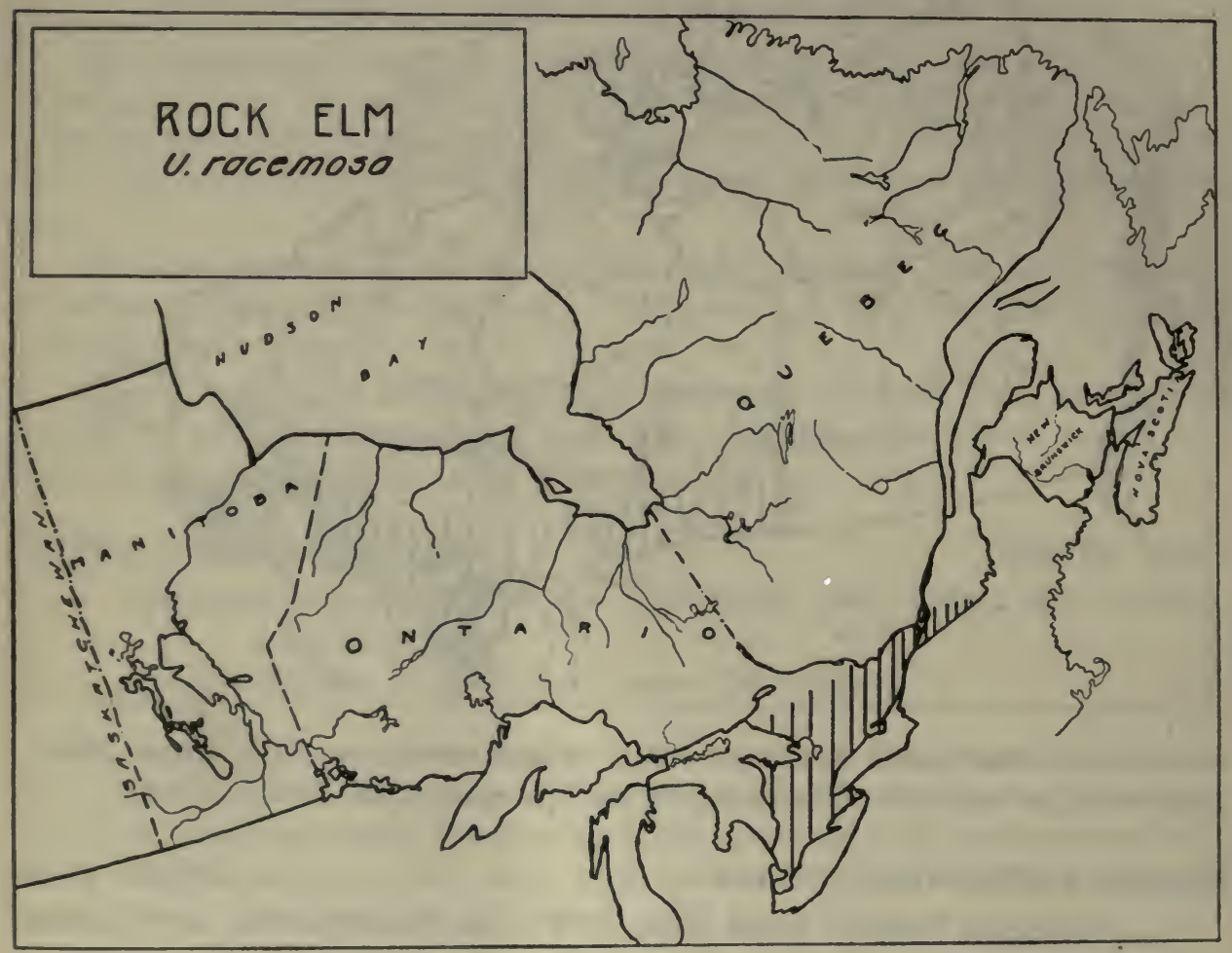

The wood of this elm is the hardest, toughest, and strongest of the American species. It is preferred to white elm for framework in pianos, heavy machinery, shipbuilding, and vehicle stock. Otherwise the two species have similar uses.

\section{THE HACKBERRIES}

Fifty or more species of hackberry (Celtis) are found throughout the world in both the north temperate and tropical regions. They are mostly shrubs and small trees of no economic importance. They belong to the same group as the elms and resemble them in many respects. The wood is like that of the elm except that it is somewhat heavier, harder, and more brittle. In cross-section it shows the zigzag lines of minute pores which is the characteristic marking of this group. 
CELTIS OCCIDENTALIS, Linn.

HACKBERRY

Common names: Hackberry, bastard elm.

French names: Orme bâtard, micocouiller occidental.

The hackberry is a tree 25 to $35 \mathrm{ft}$. high and 1 to $2 \mathrm{ft}$. in diameter. It forms a large, rounded crown, but often flat-topped and spreading. This characteristic, together with its slightly drooping lower branches and elm-like leaves, often leads one at first glance to mistake it for an elm.

It prefers rich, moist söis but will grow on dry, gravelly sites. It is confined in Canada to the valley of the St. Lawrence from Montreal westward through southern Ontario. It is local in its distribution and nowhere in Canada is it very common and for this reason is generally unknown.

While this tree at a short distance is easily mistaken for an elm, a close examination shows many differences. The bark of the trunk, instead of being flaky as in the elm, is covered with wart-like ridges which often extend well up into the branches.

The pith of the twigs is white and chambered, while in the elms it is solid. The wood when moistened has a slightly greenish tinge not visible in that of the elm.

The buds, which are chestnut-brown, flattened, pointed and somewhat hairy, generally have a dark edge about the margin of their scales. The bud at the end of the twig is lacking.

The leaves much resemble those of the elm but are more taper-pointed, and comparatively free of teeth. They are about $3 \mathrm{in}$. long, deep green in colour, and rough to the touch.

The fruit is berry-like, reddish to dark purple, the size of a currant, and contains a stone. It ripens in September and is sweet and edible.

The wood of the hackberry is very similar to that of the rock elm. The two are difficult to separate when sawn into lumber and when hackberry is utilized it is usually sold mixed with either rock or white elm.

\section{THE MULBERRIES}

Seven species of mulberry (Morus) are recognized of which two at least occur in North America, and of these one grows in Canada. Several of the species are cultivated for their leaves which furnish the principal food of the silkworm, also for their fruit which is edible. Perhaps the most widely known snecies is the white mulberry (Morus alba) which all over the world has escaped from cultivation and now grows wild. It is occasionally found growing wild in southern Ontario, but can be readily distinguished from the native species by its lighter-coloured twigs, smaller winter buds, and white, instead of red, berries.

The wood of the mulberries is of high technical value, hard, and durable. In some parts of the United States the mulberry is planted for the purpose of producing fence-posts.

$22510-7$ 
MORUS RUBRA, Linn.

RED MULBERRY

Common names: Red mulberry, black mulberry, mulberry. French names: Murier rouge, murier sauvage.

The red mulberry is found growing naturally in Canada only in the Niagara peninsula, and westward to the Detroit river, but is nowhere a common tree.

It is small, 15 to $30 \mathrm{ft}$. in height, when grown in the open. The trunk is short and the crown is broad, round-topped, and compact. On this account and for its berries it is sometimes planted on lawns and in gardens.

The bark is reddish-brown and divides into long plates or strips, which are somewhat flaky. It resembles that of the white cedar but isfirmer, notso stringy or fibrous.

The twigs are slender, reddish, and have a somewhat zigzag habit of growth. When cut on a warm day early in the spring they give out a milky juice with a rather sweetish taste.

The leaf-scars are distinctly marked with a more or less closed ring of raised bundle-scars. This is characteristic of all the mulberry species.

The winter buds are about $1 / 4$ in. long, stout, greenish to brown, shiny, sometimes slightly flattened, and stand out well from the twig.

The leaves are 3 to $5 \mathrm{in}$. in length, broadly oval, but variable in form; some are entire and others have one, two or even five lobes. They are thin, firm, dark green above, and downy beneath. The margins are saw-toothed.

The fruit resembles a blackberry, about $1 \mathrm{in}$. long, attached to a stem about one-quarter as long. It is red when full grown but dark purple when ripe. It is sweet, juicy, and edible and is eagerly devoured by bircis, and for this reason the tree is sometimes planted near gardens to distract the birds' attention from other more valuable small fruits.

The wood is bright orange-brown in colour and is fairly hard and heavy. It is very durable and is sometimes used for posts, cooperage, and boat-building in the Ohio valley where it is most abundant. It is not an important tree in Canada.

\section{THE MAGNOLIAS}

Twenty species of magnolia (Magnolia) are found throughout this continent and eastern Asia. Seven are native to North America, and only one occurs naturally in Canada. Most of them are of little economic importance except for decorative planting. For this purpose many horticultural varieties have been produced. The Asiatic species, while not as large trees as the American, have larger and more showy flowers.

MAGNOLIA ACUMINATA, Linn.

CUCUMBER TREE

Common names: Cucumber tree, magnolia, pointed-leaved magnolia.

French name: Magnolier à feuilles acuminées.

The cucumber tree is rare in Canada, and, like many other trees in this country, is to be found only in the southwestern portion of Ontario in the counties bordering on lake Erie. 
Farther south, when growing under favourable conditions, it sometimes becomes a large tree, 80 to $90 \mathrm{ft}$. high and 2 to $3 \mathrm{ft}$. in diameter. Ordinarily, however, it is much smaller. In the United States its wood is sometimes used for interior finish.

When not crowded the shape of the tree is conical with a wide base. The bark of the trunk is roughened by flaky ridges of greyish-brown colour.

The twigs are slender, brown, shiny, smooth, and aromatic. The winter buds are very blunt and covered with silky hair. The end bud of the twig is several times larger than those along the side.

The leaves are 6 to $10 \mathrm{in}$. long and 4 to 6 in. broad. In outline they are a pointed oval. They are thin, smooth on top, and slightly downy beneath. They are widely distributed along the branch, not clustered towards the end. They are numerous and produce a heavy shade.

The flowers are about $3 \mathrm{in}$. wide, yellowish-green, bell-shaped, composed of six petals, and stand upright on the ends of the twigs.

The fruit is usually oblong and curved, and, when green, resembles a cucumber in appearance. When ripe it is dark red in colour and the various sacs or pockets open, releasing the flattened, orange-red seed each contains. The seeds hang suspended by fine white threads.

\section{THE TULIP TREES}

Only two species of tulip tree (Liriodendron) are recognized. One is a small tree or shrub in China and the other is our native one, which in the United States is an important timber tree and which would be so in Canada but for its scarceness. The tulip trees were much more widely distributed at one time, for fossil remains of them are found both on this continent and in Europe.

LIRIODENDRON TULIPIFERA, Linn.

TULIP TREE

Common names: Tulip tree, yellow poplar*, whitewood*. French name: Tulipier.

The tulip tree has a very limited range in Canada, being found growing naturally only in the southern peninsula of Ontario, from Niagara westward to the Detroit river.

It is a tall, stately tree 50 to $70 \mathrm{ft}$. in height and with a trunk diameter of $2 \mathrm{ft}$. or over, sometimes reaching the immense height of $175 \mathrm{ft}$. The branches are comparatively short; those near the top usually ascending, and those near the bottom declining, make a very open, irregular crown.

The bark of the trunk is thick, brown, closely furrowed, and has the tightfitting appearance of the white ash bark. The inner bark is bitter.

The twigs are slender, reddish-brown, and smooth. They have an exceedingly bitter taste but a rather pleasant aromatic smell. The winter buds are long and $22510-7 \frac{1}{2}$ 
blunt at the tip with the terminal or end bud of the twig much larger and longer. They are reddish-brown and covered with a bloom. The leaf-scar is circular

The leaves are 5 to $6 \mathrm{in}$. long and of such a peculiar shape that they are readily distinguished from those of any other native tree. The end or top is abruptly squared or slightly notched as though it had been clipped off.

The flowers are tulip-like, 3 or 4 in. across and composed of six, greenish-

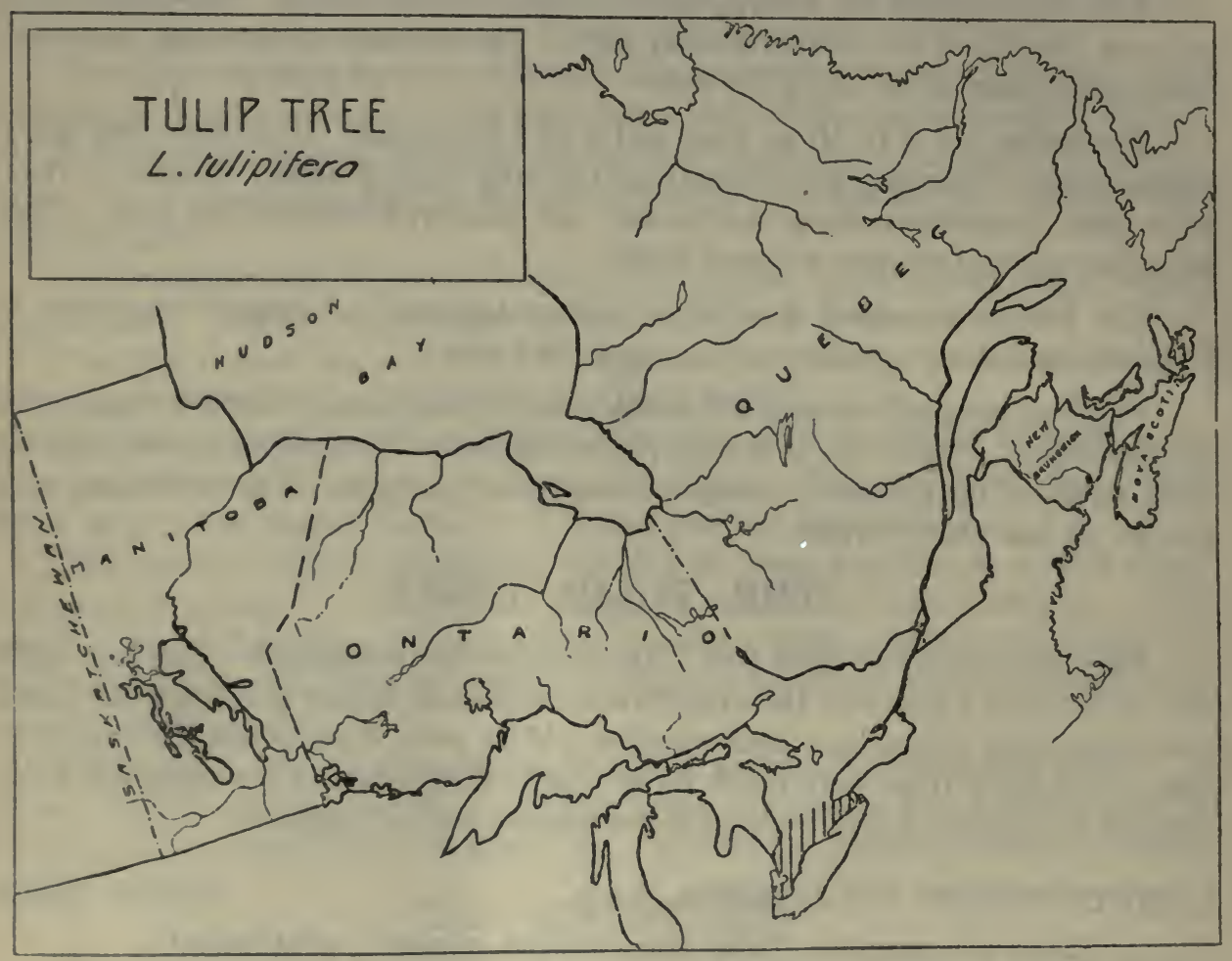

yellow petals, touched with orange inside the cup. They open in May and it is from them the tree derives its common name.

The fruit is a peculiar, erect cone 2 to 3 in. long, composed of many dry, flatwinged seed-cases, which are attached to a central spike. These gradually drop off after the seeds ripen, often leaving the central axis, with the lower scales attached, to remain on the tree during the winter.

Owing to the comparative scarcity of this tree in Canada, it is of minor commercial importance from the standpoint of lumber production. The wood has valuable physical qualities similar to those of basswood. It is soft, durable, tough, and is considered to be the best wood in America to hold its shape after seasoning. It is imported from the United States for panelling and steam-bent work by manuacturers of vehicle bodies, pianos, cars, and cabinet-work. Tulip veneer is used for cross-banding in built-up glued products. 


\section{THE PAPAWS}

The papaws (Asimina) belong to a large tropical or sub-tropical family. Six species are known. In North America one reaches tree size and extends as far north as southern Ontario, the others are shrubs and found in the southern Atlantic and Gulf states of the United States. They are of no commercial importance.

ASIMINA TRILOBA, Dunal

PAPAW

Common names: Papaw, custard apple, false banana, jasmine*. French names: Faux-bananier, jasminier*.

In Canada the papaw is confined to the townships in southern Ontario bordering on lake Erie, where it grows on deep, moist soils. It is not very common and when found is usually in the form of a shrub, although under favourable conditions

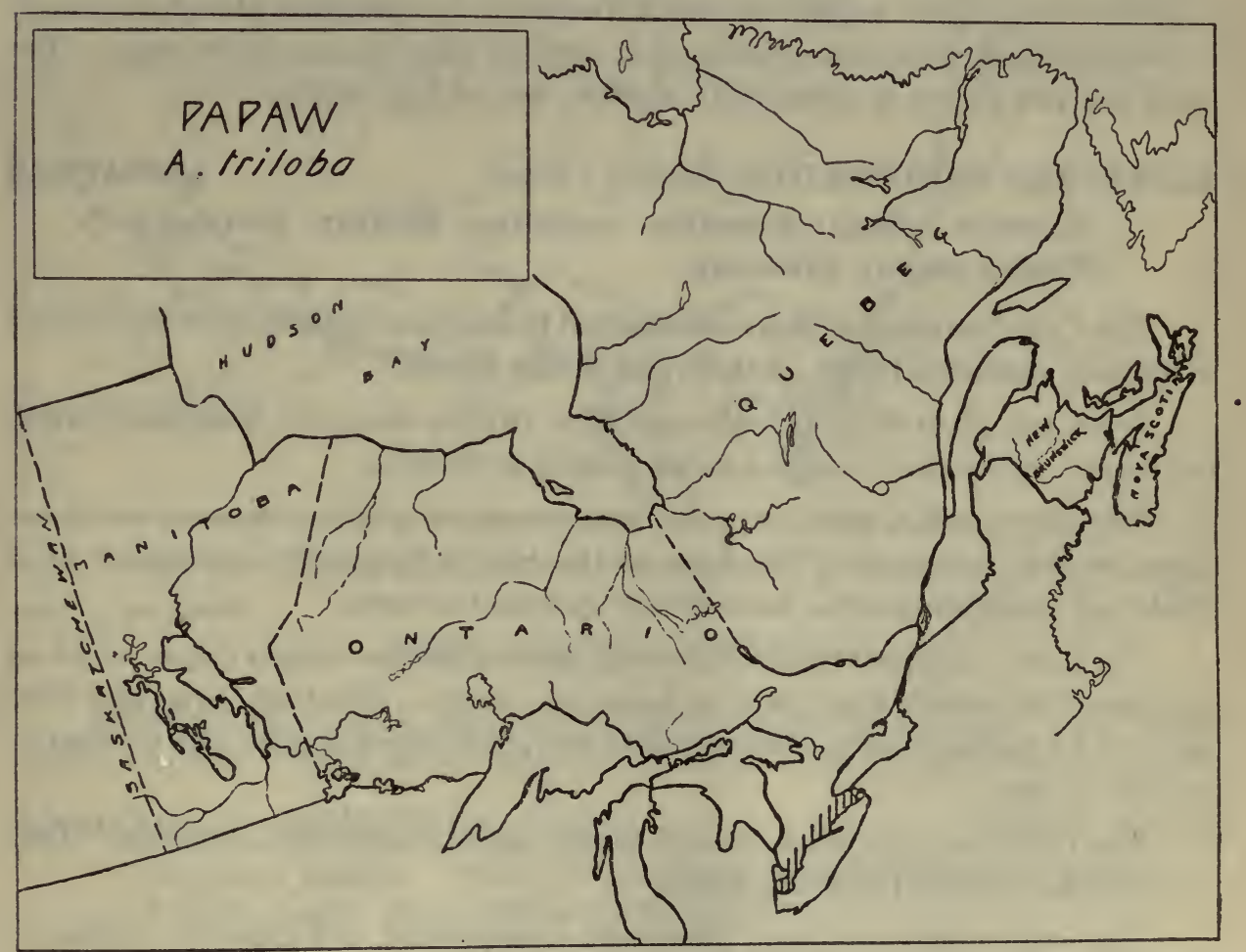

further south it gets to be $30 \mathrm{ft}$. tall. For the most part it forms the undergrowth in rich woodlands.

The bark is smooth, shiny, dark brown, and blotched with grey spots. The inner bark is fibrous and tough. The twigs are slender and spreading, tinged with red, and marked with little grooves running lengthwise. The winter buds are small, brown, hairy and slightly tapered at the top. 
The leaves are 8 to $12 \mathrm{in.}$ long and 3 to 4 in. wide, the widest part being above the middle. The margin is toothless and the upper surface is smooth and dark green. The stems are very short and stout. The leaf is very similar to that of the magnolia or cucumber tree.

The fruit is characteristic. It is 3 to $5 \mathrm{in}$. long, oblong in shape but sometimes irregular. The flesh is yellow, soft, edible, and much prized by those who have acquired a taste for it. The seeds are flat, wrinkled, and about $1 \mathrm{in}$. long and $1 / 2$ in. broad.

The wood has neither technical nor commercial value.

\section{THE SASSAFRAS}

There is only one species of Sassafras (Sassafras) known and it is found in China and the eastern portion of North America. It is nowhere abundant enough to be of economic importance, although it is widely distributed over its range. The wood is a rich brown in colour, soft, durable, and of high quality.

SASSAFRAS VARIIFOLIUM (Salisb.) Ktze.

SASSAFRAS

Common names: Sassafras, sassafrax, saxifrax, sarsaparilla*. French name: Sassafras.

The Canadian range of this tree is limited to southern Ontario, from the vicinity of Toronto westward to the southern end of lake Huron.

It is a tree 30 to $40 \mathrm{ft}$. in height and 12 to $18 \mathrm{in}$. in diameter, sometimes larger, but on dry, sandy sites is of ten a shrub growing in thickets.

The crown is flat, open, irregular, and composed of stout branches which are more or less contorted. The base of the tree is frequently surrounded by a thicket of young shoots that have sprung up from the roots.

The bark is thin, but cut by fairly deep grooves into prominent ridges, which on large trees are broken into blocks by transverse cracks. The bark, twigs and roots all have a peculiar, strong, aromatic taste and smell which enables one to identify the tree at once.

The twigs are fairly stout, reddish-brown, smooth, and shiny, as a rule. They are irregular in their branching habits.

The winter buds are large, prominent, oval-pointed, and greenish. Those on the side stand well out from the twig.

The leaves are 4 to 6 in. long, dull yellowish-green, smooth, and rather thick. They have three distinct forms, one oval-tapered at both ends, another somewhat similar, with the addition of a lobe at one side like the thumb of a mitten, and a third three-lobed, like a mitten with a thumb on each side. All these forms may be found on the same tree. 
The fruit is berry-like, small, oval, blue, soft, and single-seeded. It is borne on a fleshy, cup-shaped stem.

The sassafras is sometimes sawn into lumber in Canada and used for cabinet-

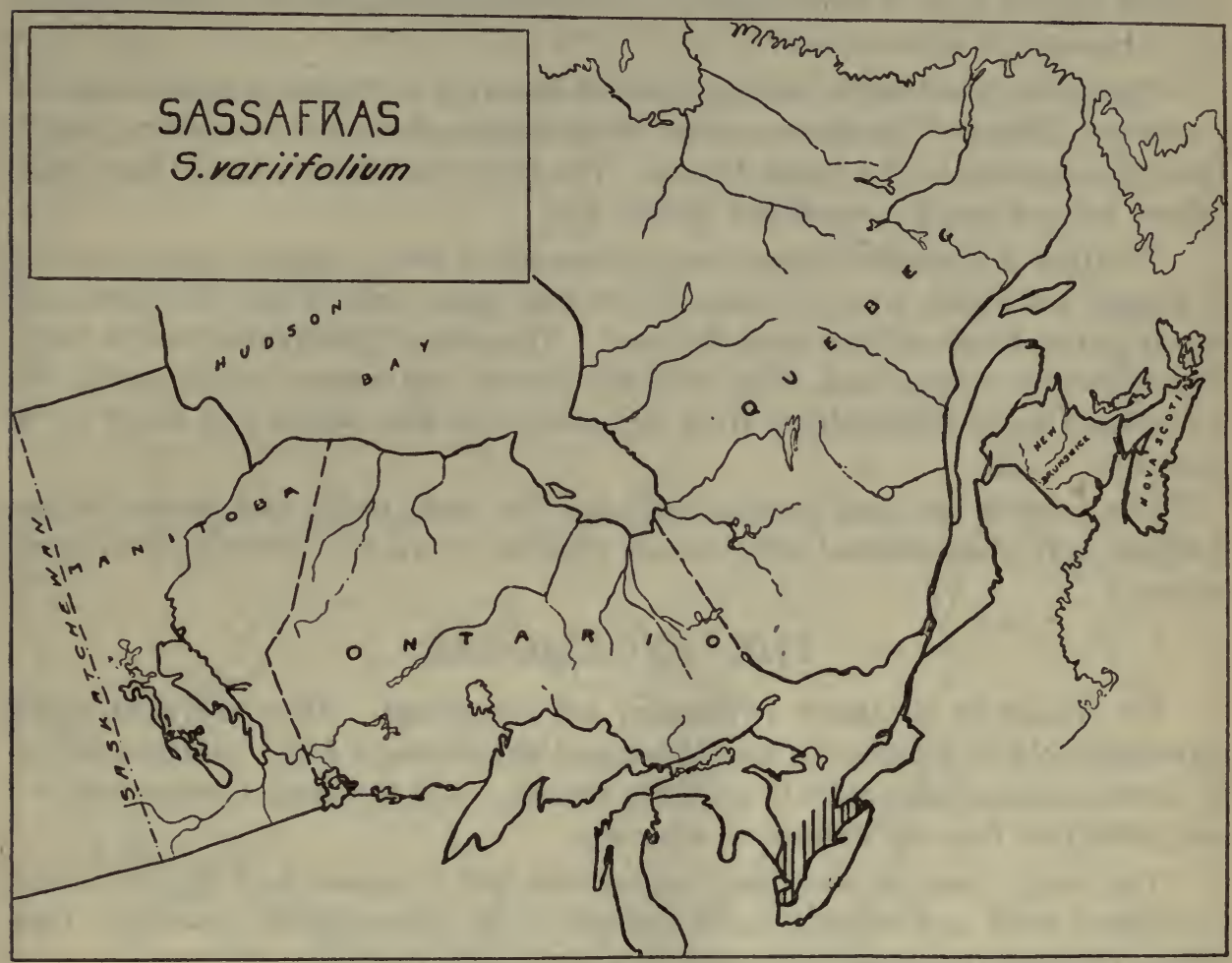

work. The wood is soft and durable, has a pleasing grain and figure, and is pleasantly aromatic.

\section{THE WITCH HAZELS}

Three species of witch hazel (Hamamelis) are known, one in North America and two in Asia. They are all small trees or shrubs and not important for lumber.

HAMAMELIS VIRGINIANA, Linn.

WITCH HAZEL

Common names: Witch hazel, winter bloom, snapping hazel. French name: Hamamélis de Virginie.

The witch hazel is sometimes a small tree 20 to $25 \mathrm{ft}$. high, but more often is a shrub growing in thickets or clumps on moist sites in ravines and on shady hillsides. In Canada it is found from Nova Scotia westward throughout the southern portions of Quebec and Ontario.

The bark is smooth, brown, and mottled on the trunk and larger branches. On the slender zigzag twigs it is shiny, sometimes downy. 
The winter buds are light brown, downy, narrow, long, slightly curved and flattened, and more or less stalked.

The leaves are 4 to 6 in. long and oval in outline. The margin is very wavytoothed and the base is unsymmetrical. The veining is depressed, giving the surface a corrugated appearance.

The witch hazel has a curious habit of flowering in the late autumn when its leaves are falling. The flowers come out in small golden-yellow clusters, which have the appearance of a tangled mass. The individual flower with its four, long, yellow, twisted petals is small and spidery-like.

The fruit is a peculiar brown, woody, two-celled pod, or capsule, about the size of a large pea which, when it ripens in October, splits open in four directions and expels its two black seeds to some distance. These dried pods remain on the twigs throughout the winter, and, along with the flowers, are features which enable the witch hazel to be distinguished from any other tree with which it is likely to be confused.

The wood is not used commercially but the bark, twigs, and leaves are astringent, and when distilled with alcohol yield the extract of witch hazel of commerce.

\section{THE SYCAMORES}

Six species of sycamore (Platanus) are recognized. They are distributed throughout North America, in Asia Minor and southwestern Asia. Of three native to North America one occurs in southern Ontario. All the species are so remarkably alike that they are difficult to separate.

The wood is not of very great importance, but it is used to a certain extent for cabinet-work and interior finish because of its characteristic marking. One species (Platanus orientalis) is a common street tree in Europe.

PLATANUS OCCIDENTALIS, Linn.

SYCAMORE

Common names: Sycamore, buttonball, buttonwood, plane tree. French names: Platane, sycomore.

Under favourable conditions the sycamore sometimes reaches a diameter of 7 or $8 \mathrm{ft}$., but the average is not more than $2 \frac{1}{2}$ to $3 \mathrm{ft}$. The height is about $100 \mathrm{ft}$.

The trunk is usually short and irregular. A cross-section of it would be eccentric. The crown is large and very wide-spreading when growing in the open. The limbs are very thick and irregular in the way they branch and grow out from the trunk. The roots are shallow and wide-spreading.

The bark of this tree is very characteristic and enables one to distinguish it from any other native tree. On the trunk it breaks off in thin, brittle, irregular plates. Higher up it is smooth, an olive-green colour, and covered with white blotches.

The twigs are smooth and shiny and have a more or less zigzag growth. The winter buds are smooth, brown, and conical in shape and are surrounded by the 
scar left by the fallen leaf. Before the leaf falls the bud is not visible since it is concealed beneath the end of the leaf-stem. The leaves are very broad for their length and in outline suggest the leaf of the maple. The fruit resembles a small brown ball about 1 in. in diameter hanging from a long stalk. It is composed of many hairy nutlets, or seeds, tightly pressed together.

The tree is confined to rich bottom lands along the stream courses and shores of lakes. It never forms pure stands but is always scattered or in small groups.

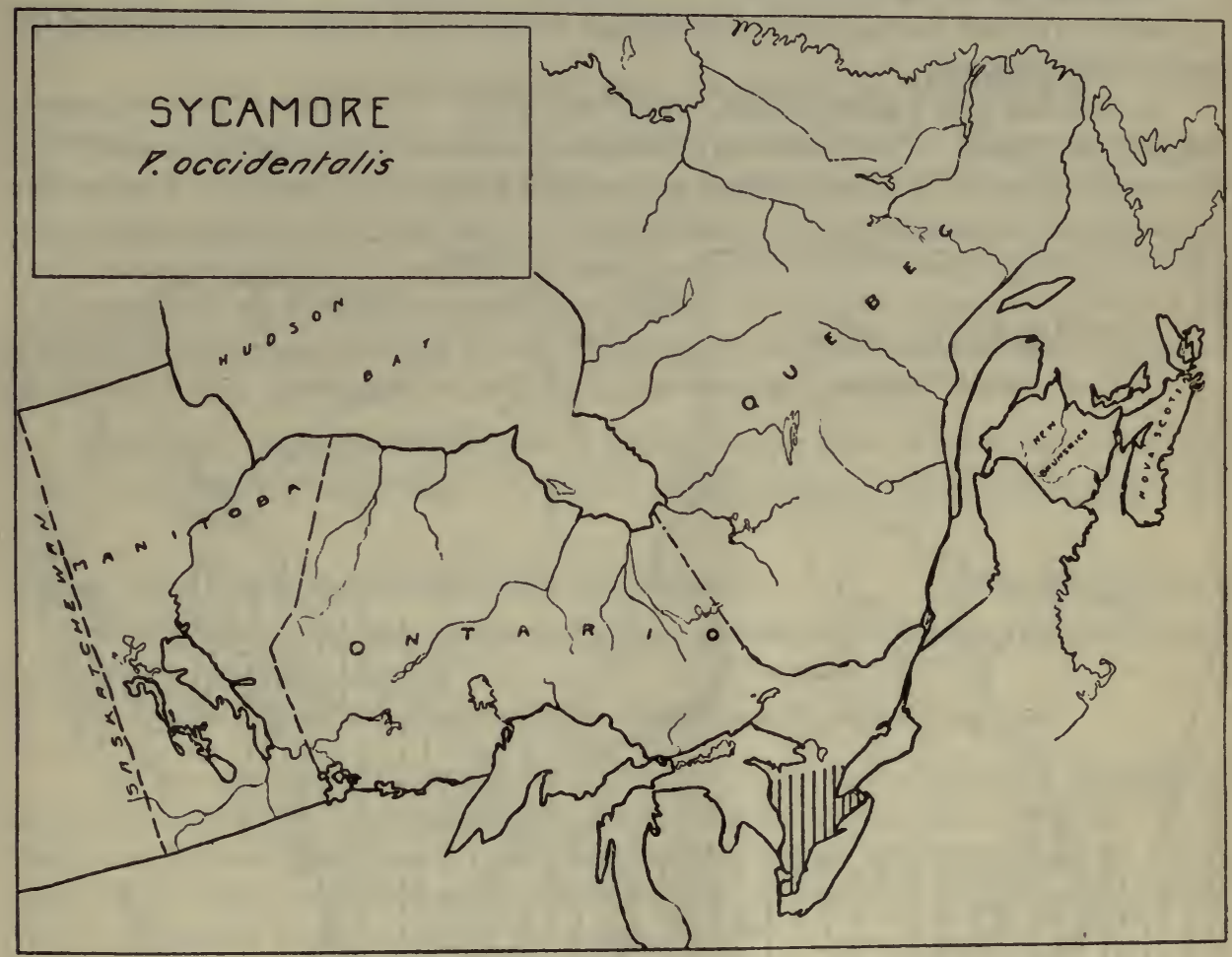

In Canada the sycamore is found growing naturally only in Ontario, and only in that part of the province west of a line joining the city of Toronto with the lower end of the Bruce peninsula on lake Huron. It has, however, been successfully planted outside of this range for ornamental purposes. Specimens are growing as far north as the city of Ottawa.

\section{MOUNTAIN ASHES OR ROWANS}

The mountain ashes or rowans (Pyrus) are found widely distributed as trees or shrubs throughout the northern hemisphere. Three or four species are found on this continent. They are of no importance except for decorative planting. The one most used for this is the European rowan (Pyrus aucuparia). It has larger berries than our native trees. 
PYRUS AMERICANA (Marsh.) De C. MOUNTAIN ASH

Common names: Mountain ash, rowan tree*, rowan berry.* French names: Cormier, sorbier d'Amérique.

The mountain ash has been found in various localities right across Canada from Cape Breton to Saskatchewan, usually in moist soil along the borders of streams and swamps, but frequently on drier sites such as rocky hillsides.

Froperly speaking it is not an ash at all, but is related to the apple tree. It is a graceful tree and having attractive foliage, flowers, and fruit, is much planted for ornamental purposes.

It does not gain a great height, rarely over $30 \mathrm{ft}$. The crown is narrow, roundtopped, and open. The bark is greyish-brown and smooth, sometimes shredding into thin scales. The stout twigs are reddish-brown and smooth. The winter

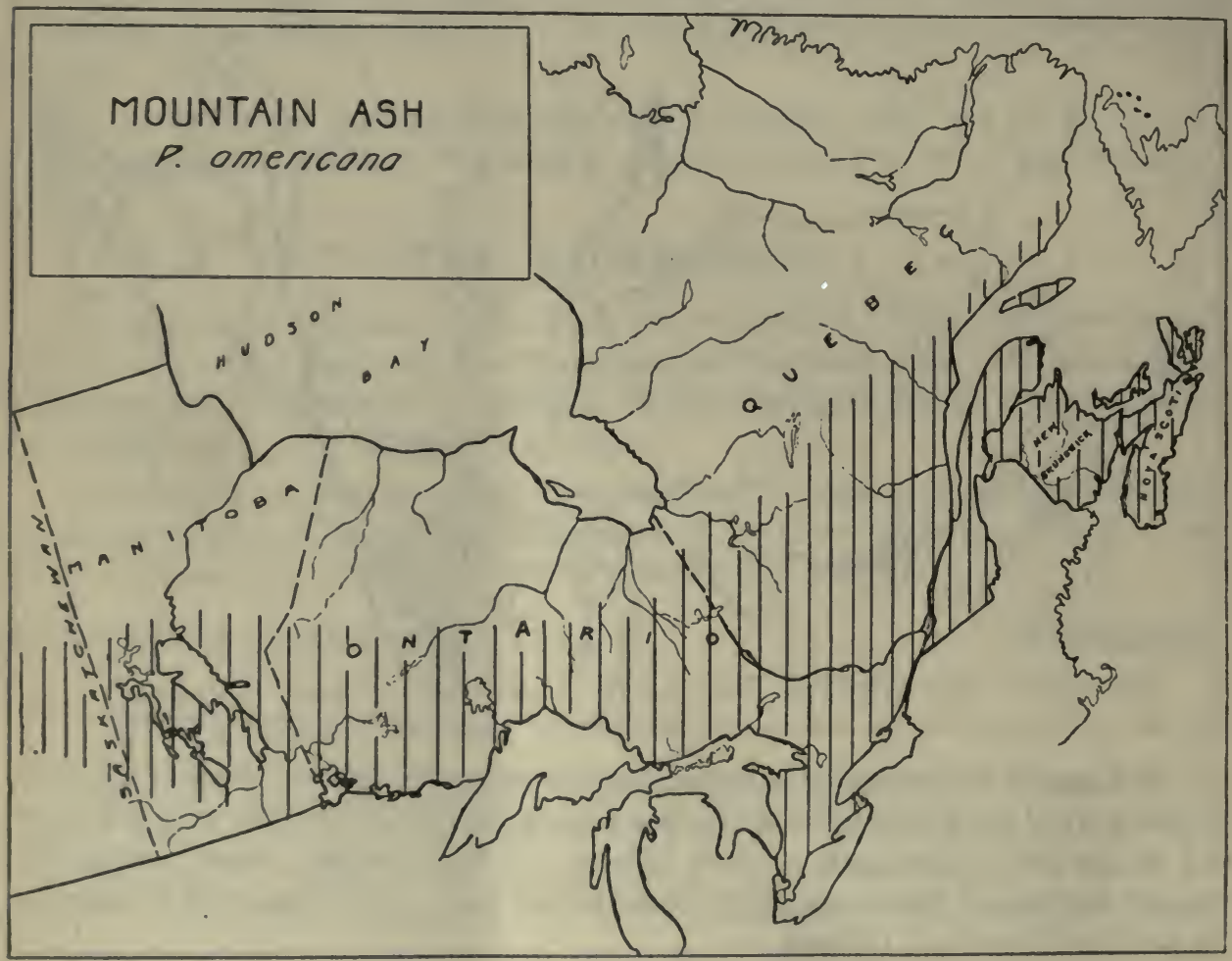

buds are large, about $1 / 4$ in. long (the end bud considerably longer), conical, with points slightly curved, gummy, and smooth. The European species, the rowan (Pyrus aucuparia), has downy buds.

The leaves are feather-like in the arrangement of the leaflets, from 6 to 8 in. long and composed of thirteen to seventeen narrow, sharp-toothed leaflets.

The fruit is a bright red berry the size of a pea, which grows in great, flat clusters. These remain on the branches all winter ard, in spite of their strong acid 
flavour, are much sought after by certain birds on their return from the south in the early spring.

The western mountain ash is considered by some anthorities a distinct species (Pyrus sitchensis) and by others only a variety of the above. It has larger flowers and fruit and a more westerly range, extending through the Rocky mountains to Alaska.

The wood of the mountain ash has no technical value but the berries are used for medicinal purposes.

\section{THE SHADBUSHES OR SERVICE-BERRIES}

The shadbush or service-berry group (Amelanchier) is widely distributed throughout the world. Most of the species are shrubs, but three of the native species sometimes reach tree size. Two of them, the Amelanchier canadensis and the Amelanchier obovalis, are eastern species which resemble each other very much and ordinarily go by the same common name. The latter, however, owing to its somewhat longer or narrower leaves, sometimes receives the name of "longleaf" shadbush. The Amelanchier alnifolia is the western species.

They have pretty, white flowers in spring and on that account are sometimes used for ornamental planting. The fruit of all species is sweet, berry-like, and edible.

AMELANCHIER CANADENSIS (L.) Medic.

SERVICE-BERRY

Common names: Service-berry, shadberry, Juneberry, wild pear, lancewood*.

French names: Amélanchier du Canada, petites poires.

The service-berry is a small tree 15 to $25 \mathrm{ft}$. high with a diameter of 4 to $8 \mathrm{in}$. Sometimes it is found growing like a shrub with many stems in a clump. It inhabits well-drained soils such as hillsides in open woods and, in Canada, is found from Nova Scotia westward throughout the St. Lawrence valley to the north shores of lake Superior, but is nowhere abundant.

The smooth, close-fitting, greyish-brown bark might lead one to mistake it for a young beech. The bark of the service-berry, however, is darker as a rule and on young trunks is quite often streaked with dark, longitudinal lines.

The winter buds, too, resemble those of the beech, being long, narrow, and sharppointed, but they are pressed close to the stem and do not stand out at the wide angle so characteristic of the beech buds. 'The bud scales are edged with white, while those of the beech are not. They are also fewer in number.

The finely-toothed, smooth-surfaced leaf, however, would never be mistaken for the leaf of the beech. It resembles somewhat that of the pear but is of finer texture.

It is a conspicuous tree in the spring, when covered with its many white flowers. The fruit is a dark, purple, edible, berry, about the size of a currant and ripens in July. 
Its wood is occasionally used for handles, fishing-rods, bows, and small turnery and is sometimes sold as lancewood.

\section{AMELANCHIER ALNIFOLIA, Nutt.}

SASKATOON

The saskatoon in Canada is found from Alaska south throughout British Columbia, and eastward to Georgian bay in Ontario. It is seldom found as a tree, but is more commonly a shrub 8 or $9 \mathrm{ft}$. in height; in the prairie region usually 3 or $4 \mathrm{ft}$. high.

It resembles the eastern tree forms of the Amelanchiers but can be distinguished by its leaves. These are rounder in outline and the lower half of the margin is smooth while the upper half is coarsely toothed.

The fruit is sweet and edible and resembles the huckleberry in appearance. It is much sought after by the settlers in the West where it is commonly called the saskatoon berry.

\section{THE HAWTHORNS}

Several hundred species of the hawthorn (Cratuegus) have been described. Twenty or more of them are found in Canada of which the greater number occur in the southern portion of the eastern provinces. One species, the black law (Crataegus Douglasii), is found in British Columbia.

There is no group of trees in Canada in which it is more difficult to separate the different species. So large is this group, and so rapidly is it modifying, that only one who has the time and patience to make a special study of hawthorns can hope to know them all. The points of distinction relied upon are found mainly in the flower and the fruit. It is beyond the scope of a book of this nature to take up their minute differences.

In habit the hawthorns are usually low, wide-spreading, bushy trees, sometimes found growing as shrubs in thickets. Within their range they are common trees along the country roadside, in open places in the farmer's woodlot, and in fence corners.

They can be readily distinguished from other trees by their somewhat zigzag twigs which are well armed with long thorns. These thorns occur just above the point at which the leaf is attached and are usually unbranched and exceedingly sharp. The thorns attached to the trunk and larger branches are frequently branched.

The winter buds are small, shiny, chestnut-brown, rounded, and covered witl many overlapping, thick scales.

The fruits, or "haws," as they are sometimes called, when ripe suggest tiny scarlet apples. They are somewhat edible, but as a rule the proportion of bony seed to flesh is so great that they are not much sought after. They sometimes remain on the tree all winter.

The wood of the hawthorns is very heavy, hard, and tough, and is sometimes used for small turnery such as handles, mallets, and wooden novelties. 


\section{THE PLUMS AND CHERRIES}

Over one hundred and twenty species of this group (Prunus) have been described. To it belong the plums, cherries, peaches, apricots, and almonds. Only one species of plum and six or seven species of cherry are native to Canada. Two of the cherries are native to the Pacific region.

All the native species, with the exception of the black cherry (Prunus serotina), are small trees or shrubs, and of little importance commercially.

The seeds of this group contain more or less prussic acid, and their twigs and bark are characteristically bitter and astringent.

The fruit of the plum is usually more or less two-lobed with a groove on one side and is often covered with a whitish bloom. The fruit of the cherry is smaller and without this bloom. The cherry seed is round instead of flat as with the plums.

PRUNUS NIGRA, Ait.

CANADA PLUM

Common names: Canada plum, red plum, wild plum*, horse plum. French name: Prunier canadien.

The Canada plum is distributed throughout the St. Lawrence valley and westward to the Red river in Manitoba.

It grows as a small tree 20 to $25 \mathrm{ft}$. in height, often as a shrub in thickets. The bark is a greyish-brown and at first smooth, but later breaks and curls back into papery plates, exposing rough inner bark.

The crown is narrow and composed of stiff, erect branches, ending in stiff, slender, smooth twigs which, in their second year, develop spiny spurs. These coarse spurs, which may develop leaves, distinguish this tree from any of the cherries

The winter buds are brown, $1 / 8$ to $1 / 4$ in. long, conical, and pointed. The terminal bud of the twig is absent.

The leaves are 3 to $5 \mathrm{in}$. long and $11 / 2$ to 3 in. broad; rather rounded in outline, with the tip suddenly drawn to a point. They are thick, firm, dark green, and dull.

The fruit, which ripens in August, is oblong in shape, $1 \mathrm{in.}$ or more in length. The skin is smooth, orange-red when ripe, thick, and tough. The plum is edible. The pit is the typical flat plum-stone.

PRUNUS EMARGINATA, Walp.

BITTER CHERRY

Common names: Bitter cherry, wild plum*, wild cherry*. French name: Cerisier amer.

The bitter cherry is a shrub or small tree, ocasionally 30 to $50 \mathrm{ft}$. high and 10 to $12 \mathrm{in.}$ in diameter. It is found throughout southern British Columbia growing in moist places in the valleys, sometimes on dry hillsides, and does not appear east of the Rocky mountains. Its wood is not utilized in Canada.

The bark is thin, smooth, greyish to brown in colour, and exceedingly bitter to the taste. 
The twigs are slender, flexible, and a bright red. The twigs of the other coast cherry, the western choke cherry, are of a light brown colour.

The winter buds are chestnut-brown, pointed, and very small, about $1 / 8$ in. long. Those of the western choke cherry are much longer and larger.

The leaves are variable in size, 1 to $3 \mathrm{in}$. long and $1 / 3$ to $11 / 2 \mathrm{in}$. broad. The teeth in the margin are minute and rounded.

The fruit is an extremely bitter, dark red cherry about the size of a pea, which grows either singly or in clusters.

PRUNUS PENNSYLVANICA, Linn.

BIRD CHERRY

Common names: Bird cherry, wild red cherry*, pin cherry, pigeon cherry.

French name: Petit merisier.

The bird cherry is a small tree or shrub 10 to $25 \mathrm{ft}$. high and 4 to $8 \mathrm{in}$. in diameter.

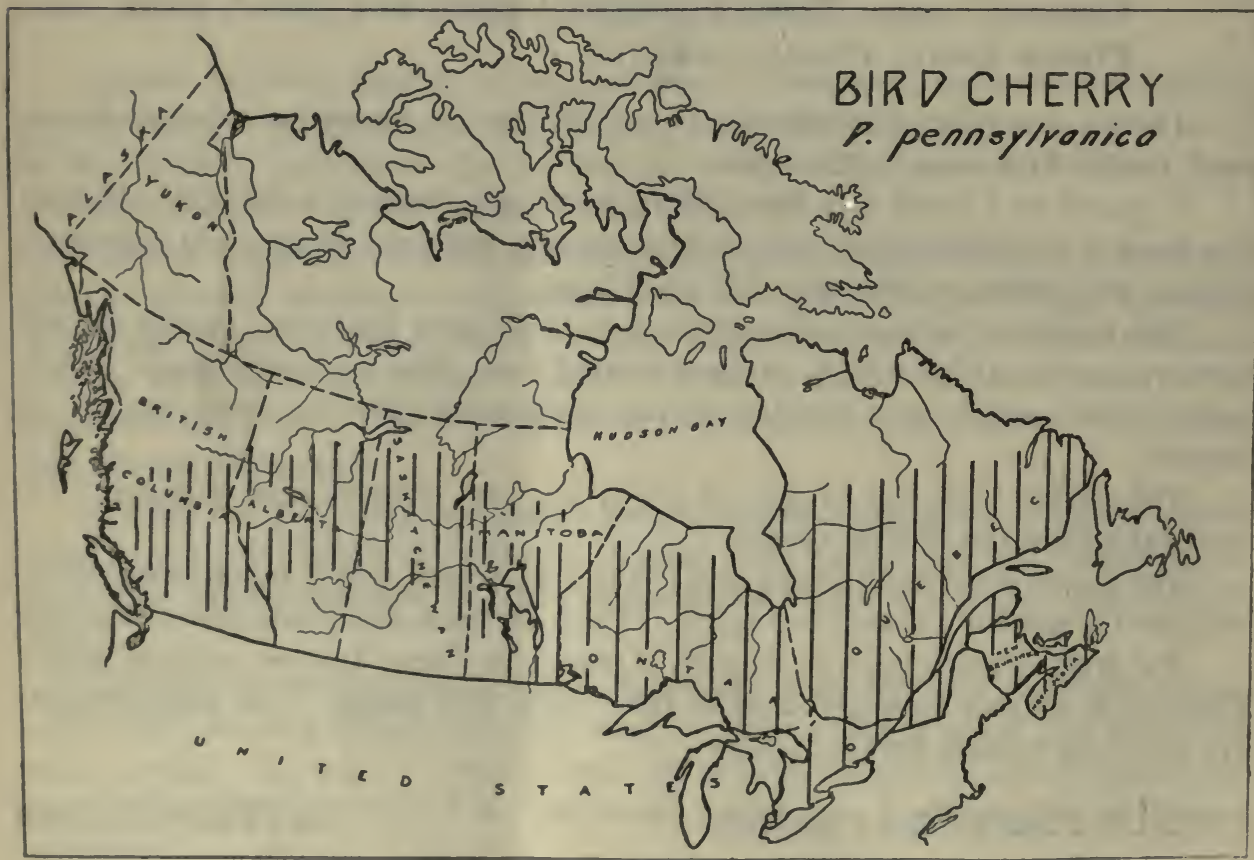

It is found in clearings, burned-over lands, and along roadsides. It is widely distributed in Canada, ranging from the Atlantic to the Coast range in British Columbia. Its wood is seldom put to any commercial use.

The bark is smooth, reddish-brown, and covered with conspicuous orange or rusty-coloured, powdery lenticels. These lenticels are not elongated to the same extent as those of the black cherry. The inner bark is a bright green. On older trunks the bark separates into papery plates. 
The twigs are slender, smonth, red, and shiny, and bitter if chewed. The two-year-old twigs send out short lateral spur-like branchlets. The winter buds are very small, blunt, reddish-brown and characteristically clustered at the tip of the twig.

The leaves are 3 to $5 \mathrm{in}$. long and $3 / 4$ to $1 \mathrm{in}$. wide-long and narrow, somewhat like the peach leaf. They are shiny, green, smooth, finely-toothed, and more tapered than those of the black cherry.

The fruit is pea-sized, cherry-red, and sour. It can readily be distinguished from the fruit of the black or choke cherries by the difference in colour and flavour and by the fact that the cherries are not in elongated clusters. Each is borne on a single long stem as are the garden cherries.

PRUNUS VIRGINIANA, Linn.

\section{CHOKE CHERRY}

Common names: Choke cherry, wild cherry*.

French names: Cerisier à grappes, cerisier de Virginie, cerisier sauvage.

The choke cherry is a shrub or small tree, more often a shrub, 10 to $20 \mathrm{ft}$. high and 4 to 6 in. in diameter.

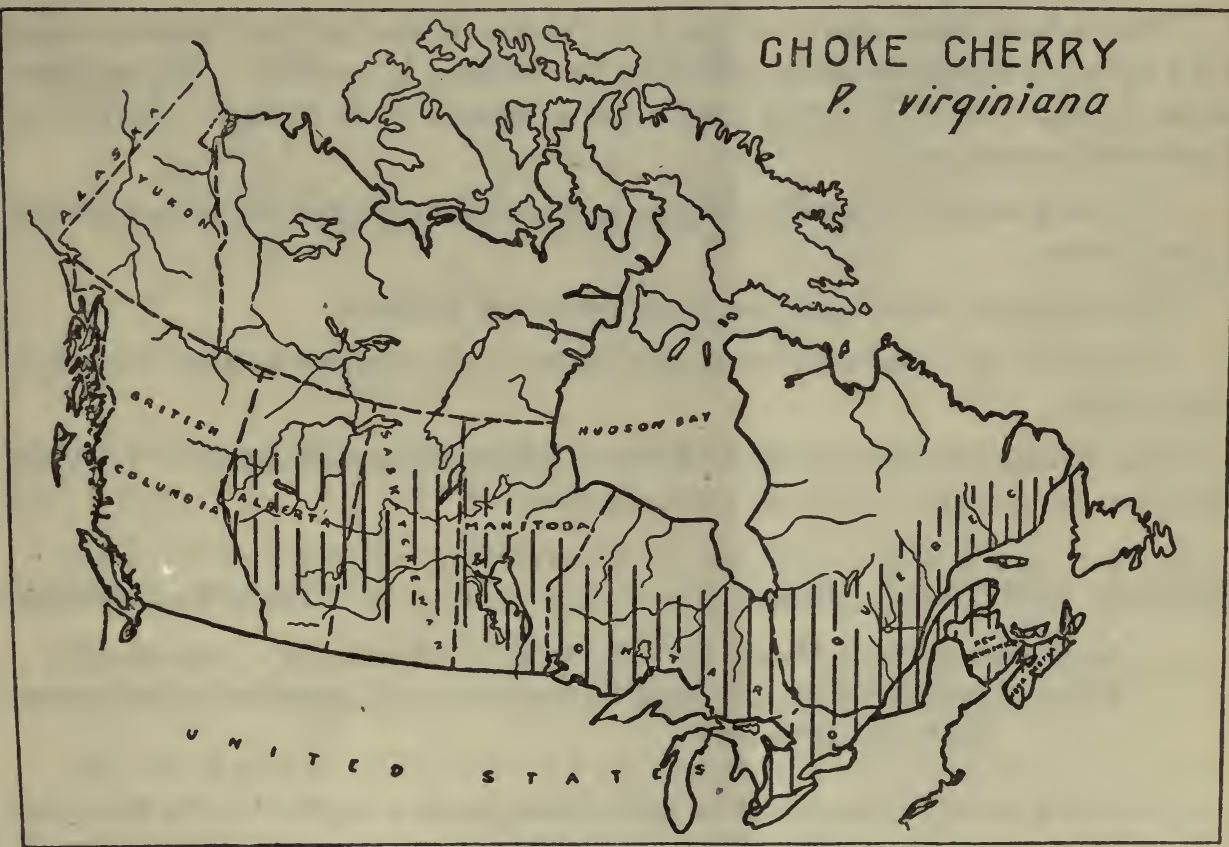

It is found all the way across Canada, from the Atlantic to the Rocky mountains, growing in fence corners, open borders of woodlots, and along the roadsides, but is not found in commercial sizes or quantities. 
The bark is smooth, dull greyish-brown, and peels easily on branches, showing a bright green, inner bark which has a disagreeable odour. It much resembles the young bird cherry but can be distinguished from it by absence of rusty-coloured powder about the slits or lenticels.

The twigs are smooth, reddish-brown, and have a strong odour when crushed and, like all cherry twigs, are bitter when chewed.

The winter buds are brownish, smooth, sharp-pointed, and somewhat turned away from the twig. The scales have a pale margin.

The leaves are 2 to $4 \mathrm{in}$. long and 1 to $2 \mathrm{in}$. wide, rather broad and blunt in appearance, with a more or less sharp tip.

The fruit is a dark red or black cherry the size of a pea and grows in elongated clusters. It has a very characteristic astringent taste from which the tree gets its name.

PRUNUS DEMISSA, Walp.

WESTERN CHOKE CHERRY

Common names: Western choke cherry, wild cherry*. French name: Cerisier sauvage de l'Ouest.

The western choke cherry is found in Canada on the British Columbia coast and Vancouver island, on moist soil along the borders of streams. It sometimes attains a height of $25 \mathrm{ft}$., but is more often a shrub 8 to $10 \mathrm{ft}$. high. It is of no commercial importance.

On young trunks the bark is brown, on older trunks it is greyish and roughened by hard scales.

The twigs are smooth and the buds brown and pointed.

The leaves are somewhat thick and leathery, the margins toothed with fine, sharp teeth.

The cherries are shiny, black, and borne in dense elongated clusters. They are astringent to the taste, hence the common name.

PRUNUS SEROTINA, Ehrh.

BLACK CHERRY

Common names: Black cherry, wild black cherry*, rum cherry.

French names: Cerisier tardif, cerisier noir, cerisier d'automne, merisier (France).

The black cherry averages 60 to $70 \mathrm{ft}$. in height and $11 / 2$ to $2 \mathrm{ft}$. in diameter. Growing in a dense stand it produces a straight, columnar trunk. The crown is narrow and irregular, owing to the zigzag growth of the branches.

In Canada this tree is found from Nova Scotia to lake Superior, growing on a wide variety of soils and associated with other hardwoods. 
The bark is smooth on young trees, with conspicuous, whitish, horizontal slits or lenticels. On old trees it cracks and breaks off in small, thin, brittle scales.

The twigs are reddish-brown, slender, rigid, and bitter to the taste.

The winter buds are a light chestnut-brown, pointed or blunt-tipped, and have

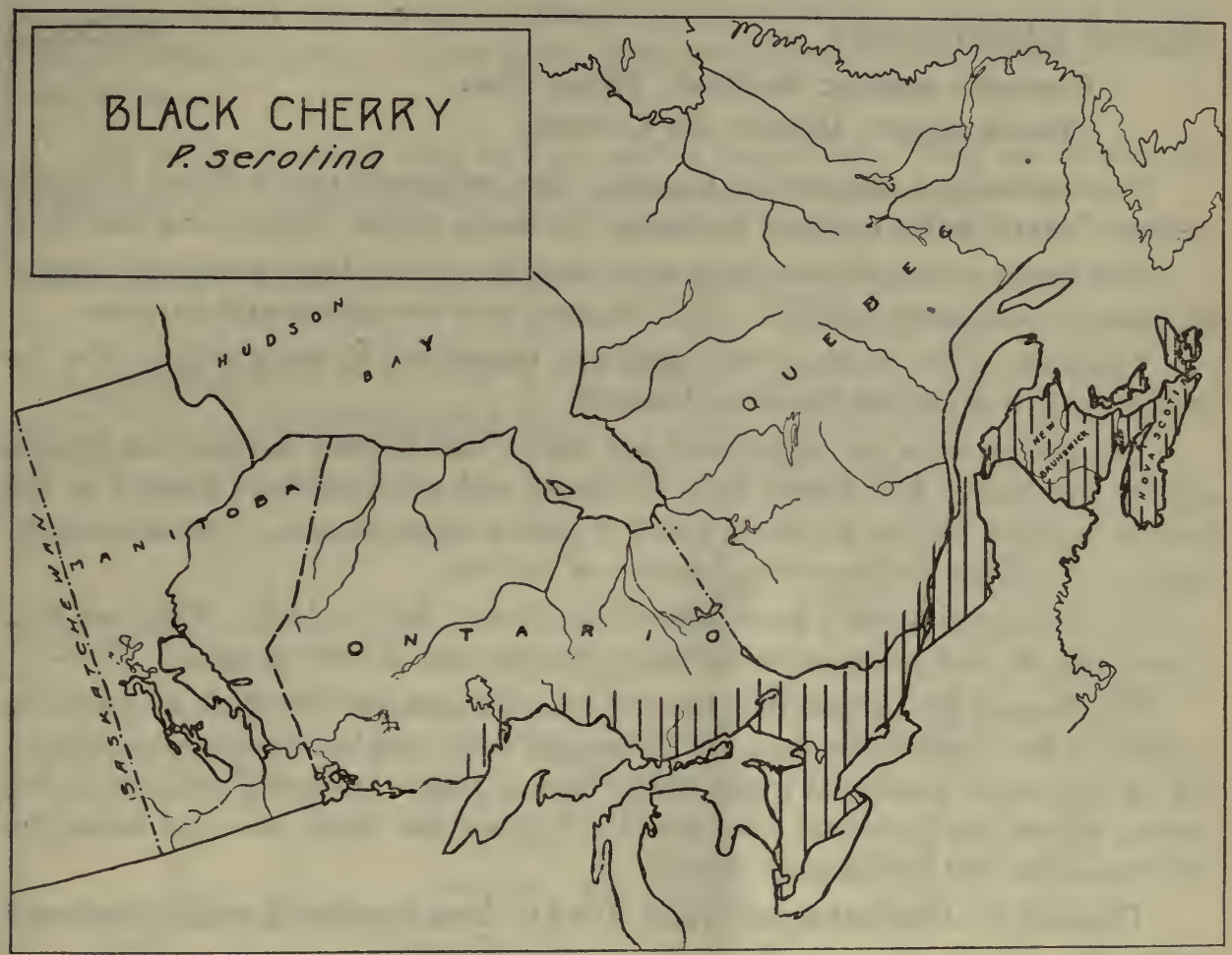

closely overlapping scales. The margins of the scales are not pale as those of the choke cherry.

The leaves on young trees are often broad and blunt with a sharp tip; on older trees they are longer. The teeth are finely and firmly cut.

The fruit is a juicy, reddish-black cherry, about the size of a large pea, and grows in elongated clusters. It has a peculiar but not unpleasant flavour.

The tree is nowhere abundant and its lumber is produced in small quantities only. The wood is one of the most valuable of American hardwoods and is prized both for its beauty of appearance and its technical qualities. It has a rich reddishbrown colour, darkening with age, and a fine, even grain with a pleasing figure when quarter-sawn. The lumber seasons easily, holds its shape well, takes a brilliant polish and is heavy, hard, and strong. It is used for furniture, cabinetwork, and decorative finish in houses, cars, boats, and vehicles. 


\section{THE REDBUDS}

Of the seven species of redbud (Cercis) three occur on this continent. One of these, Cercis canadensis, is found in southern Ontario but it is not common. None of the species is of importance except for decorative planting. They can be readily recognized by their showy, magenta flowers and simple, heart-shaped leaves.

\section{CERCIS CANADENSIS, L.}

REDBUD

Common names: Redbud, Judas tree.

French name: Gainier du Canada.

The redbud is a rare tree in Canada. An occasional tree is found in southwestern Ontario in the counties bordering the shores of lake Ontario and lake Erie.

It is small, ordinarily not much more than 20 to $25 \mathrm{ft}$. high, with a flat, irregular crown, occasionally upright. It is valuable only for ornamental purposes.

The bark of the trunk is very dark and roughened by scaly ridges. On the slender twigs it is reddish-brown and smooth.

The winter buds are small, dark red, blunt, and slightly flattened or pressed against the stem. The flower buds are larger and are sometimes located on the underside of the twig at the base, where it joins a larger branch. This latter peculiarity is one of the distinguishing features of the tree.

The leaves are broadly heart-shaped and from 3 to 5 in. long. They are dark green, smooth, and glossy, with toothless margins and slender stems.

The flowers are shaped like the pea blossom and are rose-pink to purple in colour. They come out in clusters all along the twigs and branchlets, even appearing on the larger limbs and trunk of the tree at times. Opening up early in the season, before the leaves are fully out, they colour the whole tree and make it a very beautiful and conspicuous object.

The fruit is a thin, flat-pointed pod, 2 to $3 \mathrm{in}$. long, containing small compressed seeds.

\section{THE COFFEETREES}

There are only two known species of coffeetree (Gymnocladus), one native to this continent and the other to southern and western China. Both can be readily recognized by their heavy branches, stout, blunt twigs with red pith, and large, doubly-compound leaves.

GYMNOCLADUS DIOICA (L.) Koch KENTUCKY COFFEETREE

Common names: Kentucky coffeetree, coffeetree, coffee bean. French name: Chicot du Canada.

The coffeetree is a rare species and is found, in Canada, only in southwestern Ontario from Niagara westward to lake St. Clair, but is nowhere common. Scattered trees occur in rich wonds but they have been mostly cut from the farm land on which they once grew. The wood is not used conmercially at present. 
It is a medium-sized tree sometimes attaining a height of $80 \mathrm{ft}$. and a diameter of $2 \mathrm{ft}$., but is ordinarily a smaller tree which divides comparatively near the ground into three or four upright limbs, which form a narrow head. The bark is dark brown and roughened by large scales at the base and by many thin, curved, ridges higher up and on the larger branches.

The twigs are very coarse and blunt and often downy. The pith is salmonpink or brown in colour. These stout twigs enable one to distinguish the tree at some distance.

The winter buds are very tiny for-such a large twig. They are downy and almost sunk out of sight just above a broad crescent or heart-shaped leaf-scar.

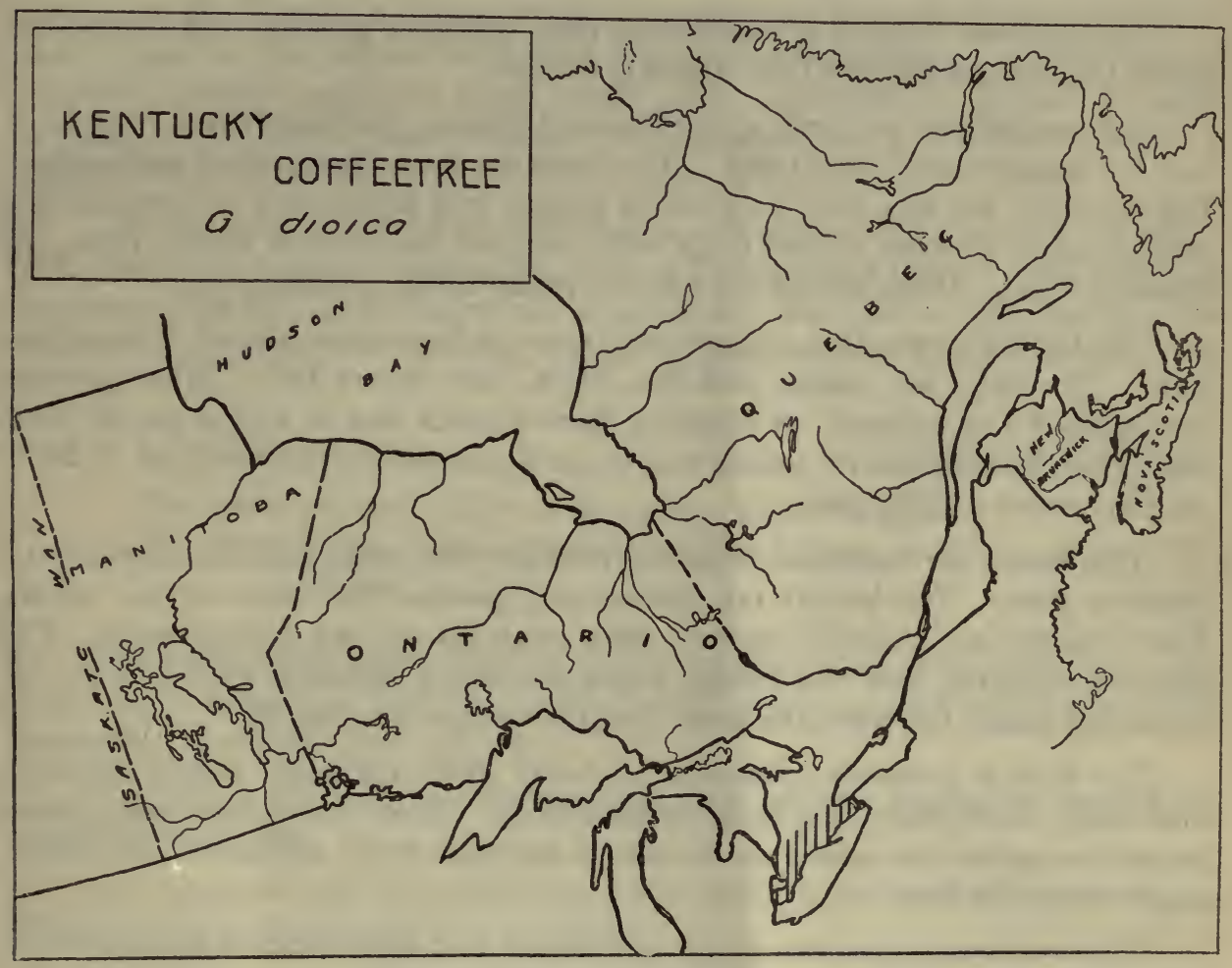

The leaf is very large, from 2 to $3 \mathrm{ft}$. long. It is doubly compound, i.e., many leaflets are attached to a common stem, these in turn are again attached to a larger stem that is attached to the twig. The dull, dark green leaflets are without teeth on the margin.

The fruit is a curved pod 4 to $8 \mathrm{in}$. long and $2 \mathrm{in}$. broad which often remains on the tree well into the winter. The seed is brown and flattened. These seeds werc at one time used as a substitute for coffee, hence the tree's common name. 


\section{THE SUMACHS}

Nearly all of the seven or eight species of sumach (Rhus) found in Canada are shrubs. Only four of the twenty or so species found on this continent reach tree size, but none of them is sufficiently large to be of importance. Some of the Asiatic species, however, are of importance because of the gum, wax, etc., they produce. The valuable lac used in lacquer ware is obtained from these trees. All of the species have a more or less sticky juice.

\section{RHUS TYPHINA, Linn.}

STAGHORN SUMACI]

Common names: Staghorn sumach, sumach.

French names: Sumac amaranthe, vinaigrier, sumac de Virginie.

The staghorn sumach is common on thin, rocky, or gravelly soils from Nova Scotia to Georgian bay and lake Huron in Ontario.

It is a small tree or shrub, often forming thickets. Ordinarily it is 10 to $15 \mathrm{ft}$. high but occasionally a little taller. The trunk is more or less crooked and inclined. The branches are also very irregular in growth and divide into a comparatively small number of stout, curved twigs which suggest the horns of a stag, hence the common name. When in leaf the tree has rather a flat, spreading top.

The bark is brown, thin, and smooth except on large trees, when it is sometimes scaly. The twigs are coated with fine, thick, soft, brown hair. When growing near roadsides, or railroads, or wherever there is much dust or soot in the air, these hairy twigs become heavily coated with it and if grasped will soil the hand. When cut they exude a milky juice.

The leaves are composed of eleven to thirty-one small leaflets attached to a common stem. The leaflets are narrow and pointed like those of the willow. Their margins are coarsely toothed, dark green above, and pale beneath. This graceful, drooping, fern-like foliage, which becomes a beautiful scarlet in the auttumn, has caused the tree to be much used for ornamental planting.

The fruit is a curious pyramidal cluster of short, red hairs, with a distinctly acid taste, which coats tiny, bony covered seeds. These conspicuous red clusters persist throughout the winter on the tips of the stout twigs, and add to the picturesqueness of the tree.

This tree is sometimes sawn into lumber and used for decorative finishing work. Its wood is orange-coloured, and is streaked with broad, green rays.

\section{THE MAPLES}

Seventy species of maple (Acer) occur throughout the world. They are most abundant in eastern Asia, thirty-five species being found in China and Japar. Nine are found in Canada, of which three are confined to British Columbia. Many exotic species have been introduced for ornamental planting, the most common of which áre the sycamore maple (Acer pseudoplatunus), and the Norway maple 
(Acer platanoides), both from Europe. Japanese varieties are also considerably used for decorative purposes.

Maple is the second Canadian hardwood in point of importance and is characterized by the diversity of its uses. It is used for flooring, furniture, vehicles, agricultural implements, boats, interior woodwork in houses, handles, etc. The sugar maple possesses the qualities of hardness, strength, and stiffness in a greater degree than any of the other species and is, therefore, most sought after. "Curly" and "bird's-eye" maple, esteemed for furniture making, are unusual forms occasionally met with. The cause of these "sports" is not understood.

The sap of all the maples contains sugar and in pioneer days, in times of scarcity, even the Manitoba maple, the least productive of the family in this respect, was tapped for the purpose of boiling the sap to obtain sugar. In commercial practice, however, only the sugar maple (Acer saccharum) is tapped for sugar making. The maple sugar industry is organized on a commercial basis in Eastern Canada and particularly in the Eastern Townships of Quebec.

I,ike the ashes and the dogwoods, the leaves and the winter buds of the maples always occur in pairs on the opposite sides of the twig, and therefore, the twigs and branches must also be of this opposite character. The fruit is composed of a pair of seeds (occasionally three or four) joined together, each seed with a distinct wing.

ACER SPICATUM, Lam. MOUNTAIN MAPLE

Common names: Mountain maple, dwarf maple*.

French names: Erable bâtard, plaine bleue, érable à épis, plaine bâtarde.

This small bushy tree or shrub is rarely more than $25 \mathrm{ft}$. in height or more than 5 to 7 in. in diameter. It is the smallest of the eastern maples and is found more commonly as a shrub than as a tree.

The bark is greyish to brown in colour, thin, smooth, sometimes slightly furrowed or roughened.

The twigs are pink to purplish in colour and covered with a delicate bloom. The pith is brown as in the striped maple.

The winter buds are small, pointed, and slender and of a red or greenish colour. They are smaller in diameter just above the point of attachment, which gives them a somewhat stalked appearance.

The leaves are three-lobed as a rule, coarsely toothed, thin and papery to the touch, and downy beneath.

The seeds, which are bright red during the summer, are brown in September. They have widespread wings and are borne in a string along a stalk or raceme. The seed portion has a pit-like depression on one side. 
The mountain maple is found in the shade of the other trees and rarely found growing by itself in the open. It prefers moist, rich soils on rocky hillsides or

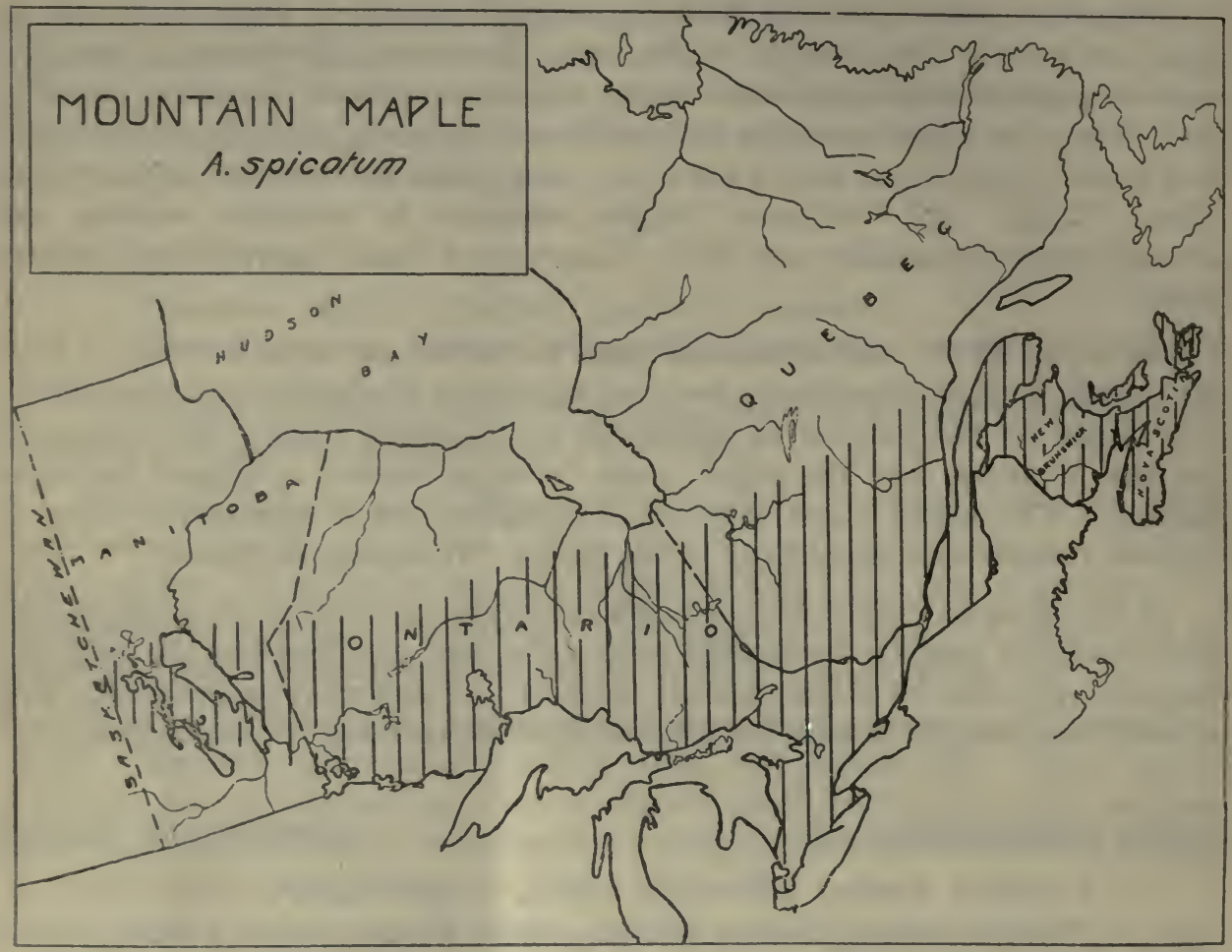

along small streams. It ranges throughout eastern Canada and extends as far west as Manitoba.

ACER PENNSYLVANICUM, Linn.

STRIPED MAPLE

Common names: Striped maple, moosewood, moose maple.

French names: Bois barré, érable de Pennsylvanie, bois noir.

The striped maple, like the mountain maple, is a small tree 15 to $30 \mathrm{ft}$. high and 5 to 7 in. in diameter. It is more often found as a large shrub growing in the shade of other hardwoods. Its wood is not used commercially.

It gets its name from its smooth, green bark which is striped with vertical, white cracks. Corky bark is not formed.

The twigs are smooth, rose-coloured or green, and without bloom. They are conspicuously ridged, with raised lines just above the leaf-scars. The leaf-scars encircle the stem. The pith is brown.

The winter buds are shiny, rose-coloured and not so sharp-pointed as those of the mountain maple They are four-sided in cross-section and have a somewhat stalked appearance. 
The leaves are large, 5 to 6 in. long, thin, and in outline not unlike a goose's foot. They are finely and sharply double-toothed.

As in the case of the mountain maple the seed is pitted on one side, but the wings of the striped maple are larger and wider spread than those of others.

This maple is found from Nova Scotia to lake Superior.

ACER MACROPHYLLUM, Pursh.

BROAD-LEAVED MAPLE

Common names: Broad-leaved maple, big-leaved maple, Oregon maple, British Columbia maple.

French name: Erable à grandes feuilles.

The broad-leaved maple is a tree 40 to $80 \mathrm{ft}$. high and 1 to $2 \frac{1}{2} \mathrm{ft}$. in diameter. On poor soil and in open positions it is often short-stemmed, crooked and not over $25 \mathrm{ft}$. in height.

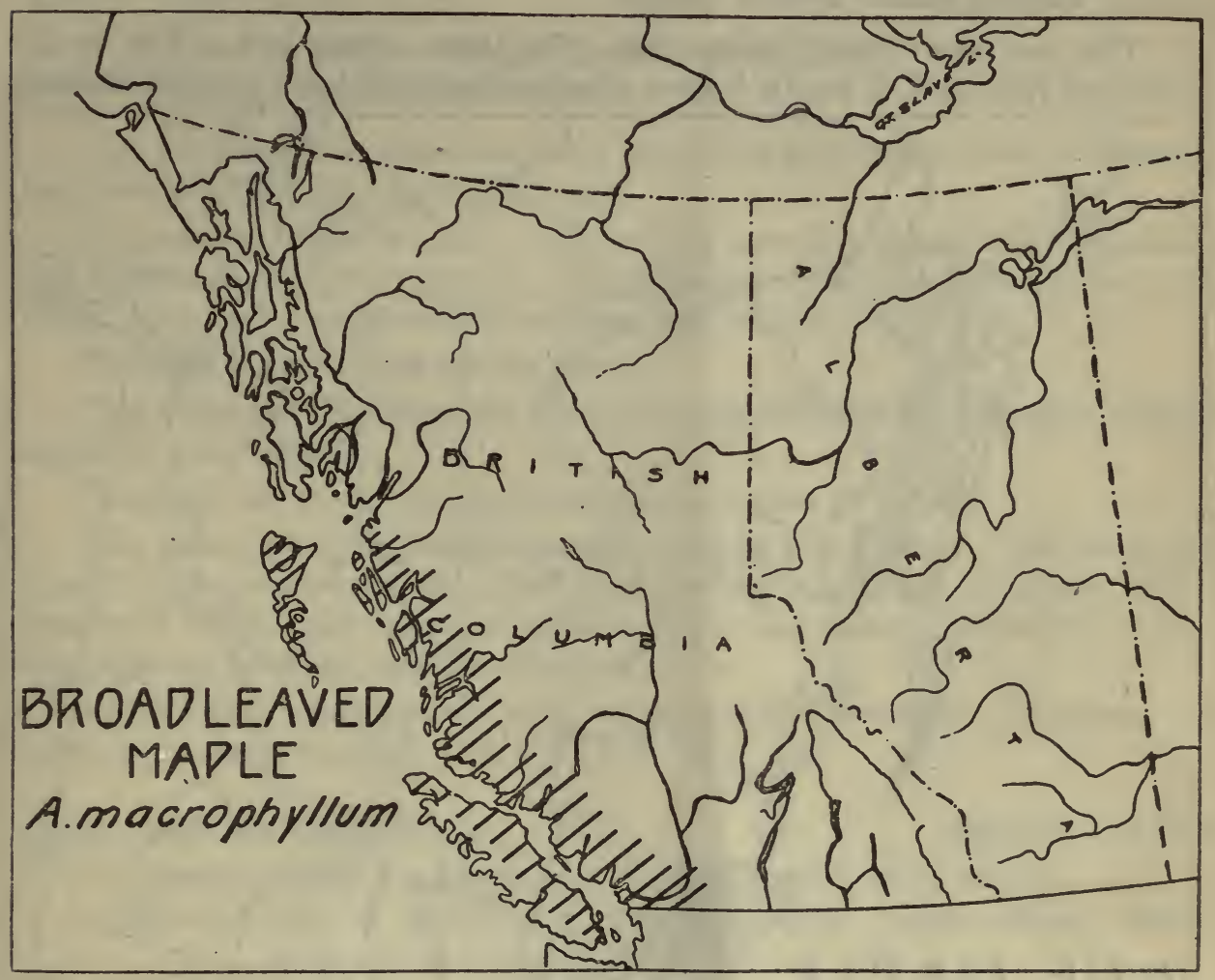

It grows at a moderate rate, is fairly persistent, and can endure considerable shading, especially when young.

It does best on moist humus or gravelly soils and where there is abundance of rainfall. In Canada it is confined to the coast and islands of British Columbia from Alaska south. 
The bark is reddish-brown, deeply furrowed, and broken into squarish scales; on the twigs it is green or dark red, and covered with pale spots.

The leaves are five-lobed, 7 to $14 \mathrm{in}$. wide, and have stems 6 to $12 \mathrm{in.}$ long. They are the largest maple leaves in Canada. They are thick, smooth, and dark green. The margins are toothless and the notches deep and narrow.

The wings of the seed are $11 / 2 \mathrm{in}$. long and $1 / 2 \mathrm{in}$. wide. Frequently three and even four seeds are joined to one stem. The seed portion of the key is covered with sharp, bristle-like hairs, a feature by which they can be readily distinguished.

The broad-leaved maple is sometimes sawn into lumber in British Columbia and used for flooring, interior finish and furniture.

ACER CIRCINATUM, Pursh.

VINE MAPLE

Common names: Vine maple, mountain maple*.

French name: Erable circiné.

The vine maple rarely stands erect The trunk, which is 3 to 6 in. in dia meter and 15 to $20 \mathrm{ft}$. in length, is more often prostrate and has a crooked, crawling

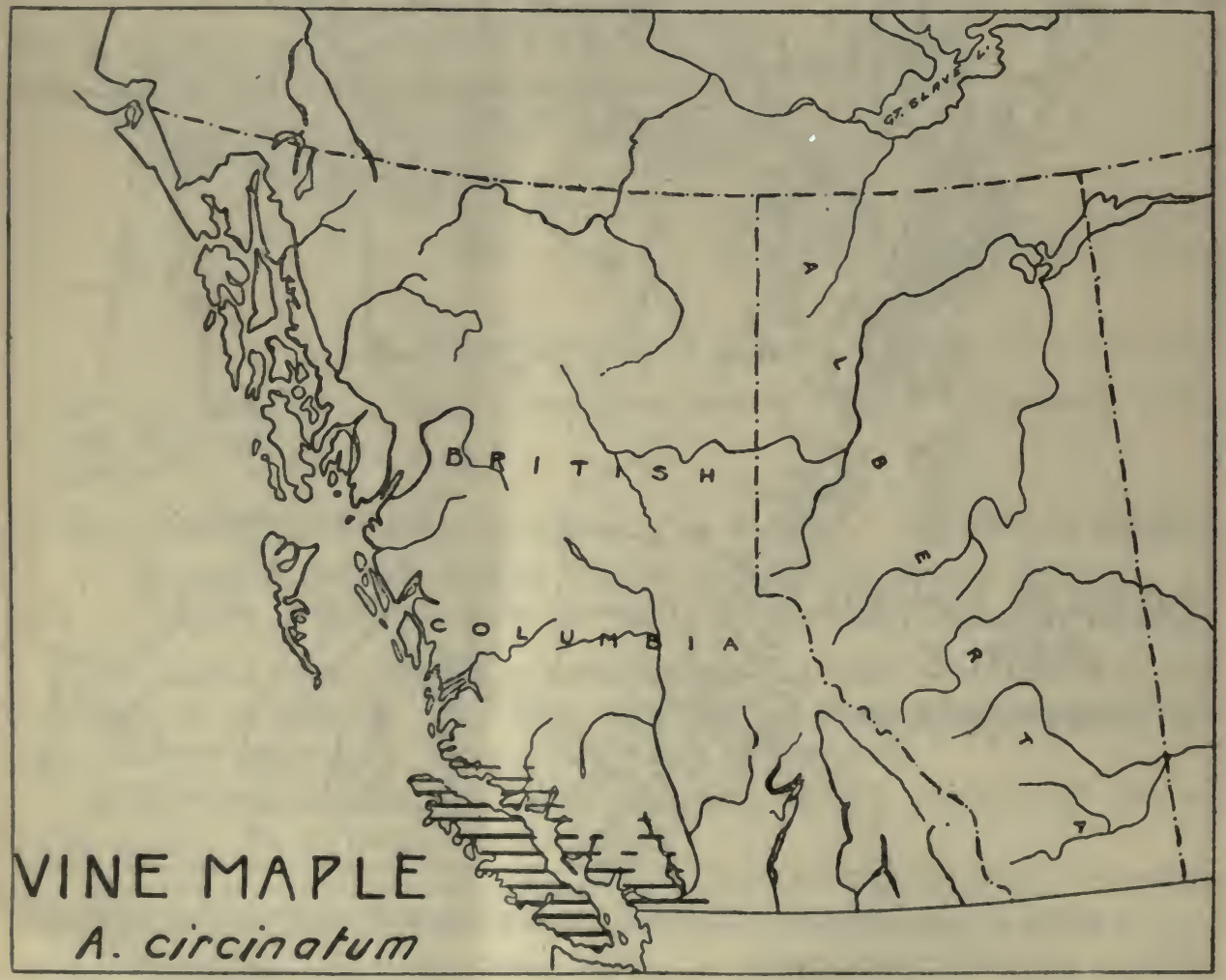

vine-like appearance. It grows in the shade of other trees and is frequently found extending its stem among their trunks toward some more open spot. Where the stem touches the ground it frequently takes root. 
It is found on the rich moist soil along streams on Vancouver island and for a short distance northward up the coast of British Columbia.

The bark is thin, smooth, marked by shallow fissures, and a dull greyishbrown in colour.

The twigs are a pale green or reddish-brown, sometimes covered with a whitish bloom in winter.

The winter buds are $1 / 8$ in. long, bright red in colour, and blunt. Those of the dwarf maple are sharp.

The leaves in general outline are circular, having from seven to nine sharppointed, sharp-toothed lobes

The wings of the fruit are red and wide-spreading and about $1 \frac{1}{2} \mathrm{in}$. long. They are wider spread and usually longer than those of the dwarf maple

ACER DOUGLASII, Hook.

DWARF MAPLE

Common names: Dwarf maple, red maple*.

French name: Erable nain.

The dwarf maple is sometimes a tree 20 to $25 \mathrm{ft}$. high and 6 to 8 in. in diameter, but more often it is a shrub 6 to $10 \mathrm{ft}$. high.

It grows singly and in small clumps on thin, gravelly soil, and along the gulches and borders of mountain streams. It is found from Alaska southward along the Pacific coast and throughout the southern part of British Columbia.

The bark is smooth and reddish-brown.

The twigs are a brighter red than the bark of the limbs and often slightly angled in cross-section.

The buds are bright red, sharp-pointed, and about $1 / 8 \mathrm{in}$. long.

The leaves are from 1 to 5 in. long and three- to five-lobed. The lower two lobes (the pair nearest the stem) are sometimes separated from the others as in a compound leaf. They are dark green in colour and smooth and shiny on top. The veins are yellowish and the stems red.

The wings of the keys are very broad and slightly spreading. They are rosered to light brown in colour.

ACER SACCHARUM, Marsh.

SUGAR MAPLE

Common names: Sugar maple, hard maple, rock maple.

French names: Erable dur, érable à sucre, érable piqué, érable moiré, érable ondé.

The sugar maple in the forest averages 80 to $90 \mathrm{ft}$. in height and 2 to $3 \mathrm{ft}$. in diameter. It is one of our tallest hardwoods, sometimes reaching the height of 130 $\mathrm{ft}$. and $5 \mathrm{ft}$. in diameter.

The crown is spreading and dense unless crowded in a close stand. The rootsystem is shallow. 
The bark on young trees is smooth and slightly furrowed. As the tree becomes older the bark ridges curl until on large trees the bark has a ploughed appearance, with smooth places between ridges.

The leaves, as is the case with all maples, come out in pairs opposite each other. There are five main lobes. The sinuses, or open spaces between the lobes, are rounded, and not narrow and pointed as with other eastern maples. The upper surface is dark green and the under surface lighter. In the autumn the leaves turn crimson, scarlet, yellow or orange in colour.

The twigs, like the leaves, come out in pairs on opposite sides of the branch and are reddish-brown in colour. The winter buds are narrow, sharp-pointed, and

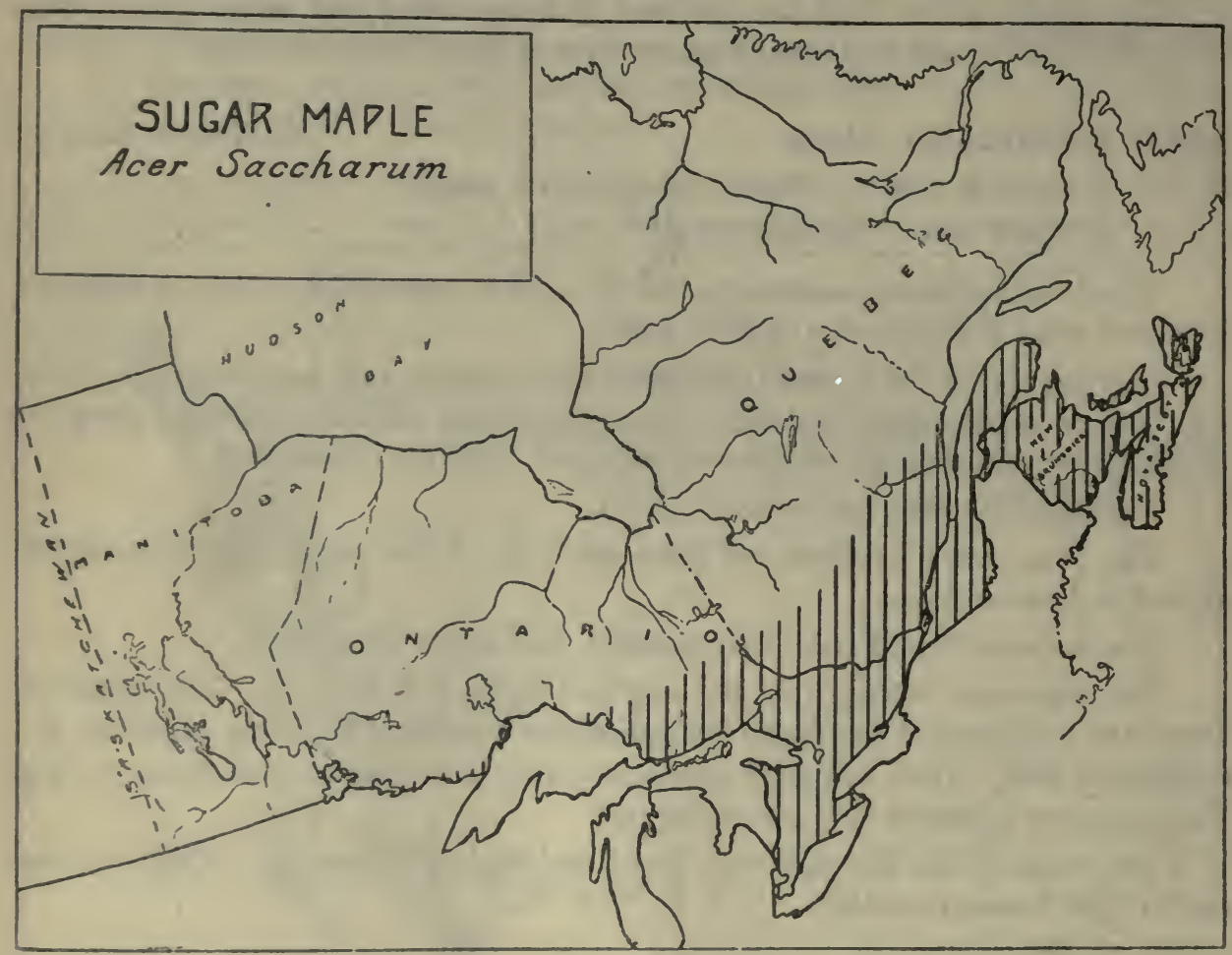

brown, a feature by which the tree is readily distinguished from the other maples. 'The fruits or keys develop from the end of the twig while those of the red maple and silver maple come from the side.

The sugar maple requires moist, rich soil, for its best development and will not do well on poor soil. It is folnd in pure stands or mixed with such other hardwoods as beech, oak, elm, basswood, and hickory. It is a slow-growing and long-lived tree. Its ability to endure heavy shading when young gives it an advantage over many other trees, and enables it to establish itself under conditions that they could not endure. 
The range of this maple is from Newfoundland westward to the lake of the Woods, but not north of the height of land dividing the watershed of the Great Lakes from that of Hudson bay.

The popularity of the wood of this tree is due to its two chief technical qualities, stiffness and hardness. It is used by manufacturers of hardwood flooring, furniture, agricultural implements, and vehicle stock, especially wagon axles. In the diversity of its uses it is rivalled by few native trees. The wood is consumed in large quantities for firewood and wood distillation.

ACER SACCHARINUM, Linn.

SILVER MAPLE

Common names: Silver maple, white maple, soft maple*, swamp maple*, river maple, water maple*, broad-fruited maple.

French names: Erable blanc, plaine blanche, érable à fruits cotonneux.

The silver maple is a tree averaging 80 to $90 \mathrm{ft}$. in height and 2 to $3 \mathrm{ft}$. in diameter; sometimes reaching $125 \mathrm{ft}$. in height and $5 \mathrm{ft}$. in diameter. It is one of our

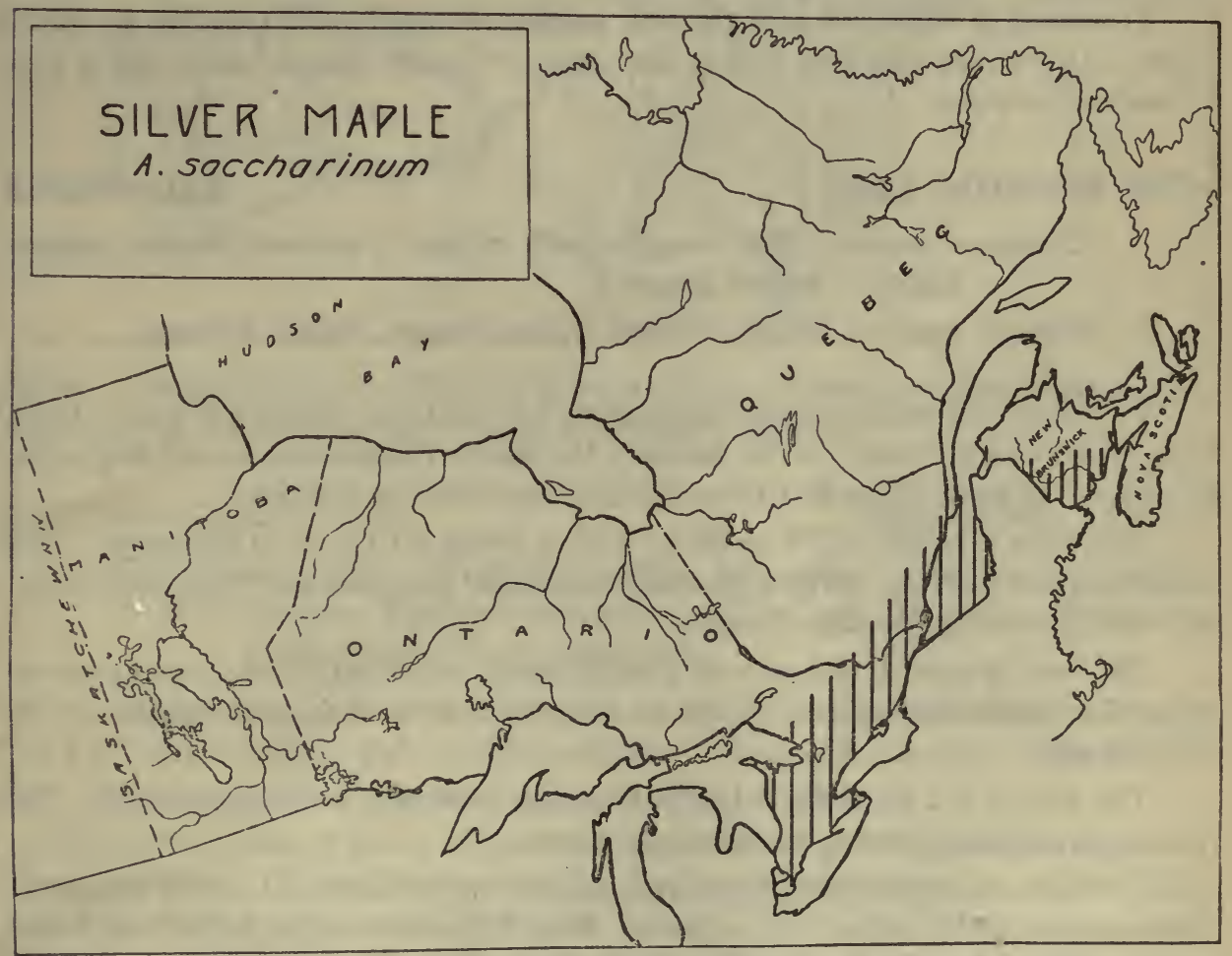

most rapid-growing hardwoods. Unless grown in a close stand the trunk divides near the ground into sereral stout, upright branches and forms a medium-spreading 
head with drooping branches. The tendency for the small branches to grow downward and then turn up again is very characteristic, and is much more marked than with the red maple.

The bark is grey with a reddish tinge, and peels off from the trunk in older trees in long pieces, which are free at either end and attached at the middle.

The twigs, which come out in pairs and opposite, as with all maples, are curved and have a distinct odour when freshly cut. The buds are blunt-pointed and red, and more clustered than with the red maple. It is one of the first trees to blossom in the spring.

The leaves are five-lobed and the sinuses or notches between the lobes are narrow and come to a sharp point. The notches are narrower than those of the red maple leaf. In autumn the leaves turn a dull yellow.

The wings of the seeds are very widespread; more so than those of either the sugar maple or red maple.

The silver maple ranges from New Brunswick westward through southern Quebec and southern Ontario and is found on deep, rich soils such as river bottoms and along the borders of swamps. It is usually mixed with other hardwoods.

The wood of the silver and the red maples is usually sold together as "soft" maple. It is not so strong as that of the sugar or "hard" maple but is often used for similar purposes.

ACER RUBRUM, Linn.

RED MAPLE

Common names: Red maple, soft maple*, scarlet maple, swamp maple*, water maple*.

French names: Erable rouge, plaine rouge, érable tendre.

The name red maple is most appropriate for this tree. Its twigs, winter buds, fruit, stems of leaves and, in the autumn, the leaves themselves, are all bright red in colour. It is one of the first trees to change its colour in autumn.

It attains a height of 70 to $90 \mathrm{ft}$. with a trunk 3 to $4 \mathrm{ft}$. in diameter. The main branches have an upright growth, the smaller branches and twigs spread out and tend to turn up towards the end.

The bark is smooth and grey on young trunks; when old it cracks and peels off in slender longitudinal flakes, which do not curl at both ends as in the case of the white maple.

The leaves are fiva-lobed; the two at the base not being prominent. The sinuses or notches between the lobes are acute.

The buds are blunt-pointed and red, usually not so shiny as those of the silver maple, nor so many of them in a cluster. The flower buds open before the leaves and it is one of the first trees to blossom in the spring. The fruit ripens in May.

It is found mostly on rich, moist lands, and along the borders of streams and swamps, where it makes rapid growth when young; on poor, dry soil it forms a 
scrubby growth. It ranges from Nova Scotia to the lake of the Woods in Ontario, but is nowhere plentiful in Canada.

The wood is slightly tougher than that of sugar maple but is much softer and

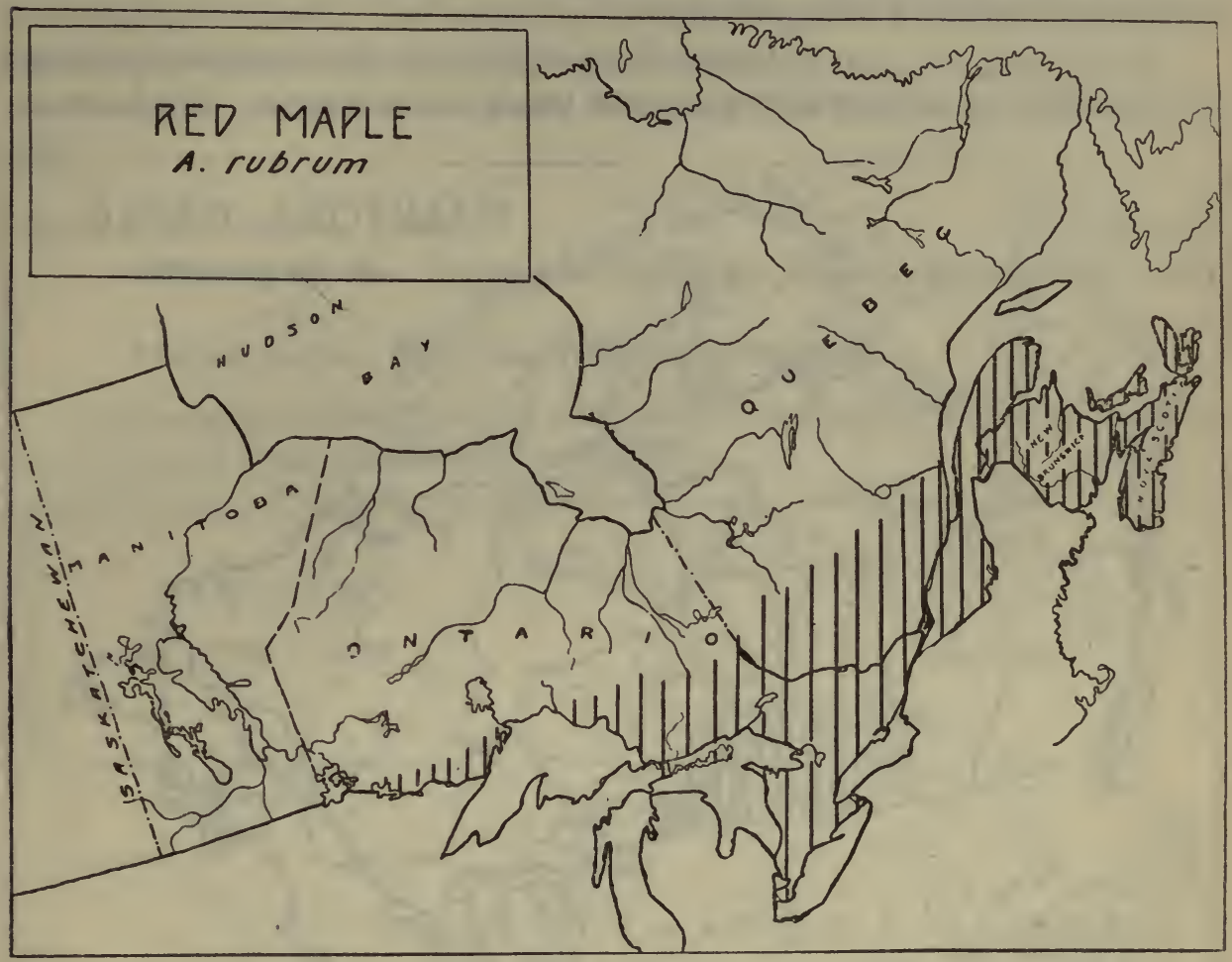

lighter. Owing to the prevalence of defects this tree is used less than silver maple, although the wood of the two is similar in most respects.

ACER NEGUNDO, Linn.

MANITOBA MAPLE

Common names: Manitoba maple, box elder*, ash-leaved maple. French names: Erable négundo, plaine à Giguère, érable à feuilles de frêne, aune-buis.

The Manitoba maple attains a height of 50 to $75 \mathrm{ft}$. and a trunk diameter of 2 to $3 \mathrm{ft}$., but usually is considerably smaller. The trunk is usually short and divides near the ground into several large, spreading branches.

'This tree is fond of moist soils and is usually found growing along streams and margins of lakes. It can, however, withstand considerable drought. Its rapidity of growth and hardiness against freezing has made it very popular for shelter-belt planting on the prairies. It is also extensively used as a shade tree in the western towns and cities. It is a native of the Prairie Provinces and is not found growing naturally in Eastern Canada. It is, however, extensively planted in the East 
because of its rapid growth, but otherwise it is not a desirable tree for Eastern Canada where there is no difficulty in growing better and longer-lived trees.

The bark is a light brown in colour, and on old trees is thick and deeply furrowed with irregular, flat-topped ridges.

The twigs are smooth and either reddish-purple or yellowish-green in colour. In winter they are covered with a down or bloom which rubs off. The leaf-scars

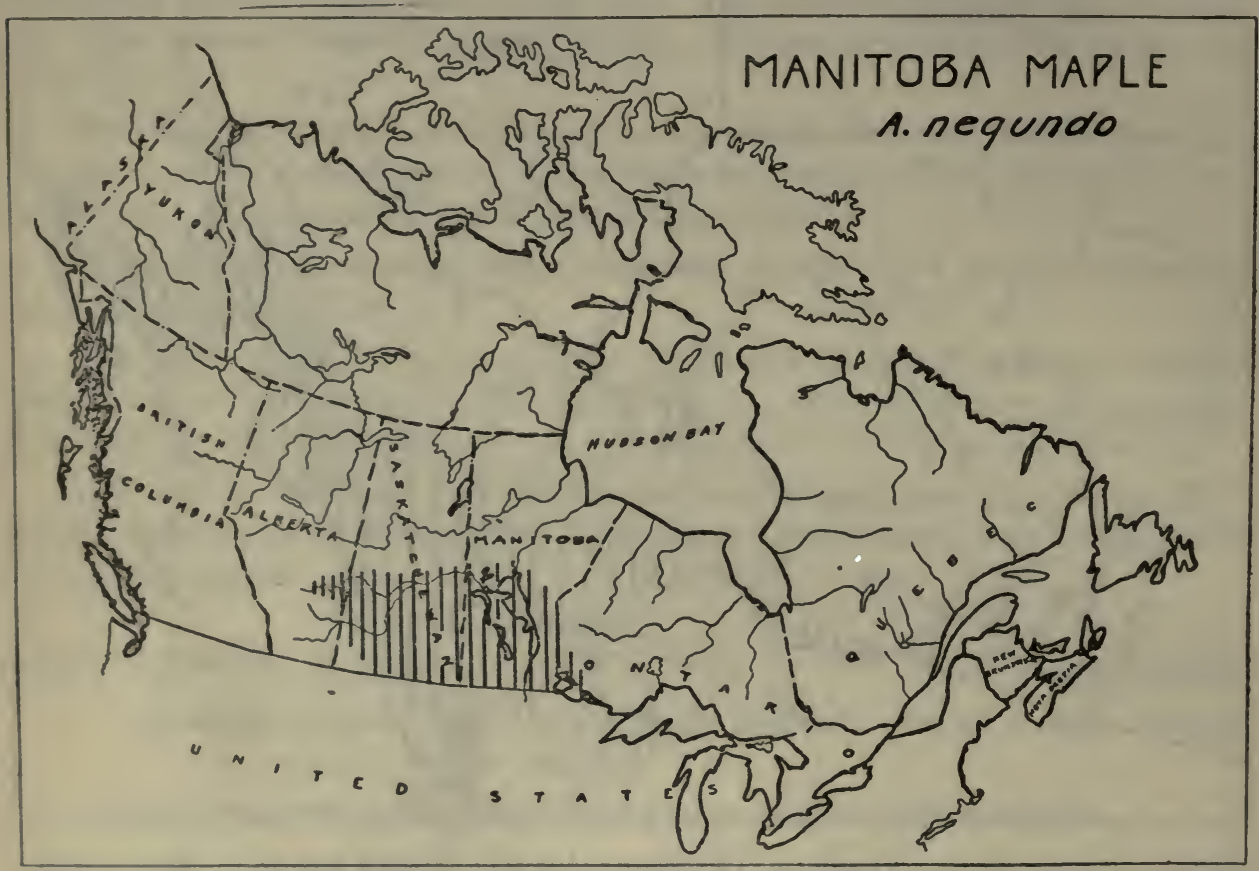

are somewhat $\mathrm{V}$-shaped and, as with all maples, are in pairs and opposite on the twig. Adjacent leaf-scars extend around the twig and almost meet.

The winter buds are grey and downy, sometimes reddish. Only two pairs of scales are exposed.

The leaves are compound, i.e., they have several (three to five or more) leaflets on a stem. 'This is the only native maple with compound leaves. The leaflets are 2 to 4 in. long, oval in outline, and coarsély toothed. They are light green above and pale beneath.

The fruit hangs in clusters from a stem 6 to $8 \mathrm{in.} \mathrm{long}$ and remains on the tree well into the winter. The wings are spread at a sharp angle. The seed portion, even when quite fresh, has a more or less withered and wrinkled appearance.

The wood of the Manitoba maple has the lowest technical value of all the native commercial species. It is soft, weak, coarse-grained, and perishable. It is sawn into lumber locally for boxes and rough construction. 


\section{THE BASSWOODS OR LINDENS}

About twenty species of linden (Tilia) are found throughout the world. Six are native to North America, of which one occurs in Canada. They are much used for ornamental planting, particularly in Europe, and a number of European species have been introduced into this country for that purpose.

The wood is soft, light, very tough, fine in texture, straight-grained, but perishable.

TILIA AMERICANA, Linn.

BASSWOOD

Common names: Basswood, American linden, lime tree, whitewood*.

French names: Bois blanc*, tilleul d'Amérique.

The basswood is found from the Atlantic coast westward to southern Manitoba, growing in rich, loamy soil in woods and pastures.

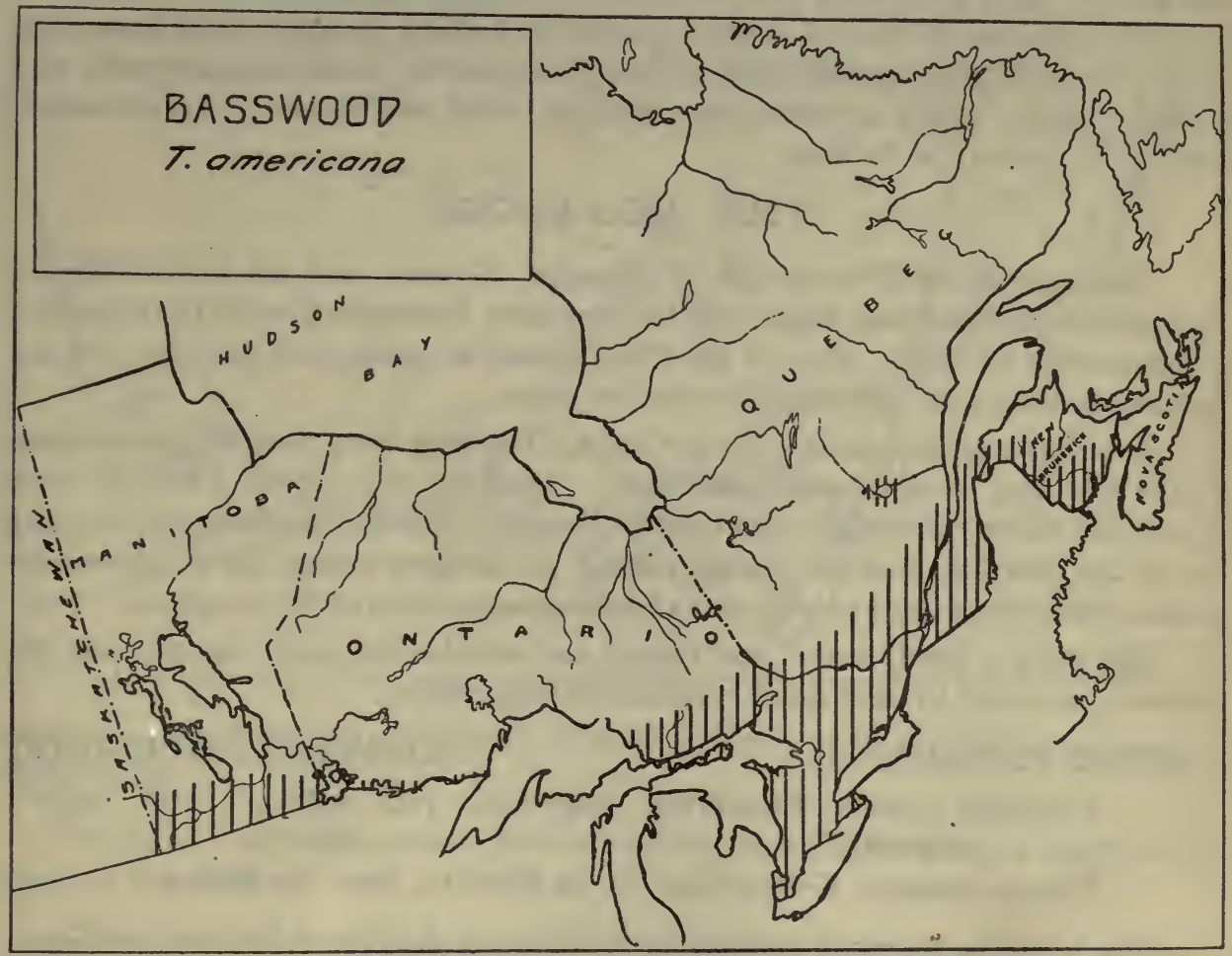

It is commonly 60 to $70 \mathrm{ft}$. in height, but sometimes over $100 \mathrm{ft}$. high and $4 \mathrm{ft}$. in diameter. The trunk is erect and the narrow, oblong, or pyramidal head is composed of many small branches. The lower branches are sometimes drooping.

The bark is dark grey, thick, tough, and deeply furrowed. The inner bark is very tough, fibrous, and mucilaginous. 
The twigs are slender and have a more or less zigzag growth. They are smooth, shiny, and either greenish or reddish in colour.

The winter buds are dark red, sometimes green, smooth, pointed and lopsided. These one-sided buds are one of the tree's best distinguishing points in winter.

The leaves are very large, 5 to 6 in. long, heart-shaped in outline, and somewhat one-sided. The margin is irregularly toothed with fine and coarse points, and the veining in the back is conspicuous and with small tufts of brown hair at the junction of the veins.

The fruit is in the form of tiny, round and woody balls, which look like peas, and which are attached singly or in clusters, by means of a common stalk, to the centre of the midrib of a narrow, leaf-like bract.

Basswood lumber is the most important of what might be called the "soft hardwoods"- broad-leaved trees with soft, light wood. Because of its toughness and lack of taste and odour it is used for slack cooperage and boxes. The ease with which it can be worked, and its quality of holding its shape after seasoning, fit this wood for the manufacture of furniture, interior finish, cabinet-work, and vehicle bodies. It is a favourite wood for panel work and veneer. It is characterized by the variety of its uses.

\section{THE DOGWOODS .}

There are about fifty species of dogwood (Cornus) and all are distributed throughout the temperate regions of the northern hemisphere, with the exception of one species in Peru. Most of them are shrubs or small trees and they are unimportant except for their high decorative value.

A dozen or more species occur in Canada, but only four, since they sometimes attain tree size, need be mentioned here. They are the Cornus florida, Cornus asperifolia, Cornus alternifolia and Cornus Nuttallii. The last mentioned is the only one of the four found on the Pacific coast. All of them except the $C$. alternifolia produce their leaves and twigs in pairs from opposites sides of the branches.

The wood is hard, heavy, and strong, and suitable for small turnery, but the trees are too small to be of much commercial importance.

CORNUS FLORIDA, Linn.

FLOWERING DOGWOOD

Common names: Flowering dogwood, red willow*, red osier*, boxwood*.

French names: Cornouiller de la Floride, bois de flèche.

The flowering dogwood is found in the Niagara district of Ontario, and westward to lake St. Clair.

It is a small tree or shrub found growing in woodlands, often planted for ornamental purposes on account of its flowering habit.

Its twigs and leaves are opposite, i.e., they come out in pairs from the opposite sides of the branchr, as do those of the maples and ashes. The single pair of scales 
on the terminal bud of the twig and the presence of many large top-shaped flower buds will distinguish it from any of the.maples or ashes during the winter.

The bark is dark brown and on large stems is broken into small, squarish plates. The twigs are slender, smooth, and bright red in colour. When chewed they are bitter.

The leaves are 3 to $5 \mathrm{in}$. long, oval to almost round in outline, with smooth or slightly wavy margins. The ribs above are indented and whitish and curved to

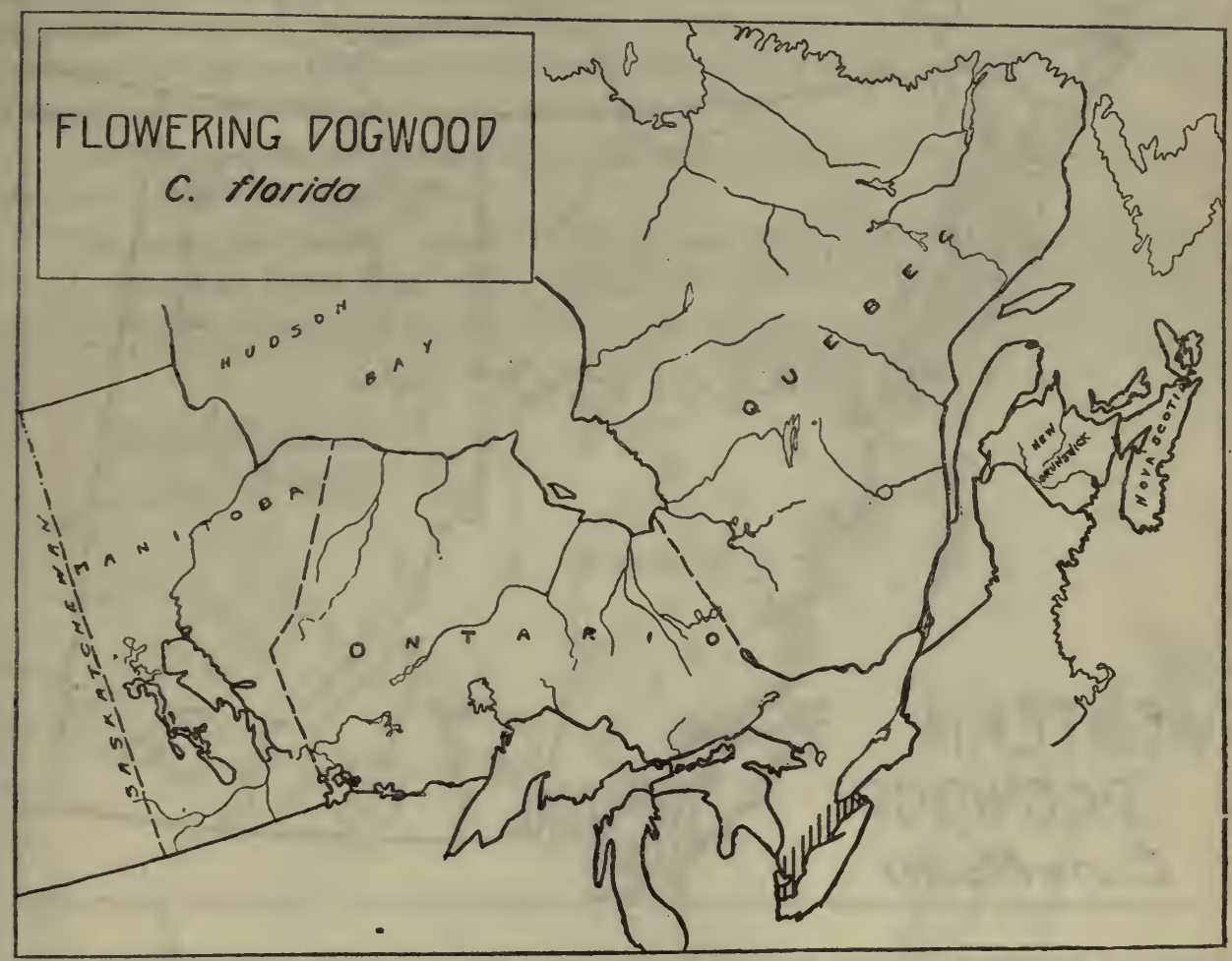

follow the general outline of the leaf. The leaves are usually clustered at the ends of the twigs.

The flowers are large, white, and very showy, making the plant a conspicuous object in the spring.

The fruit which grows in clusters and ripens to a bright red colour in the autumn is oblong, fleshy, and berry-like, and contains a grooved stone.

The wood is hard, compact, and dense. It is cut only for special uses depending on the fact that it wears smooth under friction. Shuttles are made altogether of this wood and of persimmon. It is a substitute for Turkish boxwood for spindles, bobbins, mallets, and tool-handles. 
CORNUS NUTTALLII, Aud.

WESTERN DOGWOOD

The western dogivood is found in the lower Fraser valley, and on Vancouver island in British Columbia. It is a small tree, commonly 20 to $25 \mathrm{ft}$. in height and 6 to $7 \mathrm{in}$. in diameter. In the spring the large, showy, petal-like scales of its flower clusters make it a conspicuous object. In general appearance. it resembles the

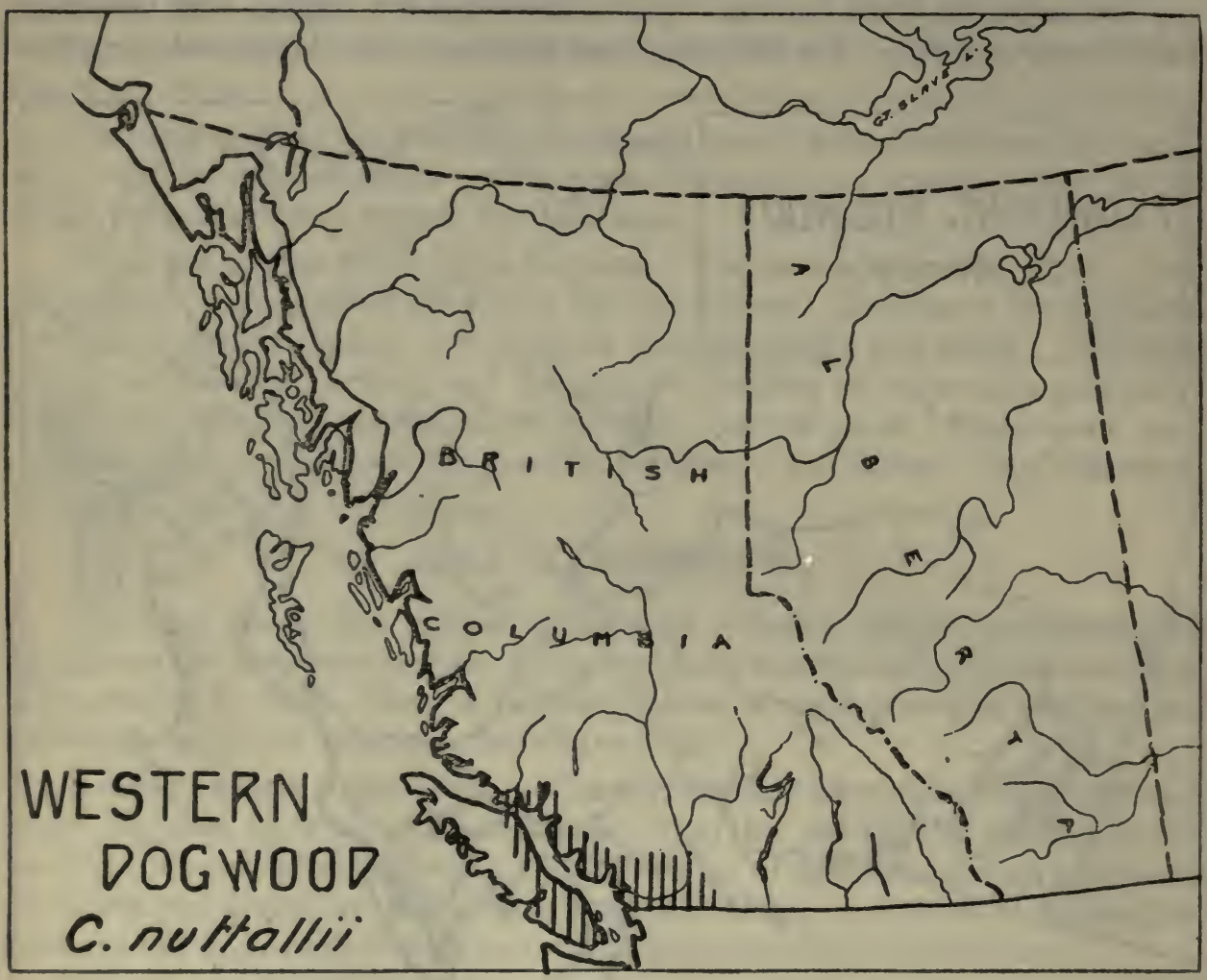

flowering dogwood (Cornus florida) of the East, but is readily differentiated from it by the differences in range and by the shape of the flower scales, which in the case of the western species are pointed at the tip, while those of the other are indented at the end and are on the whole more heart-shaped.

\section{THE GUM TREES}

Five species of gum tree (Nyssa) are recognized. Four occur in the eastern portion of this continent and one in China. Only one, Nyssa sylvatica, extends sufficiently far north to come into Canada. The gum trees are fond of damp situations and are usually found in swamps.

They can be recognized by their oval leaves with their toothless margins and smooth, shiny surfaces, and by their characteristic fruit. 
NYSSA SYLVATICA, Marsh.

BLACK GUM

Common names: Black gum, sour gum, pepperidge, tupelo.

French name: Nyssa sylvestre.

The Canadian range of the black gum is limited to the southwestern part of Ontario, bordering on lakes Erie and St. Clair, where it is found growing in swamps and along the edges of streams.

It is a large tree, averaging $60 \mathrm{ft}$. in height. In the forest the trunk is symmetrical and clear for a considerable length. The crown on old trees is often flattopped and frequently stag-headed, i.e., dead at the top. In the open the branching is very irregular, the lower branches drooping more or less and the upper ones growing out horizontally.

The bark is dark grey tinged with red, rough, deeply grooved, and broken by cross lines into many-sided plates.

The twigs are slender, smooth, reddish-brown, numerous, and have a horizontal, spreading habit of growth. The small branches are frequently covered

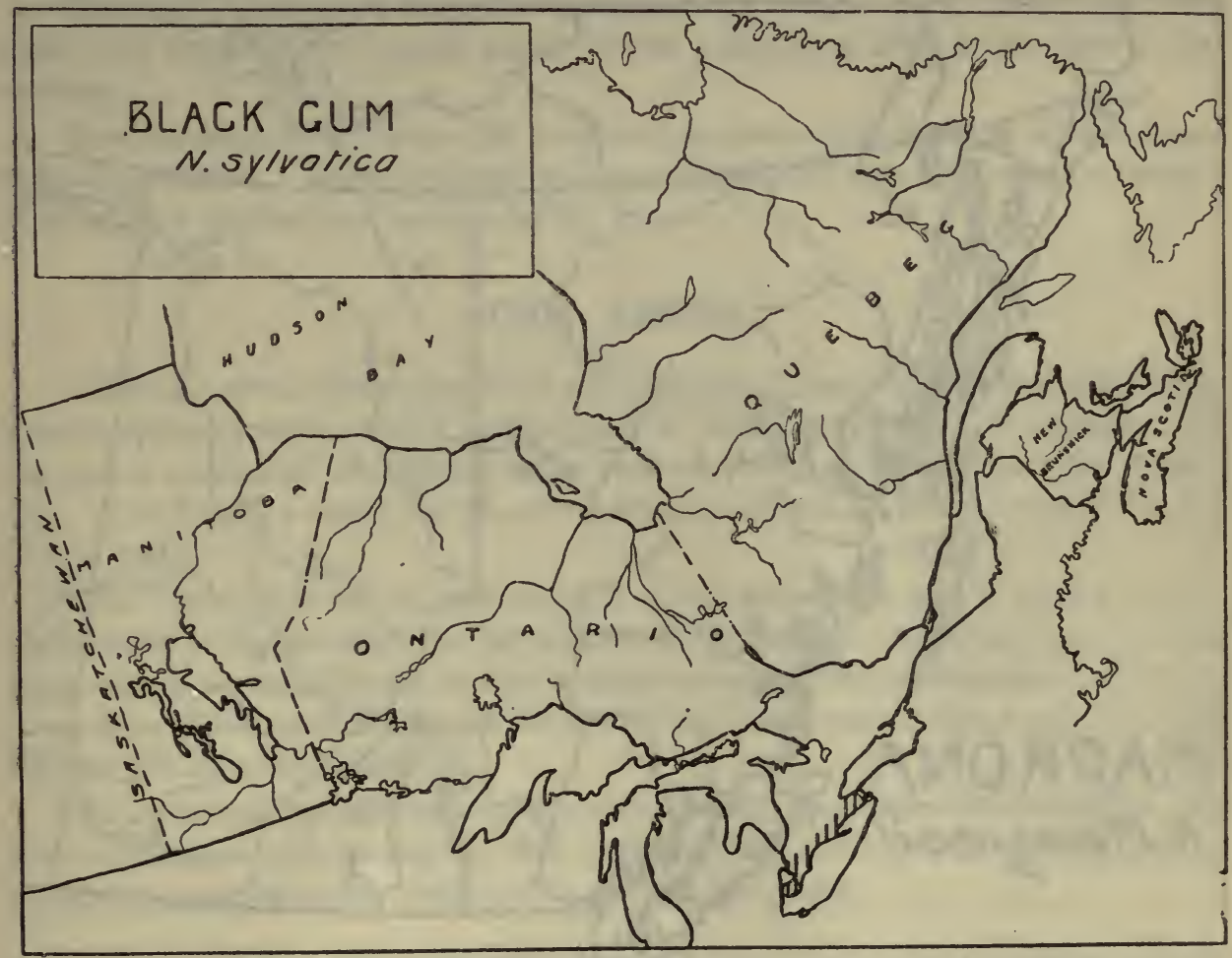

with many, short, spur-like growths which are roughened by broad, crescent-like leaf-scars.

The winter buds are about $1 / 4$ in. long, dark red, blunt-pointed, and usually. pointed well away from the twig. 
The leaves are 2 to $5 \mathrm{in}$. long, oval in outline, and leathery in texture. They are dark green and shiny above and often fuzzy beneath. The margin is smooth, not notched, and the stem is slender, sometimes short and stout, and very often red.

The fruit is berry-like, blue-black in colour, and sour to the taste. It is about $2 / 3 \mathrm{in}$. in length and contains a more or less ridged stone. There are one to three of these fruits on a single stalk.

The wood is very tough and difficult to split on account of its twisted grain. It is consequently used for wagon-hubs, rollers, turnery, cooperage, and veneer. It is seldom used commercially in Canada because of its comparative rarity.

\section{THE MADRONAS}

Twelve species of madrona (Arbutus) are known to exist either as small trees or as shrubs. Three occur as trees in the United States, but only one of them extends north far enough to come into Canada.

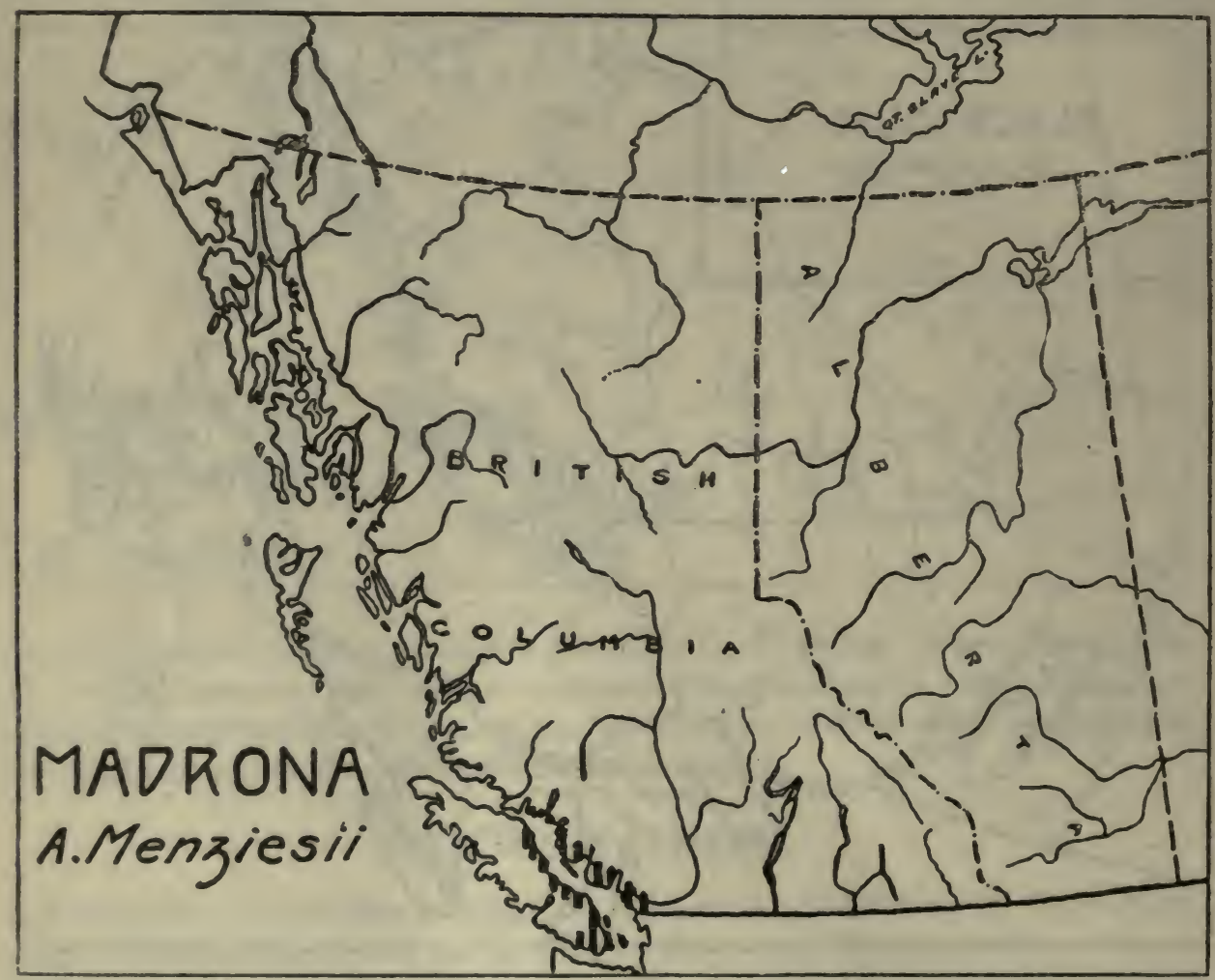

All of them have thin, smooth bark, bright red on twigs and branches; and thick, leathery, evergreen leaves. They produce hard, heavy, close-grained wood that is difficult to season and work, but makes good charcoal and fuel. 
ARBUTUS MENZIESII, Pursh.

MADRONA

Common names: Madrona, manzanita, arbutus.

French name: Arbousier de Menzies.

The madrona reaches the northern limit of its range in southern British Columbia where it is found on both sides of the straits of Georgia and on the islands therein, as far north as Bute inlet on the mainland.

It is not a large tree, very often low and shrubby with crooked, bent trunk and branches. The bark is thin and reddish-brown, and, on young stems and branches, comes off in thin, smooth plates or flakes very much in the same manner as does that of the sycamore (Platanus occidentalis).

The tree is readily distinguished by its shiny foliage which remains green all winter. It is the only broad-leaved tree native to Canada that is an evergreen. The leaves are 2 to 5 in. long, shiny above and whitish beneath, smooth, thick and leathery.

The fruit is spherical, berry-like in appearance, bright red in colour, dry, and mealy and contains many small seeds. Great numbers of these fruits ripen in the autumn.

Further south in its range this tree reaches commercial size and is sometimes sawn into lumber. The wood is dense, fine-grained, and very hard when seasoned. It is used for flooring and interior finish.

\section{THE ASHES -}

There are about forty species of ash (Fraxinus), found throughout the world. Sixteen species occur in North America and of these four are found in Canada. Of the native species all are eastern trees, one extending as far west as lake Winnipeg. A fifth ash, a variety of one of the eastern species, is found throughout the prairie region.

The winter buds, leaves, and twigs of all the ashes come out in pairs from opposite sides of the branch. In this respect they resemble the maples and certain dogwoods, but the difference in fruit and leaves will readily distinguish them from these trees. The so-called mountain ash (Pyrus americana) is not a true ash and has not this opposite branching.

The wood of the different ashes is noted for its toughness and elasticity, but great differences exist among the five native species. The more valuable species are used for vehicle stock, tool-handles and interior finish.

FRAXINUS QUADRANGULATA, Michx.

BL̇UE ASH

Common name: Blue ash.

French name: Frêne anguleux.

The blue ash is confined to southwestern Ontario in the counties bordering on lakes Erie and St. Clair, but is not very common even there. Under favourable 
conditions it reaches a height of 60 to $70 \mathrm{ft}$. and over, but commonly is considerably less. In Canada its wood is not used conmercially.

The bark is light grey and broken into thin scales. When cut it exudes a resinous juice which turns bluish on exposure.

The branchlets are rather heavy and more or less four-sided in cross-section.

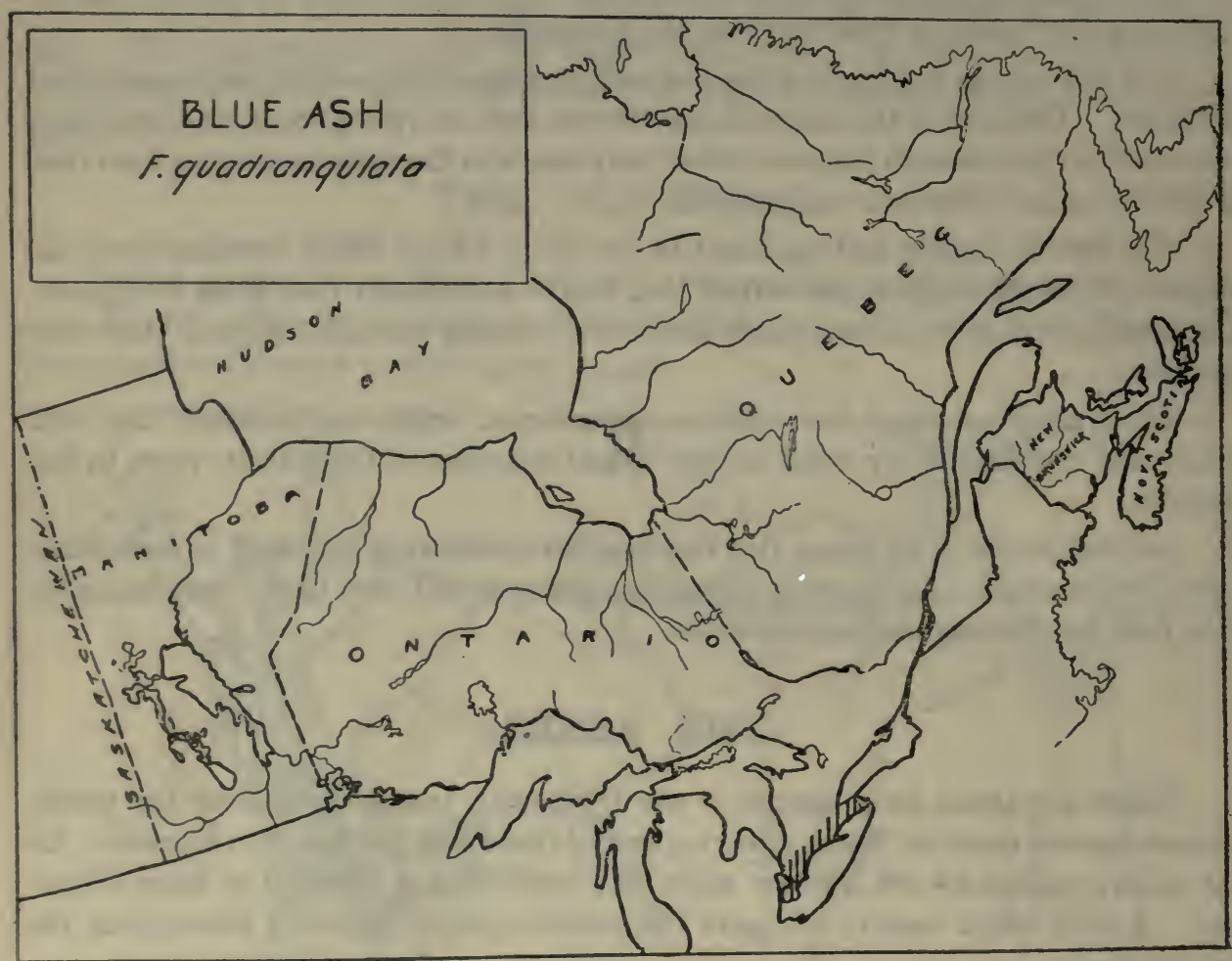

'This enables it to be distinguished from the other ashes. The winter buds are reddish-brown and slightly hairy.

The leaf, like that of all ashes, is compound, i.e., made up of several smaller leaflets. The leaflets have very short stems and the underside of their midrib is hairy. The margin of the leaflets is notched with many incurved teeth.

The wing of the seed resembles very much that of the black ash. It is very wide, blunt, notched at the end, and practically surrounds the seed portion.

FRAXINUS NIGRA, Marsh.

BLACK ASH

Common names: Black ash, swamp ash, water ash, brown ash (Maritime Provinces), hoop ash.

French names: Frêne noir, frêne à feuilles de sureau.

In Canada the black ash is distributed from the gulf of St. Lawrence to Manitoba and is found growing in river bottoms and swamps. 
It is a tall, slender tree, from 60 to $70 \mathrm{ft}$. in height, with a narrow crown of upright branches. The diameter of the trunk is small for a tree of its height, and the taper is very slight.

The bark is thinner than that of the white ash and not so deeply furrowed. It is soft and scaly, i.e., it crumbles somewhat when the surface is rubbed with the palm of the hand, and a distinct mark is left where the rubbing was done. That of the white ash is harder and the mark is not so apparent.

The twigs are coarse, smooth, and, as with all other ashes, come out in pairs from the opposite sides of the branch. They are not pinched or flattened at the bud as are those of the white ash. The upper margin of the leaf-scars is somewhat raised or extended to partly cover the winter bud.

The winter buds are very dark, almost black. They are narrower and more pointed than those of the white ash. The leaves, like those of all our ashes, are compound, i.e., they are formed of numerous smaller leaves. 'They are com-

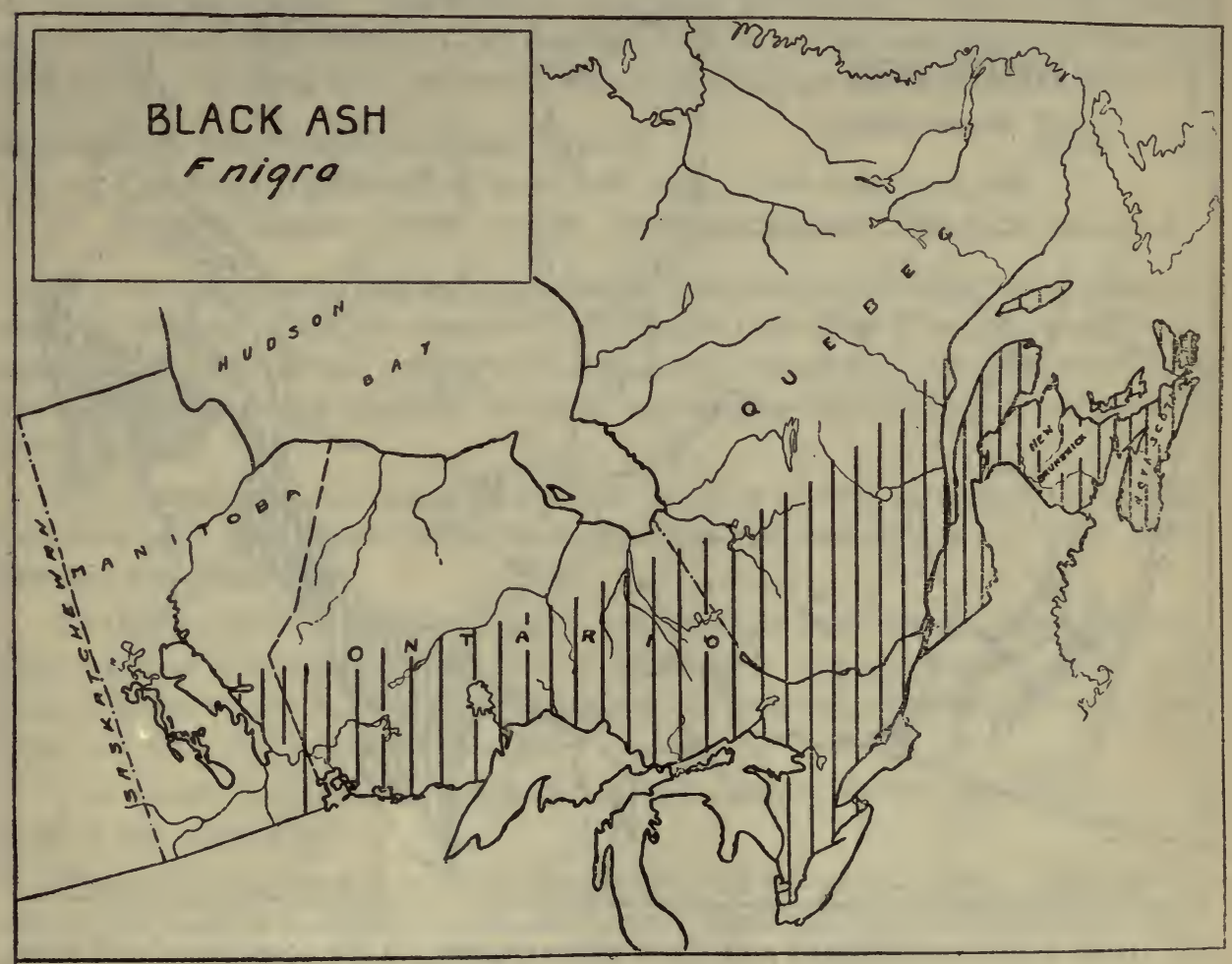

posed of from seven to eleven leaflets. The leaflets themselves, except the end one, are stemless and their margins only slightly toothed.

The fruit is a winged seed from 1 to $1 \frac{1}{2}$ in. long. The seed is somewhat flattened in cross-section and almost entirely surrounded by the wing. The ends $c \hat{i}$ the wings are squarish and usually notched. 
The wood of the black ash is softer and weaker than that of the white ash and is usually employed for more decorative purposes. It has an attractive grain and figure and can be stained to imitate more expensive woods. It is used in greatest quantities for interior finish, fixtures, and cabinet-work

FRAXINUS AMERICANA, L.

WHITE ASH

Common names: White ash, American ash, ground ash (Maritime Provinces).

French names: Frêne blanc, franc frêne.

In Canada the white ash is distributed from Nova Scotia to southwestern Ontario, and is found growing on rich, moist soils but not in wet situations.

It is a large tree, commonly 50 to $60 \mathrm{ft}$. in height and with a trunk diameter of 2 to $3 \mathrm{ft}$., but when growing in a close stand sometimes reaches a height of $100 \mathrm{ft}$.

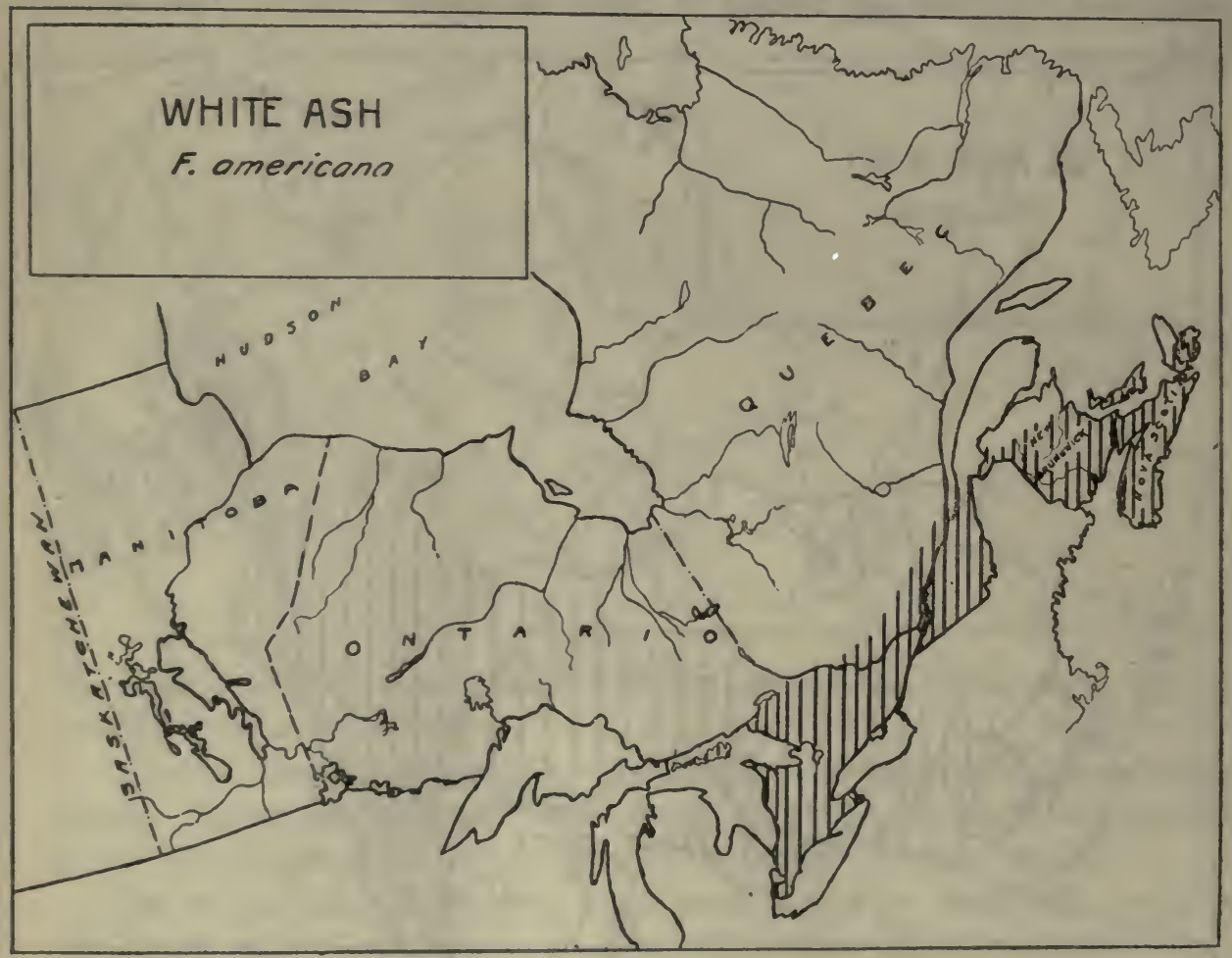

The trunk is tall and straight and, even when growing in the open, rises to a comparatively good height before dividing.

The bark is grey and thick and on the trunk deeply furrowed into narrow, flattened, interlacing ridges.

The twigs are coarse and shiny, not downy as with the red ash. They come out in pairs from opposite sides of the larger twigs and branches (a feature common 
to all ashes and maples). Those of the white ash, however, stand out at a wider angle than most of our native ashes and this gives them a cross-shaped appearance. They are somewhat pinched or flattened at right angles to the bud. The upper margin of the leaf-scar nearly surrounds the bud.

The winter buds are large, rusty-brown, and smooth. The leaves are compound, i.e., made up of several smail leaflets. The leaf is 8 to $12 \mathrm{in.} \mathrm{long} \mathrm{and} \mathrm{com-}$ posed of seven or nine leaflets 3 to $5 \mathrm{in}$. long. The leaflets have stems while those of the black ash, with the exception of the end one, are practically stemless. They usually have a smoother margin than those of any of the other native eastern ashes

The fruit is a winged seed that grows in clusters. The seed portion of the fruit is round in cross-section. The wing is narrow, wedge-shaped, more or less pointed, and not notched at the end, as a rule.

White ash wood is valued chiefly on account of its toughness and elasticity. It is used in the framework of light vehicles, cars, and agricultural implements and for long-handled tools. The wood is also used for barrels, boxes, and veneer baskets for foodstuffs, because of its additional quality of tastelessness and freedom from odour. It has a wide variety of uses depending on these technical qualities.

FRAXINUS PENNSYLVANICA, Marsh.

RED ASH

Common names: Red ash, soft ash, river ash, rim ash.

French names: Frêne rouge, frêne pubescent, frêne de savanne.

The red ash is found sparingly in Canada from southwestern Quebec throughout southern Ontario. It is also reported in Manitoba near lakes Winnipeg and Winnipegosis and in the eastern portion of Saskatchewan, along the river bottoms. It is confined mostly to the banks of streams and margins of swamps but will grow in dry localities.

It is a small tree, commonly $40 \mathrm{ft}$. high, which in general appearance resembles the white ash. The fissures of the bark, however, are somewhat finer. The inner bark has a reddish tinge.

The twigs, which as a rule are downy, are one of its best distinguishing features. They are finer than those of the white or black ashes and heavier or coarser than those of the green ash. The sets of buds along the twigs occur more frequently than is the case with the white or black ashes.

The winter buds are covered with red hair and are darker and smaller than those of the white ash.

The leaf is composed of seven to nine leaflets and is 8 to $10 \mathrm{in.} \mathrm{long} \mathrm{The} \mathrm{under-}$ sides of the leaflets and their stems are hairy. Their margins are slightly toothed but often smooth below the middle.

The fruit is a winged seed 1 to $2 \mathrm{in.}$ long, shorter than that of the green ash. The seed-bearing portion is rounded in cross-section. The wing is usually pointed and not notched, and alinost surrounds the seed.

Red ash, when sarwn into lumber, is usually used as a substitute for white ash. It is weaker, more brittle, and liable to discolorations and defects. 
FRAXINUS PENNSYLVANICA, Marsh., GREEN ASH var. LANCEOLATA (Borkh.) Sarg.

Common names: Green ash, white ash*. French name: Frêne vert.

In Canada the green ash is distributed from the western portion of southern Quebec westward along the St. I.awrence river valley to Georgian bay, also from the west side of lake Stiperior throughout the southern portion of the three Prairie Provinces.

It inhabits the banks of streams and bottom lands but is sometimes found growing on the uplands. It is a small tree, commonly 30 to $40 \mathrm{ft}$. in height and rarely going over $50 \mathrm{ft}$. It forms a low, rounded head with a short, clear trunk.

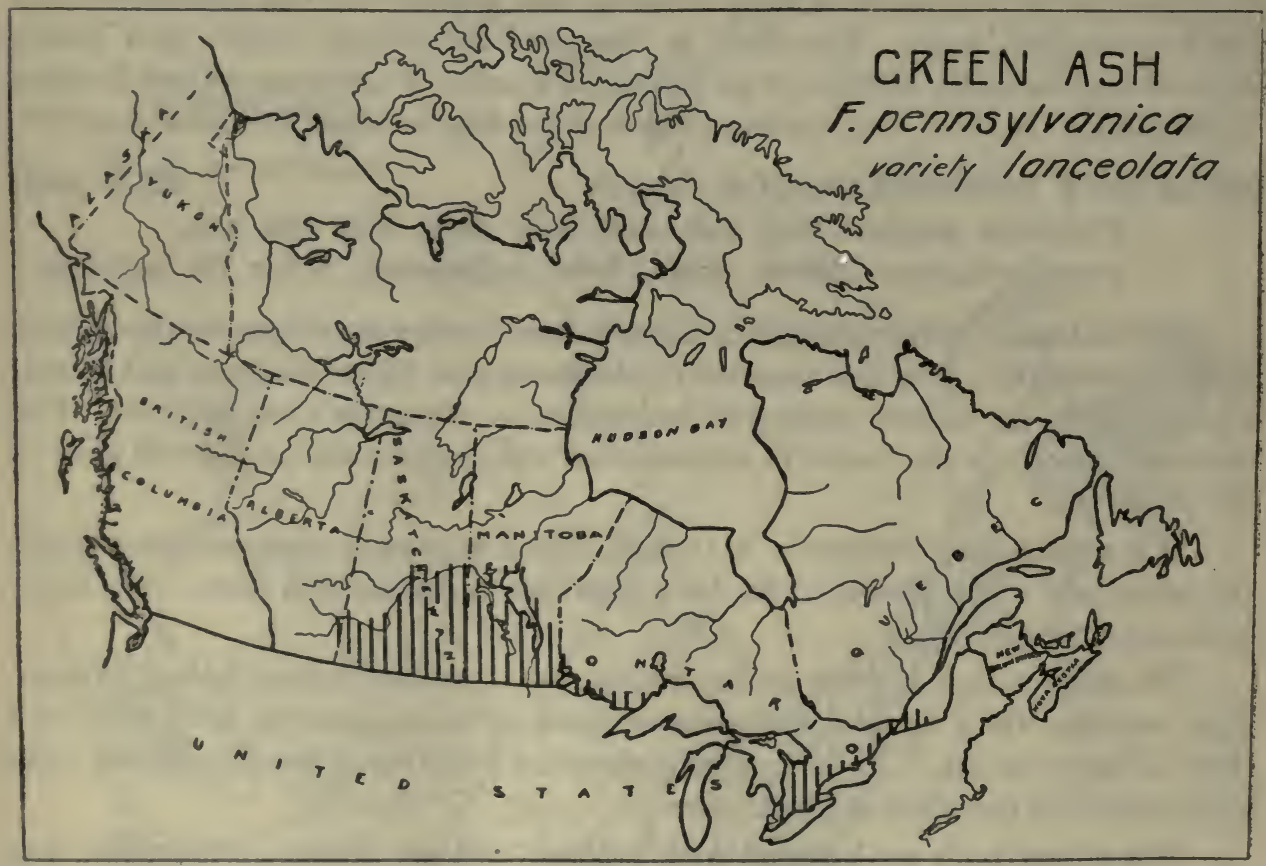

It is a fairly rapid-growing tree and very hardy, and on this account is extensively used in the prairie towns and cities of Canada for street and ornamental planting.

The green ash is considered to be a variety of the red ash. It differs from this tree mainly in the smoothness of its branches, leaves and stems. The winter buds, too, are very nearly hairless. The leaflets are somewhat narrower and shorter, and the fruit is often longer than that of the red ash.

The wood of this tree is sometimes used as a substitute for white ash. 


\begin{tabular}{|c|c|c|c|c|}
\hline 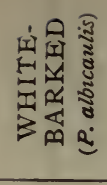 & 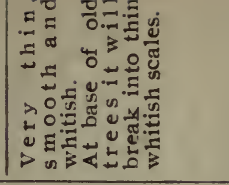 & & 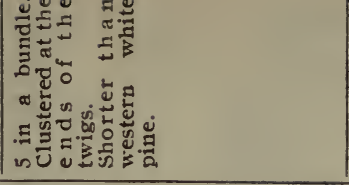 & 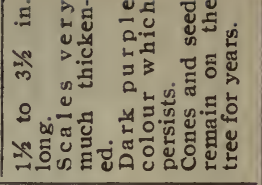 \\
\hline 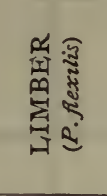 & 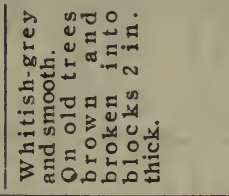 & 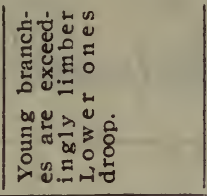 & 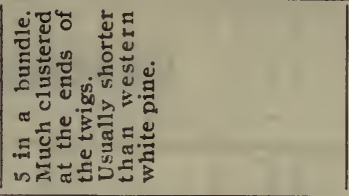 & 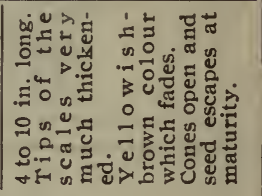 \\
\hline 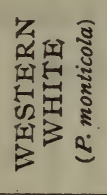 & 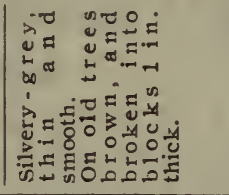 & 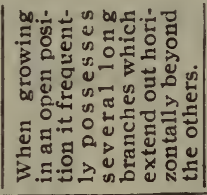 & 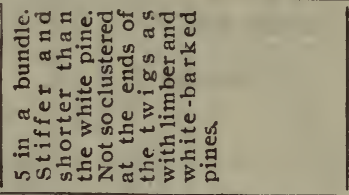 & 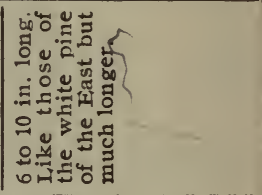 \\
\hline 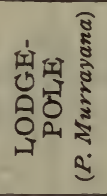 & 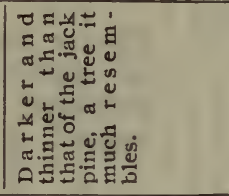 & & 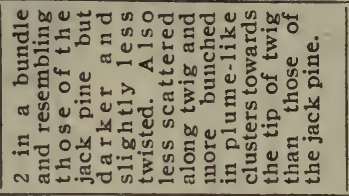 & 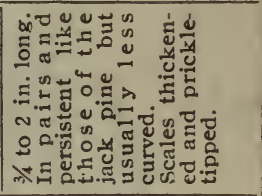 \\
\hline 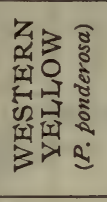 & 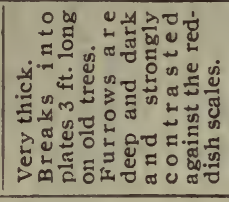 & 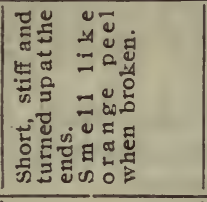 & 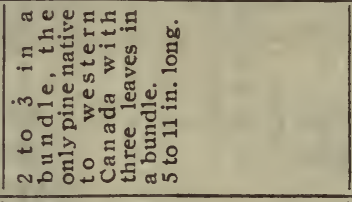 & 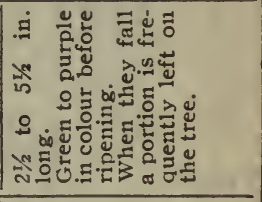 \\
\hline 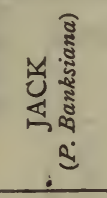 & 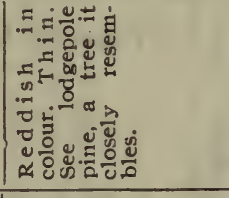 & & 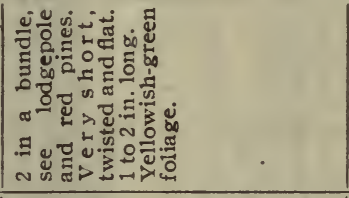 & 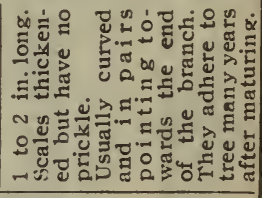 \\
\hline 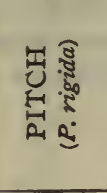 & 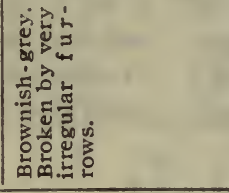 & 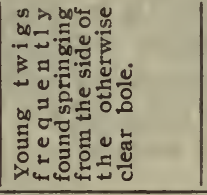 & 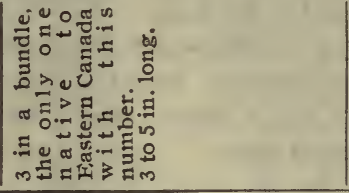 & 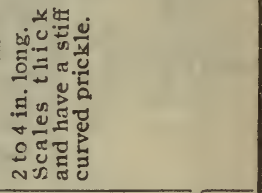 \\
\hline 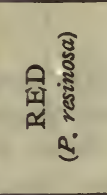 & 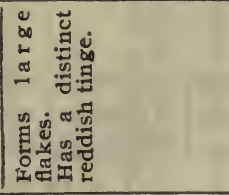 & 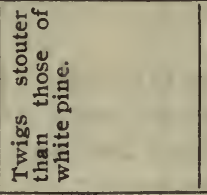 & 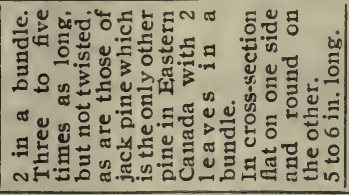 & 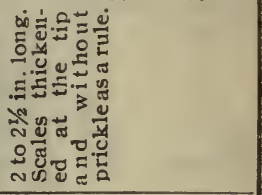 \\
\hline 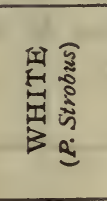 & 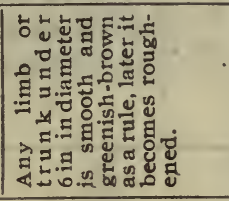 & 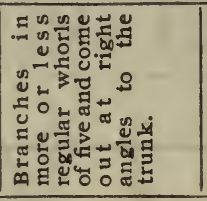 & 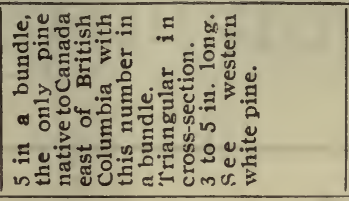 & 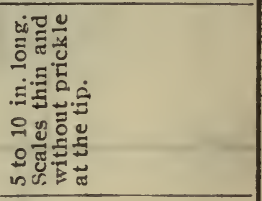 \\
\hline 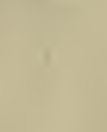 & 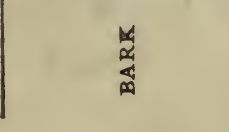 & 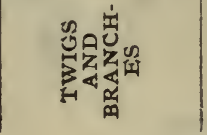 & 谣 & 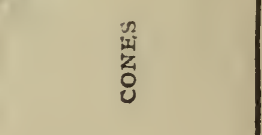 \\
\hline
\end{tabular}




\section{LARCHES (Larix)}

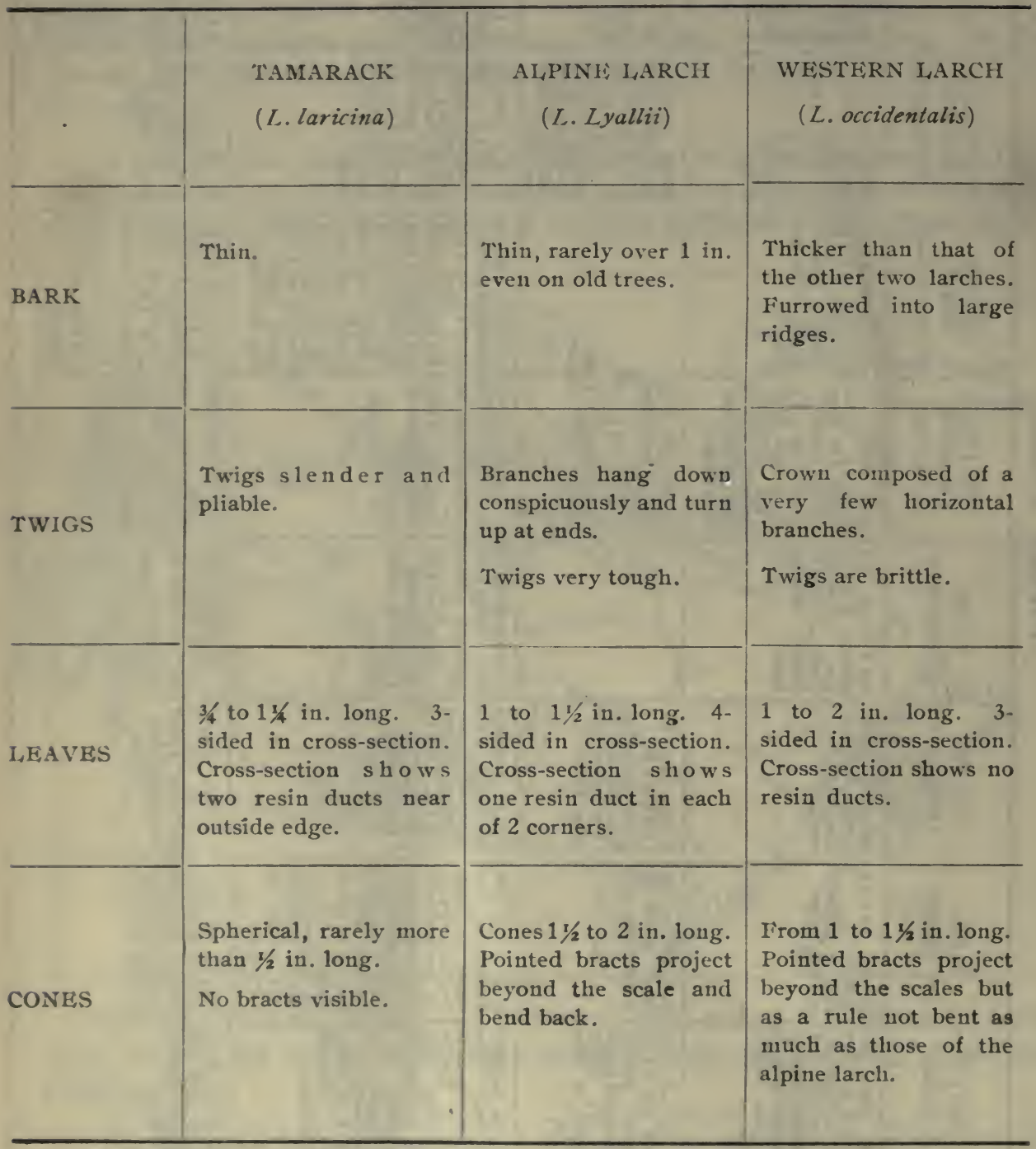




\begin{tabular}{|c|c|c|c|c|}
\hline 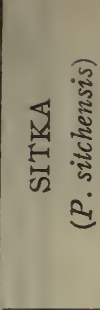 & 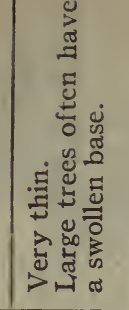 & 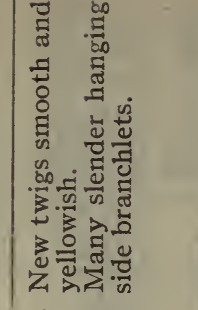 & 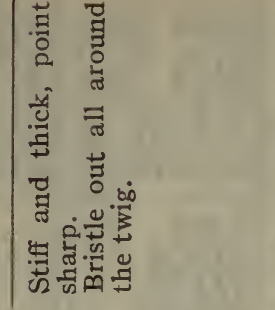 & 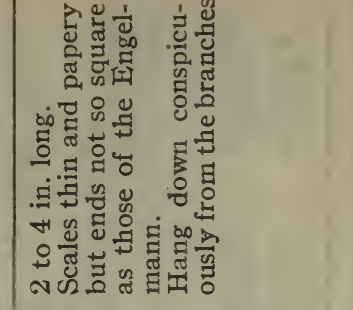 \\
\hline 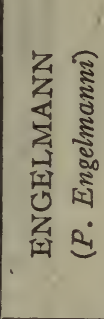 & 咅 & 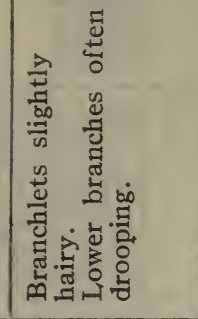 & 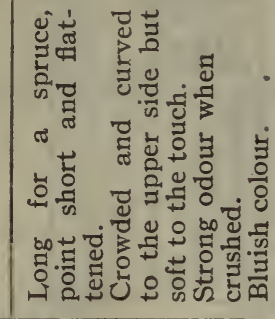 & 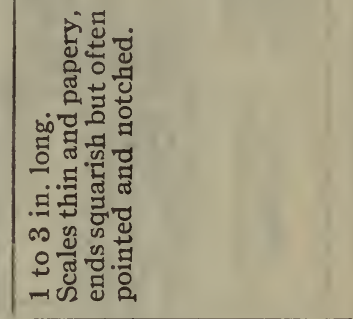 \\
\hline 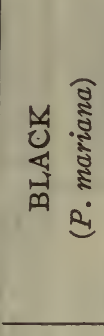 & 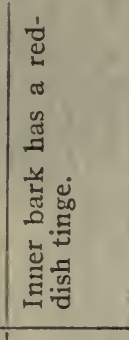 & 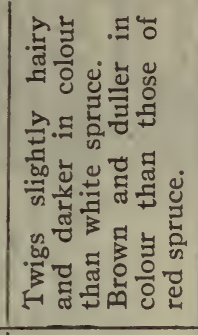 & 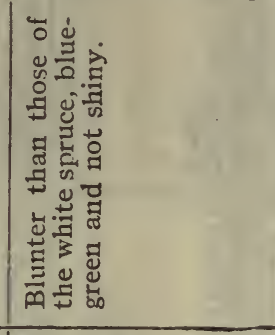 & 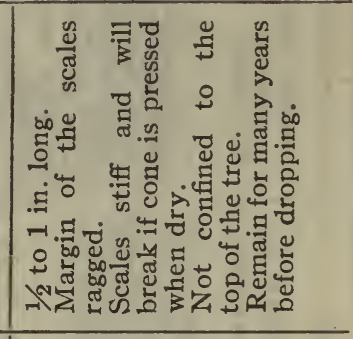 \\
\hline 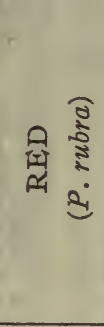 & 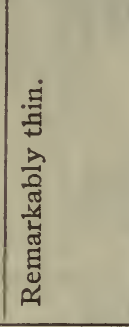 & 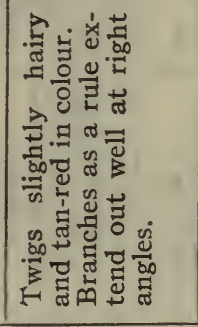 & 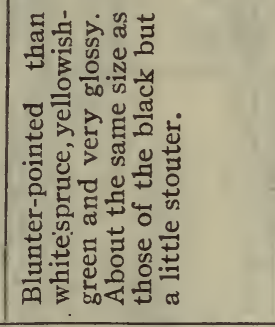 & 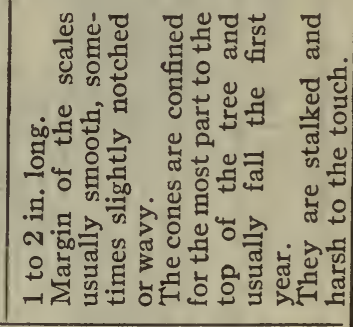 \\
\hline 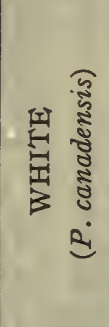 & 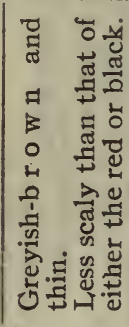 & 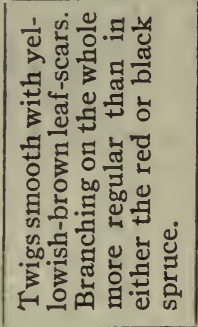 & 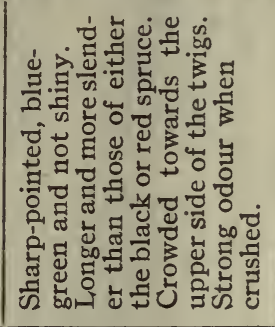 & 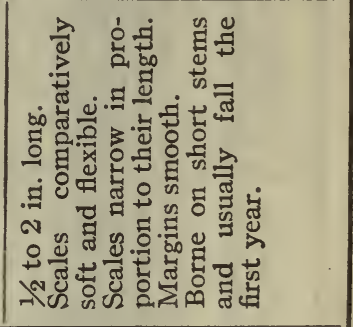 \\
\hline & $\frac{4}{4}$ & 瓷 & 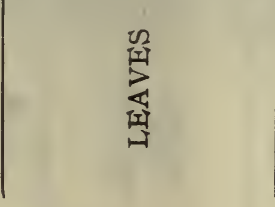 & $\begin{array}{l}\text { 留 } \\
\text { 号 }\end{array}$ \\
\hline
\end{tabular}




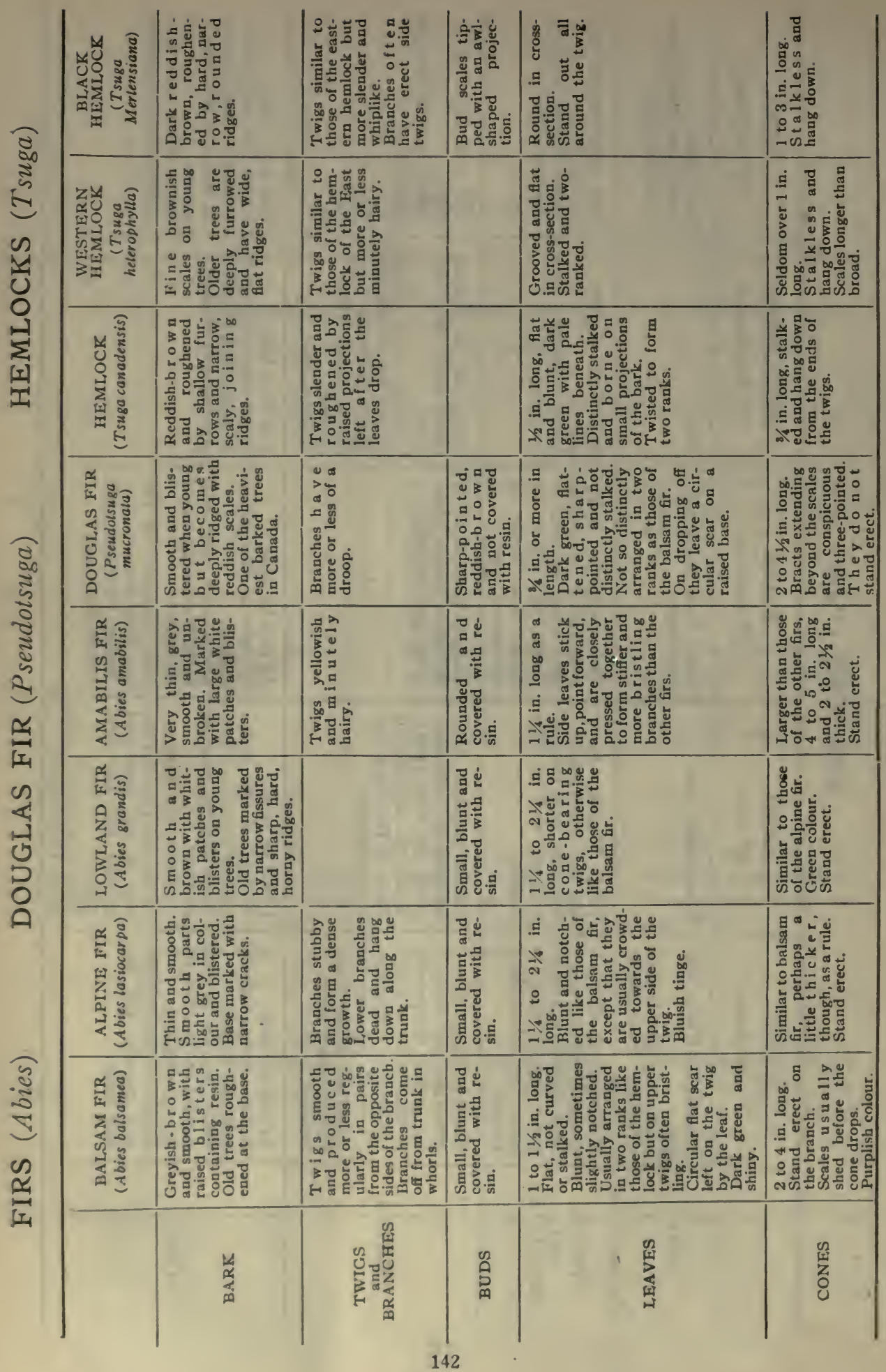




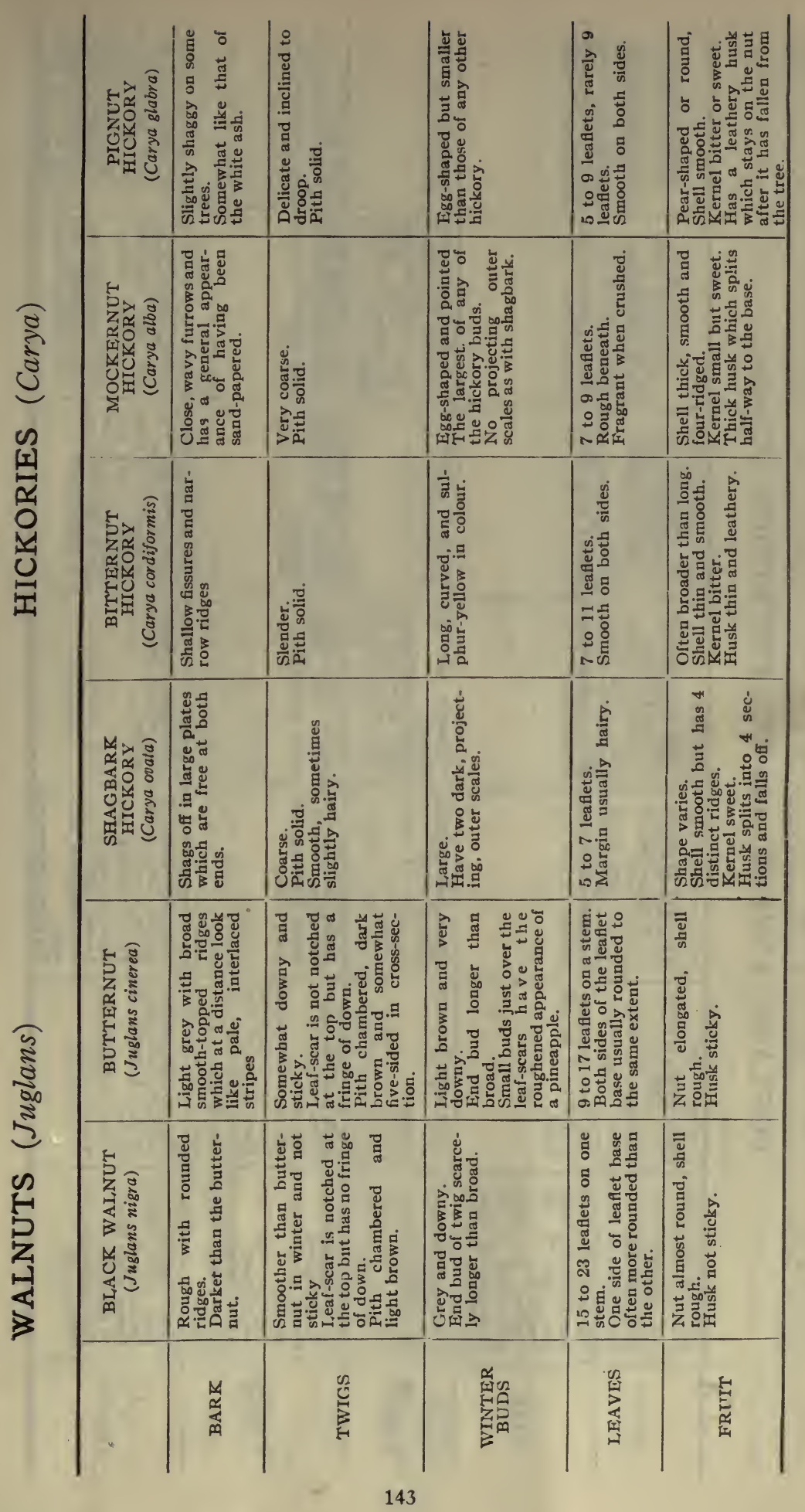




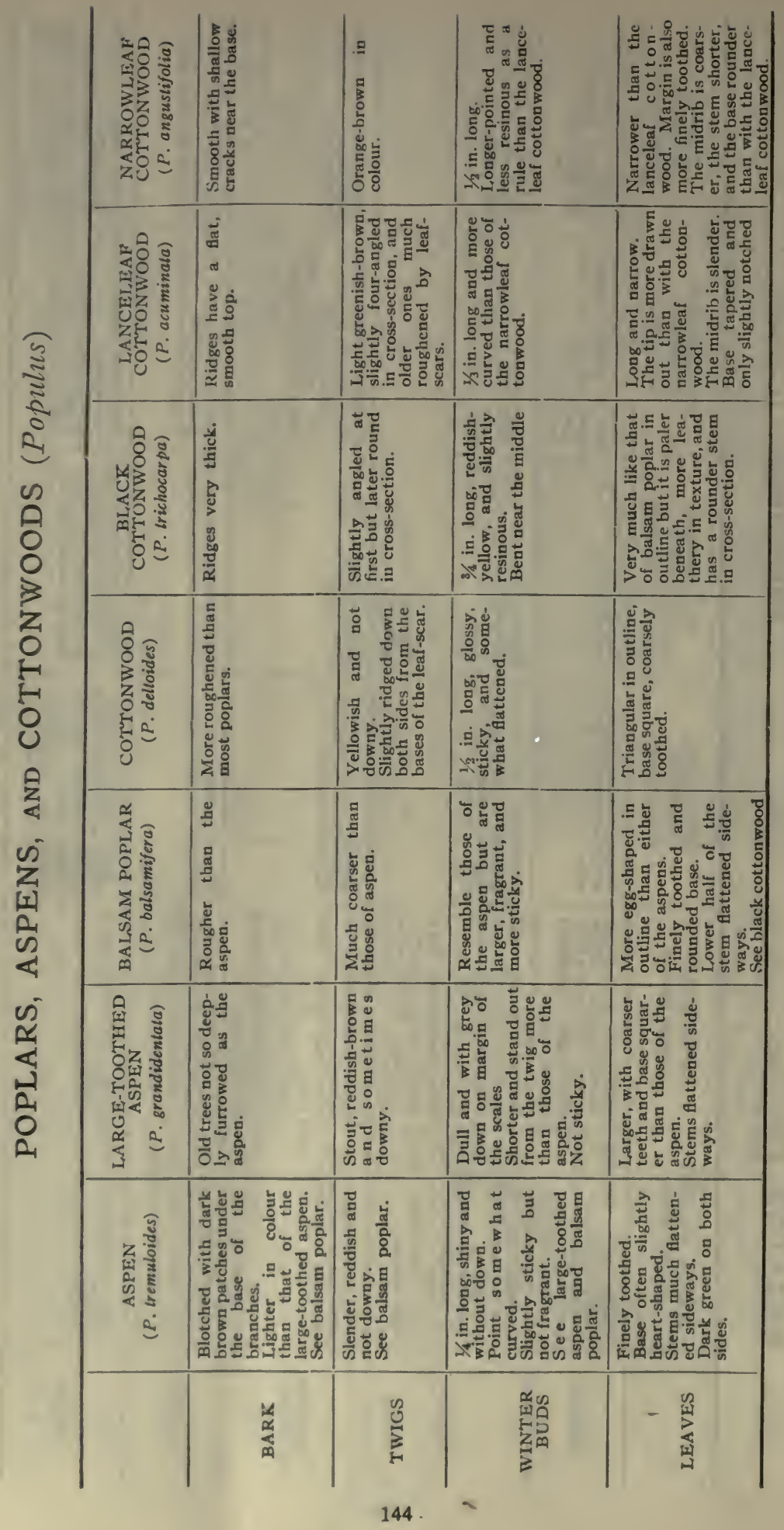




\begin{tabular}{|c|c|c|c|c|}
\hline 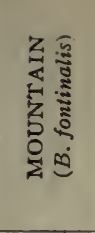 & 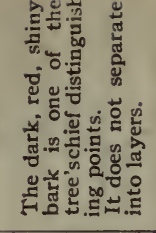 & 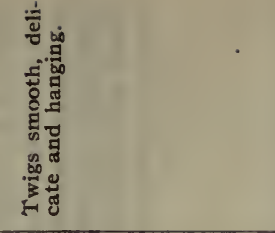 & 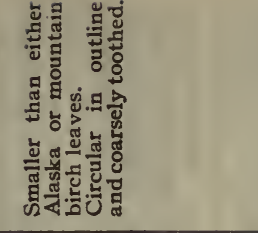 & 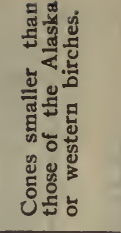 \\
\hline 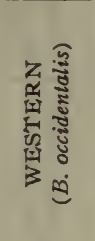 & 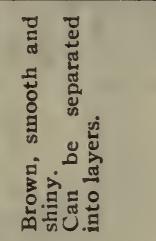 & 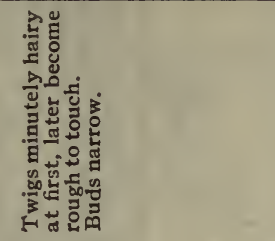 & 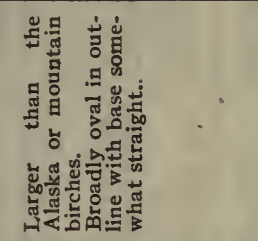 & 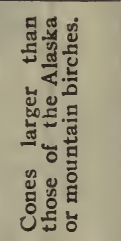 \\
\hline & 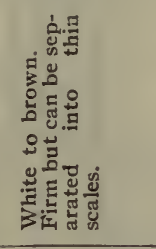 & 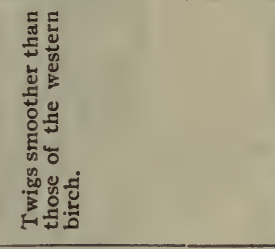 & 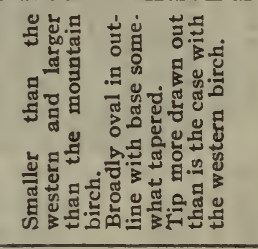 & 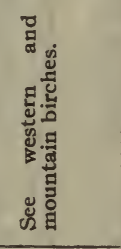 \\
\hline 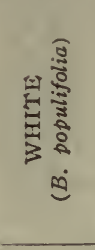 & 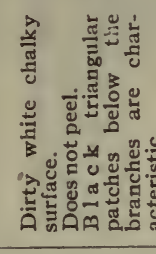 & 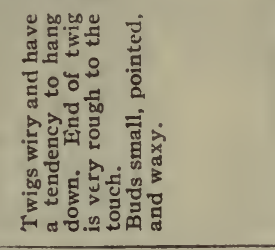 & 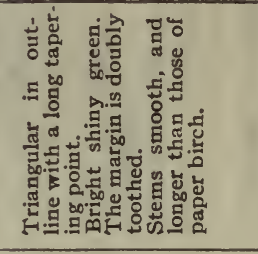 & 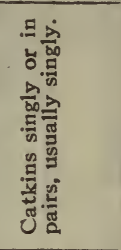 \\
\hline 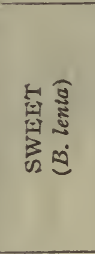 & 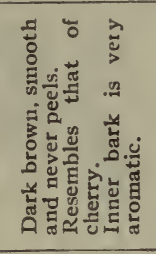 & 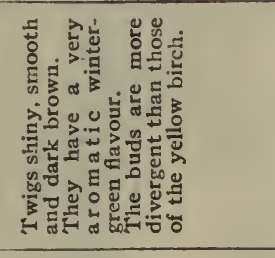 & 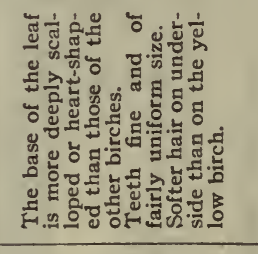 & 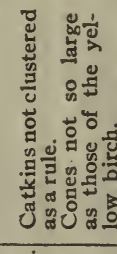 \\
\hline 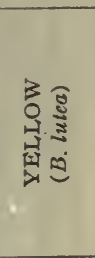 & 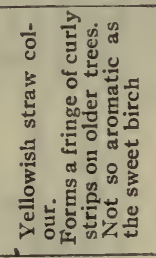 & 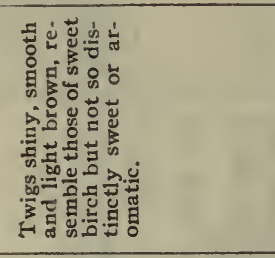 & 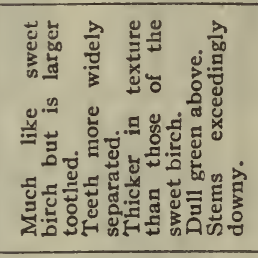 & 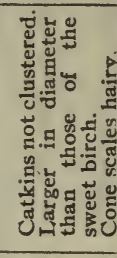 \\
\hline 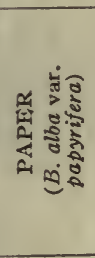 & 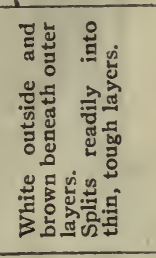 & 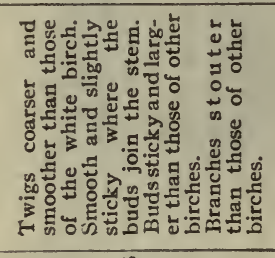 & 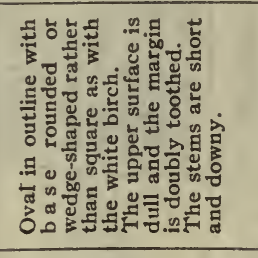 & 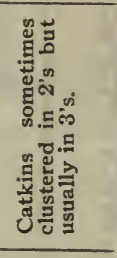 \\
\hline & $\stackrel{\text { ma }}{m}$ & 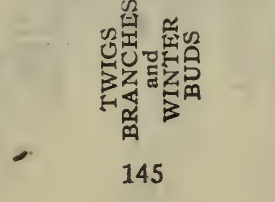 & 留 & 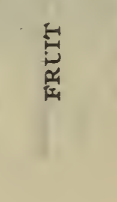 \\
\hline
\end{tabular}




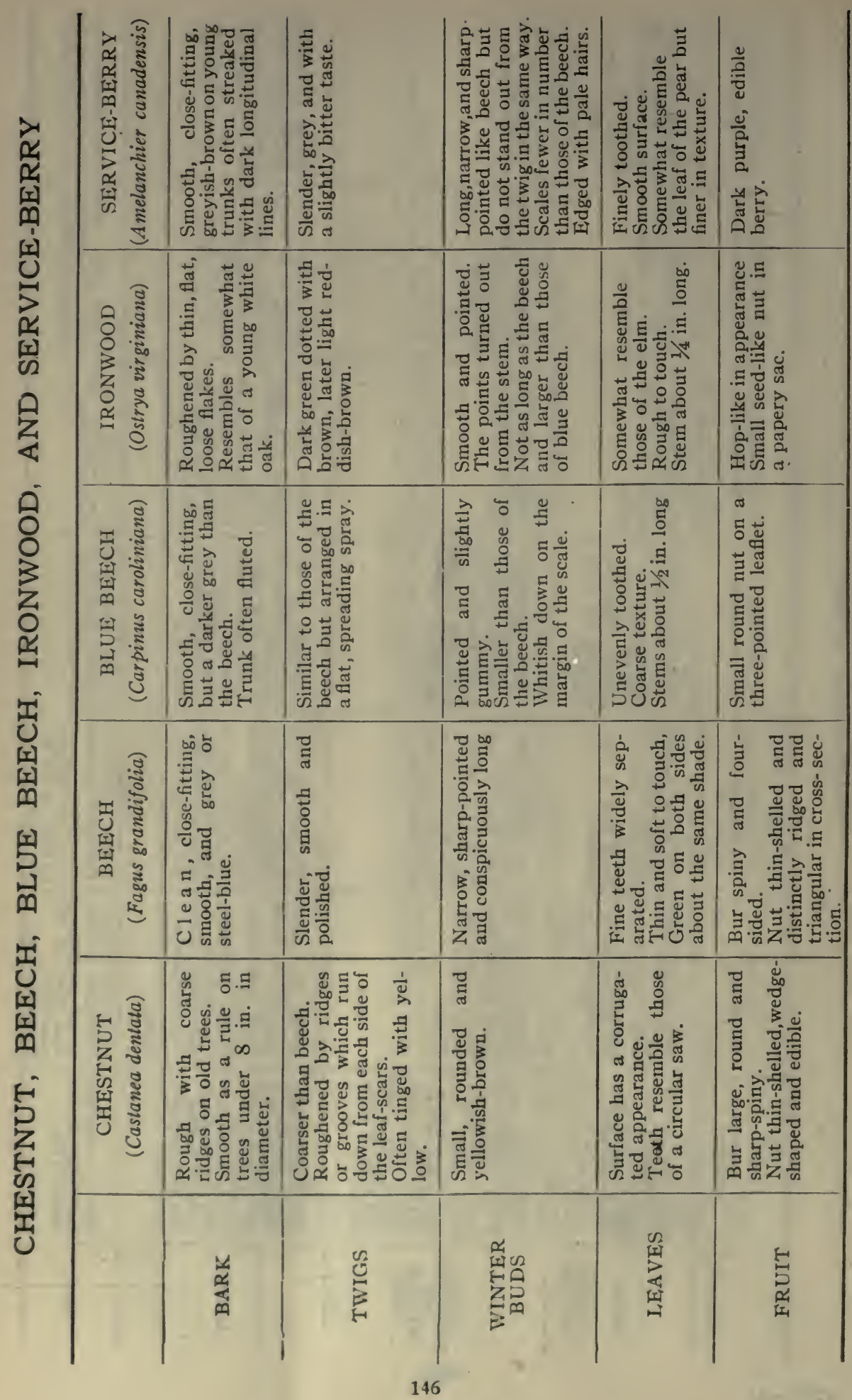




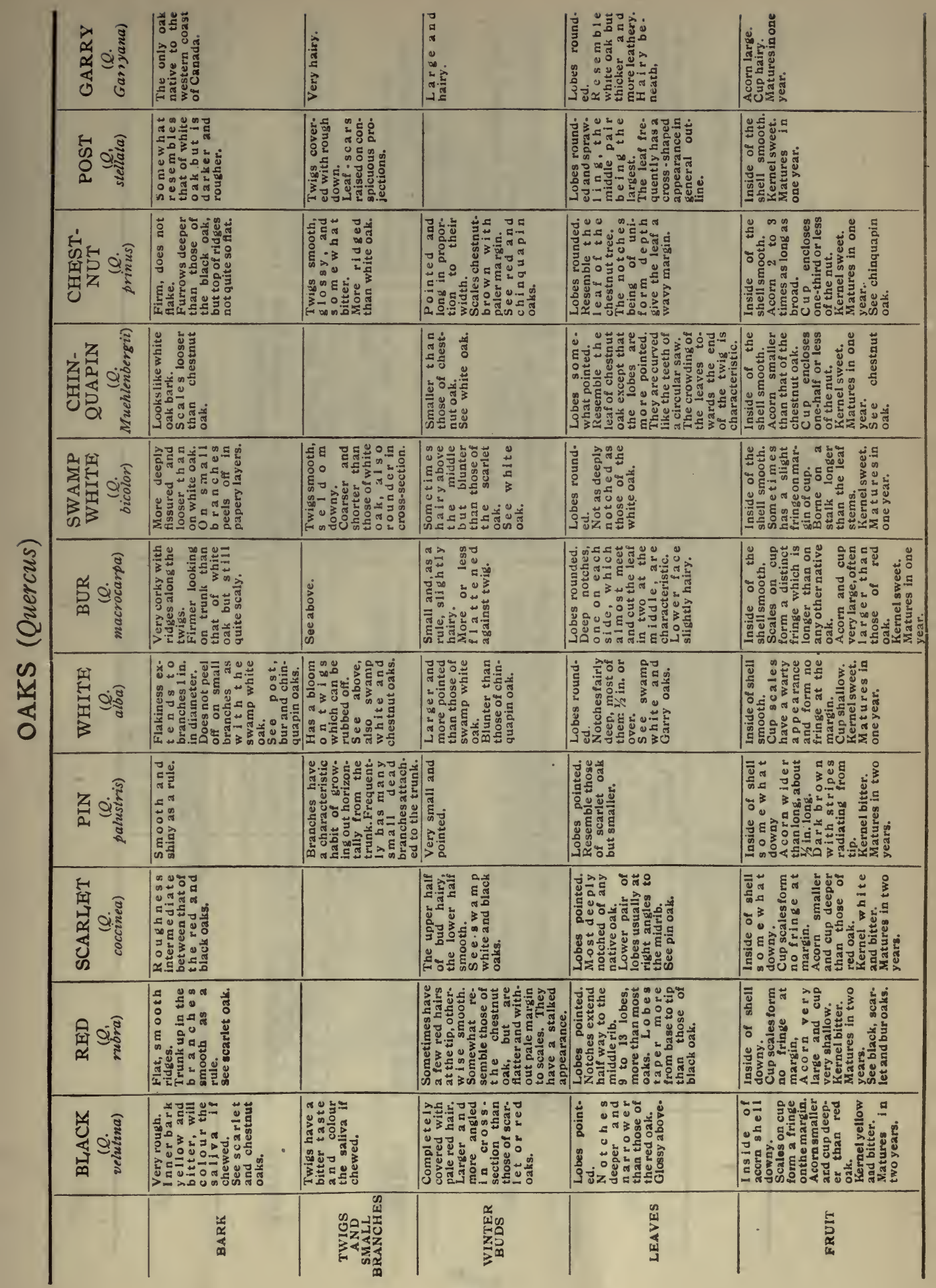




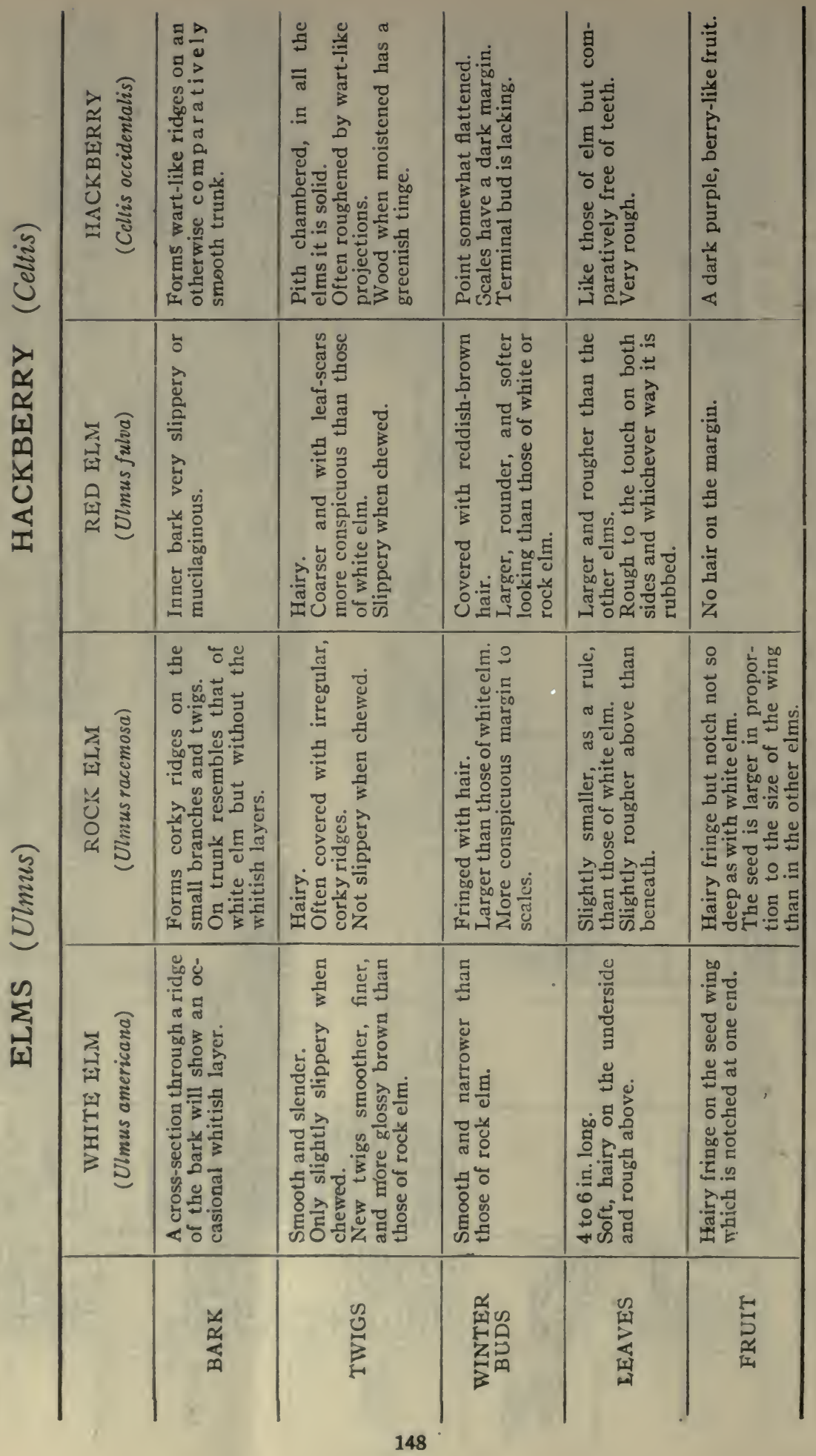




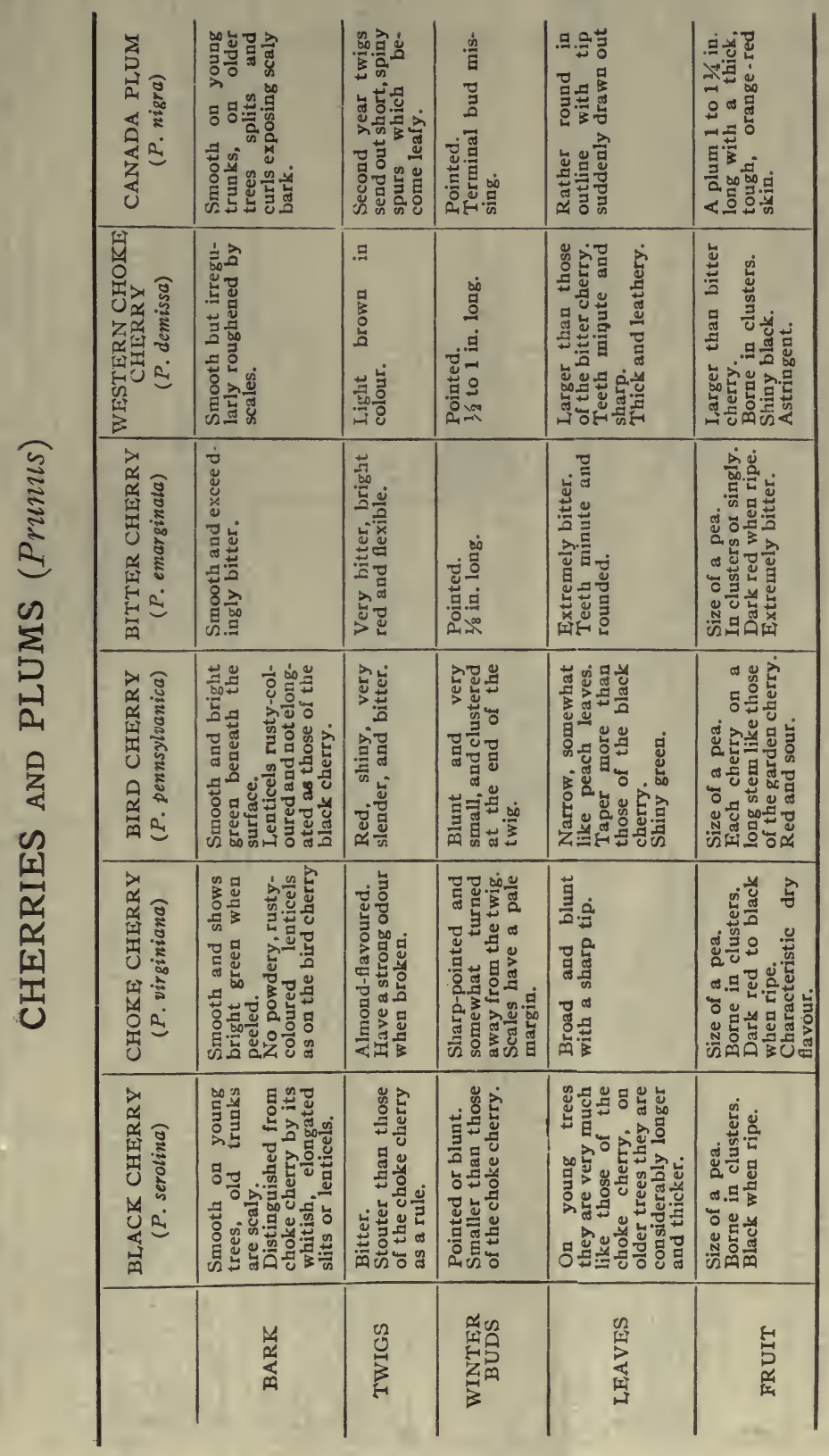




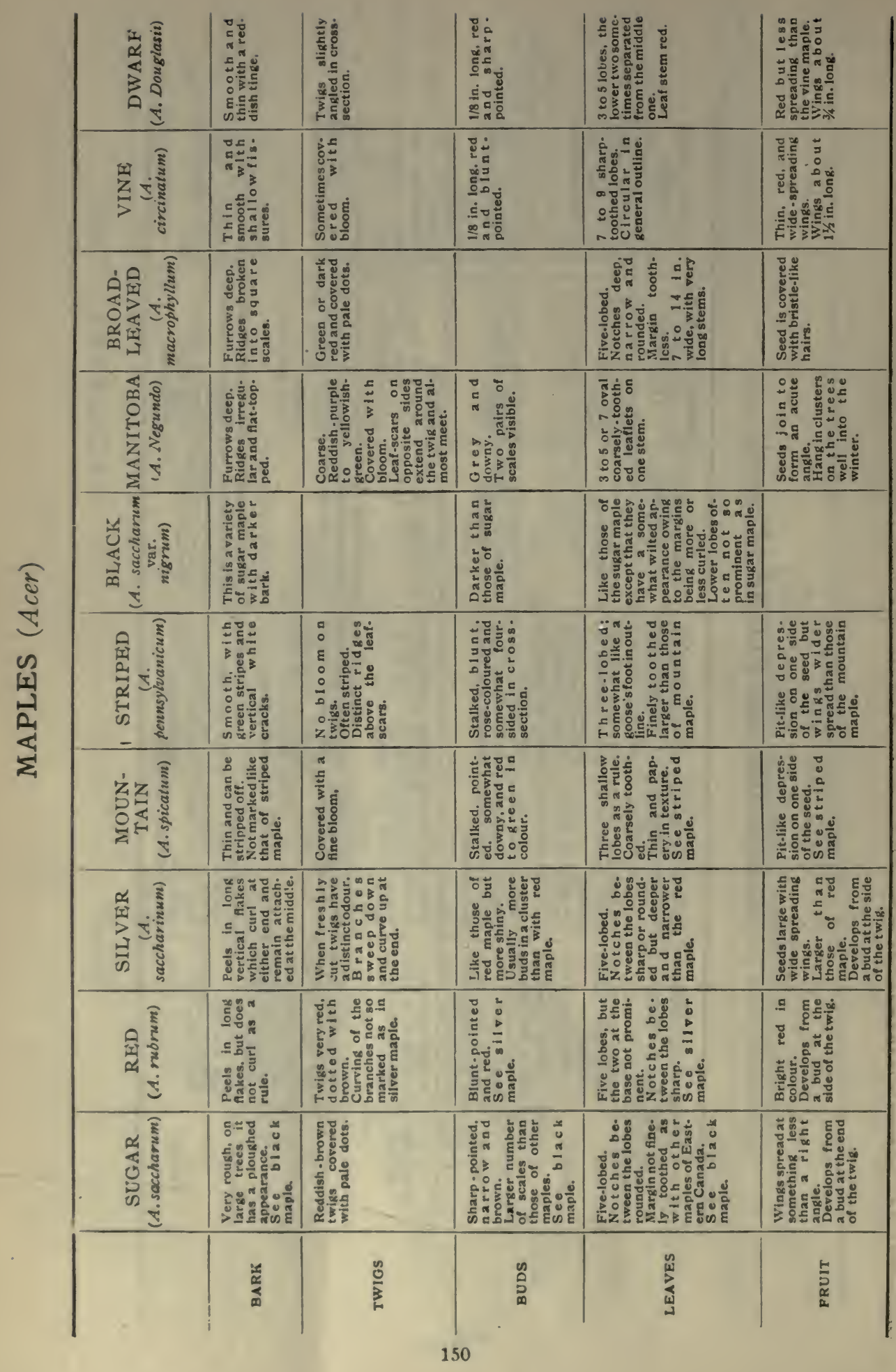




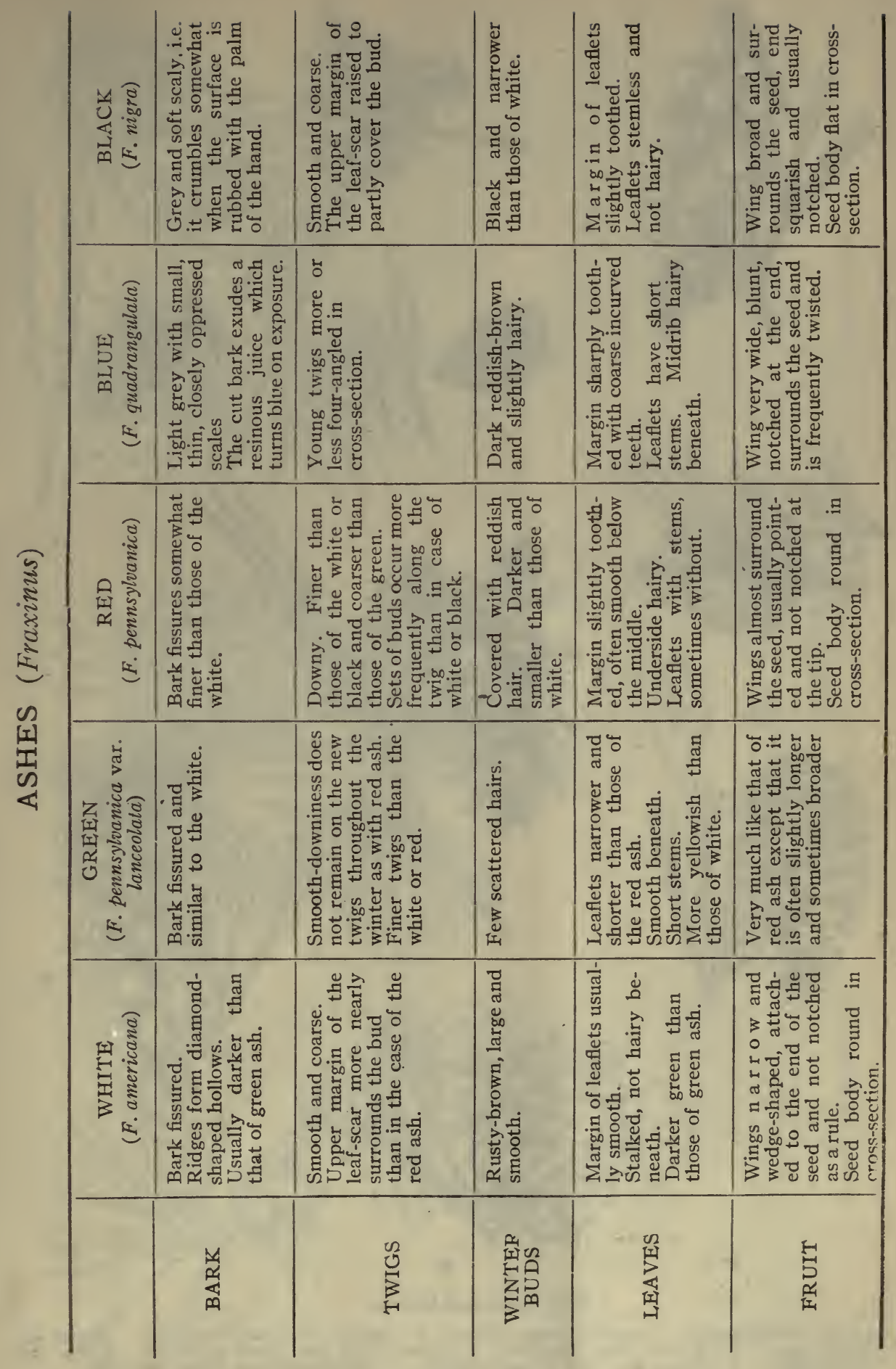



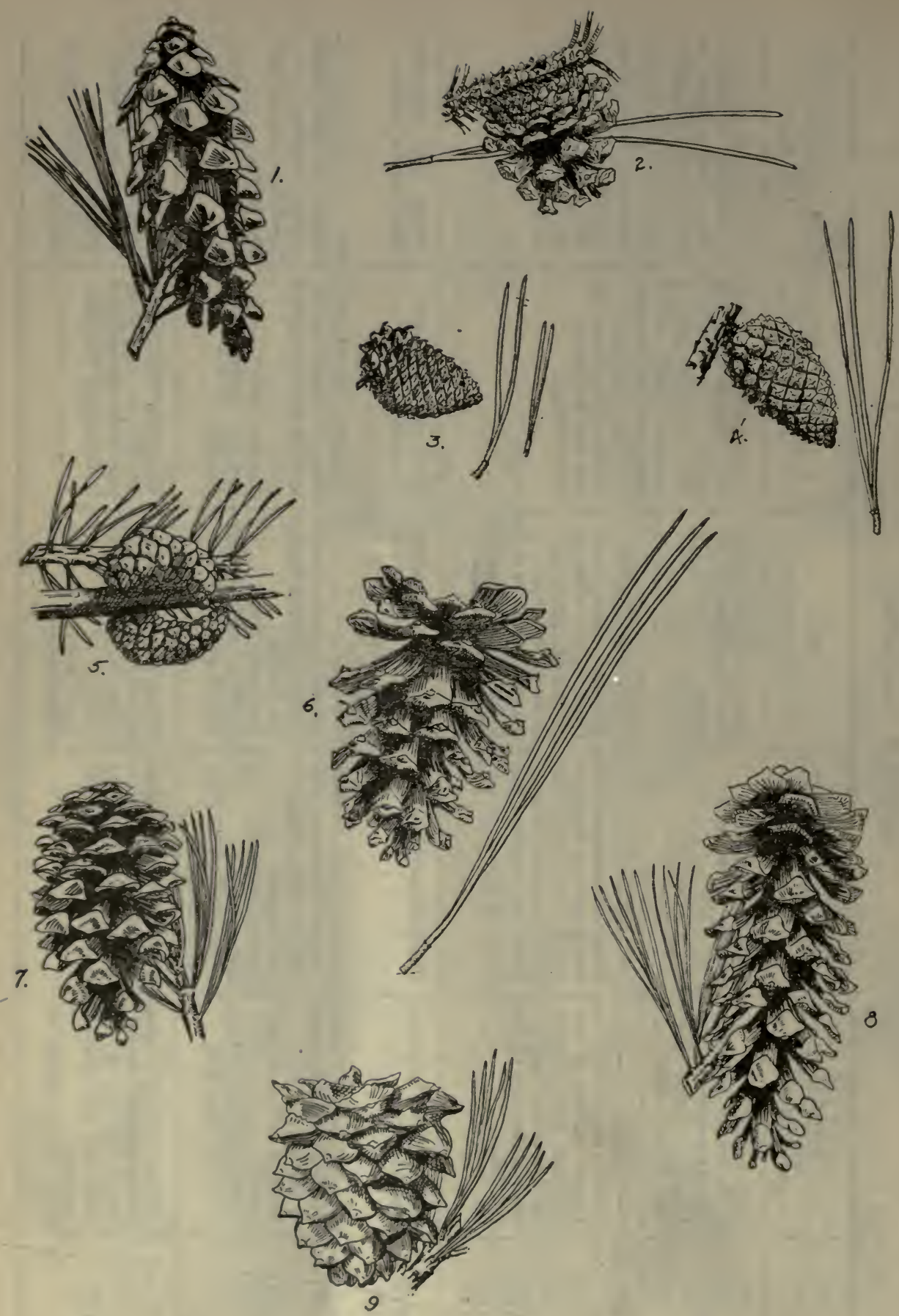

Pine Cones and Leaves

1 White pine (Pinus Strobus). 2 Red pine (Pinus resinosa), 3 Lodgepole pine (Pinus Murrayana). 4 Pitch pine (Pinus rigida). 5 Jack pine (Pinus Banksiana). 6 Western yellow pine (Pinus ponderosa). 7 Limber pine (Pinus flexilis). 8. Western white pine (Pinus monticola). 9. White-barked pine (Pinus albicaulis). 
की
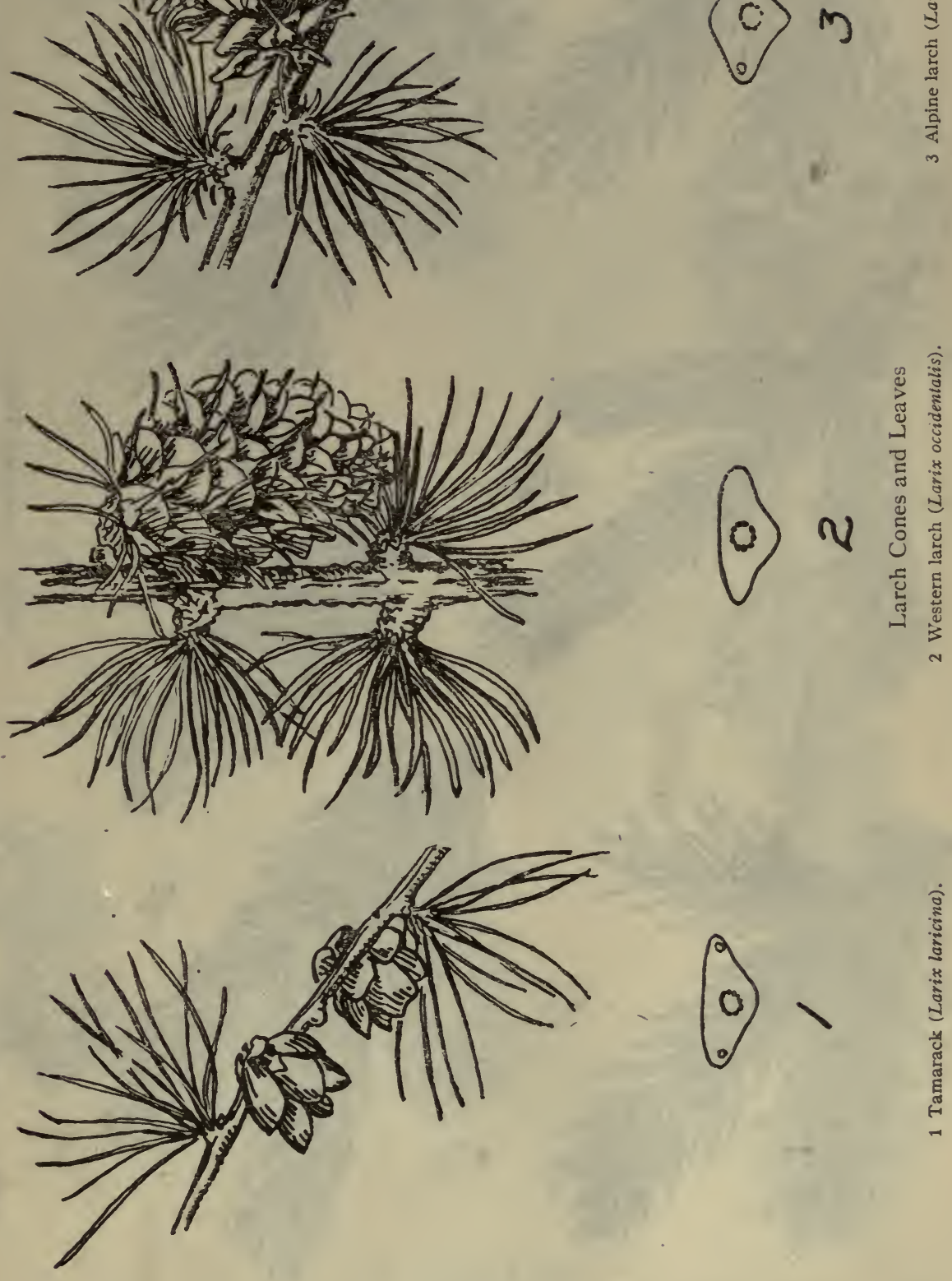

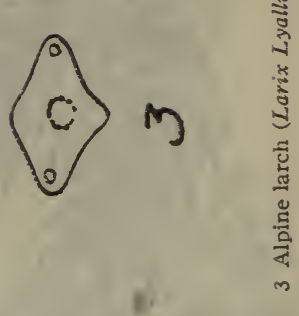

(0) $v$

¿̊ 


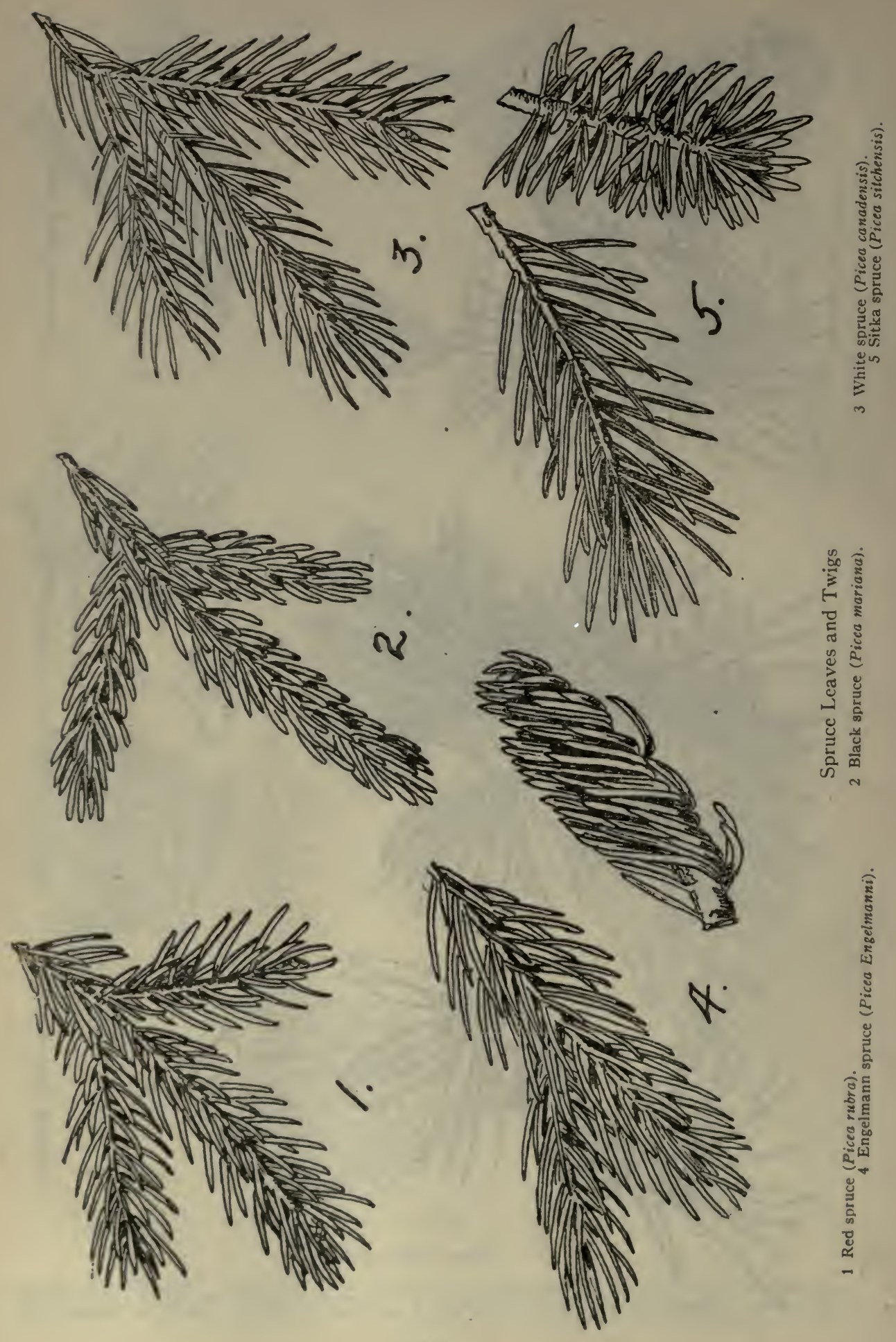




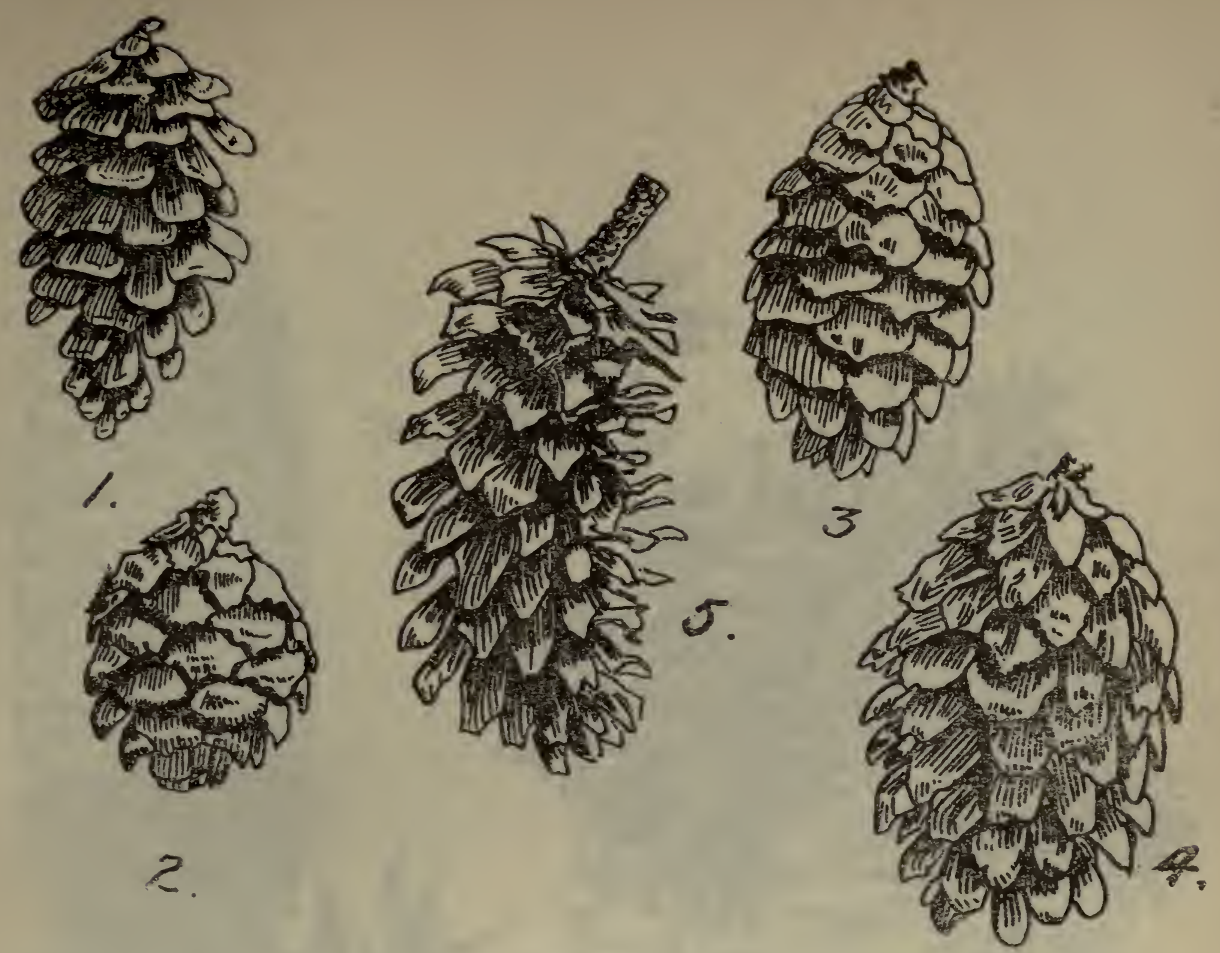

Spruce Cones

1 White spruce (Picea canadensis). 5 . Sitka spruce (Picea sitchensis)

3. Red spruce (Picea rubra).

2. Black spruce (Picea mariana).

4. Engelmann spruce (Picea Engelmanni).

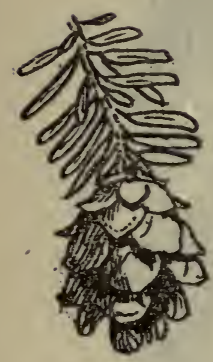

l.

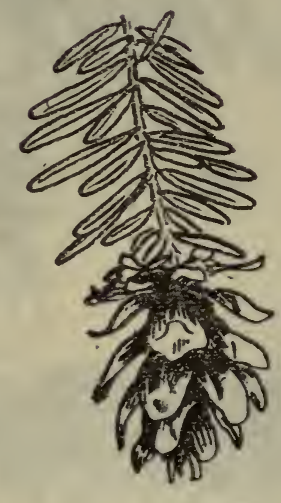

2 .
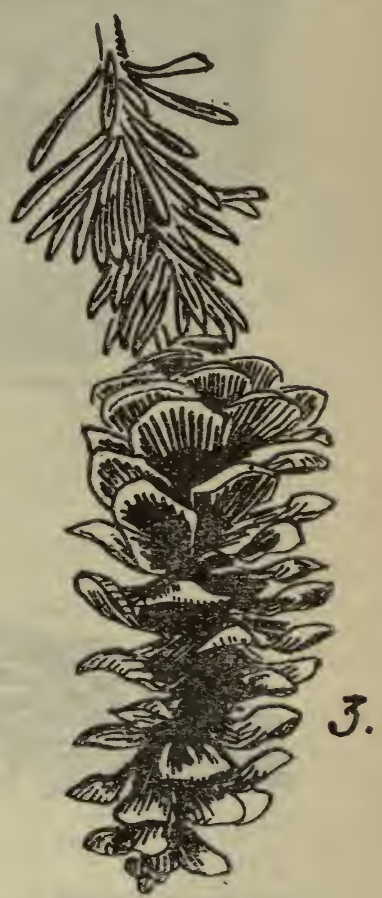

Hemlock Cones

1. Hemlock (Tsugäcanadensis). 2. Western hemlock (Tsuga heterophylla). 3. Black hemlock (Tsuga Mertensiana) 

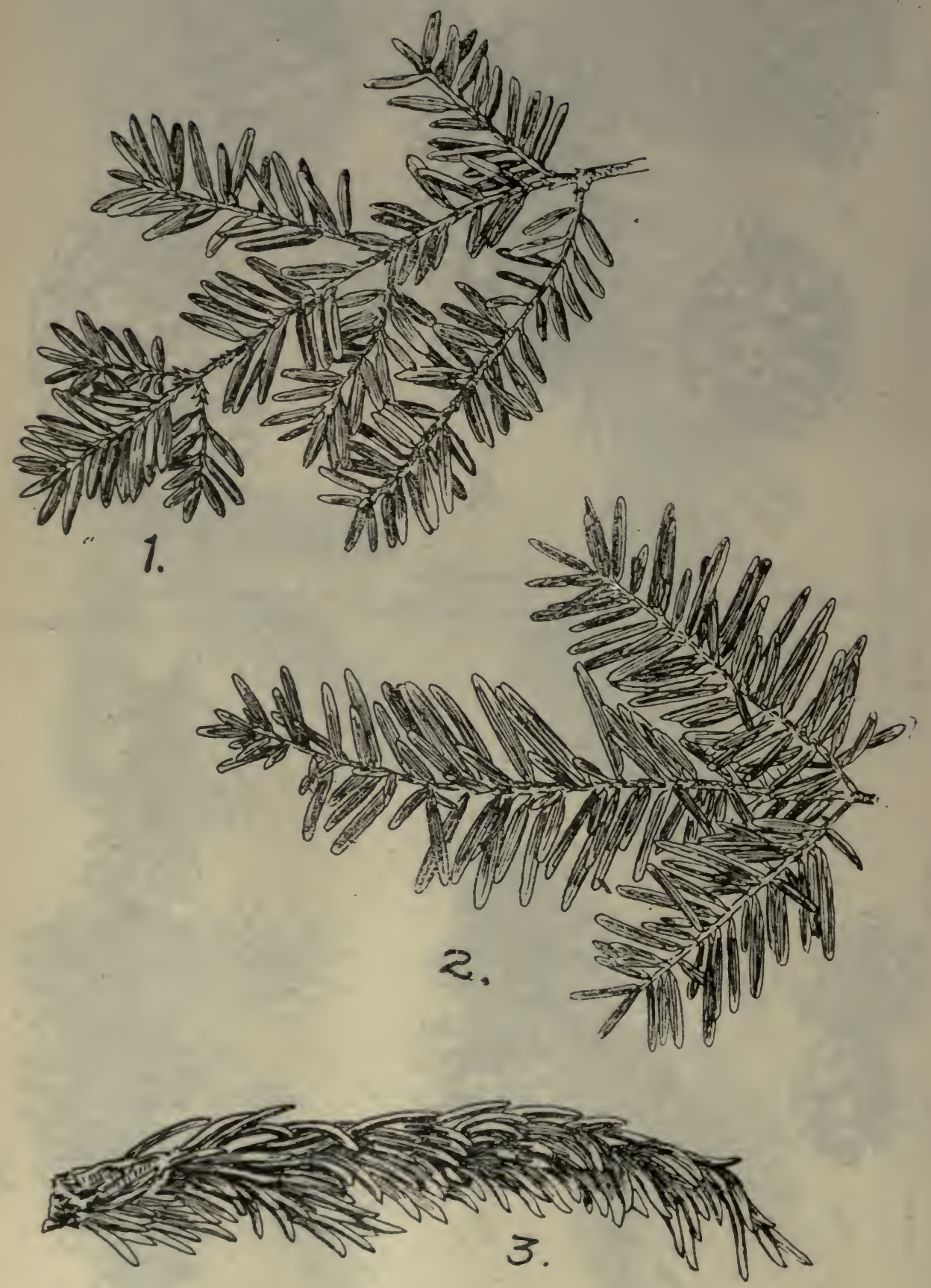

Hemlock Leaves and Twigs

1 Hemlock (Tsuga canadensis). $\quad 3$ Black hemlock (Tsuga 2 Western hemlock (Tsuga helerophylla). 

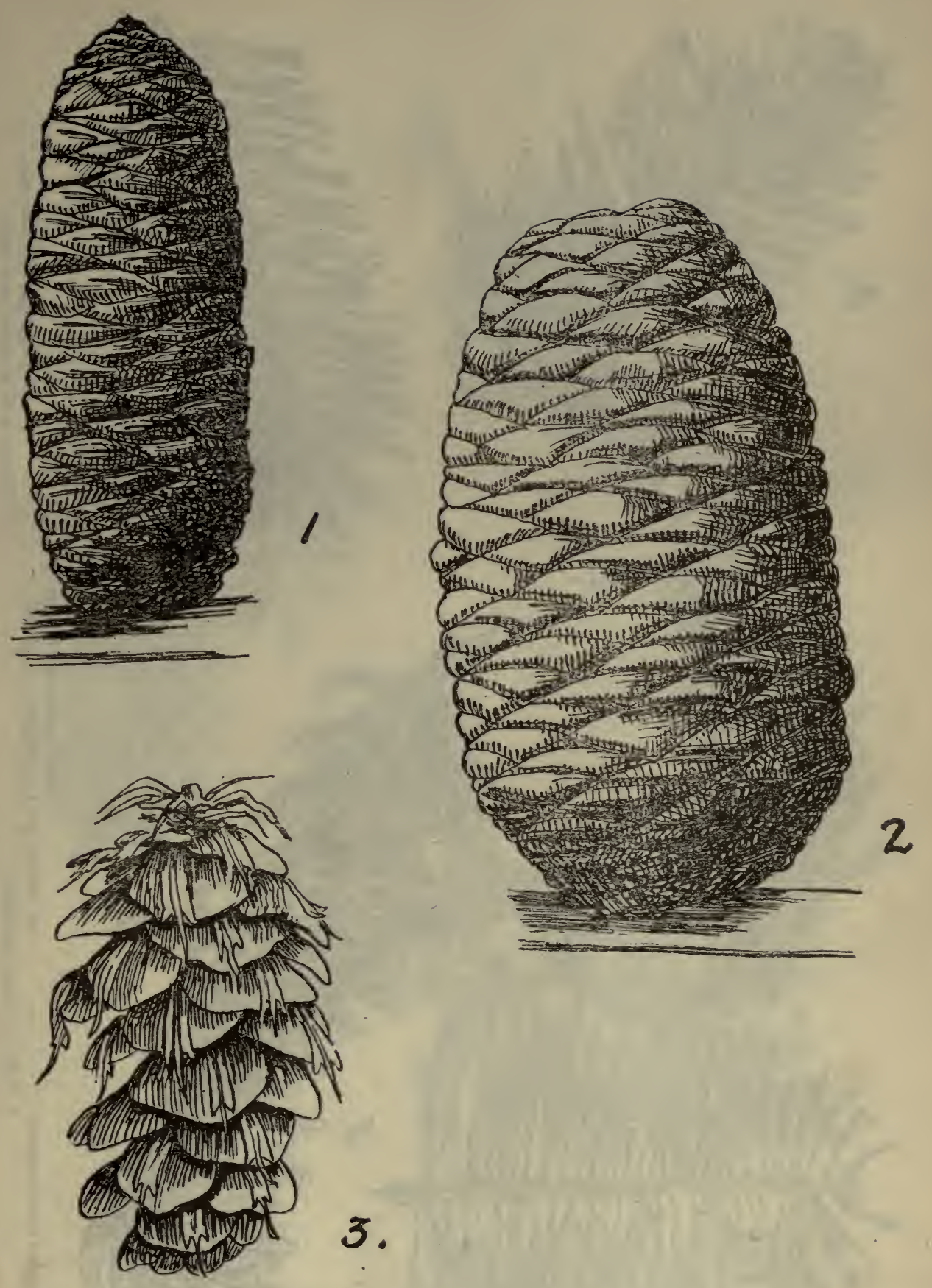

1 Balsam fir (Abies balsamea).

Fir Cones

3 Douglas fir (Pseudotsuga mucronala).

2. Amabilis fir (Abies amabilis). 

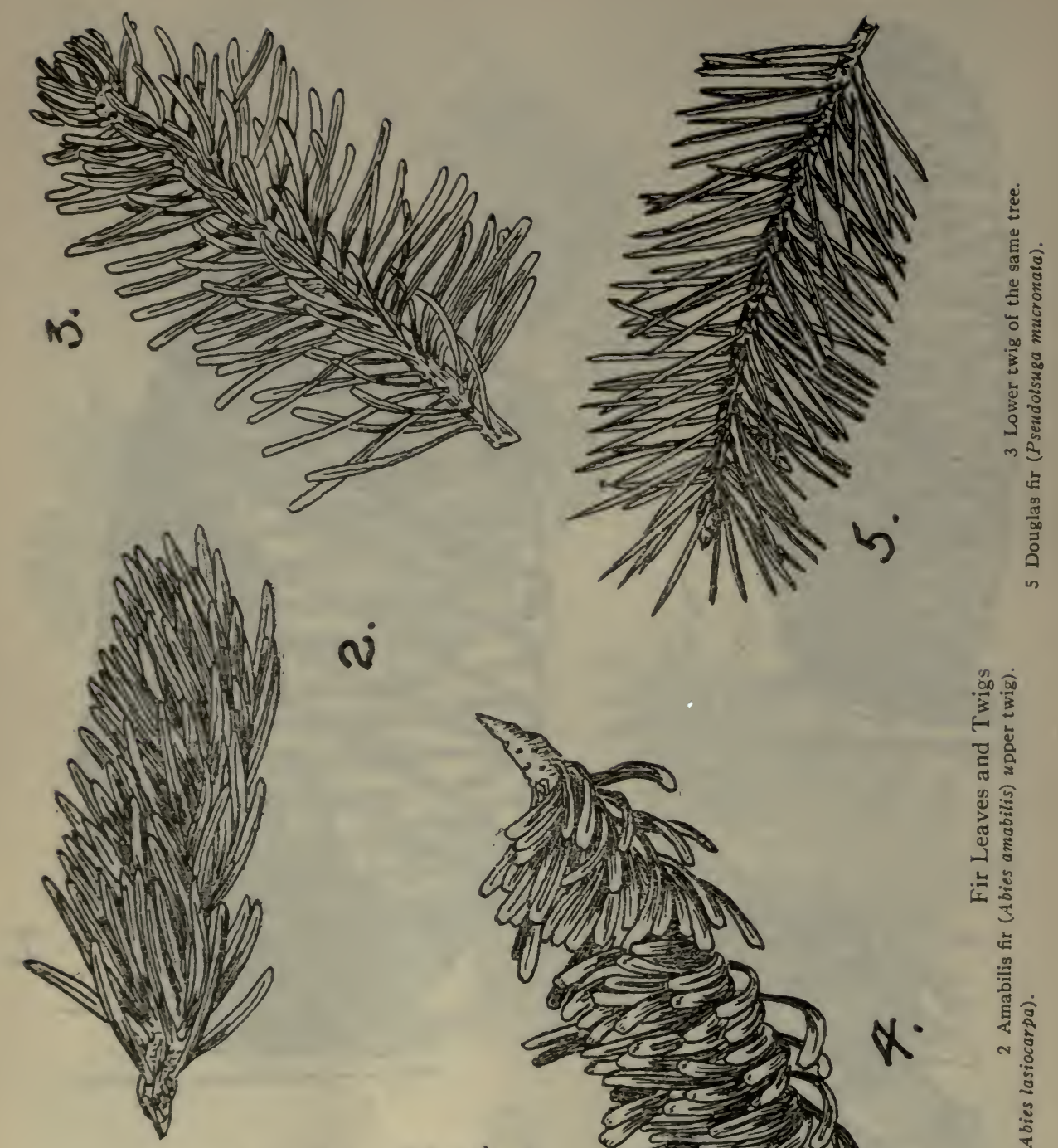

v

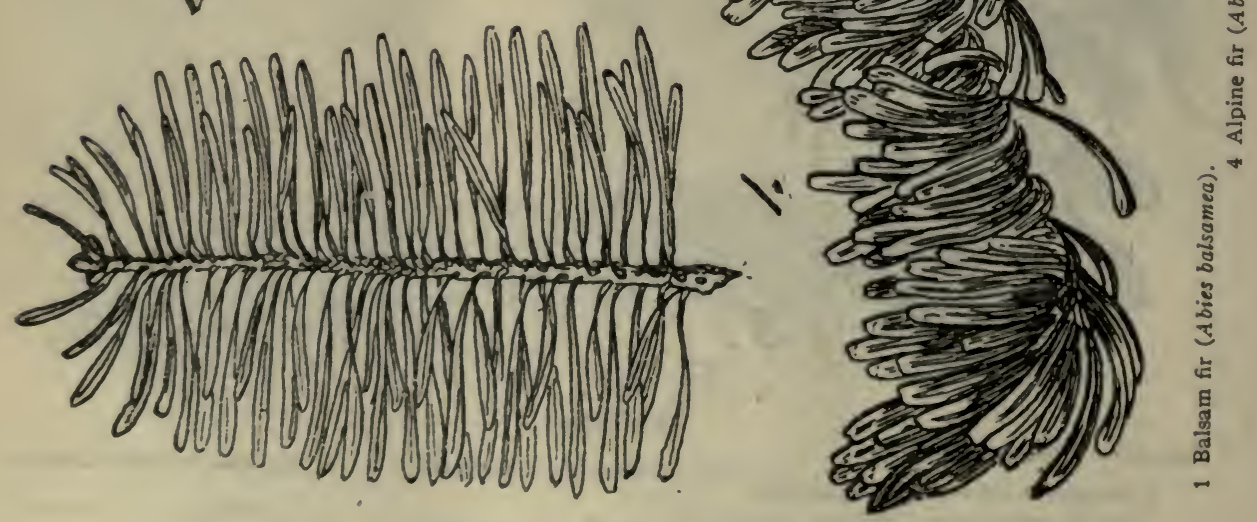



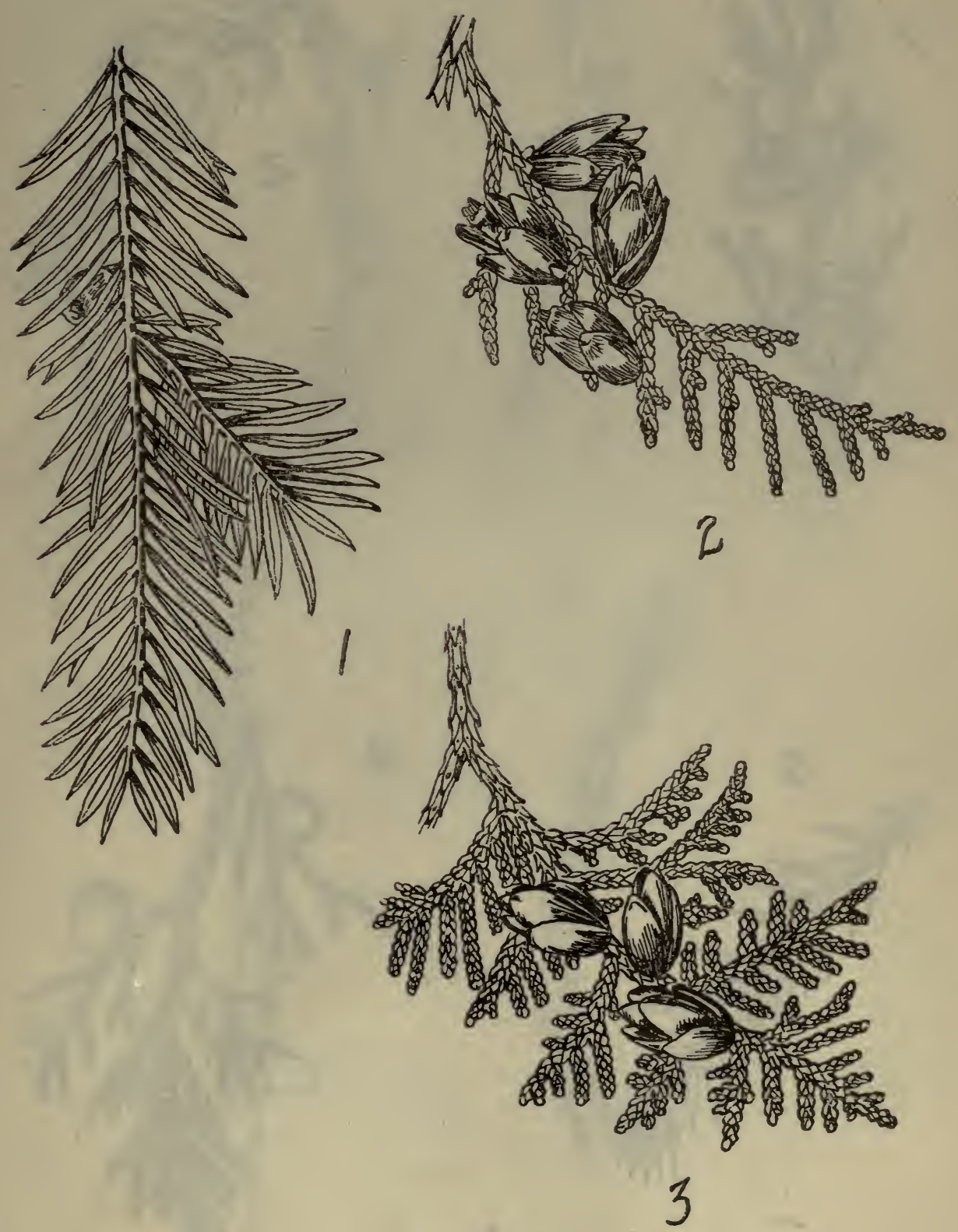

Cedar and Yew Leaves and Twigs

1 Western yew_(Taxus_brevifolia). 3 Cedar (Thuja occidentalis). 

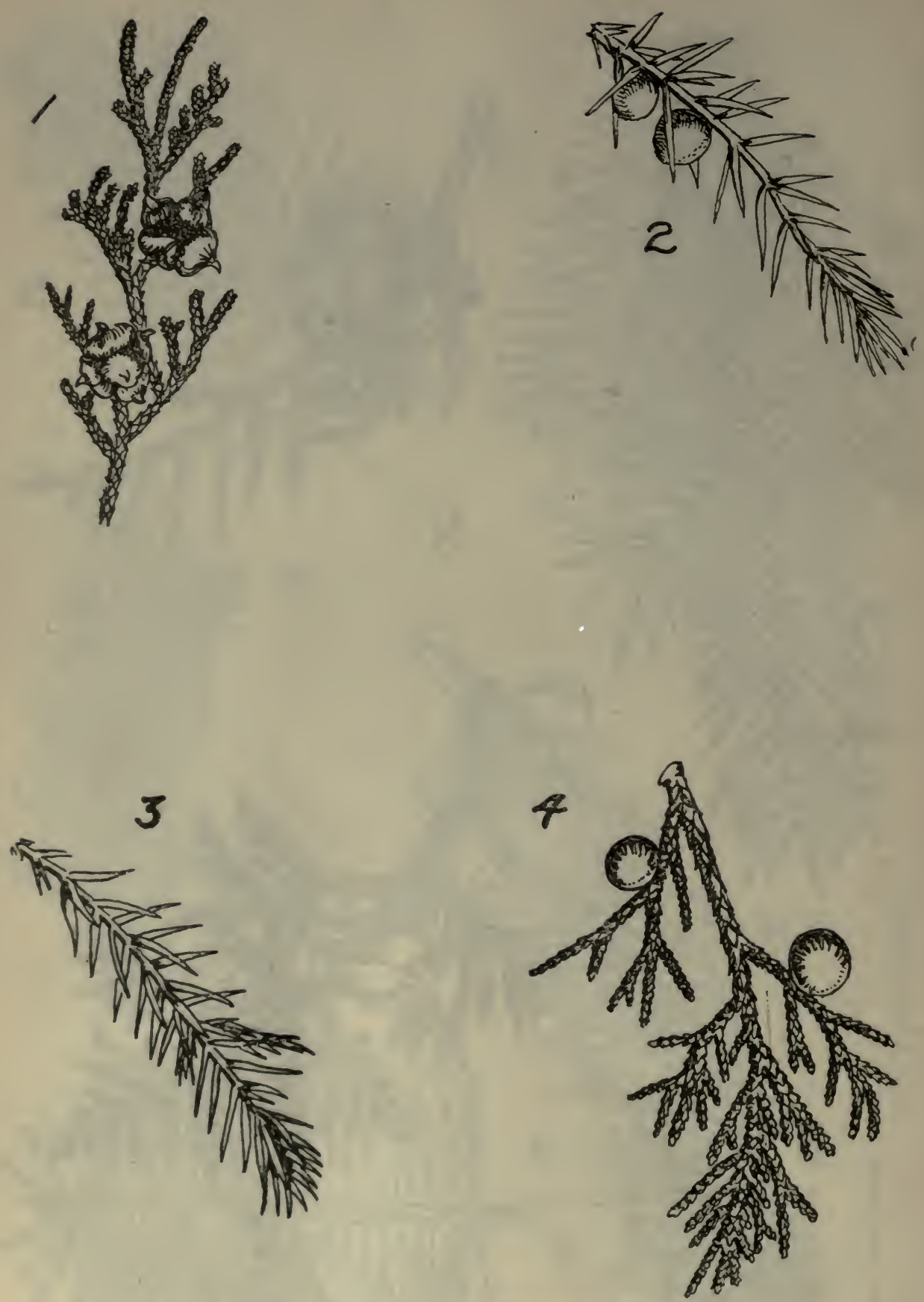

Juniper and Yellow Cypress Leaves and Twigs

1 Yellow cypress (Chamaecyparis nootkannsis).

3 and 4 Red juniper (Juniperus virginiana).

2 Common juniper (Junipcrus communis). 


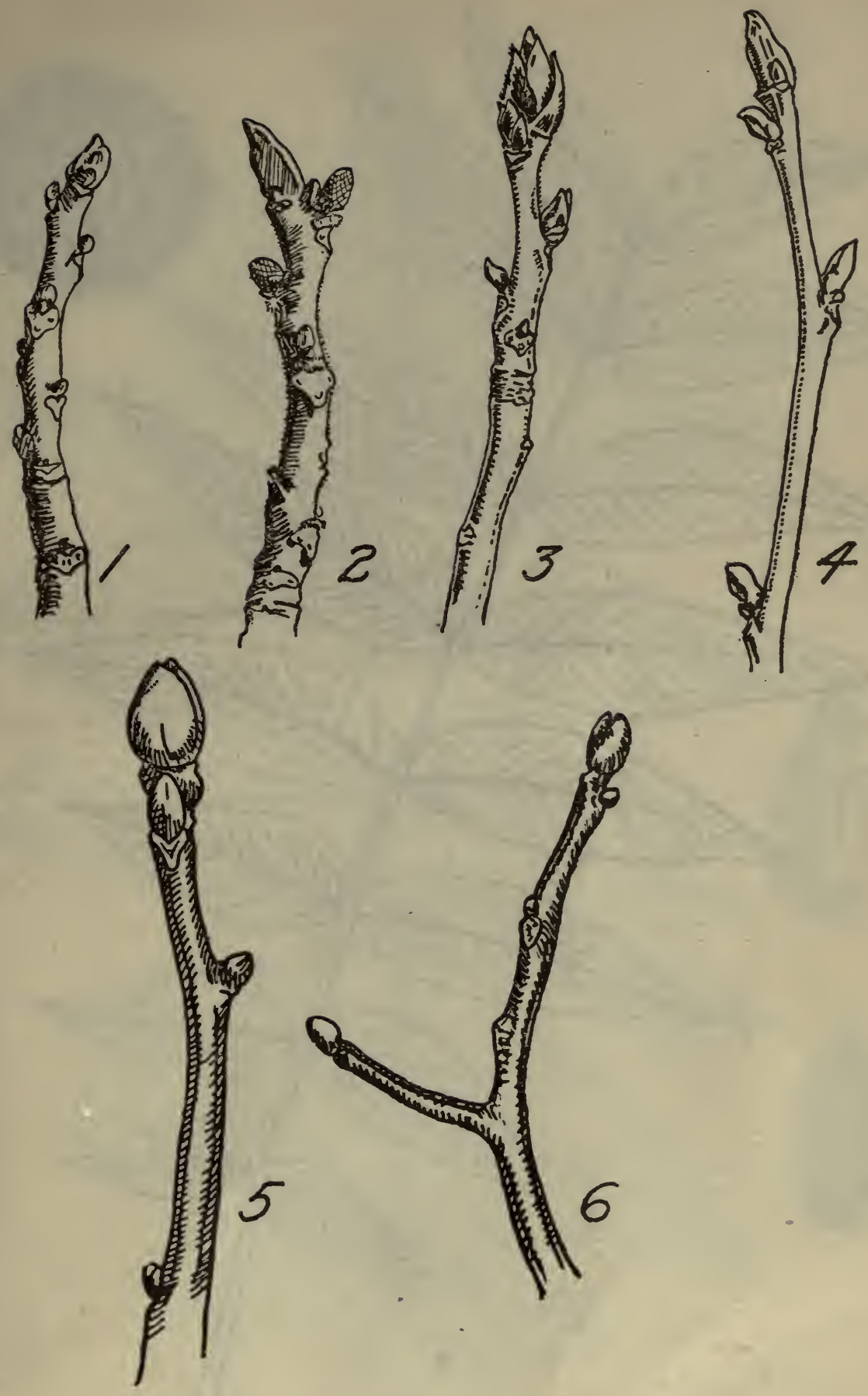

Walnut and Hickory Twigs

1 Black walnut (Juglans nigra). 2 Butternut (Juglans cinerea). 3 Shagbark hickory (Carya ovala). 4 Bitternut hickory (Carya cordiformis). 5 Mockernut hickory (Carya alba). 6 Pignut hickory (Carya glabra). 


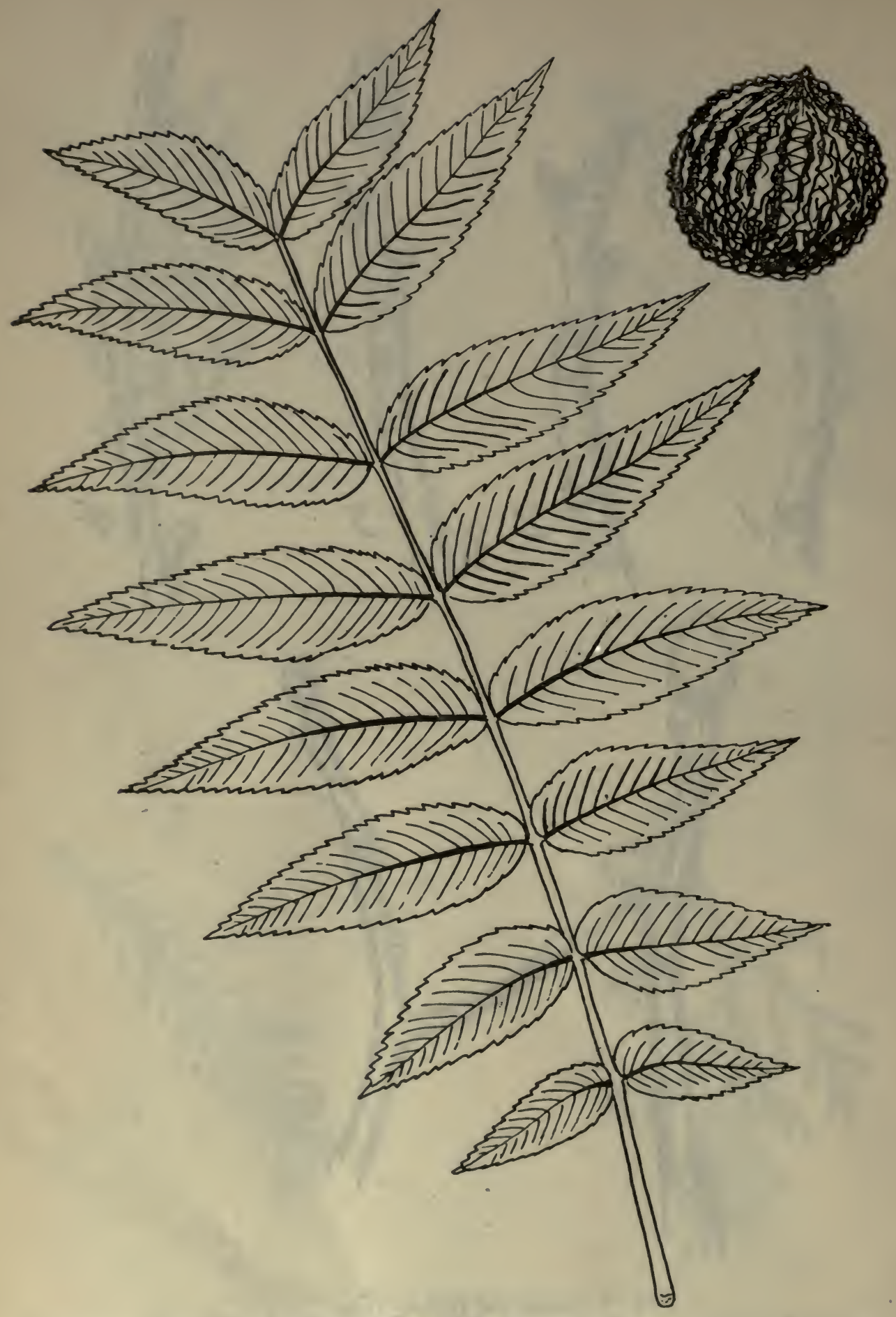

Black Walnut

Black walnut ( $J$ uglans nigra) leaf and fruit 


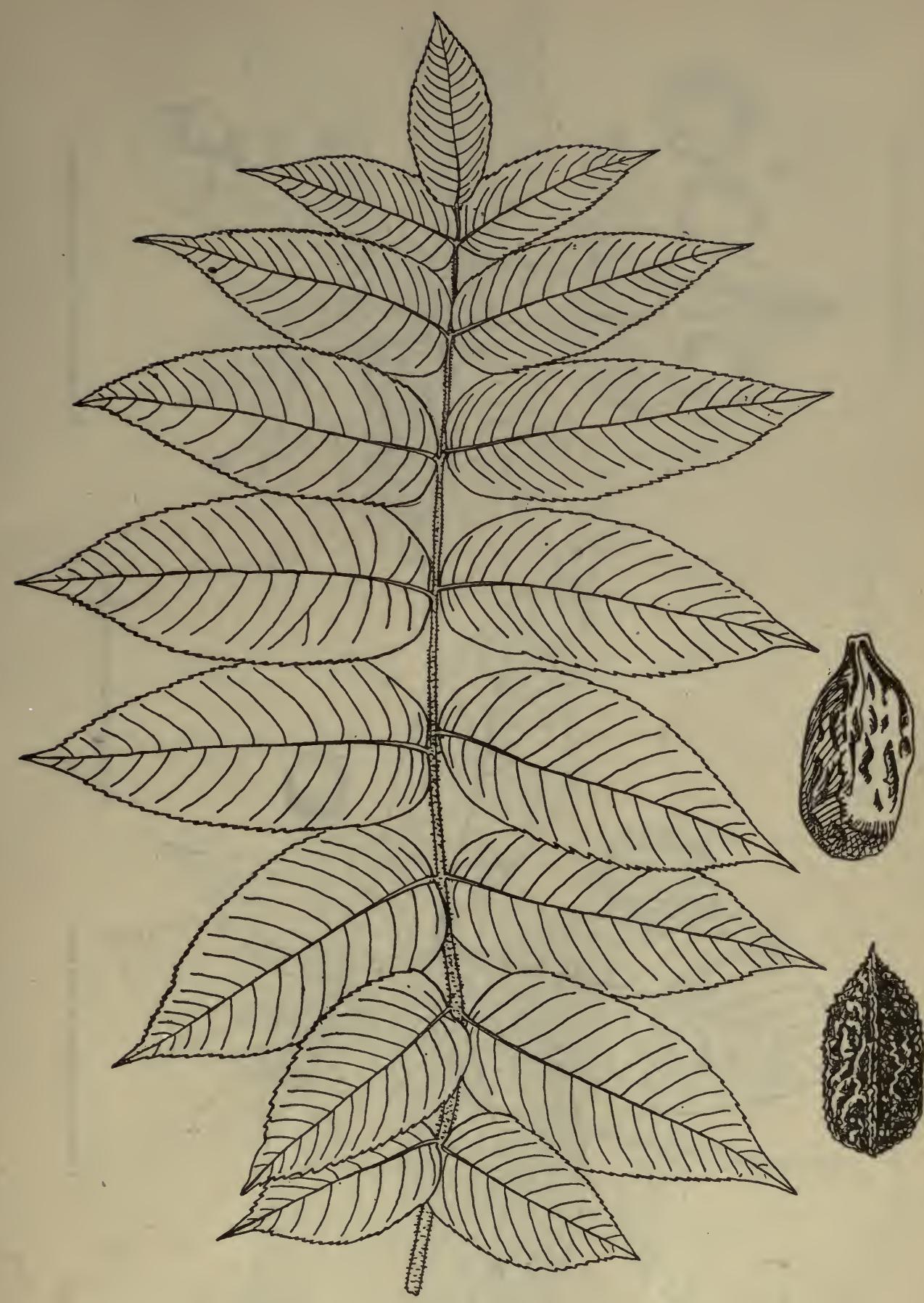

Butternut

Butternut (Juglans cinerea) leaf and fruit 


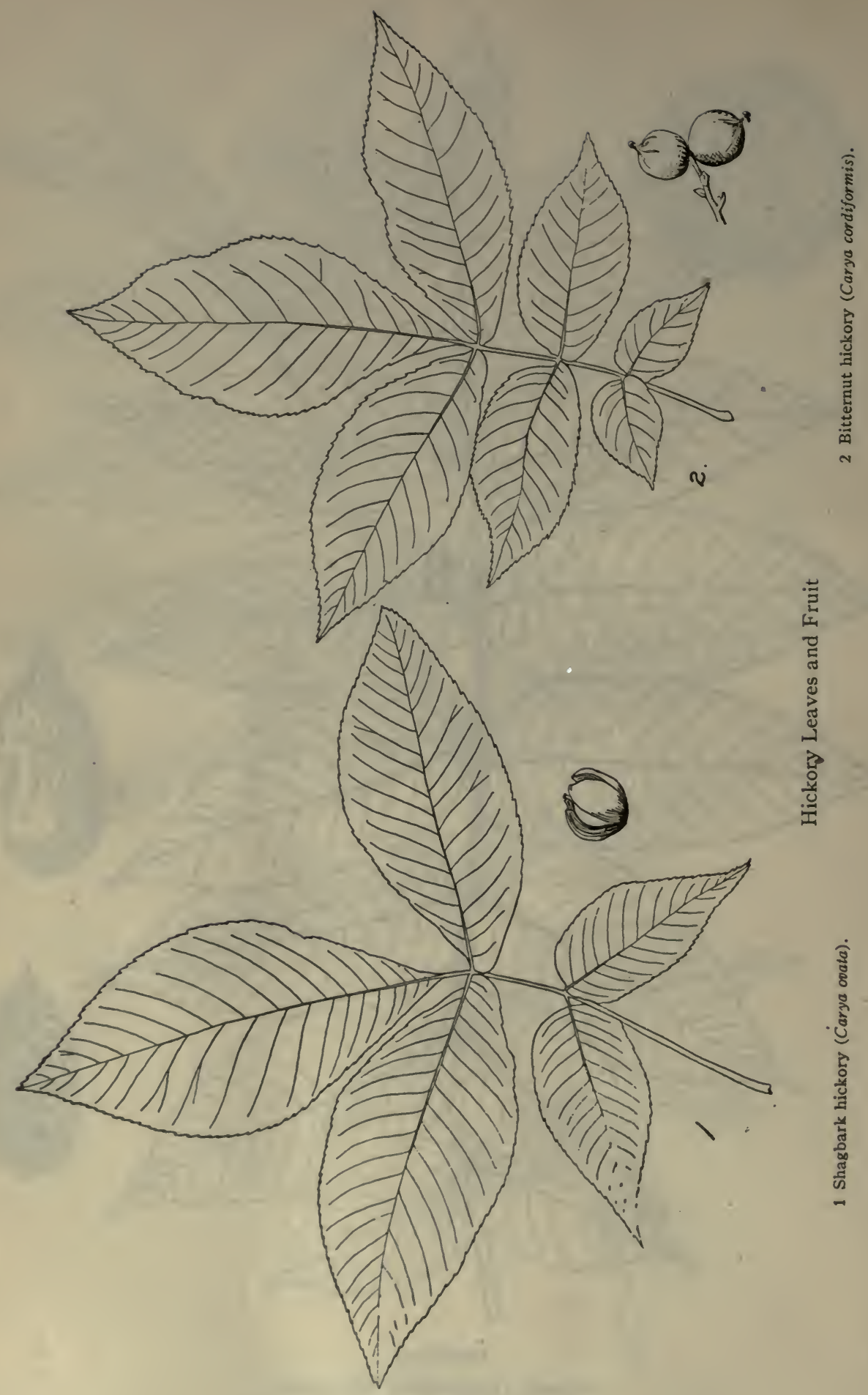



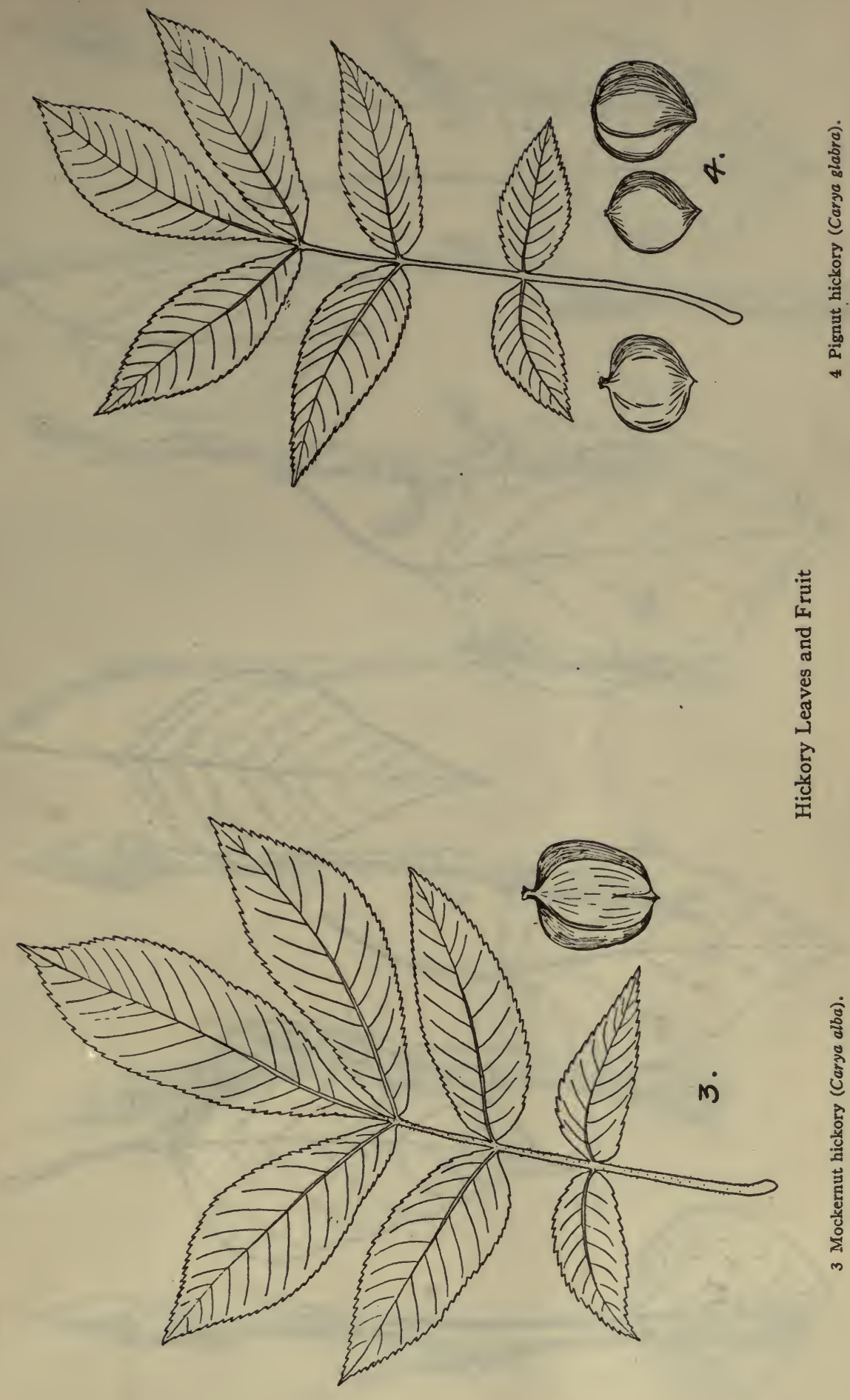

产

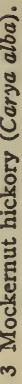




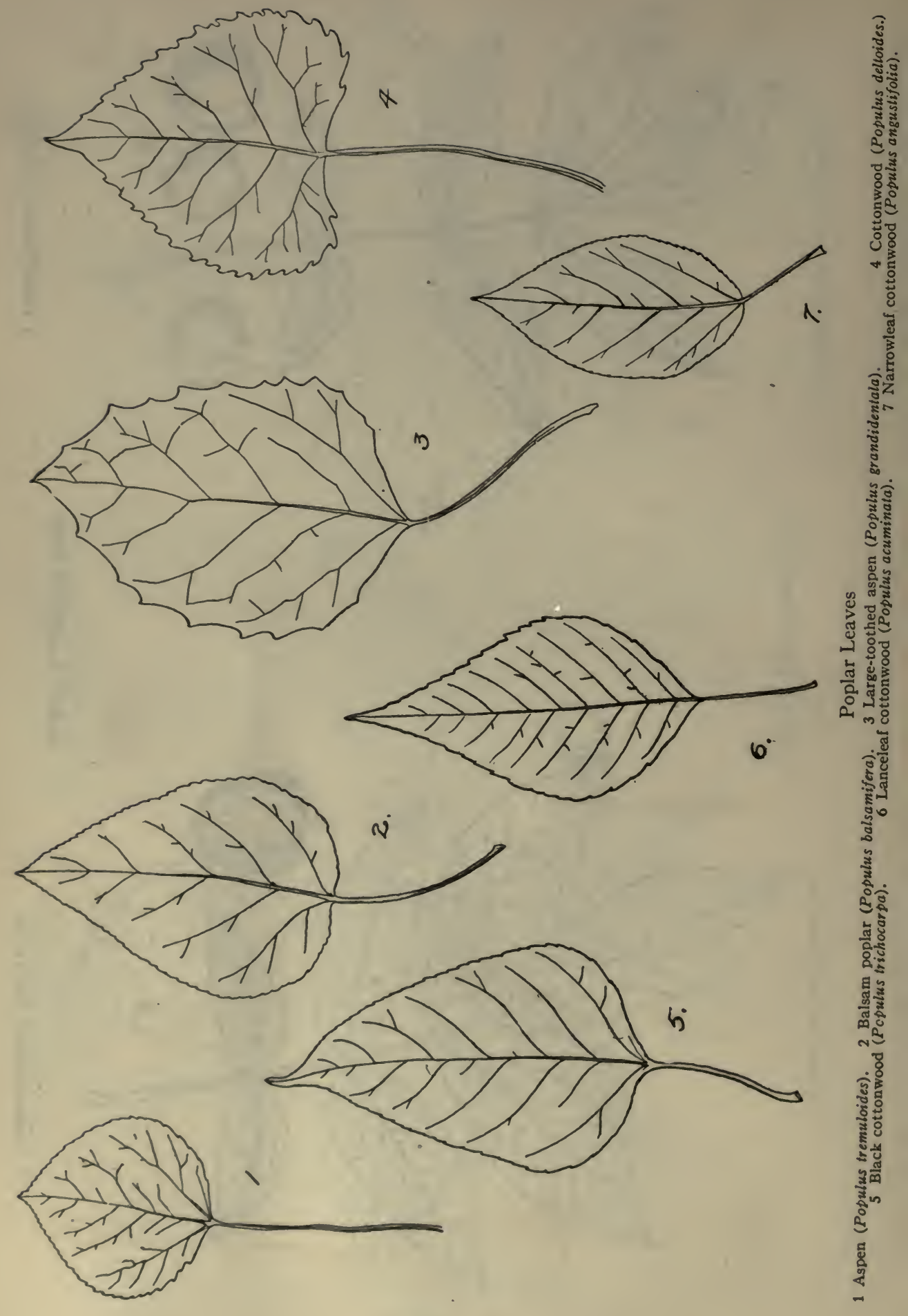




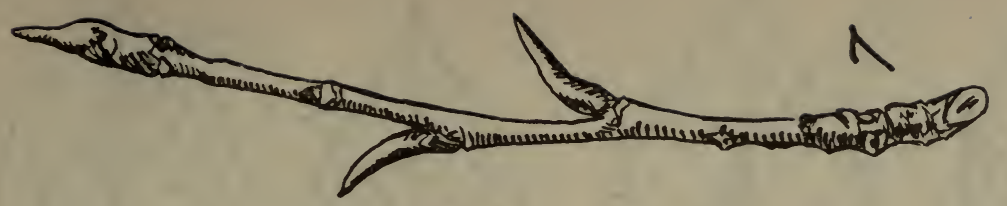

6
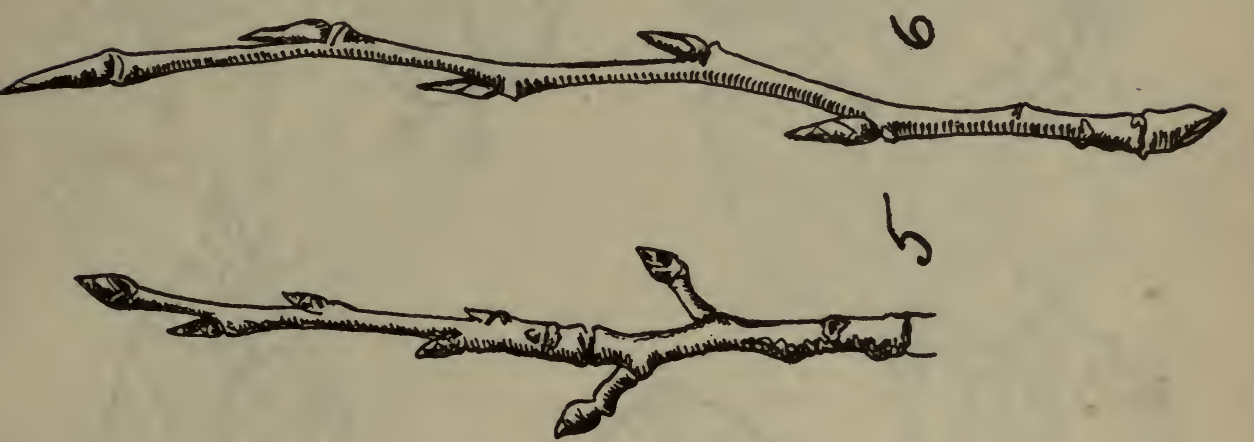

$x$
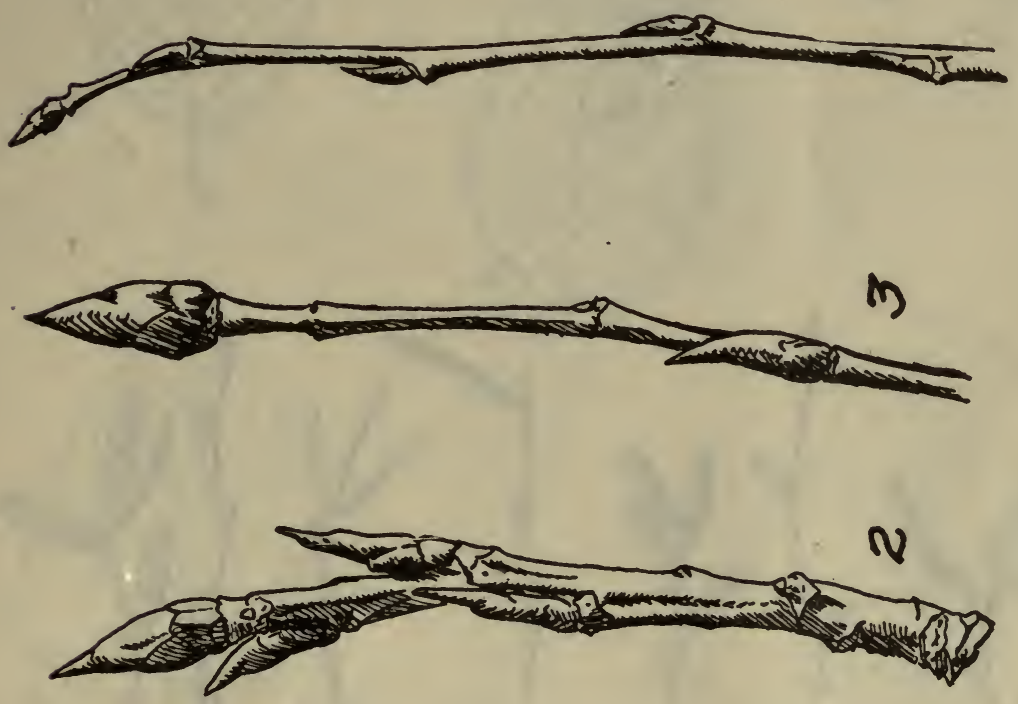

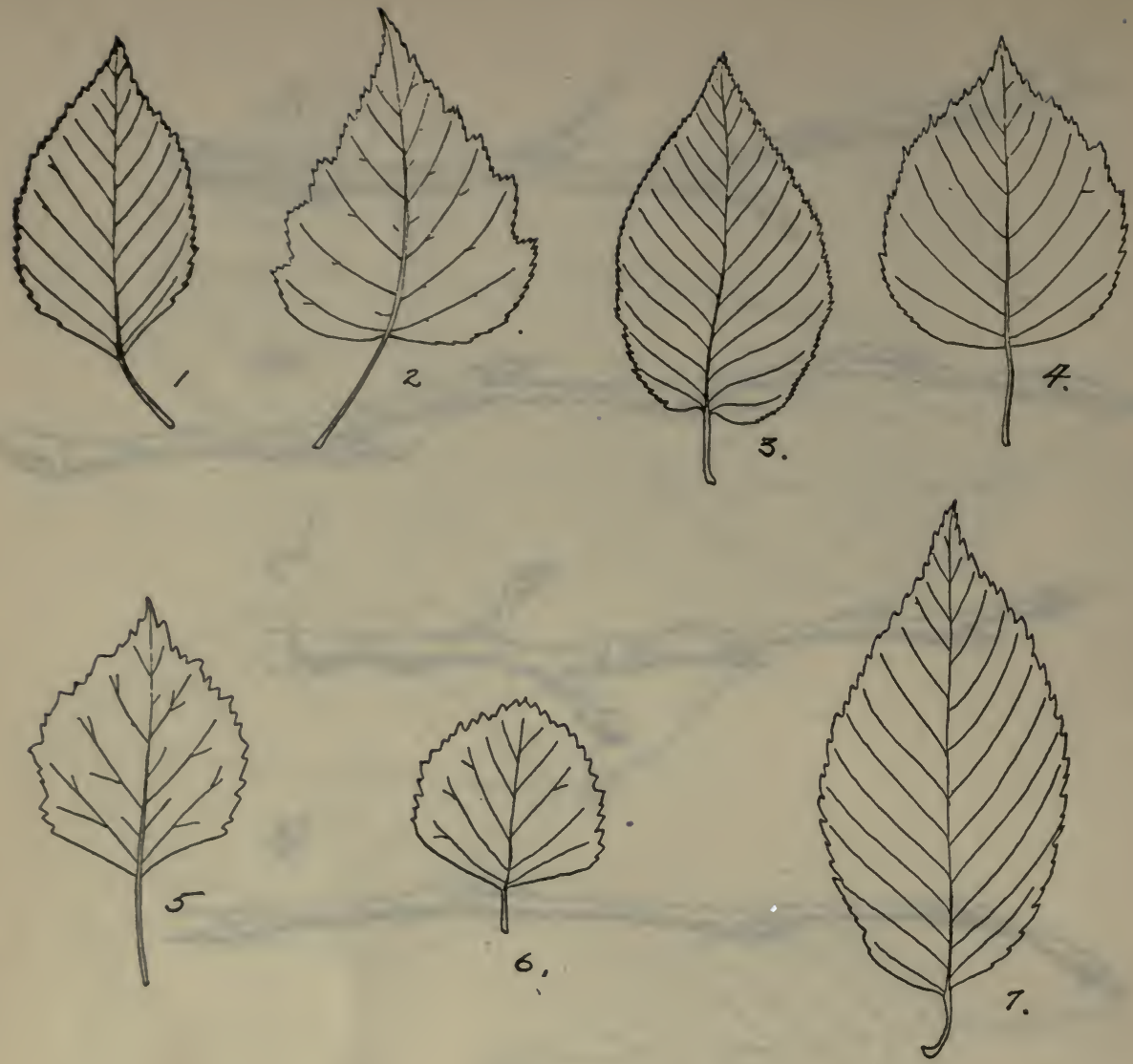

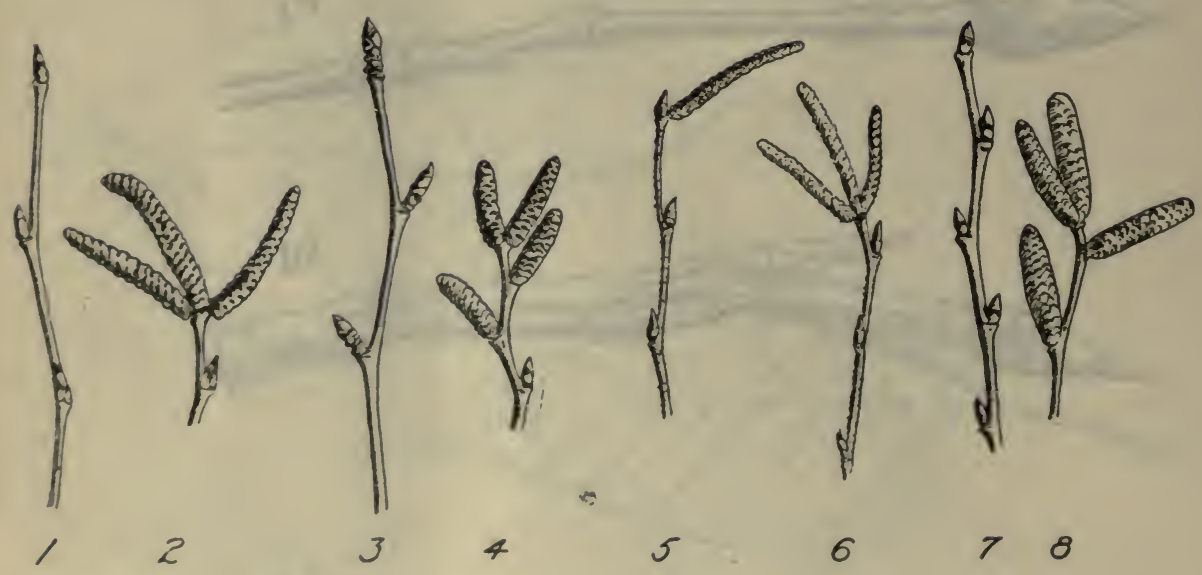

Birch Leaves and Twigs

Lraves. 1 Paper birch (Betula alba var, papyrifara), 2 White birch (Betula populifolia), 3 Sweet birch (Betula lenta). 4 Western birch (Betula occidentalis). 5 Alaska birch (Betula alaskana). 6 Mountain birch (Betula fontinalis). 7 Yellow birch (Betula lutea).

Twigs. 1 and 2 Paper birch (Betula alba var. papyrifera). 3 and 4 Sweet birch (Betula lenta). 5 White birch (Betula populifolia). 6 Western birch (Betula occidenlalis). 7 and 8 Yellow birch (Betula lutea). 

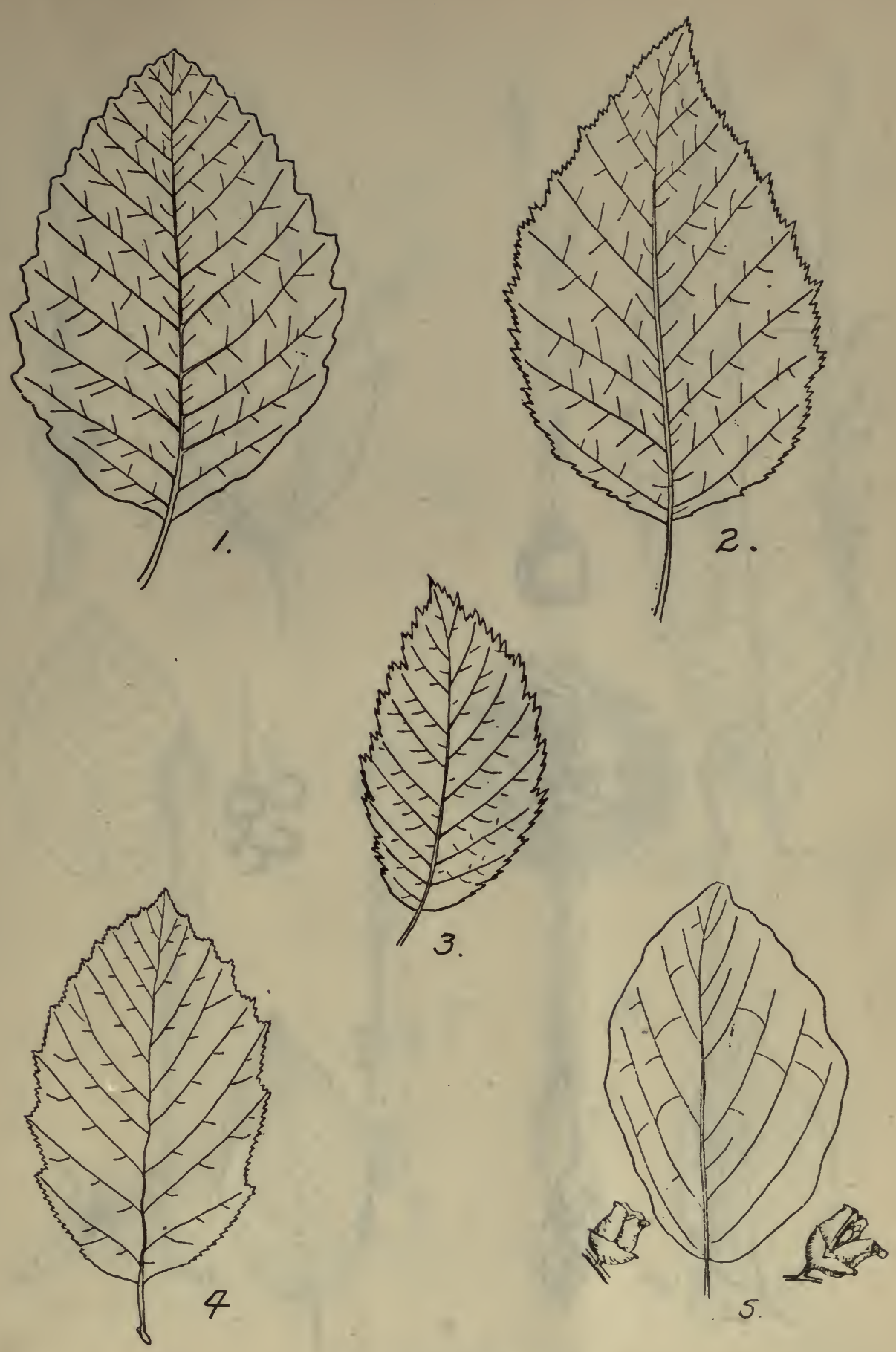

Alder and Witch Hazel Leaves

1. Red alder (Alnus oregona).

4 Speckled alder (Alnus incana).

3 Mountain alder (Alnus lenuifolia) 5 Witch hazel (Hamamelis virginiana) 

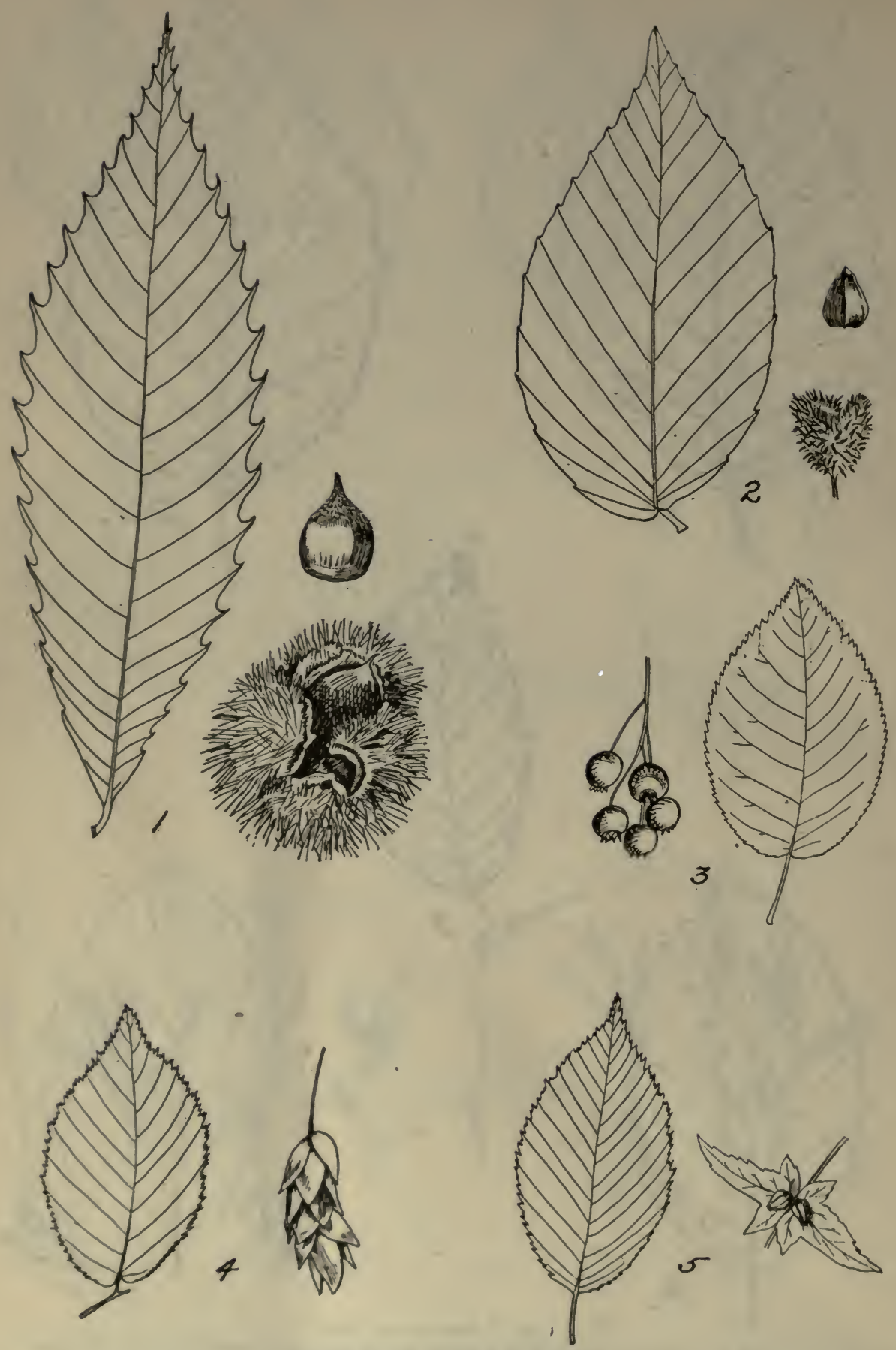

Miscellaneous Leaves and Fruit

1 Chestnut (Castanea dentata).

4. Ironwood (Ostrya virginiana).
3 Service-berry (Amelanchier canadensis).
5 Blue beech (Carpinus caroliniana).

2 Beech (Fagus grandifolia). 

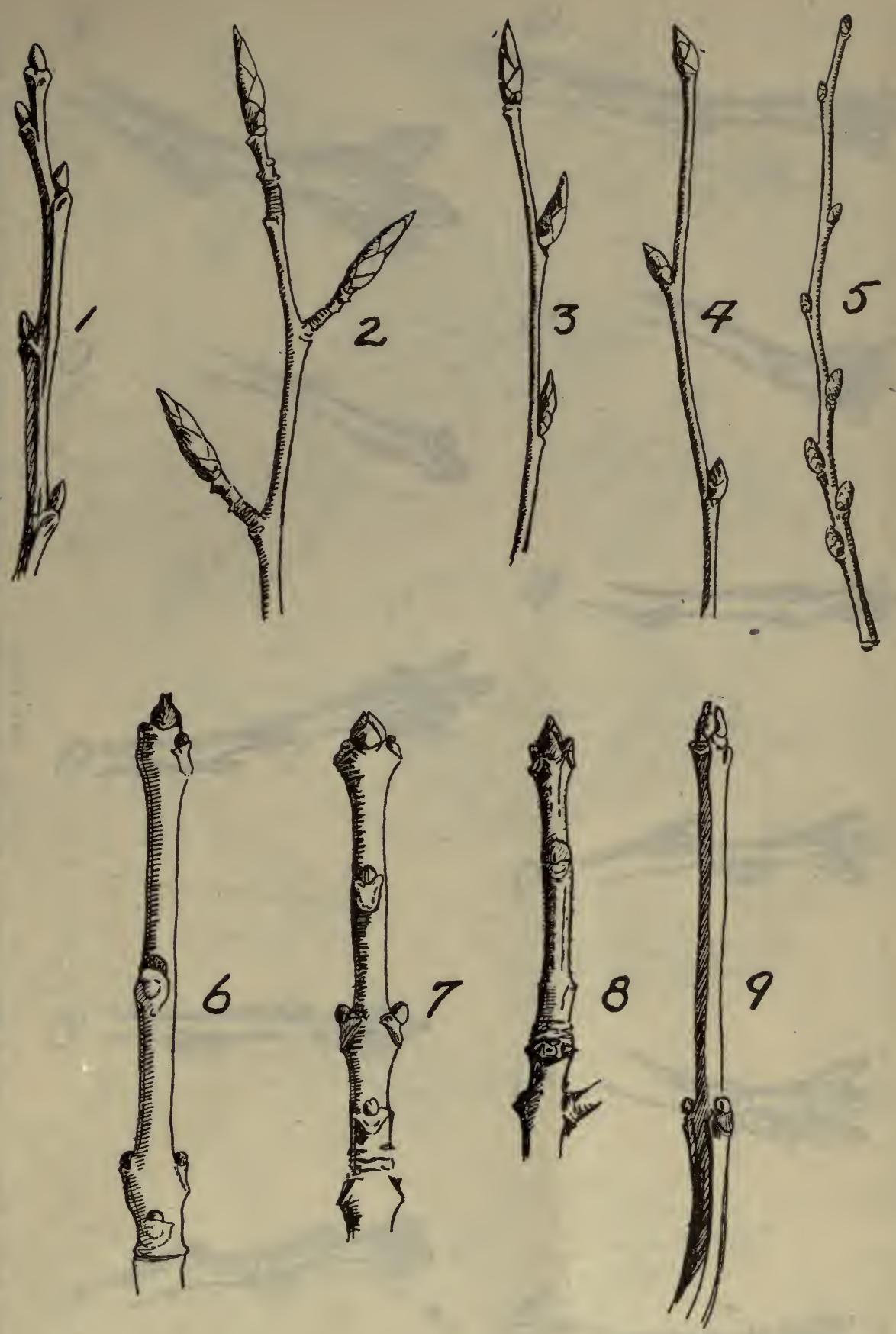

Miscellaneous Twigs

1 Chestnut (Castanea dentata). 2 Beech (Fagus grandifolia). 3 Service-berry (A melanchier canadensis). 4 Ironwood (Ostrya virginiana), 5 Blue beech (Carpinus caroliniana).

7 White ash (Fraxinus americana). 8 Red ash (Fraxinus pennsylvanica). 6 Black ash (Fraxinus nigra). 7 White ash (Fraxinus americana). 8 Blue ash (Fraxinus quadrangulata). 


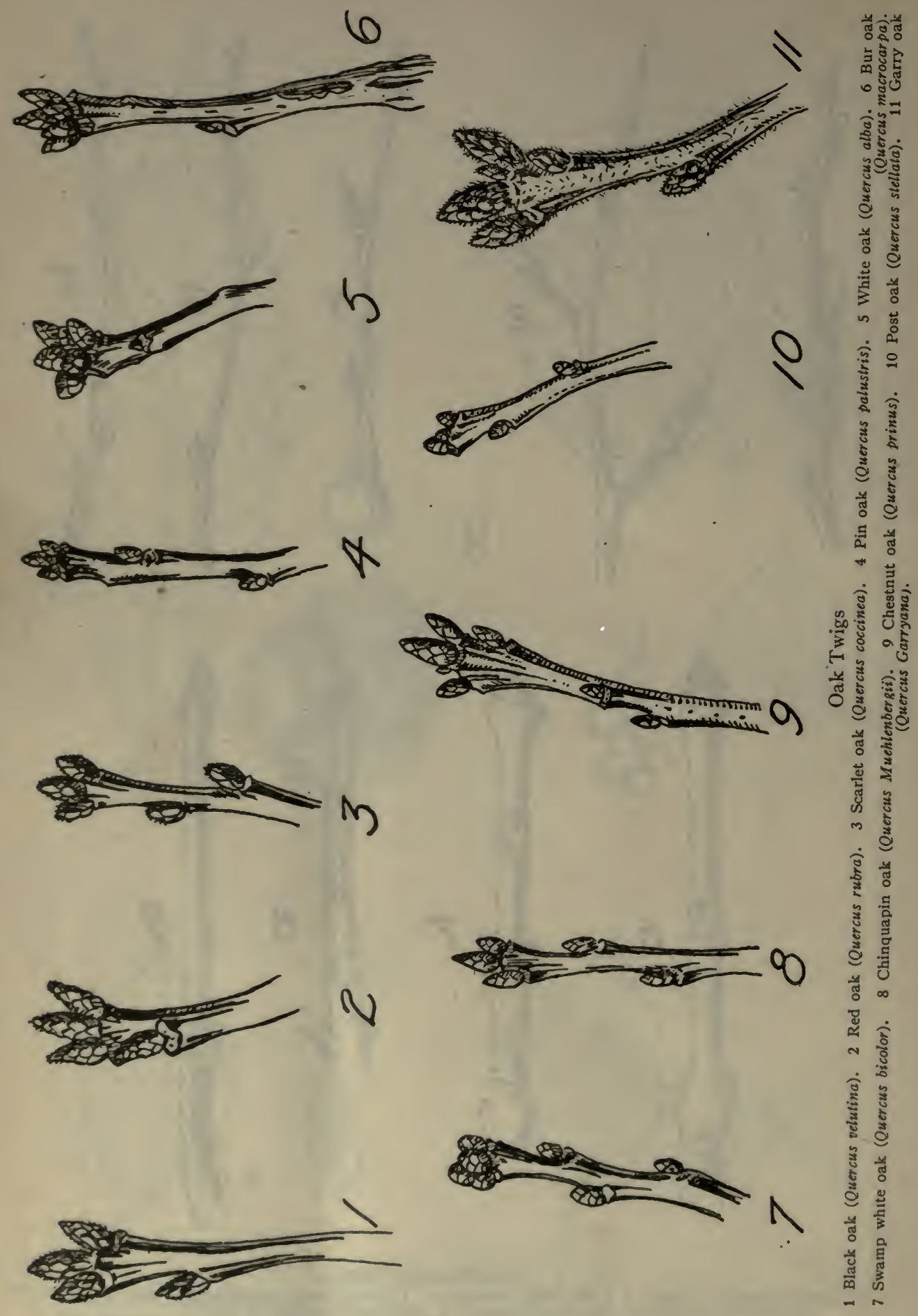




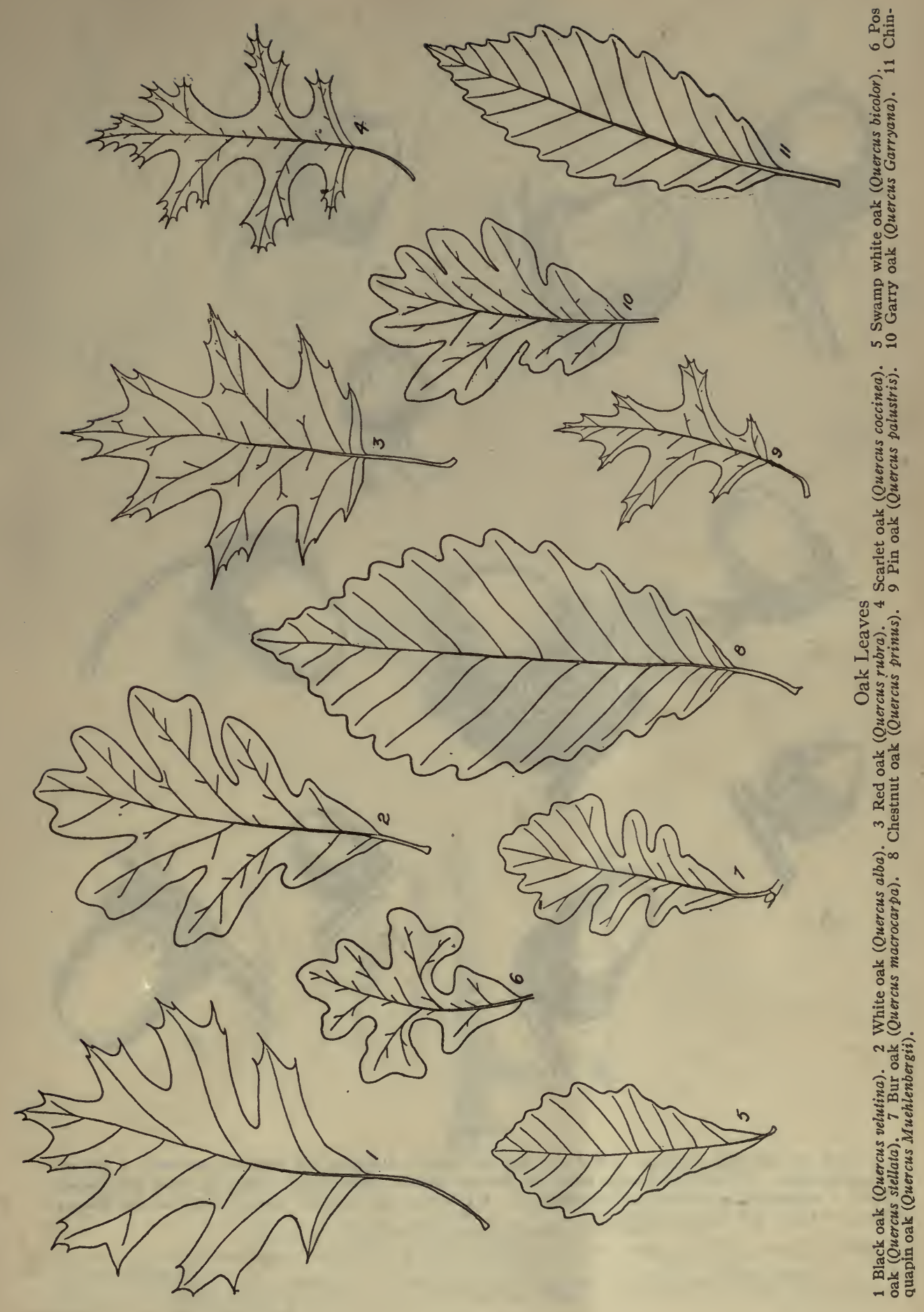



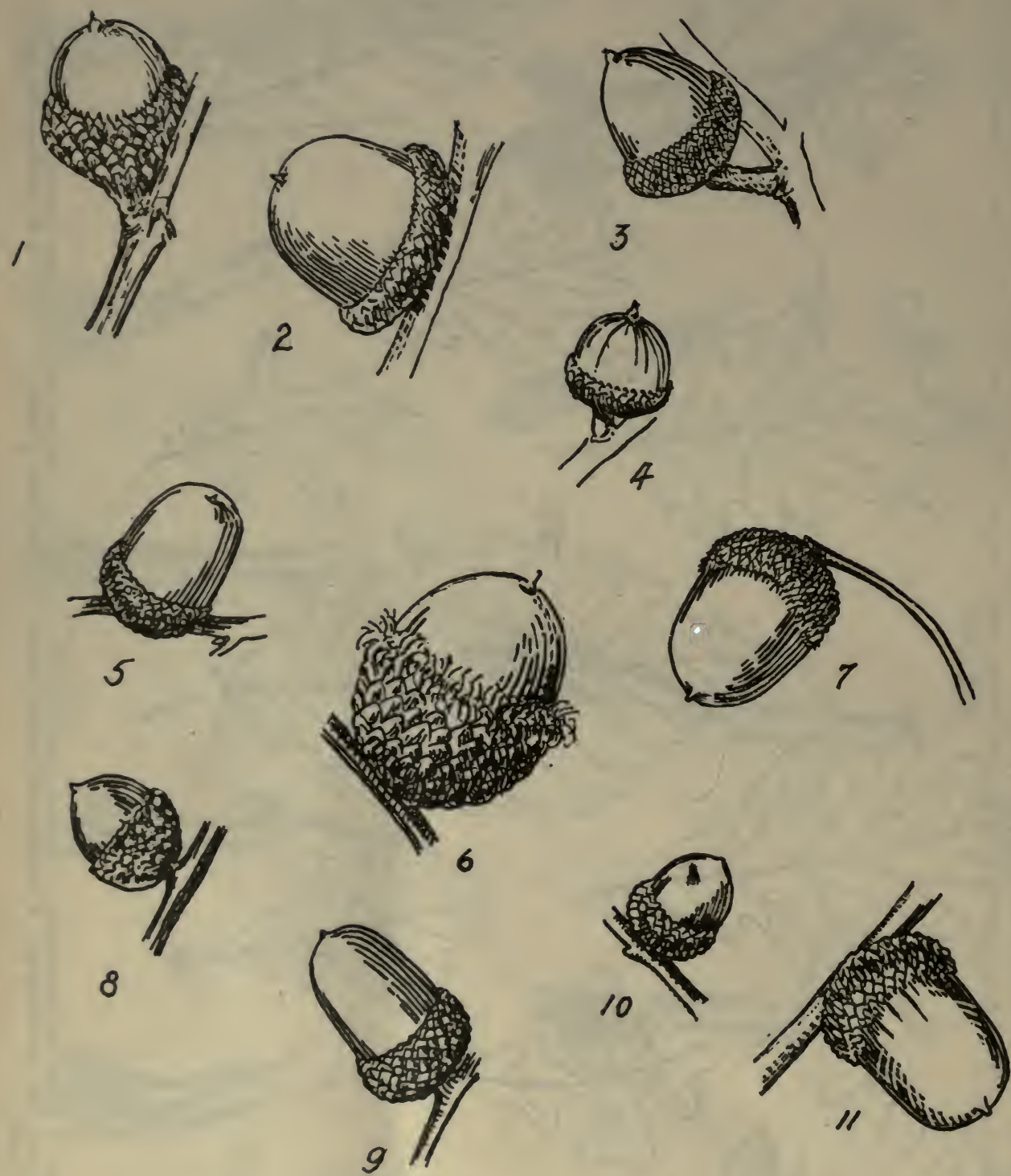

Acorns

1 Black oak (Quercus velutina). 2 Red oak (Quercus rubra). 3 Scarlet oak (Quercus coccinea). 4. Pin oak (Quercus palustris). 5 White oak (Quercus alba). 6. Bur oak (Quercus mocrocurpa). 7 Swamp white oak (Quercus bicolor). 8 Chinquapin oak (Quercus Muehlenbergii). 9 Chestnut oak (Quercus prinus). 10 Post oak (Quercus stellata). 11 Garry oak (Quercus Garryana). 


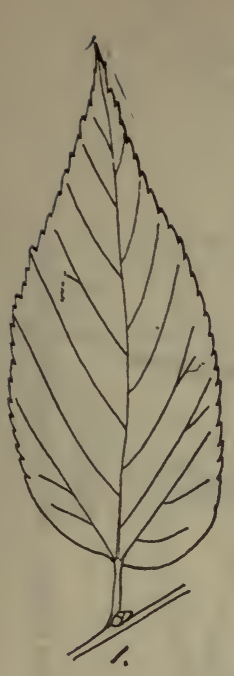

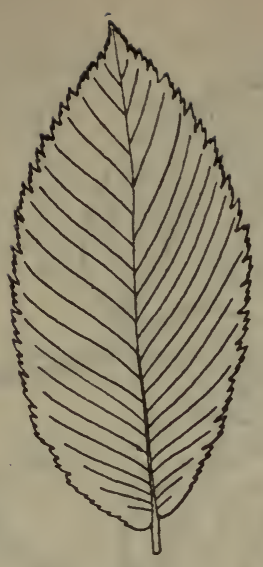

2 .

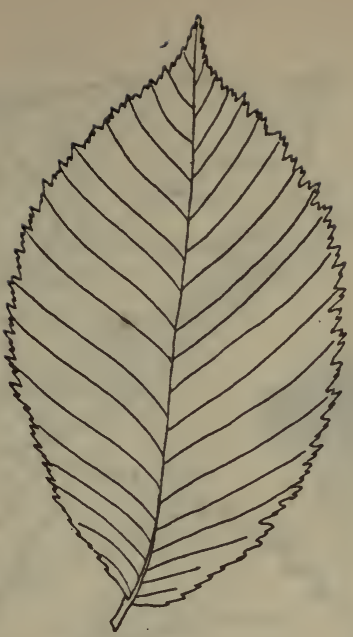

3.

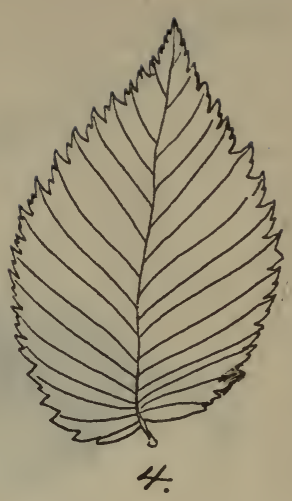

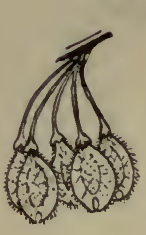

$\%$

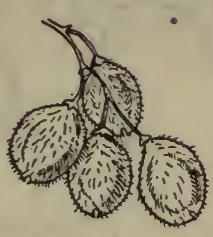

2 .

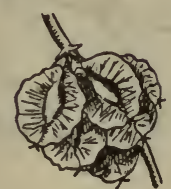

3.

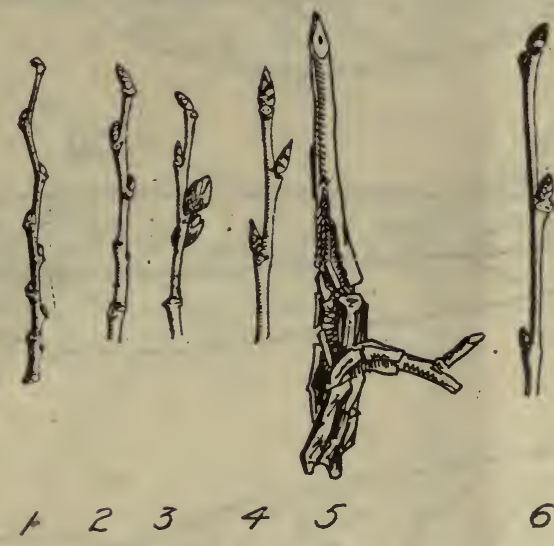

Elm and Hackberry Leaves, Fruit, and Twigs

LEAves. 1 Hackberry (Celtis occidentalis). 2 Rock elm (Ulmus racemosa). 3 Red elm (Ulmus fulva). 4 White elm (Ulmus americana).

HRUTT. 1 White elm (Ulmus americana), 2 Rock elm (Ulmus racemosa). 3 Red gum (Ulmus fulva).

TwIGs. 1 Hackberry (Celtis occidentalis), 2 and 3 White elm (Ulmus americana). 4 and 5 Rock elm (Ulmus racemosa). 6 Red elm (Ulmus fulva). 

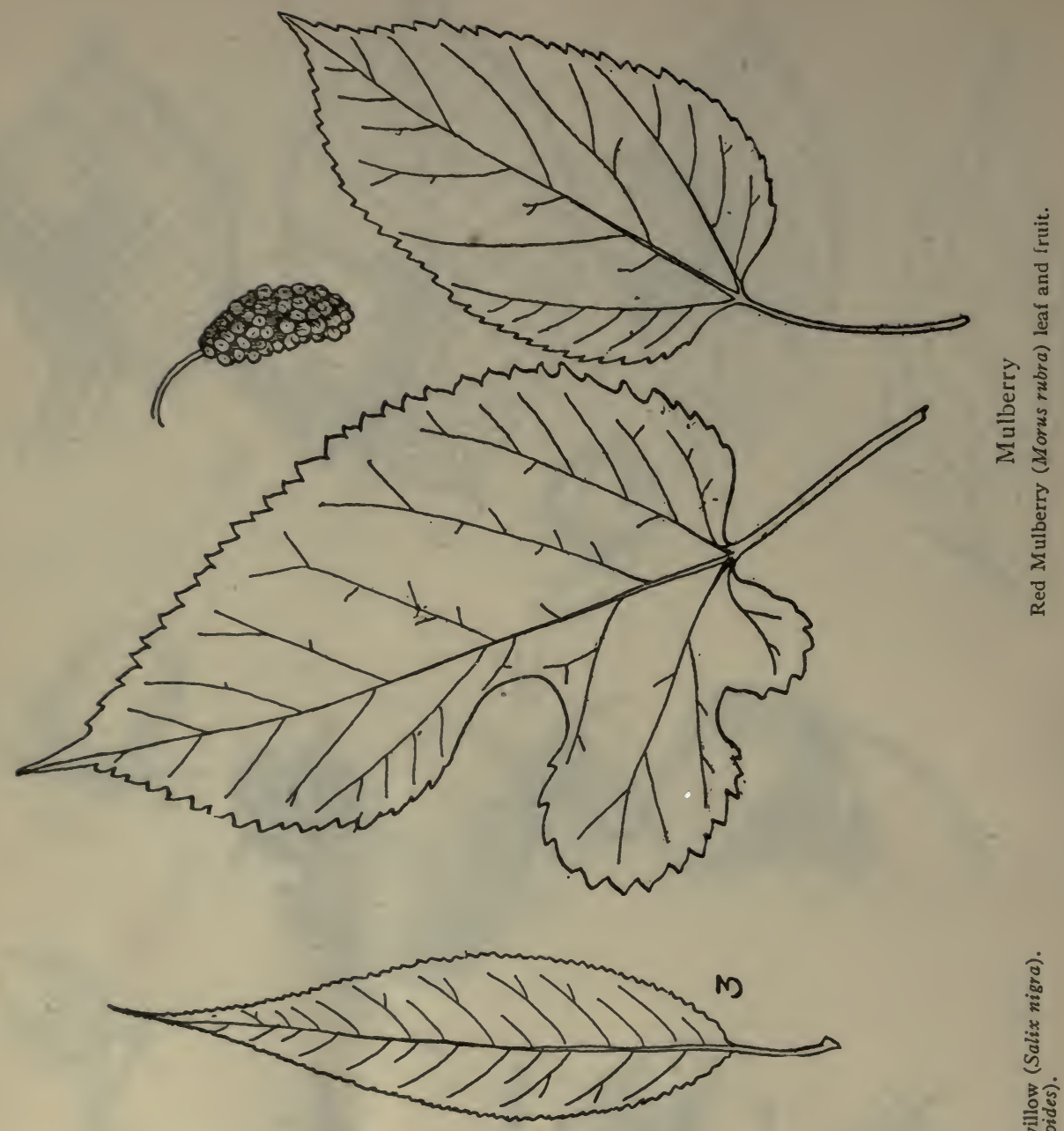

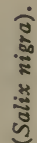

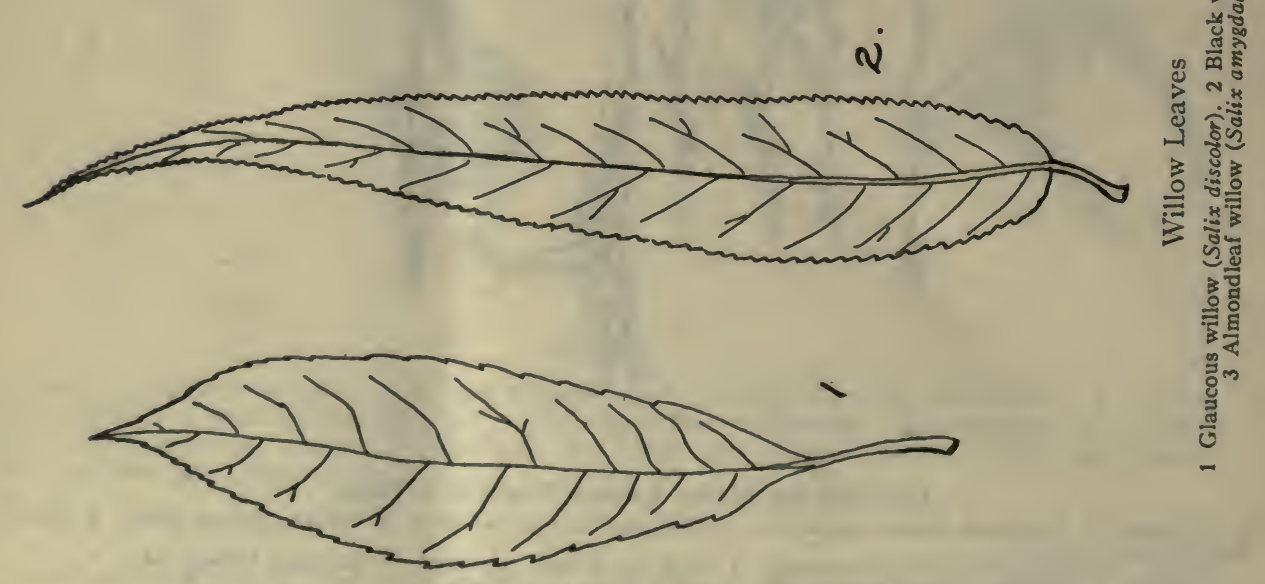



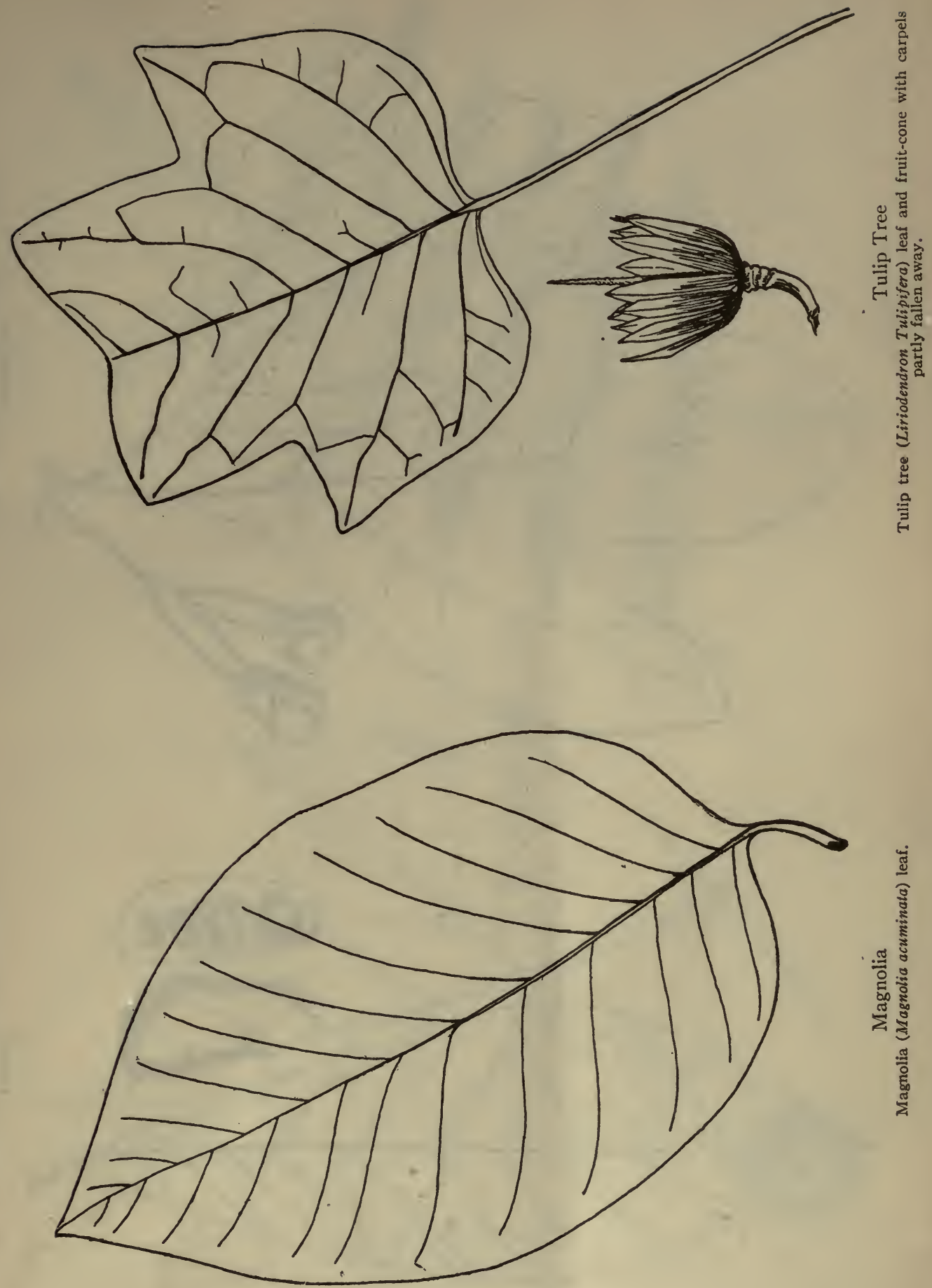

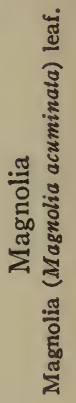



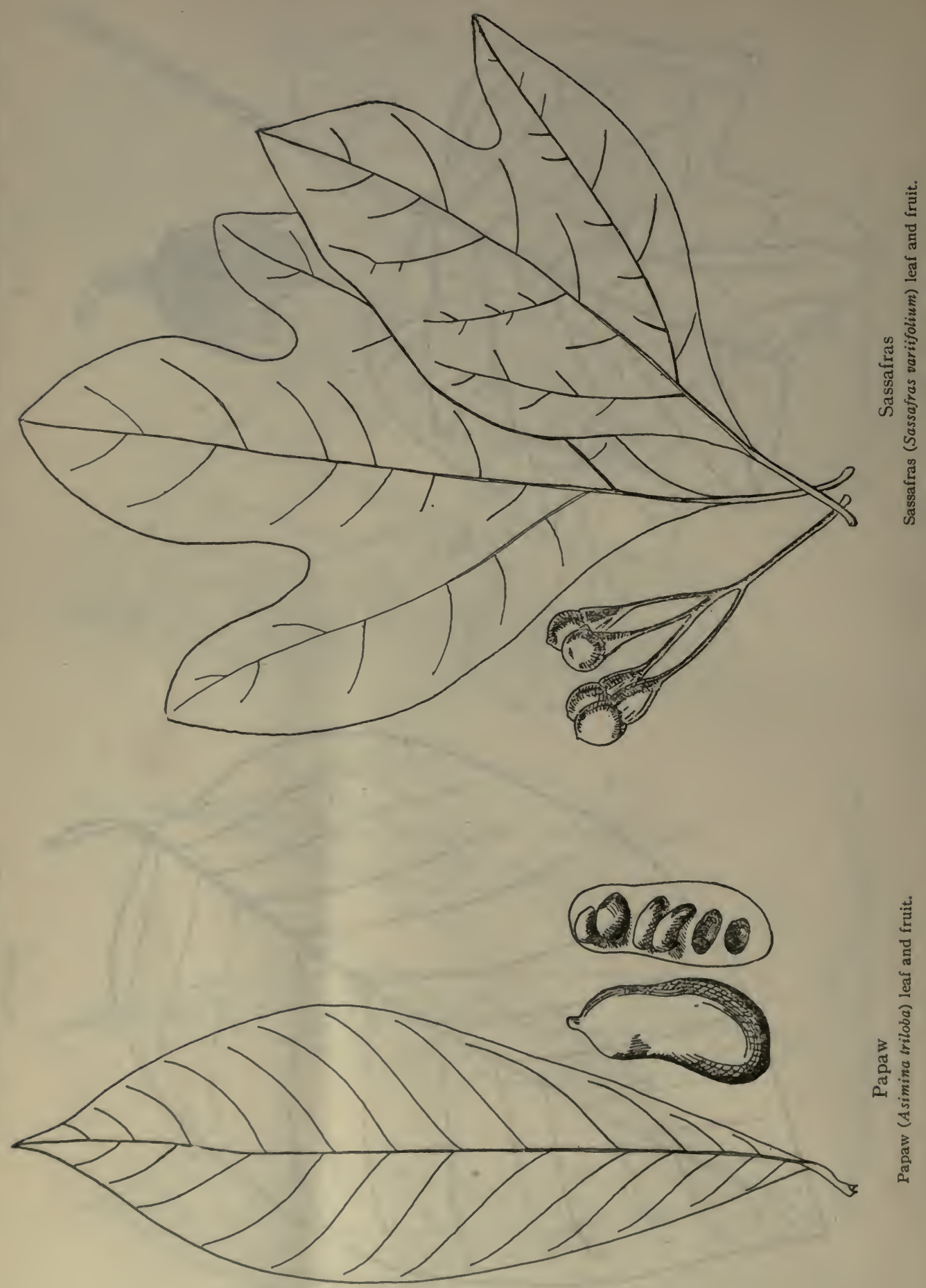

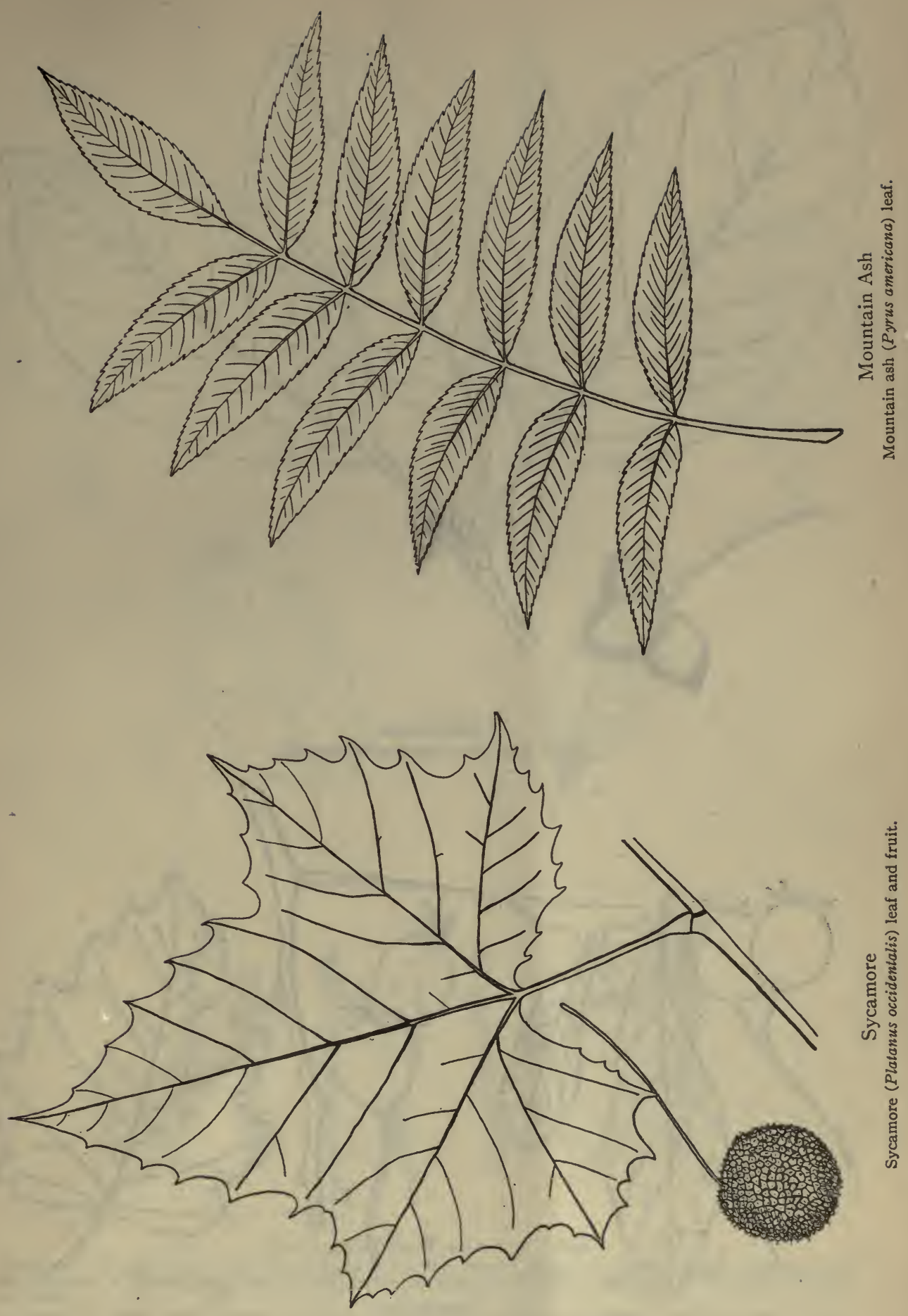

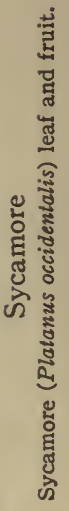




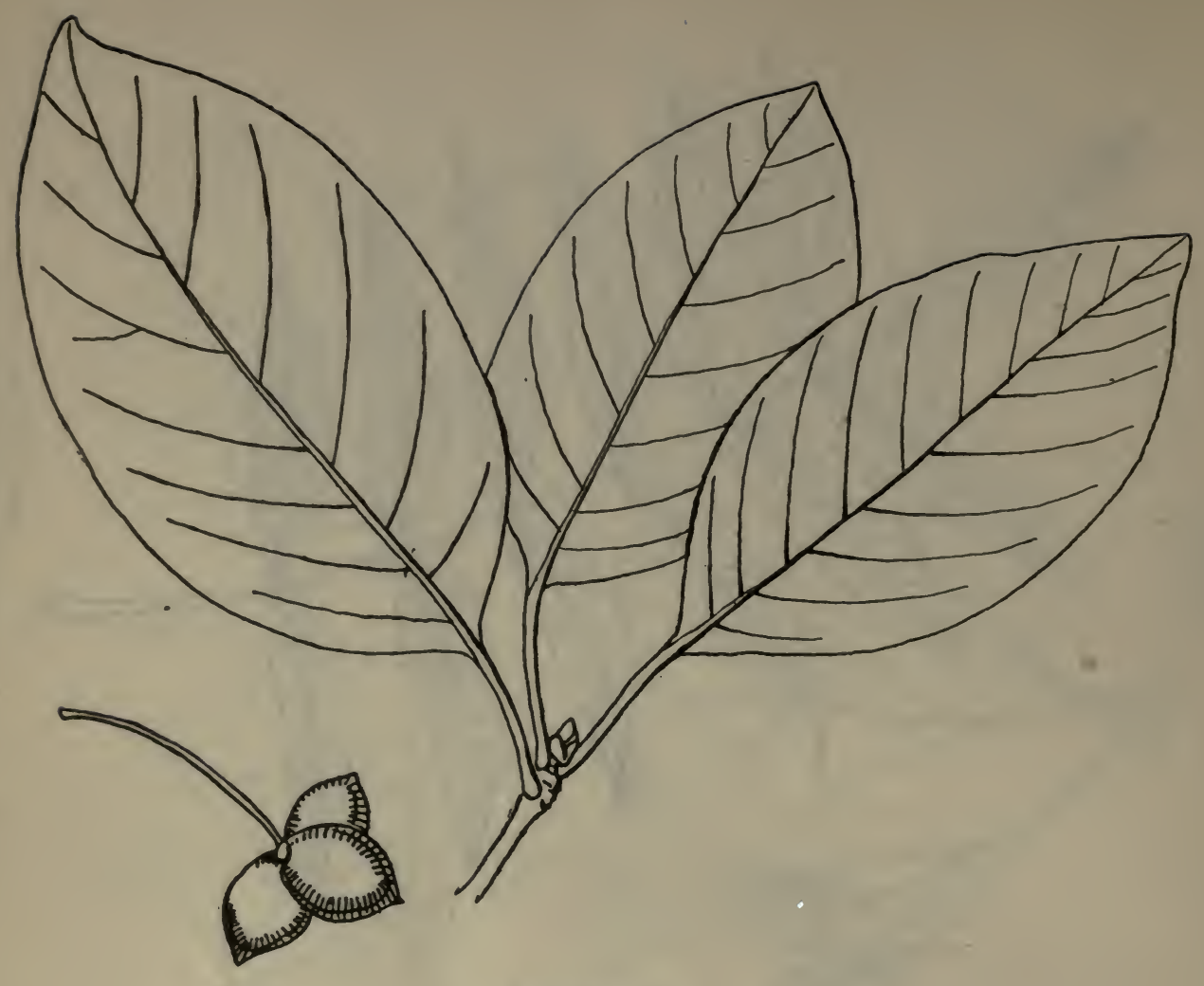

Black Gum

Black gum (Nyssa Sylvatica) leaf and fruit.

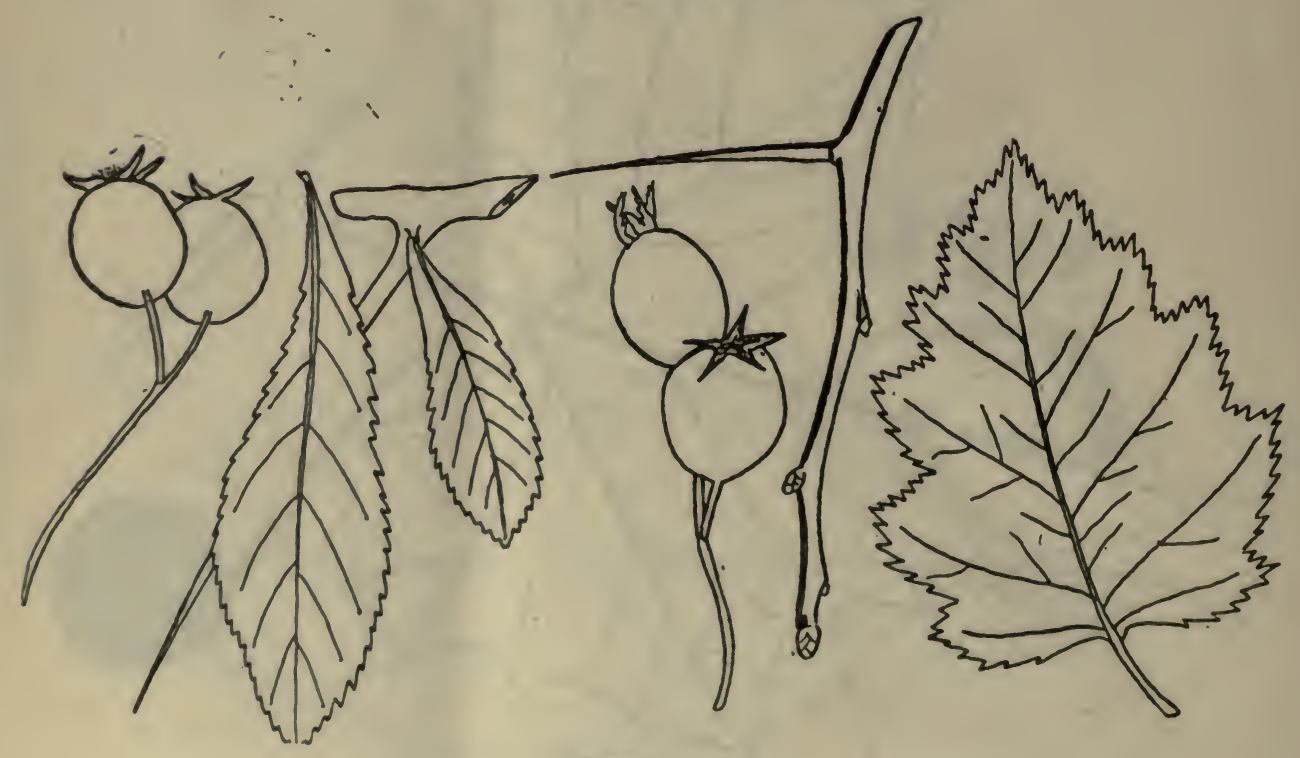

Hawthorn

Hawthorn (Crelaegus) loaves and truit. 

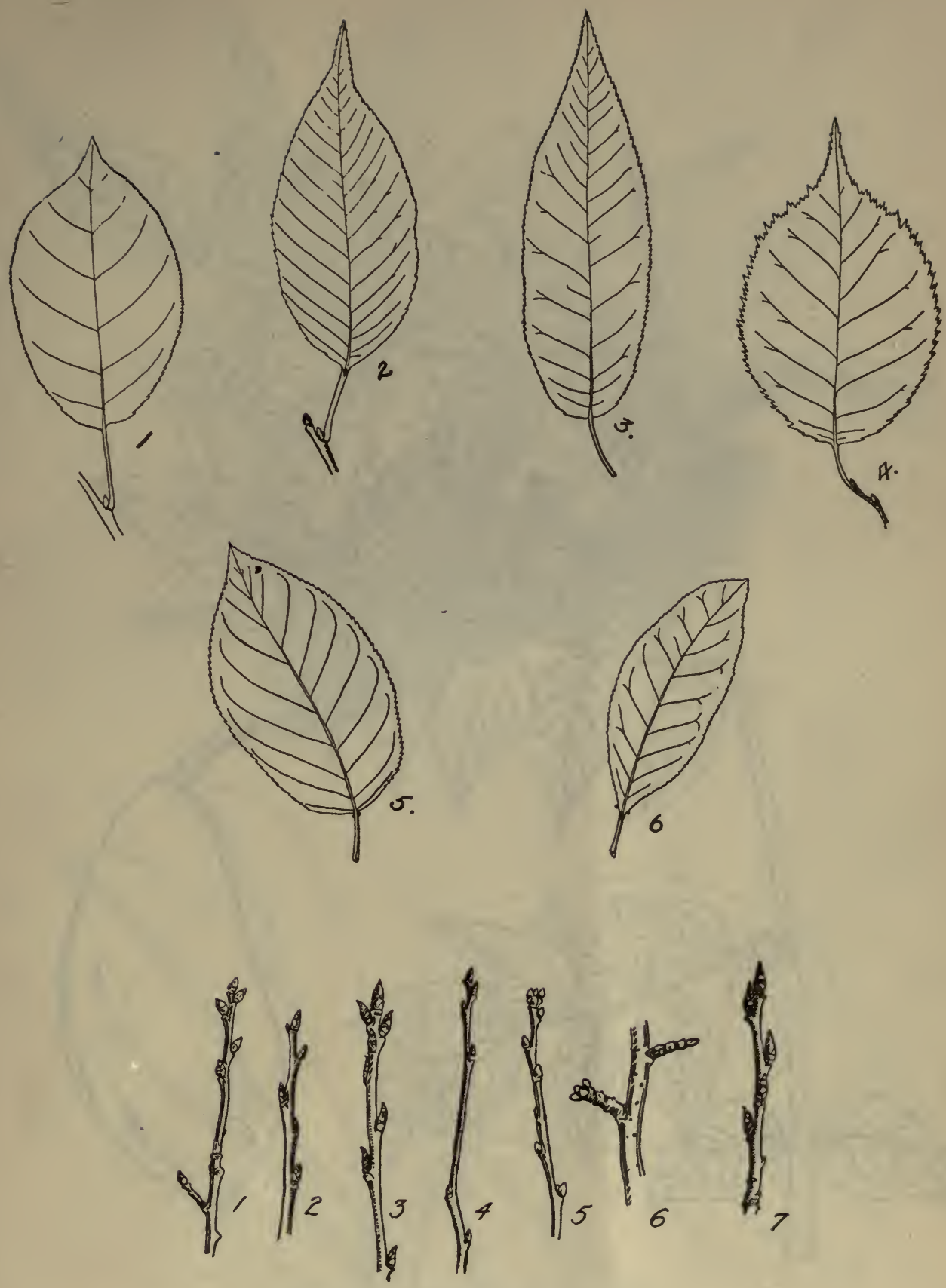

Cherry and Plum Leaves and Twigs

Leaves. 1 Choke cherry (Prunus virginiana). 2 Black cherry (Prunus serolina). 3 Bird cherry (Prunus pennsylvanica). 4 Canada plum (Prunus nigra). 5 Western choke cherry (Prunus demissa). 6 Bitter cherry (Prunus emarginata).

Twigs. 1 Black cherry (Prunus serotina). 2 Bitter cherry (Prunus emarginata). 3 Choke cherry (Prunus virginiana). 4 Canada plum (Prunus nigra). 5 and 6 Bird cherry (Prunus pennsylvanica). 7 Western choke cherry (Prunus demissa). 


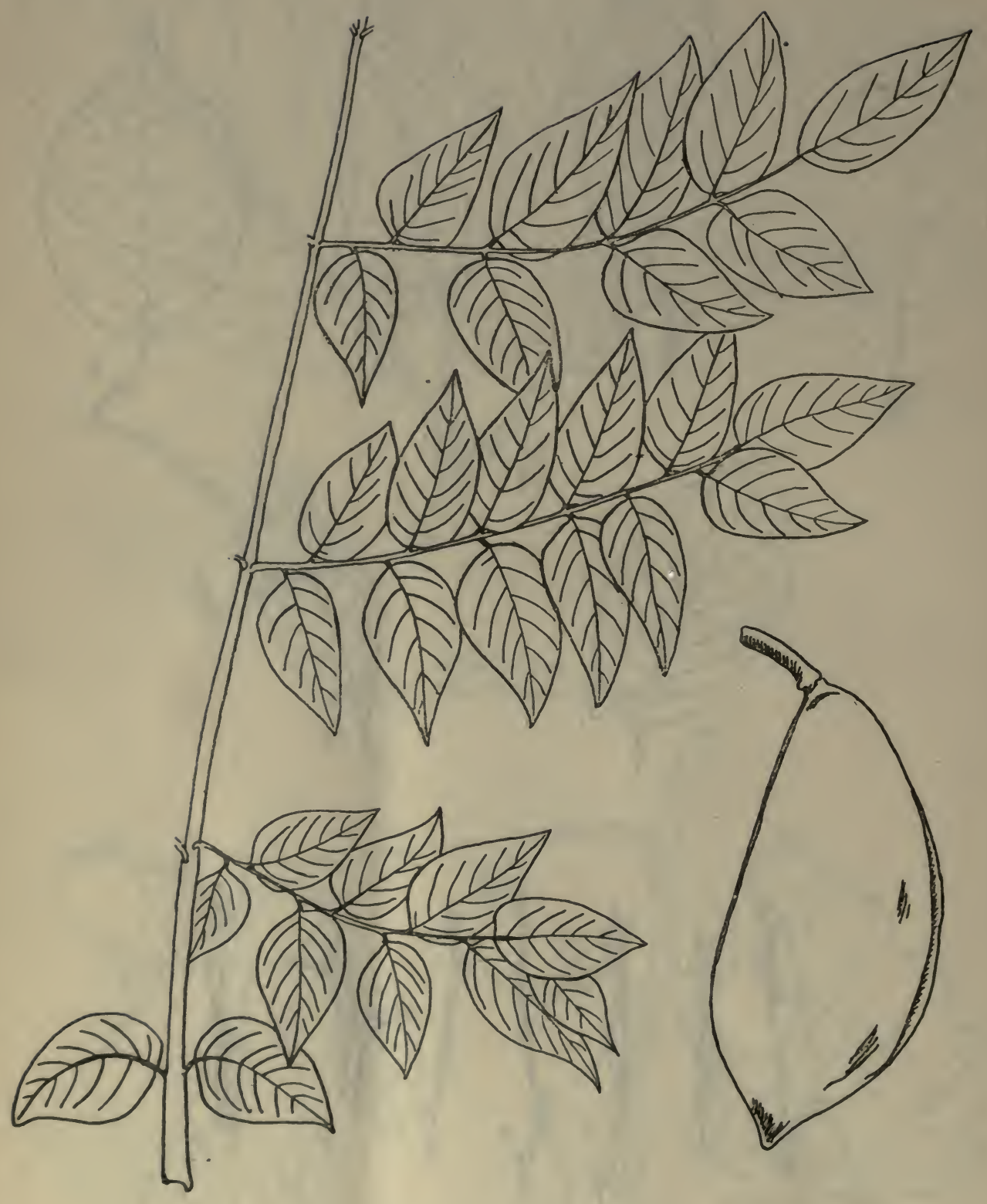

Coffectree

Kentucky coffeetree (Gymnocladus dioica) portion of leaf and fruit 

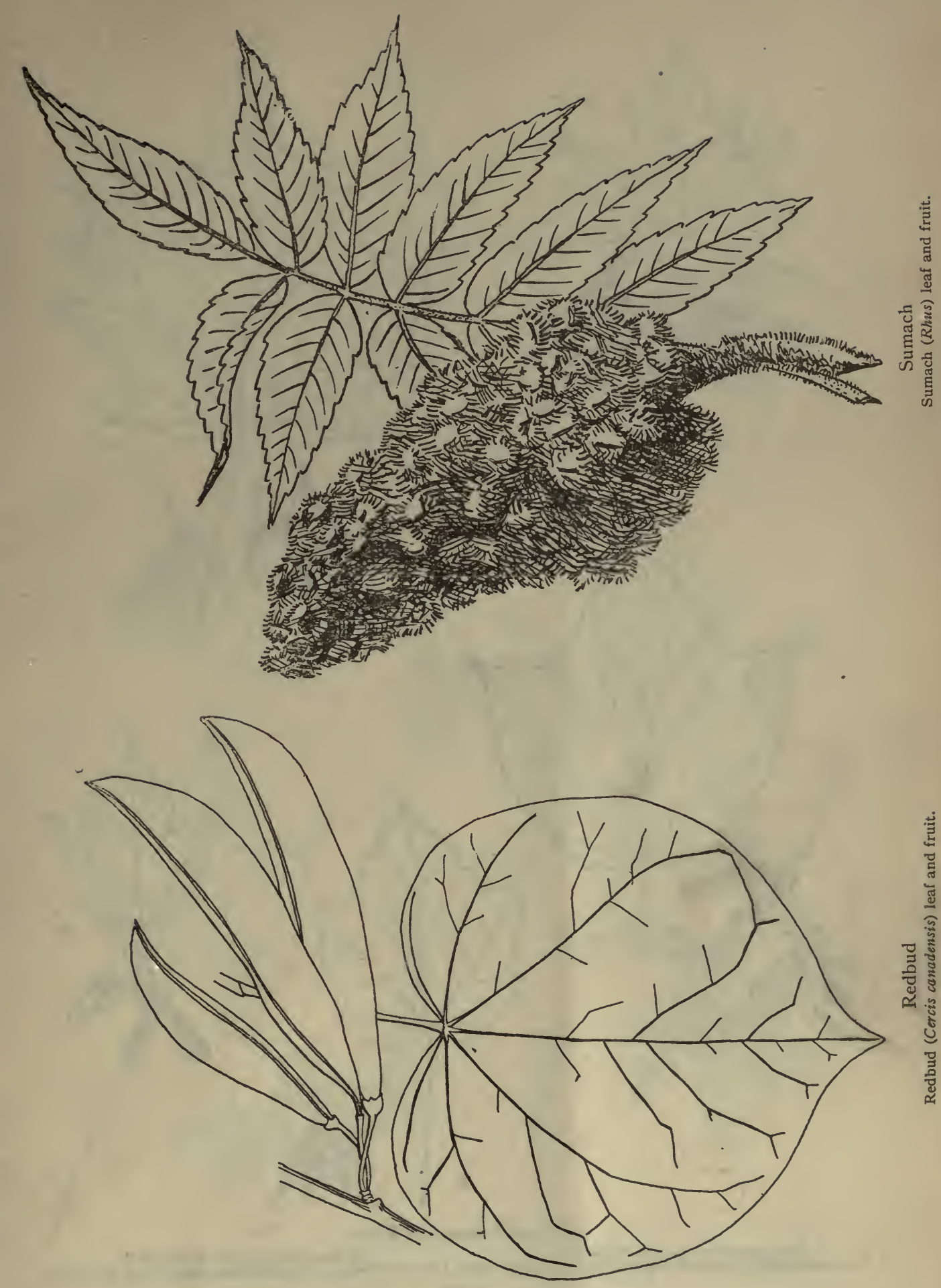

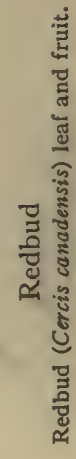




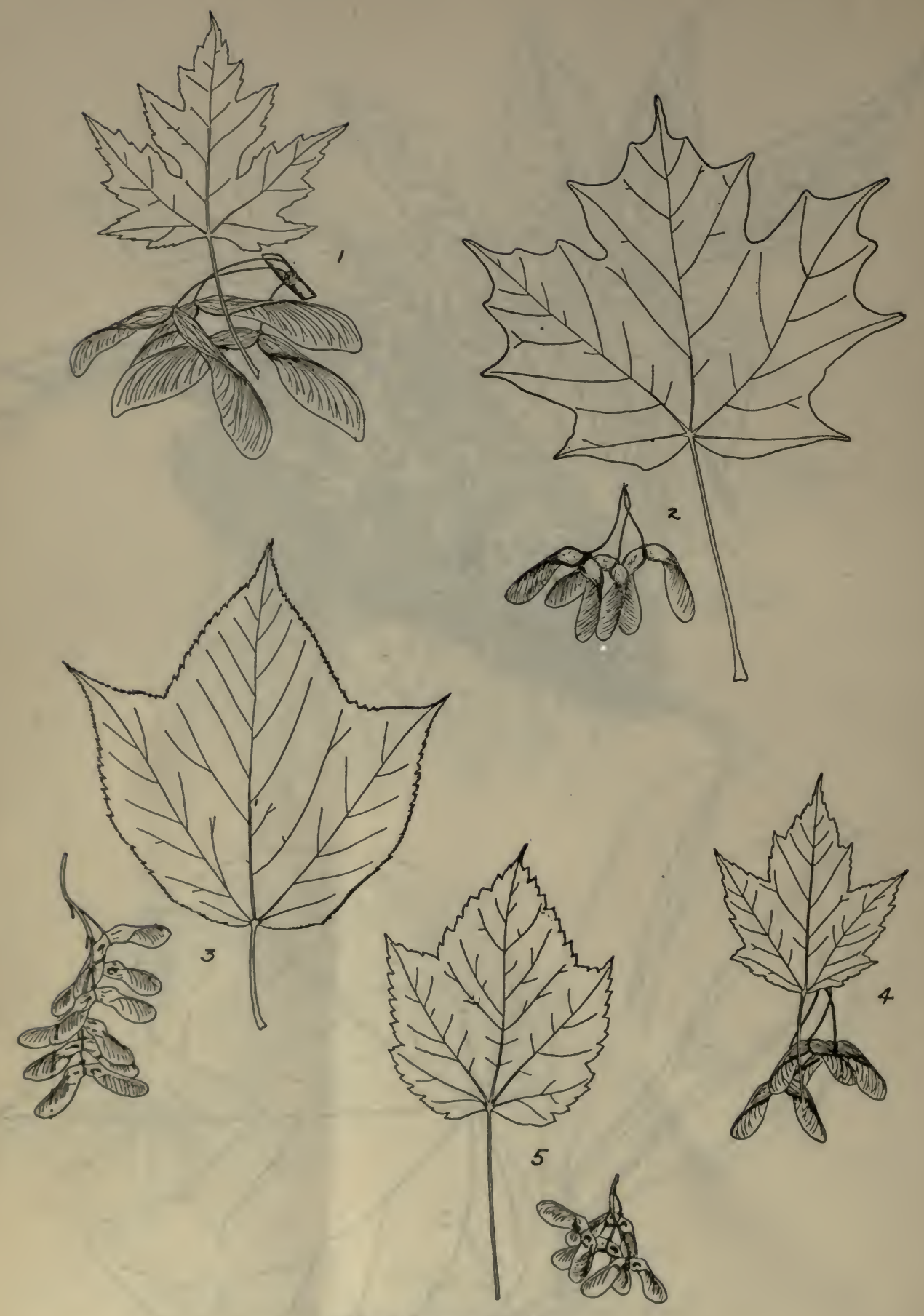

Maple Leaves and Fruit

1 Silver maple (Acer saccharinum).

2 Sugar maple (Acer saccharum).
5 Mountain maple $(A$ cer spicalum).

3 Striped maple (Acer pennsylvanicum). 


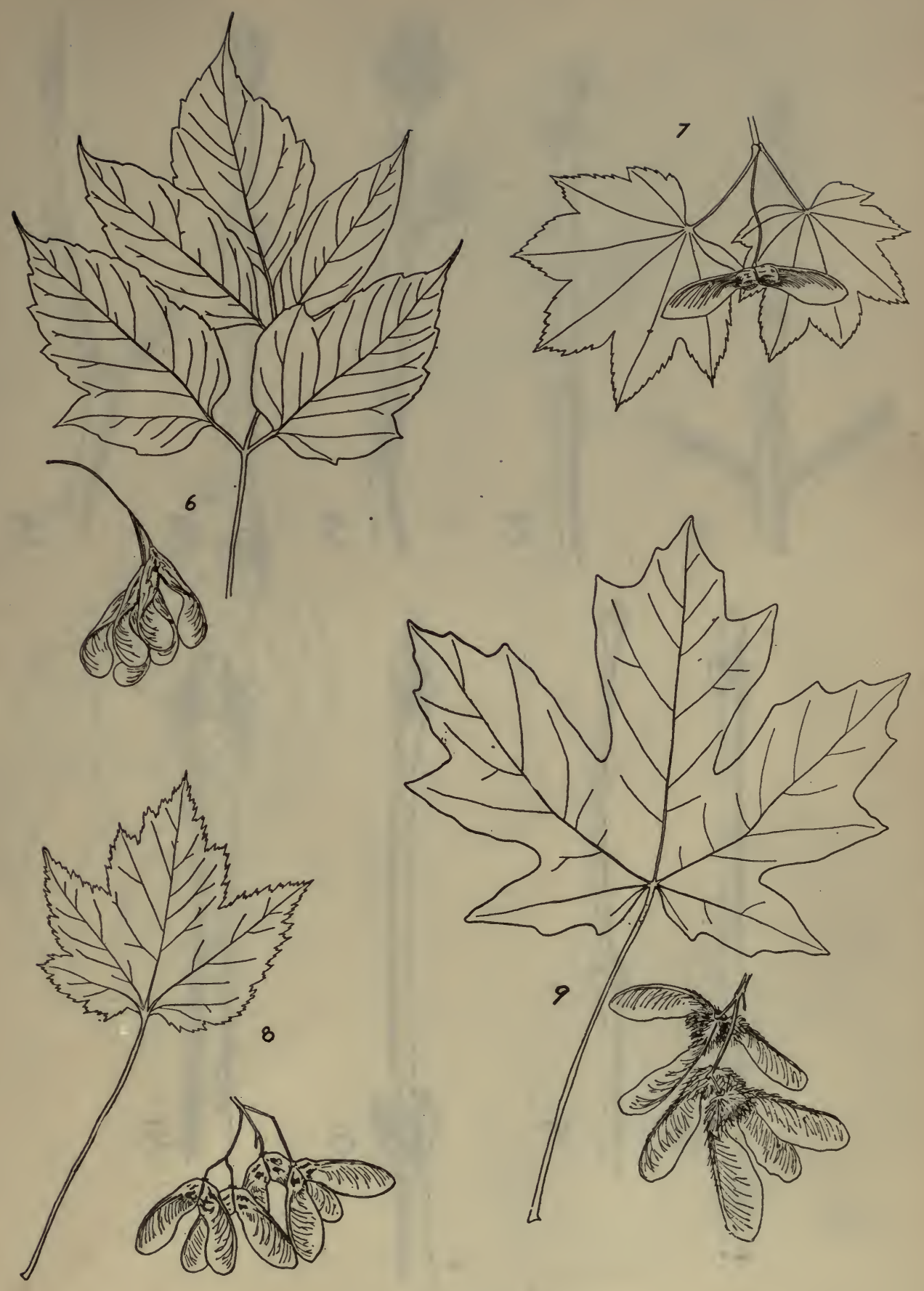

Maple Leaves and Fruit

6 Manitoba maple (Acer Negundo).

8 Dwarf maple (Acer Douglasii).
7 Vine maple (Acer circinatum). 9 Broad-leaved maple (Acer macrophyllum). 


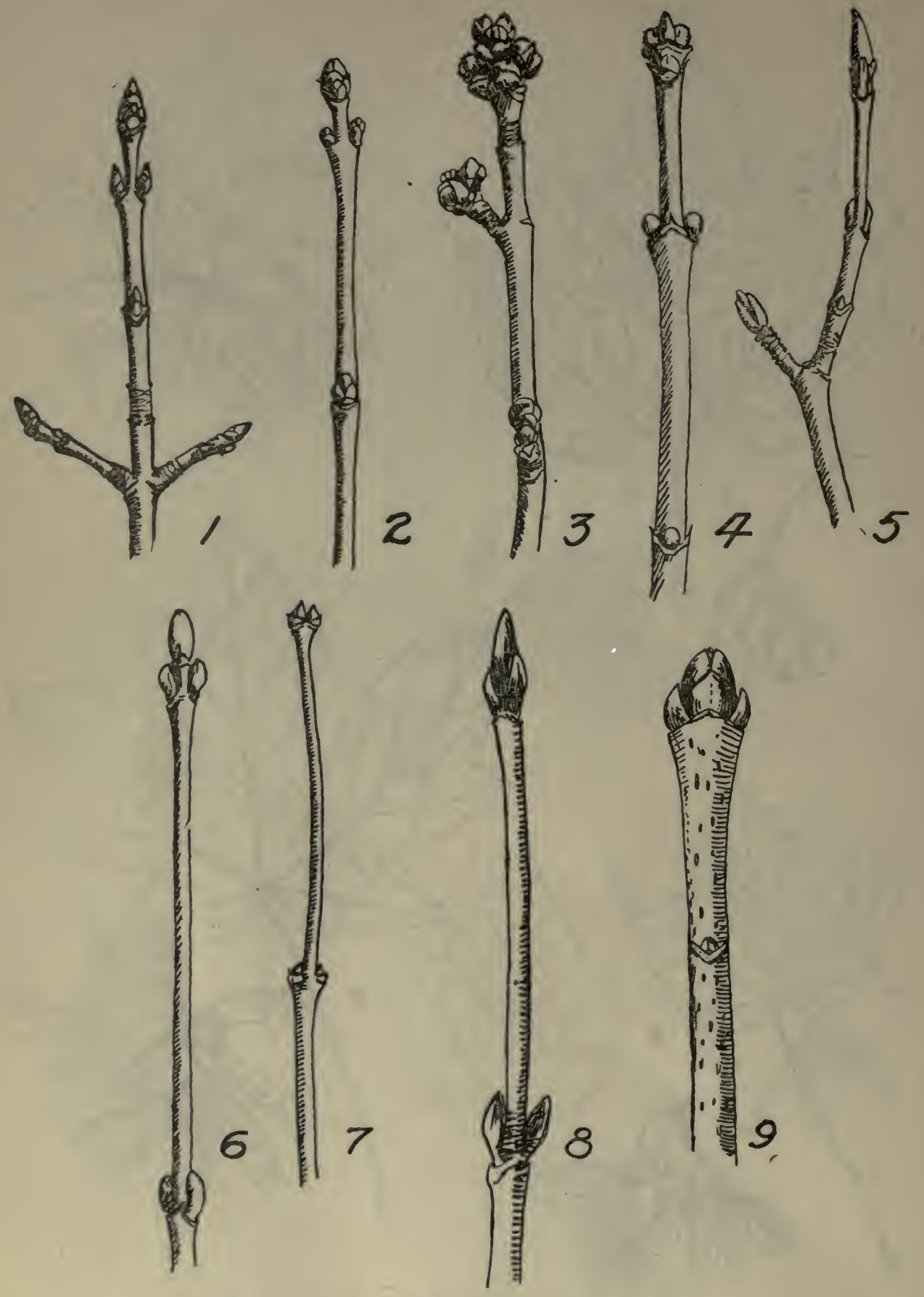

Maple Twigs

Sugar maple (Acer saccharum). 2 Red maple (Acer rubrum). 3 Silver maple (Acer saccharinum).・ 4 Manitoba maple (Acer Negundo), 5. Mountain maple (A , spicalum), 6 Dwarf maple (Acer Douglasii).

Vine maple.(Acer_circinalum). 8 Striped maple (Acer pe ylvanicum). 9 Broad-leaved maple (Acer macrophyllu $n$ 

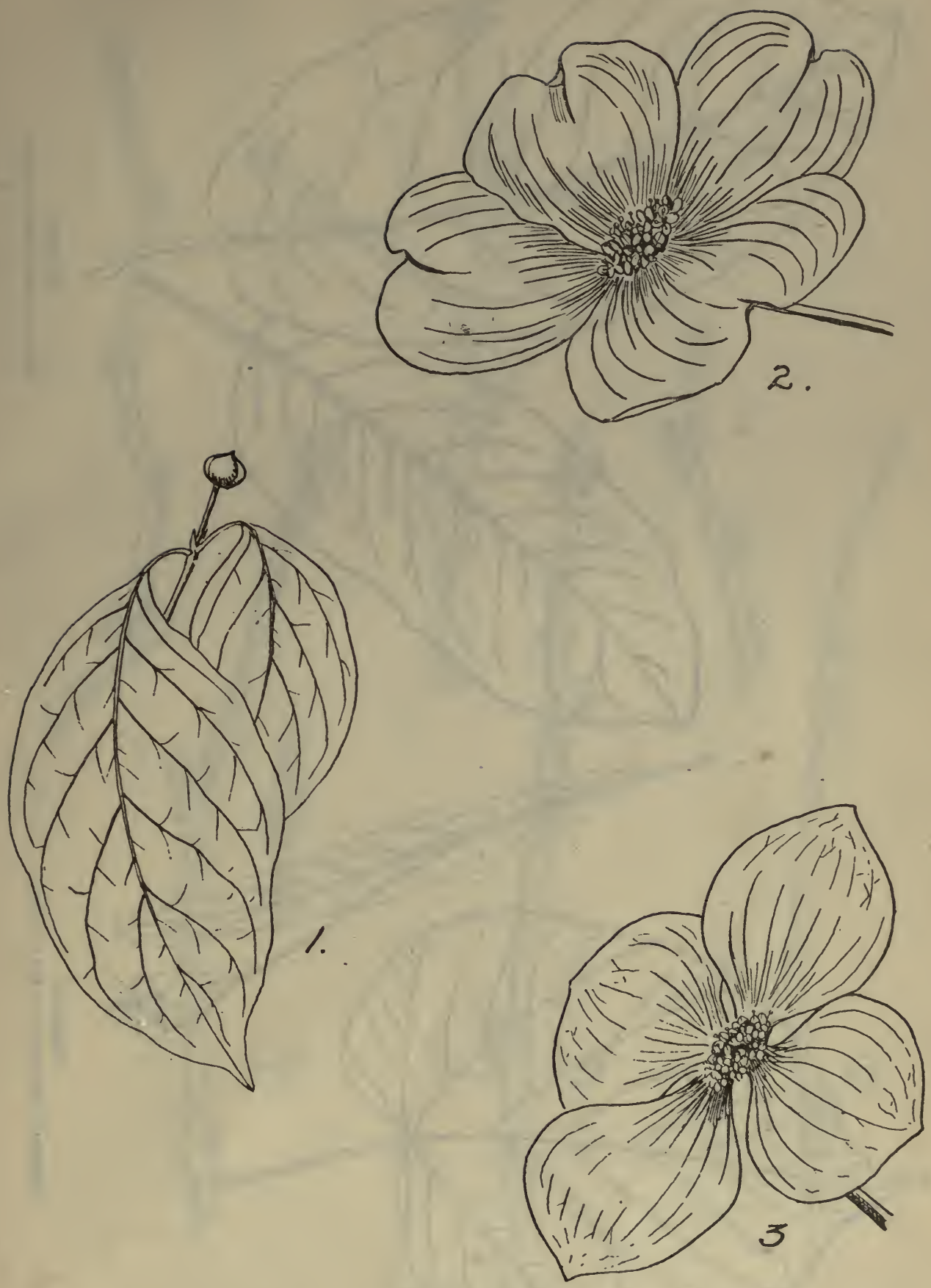

Dogwood Flowers and Leaf

1. Flowering dogwood (Cornus florida) leaves.
3 Western flowering dogwood (Cornus Nuttallii) flower). 

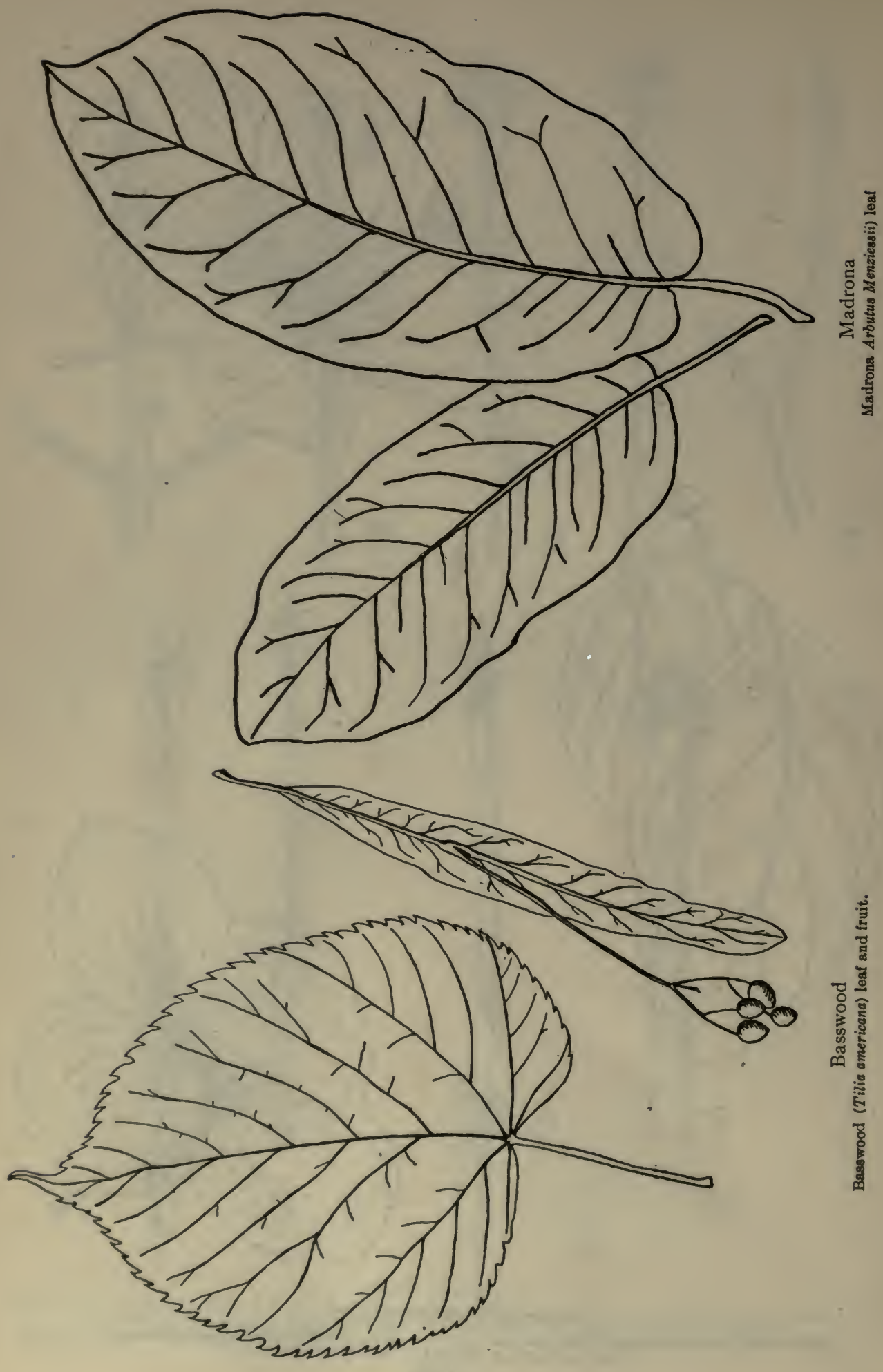


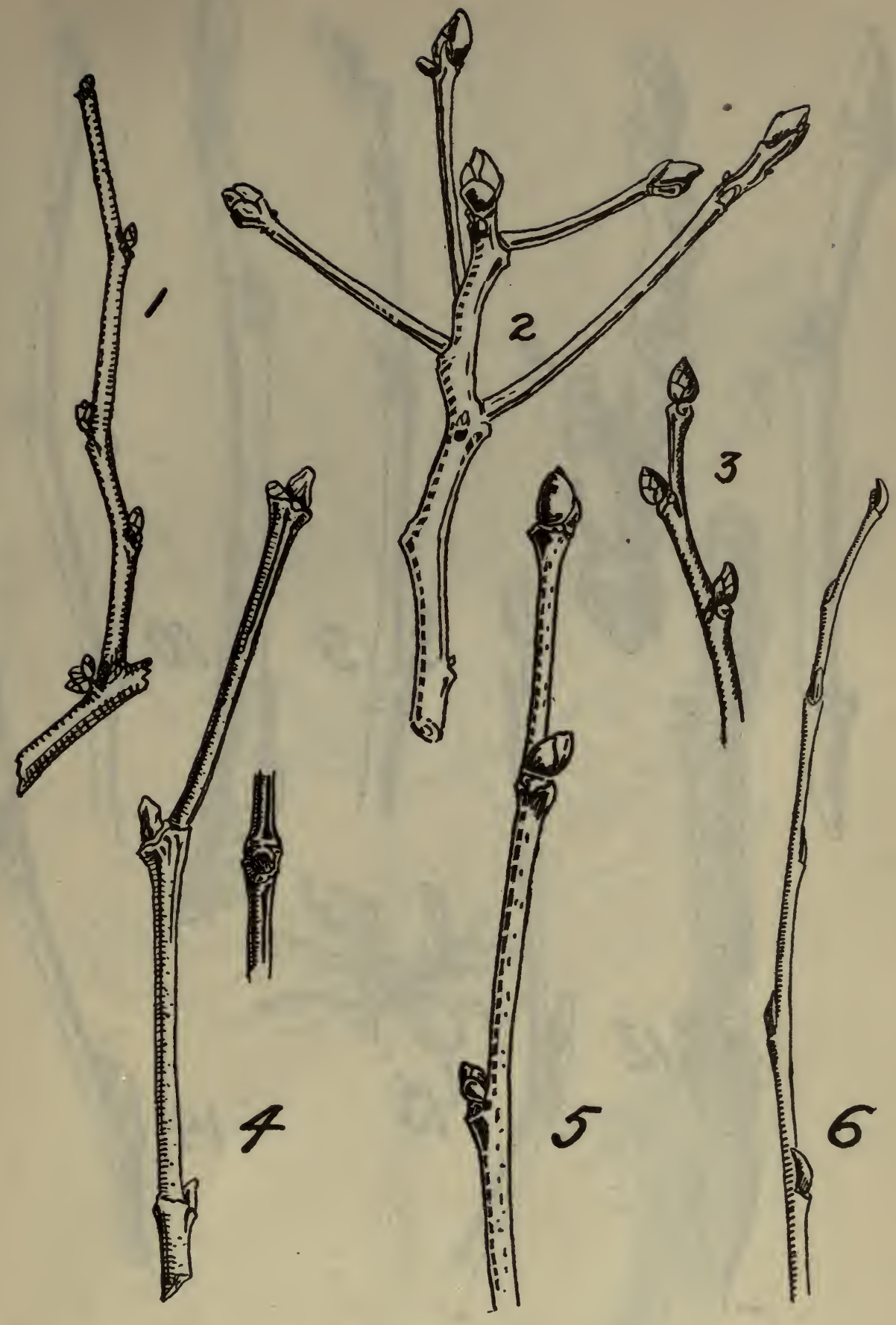

Miscellaneous Twigs

1 Redbud (Ceris canadensis). 2 Sassafras (Sassafras variifolium). 3 Mulberry (Morus rubra).

4 Sycamore (Platanus occidentalis). 5 Basswood (Tilia americana). 6 Willow (Salix). 


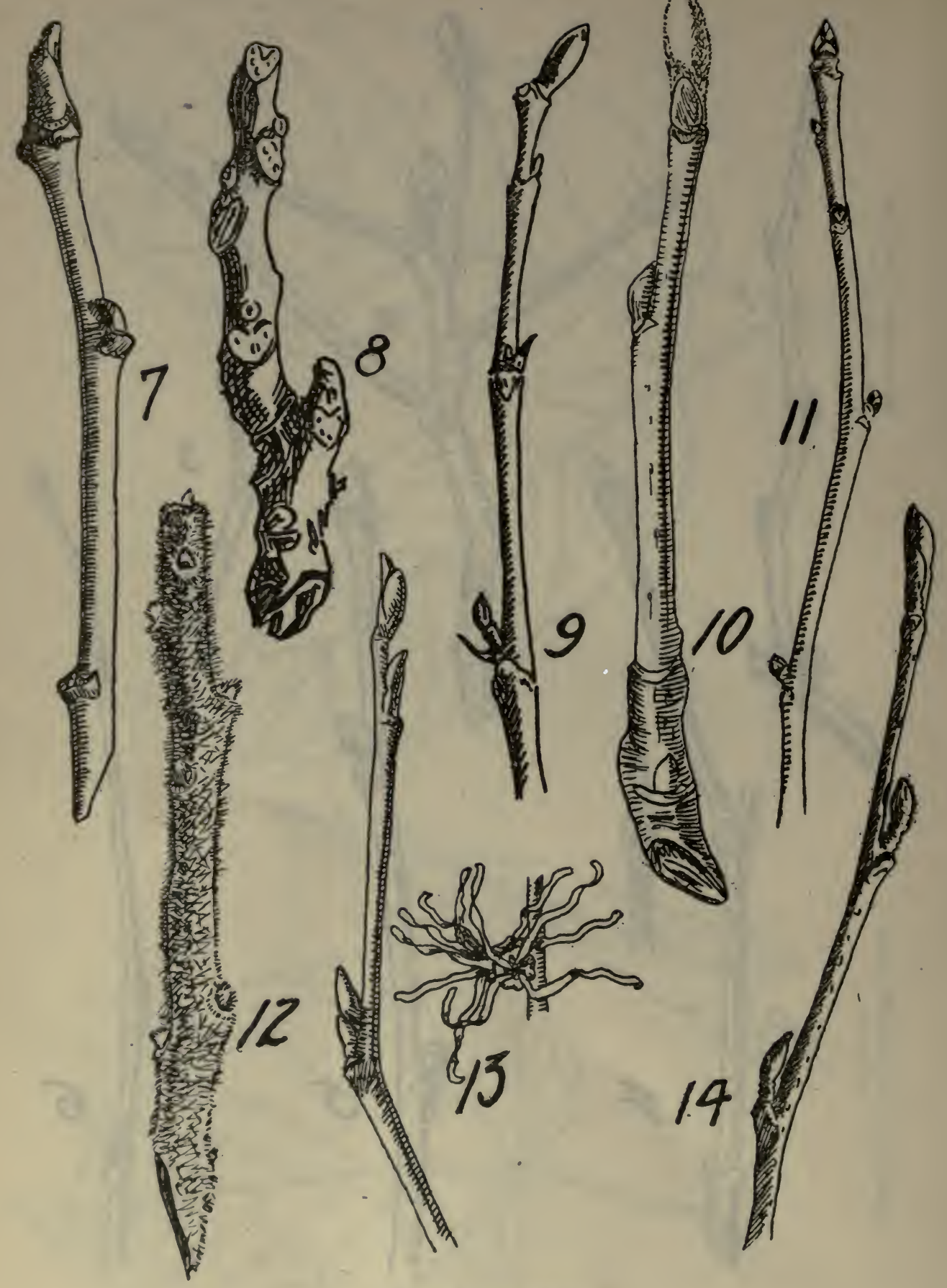

Miscellaneous Twigs

7 Mountain ash (Pyrus americana). 8 Coffeetree (Gymnocladus dioica). 9 Tulip tree (Liriodendron Tulipifera). 10 Magnolia (Magnolia acuminata). 11 Black gum (Nyssa sylvatica).

12 Sumach (Rhus lyphina). 13 Witch hazel (IIamamelis virginiana): twig and flower. 14 Alder (Alnus). 


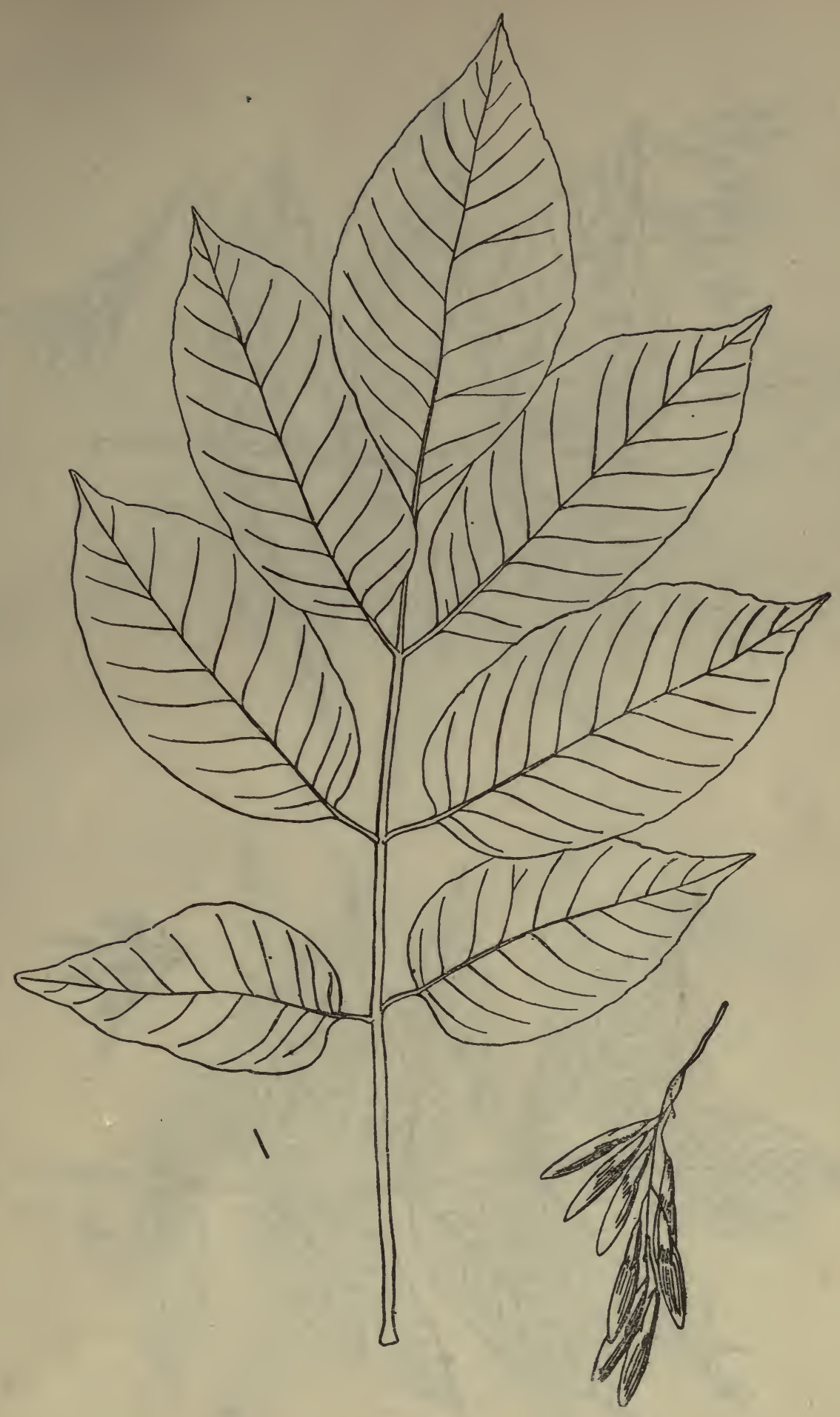

Ash Leaves

1 White ash (Fraxinus americana) leaf and fruit. 

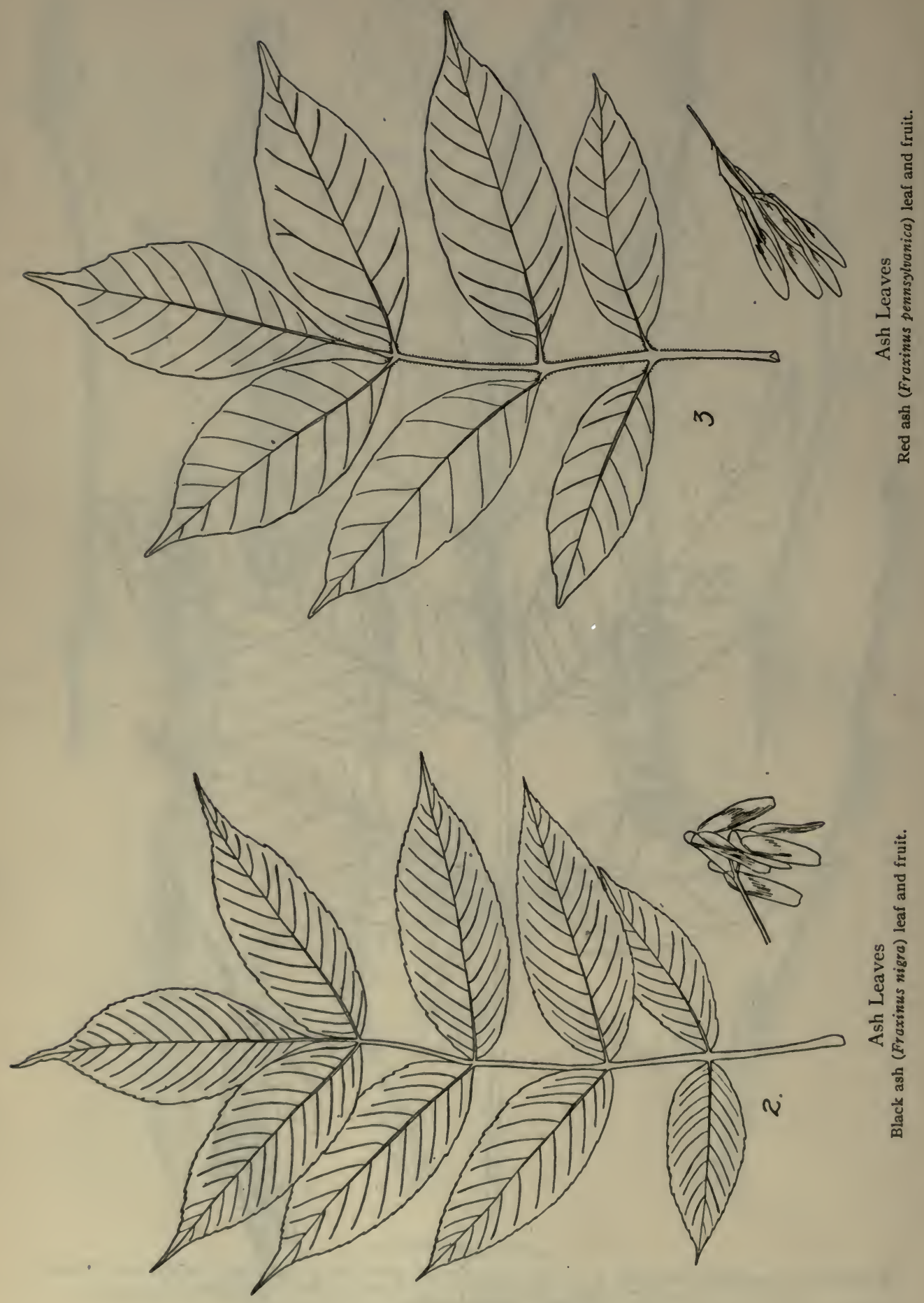

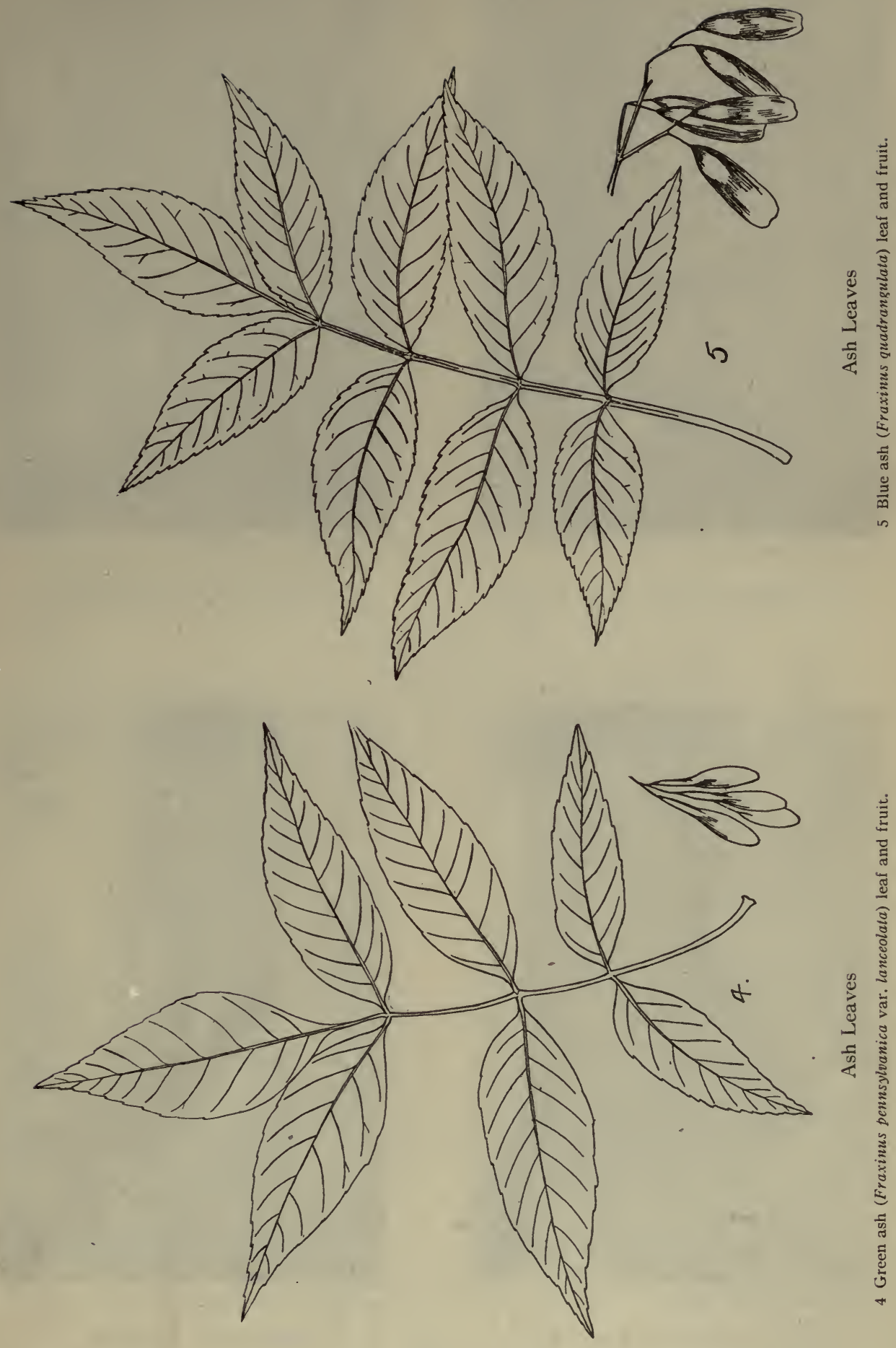

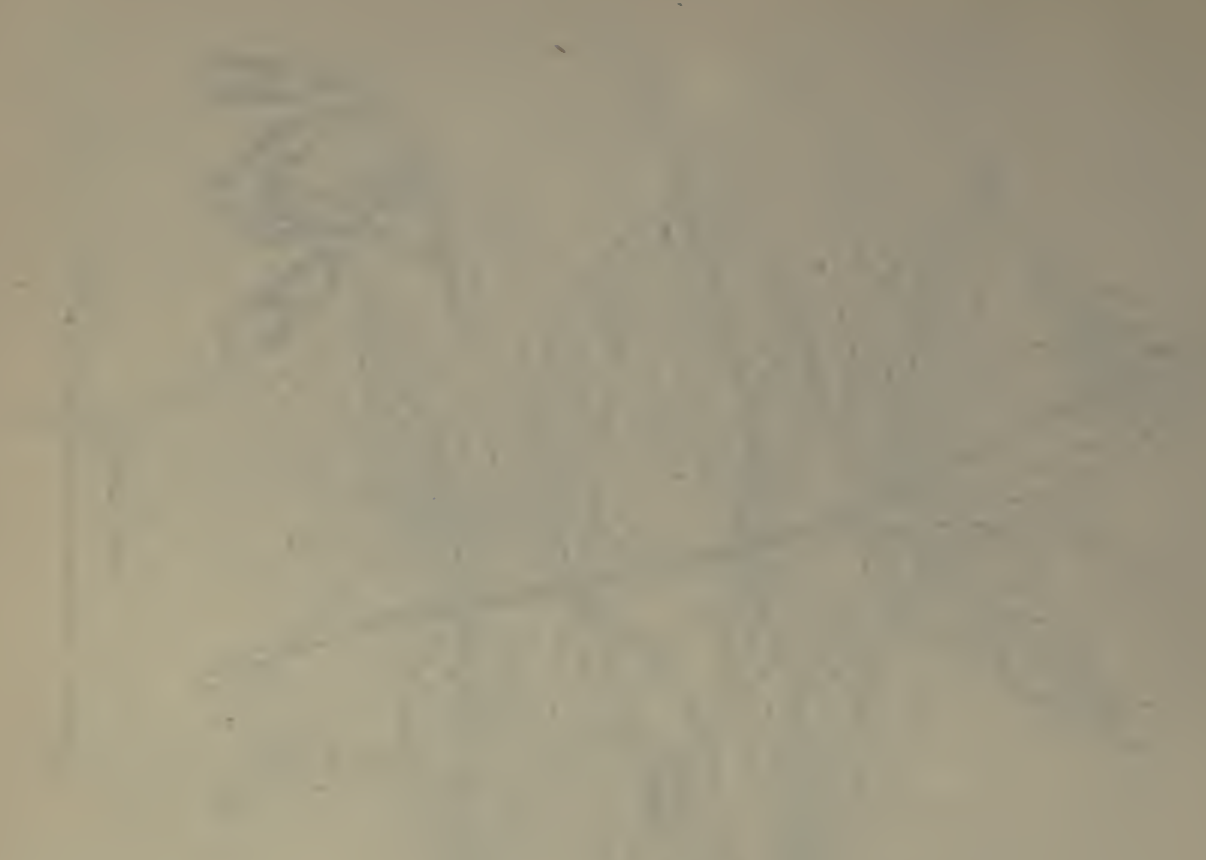

(4) 1

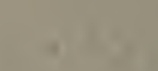




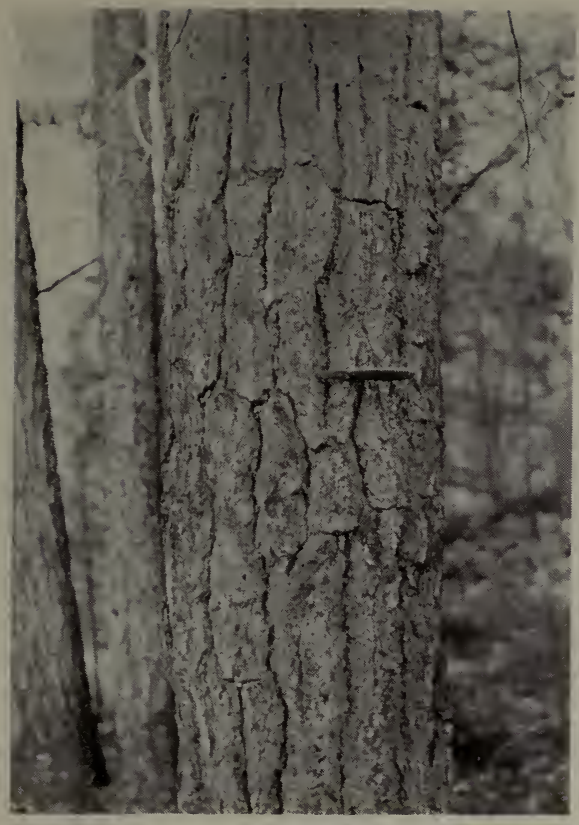

Photo. 8601. R. B. Morton.

White Pine (Pinus Strobus)

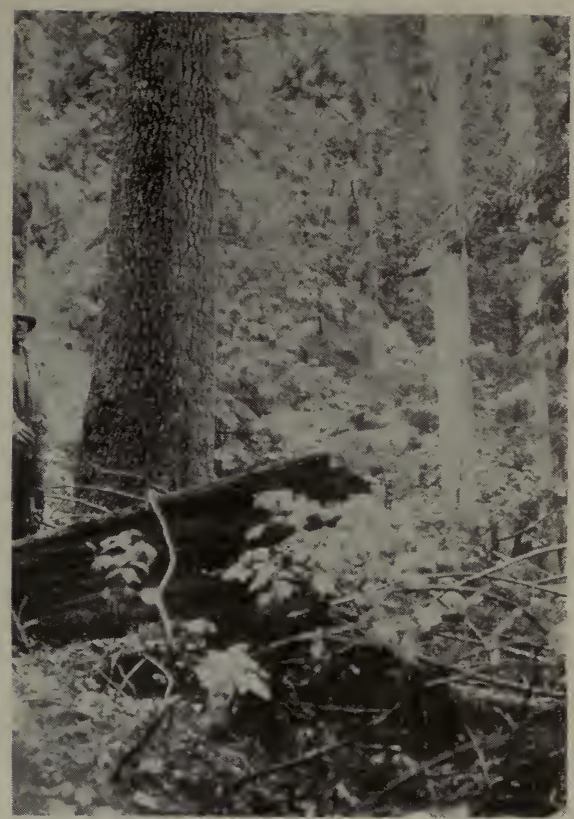

Pholo. 331. E. Stewart.

Western white pine (Pinus monticola)

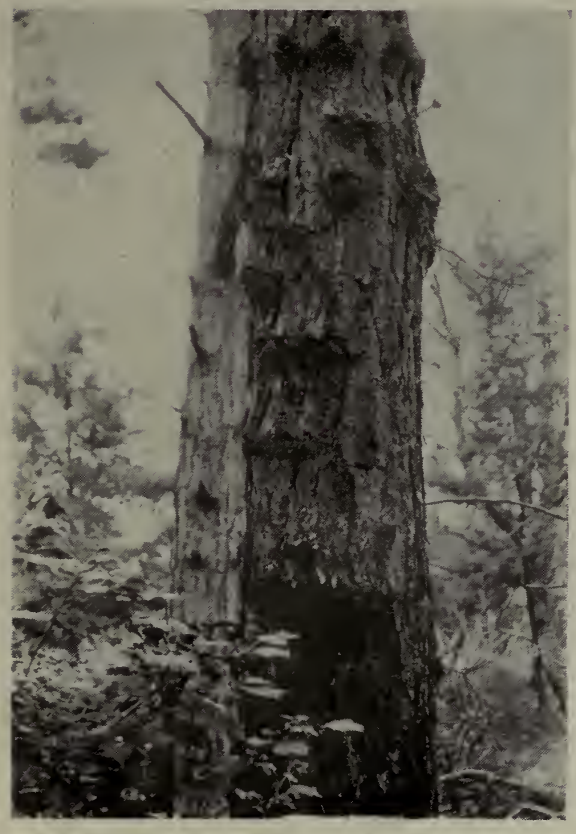

Photo. 5587. R. B. Morlon.

Pitch pine (Pinus rigida)

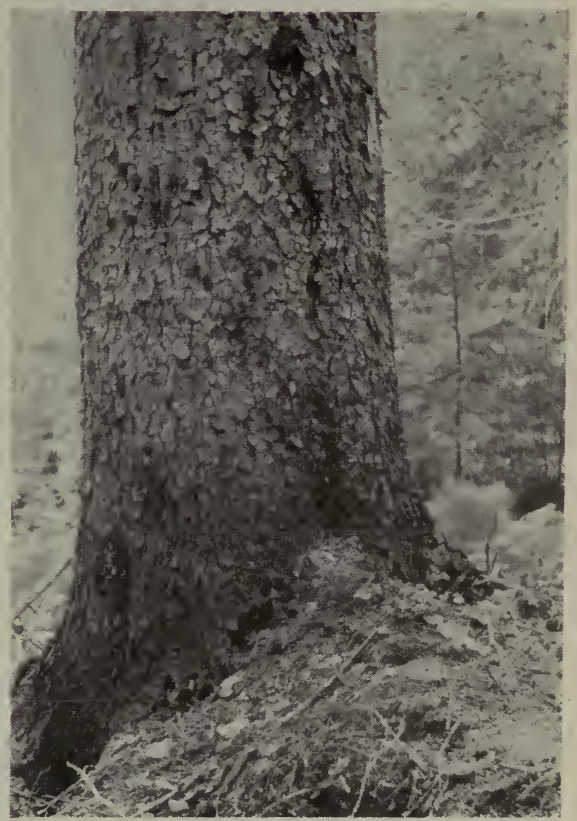

Photo. 2775. H. C. Wallin.

Sitka spruce (Picea sitchensis) 

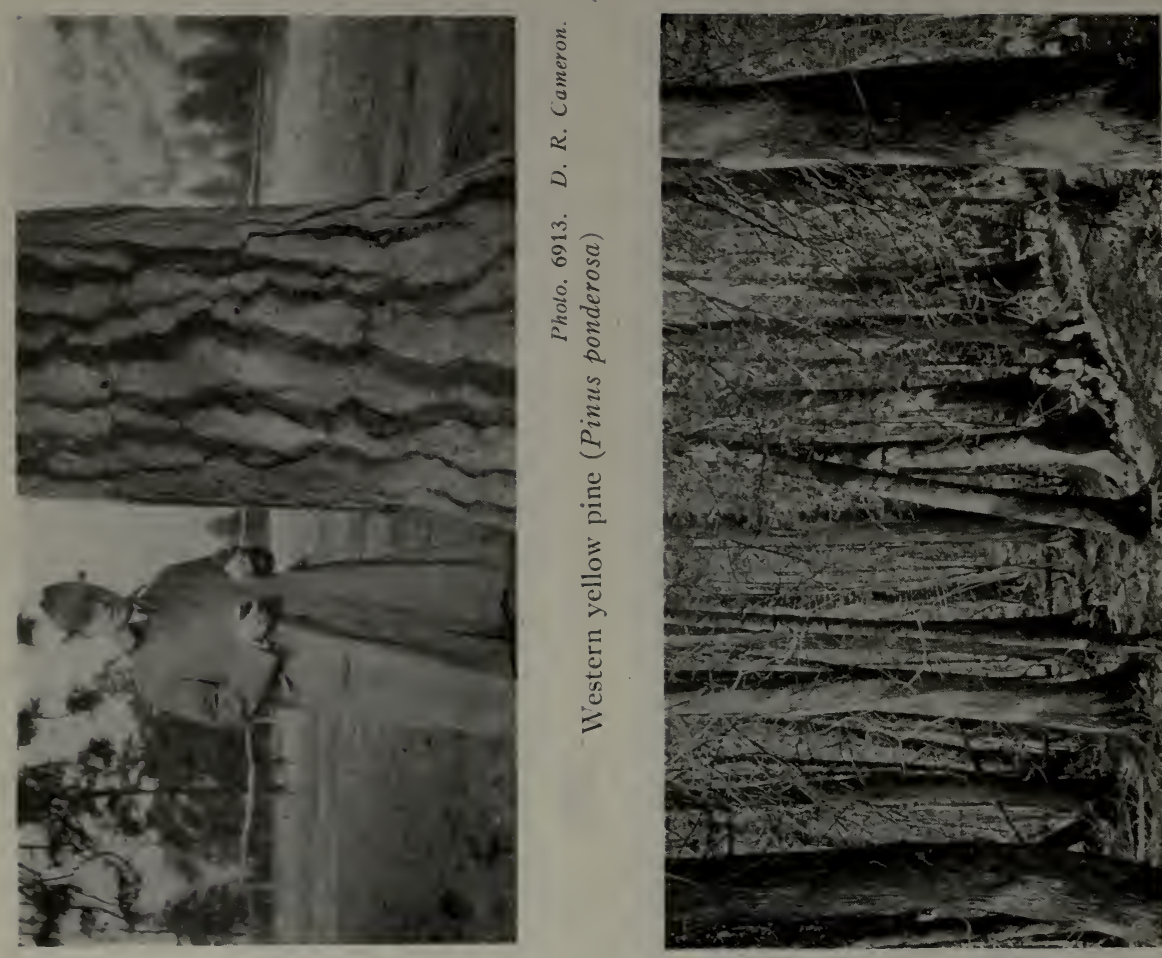

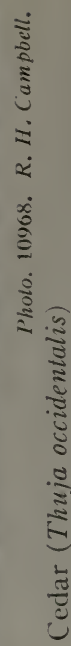
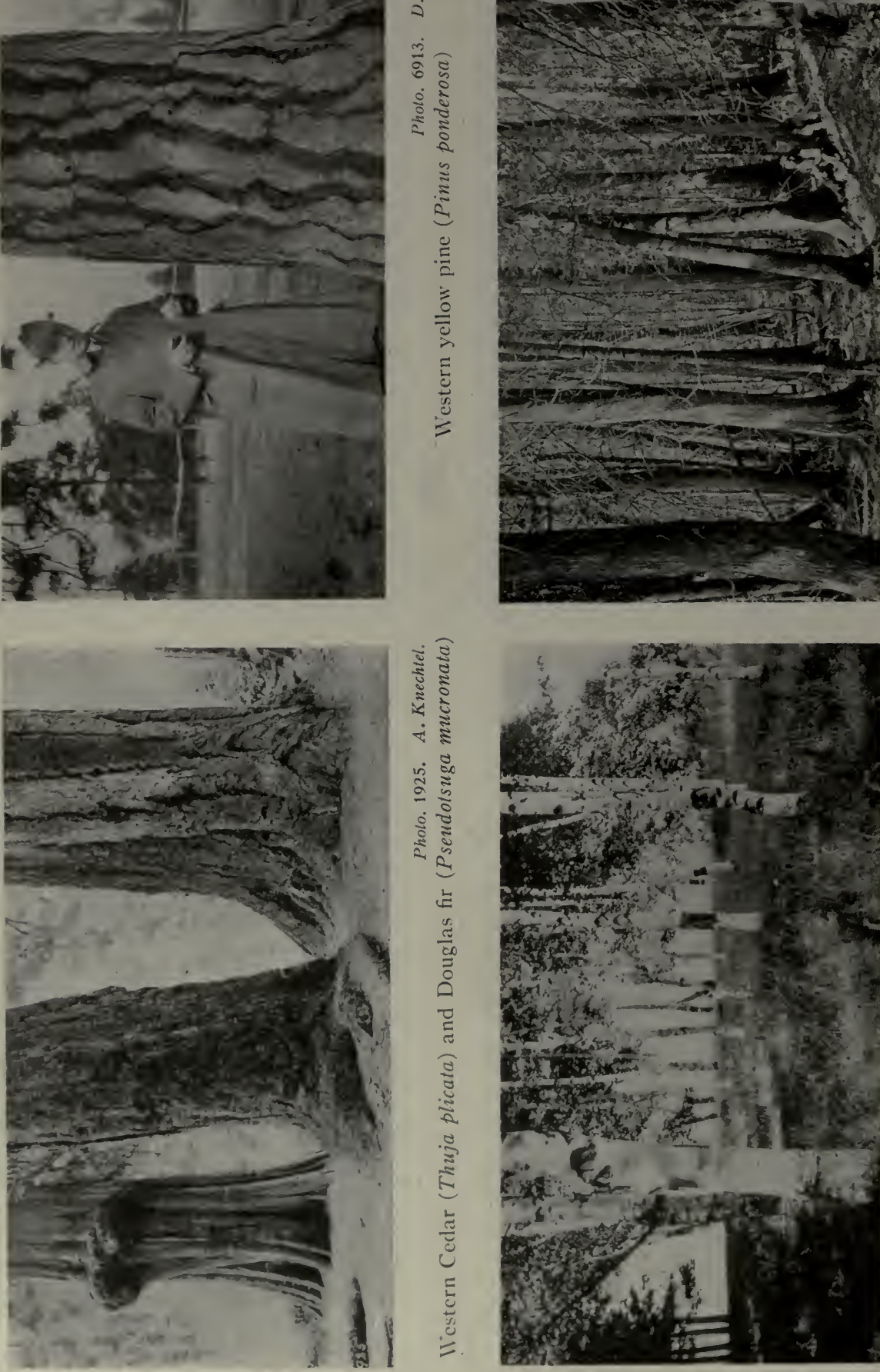

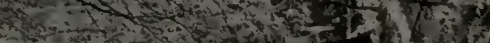

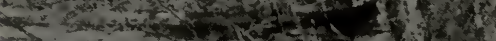

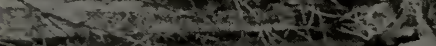

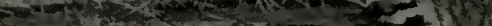

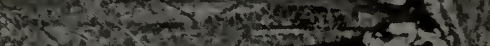

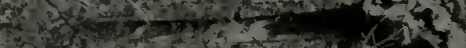

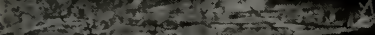

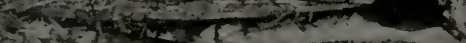

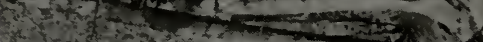

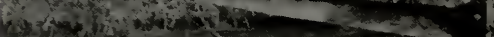

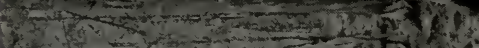

C.

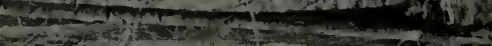

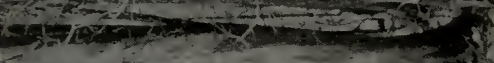

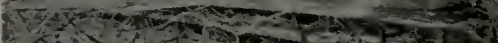

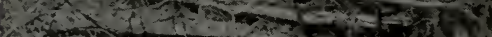

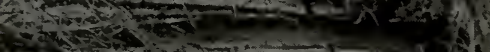

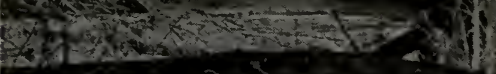

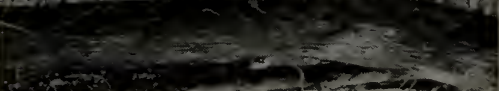

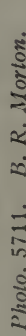

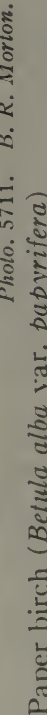




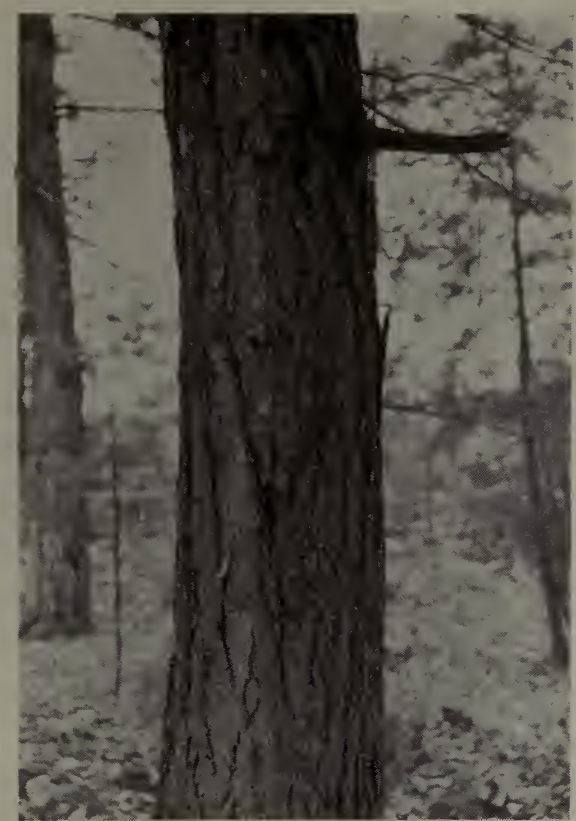

Photo. 8602. B. R. Morton.

Hemlock (Tsuga canadensis)

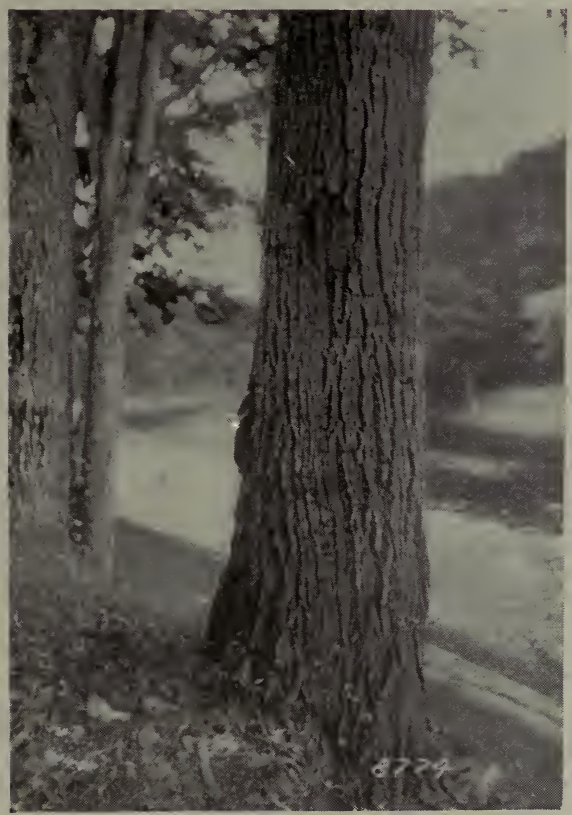

Photo. 8774. B. R. Morton.

Large-toothed aspen (Populus grandidentala)

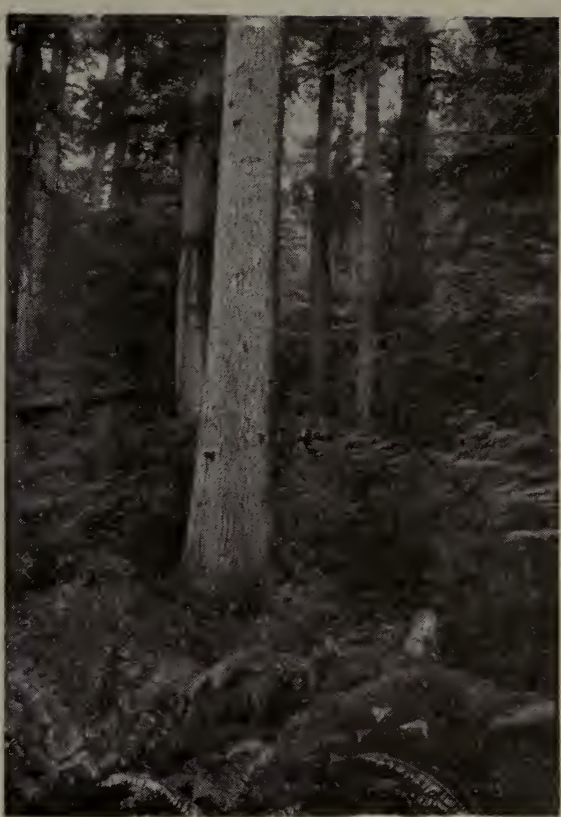

Photo. 485. R. D. Craig.

Western hemlock (Tsuga heierophylla)

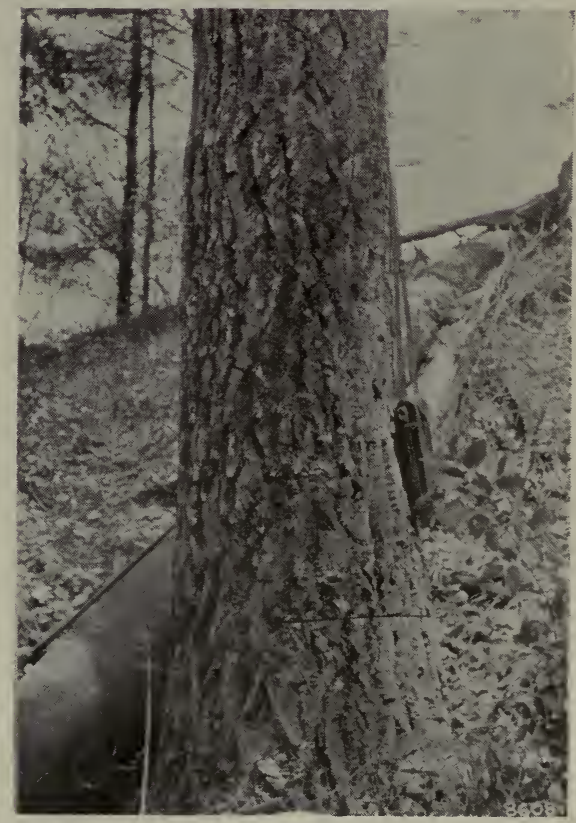

Photo. 8608. B. R. Morton.

Cottonwood (Populus deltoides) 


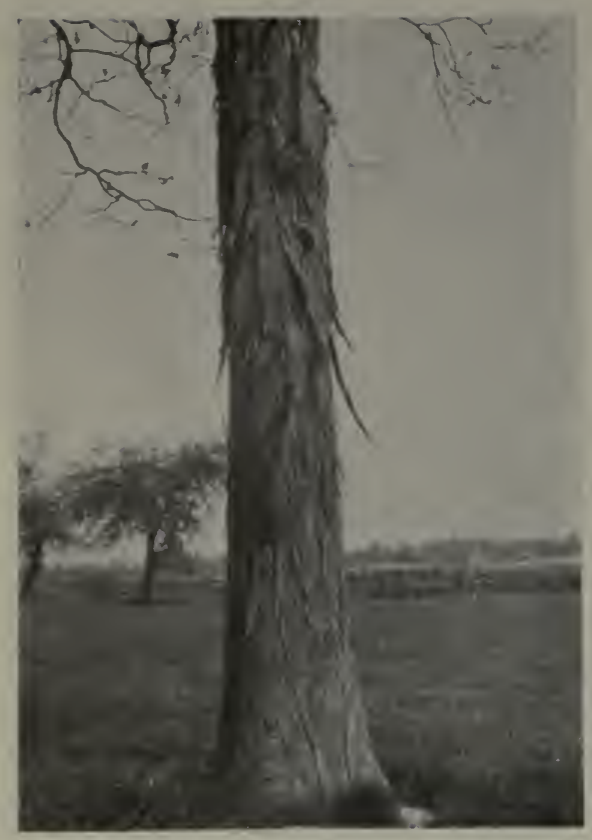

Photo. 8613. B. R. Morton.

Shagbark hickory (Carya ovata)

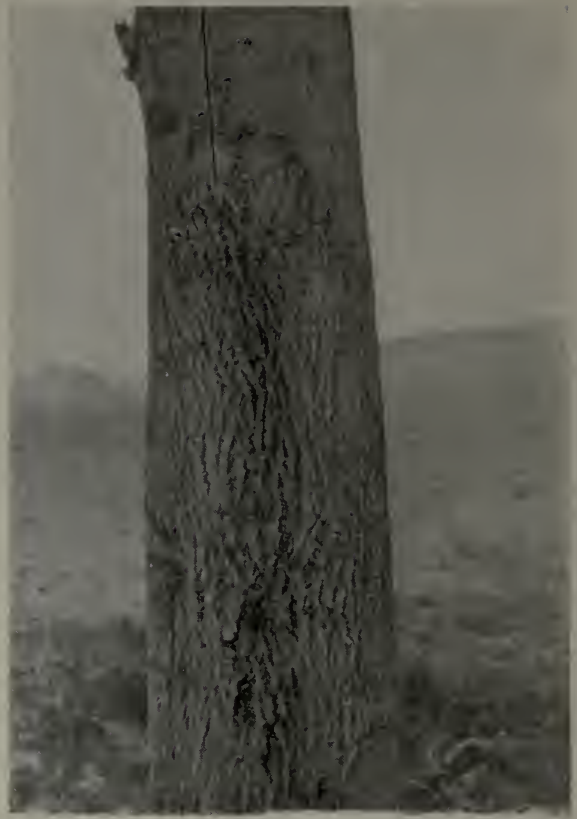

Photo. 8572. B. R. Morlon.

Bitternut hickory (Carya cordiformis)

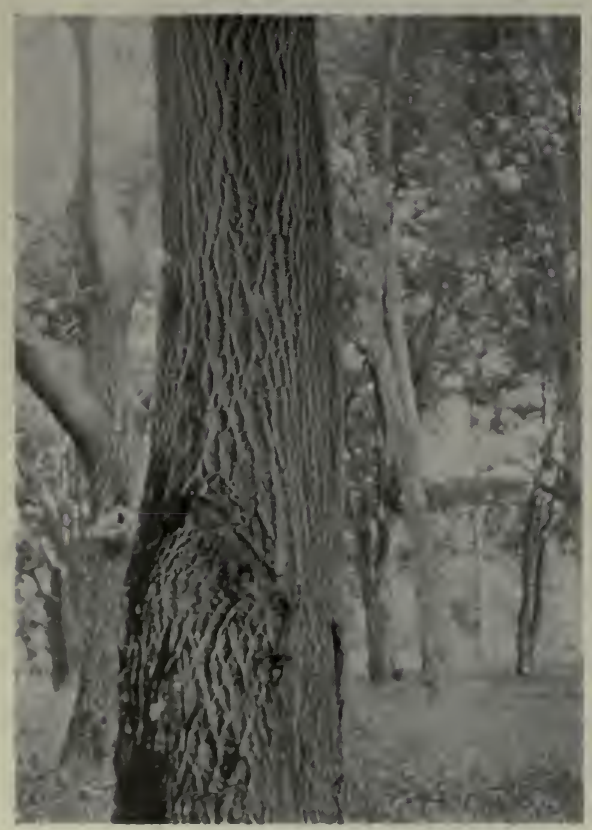

I'holo. 8753. B. R. Morton。

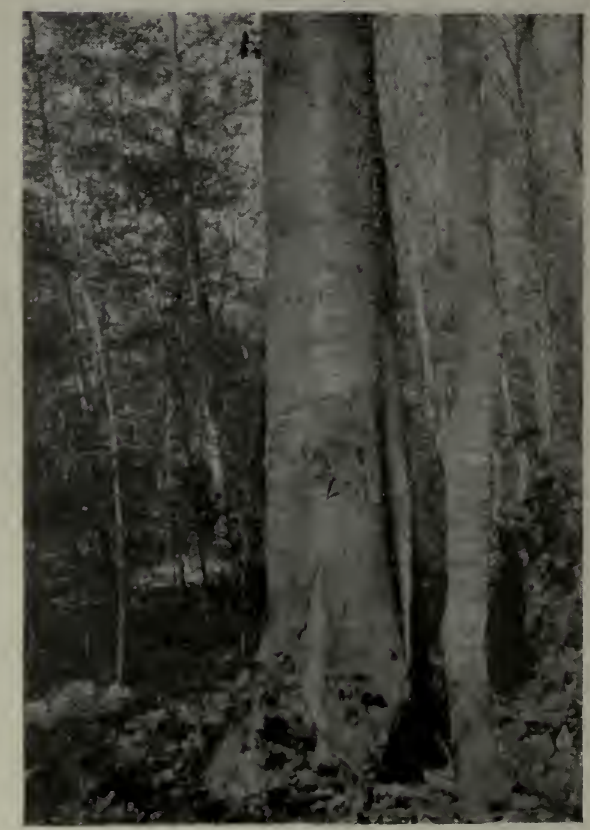

I'hoto. 9424. B. R. Morton.

Yellow birch (Betula lutea) 


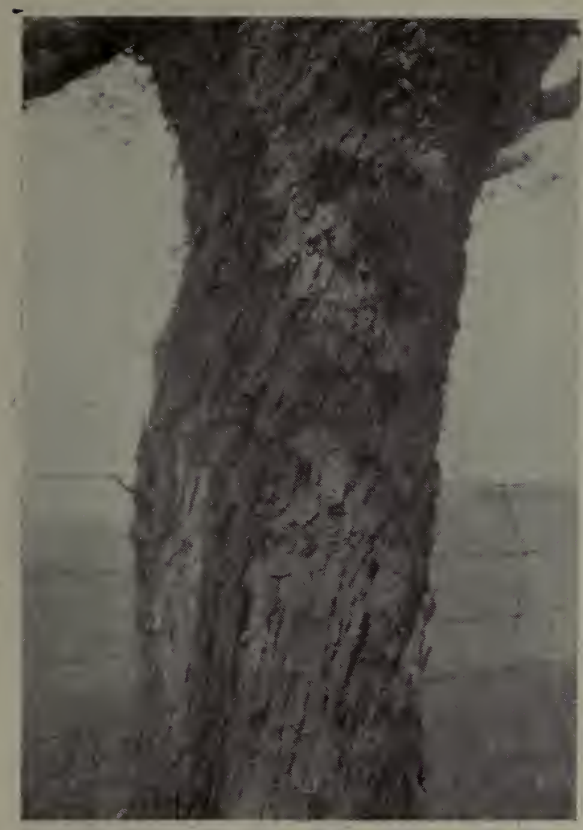

Photo. 8574. B. R. Morton.

Ironwood (Ostrya virginiana)

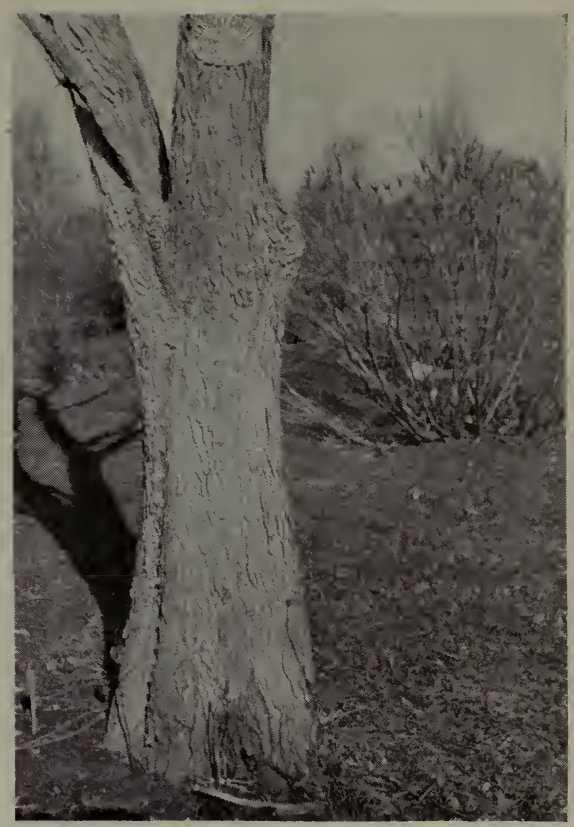

Photo. 10039. B. R. Morton.

Kentucky cof'eetree (Gymnocladus dioica)

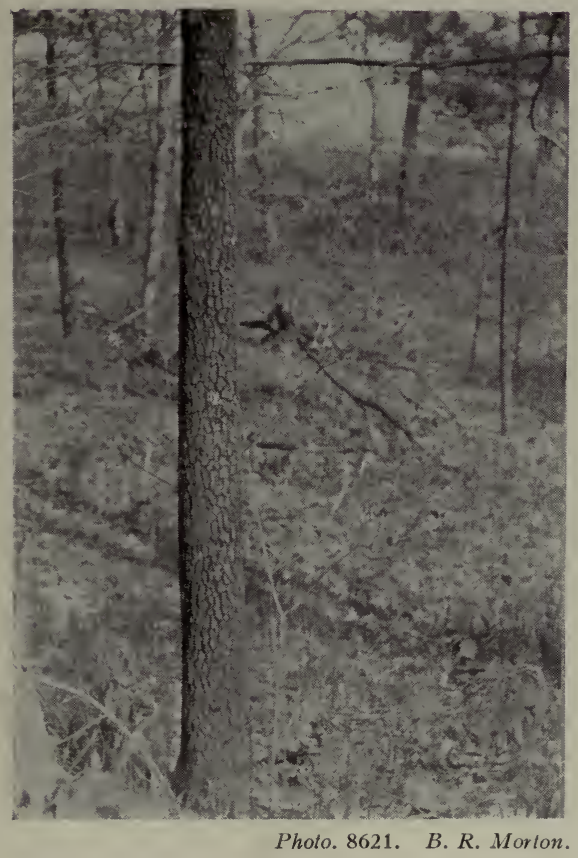

Flowering dogwoed (Cornus florida)

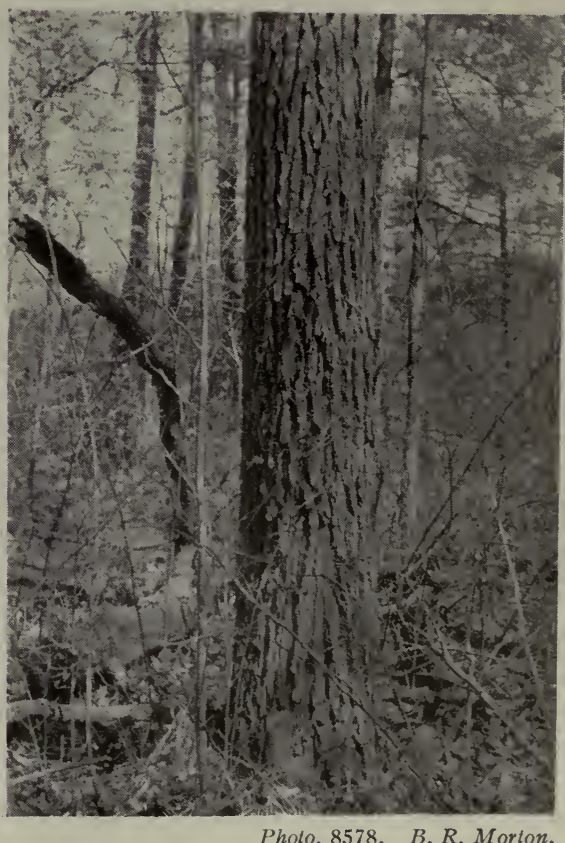

Black gum (Nyssa sylvatica) 


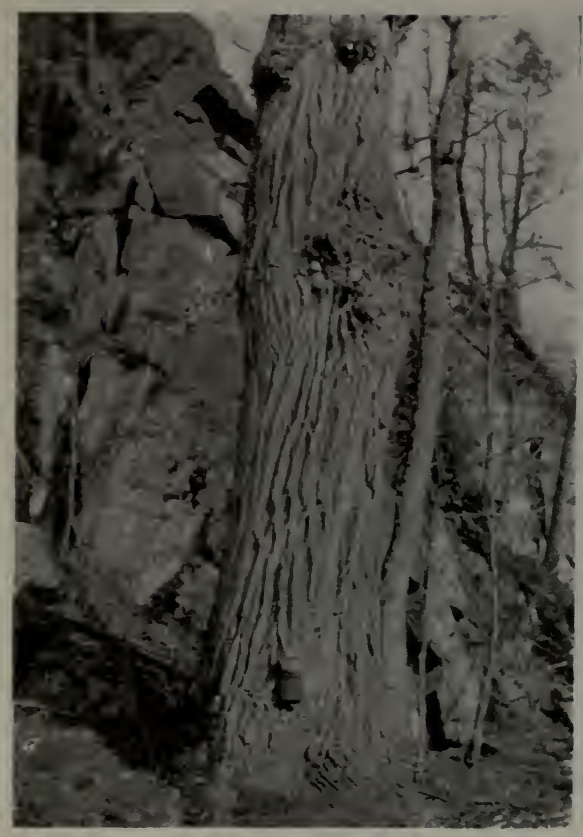

Photo. 8597. B. R. Mortont

White oak (Quercus alba)

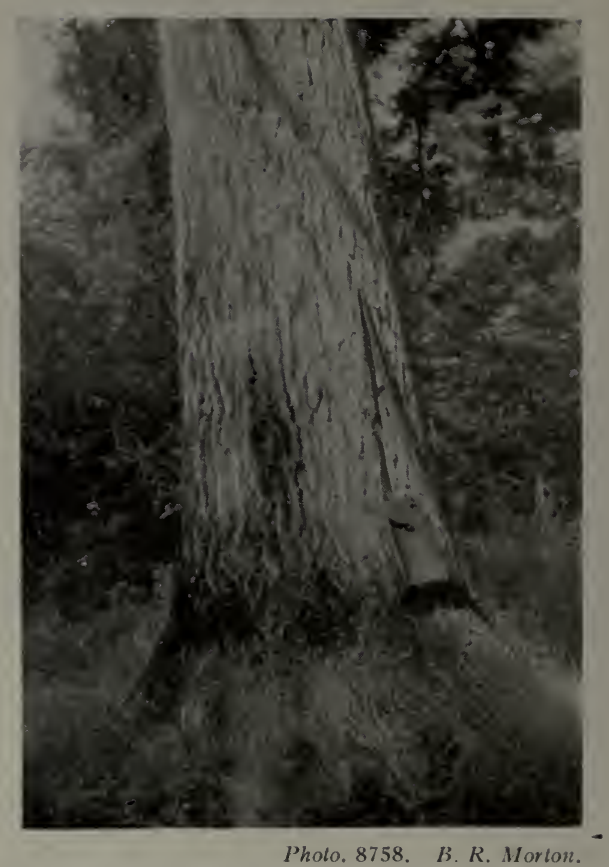

- Red oak (Quercus rubra)

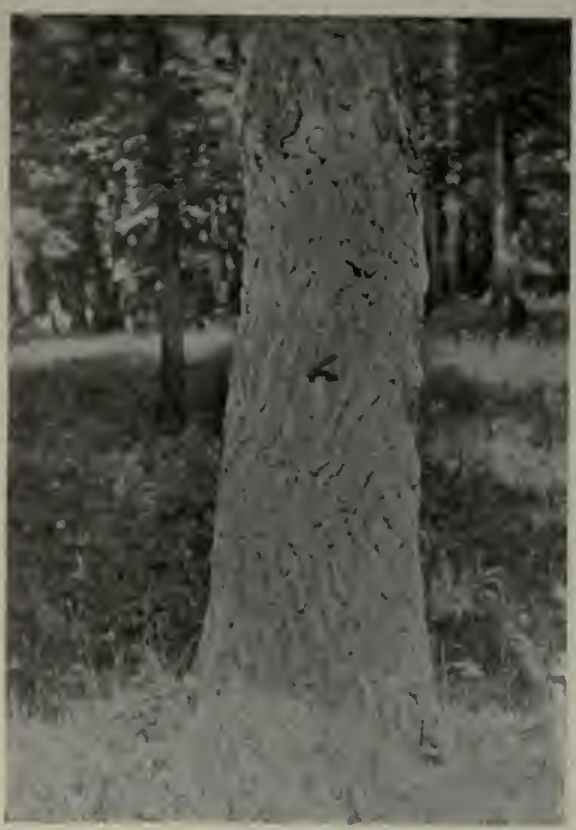

I'hoto. 8756. B. R. Morlon.

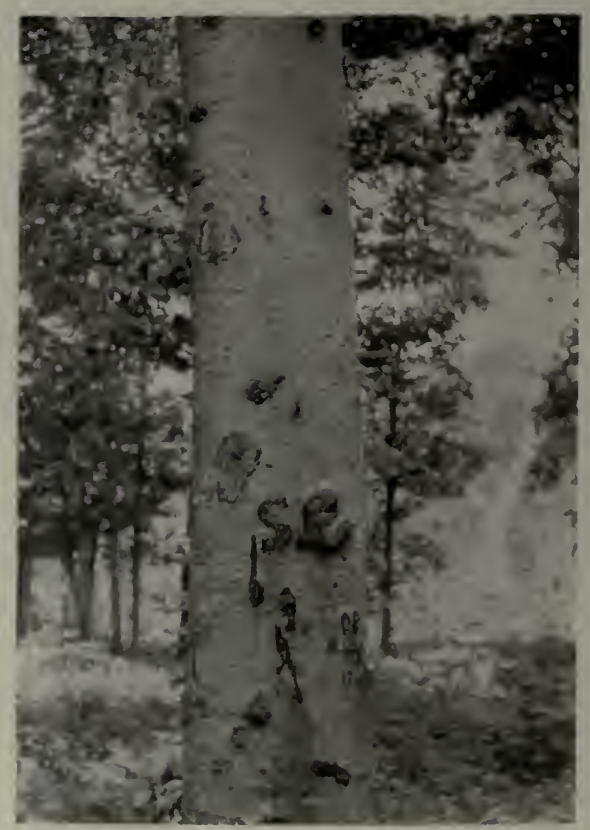

I'holo. 8750. B. R. Morlon.

Beech (Fagus grandiflolia)

Bur oak (Quercus macrocarpa) 


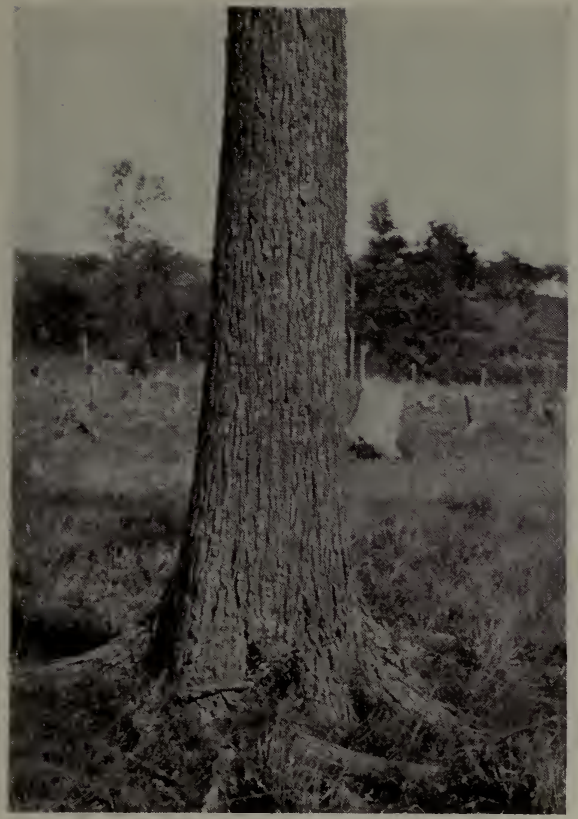

Photo. 9333. B. R. Morton.

White elm (Ulmus americana)

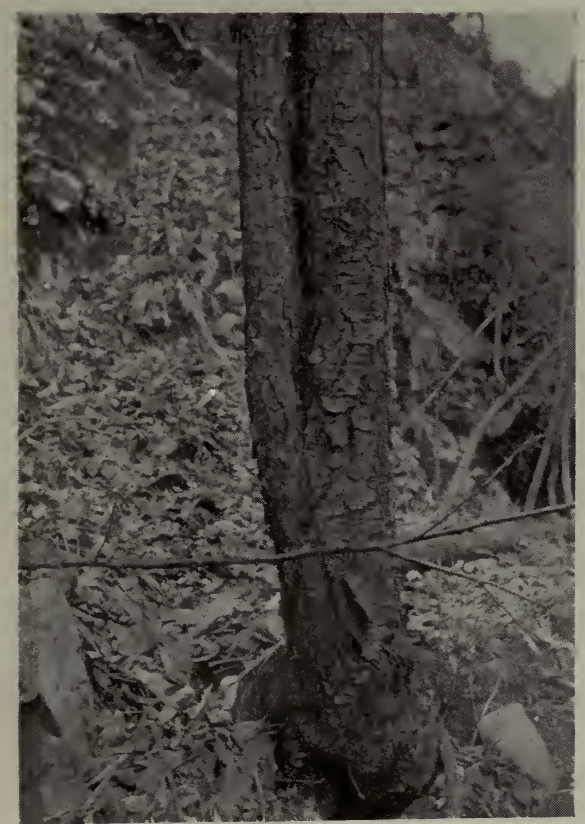

Photo. 8587. B. R. Morton.

Black cherry (Prunus serotina)

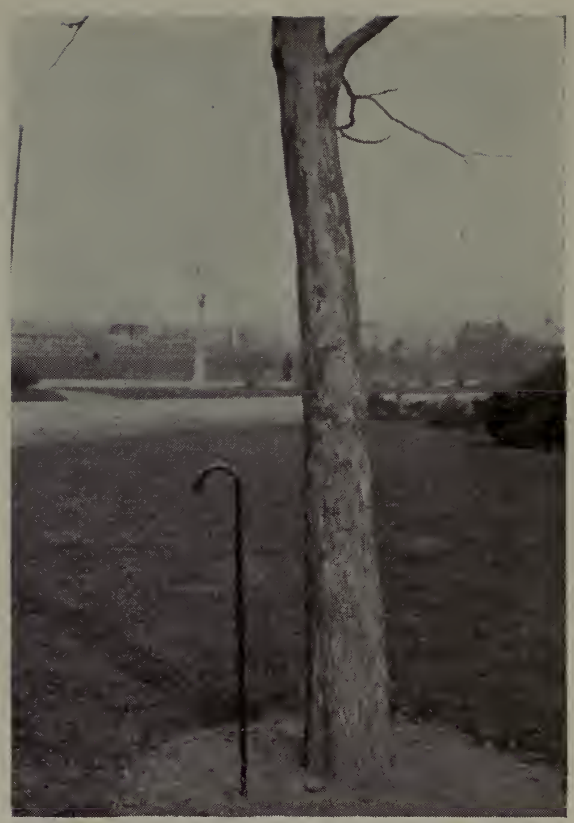

Photo. 10065. B. R. Morton

Sycamore (Platanus occidentalis)

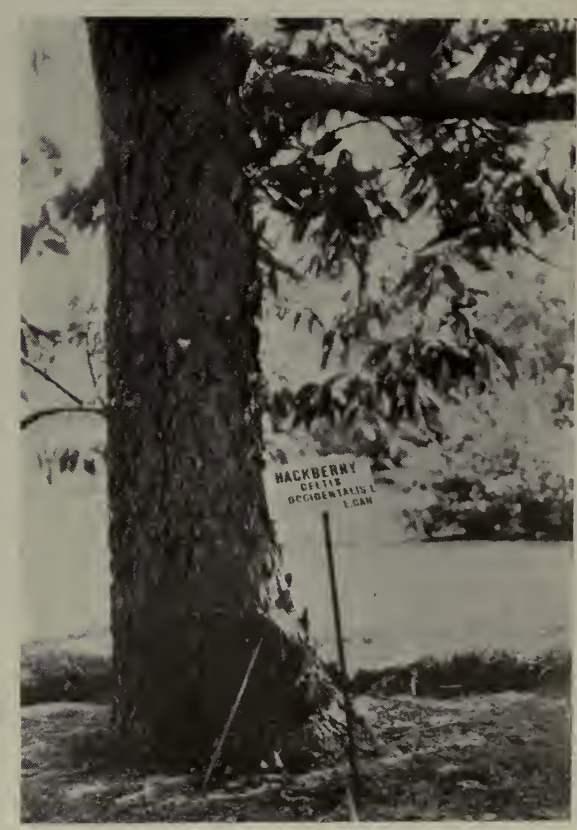

Photo. 6061. B. R. Morton.

Hackberry (Celtis occidentalis) 


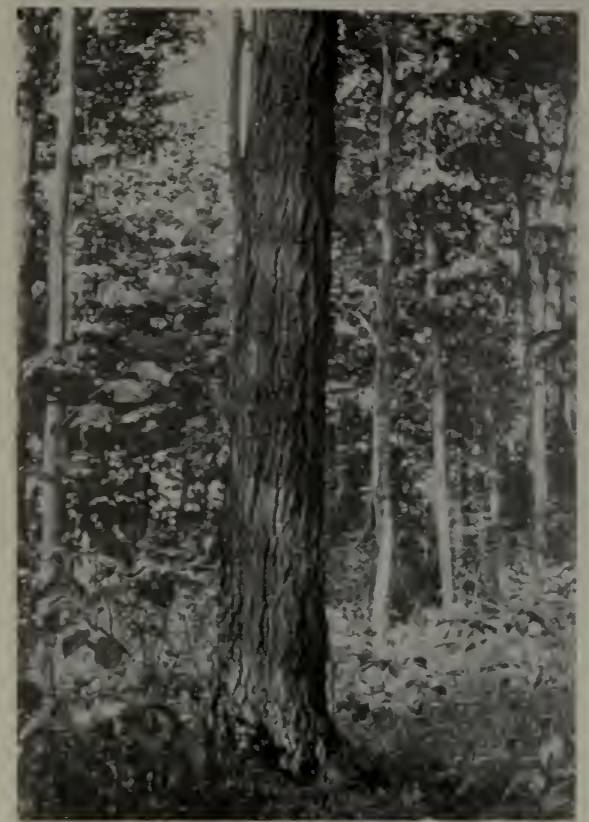

Photo. 10568. B. R. Morton.

Sugar maple (Acer saccharum)

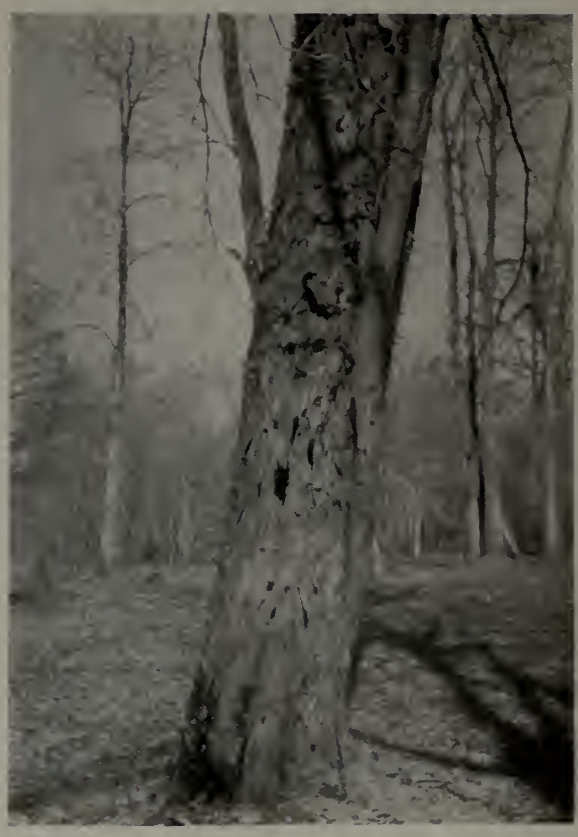

Pinsts. 830 . B. R. Morton.

Silver maple (Acer saccharinum)

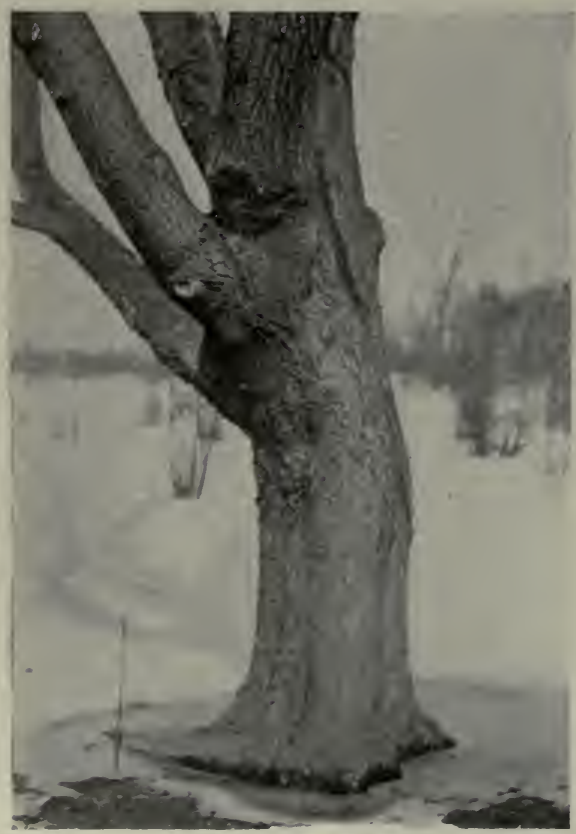

I'hoto. 8288. B. R. Morton。

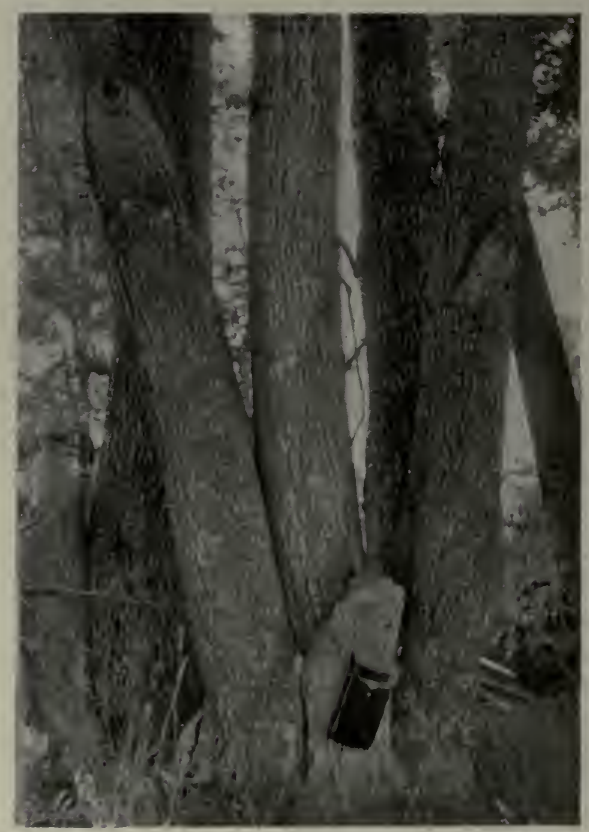

P'holo. 8748. B. R. Morton.

Basswood (Tilia americana) 


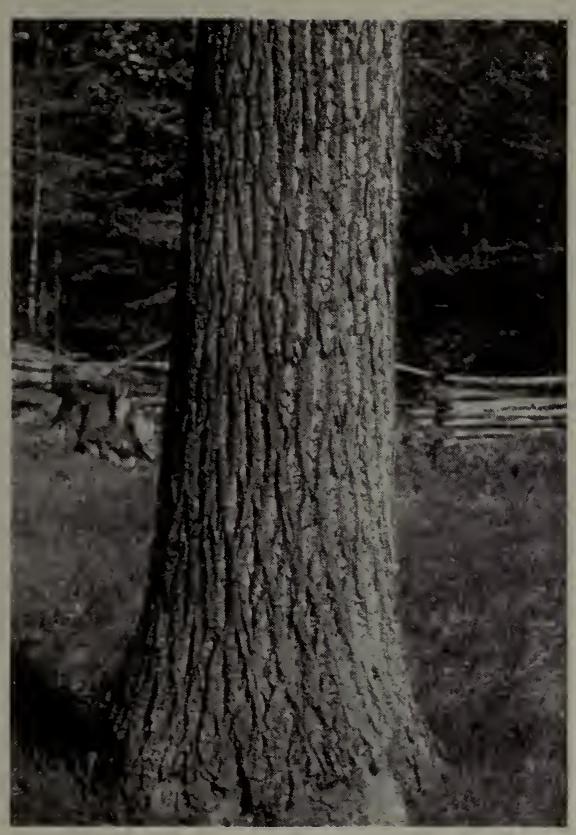

Photo. 8515. B. R. Morton.

White ash (Fraxinus americana)

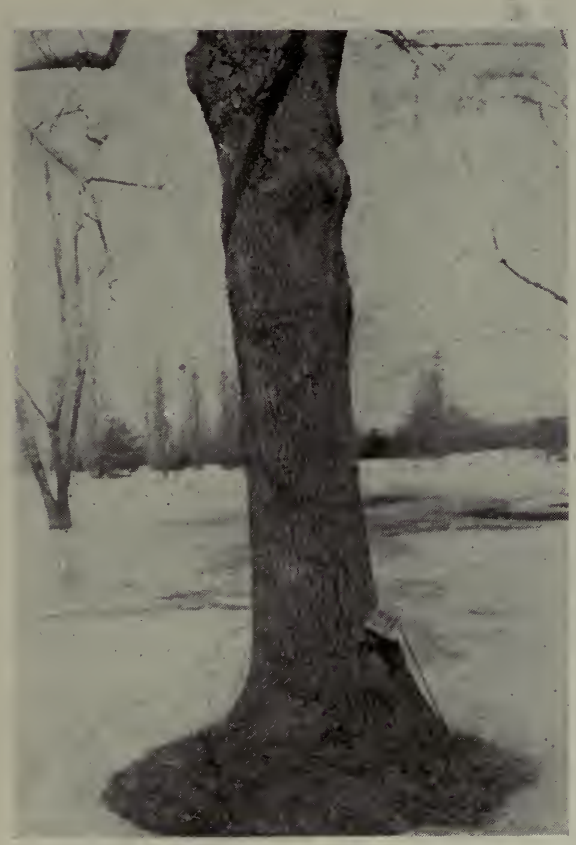

Photo. 8292. B. R. Morton. Red ash (Fraxinus pennsylvanica)

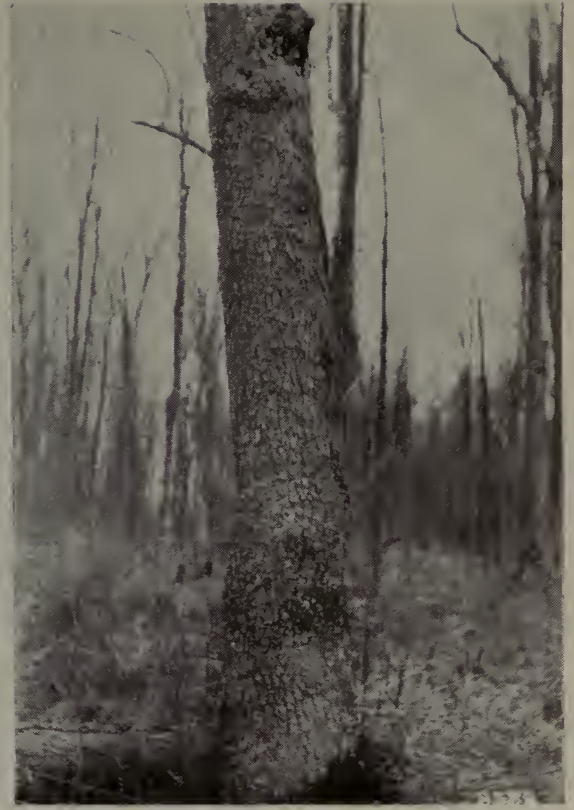

Photo. 8588. B. R. Morton

Black ash (Fraxinus nigra)

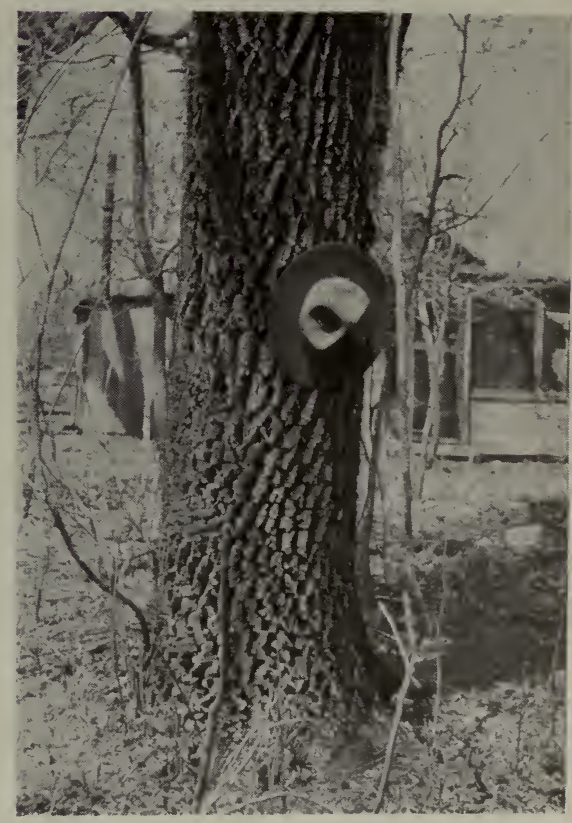

Photo, 10203. B. R. Morton.

Green ash (Fraxinus pennsylvanica, var. lanceolata) 


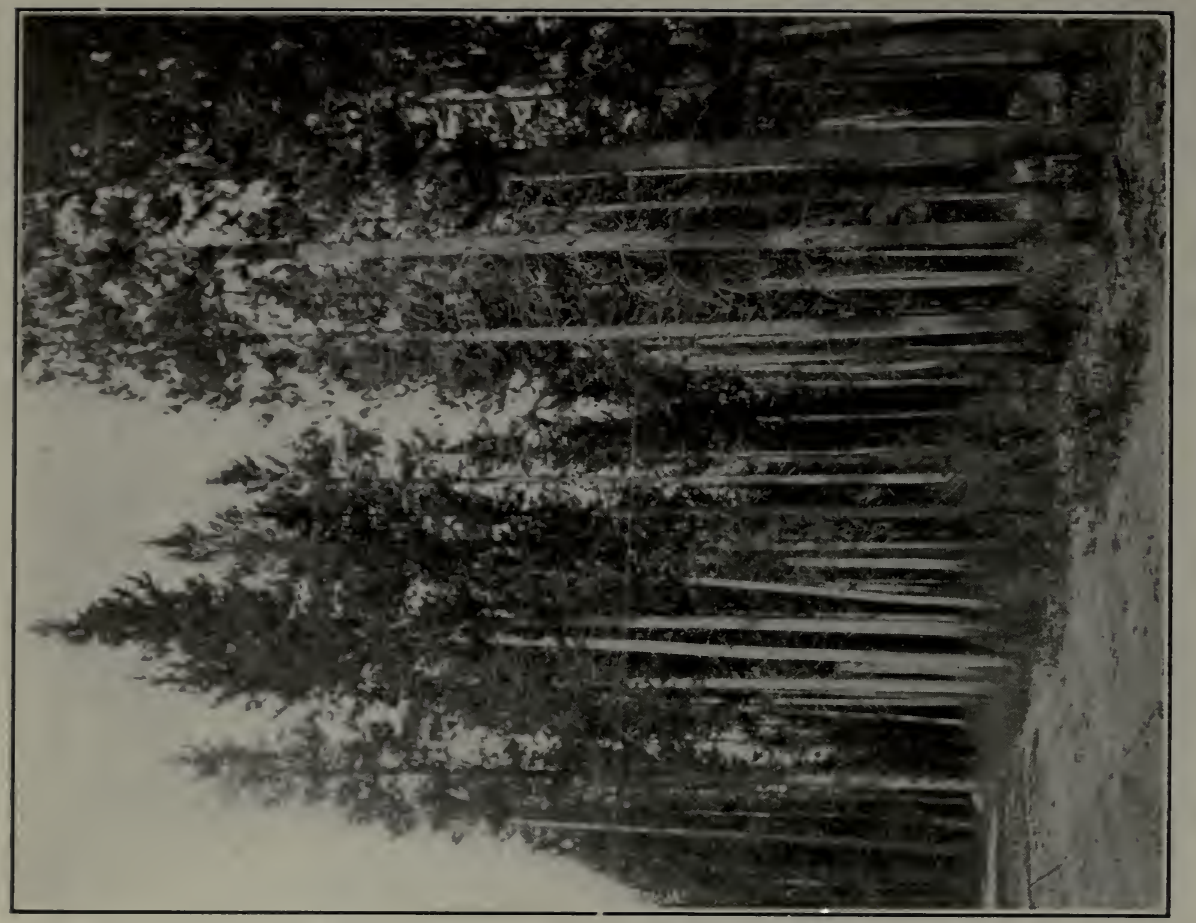

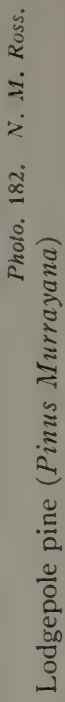

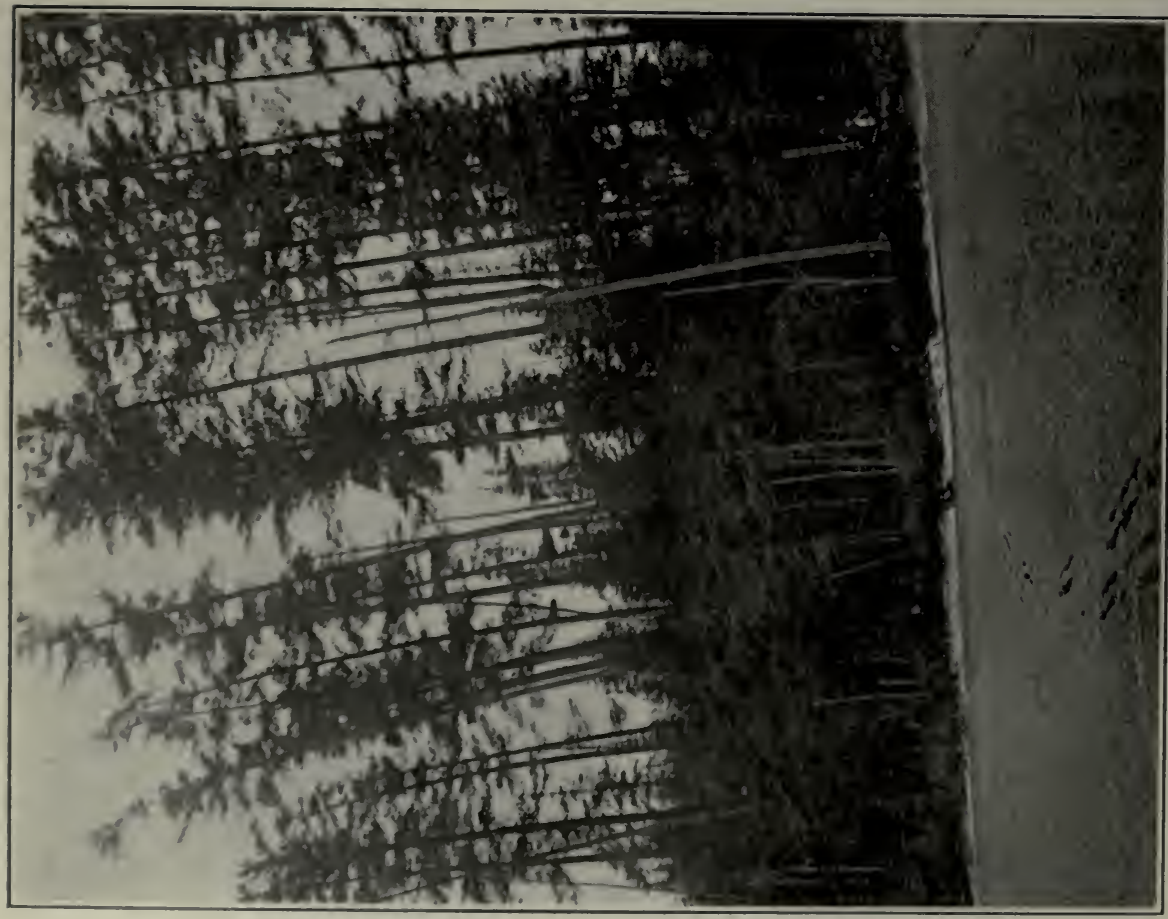

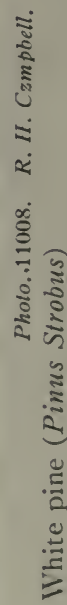




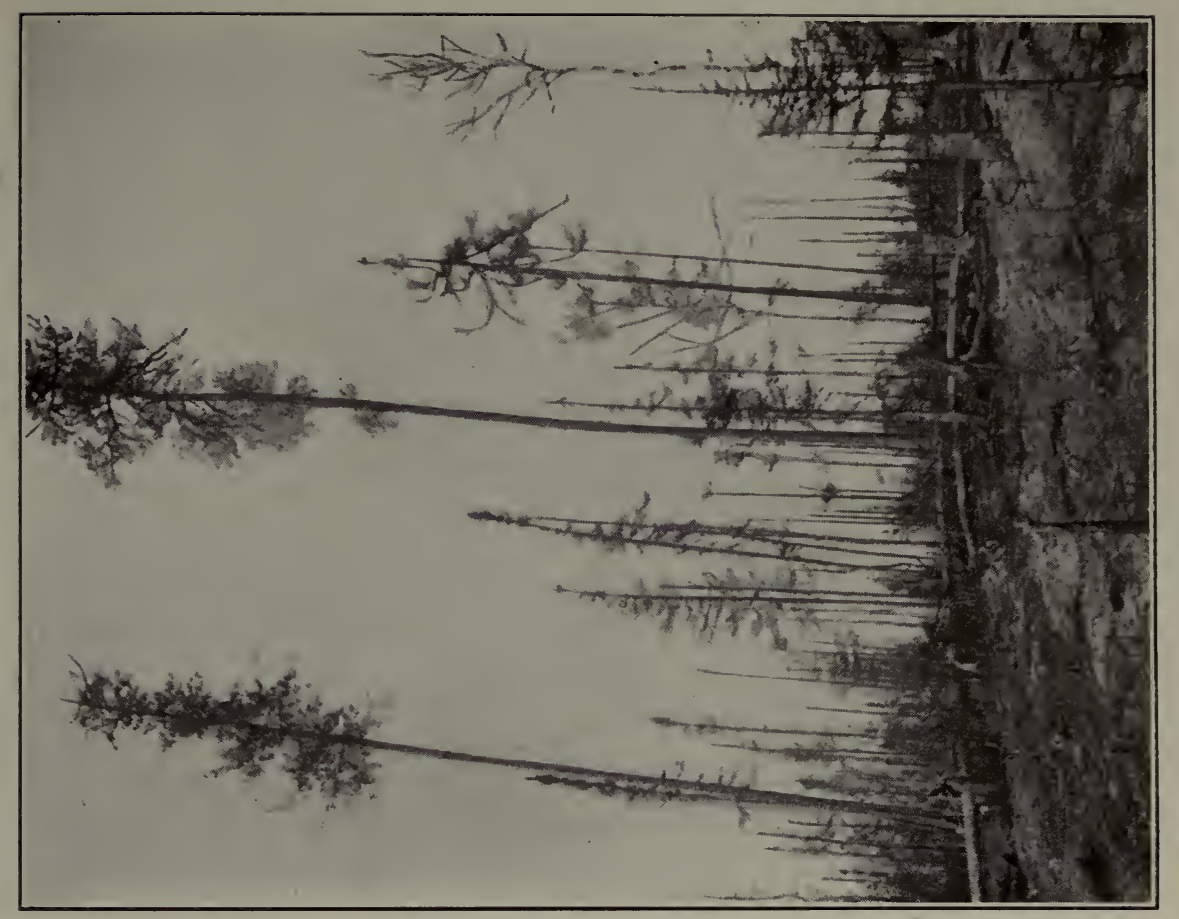

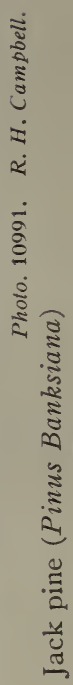

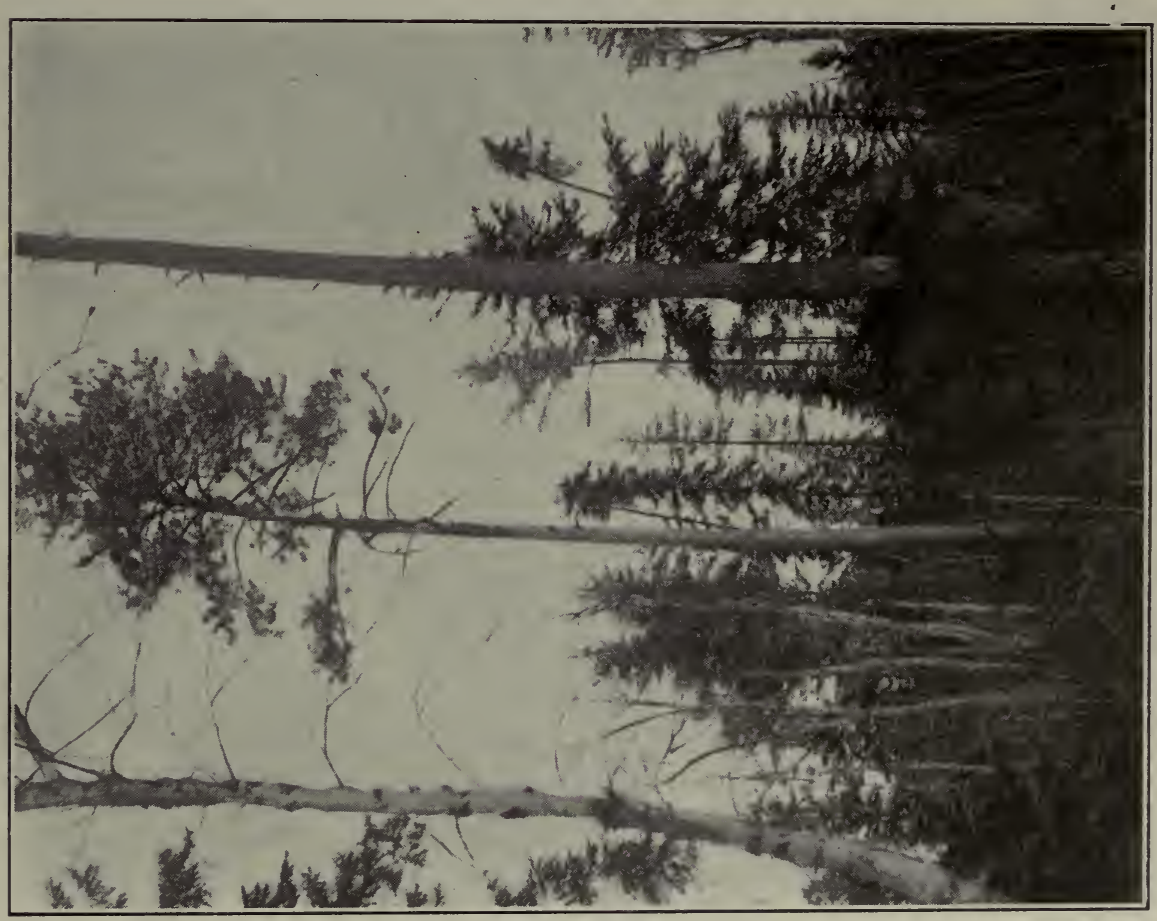

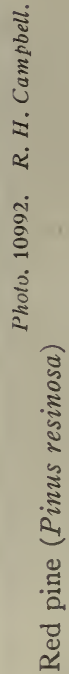



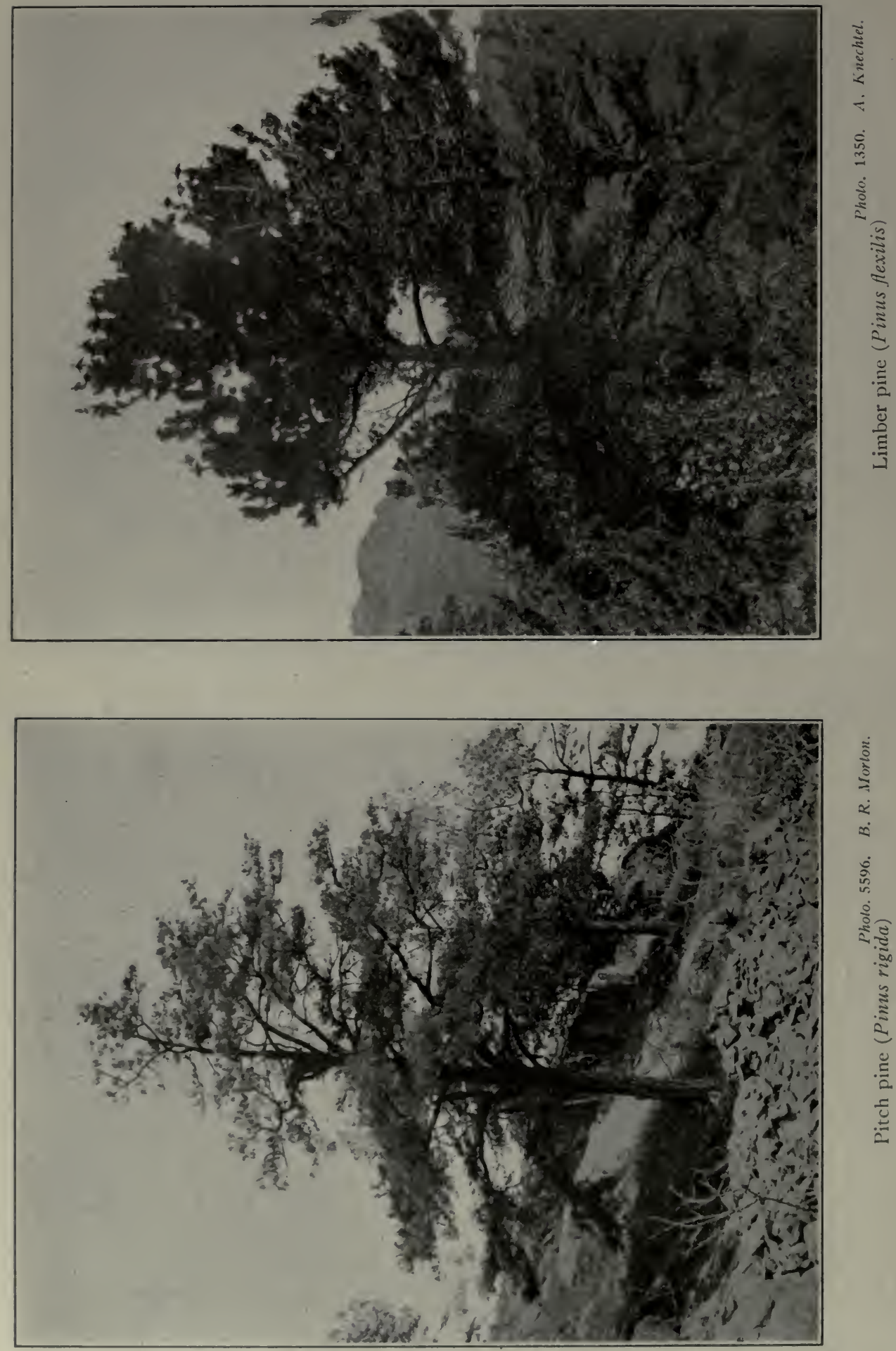

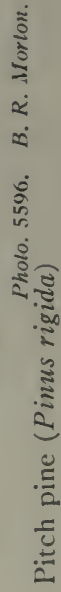




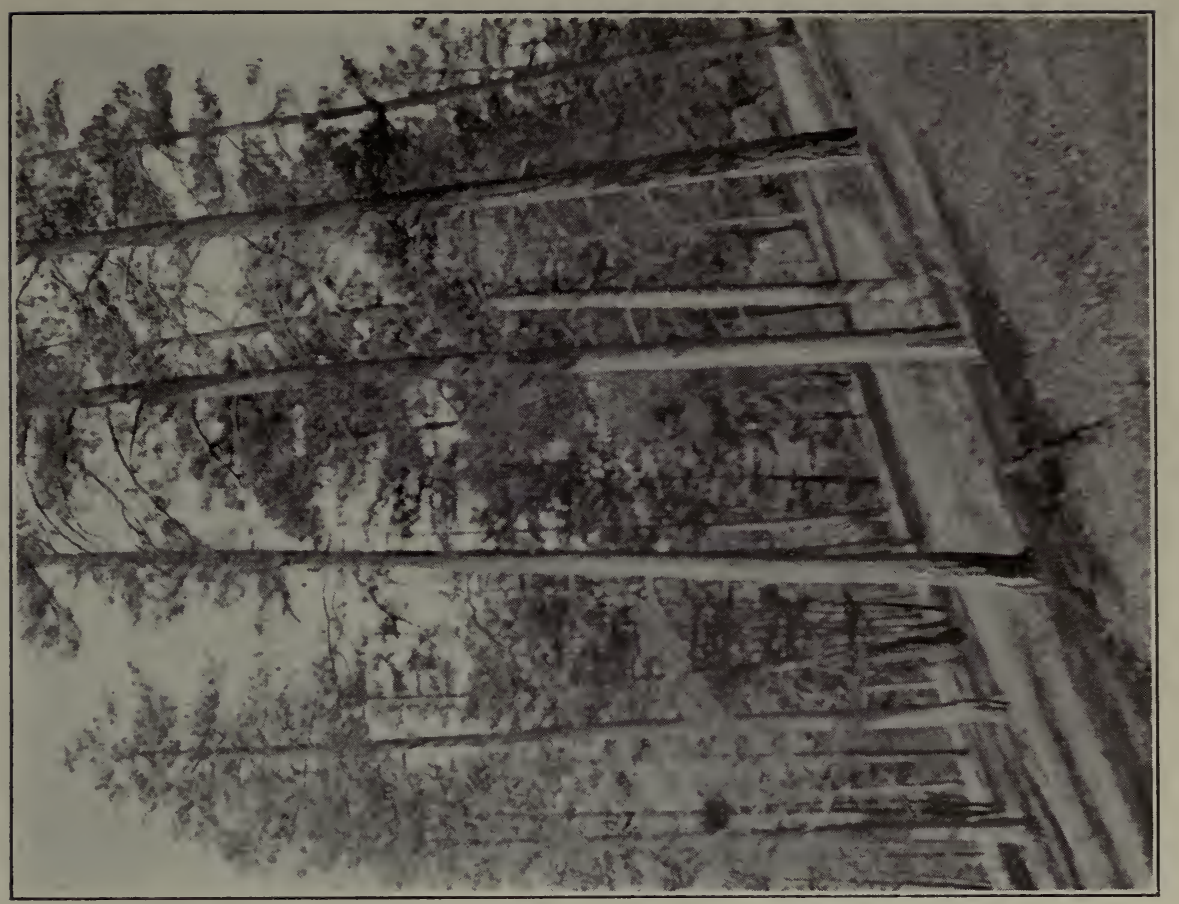

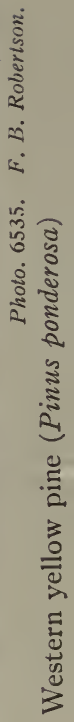

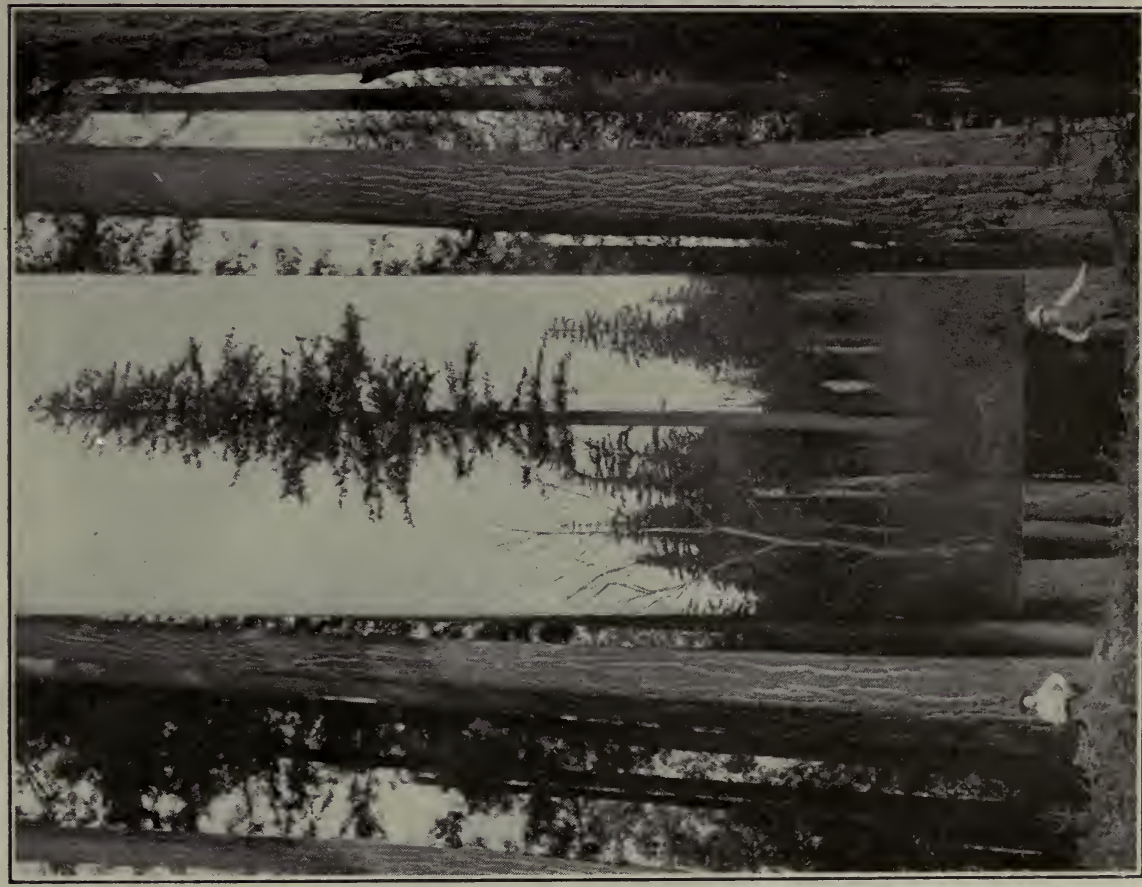




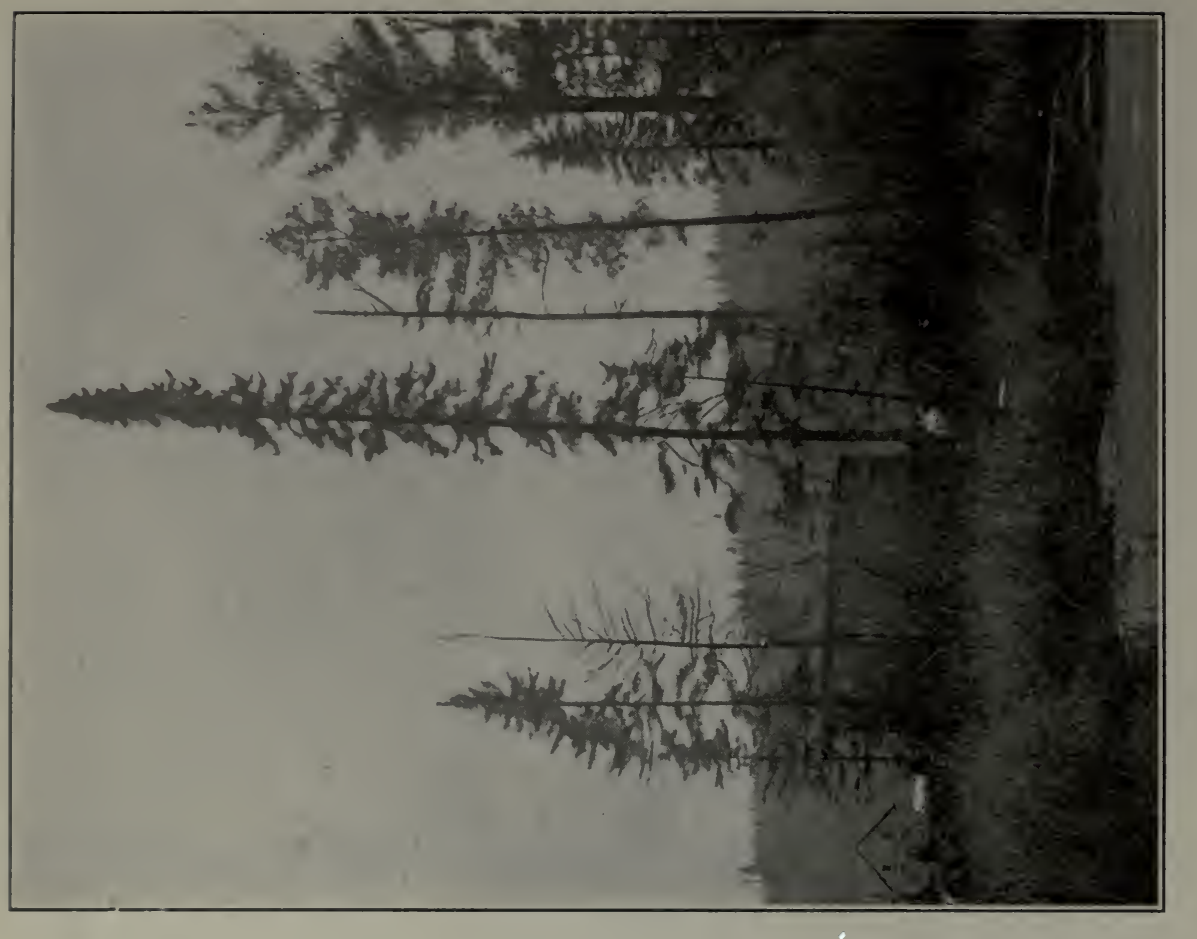

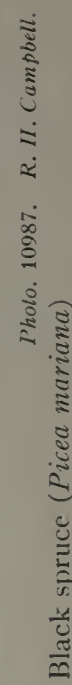

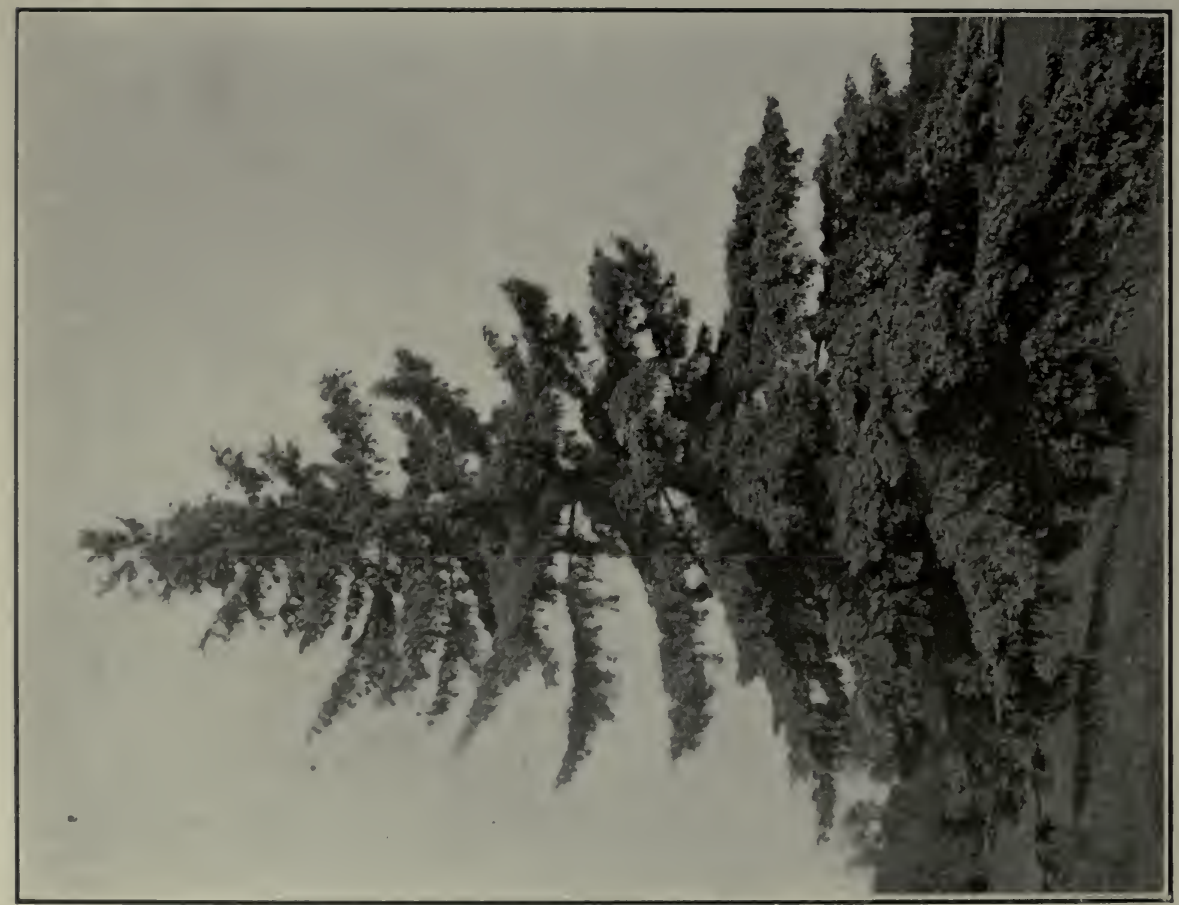

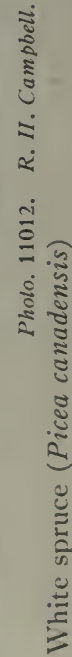




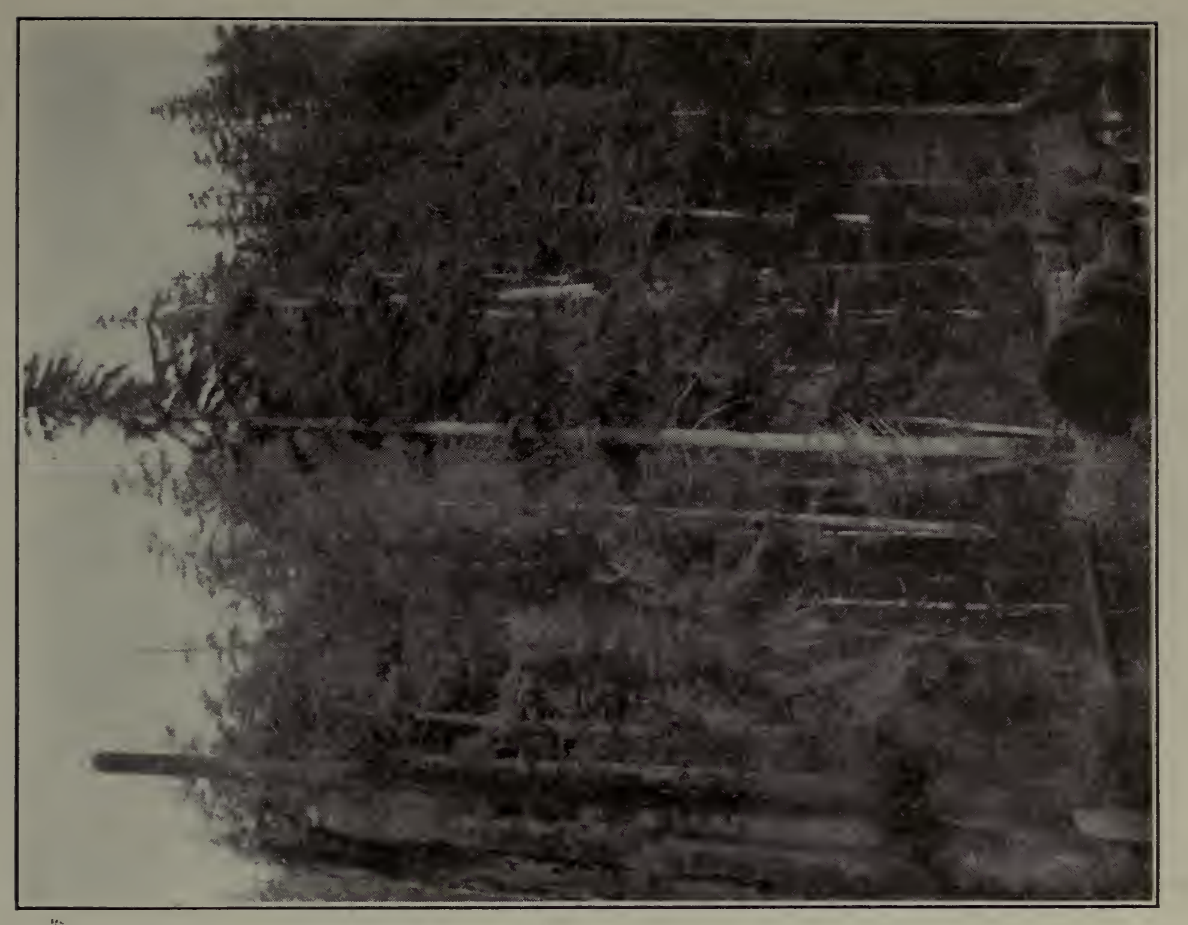

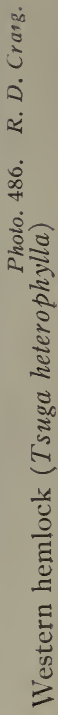

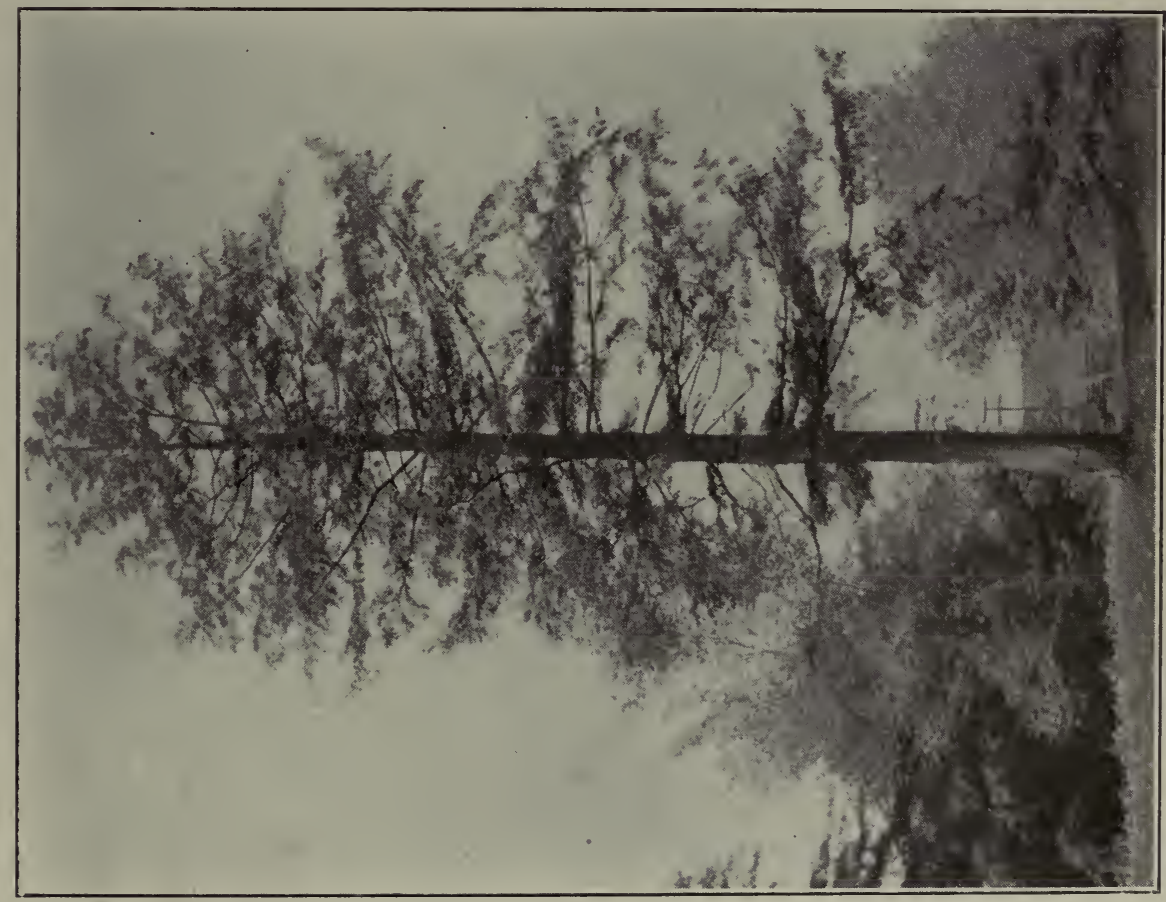

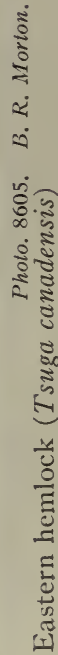




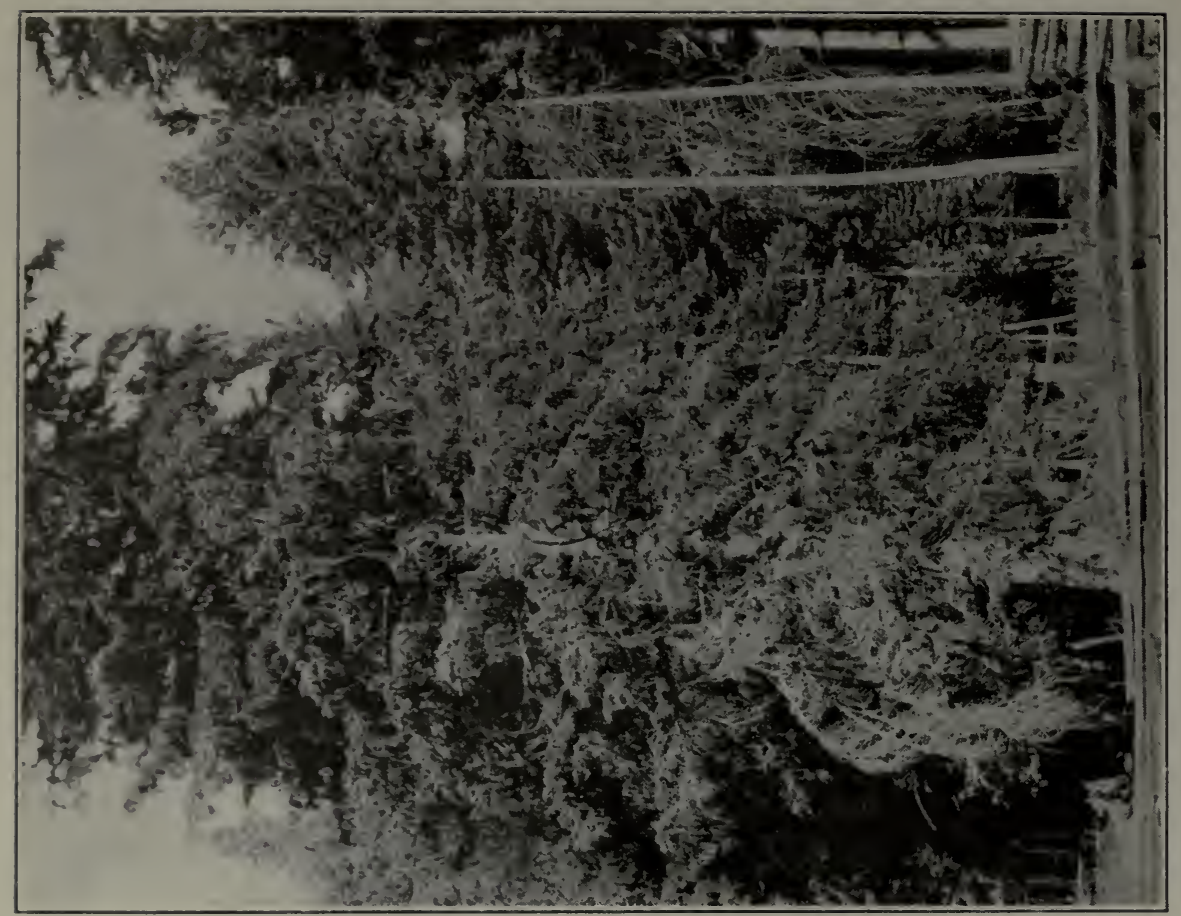

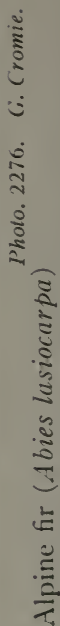

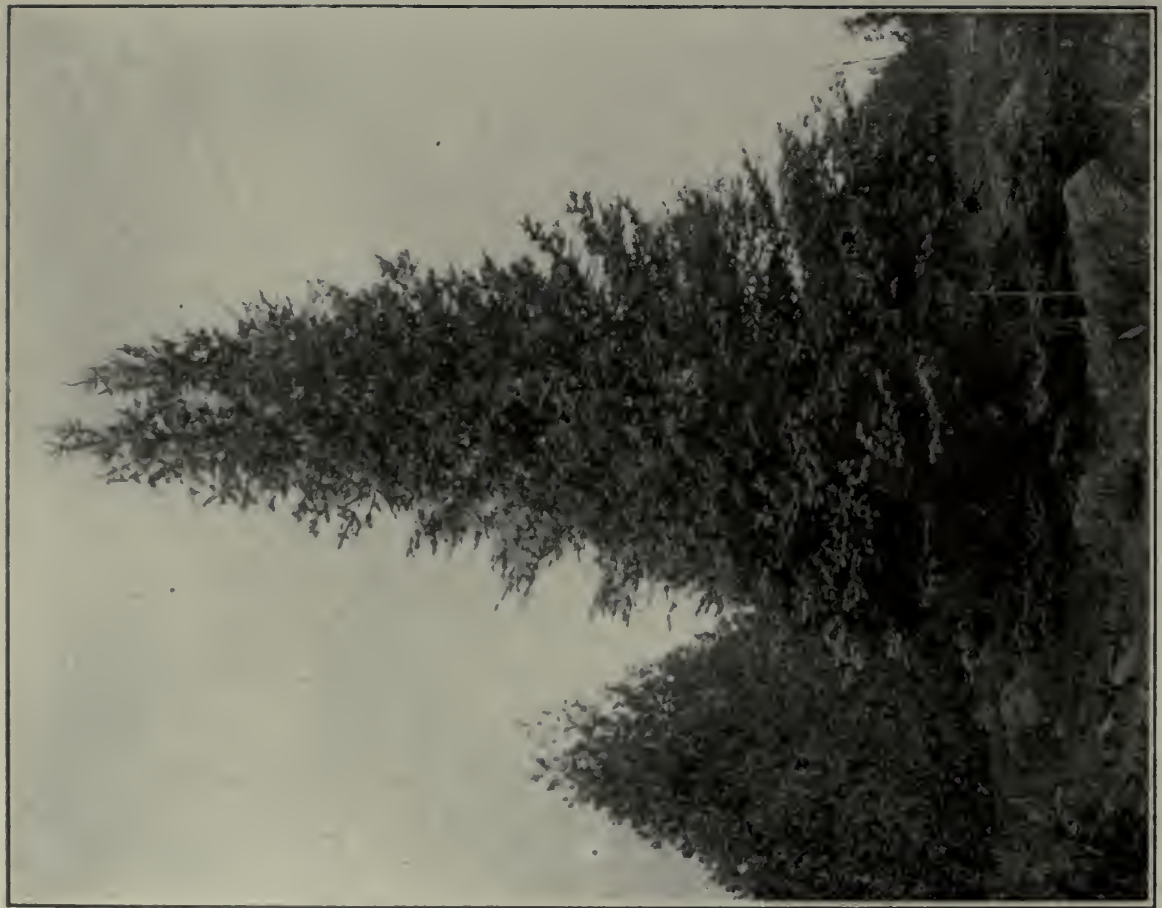

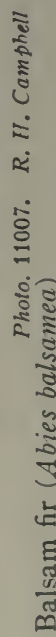




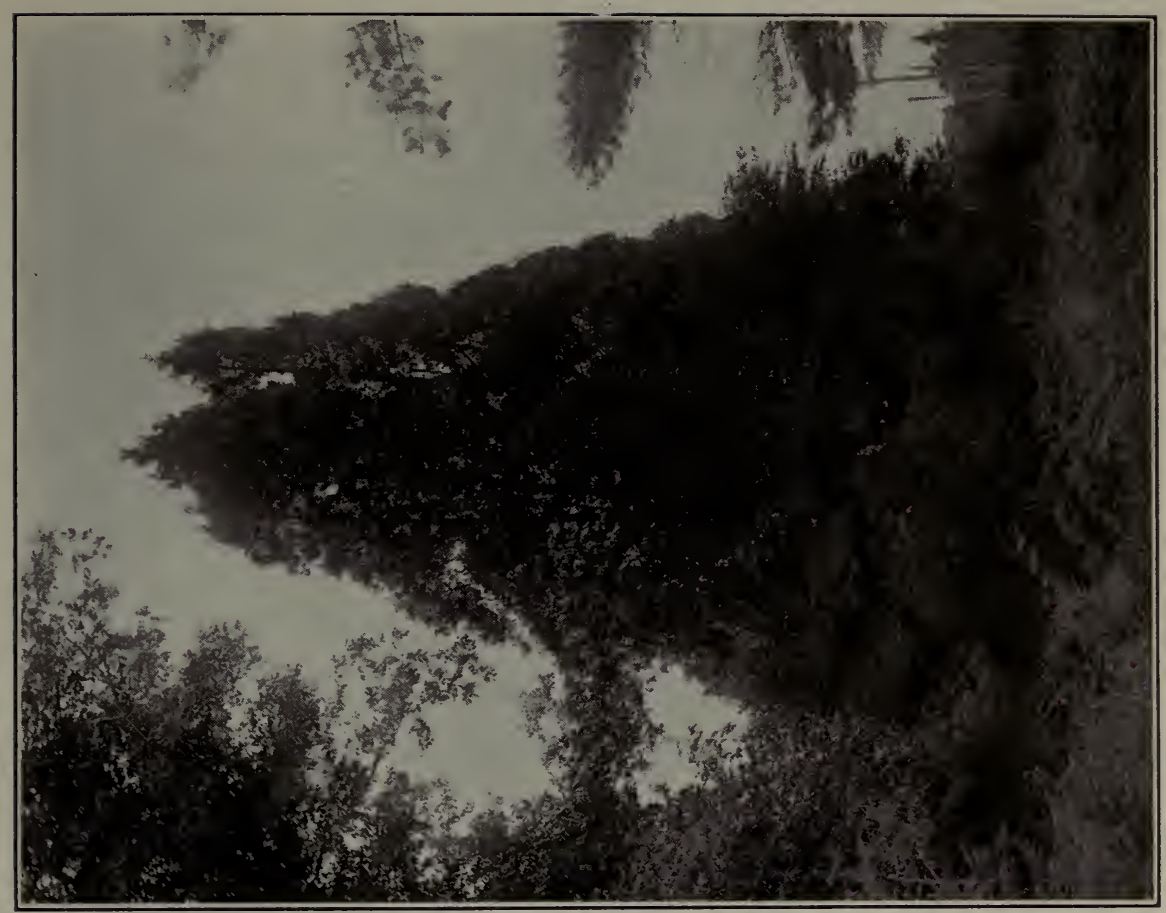

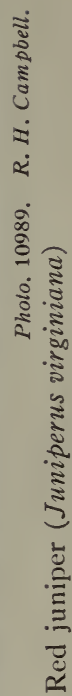

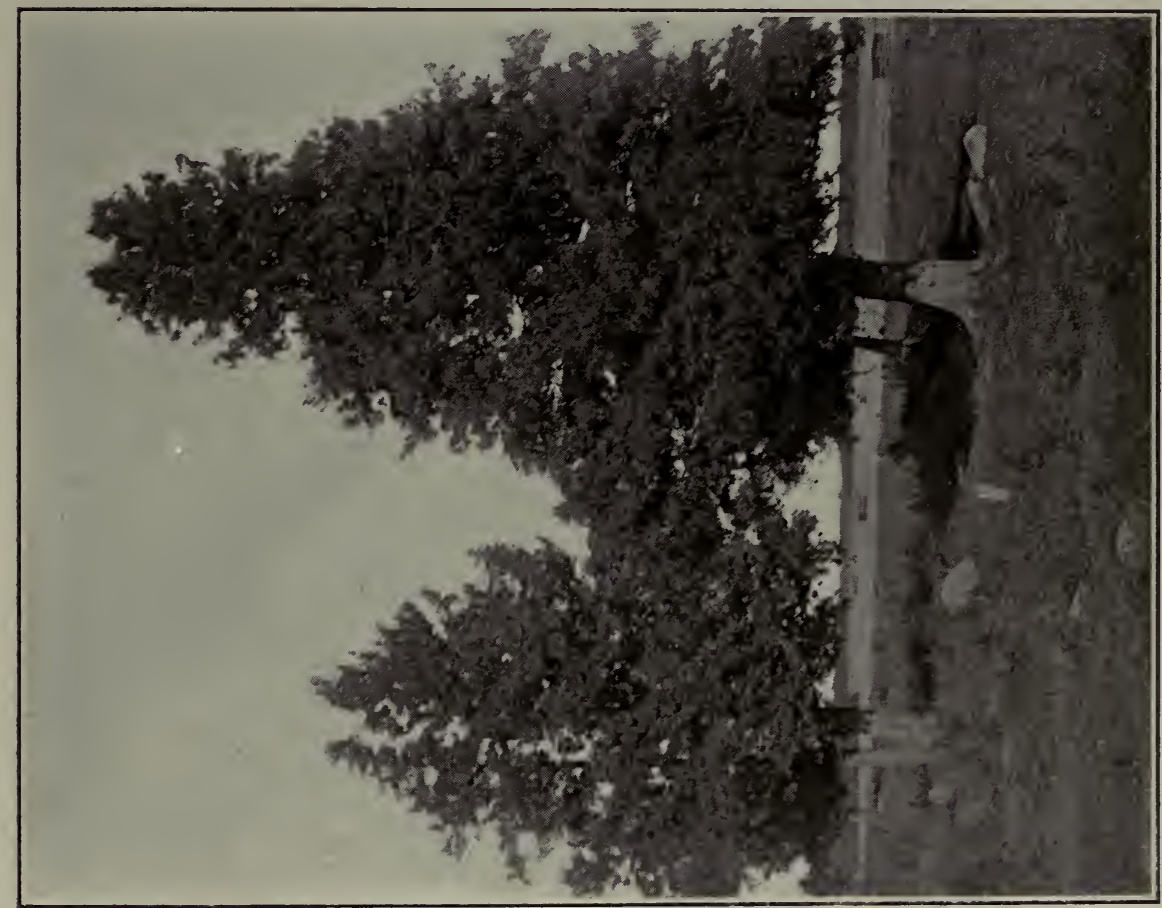

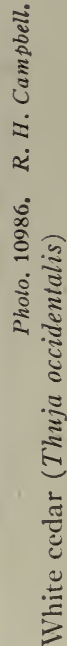




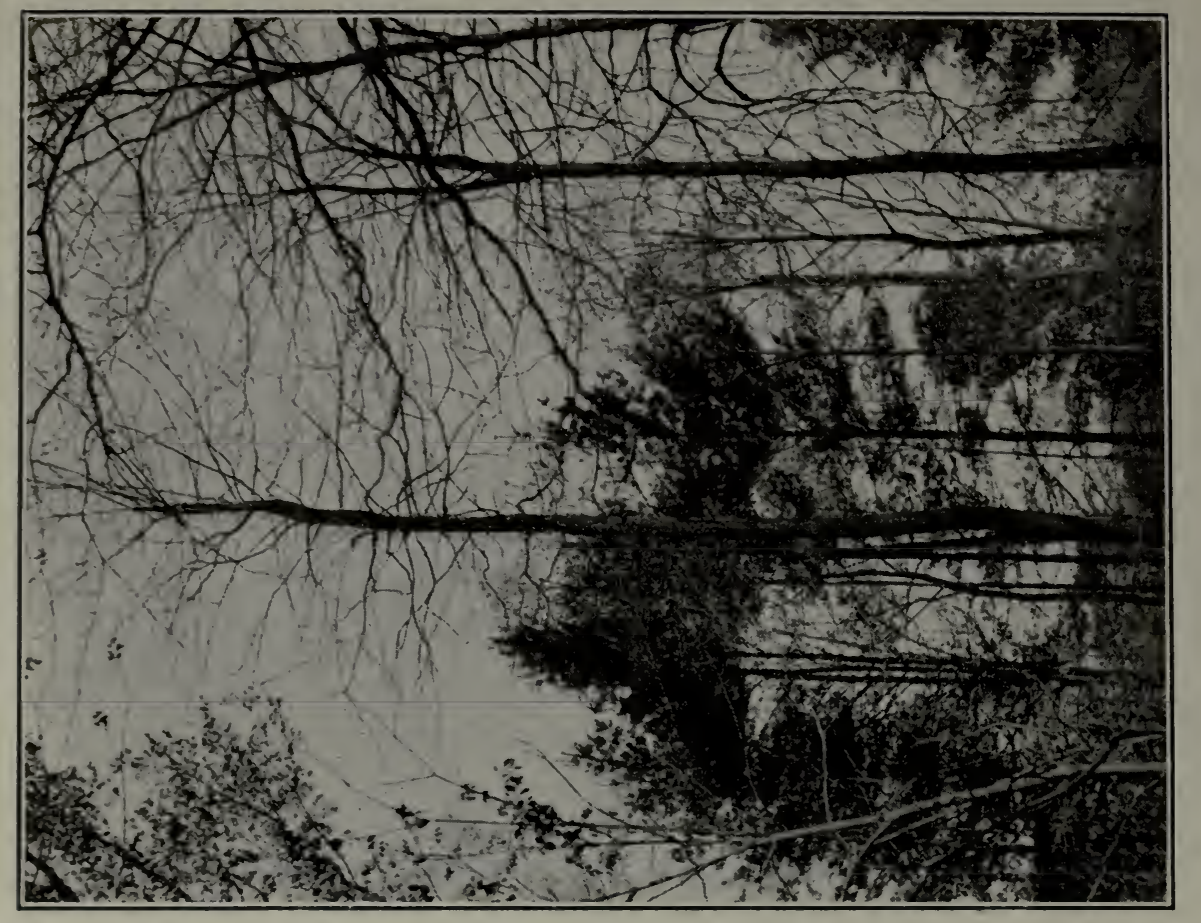

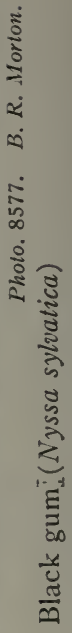

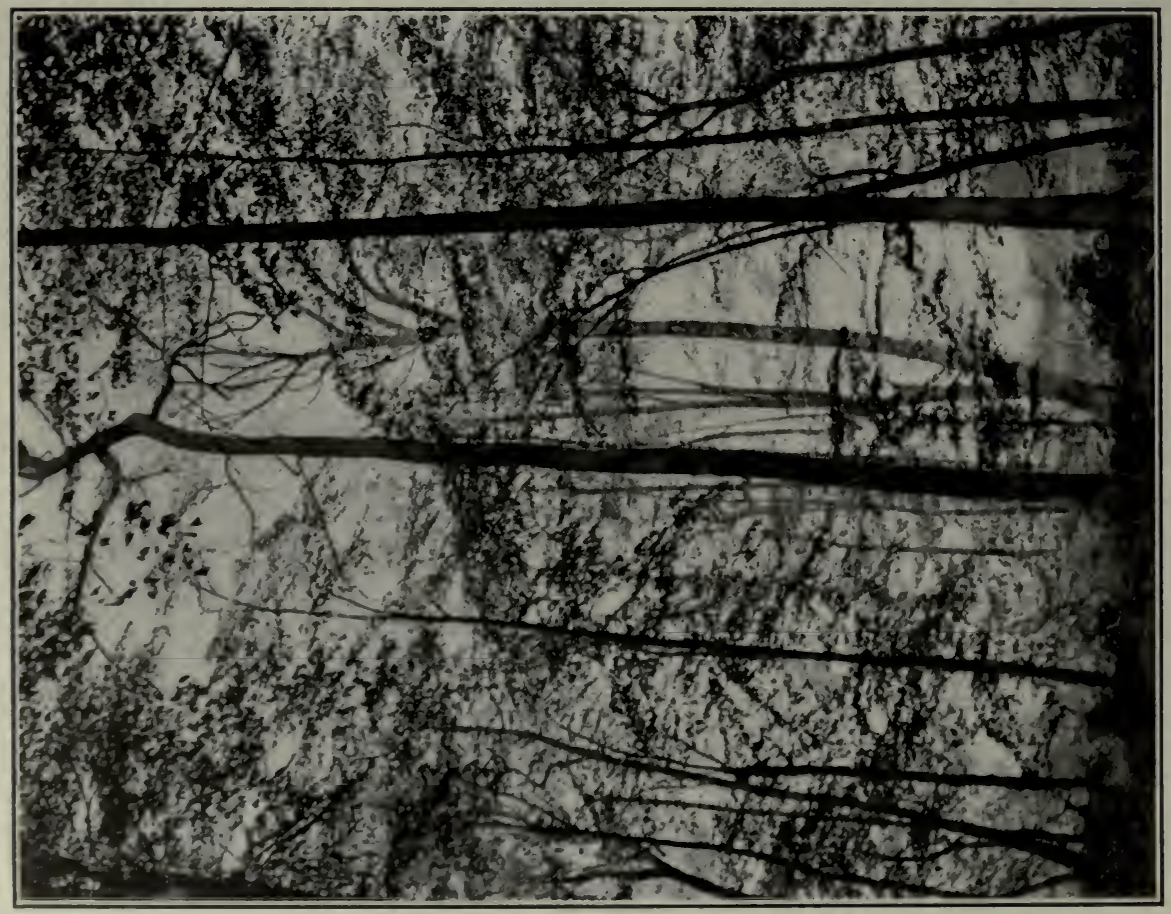



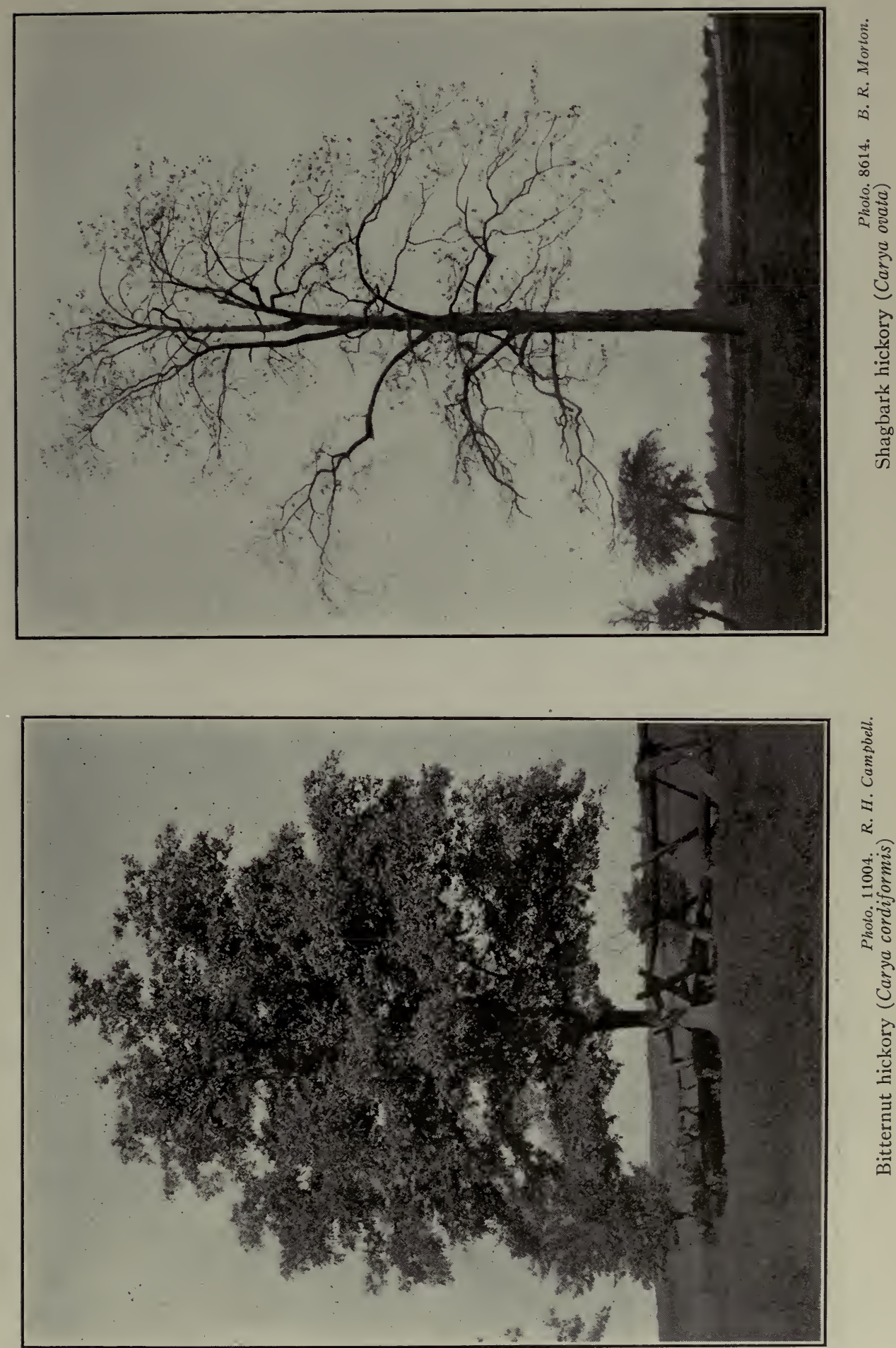

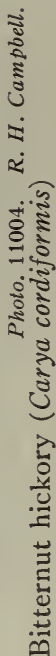




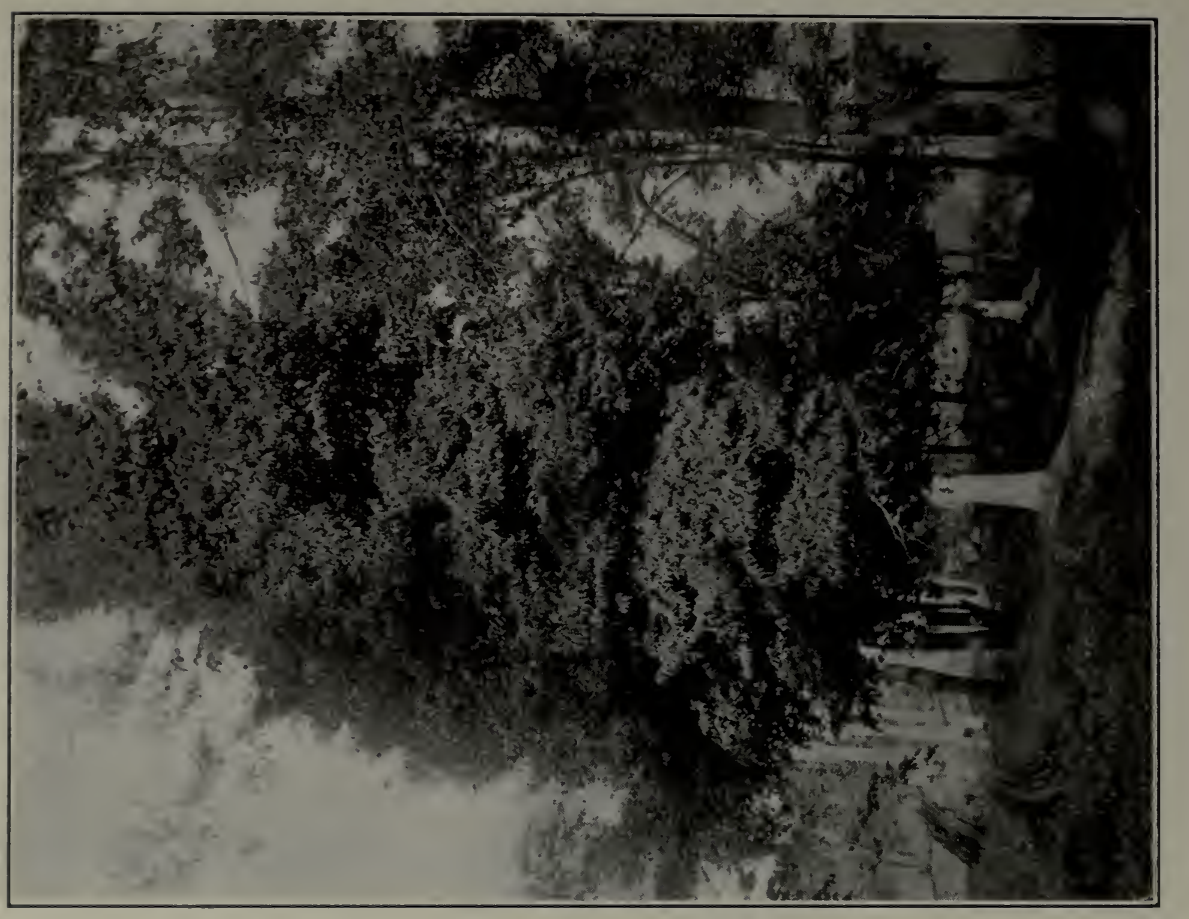

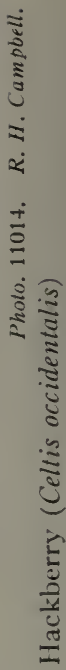

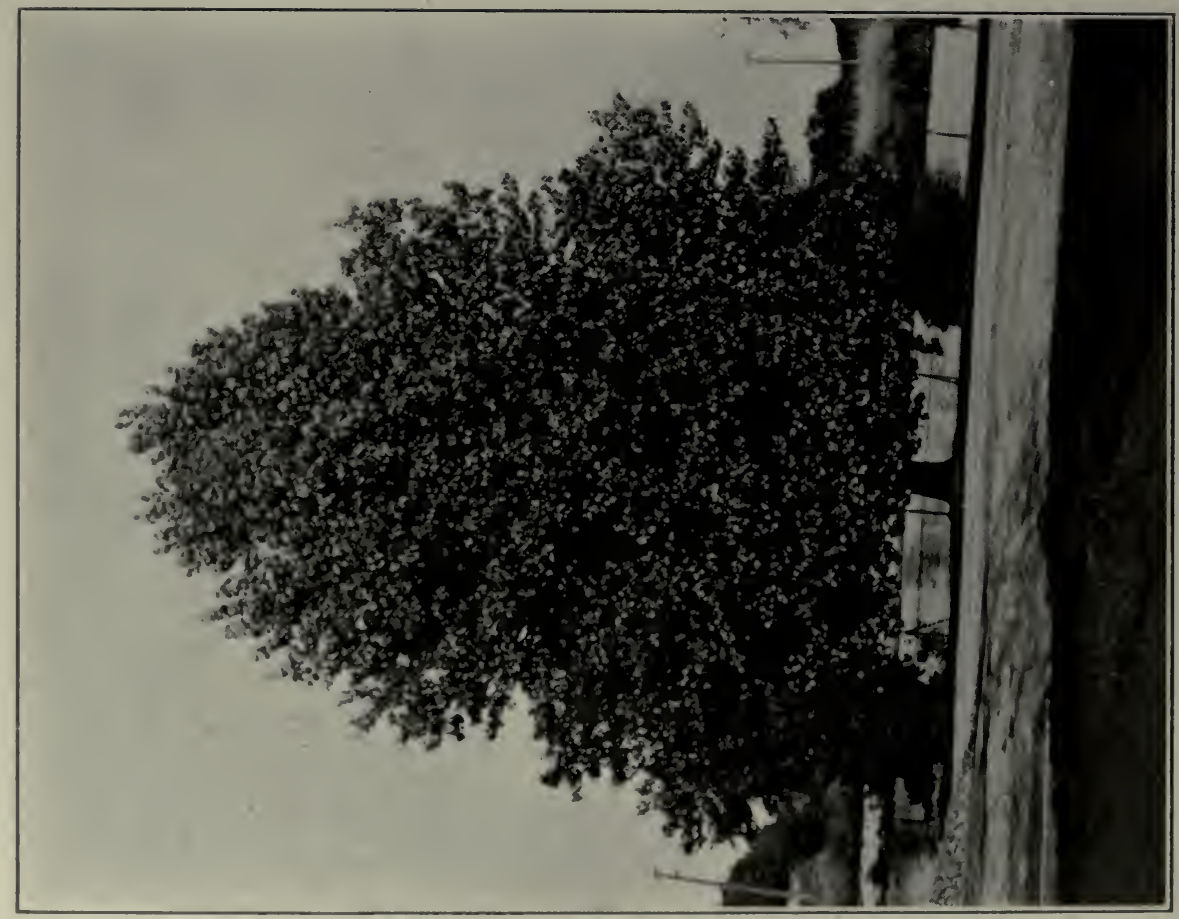

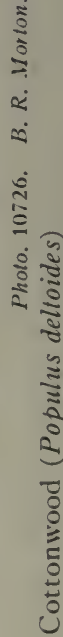




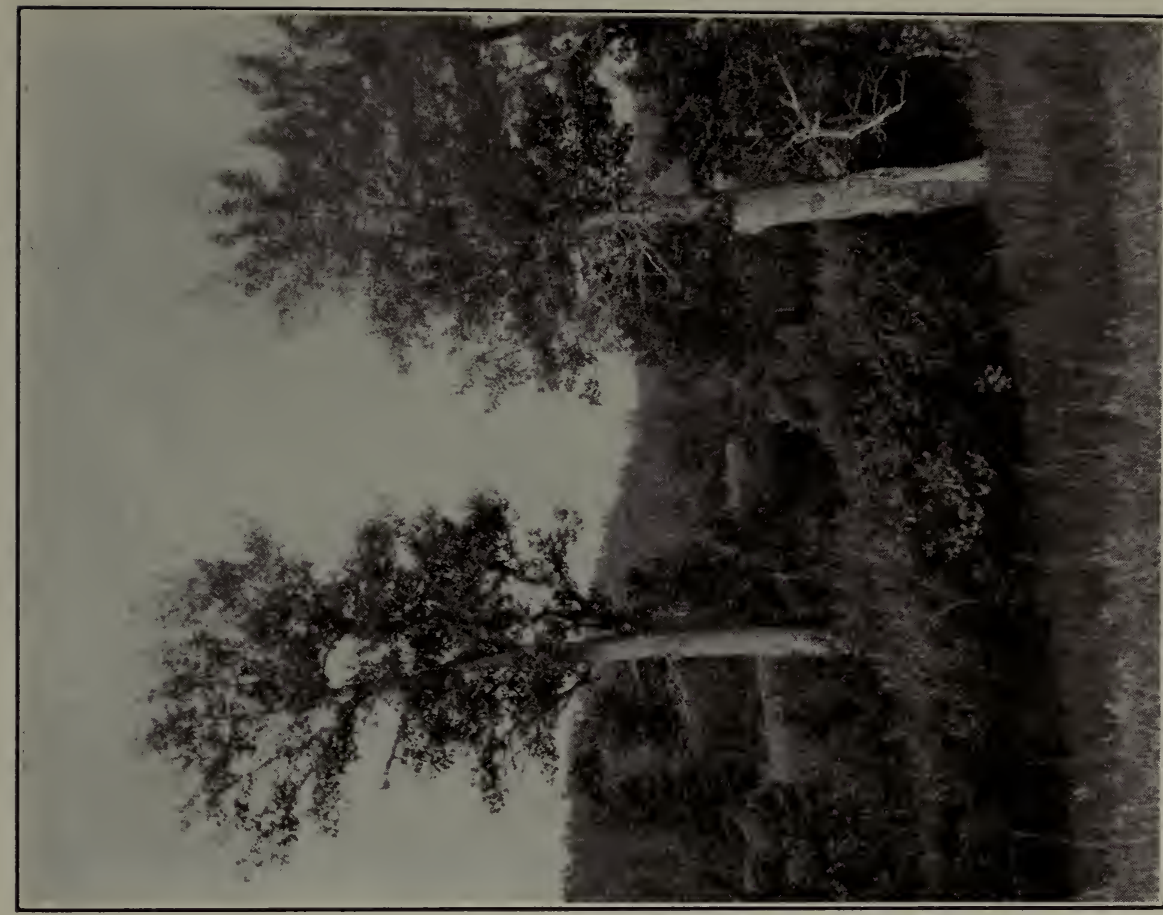

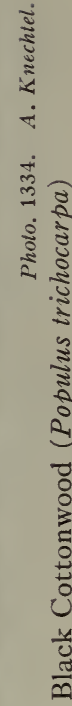

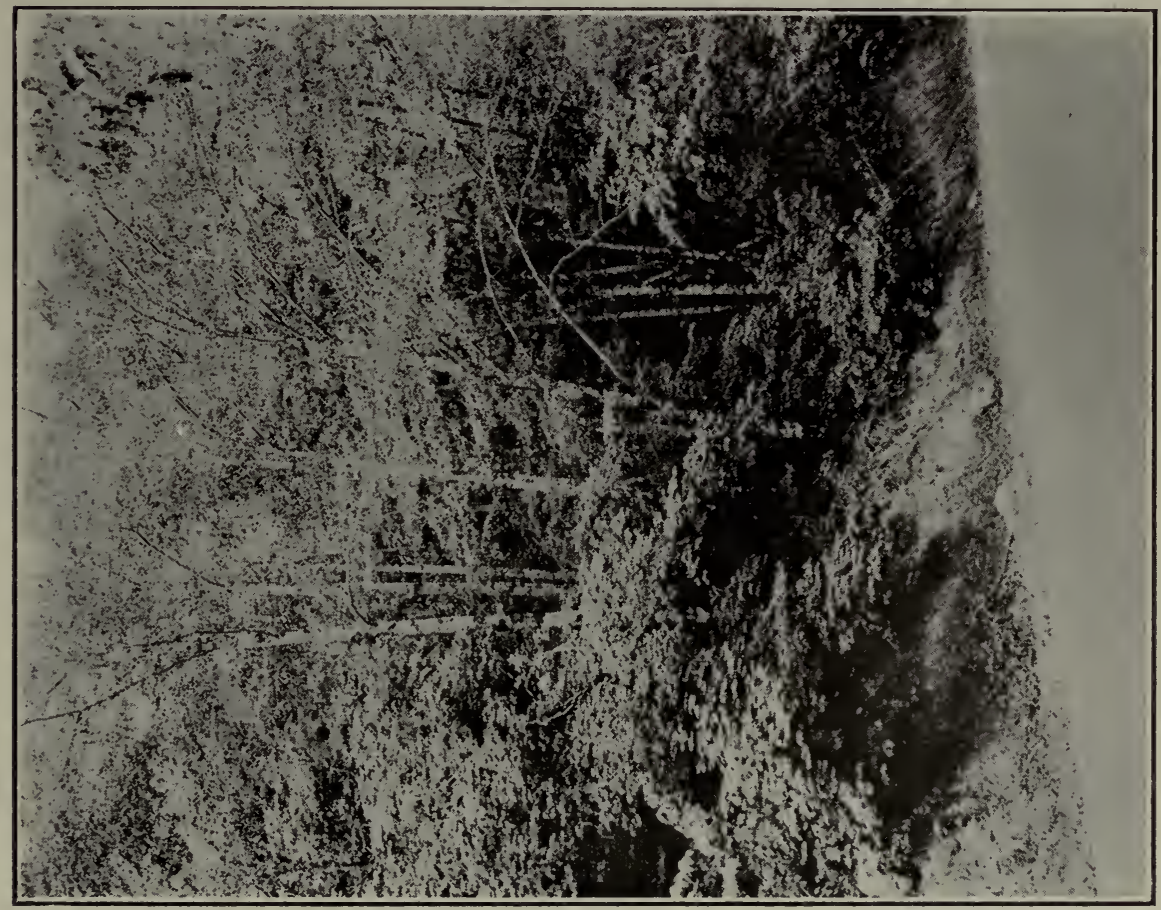

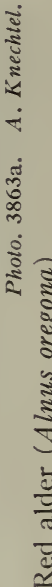




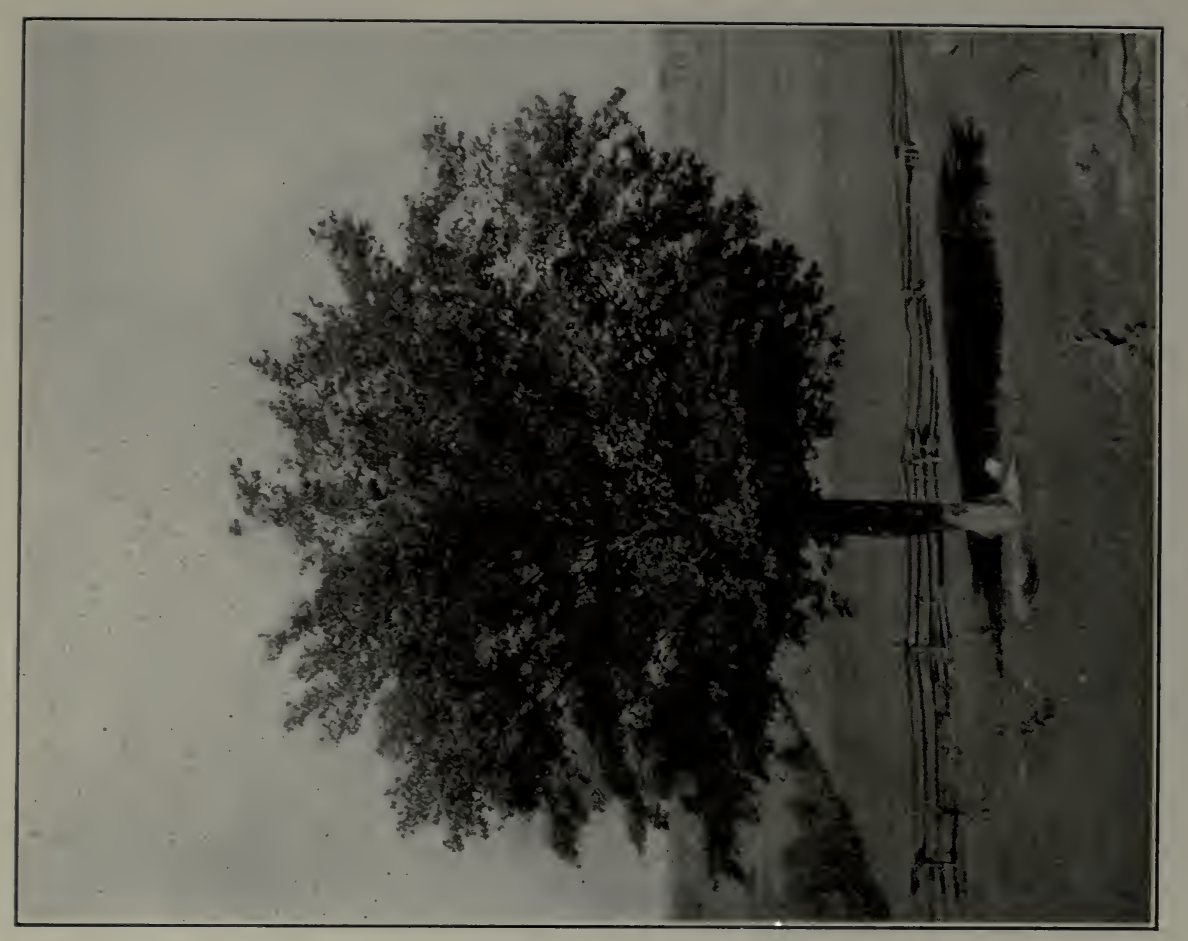

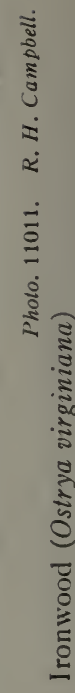

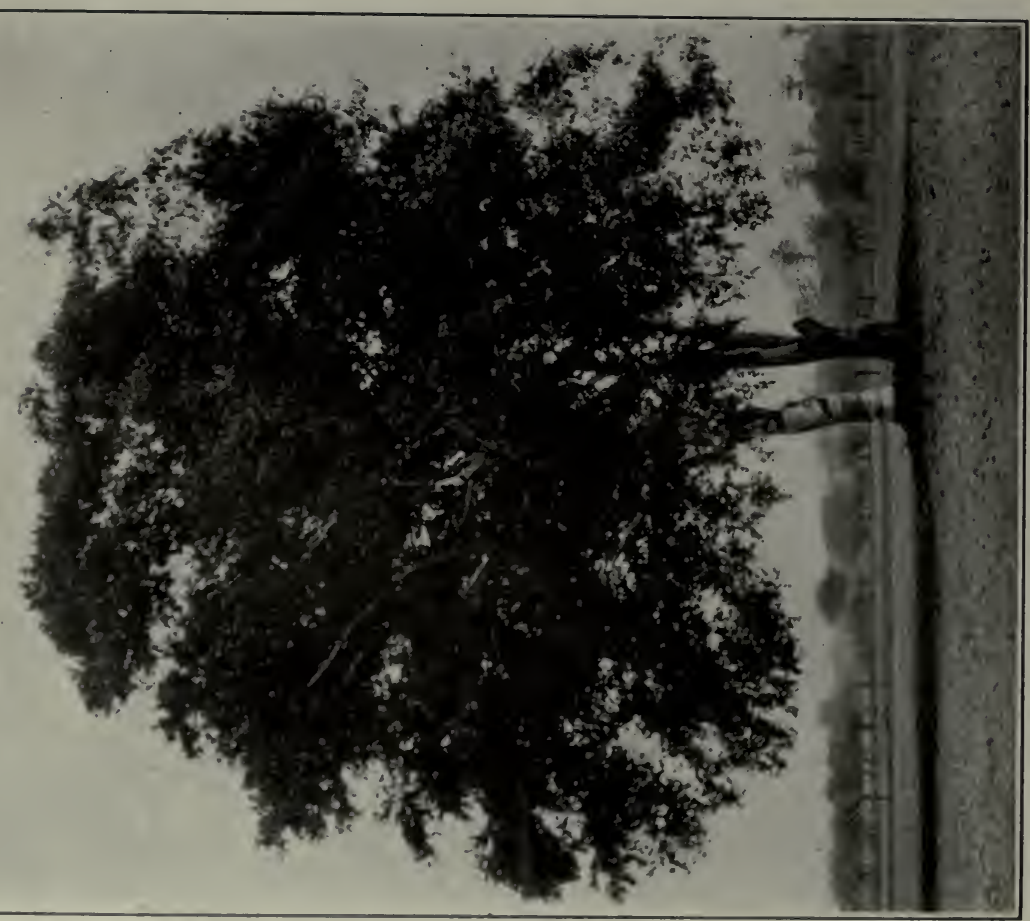

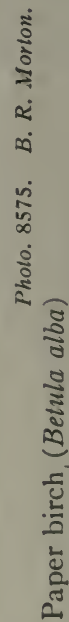




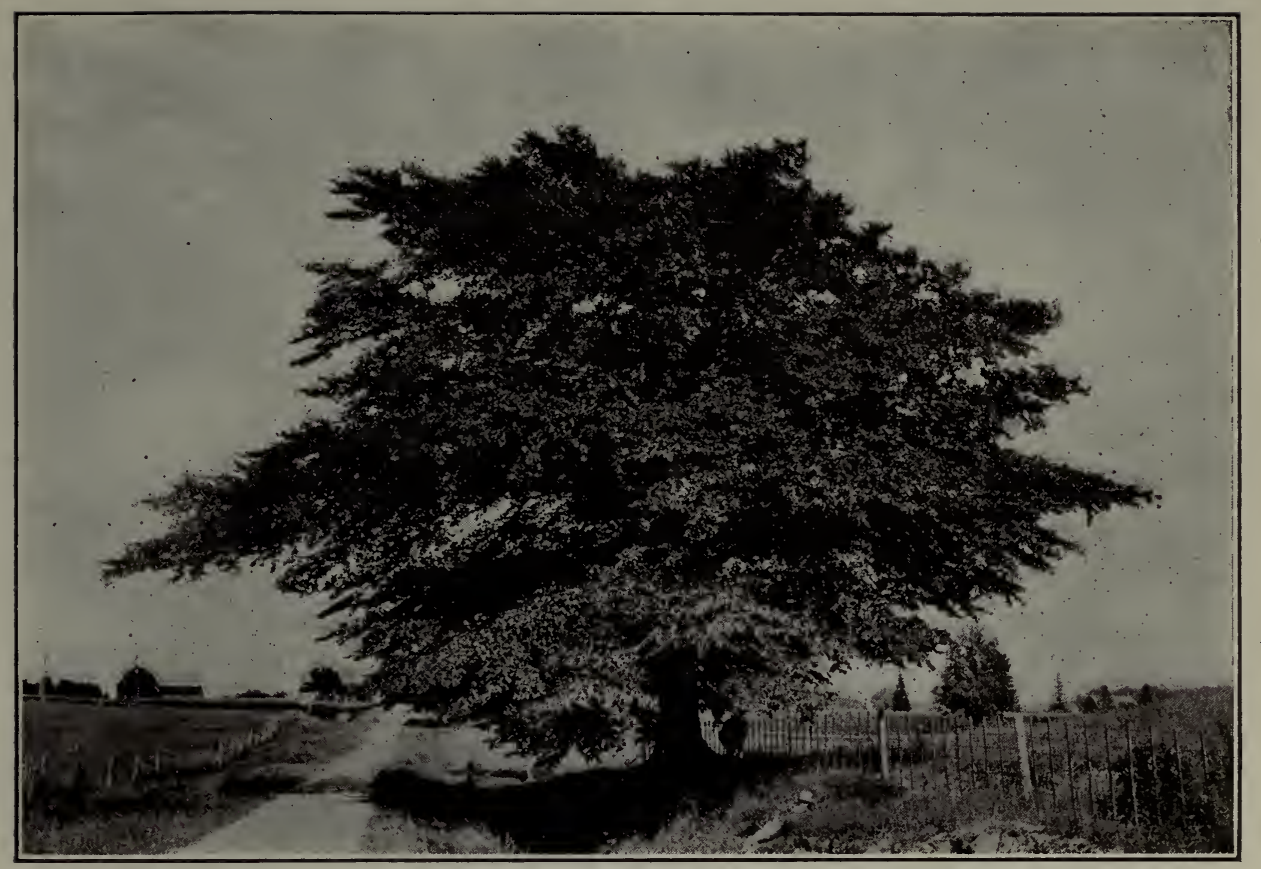

Beech (Fagus grandifolia)

Photo. Geological Survey, Canada.

Beech (Fagus grandifolia)

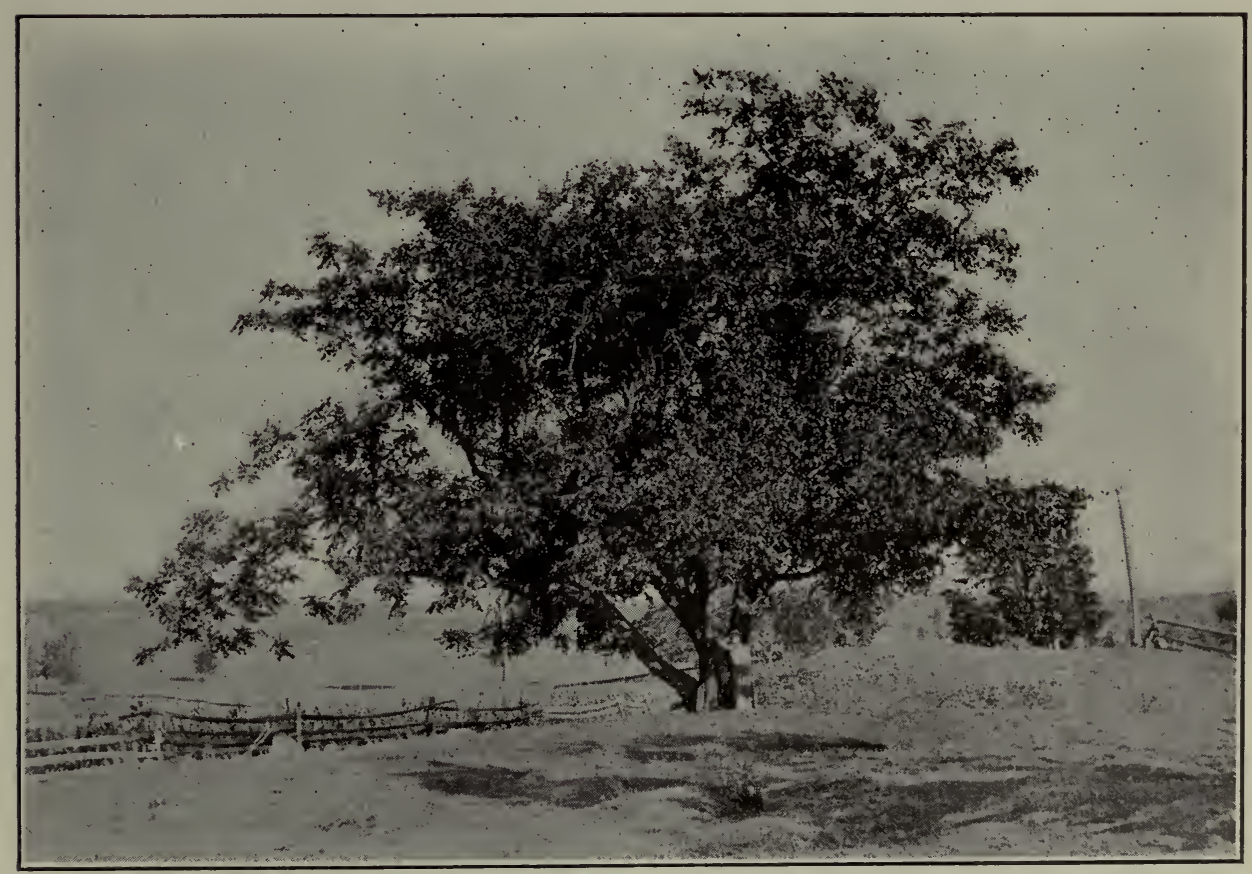

Butternut (Juglans cinerea)

Photo. 11003. R. H. Campbell. 


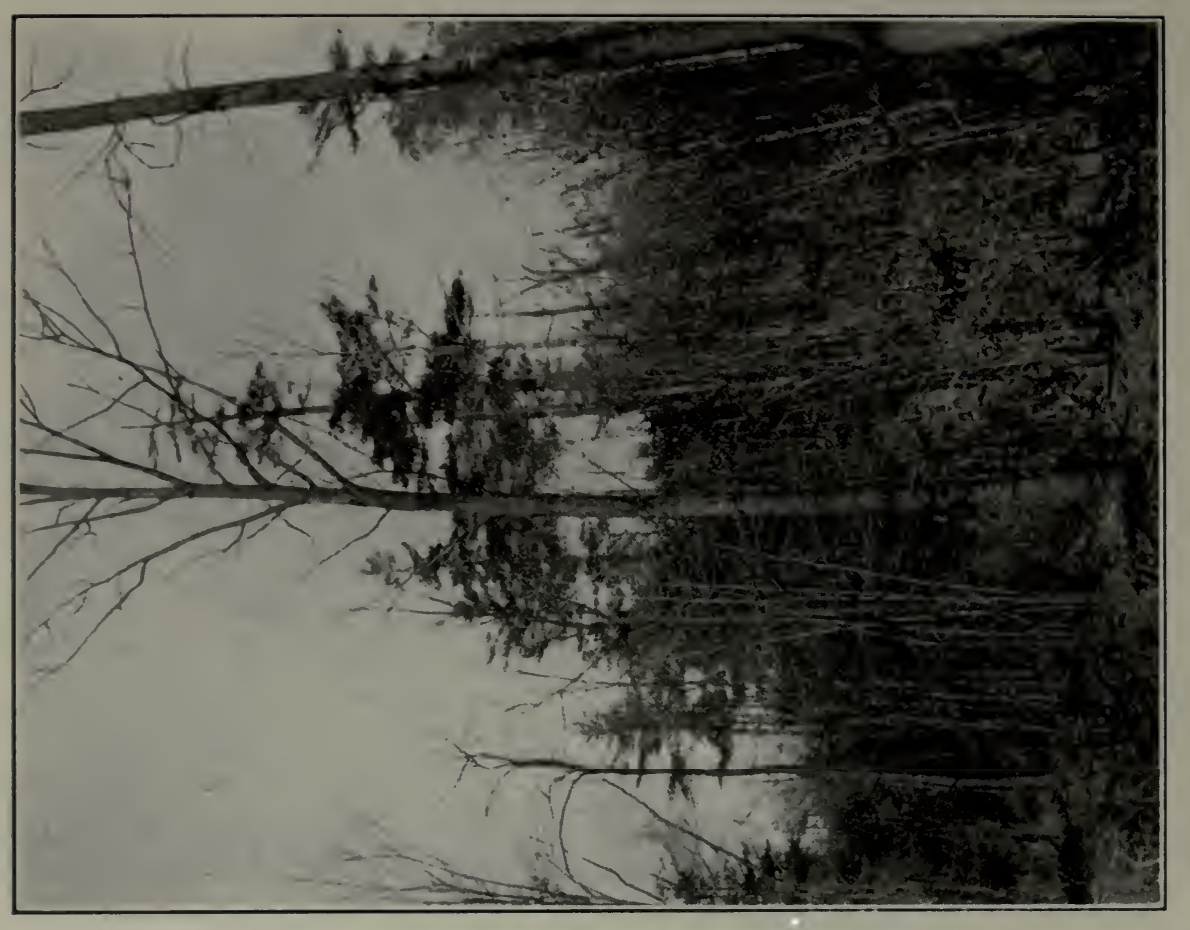

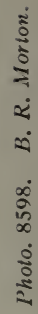

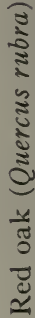

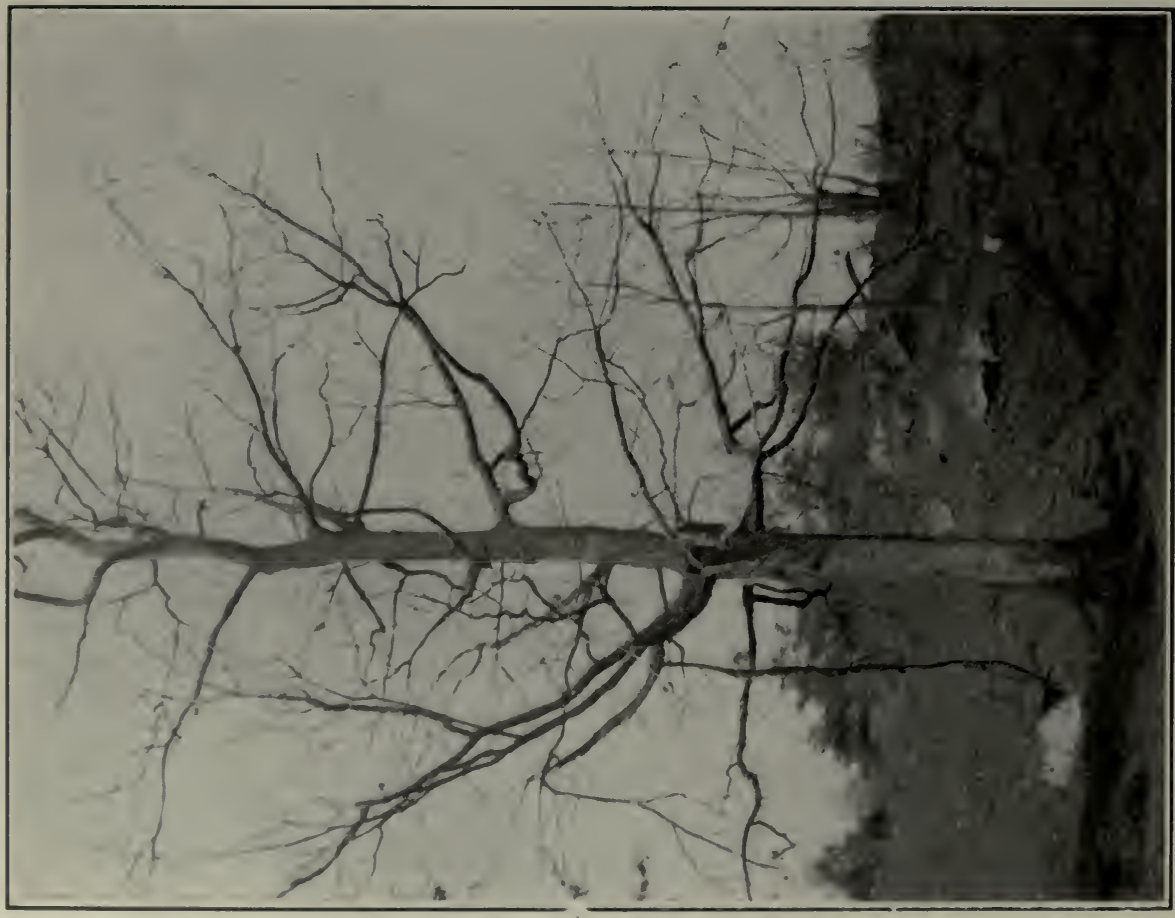

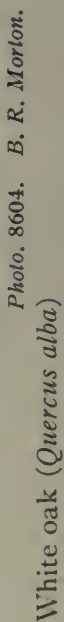



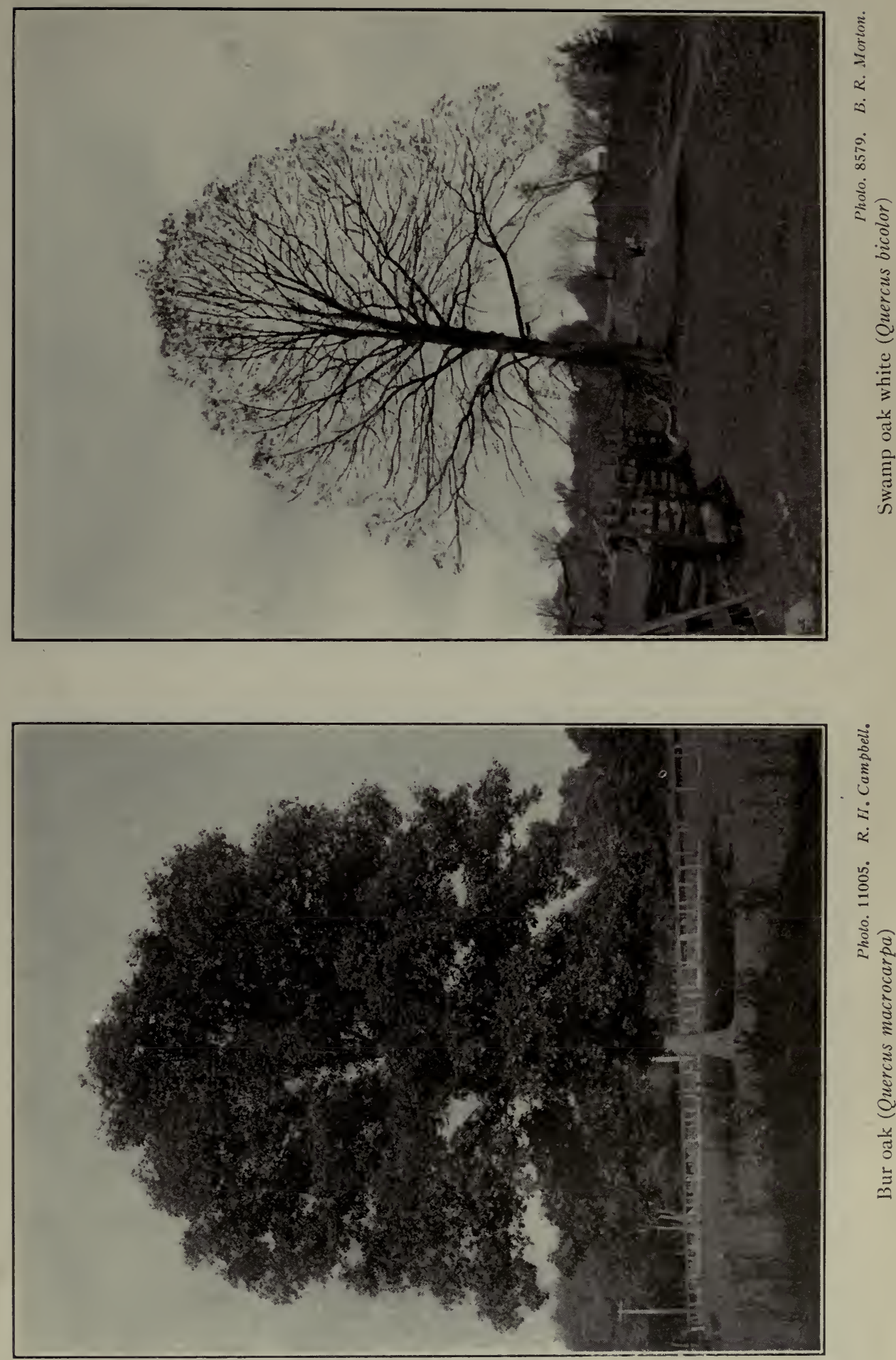

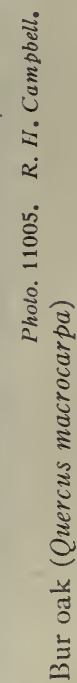




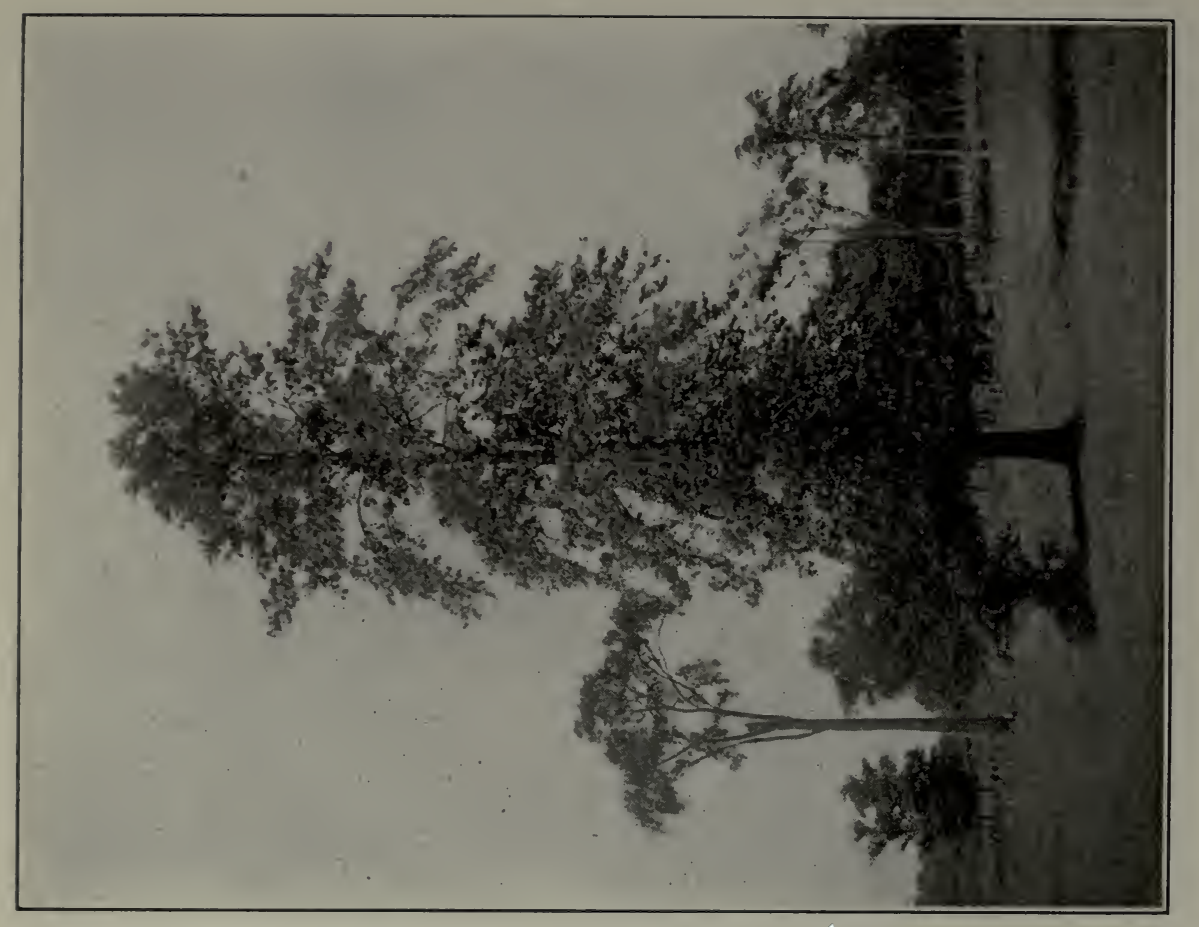

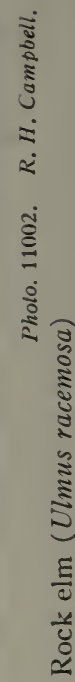

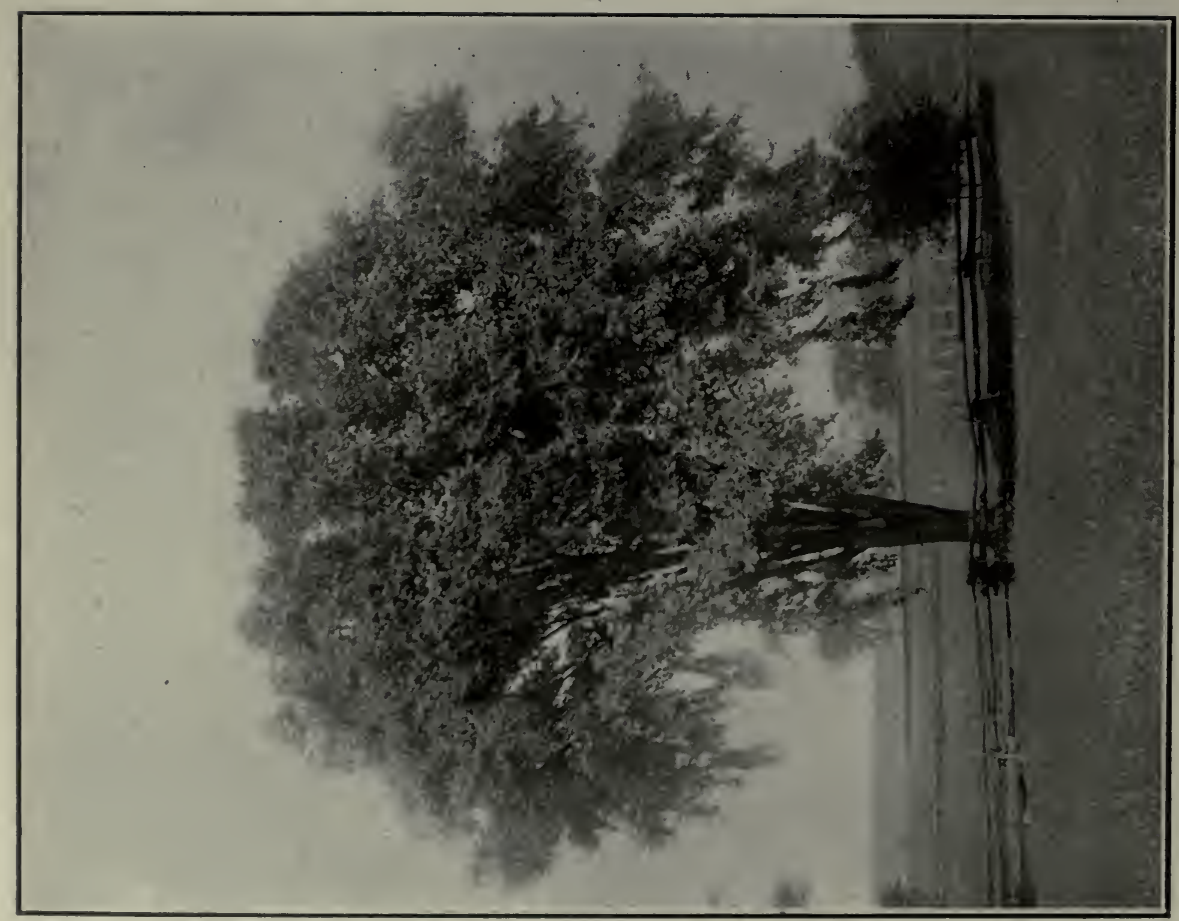

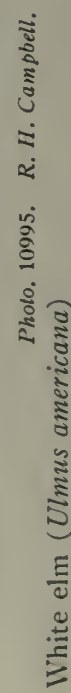




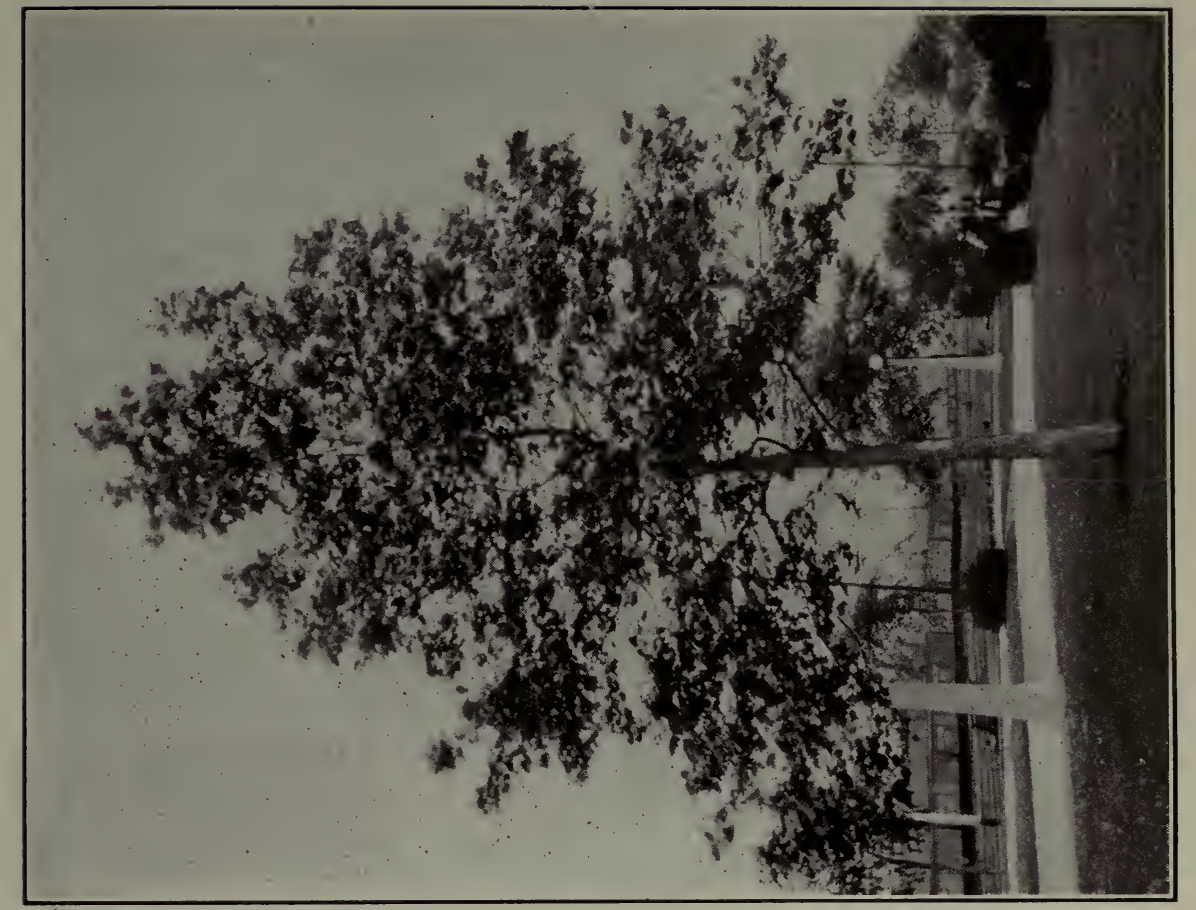

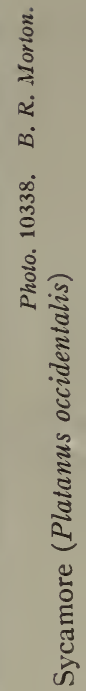

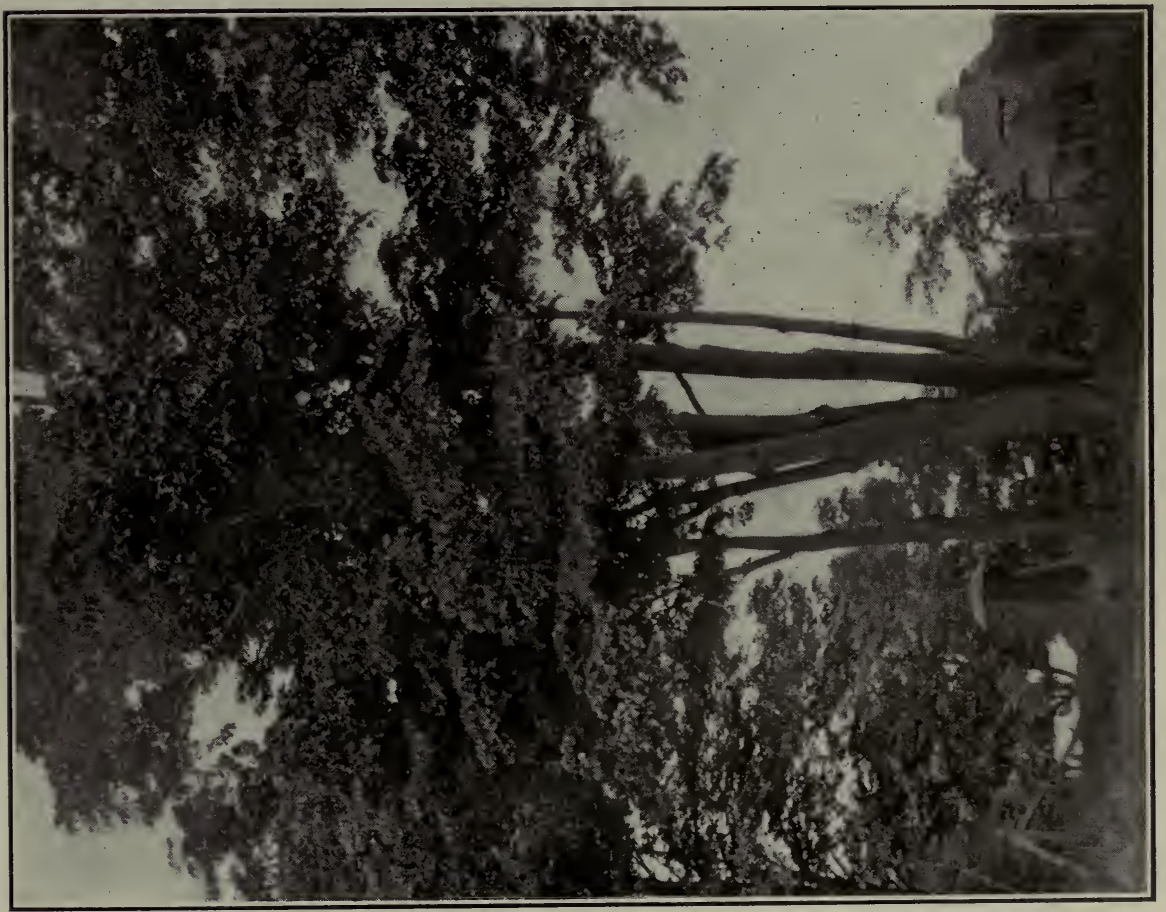



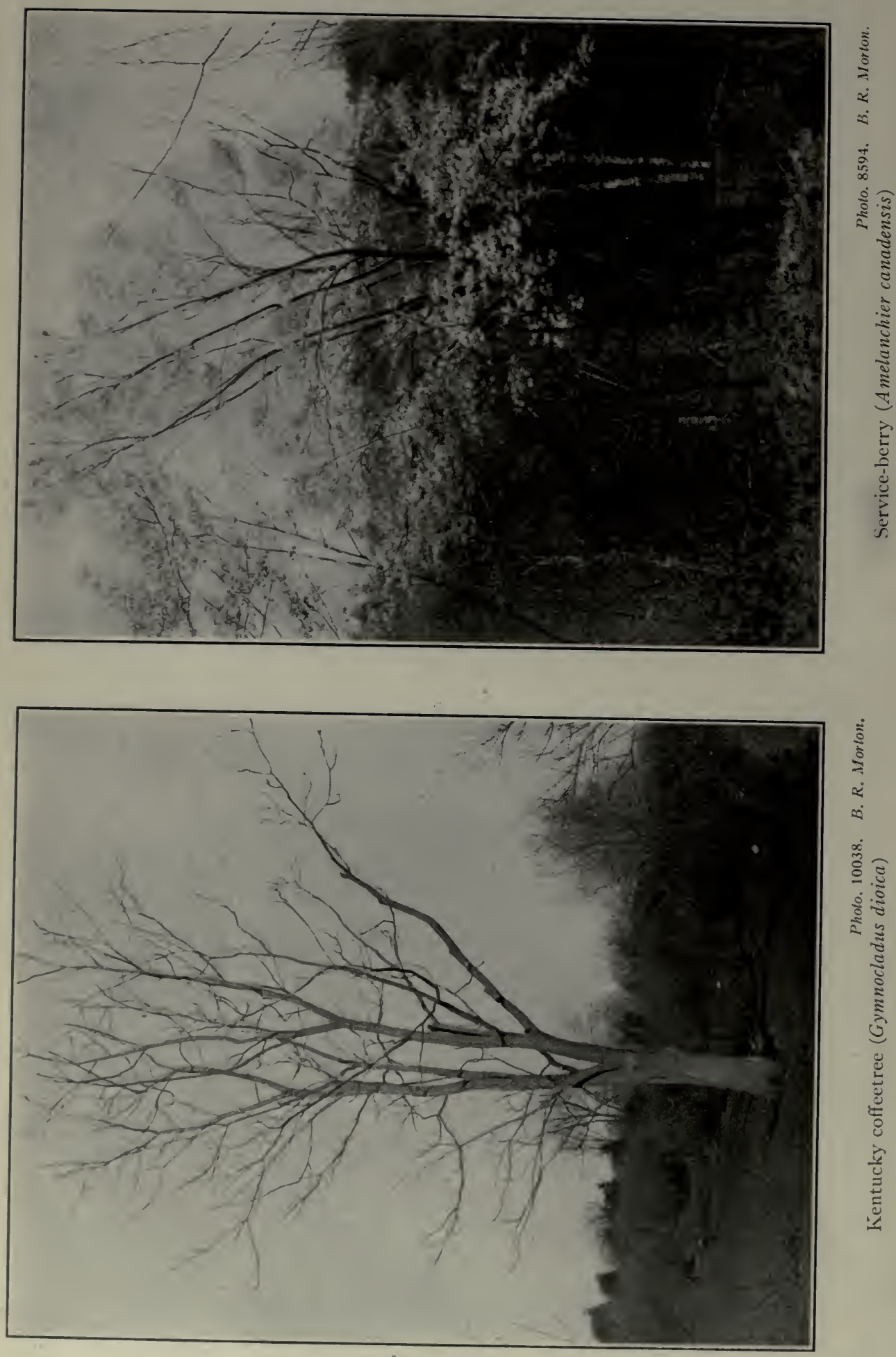

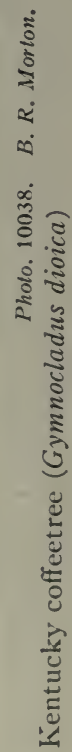




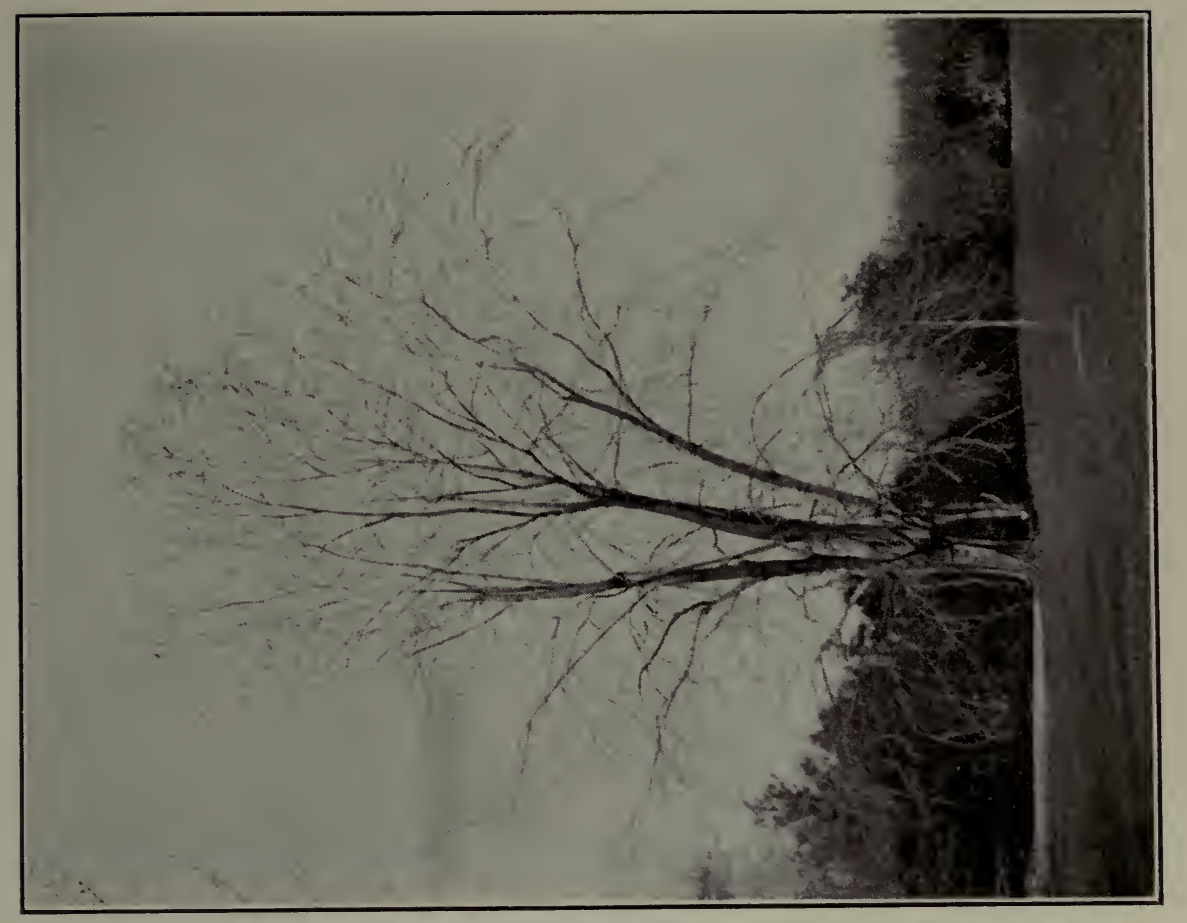

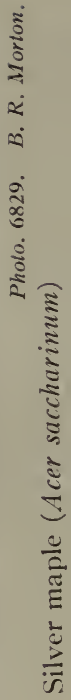

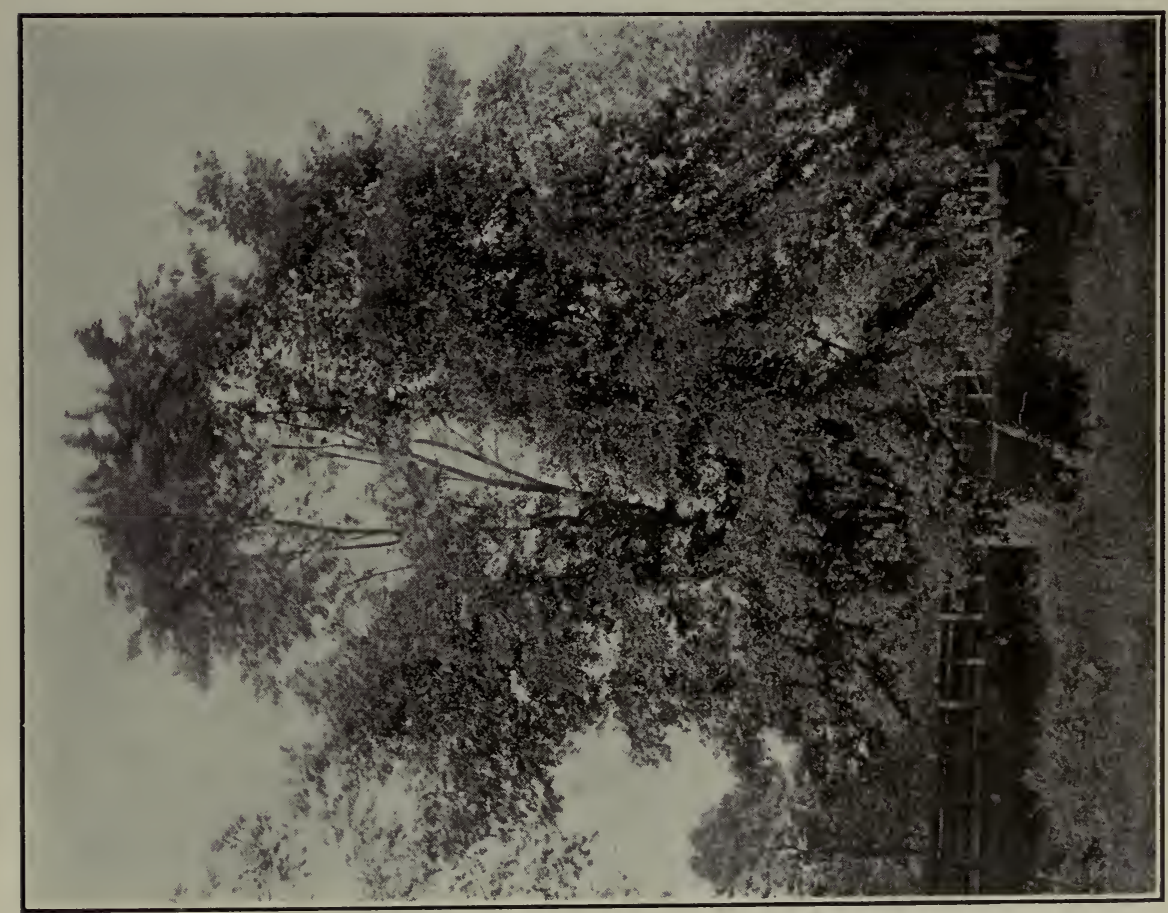

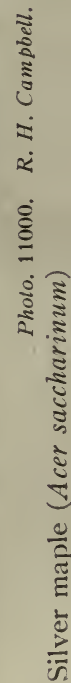




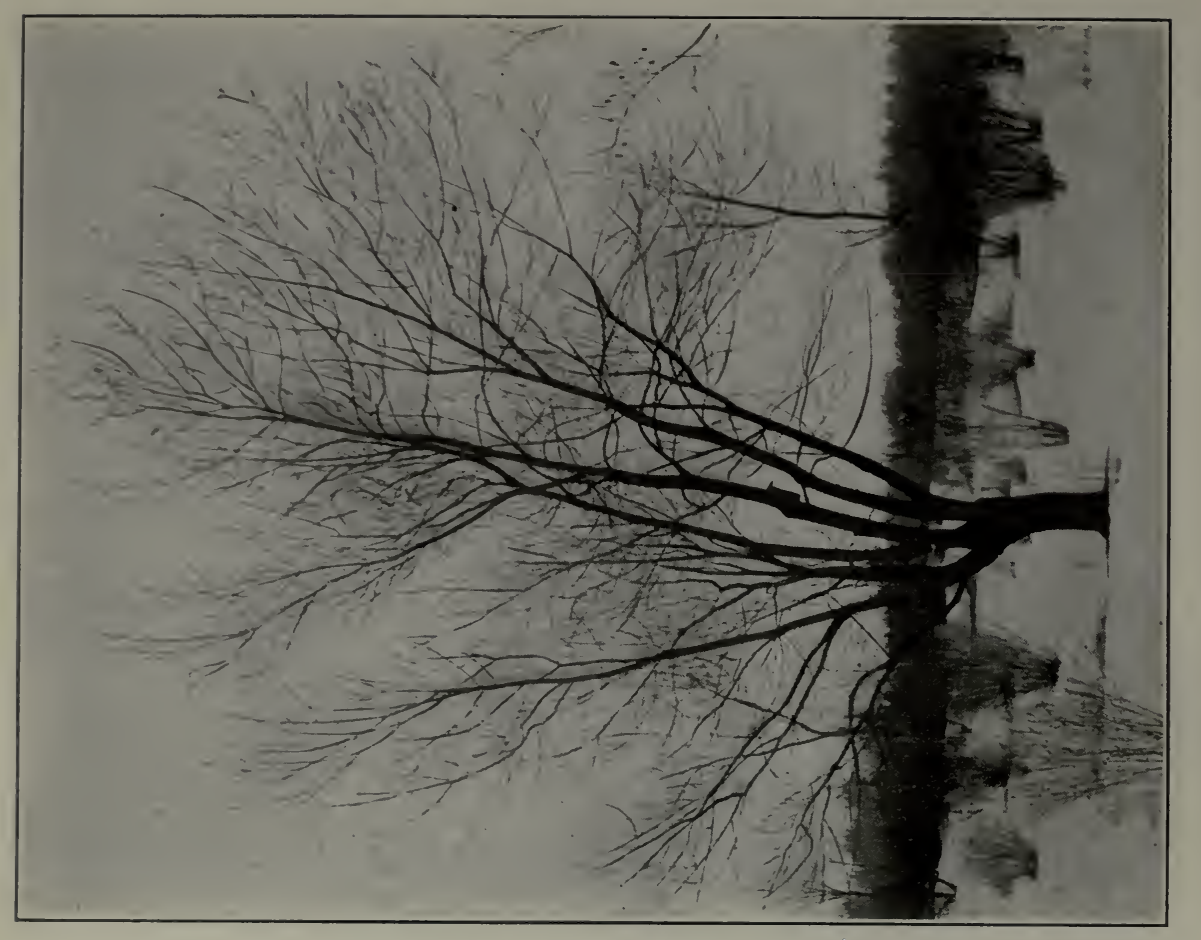

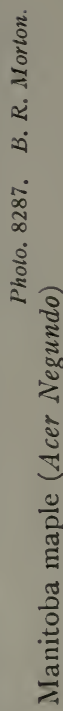

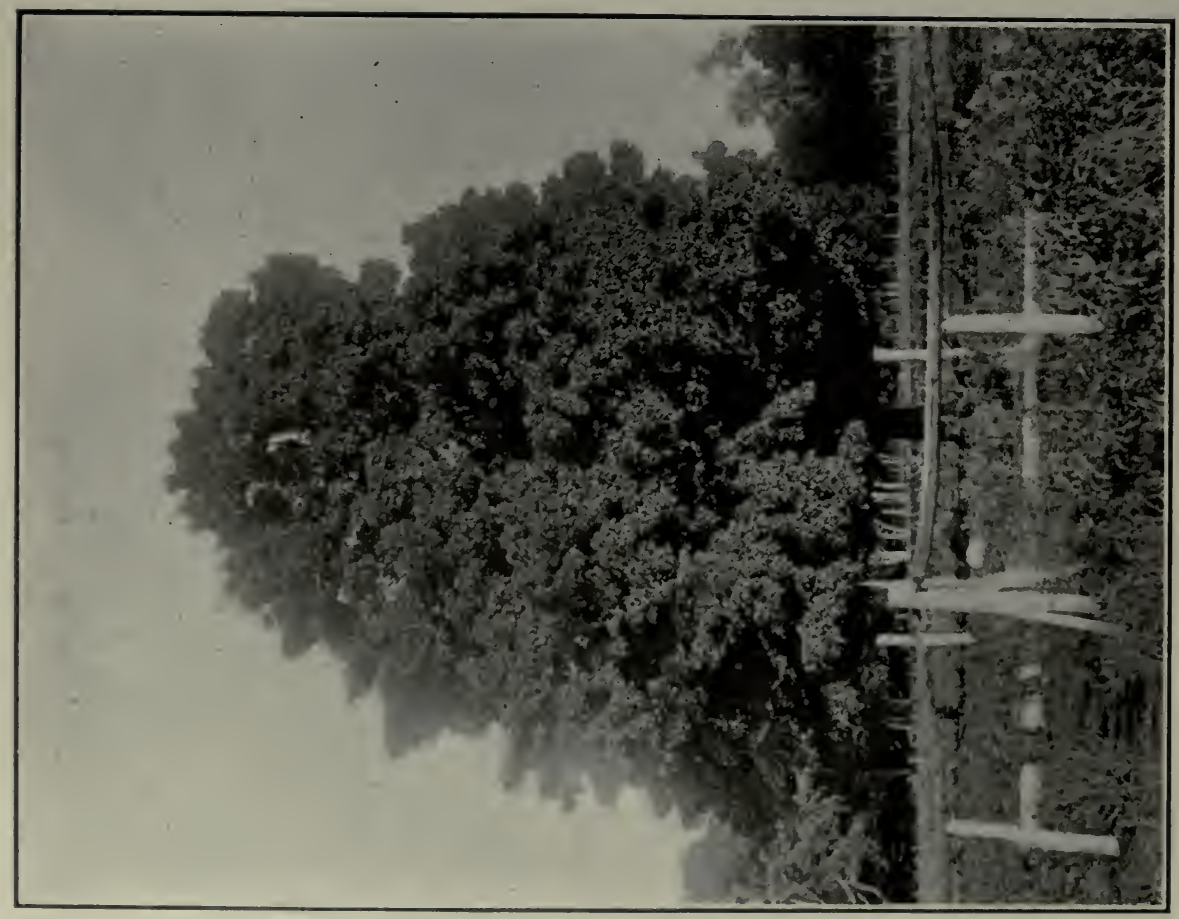

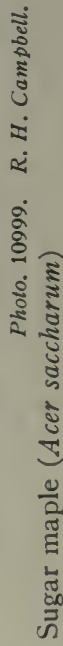



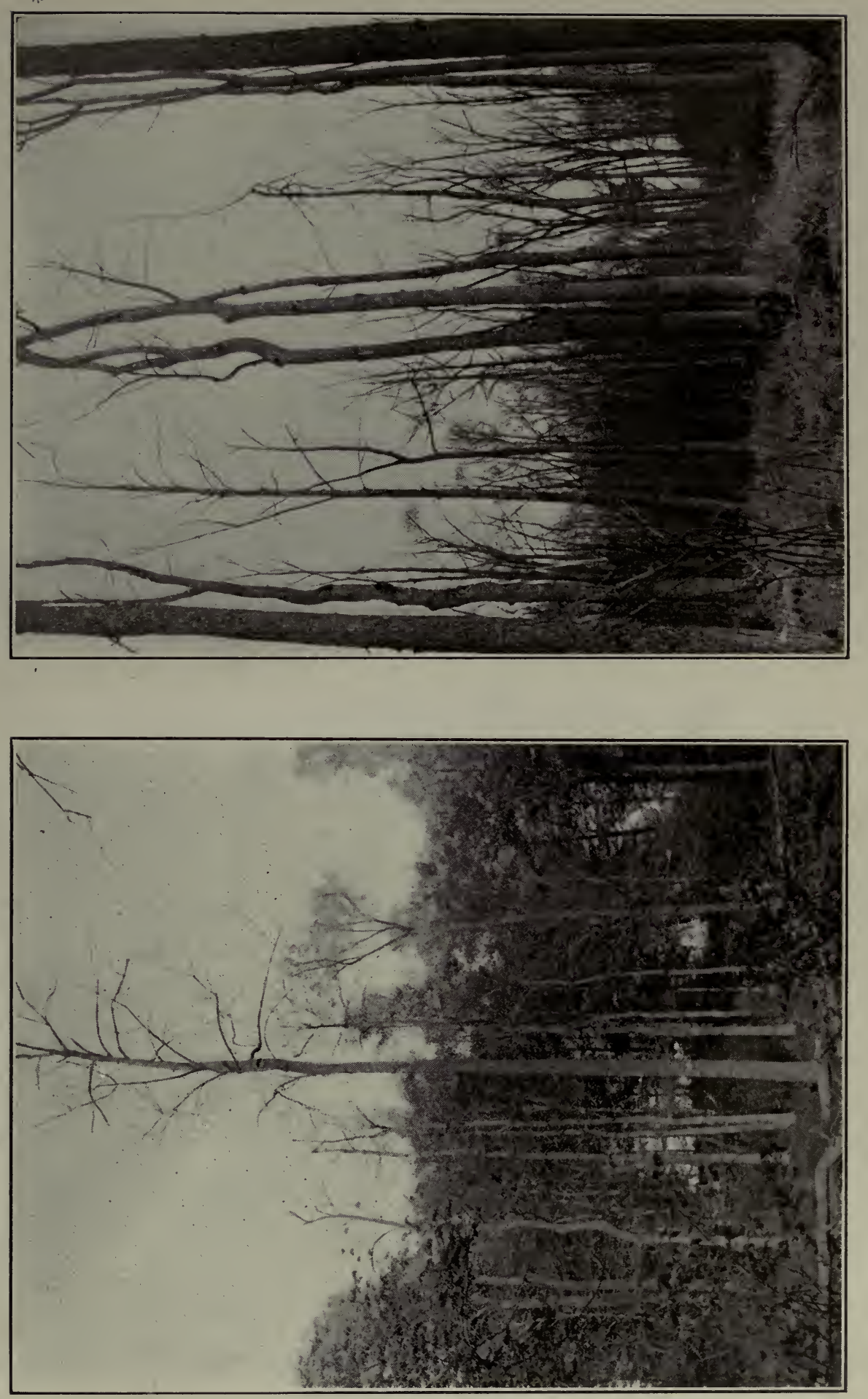


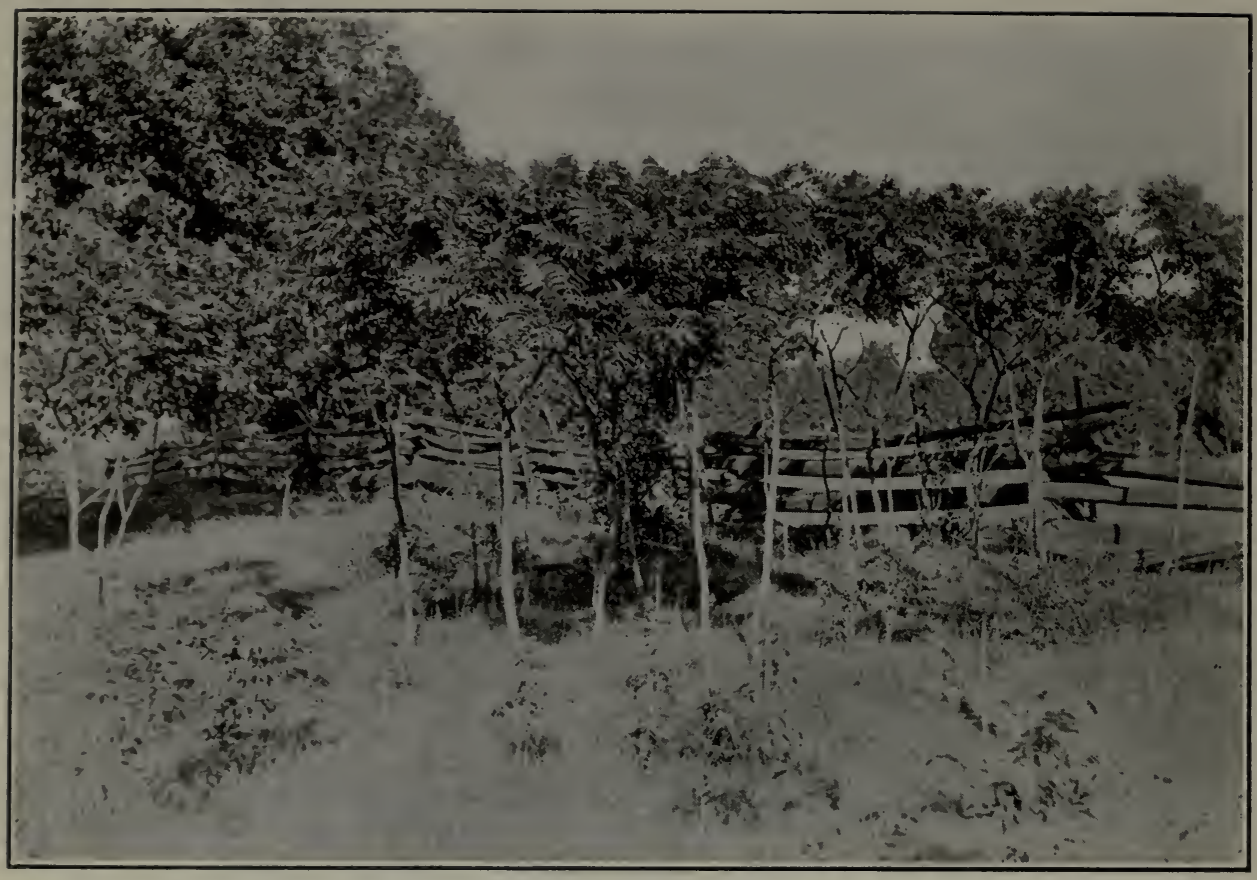

Sumach (Rhus typhina)

Photo. 11006. R. II. Campbell.

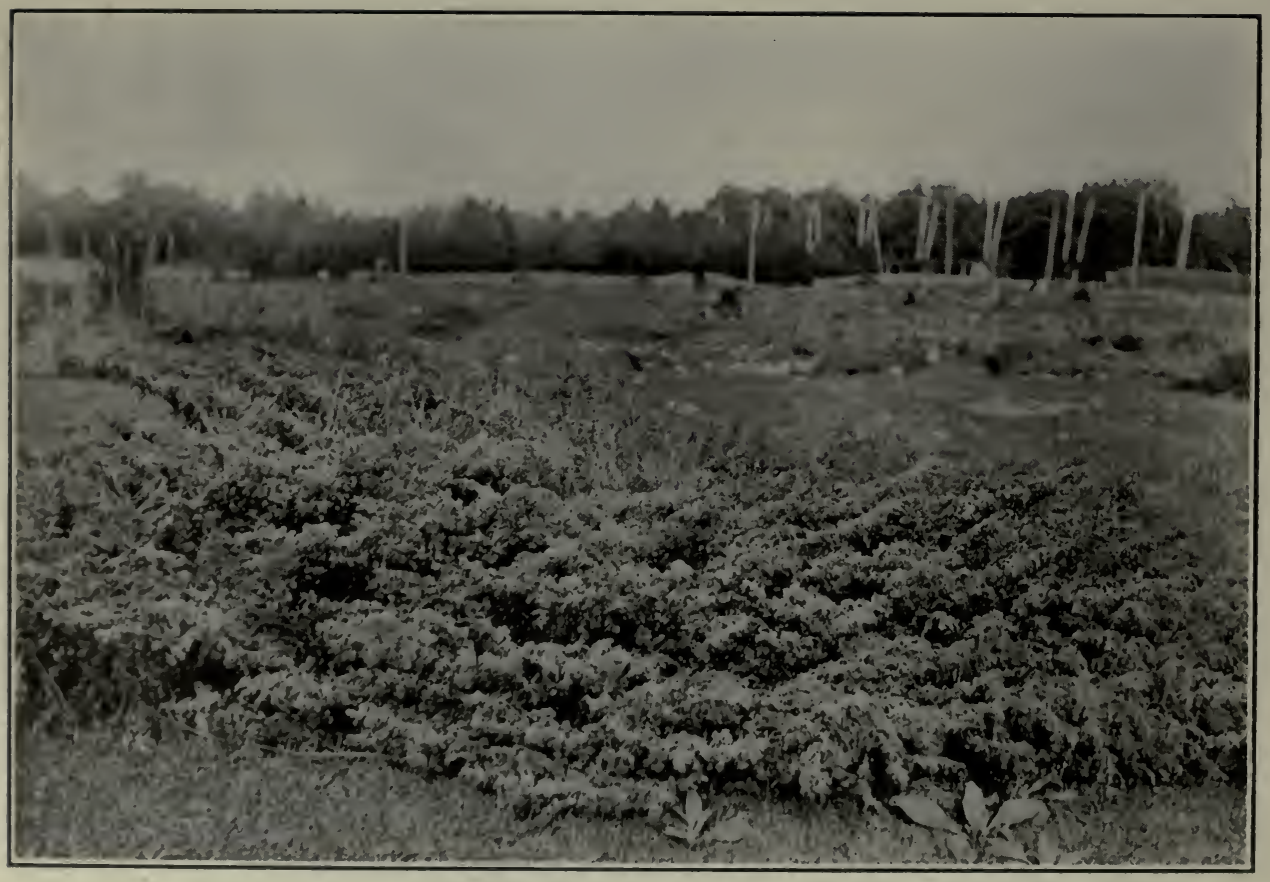

Pholi. 10979. R. II. Campbell.

Juniper (Juniperus communis) 


\section{INDEX}

Names adopted as standard are printed in ordinary type. Synonyms, which for one reason or another are not recognized as standard names, are printed in italic, as Hornbeam.

Page numbers lower than 139 refer to text descriptions of the trees; numbers higher than 138 refer to tables and illustrations.

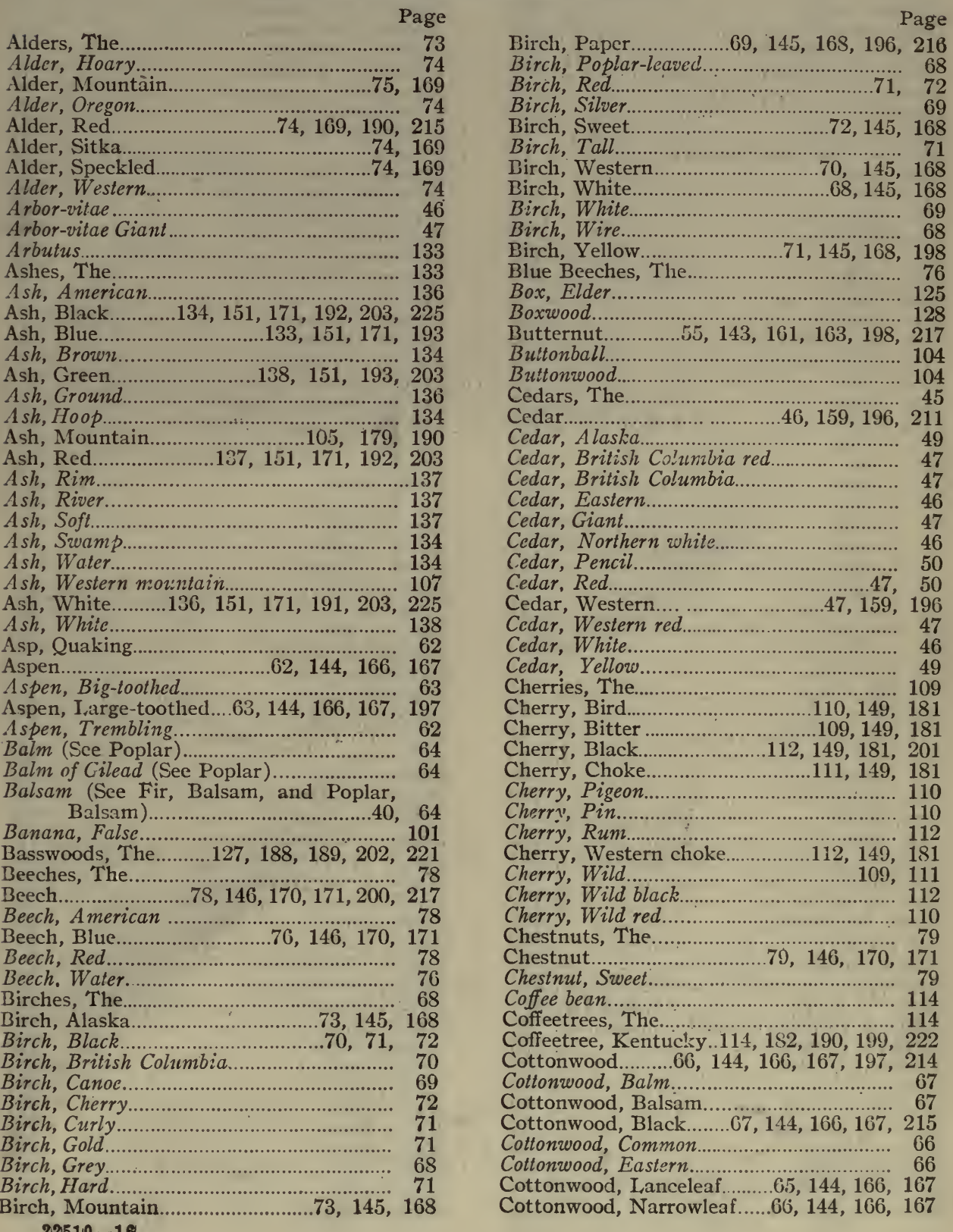


Cottonwood, Western balm......................... 67

Cucumber Tree............................................. 98

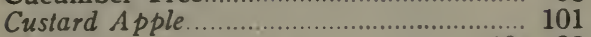

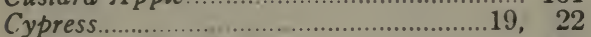

Cypresses, The Western ............................... 48

Cypress, Alaska ............................................ 49

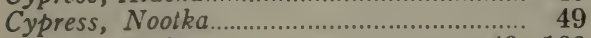

Cypress, Yellow ……..............................49, 160

Dogwoods, The ..............................28, 187, 199

Dogwood, Flowering ……….......................... 128

Dogwood, Western........................................ 130

Douglas Fir............................................... 38

Elms, The ............................................... 92

Elm, American ..................................... 94

Elm, Bastard (See Hackberry)................. 97

Elm, Budded ............................................ 93

Elm, Cork .................................................. 95

Elm, Cork-barked............................................. 95

Elm, Hickory .............................................. 95

Elm, Red ......................................93, 148, 175

Elm, Rock ............................ 95, 148, 175, 220

Elm, Rock............................................. 94

Elm, Slippery.............................................. 93

Elm, Slippery-barked.................................... 93

Eim, Soft................................................. 93

Elm, Swamp.............................................. 94

Elm, Water.............................................. 94

Elm, White..................94, 148, 175, 201, 220

Elm, White ............................................... 95

Firs, The ............................................... 40

Fir, Alpine............................41, 142, 158, 210

Fir, Alpine

Fir, Amabilis

$44,142,157,158$

Fir, Balsam...........40, 142, 157, 158210

Fir, British Columbia................................ 38

Fir, Canadian ................................................. 40

Fir, Caribou .............................................. 41

Fir, Douglas.........38, 142, 157, 158, 196, 207

Fir, Lowland...........................................43, 142

Fir, Mountain ..................................................... 41

Fir, Red ..................................................38, 44

Fir, Silver................................................... 43

Fir, Western bclsam........................................ 41

Fir, White

Fir, Yellow................................................. 38

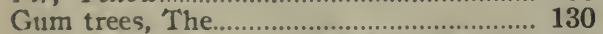

Gum, Black................131, 180, 190, 199, 212

Gum, Sour.............................................. 131

Hackberries, The.........96, 148, 175, 201, 214

Hackmatack.

Hawthorns, The ......................................108, 180

Hazel, Snapping........................................... 103

Hazel, Witch................................................. 103

Hemlocks, The................................. 34

Hemlock

Hemlock, Black..................37, 142, 155, 156

Hemlock, British Columbia....................... 36

Hemlock, Canadian........................................ 35

Hemlock, Eäastern....................................... 35

Hemlock, False........................................... 38

Hemlock, Ground (See Yew).................... 52

Hemlock, Mountain................................. 37

Hemlock, Spruce............................................ 35

Hemlock, While.................................... 35

Hemlock, Western.36, 142, 155, 156, 197, 198

Hickories, The.

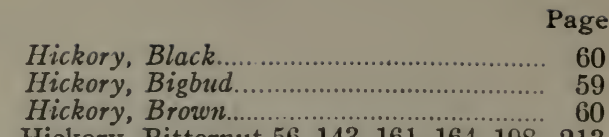

Hickory, Bitternut.56, 143, 161, 16.1, 198, 213

Hickory, Little pignut............................. 61

Hickory, Mockernut ...............59, 143, 161, 165

Hickory, Pignut...................60, 143, 161, 165

Hickory, Shagbark.58, 143, 161, 164, 198, 213

Hickory, Shellbark.................................... 58

Itickory, Swamp........................................... 56

Hickory, Whiteheart...................................... 59

Hornbeam.............................................. 76

Hornbeam, Hop...................................75, 76

Ironwoods, The ...................................... 75

Ironwood...............75, 146, 170, 171, 199, 216

Ironwood, Rough-barked......................... 75

Ironwood, Smooth-barked............................. 76

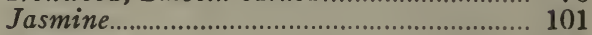

Judas tree................................................. 114

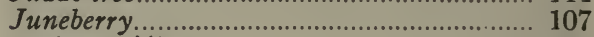

Junipers, The

Juniper............................................19, 24

Juniper, Common..........................50, 160, 226

Juniper, Dwarf........................................... 50

Juniper, Pencil............................................... 50

Juniper, Red......................................50, 160, 211

Juniper, Rocky Mountain.......................... 52

Lancewood....................................................... 107

I arches, The............................................. 24

Larch.....................................................43, 44

Larch, Alpine

Larch, American....................................... 24

Larch, Black.................................................. 24

Larch, Lyall's............................................... 27

Larch, Mountain ...................................... 27

Larch, Western.............................26, 140, 153

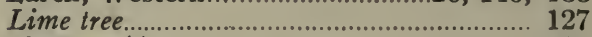

Lindens, The............................................. 127

Linden, American ...................................... 127

Madronas, The............................................... 132

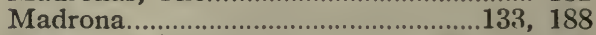

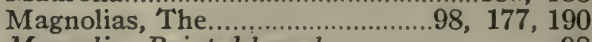

Magnolia, Pointed-leaved............................ 98

Manzanita.................................................... 133

Maples, The................................................... 116

Maple, A sh-leaved ....................................... 125

Maple, Big-leaved....................................... 119

Maple, British Columbia............................. 119

Maple, Broad-leaved.............119, 150. 185, 186

Maple, Broad-fruited................................... 123

Maple, Dwarf.........................121, 150, 185, 186

Maple, Dwarf.......................................... 117

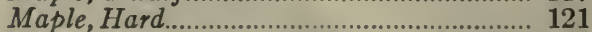

Maple, Manitoba..........125, 150, 185, 202, 224

Maple, Moose......................................... 118

Maple, Mountain ...............117, 150, 184, 186

Maple, Mountain ....................................... 120

Maple, Oregon................................................. 119

Maple, Red.............................. 124, 150, 184, 186

Maple, Red................................................ 121

Maple, River................................................ 123

Maple, Rock ............................................ 121

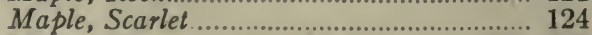

Maple, Silver.....123, 150, 184, 186, 202, 223

Maple, Soft....................................123, 124

Maple, Striped....................118, 150, 184, 186 
Maple, Sugar.......121, 150, 184, 186, 202, 224 Maple, Swamp................................123, 124 Maple, Vine..........................120, 150, 185, 186 Maple, Water ......................................123, 124 Maple, White............................................. 123

Moosewood.................................................. 118

Mountain ash........................................... 106

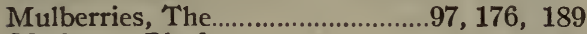

Mulberry, Black........................................... 98

Mulberry, Red............................................ 98

Oaks, The .............................................. 80

Oak, Black....................88, 147, 172, 173, 174

Oak, Black ............................................89, 91

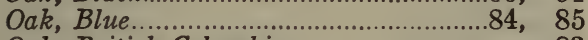

Oak, British Columbia............................ 83

Oak, Bur........ 85, 147, 172, 173, 174, 200, 219

Oak, Chestnut...............87, 147, 172, 173, 174

Oak, Chinquapin............87, 147, 172, 173, 174

Oak, Dwarf chinquapin........................ 81

Oak, Garry ....................83, 147, 172, 173, 174

Oak, Mossy.

85

Oak, Mossycup........................................... 85

Oak, Oregon ……............................................ 83

Oak, Overcup ............................................ 85

Oak, Pacific post......................................... 83

Oak, Pacific while ................................... 83

Oak, Pin .................... $147,172,173,174$

Oak, Post.....................84, 147, 172, 173, 174

Oak, Red.......89, 147, 172, 173, 174, 200, 218

Oak, Red ............................................. 88,91

Oak, Rock................................................ 87

Oak, Scarlet..............91, 147, 172, 173, 174

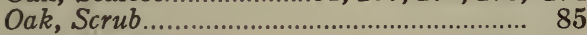

Oak, Stave .................................................... 81

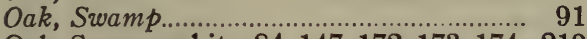

Oak, Swamp white, 84, 147, 172, 173, 174, 219

Oak, Water ........................................ 91

Oak, White.....81, 147, 172, 173, 174, 200, 218

Oak, Yellow......................................87, 88

Oak, Yellow-barked......................................... 88

Osier, Red.................................................. 128

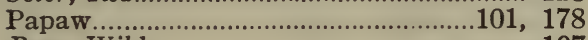

Pear, Wild .................................................... 107

Pepperidge .................................................. 131

Pines, The................................................... 13

Pine.................................................. $\quad 30$

Pine, Alaska ............................................. 36

Pine, Banksian........................................ 19

Pine, Black.......................................... 22

Pine, British Columbia soft....................... 21

Pine, Bull................................................. 21

Pine, Canadian red..................................... 18

Pine, Cork ................................................. 13

Pine, Douglas ............................................. 38

Pine, Eastern white................................... 13

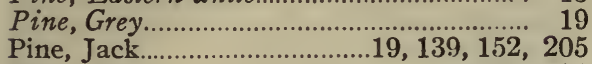

Pine, Jack.

Pine, Limber

Pine, Lodgepole

20,21

Pine, Mountain Weymouth...................... 15

Pine, Norway.......................................... 18

Pine, Oregon............................................. 38

Pine, Pattern ......................................... 13

Pine, Pitch ................20, 139, 152, 195, 206

Pine, Princess..
Pine, Pumpkin........................................ 13

Pine, Quebec ............................................ 13

Pine, Red................................18, 139, 152

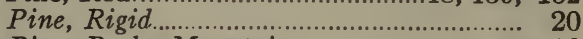

Pine, Rocky Mountain............................... 16

Pine, Sapling............................................. 13

Pine, Scrub ........................17, 19, 20, 22

Pine, Shore................................................. 22

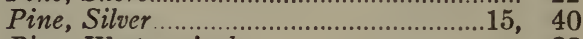

Pine, Western jack................................ 22

Pine, Western white................15, 139, 152, 195

Pine, Western yellow....21, 139, 152, 196, 207

Pine, Weymouth ................................... 13

Pine, White.................13, 139, 152, 195, 204

Pine, White....................................15, 22

Pine, White-barked.......................17, 139, 152

Pine, White-stemmed................................... 17

Pine, Yellow............................................13, 21

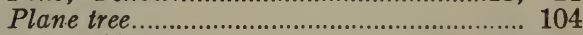

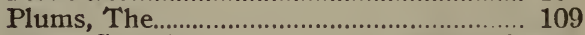

Plum, Canada..............................109, 149, 181

Plum, Horse................................................ 109

Plum, Red ............................................... 109

Plum, Wild.................................................. 109

Poplars, The .................................................. 61

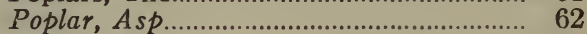

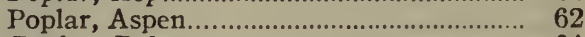

Poplar, Balm.................................................. 64

Poplar, Balm of Gilead.......................... 64

Poplar, Balsam....................64, 144, 166, 167

Poplar, Big-toothed..................................... 63

Poplar, Black ............................................... 64

Poplar, Large-toothed aspen....................... 63

Poplar, Rough-barked.................................. 64

Poplar, Smooth-barked.................................... 62

Poplar, Trembling aspen................................ 62

Poplar, White.............................................. 62

Poplar, Yellow.............................................. 99

Popple

Redbuds, The.........................114, 183, 189

Rowans, The................................................. 105

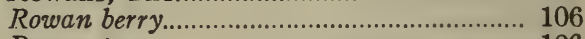

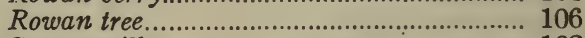

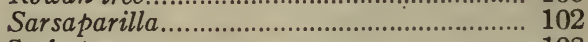

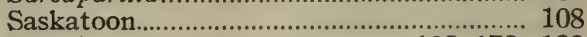

Sassafras......................................102, 178, 189

Sassafrax................................................... 102

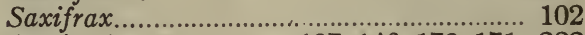

Service-berry..............107, 146, 170, 171, 222

Shadberry................................................. 107

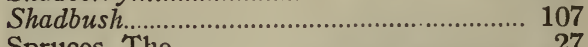

Spruces, The The................... 141, 154, 155, 208

Spruce, Black...............28, 141, 154, 155, 208

Spruce, Coast.................................................. 33

Spruce, Double ............................................... 28

Spruce, Douglas......................................... 38

Spruce, Engelmann.....................141, 154, 155

Spruce, Hemlock (See Hemlock) ................. 35

Spruce, Menzies................................................ 33

Spruce, Mountain.......................................... 32

Spruce, Northern........................................... 30

Spruce, Oregon.............................................. 38

Spruce, Red..........................29, 141, 154, 155

Spruce, Red................................................ 28

Spruce, Rocky Mountain............................... 32 
Page

Spruce, Single. $33,141,154,155,195$

Spruce, Sitka.

Spruce, Skunk.

Spruce, Sivamp.

Spruce, Tideland

Spruce, Wcter

Spruce, Hestern white

Spruce, White

Spruce, White.

Spruce, Yellow

Sumach, Staghorn

Sycamores, The.

Tacamaluac (See Poplar, Balsam)............ 6

Tamarack, Western.................................. 26

Tamarack.

$24,140,153$
Tulip Trees, The.

Tulip tree.

Tupelo

Var....

Valnuts, The

Walnut, American

Walnut, Black.

Walnut, While

Whitewood.

Willows, The.

Willow, Red.

Winter bloom

Witch hazel.
Yews, The...

Yew, Western
Page

$99,177,100$

131

40

53

54 $.54,143,161,162,212$

55 $61,176,189$ 128 103 190 190 52,159

\section{BOTANICAL NAMES}

Abies

Abies amabilis.

Abies balsamea.

Abies grandis.

Abies lasiocarpa

Acer

Acer circinatum.

Acer Douglasii.

Acer macrophyllum.

Acer Negundo.

Acer pennsylvanicum

Acer platanoides.

Acer pseudoplatanus............................. 116

Acer rubrum....................................... 124

Acer saccharum...................................... 121

Acer saccharinum................................. 123

Acer spicatum.................................. 117

Alnus................................................ $\quad \mathbf{7 3}$

Alnus incana..................................... 74

Alnus oregona................................... 74

Alnus sitchensis................................... 74

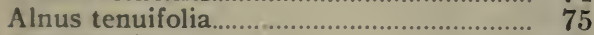

Amelanchier.......................................... 107

Amelanchier alnifolia........................... 108

Amelanchier canadensis......................... 107

Amelanchier obovalis.............................. 107

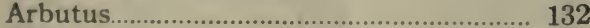

Arbutus Menziesii................................. 133

Asimina ............................................. 101

Asimina triloba..................................... 101

Betula ................................................ 6.9

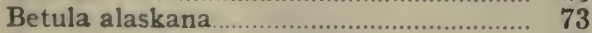

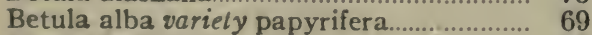

Betula fontinalis................................. 73

Betula lenta.......................................... $\quad 72$

Betula lutea ........................................ 71

Betula occidentalis................................. $\quad 70$

Betula populifolia.................................... 68

Castanea............................................. 79

Castanea dentata.................................... $\quad 79$

Carpinus............................................. 76

Carpinus Betulus.................................. $\quad 76$

Carpinus caroliniana............................ $\quad 76$

Carya.................................................. 56

Carya alba .............................................. 59

Carya cordiformis.................................... 56

Carya glabra..
Carya microcarpa

Carya ovata.............................................. $\quad 58$

Celtis.................................................. 96

Celtis occidentalis.................................... 97

Cercis.................................................. 114

Cercis canadensis................................... 114

Chamaecyparis................................... 48

Chamaecyparis nootkatensis................... 49

Cornus............................................ 128

Cornus alternifolia.................................. 128

Cornus asperifolia.................................... 128

Cornus florida........................................ 128

Cornus Nuttallii..................................... 130

Crataegus............................................... 108

Crataegus Douglasii................................ 108

Fagus............................................... 78

Fagus grandifolia................................... 78

Fraxinus.............................................. 133

Fraxinus americana............................. 136

Fraxinus nigra.................................... 134

Fraxinus pennsylvanica...................... 137

Fraxinus pennsylvanica variety lanceolata..138

Fraxinus quadrangulata......................... 133

Gymnocladus...................................... 114

Gymnocladıs dioica............................... 114

Hamamelis ........................................ 103

Hamamelis virginiana.......................... 103

Juglans ............................................... 53

Juglans cinerea.................................... 55

Juglans nigra.......................................... 54

Juglans regia.................................... 53

Juniperus.......................................... 50

Jiniperus communis................................. 50

Juniperus scopulorum........................... 52

Juniperus virginiana............................. $\quad 50$

Larix ........................................... 24

Larix alaskensis..................................... 21

Larix laricina........................................... 24

Larix Lyallii............................................ 27

Larix occidentalis................................... 26

I.iriodendron............................................ 99

Liriodendron Tulipifera.......................... 99

Magnolia.............................................. 98

Magnolia acuminata................................ 98

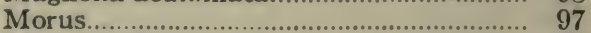

Morus alba............................................. 97

Morus rubra.......................................... 98 


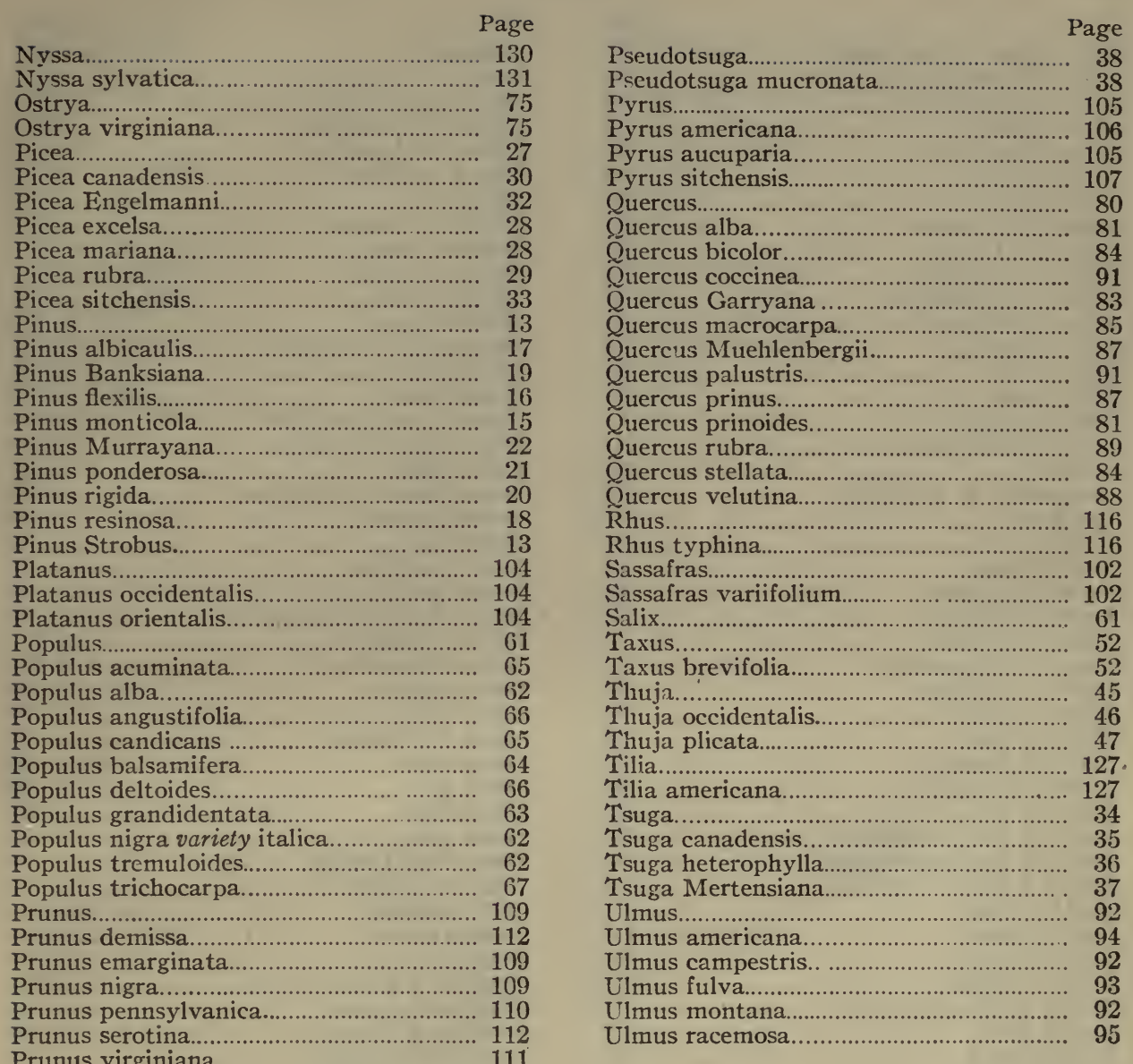

\section{FRENCH NAMES}

Amélanchier du Canada......................... 107

Arbousier de Menzies...................................... 133

Arbres à noix longues.................................... 55

Aune-buis...................................................... 125

Aune commun................................................ 74

Aune de l'Orégon........................................ 74

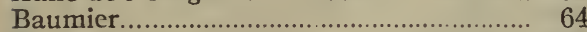

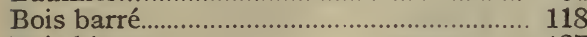

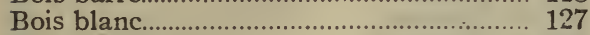

Bois de fer................................................ 75

Bois de flèche.................................................. 128

Bois dur.................................................. 75

Bois noir................................................... 118

Bouleau acajou............................................ 72

Bouleau à canot.......................................... 69

Bouleau à feuilles de peuplier..................... 68

Bouleau à papier............................................. 69

Bouleau à sucre............................................ 72

Bouleau blanc.................................................. 69

Bouleau occidental...................................... 70

Bouleau gris...................................................... 68
Bouleau jaune........................................... 71

Bouleau merisier........................................... 72

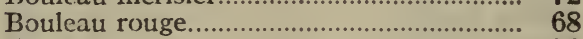

Carya amer.................................................... 56

Carya blanc................................................. 58

Carya des pourceaux...................................... 60

Carya glabre..................................................... 60

Carya tomenteux............................................ 59

Cèdre ............................................................ 46

Cèdre blanc.............................................. 46

Cèdre rouge.................................................... 50

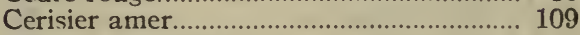

Cerisier à grappes...................................... 111

Cerisier d'automne........................................ 112

Cerisier noir............................................... 112

Cerisier tardif................................................. 112

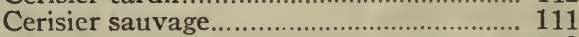

Cerisier sauvage de l'Ouest......................... 112

Cerisier de virginie.......................................... 111

Charme d'Amérique....................................... 76

Châtaignier....................................................... 79 
Chêne à gros glands...... 84

Chêne à lobes obtus............................... 84

Chêne blanc... ....................................... 81

Chêne blanc frisé........................................ 85

Chêne bicolore.......................................... 84

Chêne blett............................................. 84

Chêne chinquapin................................. 87

Chêne de Garry........................................ 83

Chêne de marais...................................... 91

Chêne des teinturiers.............................. 88

Clîne écarlate...................................... 91

Chêne étoile............................................. $\$$

Chêne noir............................................. 88

Chêne prin ................................................. 87

Chêne rouge............................................. 89

Chicot du Canada..................................... 114

Cormier.............................................. 106

Cornouiller de la Floride.......................... 128

Cotonnier................................................ 66

Cyprès...................................................... 19

Cyprès jaune............................................ 49

I:pinette à bière......................................... 30

Finctte bâtarde...................................... 28

Epinette blanche ..................................... 30

Iipinette d'Engelmann............................. 32

Iipinette de Sitka................................... 33

I

Iipinet te jaune........................................ 28

I:pinette noire........................................... 28

Epinette rouge............................................ 29

Iirable à épis ......................................... 117

Frable à feuilles de frêne........................ 125

Errable à fruits cotonneux...................... 123

Frable 丸 grandes feuilles......................... 119

Erable à sucre....................................... 121

Erable bâtard......................................... 117

Frable blanc........................................... 123

Erable circiné........................................... 120

Erable de Pennsylvanic............................ 118

Erable dur........................................... 121

Erable moiré........................................... 121

Erahle nain.......................................... 121

Erable Négundo.................................... 125

Erable ondé............................................ 121

Erable piqué........................................... 121

Erable rouge........................................... 124

Erable tendre........................................... 124

Faux-bananier..................................... 101

Faux-cyprès de Nootka........................... 49

Faux-tremble....................................... 62

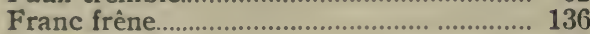

Frêne anguleux...................................... 133

Frêne à feuilles de sureau...................... 134

Fréne blanc.......................................... 136

Frêne noir........................................... 134

Frêne de Savanne.................................. 137

Frêne pubescent.................................. 137

Frêne rouge.......................................... 137

Frêne vert.............................................. 188

Gainier du Canada................................. 114

Génévrier rouge....................................... 50

Grand tremble...................................... 63

Hamamélis de Virginie........................... 103

Hêtre.................................................. 78

Hêtre rouge......................................... 78
Jasminier ......................................... 101

$\begin{array}{lr}\text { Liard....................................................... } & 66 \\ \text { Magnolier à feuilles acuminées.................. } & 99\end{array}$

Mélèze d'Amérique.................................. 24

Mélèze de Lyall....................................... 27

Mélèze occidental................................. 26

Merisier..................................................... 71

Merisier (France).................................. 112

Merisier jaune....................................... 71

Merisier odorant...................................... 72

Merisier ondé.......................................... 71

Merisier rouge......................................... 72

Micocouiller occidental........................... 97

Murier sauvage........................................ 98

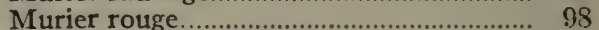

Noyer à noix de cochon.......................... 60

Noyer à noix douces.................................. 59

Noyer blanc.......................................... 59

Noyer blanc d'A mérique ........................ 58

Noyer cendré........................................... 55

Noyer dur.............................................. 56

Noyer écailleux........................................ 58

Noyer gris.......................................... 55

Noyer noir (d'Amérique)........................ 54

Noyer tendre.......................................... 55

Nyssa sylvestre..................................... 131

Orme bâtard........................................... 97

Orme blanc............................................... 94

Orme d'Amérique..................................... 94

Orme fattve........................................... 93

Orme gras.................................................. 93

Orme liège................................................. 95

Orme rouge............................................... 93

Ostryer de Virginie................................... 75

Pérusse (France) ...................................... 35

Petit merisier.......................................... 110

Petites poires............................................ 107

Peuplier............................................... 62

Peuplier à grandes dents........................... 63

Peuplier baumier........................................ 64

Peuplier d'Athènes................................... 62

Peuplier de l'Ouest.................................... 67

Peuplier monalifère................................ 66

Peuplier tremble........................................ 62

Pin argenté............................................ 15

Pin a blanche écorce.................................. 17

Pin a bois lourd..................................... 21

Pin à feuilles rigides.................................. $\quad 20$

Pin baliveau............................................. 13

Pin blanc................................................. 13

Pin blanc de l'Ouest................................ 16

Pin chétif............................................. 19

Pin de Banks............................................ 19

Pin de Douglas........................................ 39

Pin de Murray.......................................... 22

Pin de Norvège....................................... 18

Pin des rochers...................................... 19

Pin du lord........................................... 13

Pin gris.................................................. 19

Pin jaune ............................................... 13

Pin potiron................................................. 13

Pin résineux.......................................... 18

Pin rouge

Pin Weymouth........................................ 13

Plaine à Guigère................................. 125

Plaine bâtarde....................................... 117 
Index 233

Page

Plaine blanche

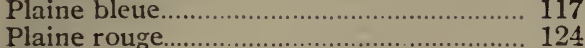

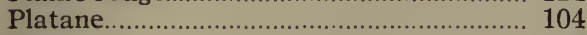

Pruche............................................................ 35

Prunier canadien ..................................... 109

Sapin baumier.......................................... 40

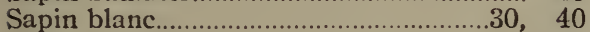

Sapin concolore.

41

Sapin de Douglas.

41

Sapin du Canada.......................................... 35

Sapin graciet1x......................................... 44

Sapin grandissime.......................................... 43

Sapin noir................................................ 28

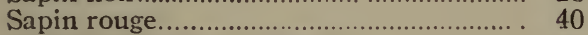

Sapinette blanche (France)

Sapinette noire (France) ...................... 28

Sassafras.................................................... 102

Sorbier d'Amérique........................................ 106

Sumac amaranthe ................................... 116

Sumac de Virginie............................................... 116

Sycomore............................................... 104

Tamarac..................................................... 24

Thuja....................................................... 46

Thuja géant............................................. 47

Tilleul d'Amérique....................................... 127

Tsuga de l'Ouest...................................... 36

Tsuga de Patton ........................................ 37

Tsuga du Canada ......................................... 35

Tremble.................................................... 62

Tulipier ........................................................ 99

Vinaigrier. ................................................ 116 


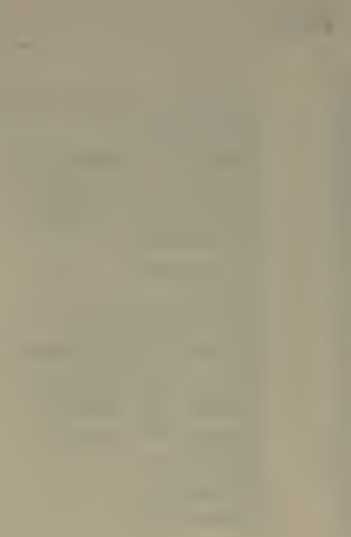



. 



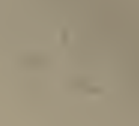

- 


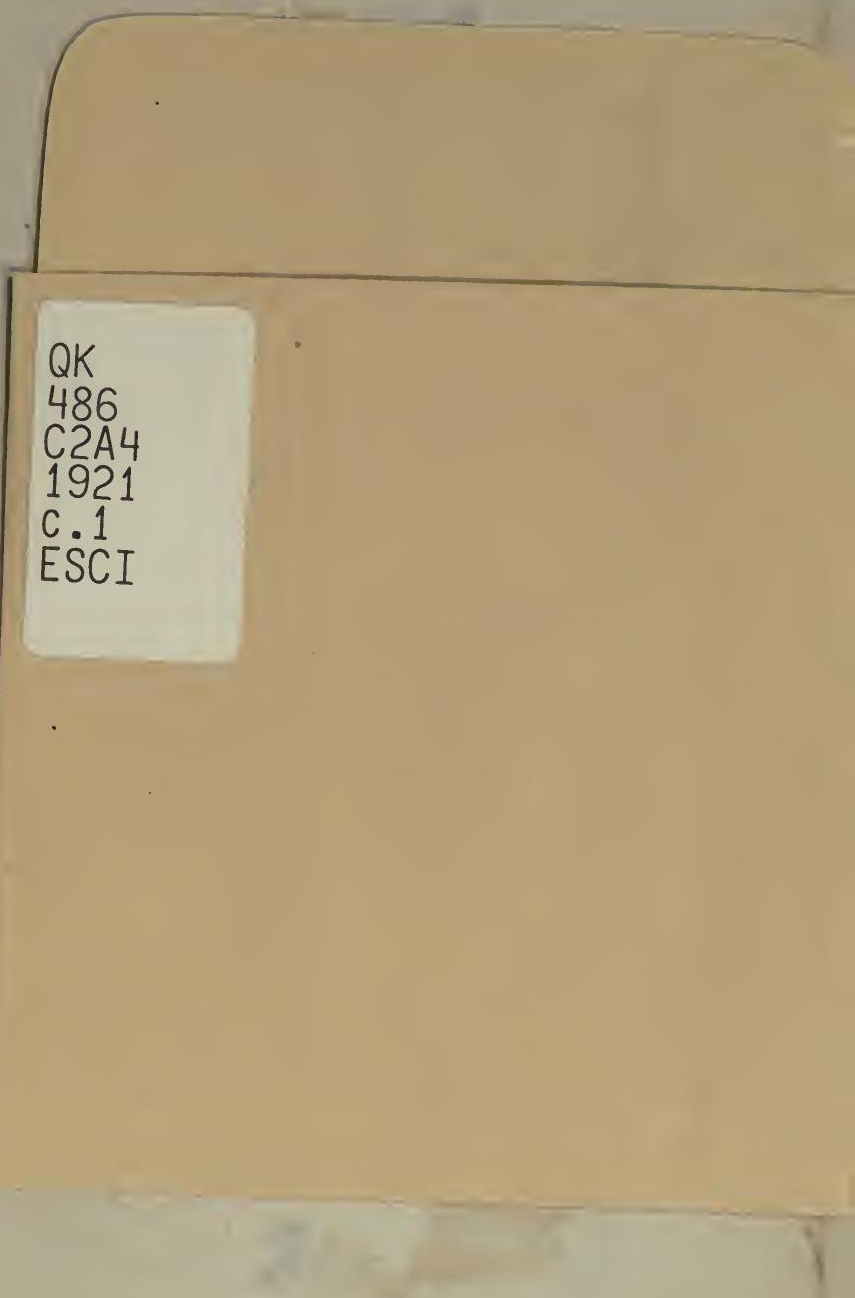




$$
\text { (at) } 182^{\circ}
$$

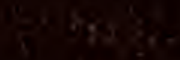

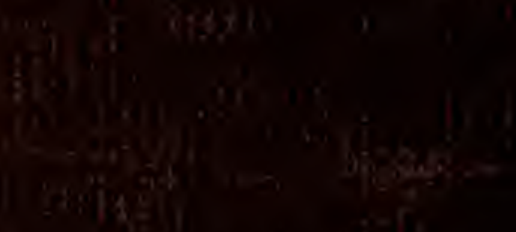

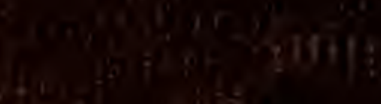

$$
\begin{aligned}
& \text { ing } \\
& \text { a.t }
\end{aligned}
$$

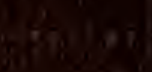

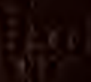

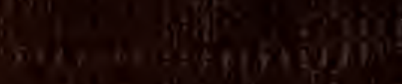

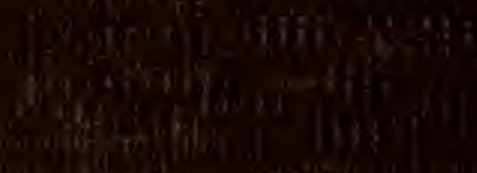

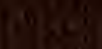

